FLOTAÇÃO APLICADA AO PÓS-TRATAMENTO DO EFLUENTE DE REATOR ANAERÓBIO DE LEITO EXPANDIDO TRATANDO ESGOTO SANITÁRIO

\author{
ROGÉRIO GOMES PENETRA
}

Orientador: Prof. Dr. MARCO ANTONIO PENALVA REALI 


\section{FLOTAÇÃO APLICADA AO PÓS-TRATAMENTO DO EFLUENTE DE REATOR ANAERÓBIO DE LEITO EXPANDIDO TRATANDO ESGOTO SANITÁRIO}

Eng. Civil ROGÉRIO GOMES PENETRA

Tese apresentada à Escola de Engenharia de São Carlos da Universidade de São Paulo, como parte dos requisitos para obtenção do título de Doutor em Hidráulica e Saneamento

ORIENTADOR: Prof. Dr. Marco Antonio Penalva Reali 
Ficha catalográfica preparada pela Seção de Tratamento da Informação do Serviço de Biblioteca - EESC/USP

Penetra, Rogério Gomes

Flotação aplicada ao pós-tratamento do efluente de reator anaeróbio de leito expandido tratando esgoto sanitário / Rogério Gomes Penetra. -- São Carlos, 2003 .

Tese (Doutorado)- Escola de Engenharia de São Carlos-Universidade de São Paulo, 2003.

Área: Hidráulica e Saneamento.

Orientador: Prof. Dr. Marco Antonio Penalva Reali.

1. Flotação por ar dissolvido. 2. Pós-tratamento de reatores anaeróbios. 3. Remoção de fósforo por flotação. I. Título. 
FOLHA DE JULGAMENTO

Candidato: Engenheiro ROGERIO GOMES PENETRA

Tese defendida e julgada em 23-05-2003 perante a Comissão Julgadora:

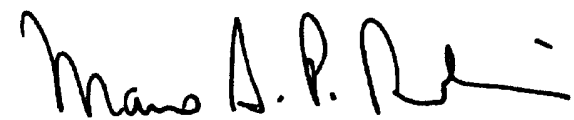

Prof. Dr. MARCO ANTONIO PENALVA REALI (Orientador)

AProvado

(Escola de Engenharia de São Carlos/USP)
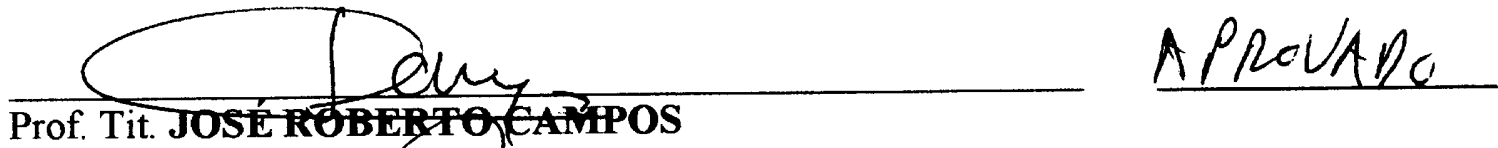

(Escola de Engenharia de São Carlos/USP)

Escola de Engenhariage São Carlos/OSP)

$A D R O \cup A A O$

Prof. Tit. EUGEXfOFORESTI

(Escola de Engendaria de São Carlos/USP)

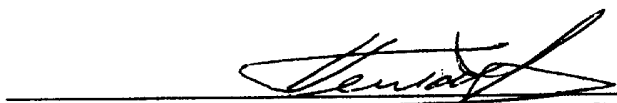

Prof. Dr. HENIO NORMANDO DE SOUZA MELO

$A P \ll Q L A D$

(Universidade Federal do Rio Grande do Norte/UFRN)

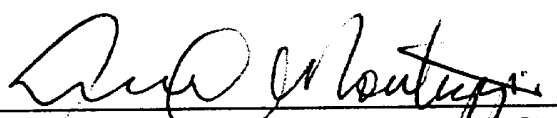

APROUN20

Prof. Dr. LUIZ OLANTO MONTtLGGA

(Universidade Federal do Rio Grande do Sul/UFRGS)

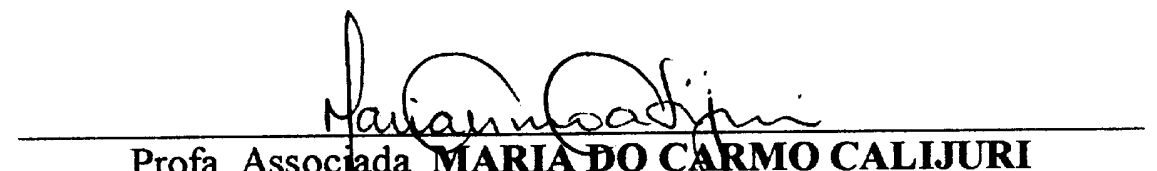

Profa. Associada MARIADO CARMO CALIJURI

Coordenadora do Programa de Pós-Graduação em

Engenharia (Hidráulica e Saneamento) e

Presidente da Comissão de Pós-Graduação 
Aos meus pais Jair e Arlinda, pois sem eles o autor desta tese seria outro; a Evaldo Müller da Silva (in memoriam), sogrão inesquecível pelo seu bom humor e carisma. 


\section{AGRADECIMENTOS}

Ao Prof. Dr. Marco Antonio Penalva Reali, pela oportunidade, pela confiança, pela amizade e pela orientação no decorrer deste trabalho,

Ao Prof. Tit. José Roberto Campos, pelo incentivo, pela confiança e pelo reator anaeróbio de leito expandido,

Ao Prof. Tit. Eugênio Foresti, pessoalmente um amigo e profissionalmente o melhor consultor em tratamento anaeróbio que eu poderia desejar,

Aos Prof. Marcelo Zaiat e Prof. Luiz Antonio Daniel, pelo conhecimento compartilhado e a amizade e confiança mútua,

Aos técnicos Francisco, Luiz e Edson, do Depto. de Hidráulica e Saneamento da Escola de Engenharia de São Carlos da Universidade de São Paulo (EESC-USP), pela parceria na montagem e manutenção dos equipamentos utilizados neste trabalho,

Aos funcionários da Seção de Veículos da EESC-USP, que forneceram apoio ferramental e compreensão,

Aos técnicos da Oficina Mecânica da EESC-USP,

Aos técnicos do Laboratório de Saneamento, Paulo, Júlio e Cidinha, pela constante colaboração, amizade e atenção oferecida ao longo do trabalho,

Às secretárias e demais funcionários administrativos do Departamento de Hidráulica e Saneamento da EESC-USP, pelo trabalho e atenção diariamente prestados, propiciando a elaboração deste e de tantos outros trabalhos desenvolvidos neste Departamento,

Aos companheiros de laboratório (LATAR), pelo incentivo diário, sobretudo a Marilu e a Leila, amigas desde o início do mestrado,

À Renata Cristina Moretti e Marcelo Eustáquio de Carvalho, pelo companheirismo e auxílio durante a operação do flotador;

A todos os meus amigos que me acompanharam e incentivaram durante esta pesquisa, sobretudo a Lara Steil, pesquisadora incansável do mundo anaeróbio,

Ao meu irmão Gustavo, pelo companheirismo, pela ajuda mútua e por suportar meu mau humor nas horas difíceis do doutorado,

À Graziella, uma amiga muito querida,

E, principalmente, à Ana Daysi, pela motivação, pelo carinho e amor dedicados.

Ao Conselho Nacional de Desenvolvimento Científico e Tecnológico (CNPq), pela bolsa de doutorado (Processo n ${ }^{\circ}$ 199814/3536-2), ao PRONEX e ao PROSAB, pelo auxílio financeiro para aquisição de materiais e de equipamentos necessários a este trabalho. 


\section{SUMÁRIO}

LISTA DE FIGURAS

LISTA DE TABELAS $\quad$ ix

LISTA DE ABREVIATURAS, SIGLAS E SÍMBOLOS xi

RESUMO xiii

ABSTRACT xiv

1 INTRODUÇÃO 1

2 OBJETIVOS 4

3 REVISÃO DA LITERATURA 5

3.1 A flotação por ar dissolvido (FAD) 5

3.1.1 Aspectos gerais da flotação por ar dissolvido (FAD) 6

3.1.2 Unidades de um sistema de flotação por ar dissolvido

3.1.3 A flotação por ar dissolvido no tratamento de águas residuárias 12

$\begin{array}{lll}\text { 3.1.4 Coagulação e floculação em sistemas de flotação por ar dissolvido } & 14\end{array}$

3.1.5 Aspectos positivos do emprego da coagulação/floculação/flotação como $\quad 18$

3.2 Alternativas para o pós-tratamento de efluentes anaeróbios 20

3.3 Remoção e recuperação de fósforo no esgoto sanitário 29

$\begin{array}{lll}3.4 & \text { Reatores anaeróbios de leito expandido } & 42\end{array}$

4 MATERIAIS E MÉTODOS 46

$\begin{array}{lll}4.1 & \text { Considerações iniciais } & 46\end{array}$

$\begin{array}{lll}4.2 & \text { Programação dos ensaios } & 47\end{array}$

4.2.1 Ensaios de laboratório utilizando o equipamento Flotateste 47

4.2.2 Ensaios de campo utilizando unidade de flotação em escala piloto 48

4.3 Descrição das instalações $\quad 53$

4.3.1 Equipamento de floculação/flotação em escala de laboratório (flotateste) $\quad 53$

4.3.2 Instalação piloto de coagulação/floculação/flotação por ar dissolvido com 53

4.3.3 Descrição do Reator Anaeróbio de Leito Expandido (RALEx) 67

$\begin{array}{lll}4.4 & \text { Efluente do reator RALEx } & 69\end{array}$

$\begin{array}{lll}4.5 & \text { Produtos químicos empregados } & 70\end{array}$

4.6 Ensaios preliminares em escala de laboratório, utilizando o flotateste e com aplicação de polímeros sintéticos, isoladamente ou associados ao cloreto férrico 
4.6.2 Ensaios com variação do tipo de polímero sintético, dosado conjuntamente com cloreto férrico

4.7 Ensaios em escala de laboratório, utilizando o flotateste e com aplicação de cloreto férrico e polímero sintético, durante período de partida do RALEx

4.7.1 Ensaios com variação da dosagem de cloreto férrico associada a diferentes dosagens de polímero sintético

Ensaios com variação do tempo total de floculação associado a diferentes valores de tempo de floculação do polímero sintético

4.10 Caracterização físico-química simplificada do esgoto bruto e do efluente do reator RALEx ao longo de 24 horas

$5 \quad$ RESULTADOS E DISCUSSÕES

5.1 Ensaios com a câmara de saturação visando determinação da quantidade de ar fornecida ao processo

5.2 Caracterização físico-química simplificada do esgoto bruto e do efluente do reator RALEx ao longo de 24 horas

5.3 Resultados dos ensaios preliminares de pós-tratamento do efluente do reator RALEx em escala de laboratório, utilizando o flotateste e com aplicação de polímeros sintéticos, isoladamente ou associados ao cloreto férrico

5.3.1 Ensaios com variação do tipo de polímero sintético, dosado isoladamente 
5.3.2 Ensaios com variação do tipo de polímero sintético, dosado conjuntamente com cloreto férrico

5.4 Ensaios em escala de laboratório, utilizando o flotateste e com aplicação de cloreto férrico e polímero sintético, durante período de partida do

RALEx

5.4.1 Ensaios com variação da dosagem de cloreto férrico associada a diferentes dosagens de polímero sintético

Ensaios com variação do tempo total de floculação associado a diferentes valores de tempo de floculação do polímero sintético

5.4.3 Ensaios com variação do tempo total de floculação associado a diferentes valores de gradiente médio de velocidade de floculação

Ensaios com utilização dos valores mais adequados dos parâmetros discutidos nos itens 5.2.1 a 5.2.4 polímero sintético (dosado isoladamente), do tipo de polímero sintético e da dosagem de polímero (dosado conjuntamente com cloreto férrico), durante partida de reator RALEx

Flotação sem aplicação de produtos químicos durante partida do reator RALEx

Flotação com aplicação somente de cloreto férrico durante partida do reator RALEx

Flotação com aplicação somente de polímeros durante partida do reator RALEx

Flotação com aplicação de cloreto férrico associado a polímero sintético durante partida do reator RALEx

Ensaios em escala de laboratório, utilizando o flotateste e com aplicação de cloreto férrico para amostras coletadas ao longo do dia

Ensaios com variação da dosagem de cloreto férrico para coagulação/ floculação/flotação de amostras de efluente anaeróbio coletadas ao longo do dia

Ensaios com variação da dosagem de cloreto férrico e do $\mathrm{pH}$ de coagulação para coagulação/floculação/flotação de amostras de efluente anaeróbio

Ensaios com a instalação piloto de flotação utilizando somente cloreto férrico

Ensaios com a instalação piloto de flotação operada com TAS=180 $\mathrm{m}^{3} / \mathrm{m}^{2} / \mathrm{d}$

Ensaios com a instalação piloto de flotação operada com $\mathrm{R}=12 \%$.

Ensaios com a instalação piloto de flotação operada com $\mathrm{R}=18 \%$

Ensaios com a instalação piloto de flotação operada com TAS=250 $\mathrm{m}^{3} / \mathrm{m}^{2} / \mathrm{d}$ 

$\mathrm{m}^{3} / \mathrm{m}^{2} / \mathrm{d}$ $\mathrm{R}=18 \%$

Ensaios com a instalação piloto de flotação operada $\mathrm{DCF}=50 \mathrm{mg} / \mathrm{L}$ e com $\mathrm{R}$ entre $12 \%$ e $18 \%$.

6 CONSIDERAÇÕES FINAIS ACERCA DA UTILIZAÇÃO DA FLOTAÇÃO POR AR DISSOLVIDO COMO PÓS-TRATAMENTO DE REATOR RALEX

7 CONCLUSÕES E RECOMENDAÇÕES

8 REFERÊNCIAS BIBLIOGRÁFICAS 


\section{LISTA DE FIGURAS}

FIGURA 3.1 - Definição esquemática da formação de pontes entre partículas com aplicação de polímeros orgânicos.

FIGURA 3.2 - Rampa de escoamento superficial.

FIGURA 3.3 - Fluxograma do tratamento de esgotos sanitários empregando reator anaeróbio seguido por sistema de flotação.

FIGURA 3.4 - Diagramas de equilíbrio de solubilidade para fosfatos de $\mathrm{Fe}, \mathrm{Al}$ e $\mathrm{Ca} . \quad 34$

FIGURA 3.5 - Concentração de ortofosfato residual em função da dosagem de $\mathrm{Fe}^{3+} 34$ ( $\mathrm{pH}$ não controlado e concentração de ortofosfato afluente entre 6 e 7 $\mathrm{mg} / \mathrm{L})$.

FIGURA 3.6 - Curva característica da concentração de ortofosfato residual em função da dosagem de Fe.

FIGURA 3.7 - Comportamento característico da concentração de fosfato total residual em função da dosagem de $\mathrm{Fe}$, observado em ensaios de flotação de efluentes de reatores anaeróbios.

FIGURA 3.8 - Esquema do reator anaeróbio de leito expandido.

FIGURA 4.1 - Fluxograma do método adotado para ensaios preliminares de coagulação-floculação-flotação utilizando cloreto férrico e polímero sintético no pós-tratamento físico-químico de efluentes de reator RALEx.

FIGURA 4.2 - Fluxograma do método adotado para ensaios de coagulaçãofloculação-flotação utilizando cloreto férrico e polímero sintético no pós-tratamento físico-químico de efluentes de reator RALEx.

FIGURA 4.3 - Fluxograma do método adotado para ensaios de coagulaçãofloculação-flotação utilizando cloreto férrico no pós-tratamento físico-químico de efluentes de reator RALEx, utilizando unidade piloto com escoamento contínuo (flotador).

FIGURA 4.4 - Fluxograma do método adotado para ensaios de coagulaçãofloculação-flotação utilizando cloreto férrico e polímero sintético no pós-tratamento físico-químico de efluentes de reator RALEx, utilizando unidade piloto com escoamento contínuo (flotador).

FIGURA 4.5 - Fotografia do equipamento de floculação/flotação em escala de laboratório (flotateste).

FIGURA 4.6 - Esquema geral do flotateste.

FIGURA 4.7 - Esquema simplificado da instalação piloto de coagulação/floculação/ flotação por ar dissolvido com escoamento contínuo (flotador).

FIGURA 4.8 - Vistas superiores e laterais da instalação piloto de coagulação/floculação/flotação por ar dissolvido com escoamento contínuo (flotador).

FIGURA 4.9 - Vistas do sistema de floculação da unidade piloto de coagulaçãofloculação-flotação. 
FIGURA 4.10 - Fotografia da instalação piloto de coagulação/floculação/ flotação por ar dissolvido com escoamento contínuo (flotador).

FIGURA 4.11 - Fotografia do sistema de tratamento composto por reator RALEx e flotador.

FIGURA 4.12 - Unidades constituintes do sistema de coagulação-floculação-flotação em escala piloto.

FIGURA 4.13 - Unidades constituintes do sistema de coagulação-floculação-flotação em escala piloto.

FIGURA 4.14 - Unidades constituintes do sistema de coagulação-floculação-flotação em escala piloto.

FIGURA 4.15 - Características e dimensões da unidade de mistura rápida.

FIGURA 4.16 - Corte esquemático do Reator Anaeróbio de Leito Expandido.

FIGURA 4.17 - Fotografia do Reator Anaeróbio de Leito Expandido.

FIGURA 4.18 - Esquema do sistema experimental no desenvolvimento do estudo da partida do reator anaeróbio de leito expandido.

FIGURA 5.1 - Valores de temperatura do ar, do esgoto bruto e do efluente do reator RALEx, de DQO bruta (amostras não filtradas), de concentração de fósforo total e de sólidos suspensos totais observados durante a primeira caracterização físico-química, no período entre 06:00 de 07 de outubro e 06:00 do dia 08 de outubro de 1999.

FIGURA 5.2 - Valores de temperatura do ar, do esgoto bruto e do efluente do reator RALEx, de DQO bruta (amostras não filtradas) e de concentração de fósforo total observados durante a primeira caracterização físicoquímica, no período entre 06:00 de 08 de fevereiro e 06:00 do dia 09 de fevereiro de 1999.

FIGURA 5.3 - Fotografia do reator UASB.

FIGURA 5.4 - Dados de DQO das amostras de esgoto bruto coletadas entre março e setembro de 2001, durante as etapas de trabalho descritas nos itens 4.9.2 e 4.9.3, entre 08:00 e 20:00.

FIGURA 5.5 - Dados de DQO das amostras de efluente do reator RALEx coletadas entre março e setembro de 2001, após operação de partida biológica, entre 08:00 e 20:00.

FIGURA 5.6 - Eficiências de remoção de carga diária de DQO alcançadas pelo RALEx entre março e setembro de 2002.

FIGURA 5.7 - Fração remanescente de turbidez (T/T0) nas amostras coletadas em função da velocidade de flotação para ensaios empregando diferentes polímeros e com dosagem de $4 \mathrm{mg} / \mathrm{L}$.

FIGURA 5.8 - Fração remanescente de DQO nas amostras coletadas em função da velocidade de flotação para ensaios empregando diferentes polímeros e com dosagem de $4 \mathrm{mg} / \mathrm{L}$. 
FIGURA 5.9 - Fração remanescente de turbidez (T/T0) nas amostras coletadas em 103 função da velocidade de flotação para ensaios empregando diferentes polímeros e com dosagem de $4 \mathrm{mg} / \mathrm{L}$.

FIGURA 5.10 - Fração remanescente de DQO nas amostras coletadas em função da velocidade de flotação para ensaios empregando diferentes polímeros e com dosagem de $4 \mathrm{mg} / \mathrm{L}$.

FIGURA 5.11 - Fração remanescente de turbidez (T/T0) em função da velocidade de flotação para dosagem de cloreto férrico $(\mathrm{DCF})=15 \mathrm{mg} / \mathrm{L}$ e dosagem de polímeros $(\mathrm{DP})=0,4 \mathrm{mg} / \mathrm{L}$. Polímeros catiônicos $(\mathbf{A})$, aniônicos (B) e não iônicos e policloreto de alumínio (C).

FIGURA 5.12 - Fração remanescente de turbidez (T/T0) em função da velocidade de flotação para dosagem de cloreto férrico $(\mathrm{DCF})=15 \mathrm{mg} / \mathrm{L}$ e dosagem de polímeros $(\mathrm{DP})=1,0 \mathrm{mg} / \mathrm{L}$. Polímeros catiônicos $(\mathbf{A})$, aniônicos (B) e não iônicos e policloreto de alumínio (C).

FIGURA 5.13 - Fração remanescente de turbidez (T/T0) em função da velocidade de flotação para dosagem de cloreto férrico $(\mathrm{DCF})=30 \mathrm{mg} / \mathrm{L}$ e dosagem de polímeros $(\mathrm{DP})=0,4 \mathrm{mg} / \mathrm{L}$. Polímeros catiônicos $(\mathbf{A})$, aniônicos (B) e não iônicos e policloreto de alumínio (C).

FIGURA 5.14 - Fração remanescente de turbidez (T/T0) em função da velocidade de flotação para dosagem de cloreto férrico $(\mathrm{DCF})=30 \mathrm{mg} / \mathrm{L}$ e dosagem de polímeros $(\mathrm{DP})=1,0 \mathrm{mg} / \mathrm{L}$. Polímeros catiônicos $(\mathbf{A})$, aniônicos (B) e não iônicos e policloreto de alumínio (C).

FIGURA 5.15 - Fluxograma simplificado da Primeira Etapa de Ensaios em laboratório, para investigação do emprego de polímeros sintéticos no pós-tratamento físico-químico por flotação, descrita nos itens 4.6.1 e 4.6.2.

FIGURA 5.16 - Fração remanescente de turbidez (T/T0) em função da velocidade de flotação para dosagem de cloreto férrico (DCF) entre 0 e $20 \mathrm{mg} / \mathrm{L}$ e dosagem de polímero catiônico (DPC) entre 0 e $1,25 \mathrm{mg} / \mathrm{L}$. DCF $=0$ $\mathrm{mg} / \mathrm{L}(\mathbf{A}), \mathrm{DCF}=10 \mathrm{mg} / \mathrm{L}(\mathbf{B})$ e $\mathrm{DCF}=20 \mathrm{mg} / \mathrm{L}(\mathbf{C})$.

FIGURA 5.17 - Fração remanescente de turbidez (T/T0) em função da velocidade de flotação para dosagem de cloreto férrico (DCF) entre 30 e $40 \mathrm{mg} / \mathrm{L}$ e dosagem de polímero catiônico (DPC) entre 0 e 1,25 mg/L. DCF = $30 \mathrm{mg} / \mathrm{L}(\mathbf{A})$ e $\mathrm{DCF}=40 \mathrm{mg} / \mathrm{L}(\mathbf{B})$.

FIGURA 5.18 - Concentração de fósforo (P) das amostras coletadas nos ensaios com dosagem de cloreto férrico (DCF) entre 0 e $40 \mathrm{mg} / \mathrm{L}$ e dosagem de polímero catiônico (DPC) entre 0 e $1,25 \mathrm{mg} / \mathrm{L}$. Vf $=10 \mathrm{~cm} / \mathrm{min}(\mathbf{A})$ e $\mathrm{Vf}=25 \mathrm{~cm} / \mathrm{min}(\mathbf{B})$.

FIGURA 5.19 - Demanda química de oxigênio (DQO) das amostras coletadas nos ensaios com dosagem de cloreto férrico (DCF) entre 0 e $40 \mathrm{mg} / \mathrm{L} \mathrm{e}$ dosagem de polímero catiônico (DPC) entre 0 e $1,25 \mathrm{mg} / \mathrm{L} . \mathrm{Vf}=10$ $\mathrm{cm} / \mathrm{min}(\mathbf{A})$ e $\mathrm{Vf}=25 \mathrm{~cm} / \mathrm{min}(\mathbf{B})$.

FIGURA 5.20 - Fração remanescente de turbidez (T/T0) em função da velocidade de flotação para diferentes valores de tempo total de floculação associado a diferentes valores de tempo de floculação do polímero. 
FIGURA 5.21 - Concentração de fósforo (P) das amostras coletadas nos ensaios com diferentes valores de tempo total de floculação associado a diferentes valores de tempo de floculação do polímero. $\mathrm{Vf}=10 \mathrm{~cm} / \mathrm{min}(\mathbf{A})$ e $\mathrm{Vf}=25 \mathrm{~cm} / \mathrm{min}(\mathbf{B})$.

FIGURA 5.22 - Demanda química de oxigênio (DQO) das amostras coletadas nos ensaios com diferentes valores de tempo total de floculação associado a diferentes valores de tempo de floculação do polímero. $\mathrm{Vf}=10 \mathrm{~cm} / \mathrm{min}(\mathbf{A})$ e $\mathrm{Vf}=25 \mathrm{~cm} / \mathrm{min}(\mathbf{B})$.

FIGURA 5.23 - Fração remanescente de turbidez (T/T0) em função da velocidade de flotação para diferentes valores de tempo total de floculação (Tf) associado a diferentes valores de gradiente médio de floculação (Gf). $\mathrm{Tf}=12 \min (\mathbf{A}) ; \mathrm{Tf}=18 \min (\mathbf{B})$ e $\mathrm{Tf}=24 \min (\mathbf{C})$.

FIGURA 5.24 - Concentração de fósforo (P) das amostras coletadas nos ensaios com diferentes valores de tempo total de floculação associado a diferentes valores de gradiente médio de floculação. $\mathrm{Vf}=10 \mathrm{~cm} / \mathrm{min}(\mathbf{A})$ e $\mathrm{Vf}=$ $25 \mathrm{~cm} / \mathrm{min}(\mathbf{B})$.

FIGURA 5.25 - Demanda química de oxigênio (DQO) das amostras coletadas nos ensaios com diferentes valores de tempo total de floculação associado a diferentes valores de gradiente médio de floculação. Vf $=10 \mathrm{~cm} / \mathrm{min}(\mathbf{A})$ e $\mathrm{Vf}=25 \mathrm{~cm} / \mathrm{min}(\mathbf{B})$.

FIGURA 5.26 - Fração remanescente de turbidez (T/T0) em função da velocidade de flotação para diferentes valores de fração de recirculação (R).

FIGURA 5.27 - Concentração de fósforo (P) das amostras coletadas nos ensaios com diferentes valores de fração de recirculação $(\mathrm{R})$.

FIGURA 5.28 - Demanda química de oxigênio (DQO) das amostras coletadas nos ensaios com diferentes valores de fração de recirculação (R).

FIGURA 5.29 - Turbidez (A), DQO (B), fósforo (C) e sólidos suspensos totais (D) das amostras coletadas nos ensaios com utilização dos valores mais adequados dos parâmetros discutidos nos itens 5.2.1 a 5.2.4.

FIGURA 5.30 - Fluxograma com o resumo dos resultados mais conclusivos da Segunda Etapa de Ensaios em laboratório, para investigação do emprego de polímeros sintéticos associado a cloreto férrico no póstratamento físico-químico por flotação, descrita nos itens 4.7.1 a 4.7.5.

FIGURA 5.31 - Resultados de remoção e de residual de turbidez nos ensaios de coagulação/ floculação/flotação com aplicação de cloreto férrico (DCF) e/ou polímeros (DP).

FIGURA 5.32 - Fluxograma simplificado da Primeira Etapa de Ensaios em laboratório, durante partida biológica do reator RALEx, para investigação do emprego de polímeros sintéticos e/ou cloreto férrico no pós-tratamento físico-químico por flotação, descrita no item 4.7.6. 
FIGURA 5.33 - Fração remanescente de turbidez (T/T0) e turbidez das amostras coletadas nos ensaios com variação da dosagem de cloreto férrico para coagulação/ floculação/flotação de amostras de efluente do reator anaeróbio coletadas ao longo do dia.Horários de coleta: 08:00 (A); 11:00 (B); 14:00 (C); 17:00 (D) e 20:00 (E).

FIGURA 5.34 - Demanda química de oxigênio (DQO) das amostras coletadas nos ensaios com variação da dosagem de cloreto férrico para coagulação/floculação/flotação de amostras de efluente do reator anaeróbio coletadas ao longo do dia.

FIGURA 5.35 - Concentração de fósforo (P) das amostras coletadas nos ensaios com variação da dosagem de cloreto férrico para coagulação/floculação/ flotação de amostras de efluente do reator anaeróbio coletadas ao longo do dia.

FIGURA 5.36 - Fluxograma-resumo dos ensaios realizados com amostra do efluente do RALEx coletada às $11: 00$, com $\mathrm{DQO}=248 \mathrm{mg} / \mathrm{L}$, turbidez $=78,0$ uT, $\mathrm{P}=5,96 \mathrm{mg} / \mathrm{L}$ e com aplicação de dosagens de cloreto férrico entre 0 e $85 \mathrm{mg} / \mathrm{L}$ e Vflot $=10 \mathrm{~cm} / \mathrm{min}$.

FIGURA 5.37 - Fração remanescente de turbidez (T/T0) e turbidez das amostras coletadas nos ensaios com variação da dosagem de cloreto férrico e do $\mathrm{pH}$ de coagulação para coagulação/floculação/flotação de amostras de efluente do reator anaeróbio.

FIGURA 5.38 - Demanda química de oxigênio (DQO) das amostras coletadas nos ensaios com variação da dosagem de cloreto férrico e do $\mathrm{pH}$ de coagulação para coagulação/floculação/flotação de amostras de efluente do reator anaeróbio.

FIGURA 5.39 - Concentração de fósforo (P) das amostras coletadas nos ensaios com variação da dosagem de cloreto férrico e do $\mathrm{pH}$ de coagulação para coagulação/floculação/flotação de amostras de efluente do reator anaeróbio.

FIGURA 5.40- Temperatura, $\mathrm{pH}$, turbidez, demanda química de oxigênio, fósforo e sólidos suspensos totais das amostras de esgoto bruto, de efluente do reator RALEx e de efluente do flotador coletadas ao longo do dia de ensaio $(31 / 05 / 2001)$.

FIGURA 5.41 - Temperatura, pH, turbidez, demanda química de oxigênio, fósforo e sólidos suspensos totais das amostras de esgoto bruto, de efluente do reator RALEx e de efluente do flotador coletadas ao longo do dia de ensaio (01/06/2001).

FIGURA 5.42 - Temperatura, pH, turbidez, demanda química de oxigênio, fósforo e sólidos suspensos totais das amostras de esgoto bruto, de efluente do reator RALEx e de efluente do flotador coletadas ao longo do dia de ensaio $(02 / 06 / 2001)$.

FIGURA 5.43 - Temperatura, pH, turbidez, demanda química de oxigênio, fósforo e sólidos suspensos totais das amostras de esgoto bruto, de efluente do reator RALEx e de efluente do flotador coletadas ao longo do dia de ensaio $(23 / 05 / 2001)$. 
FIGURA 5.44 - Temperatura, pH, turbidez, demanda química de oxigênio, fósforo e sólidos suspensos totais das amostras de esgoto bruto, de efluente do reator RALEx e de efluente do flotador coletadas ao longo do dia de ensaio $(25 / 05 / 2001)$.

FIGURA 5.45 - Temperatura, pH, turbidez, demanda química de oxigênio, fósforo e sólidos suspensos totais das amostras de esgoto bruto, de efluente do reator RALEx e de efluente do flotador coletadas ao longo do dia de ensaio $(30 / 05 / 2001)$.

FIGURA 5.46 - Temperatura, pH, turbidez, demanda química de oxigênio, fósforo e sólidos suspensos totais das amostras de esgoto bruto, de efluente do reator RALEx e de efluente do flotador coletadas ao longo do dia de ensaio $(08 / 03 / 2001)$.

FIGURA 5.47 - Temperatura, pH, turbidez, demanda química de oxigênio, fósforo e sólidos suspensos totais das amostras de esgoto bruto, de efluente do reator RALEx e de efluente do flotador coletadas ao longo do dia de ensaio $(09 / 03 / 2001)$.

FIGURA 5.48 - Temperatura, pH, turbidez, demanda química de oxigênio, fósforo e sólidos suspensos totais das amostras de esgoto bruto, de efluente do reator RALEx e de efluente do flotador coletadas ao longo do dia de ensaio $(15 / 03 / 2001)$.

FIGURA 5.49 - Temperatura, pH, turbidez, demanda química de oxigênio, fósforo e sólidos suspensos totais das amostras de esgoto bruto, de efluente do reator RALEx e de efluente do flotador coletadas ao longo do dia de ensaio $(16 / 03 / 2001)$.

FIGURA 5.50 - Temperatura, pH, turbidez, demanda química de oxigênio, fósforo e sólidos suspensos totais das amostras de esgoto bruto, de efluente do reator RALEx e de efluente do flotador coletadas ao longo do dia de ensaio $(20 / 03 / 2001)$.

FIGURA 5.51 - Temperatura, pH, turbidez, demanda química de oxigênio, fósforo e sólidos suspensos totais das amostras de esgoto bruto, de efluente do reator RALEx e de efluente do flotador coletadas ao longo do dia de ensaio $(21 / 03 / 2001)$.

FIGURA 5.52 - Temperatura, pH, turbidez, demanda química de oxigênio, fósforo e sólidos suspensos totais das amostras de esgoto bruto, de efluente do reator RALEx e de efluente do flotador coletadas ao longo do dia de ensaio $(24 / 06 / 2001)$.

FIGURA 5.53 - Temperatura, pH, turbidez, demanda química de oxigênio, fósforo e sólidos suspensos totais das amostras de esgoto bruto, de efluente do reator RALEx e de efluente do flotador coletadas ao longo do dia de ensaio $(22 / 06 / 2001)$.

FIGURA 5.54 - Turbidez e demanda química de oxigênio das amostras de esgoto bruto, de efluente do reator RALEx e de efluente do flotador, operado com $70 \mathrm{mg} / \mathrm{L}$ de cloreto férrico, coletadas ao longo do dia de ensaio (13/09/2001). 
FIGURA 5.55 - Turbidez e demanda química de oxigênio das amostras de esgoto bruto, de efluente do reator RALEx e de efluente do flotador, operado com $90 \mathrm{mg} / \mathrm{L}$ de cloreto férrico, coletadas ao longo do dia de ensaio (17/09/2001).

FIGURA 5.56 - Turbidez e demanda química de oxigênio das amostras de esgoto bruto, de efluente do reator RALEx e de efluente do flotador, operado com dosagem variável de cloreto férrico, coletadas ao longo do dia de ensaio $(25 / 09 / 2001)$.

FIGURA 5.57 - Concentração de fósforo e de sólidos suspensos totais das amostras de esgoto bruto, de efluente do reator RALEx e de efluente do flotador, operado com dosagem variável de cloreto férrico, coletadas ao longo do dia de ensaio (25/09/2001).

FIGURA 5.58 - Temperatura, pH, turbidez, demanda química de oxigênio, fósforo e sólidos suspensos totais das amostras de esgoto bruto, de efluente do reator RALEx e de efluente do flotador coletadas ao longo do dia de ensaio $(13 / 07 / 2001)$.

FIGURA 5.59 - Temperatura, pH, turbidez, demanda química de oxigênio, fósforo e sólidos suspensos totais das amostras de esgoto bruto, de efluente do reator RALEx e de efluente do flotador coletadas ao longo do dia de ensaio (30/06/2001).

FIGURA 5.60 - Temperatura, pH, turbidez, demanda química de oxigênio, fósforo e sólidos suspensos totais das amostras de esgoto bruto, de efluente do reator RALEx e de efluente do flotador coletadas ao longo do dia de ensaio $(29 / 06 / 2001)$.

FIGURA 5.61 - Temperatura, pH, turbidez, demanda química de oxigênio, fósforo e sólidos suspensos totais das amostras de esgoto bruto, de efluente do reator RALEx e de efluente do flotador coletadas ao longo do dia de ensaio $(20 / 07 / 2001)$.

FIGURA 5.62 - Temperatura, pH, turbidez, demanda química de oxigênio, fósforo e sólidos suspensos totais das amostras de esgoto bruto, de efluente do reator RALEx e de efluente do flotador coletadas ao longo do dia de ensaio $(24 / 07 / 2001)$.

FIGURA 5.63- Temperatura, $\mathrm{pH}$, turbidez, demanda química de oxigênio, fósforo e sólidos suspensos totais das amostras de esgoto bruto, de efluente do reator RALEx e de efluente do flotador coletadas ao longo do dia de ensaio $(25 / 07 / 2001)$.

FIGURA 5.64 - Temperatura, pH, turbidez, demanda química de oxigênio, fósforo e sólidos suspensos totais das amostras de esgoto bruto, de efluente do reator RALEx e de efluente do flotador coletadas ao longo do dia de ensaio $(26 / 07 / 2001)$.

FIGURA 5.65- Temperatura, $\mathrm{pH}$, turbidez, demanda química de oxigênio, fósforo e sólidos suspensos totais das amostras de esgoto bruto, de efluente do reator RALEx e de efluente do flotador coletadas ao longo do dia de ensaio $(06 / 08 / 2001)$. 
FIGURA 5.66 - Temperatura, pH, turbidez, demanda química de oxigênio, fósforo e 237 sólidos suspensos totais das amostras de esgoto bruto, de efluente do reator RALEx e de efluente do flotador coletadas ao longo do dia de ensaio $(05 / 08 / 2001)$.

FIGURA 5.67 - Temperatura, pH, turbidez, demanda química de oxigênio, fósforo e sólidos suspensos totais das amostras de esgoto bruto, de efluente do reator RALEx e de efluente do flotador coletadas ao longo do dia de ensaio $(04 / 08 / 2001)$.

FIGURA 5.68 - Temperatura, pH, turbidez, demanda química de oxigênio, fósforo e sólidos suspensos totais das amostras de esgoto bruto, de efluente do reator RALEx e de efluente do flotador coletadas ao longo do dia de ensaio $(19 / 09 / 2001)$.

FIGURA 5.69 - Temperatura, pH, turbidez, demanda química de oxigênio, fósforo e sólidos suspensos totais das amostras de esgoto bruto, de efluente do reator RALEx e de efluente do flotador coletadas ao longo do dia de ensaio $(22 / 08 / 2001)$.

FIGURA 5.70 - Temperatura, pH, turbidez, demanda química de oxigênio, fósforo e sólidos suspensos totais das amostras de esgoto bruto, de efluente do reator RALEx e de efluente do flotador coletadas ao longo do dia de ensaio $(21 / 08 / 2001)$. 


\section{LISTA DE TABELAS}

TABELA 3.1 - Tecnologias de remoção e de recuperação de fósforo - resumo dos 30 processos.

TABELA 3.2 - Tecnologias de remoção e de recuperação de fósforo - contexto.

TABELA 4.1- Características dos polímeros sintéticos utilizados no estudo.

TABELA 4.2 - Sequiência das etapas de ensaios realizados em laboratório com uso do flotateste.

TABELA 4.3 - Seqüência das etapas de ensaios realizados com flotateste e cloreto férrico associado a polímero sintético (4.7.1 a 4.7.4).

TABELA 4.4 - Seqüência das etapas de ensaios realizados com flotateste e cloreto férrico associado a polímero sintético (4.7.5.a 4.7.7).

TABELA 4.5 - Seqüência das etapas de ensaios realizados com aplicação de cloreto férrico no afluente ao sistema de flotação.

TABELA 4.5 - Seqüência das etapas de ensaios realizados com aplicação de cloreto férrico associado a polímero sintético no afluente ao sistema de flotação.

TABELA 5.1 - Resultados dos ensaios com a câmara de saturação.

TABELA 5.2 - Dados de carga de diferentes parâmetros observados em amostras de esgoto bruto, de efluente de reator RALEx e de reator UASB (PENETRA, 1998), coletadas durante caracterização simplificada de efluentes ao longo de 24 horas.

TABELA 5.3 - Valores mínimos, médios e máximos de DQO e respectivos desvios-padrões das amostras de esgoto bruto e de efluente de reator anaeróbio entre os meses de março e setembro de 2001.

TABELA 5.4 - Valores de Demanda Química de Oxigênio (DQO) e de Fosfato Total $\left(\mathrm{PO}_{4}^{-}\right)$em função da velocidade de flotação para dosagem de cloreto férrico $(\mathrm{DCF})$ de $15 \mathrm{e}$ de $30 \mathrm{mg} / \mathrm{L}$ associada à dosagem de polímeros (DP) de 0,4 e $1,0 \mathrm{mg} / \mathrm{L}$.

TABELA 5.5 - Valores de Temperatura, pH, Turbidez, Demanda Química de Oxigênio (DQO), de Fosfato Total $\left(\mathrm{PO}_{4}^{-}\right)$e de SST em função da velocidade de flotação para dosagem de cloreto férrico (DCF) de 15 e de $30 \mathrm{mg} / \mathrm{L}$ associada à dosagem de polímeros (DP) de 0,4 e 1,0 $\mathrm{mg} / \mathrm{L}$, quando da partida biológica do reator RALEx.

TABELA 5.6 - Valores de turbidez média e de carga de DQO, de fósforo e de SST para as amostras de esgoto bruto, de efluente do RALEx e de efluente do flotador, entre 08:00 e 20:00, e respectivas remoções observadas no reator RALEx, no flotador e no sistema conjugado, de acordo com a etapa 5.6.1.1.1. 
TABELA 5.7 - Valores de turbidez média e de carga de DQO, de fósforo e de SST 199 e de concentração de ferro para as amostras de esgoto bruto, de efluente do RALEx e de efluente do flotador, entre 08:00 e 20:00, e respectivas remoções observadas no reator RALEx, no flotador e no sistema conjugado, de acordo com a etapa 5.6.1.1.2.

TABELA 5.8 - Concentração de diversos parâmetros das amostras de esgoto bruto, de efluente do RALEx e de efluente do flotador, operando com dosagem variável de cloreto férrico, coletadas ao longo do dia de ensaio $(25 / 09 / 2001)$.

TABELA 5.9 - Valores de turbidez média e de carga de DQO, de fósforo e de SST para as amostras de esgoto bruto, de efluente do RALEx e de efluente do flotador, entre 08:00 e 20:00, e respectivas remoções observadas no reator RALEx, no flotador e no sistema conjugado, de acordo com a etapa 5.6.1.2.

TABELA 5.10 - Valores de turbidez média e de carga de DQO, de fósforo e de SST para as amostras de esgoto bruto, de efluente do RALEx e de efluente do flotador, entre 08:00 e 20:00, e respectivas remoções observadas no reator RALEx, no flotador e no sistema conjugado, de acordo com a etapa 5.6.2.1.1.

TABELA 5.11 - Valores de turbidez média e de carga de DQO, de fósforo e de SST 248 para as amostras de esgoto bruto, de efluente do RALEx e de efluente do flotador, entre 08:00 e 20:00, e respectivas remoções observadas no reator RALEx, no flotador e no sistema conjugado, de acordo com a etapas 5.6.2.1.2 e 5.6.3.1.1.

TABELA 5.12 - Valores de turbidez média e de carga de DQO, de fósforo e de SST para as amostras de esgoto bruto, de efluente do RALEx e de efluente do flotador, entre 08:00 e 20:00, e respectivas remoções observadas no reator RALEx, no flotador e no sistema conjugado, para $\mathrm{DCF}=50 \mathrm{mg} / \mathrm{L}$ e TAS $=250 \mathrm{~m}^{3} / \mathrm{m}^{2} / \mathrm{d}$, de acordo com as etapas 5.6.1.2 e 5.6.3.1.1.

TABELA 5.13 - Dados de produção estimada de lodo para diferentes ensaios 271 durante utilização de instalação piloto de flotação. 


\section{LISTA DE ABREVIATURAS, SIGLAS E SÍMBOLOS}

\begin{tabular}{|c|c|}
\hline A & Área em planta da câmara de flotação $\left(\mathrm{m}^{2}\right)$ \\
\hline $\mathrm{DBO}$ & Demanda bioquímica de oxigênio $(\mathrm{mg} / \mathrm{L})$ \\
\hline DCF & Dosagem de cloreto férrico $(\mathrm{mg} / \mathrm{L})$ \\
\hline $\mathrm{DN}$ & Diâmetro nominal (m) \\
\hline DPC & Dosagem de polímero catiônico (mg/L) \\
\hline DQO & Demanda química de oxigênio (mg/L) \\
\hline $\mathrm{DQO}_{\text {filtr }}$ & $\begin{array}{l}\text { Demanda química de oxigênio da amostra filtrada em membrana de } 1,2 \mu \mathrm{m} \\
(\mathrm{mg} / \mathrm{L})\end{array}$ \\
\hline DQO bruta & Demanda química de oxigênio da amostra não filtrada (mg/L) \\
\hline ETA & Estação de Tratamento de Água \\
\hline ETE & Estação de Tratamento de Esgotos \\
\hline ETEB-Sul & Estação de Tratamento de Esgotos de Brasília/DF - Sul \\
\hline $\begin{array}{l}\text { ETE- } \\
\text { Piracicamirim }\end{array}$ & Estação de Tratamento de Esgotos Piracicamirim, localizada em Piracicaba/SP \\
\hline$\phi$ & Diâmetro (m) \\
\hline FAD & Flotação por ar dissolvido \\
\hline GAC & Carvão ativado granular \\
\hline Gf & Gradiente médio de velocidade de floculação $\left(\mathrm{s}^{-1}\right)$ \\
\hline $\mathrm{Gmr}$ & Gradiente médio de velocidade de mistura rápida $\left(\mathrm{s}^{-1}\right)$ \\
\hline NA & Nível de água \\
\hline $\mathrm{N}_{\mathrm{B}}$ & $\begin{array}{l}\text { Concentração numérica das bolhas, definida como a razão entre a concentração } \\
\text { volumétrica de bolhas e o volume médio das bolhas }\end{array}$ \\
\hline NTK & Nitrogênio total Kjeldahl (mg/L) \\
\hline OD & Oxigênio dissolvido (mg/L) \\
\hline $\mathrm{PC}$ & Polímero catiônico \\
\hline $\mathrm{pH}$ & Potencial hidrogeniônico \\
\hline $\mathrm{pH}_{\text {coag }}$ & Potencial hidrogeniônico na coagulação \\
\hline Psat & Pressão no interior da câmara de saturação $(\mathrm{kPa})$ \\
\hline Q & Vazão floculada afluente à câmara de flotação $\left(\mathrm{m}^{3} / \mathrm{h}\right)$ \\
\hline$Q_{\text {afl }}$ & Vazão afluente à câmara de floculação $\left(\mathrm{m}^{3} / \mathrm{h}\right)$ \\
\hline$\theta_{\chi}$ & Tempo de residência celular, ou idade do lodo (d) \\
\hline
\end{tabular}


Q $\quad$ Vaagão referente à dosagem de coagulante $\left(\mathrm{m}^{3} / \mathrm{h}\right)$

Qdescarte Vazão de líquido floculado descartado imediatamente antes de sua entrada na câmara de flotação $\left(\mathrm{m}^{3} / \mathrm{h}\right)$

$\mathrm{Q}_{\mathrm{R}} \quad$ Vazão de recirculação $\left(\mathrm{m}^{3} / \mathrm{h}\right)$

QRALEX Vazão efluente do reator RALEx e afluente à instalação piloto $\left(\mathrm{m}^{3} / \mathrm{h}\right)$

$\mathrm{R} \quad$ Fração de recirculação pressurizada (\%)

RA Registro de agulha

RALEx Reator anaeróbio de leito expandido

RSB Reator seqüencial em batelada

RSBAn Reator sequiencial em batelada anaeróbio

S* Quantidade de ar fornecida à flotação $\left(\mathrm{g}\right.$ de $\operatorname{ar}$ por $\mathrm{m}^{3}$ de efluente)

SHS-EESC- Departamento de Hidráulica e Saneamento da Escola de Engenharia de São

USP Carlos da Universidade de São Paulo

SST Sólidos suspensos totais $(\mathrm{mg} / \mathrm{L})$

ST Sólidos totais $(\mathrm{mg} / \mathrm{L})$

TAS Taxa de aplicação superficial $\left(\mathrm{m}^{3} / \mathrm{m}^{2} / \mathrm{d}\right)$

TAScs Taxa de aplicação superficial da câmara de saturação $\left(\mathrm{m}^{3} / \mathrm{m}^{2} / \mathrm{d}\right)$

TDH Tempo de detenção hidráulica (h)

Tf Tempo de floculação (min)

Tfpol Tempo de floculação do polímero (min)

Tmr Tempo de mistura rápida (s)

UASB Reator anaeróbio de manta de lodo

V Volume total da unidade de floculação $\left(\mathrm{m}^{3}\right)$

Vf i Velocidade de flotação i $(\mathrm{cm} / \mathrm{min})$

Vflot Velocidade de flotação $(\mathrm{cm} / \mathrm{min})$

VR Válvula de retenção

$\phi_{\mathrm{B}} \quad$ Concentração volumétrica das bolhas, definida como a razão entre a concentração em massa do ar liberado e a densidade do ar saturado 


\section{RESUMO}

PENETRA, R.G. (2003). Flotação aplicada ao pós-tratamento do efluente de reator anaeróbio de leito expandido tratando esgoto sanitário. São Carlos, 2003. 288p. Tese (Doutorado) - Escola de Engenharia de São Carlos, Universidade de São Paulo.

Este trabalho apresenta e discute os resultados de um estudo amplo e aprofundado sobre os principais parâmetros operacionais da flotação por ar dissolvido, utilizada no póstratamento de efluentes de um reator anaeróbio de leito expandido (RALEx), tratando 10 $\mathrm{m}^{3} /$ hora de esgoto sanitário. Foram realizados preliminarmente ensaios utilizando o flotateste, unidade de flotação em escala de laboratório, para identificar as melhores dosagens de coagulante (cloreto férrico), o polímero mais adequado, dentre os 26 testados, e sua respectiva dosagem, o pH de coagulação adequado, o tempo (Tf) e o gradiente de velocidade (Gf) de floculação mais apropriados e a quantidade de ar $\left(\mathrm{S}^{*}\right)$ requerida. Para obtenção das condições operacionais adequadas para a unidade piloto de flotação, os valores de Tf e de Gf foram variados de zero a 24 minutos e de 40 a $100 \mathrm{~s}^{-1}$, respectivamente. As concentrações de cloreto férrico e de polímero sintético variaram de 15 a $92 \mathrm{mg} / \mathrm{L}$ e de 0,25 a $7,0 \mathrm{mg} / \mathrm{L}$, respectivamente. $\mathrm{S}^{*}$ variou de 2.85 a 28.5 gramas de ar por metro cúbico de efluente e a taxa de aplicação superficial na unidade de flotação abrangeu de 180 a 250 $\mathrm{m}^{3} / \mathrm{m}^{2} / \mathrm{d}^{1}$. O desempenho da flotação durante a partida do reator anaeróbio também foi investigado. O uso de $50 \mathrm{mg} / \mathrm{L}$ de cloreto férrico, de Tf igual a 20 min e Gf de $80 \mathrm{~s}^{-1}$, de $\mathrm{S}^{*}$ de $19,7 \mathrm{~g}$ de ar por $\mathrm{m}^{3}$ de efluente e taxa de $180 \mathrm{~m}^{3} / \mathrm{m}^{2} / \mathrm{d}$ produziu excelentes resultados nos ensaios com a instalação piloto de flotação, com elevadas remoções de carga de DQO $(80,6 \%)$, de fósforo total $(90,1 \%)$ e de sólidos suspensos totais $(92,1 \%)$ e com turbidez entre 1,6 e 15,4 uT e residuais de ferro de $0,5 \mathrm{mg} / \mathrm{L}$, com remoção estimada, na forma de lodo, de 77 gramas de SST por $\mathrm{m}^{3}$ de efluente tratado. Nestas mesmas condições, no sistema RALEx+FAD, foram observadas remoções globais de $91,6 \%$ de carga de DQO, de 90,1\% de carga de fósforo e de 96,6\% de carga de SST.

O emprego da flotação por ar dissolvido (FAD) mostrou-se alternativa bastante atraente para o pós-tratamento de efluentes de reatores anaeróbios. Se a coagulação estiver bem ajustada, o sistema composto de reator anaeróbio seguido de unidade de flotação consegue alcançar excelente remoção de matéria orgânica, redução significativa da concentração de fósforo e de sólidos suspensos, além de precipitação dos sulfetos dissolvidos, gerados no reator anaeróbio. Bons resultados foram alcançados mesmo quando o reator RALEx produziu efluentes de baixa qualidade durante seu período de partida. Nesse período, o sistema de flotação atuou como barreira eficaz, evitando a emissão de efluente de baixa qualidade do sistema.

Palavras-chave: Flotação por ar dissolvido, pós-tratamento de reatores anaeróbios, remoção de fósforo por flotação. 


\section{ABSTRACT}

PENETRA, R.G. (2003). Flotation applied to the post-treatment of effluents from expanded bed anaerobic reactor treating domestic sewage. São Carlos, 2003. 288p. Tese (Doutorado) - Escola de Engenharia de São Carlos, Universidade de São Paulo.

This research work presents ad discusses the results of a wide and deep study on the main operational parameters of DAF while used for the post-treatment of effluents from a pilot expanded-bed anaerobic (RALEx) reactor. The system received $10 \mathrm{~m}^{3}$ per hour of domestic sewage. Bench-scale assays in flota-test units were first carried out to achieve the best dosage of coagulants (ferric chloride), the best polymer and respective dosages, the adjusted $\mathrm{pH}$ for coagulation, the flocculation time (Tf), the proper velocity gradient (Gf) and the amont of air $\left(\mathrm{S}^{*}\right)$ required. In order to obtain the proper operational conditions in the pilot DAF plant, Tf and Gf were made to vary from zero to 24 minutes and from 40 to $100 \mathrm{~s}^{-}$ ${ }^{1}$, respectively. The chemicals ferric chloride and synthetic polymer concentrations ranged from 15 to $92 \mathrm{mg} . \mathrm{l}^{-1}$ and 0.25 to $7.0 \mathrm{mg} . \mathrm{l}^{-1}$, repectively. $\mathrm{S}^{*}$ varied from 2.85 to 28.5 grams of air per cubic meter of wastewater and the applied flotation rates ranged from 180 to 250 $\mathrm{m}^{3} \cdot \mathrm{m}^{-2} \cdot \mathrm{d}^{-1}$. DAF performance was also investigated during RALEx start-up period.

At the DAF operational conditions of $50 \mathrm{mgFeCl}_{3} \cdot \mathrm{l}^{-1}$, Tf of $15 \mathrm{~min}$, Gf of $80 \mathrm{~s}^{-1}, \mathrm{~S}^{*}$ of $19.7 \mathrm{~g}$ of air per $\mathrm{m}^{3}$ of wastewater and the applied loading rate of $180 \mathrm{~m}^{3} \cdot \mathrm{m}^{-2} \cdot \mathrm{d}^{-1}$, the removal efficiencies attained $80.6 \%$ for COD, $90.1 \%$ for phosphorus, $92.1 \%$ for suspended solids, producing effluents with turbidity ranged from 1.6 to 15.4 NTU, residual Fe of 0.5 mg. $1^{-1}$, removing 77 grams of SST per cubic meter of wastewater. At the same conditions, the system RALEx-DAF presented global efficiencies of $91.6 \%$ for COD, $90.1 \%$ for phosphorus and $96.6 \%$ for suspended solids.

The utilization of dissolved-air flotation (DAF) constitutes an attractive alternative for the post-treatment of anaerobic reactor's effluents. If coagulation is well adjusted, such system composed of anaerobic reactor followed by DAF can achieve excellent organic matter removal, expressive solids and phosphorus reduction and precipitation of dissolved sulfide generated in the anaerobic unit.

Good results were also obtained even when RALEx produced low quality effluents during start-up period. In such period, the DAF unit functioned as an efficient barrier for avoiding the emission of low quality system effluent.

Keywords: Dissolved-air flotation, post-treatment for anaerobic reactors, phosphorus removal by flotation. 


\section{INTRODUÇão}

Historicamente, o Brasil não tem tradição no emprego difundido de sistemas de tratamento de esgoto. A reduzida parcela da população atendida por tratamento de esgoto atesta a veracidade da afirmação.

O Brasil recentemente começa a preocupar-se com a preservação da água. A abundância desse precioso bem foi provavelmente responsável pela demora da sociedade brasileira em perceber os limites do desperdício de água e o imperativo de sua preservação (MUSETTI, 2001).

Países europeus e norte-americanos têm mais tradição no tratamento de esgoto, em larga escala, em consequiência de aumento regional da escassez de água, ora decorrente da forte poluição industrial, ora das características hídricas locais. A partir da necessidade de tratamento em larga escala, tratamentos mais eficientes e compactos foram sendo desenvolvidos por estes países. Em contrapartida, esses sistemas apresentavam maiores custos de implantação e de operação, a exemplo daqueles baseados nos processos aeróbios e físico-químicos.

Quando da construção das primeiras estações de tratamento de esgoto sanitário de grande porte no Brasil, por influência técnica estrangeira e carência de exemplos locais bem sucedidos, foram construídas estações de tratamento baseadas nos processos biológicos aeróbios. Felizmente, o Brasil não adotou em larga escala esses sistemas, certamente em decorrência da afirmação anterior de MUSETTI (2001) e dos altos custos envolvidos.

Com a evidência de que a água é um bem finito e está sendo muito mal preservada, atualmente há relativo empenho para implantação de novas estações de tratamento de esgotos, exigidas pela legislação pertinente. Felizmente, a pesquisa científica na área avançou independentemente da ampliação efetiva da população atendida por tratamento de esgotos. Tendo em vista as características geográficas, climáticas, sociais, técnicas, econômicas e ambientais nacionais, diversos pesquisadores empreenderam busca de alternativas que melhor atendessem às necessidades locais. Os reatores anaeróbios, muitas vezes não plenamente utilizados em outros países devido às condições climáticas impróprias, atendiam satisfatoriamente às necessidades brasileiras. Desta forma, o conceito 
de que o emprego de reatores anaeróbios seria uma alternativa atraente e extremamente vantajosa para as condições brasileiras foi sendo efetivamente incorporado ao pensar técnico nacional.

Os reatores anaeróbios proporcionam redução nos custos de disposição final de biossólidos gerados no tratamento, redução dos custos para implantação e operação, conservação de energia, garantindo benefícios ecológicos e econômicos significativos, minimização das necessidades de atenção operacional, biodegradação de compostos não biodegradáveis aerobiamente (SPEECE, 1996). Destaca-se também a satisfatória remoção de matéria orgânica biodegradável, o rápido reinício após períodos de paralisação e o bom desaguamento do lodo (VON SPERLING, 1995). Entretanto, a experiência tem mostrado que os reatores anaeróbios produzem efluentes que, na maioria das vezes, não atendem à legislação atual, quanto à sua qualidade. Sabe-se que há dificuldades para satisfazer padrões de lançamento restritivos, que as remoções de nitrogênio e de fósforo são insatisfatórias, que há possibilidade de geração de maus odores, que a partida do processo é geralmente lenta, que o processo é relativamente sensível a variações de cargas, requerendo a adoção de unidades de pós-tratamento.

Para tanto, há diferentes possibilidades de combinação de sistemas anaeróbios com outros sistemas, que atuem como pós-tratamento, produzindo efluentes com excelente qualidade, comparável àquela observada em tratamentos convencionais, além de proporcionar vantagens ambientais e econômicas adicionais.

O emprego de sistemas físico-químicos de tratamento constitui-se em alternativa potencialmente adequada ao pós-tratamento de efluentes de reatores anaeróbios. Muitos pesquisadores ainda têm uma noção pré-concebida e preconceituosa de que os sistemas de tratamento físico-químico necessariamente produzem grandes volumes de lodo e, portanto, devem ser evitados a todo custo no tratamento de esgotos sanitários. Esse conceito errôneo é decorrente da análise de dados de produção de lodo de sistemas físico-químicos utilizados no tratamento primário e/ou secundário de esgotos, quando o sistema é responsável por tratar até $100 \%$ da carga orgânica presente no esgoto sanitário bruto. O pré-tratamento do esgoto em reatores anaeróbios reduziria a carga afluente ao pós-tratamento físico-químico para cerca de $25 \%$ a $35 \%$ da original, proporcionando redução no volume final de lodo e a possibilidade de sua estabilização dentro do próprio reator anaeróbio.

Neste estudo, propõe-se o uso de unidade de flotação por ar dissolvido, à qual foram incorporadas as etapas de coagulação e floculação, como unidade de pós-tratamento dos efluentes de reatores anaeróbios. A associação de um sistema anaeróbio com um sistema 
físico-químico de tratamento traz diversas vantagens, sobretudo ao considerar-se que certas características inerentes ao tratamento físico-químico podem suprir certas deficiências do processo anaeróbio.

O sistema físico-químico pode facilmente remover fósforo mediante a adição de produtos químicos. O sulfeto presente em efluentes de reatores anaeróbios é removido pela reação com cloreto férrico, eliminando o mau odor do efluente final. Durante o processo de partida biológica, as dosagens de produtos químicos podem ser aumentadas para compensar a baixa eficiência do reator anaeróbio, tendo como consequiência o aumento momentâneo da retenção de lodo. Quando o reator sofrer perda de sua biomassa, devido a variações de cargas ou à toxicidade do esgoto, flotadores podem impedir o lançamento dos biossólidos nos cursos d’água, sem prejuízo de seu funcionamento, permitindo o retorno do material biológico aos reatores anaeróbios. A coagulação/floculação/flotação, atuando no póstratamento, permite, ainda, a produção de efluente como baixíssima presença de sólidos suspensos, propiciando a utilização de sistemas de desinfecção mais econômicos, sobretudo a radiação ultravioleta. 


\section{OBJETIVOS}

O objetivo geral do presente trabalho é:

- Investigar o desempenho de unidade de flotação por ar dissolvido em escala piloto como pós-tratamento físico-químico por flotação de efluentes de reatores anaeróbios de leito expandido, visando remoção complementar de matéria orgânica e de fósforo, com a utilização de cloreto férrico e de polímero sintético, aplicados isoladamente ou de forma associada.

Para consecução deste objetivo principal, foram realizadas diferentes etapas de trabalho, compreendendo os seguintes objetivos específicos:

A partir de ensaios com utilização de unidade de flotação por ar dissolvido em escala de laboratório (Flotateste), identificar a influência:

- Da dosagem de cloreto férrico e de polímero sintético, isolados ou associados, dos parâmetros de floculação (tempo e gradiente médio de velocidade de floculação) e da quantidade de ar fornecida no desempenho da flotação;

A partir de ensaios com emprego de unidade piloto de flotação por ar dissolvido, identificar a influência na qualidade do efluente final, em função das variações horárias das características do efluente do reator anaeróbio, de:

- Dosagem de cloreto férrico e de polímero sintético, isolados ou associados;

- Tempo e do gradiente médio de velocidade de floculação;

- Quantidade de ar fornecida ao processo e

- Taxa de aplicação superficial. 


\section{REVISÃO DA LITERATURA}

Nas páginas seguintes, são apresentados os aspectos atuais da flotação por ar dissolvido, alguns exemplos de sua utilização no tratamento de diversos efluentes industriais e de águas residuárias em geral e em particular no tratamento de esgoto sanitário. Também são descritas as diferentes unidades de um sistema de flotação por ar dissolvido e são mencionados alguns aspectos sobre a influência da coagulação e da floculação nesta técnica. São mencionadas alternativas para o pós-tratamento de efluentes de reatores anaeróbios, para contextualizar a flotação como uma das alternativas. A remoção e a recuperação de fósforo do esgoto sanitário são abordadas, devido à sua importância ambiental. Também é apresentada uma breve explanação das características dos reatores anaeróbios de leito expandido (RALEx).

\subsection{A flotação por ar dissolvido (FAD)}

A aplicação industrial de bolhas para flotar pequenas partículas presentes na água teve origem no século passado, nas indústrias de processamento de minérios. O uso da flotação em outras atividades industriais era muito pequeno até por volta de 1960, quando a flotação por ar dissolvido (FAD), que já havia sido utilizada com êxito em indústrias de papel, foi empregada no tratamento de água e de águas residuárias. A partir de então, a FAD apresentou um crescente desenvolvimento como processo e em suas aplicações (IVES, 1984).

LUNDGREN (1970) afirma que os aperfeiçoamentos dos projetos de unidades de flotação e o desenvolvimento de auxiliares de coagulação altamente eficientes ampliaram o campo de aplicação do processo de flotação.

Segundo REALI (1991), mais recentemente, a FAD tem sido empregada com bastante sucesso na clarificação de águas de abastecimento, em substituição aos decantadores, pois, inversamente à sedimentação, é um processo que promove a ascensão das partículas no interior do reator, mediante aderência das microbolhas de gás às partículas previamente floculadas, o que as torna menos densas que a água (flutuáveis), 
proporcionando sua rápida remoção na parte superior da unidade de flotação. Portanto, a FAD apresenta alguns aspectos positivos:

- possibilidade de arraste de parcela de substâncias voláteis porventura presentes na água;

- possibilidade de oxidação de íons metálicos dissolvidos na água, como o ferro, por exemplo;

- produção de lodo com elevado teor de sólidos na superfície do flotador, podendo atingir até $12 \%$, dependendo do tipo de dispositivo de coleta utilizado e das características da dispersão;

- processo de alta taxa, resultando em unidades compactas e versáteis, que possibilitam controle operacional eficiente através do monitoramento da quantidade de ar fornecida ao processo;

- dosagens menores de coagulante em relação às observadas para sedimentação, para obtenção de eficiências de remoção semelhantes.

Em vista das vantagens mencionadas, a FAD tem sido objeto de estudos de diversos pesquisadores da área de saneamento, visando determinar e otimizar os parâmetros influentes no processo e descobrir novas aplicações nesta área. O Departamento de Hidráulica e Saneamento da Escola de Engenharia de São Carlos da Universidade de São Paulo (SHS-EESC-USP) estabeleceu uma linha de pesquisa sobre FAD desde 1982, através da qual vem estudando e aperfeiçoando o processo e desenvolvendo novas aplicações e novos sistemas de tratamento nos quais a flotação efetivamente apresente eficiência comprovada.

\subsubsection{Aspectos gerais da flotação por ar dissolvido (FAD)}

SHAWWA \& SMITH (1998) afirmam que a flotação por ar dissolvido é uma tecnologia aprovada no tratamento de água de abastecimento em muitos países europeus, enquanto ainda é considerada como uma tecnologia emergente na América do Norte. A flotação pode ser considerada como uma combinação de diversos processos físicos e químicos. O processo pode ser dividido em dois subprocessos: o pré-tratamento, que inclui coagulação e floculação e a flotação propriamente dita. No pré-tratamento, que é considerado vital para a eficiência global da FAD, as partículas são desestabilizadas e flocos pequenos e fortes são produzidos para que colisões efetivas e agregação entre bolhas e flocos possam ocorrer na unidade de flotação. A flotação pode ser dividida em três fases interativas: geração de bolhas e concentração de bolhas de ar, interação bolha-partícula, que inclui contato e agregação, e ascensão e remoção dos aglomerados bolhas-partículas. As 
bolhas de ar, que tipicamente apresentam diâmetro entre 10 e $120 \mu \mathrm{m}$, são geradas pelo desprendimento do ar dissolvido em parcela recirculada e pressurizada do líquido tratado. A introdução de ar dissolvido no líquido ocorre em tanque pressurizado, chamado câmara de saturação. Valores usuais de pressão de saturação estão entre 350 e $585 \mathrm{kPa}$. A vazão a ser saturada é chamada de vazão de recirculação. A redução da pressão da vazão de recirculação, por causa de sua liberação em pressão próxima à atmosférica através de válvulas de agulha ou de bocais especialmente projetados dispostos no tanque de flotação, permite que o ar dissolvido se desprenda da solução. A quantidade de bolhas de ar produzidas pode ser expressa em termos de: (1) a fração de recirculação, R, definida como a razão entre a vazão de recirculação e a vazão afluente ao sistema, (2) a concentração em massa do ar liberado $\left(\mathrm{S}^{*}\right),(3)$ a concentração volumétrica das bolhas $\left(\phi_{\mathrm{B}}\right)$, definida como a razão entre a concentração em massa do ar liberado e a densidade do ar saturado, e (4) a concentração numérica das bolhas $\left(\mathrm{N}_{\mathrm{B}}\right)$, definida como a razão entre a concentração volumétrica de bolhas e o volume médio das bolhas.

Resumidamente, um sistema de FAD utilizado como tratamento físico-químico de água ou de esgoto sanitário é composto por uma unidade de coagulação e outra de floculação, seguida de uma câmara de flotação. Uma fração do líquido tratado é recirculada, pressurizada e saturada com ar em uma câmara de saturação. O líquido recirculado é introduzido na câmara de flotação, através de uma série de dispositivos injetores, e misturado à vazão afluente floculada. Nos dispositivos injetores, a pressão é reduzida à pressão atmosférica, liberando o ar na forma de pequenas bolhas. As bolhas de ar fixam-se aos flocos e ascendem à superfície da câmara de flotação, formando o lodo flotado, retirado através de raspadores mecanizados ou pela operação de inundação (ZABEL, 1985). Portanto, o tratamento químico efetivo, a floculação, a quantidade de ar fornecido, os dispositivos injetores e a remoção do lodo flotado afetam a eficiência global da FAD.

\subsubsection{Unidades de um sistema de flotação por ar dissolvido}

Basicamente, uma unidade de flotação é composta por uma unidade de geração de microbolhas, onde o ar é dissolvido no líquido mediante elevação da pressão, e a câmara de flotação, onde o líquido floculado mistura-se ao líquido pressurizado, proporcionando a agregação entre as microbolhas de ar e as partículas a serem removidas. A seguir, ambas as unidades são explicadas mais detalhadamente. 


\section{Unidade de geração de microbolhas}

"Uma unidade de geração de microbolhas convencional é composta basicamente de um conjunto moto-bomba para pressurização da água, seguido de uma câmara de saturação onde o gás (normalmente o ar) é dissolvido na massa líquida sob pressão, e finalmente de um dispositivo de despressurização da água que sai da câmara de saturação" (REALI \& CAMPOS, 1992).

REES et al. (1980) desenvolveram estudo experimental com o objetivo de otimização de projetos de câmaras de saturação. $\mathrm{O}$ autor concluiu que a distribuição uniforme da água recirculada sobre o recheio é essencial para obtenção de sua melhor eficiência e que a eficiência de saturação de uma câmara sem recheio foi consideravelmente menor (40\%) do que aquela alcançada pela câmara com recheio

REALI \& CAMPOS (1992) estudaram o desempenho de uma câmara de saturação contendo recheio composto por segmentos de tubo de PVC (DN 30), em busca de uma alternativa mais econômica, tendo em vista que os recheios patenteados existentes no mercado têm custo significativamente maior. Ao término do trabalho, o autor conclui que a câmara contendo o recheio em estudo apresentou bom desempenho em taxas de aplicação superficial entre 290 e $1060 \mathrm{~m}^{3} / \mathrm{m}^{2} / \mathrm{d}$ e em pressão entre 200 a $490 \mathrm{kPa}$, alcançando capacidade de saturação de 96\% em comparação àquela proposta por ZABEL (1984), que alerta para uma possível desvantagem do uso de recheio: o risco de entupimento devido ao crescimento biológico. Entretanto, o próprio autor relata que ainda não foi observada nenhuma situação desse tipo.

Outro fator a ser considerado no sistema de geração de microbolhas é o dispositivo injetor, responsável pela despressurização do líquido oriundo da câmara de saturação. Sob condições altamente turbulentas, provocadas pela passagem do líquido saturado pelos dispositivos injetores, a pressão é repentinamente reduzida e ocorre a liberação do ar na forma de microbolhas. Os dispositivos devem estar localizados tão próximos quanto possível do ponto onde ocorre a mistura do líquido recirculado com a vazão afluente floculada, de forma a minimizar a perda de microbolhas de ar resultantes de sua aglutinação (ZABEL, 1985). A aglutinação das microbolhas é prejudicial à FAD, tendo em vista que as bolhas resultantes possuem diâmetro, empuxo e velocidade ascensional maiores, o que acarreta diminuição do número total de bolhas e aumento da turbulência do líquido no interior da câmara de flotação. $\mathrm{O}$ aumento da turbulência pode vir a provocar quebra dos flocos.

As características dos dispositivos injetores (diâmetro da entrada e da saída e configuração interna) também devem ser consideradas no projeto, tendo em vista que altas 
velocidades de entrada do líquido recirculado na câmara de flotação podem acarretar quebra de flocos e piora na qualidade final do efluente. Bocais especiais patenteados, registros de agulha e até simples registros de gaveta podem ser utilizados como dispositivos injetores (ZABEL, 1985).

A quantidade de ar fornecida à câmara de flotação pode ser variada mediante alteração da fração de recirculação, da pressão na câmara de saturação ou por ambas. Experimentos variando a fração de recirculação e a pressão demonstraram que a qualidade da água tratada era dependente somente da quantidade de ar fornecida ao sistema, independente dos valores individuais de pressão e de recirculação (ZABEL, 1984). Entretanto, em estudo realizado por REALI (1994), o autor recomenda que, antes de serem adotados valores elevados de fração de recirculação, seja maximizada a pressão de operação na câmara de saturação. Tal observação é importante para unidades de clarificação de alguns tipos de águas residuárias, onde podem ser requeridos valores elevados de fração de recirculação (acima de 50\%, em certos casos), devido à necessidade de fornecimento de grande quantidade de ar ao processo. A observação demonstra também a importância da adoção de câmaras de saturação mais eficientes. Além disso, pressões elevadas produzem bolhas menores. Entretanto, acima de $500 \mathrm{kPa}$, o aumento na pressão de saturação tem pequeno efeito sobre o diâmetro das bolhas. $\mathrm{Na}$ prática, para garantir pequenas bolhas (apropriadas à FAD), é recomendável que a câmara de saturação opere com pressão na faixa de 350 a $600 \mathrm{kPa}$.

Nos estudos de flotação, é importante que seja mensurada, o mais precisamente possível, a quantidade de ar liberada pela despressurização do líquido que sai da câmara de saturação. Diversos pesquisadores (LEININGER \& WALL, 1974; BRATBY \& MARAIS, 1975; PACKHAM \& RICHARDS, 1975; ROBERTS et al., 1978; REES et al., 1980; SHANNON \& BUISSON, 1989; CONWAY et al., 1981; HENRY \& GEHR, 1981; LOVETT et al., 1984; VOSLOO et al., 1986; CASEY \& NAOUM, 1986) têm proposto diferentes métodos para quantificação desse parâmetro. REALI \& CAMPOS (1992) apresentaram método original, desenvolvido para obtenção da quantidade de ar liberada nos testes com a câmara de saturação e, posteriormente, adotado nos demais estudos, envolvendo a flotação por ar dissolvido na Escola de Engenharia de São Carlos - USP. Mais recentemente, STEINBACH \& HAARHOFF (1998) também propuseram um método simplificado para medição da eficiência de sistemas de saturação de ar usados na flotação por ar dissolvido. É baseado em revisão de métodos sugeridos por outros pesquisadores da área, mas diversas melhorias nos métodos existentes foram feitas. Leva-se em consideração 
que a composição do ar saturado é diferente daquela do ar atmosférico e que a precipitação das microbolhas é incompleta nas unidades de medida após a queda de pressão.

\section{Câmara de flotação}

Na flotação convencional, as câmaras de flotação são divididas em duas zonas: zona de contato e zona de clarificação. A zona de contato, também denominada zona de reação ou de mistura, é o local onde ocorre a mistura entre a fração de recirculação do líquido saturado e vazão floculada afluente à câmara. Desta forma, o tempo de detenção hidráulica da mistura nesta zona deverá ser suficiente para promover o contato entre as microbolhas de ar e os flocos, garantido a máxima eficiência possível. Segundo EDZWALD et al. (1992), a função da zona de contato é proporcionar contato e aderência dos flocos às microbolhas, enquanto a função da zona de clarificação é a de promover condições adequadas de repouso (baixas velocidades descendentes) para que o conjunto bolhas-floco alcance à superfície.

SHAWWA \& SMITH (1998) relatam algumas condições hidrodinâmicas apropriadas para a zona de contato: (1) agitação suficiente deve ser provida para a mistura da vazão floculada afluente e o líquido saturado de ar, mas não muito alto para quebrar os aglomerados bolhas-partículas, (2) algum grau de agitação para promover oportunidades de colisões suficientes para a agregação entre bolhas e partículas e (3) tempo de contato suficiente deveria ser provido para aumentar as oportunidades de colisão entre bolhas e partículas. Tradicionalmente, a velocidade superficial do líquido $\left(\mathrm{U}_{\mathrm{L}}\right)$, definida como a razão entre a vazão total afluente e a área da seção transversal da zona de contato, é adotada para medida alternativa do grau de agitação na zona de contato. Para tanques retangulares de flotação, recomendam-se velocidades médias do líquido variando entre $200 \mathrm{~m} / \mathrm{h}$, perto do dispositivo injetor, e $70 \mathrm{~m} / \mathrm{h}$ no topo do defletor inclinado. Na zona de contato, também é possível basear-se no seu tempo de detenção hidráulica, que geralmente varia entre 1 e 4 minutos, para quantificar a agitação em seu interior.

Novas configurações de câmaras de flotação vêm sendo pesquisadas constantemente, em busca de redução da área de construção, de melhoria da qualidade do efluente e de simplificação de sua operação. Neste sentido, KIURI (2001) fornece uma breve descrição do desenvolvimento da flotação por ar dissolvido como sistema para a remoção dos sólidos no tratamento da água e de águas residuárias durante os últimos 80 anos. Segundo o autor, os primeiros sistemas de flotação usados na indústria de água são da década de 20 e alguns ainda encontram-se em funcionamento. Os tanques de flotação nesses sistemas eram muito rasos, estreitos e compridos. A taxa de aplicação superficial variava entre 2 e $3 \mathrm{~m} / \mathrm{h}$, e sempre abaixo de $5 \mathrm{~m} / \mathrm{h}$. A camada de microbolhas era muito fina abaixo 
da superfície da água, entre a camada de lodo flotado e a zona de clarificação. Além disso, o fluxo de água na zona de clarificação era quase horizontal, desde a saída da zona de contato, na extremidade anterior, até o ponto de coleta do efluente clarificado, na extremidade posterior. A segunda geração do FAD foi introduzida na década de 60 e a maioria destas unidades ainda estão em uso atualmente. Seus tanques de flotação são quase quadrados, com seu comprimento sendo um pouco maior que sua largura, e preferencialmente mais profundos. Utiliza-se taxa de aplicação superficial normalmente entre 5 e $7 \mathrm{~m} / \mathrm{h}$ e sempre menor que $10 \mathrm{~m} / \mathrm{h}$. O sentido predominante do fluxo da água na zona de clarificação é inclinado, com ângulos entre 30 e $45^{\circ}$ abaixo do horizontal. Há uma camada mais espessa de microbolhas no começo do tanque de flotação e abaixo da camada de lodo flotado. Esta camada torna-se mais fina à medida que avança até a extremidade posterior do tanque. Há também tanques circulares que são baseados nos mesmos princípios hidráulicos que os retangulares apresentados acima. Uma aplicação especial do FAD, chamada de floto-filtro, foi desenvolvida no final da década de 60. Trata-se da combinação da flotação e da filtração rápida em leito de areia, com ambos posicionados no mesmo tanque. A flotação ocorre na parte superior do tanque e o filtro de areia está posicionado na parte mais inferior deste. $\mathrm{O}$ sentido do fluxo da água é vertical e descendente. A taxa de aplicação superficial nos flotofiltros pode variar entre 10 e $15 \mathrm{~m} / \mathrm{h}$, mas as condições do fluxo ainda são laminares. É a possibilidade de que a perda de carga dos filtros cresça rapidamente que, na prática, limita a taxa de aplicação superficial nos floto-filtros. A terceira geração do FAD foi desenvolvida no final dos anos 90. O princípio operacional é baseado no dos floto-filtros. A camada de areia no fundo do tanque foi substituída por uma placa rígida e fina e com abundância de orifícios circulares em toda a placa. Esta placa, por apresentar resistência de fluxo de água muito menor do que o filtro de areia, controla o fluxo vertical da água na zona de clarificação, distribuindo-a uniformemente sobre toda a área em planta do tanque. O tanque de flotação apresenta forma praticamente quadrada, em planta. Esse tipo da unidade da flotação pode ser operado com taxas de aplicação superficial na faixa de 25 a 40 m/h. Já foi relatada unidade com até $60 \mathrm{~m} / \mathrm{h}$. Vale lembrar que não há risco de obstrução da placa pelos sólidos suspensos, o que poderia limitar a taxa de aplicação superficial. Desta forma, é possível operar a FAD também em condições de fluxo turbulento. A espessura da camada de microbolhas abaixo da superfície da água pode variar entre 1,5 e 2,5 m. Esta camada de microbolhas, continuamente renovada, promove a filtração da água corrente. Após a passagem da água pela camada de microbolhas, o líquido está totalmente claro. Pode-se afirmar que neste caso a remoção de sólidos suspensos ocorre predominantemente pela 
filtração da água pela espessa camada de microbolhas em detrimento da agregação das microbolhas às partículas, até porque o tempo médio de detenção na zona de contato é muito pequeno.

\subsubsection{A flotação por ar dissolvido no tratamento de águas residuárias}

Apesar de o tratamento físico-químico do esgoto sanitário ter sido prática comum no início do século, o tratamento biológico praticamente o substituiu ao longo dos anos. As vantagens do tratamento físico-químico são o menor investimento inicial, o controle operacional facilitado, a reduzida susceptibilidade em relação à carga tóxica afluente e possibilidade de remoção quase completa de nutrientes (nitrogênio e fósforo). Entretanto, suas desvantagens são: problemas relacionados ao lodo altamente putrecível produzido e os altos custos da adição química. Independentemente, parece ter havido um novo interesse pelo tratamento físico-químico, particularmente para medidas emergenciais, para aplicações sazonais e para tratamento preliminar antes de sistemas biológicos. Além disso, já é amplamente empregado no tratamento terciário das águas residuárias (BRATBY, 1982).

Embora o presente estudo tenha ênfase no emprego da flotação por ar dissolvido no pós-tratamento de efluentes de reatores anaeróbios, vale ressaltar que a flotação tem sido utilizada em diversos sistemas de tratamento de efluentes, industriais ou sanitários, ora como tratamento primário ou secundário, ora como terciário. A seguir, são apresentados alguns trabalhos bastante interessantes. Outros exemplos podem ser encontrados em PENETRA (1998).

KROFTA et al. (1996) estudaram um sistema de pós-tratamento de efluente clorado de lagoas de estabilização utilizando flotação e filtração, para irrigação de campos de golfe. Os autores comentam que, apesar de a irrigação com esgoto sanitário ser, por si mesma, uma alternativa eficiente de tratamento de esgoto, freqüentemente tratamento adicional é necessário antes de que essa água possa ser usada para irrigação paisagística. O grau de tratamento é um importante fator no planejamento, no projeto e no gerenciamento de sistemas de irrigação com esgoto sanitário. De acordo com esta premissa, o tratamento avançado de efluentes municipais aparece como uma alternativa lógica, independentemente do processo utilizado. Para fins de clarificação, a flotação por ar dissolvido, com 3 a 5 minutos de tempo de detenção, pode substituir com sucesso a sedimentação com incomparáveis valores de tempo de detenção entre 2 a 3 horas. O sistema estudado pelos referidos autores proporcionou a obtenção de baixos valores de turbidez ( 2 uT) a partir de efluente das lagoas com 82,5 uT, na média, e 85,5 mg SST/L. Para tanto, foi usado 175 $\mathrm{mg} / \mathrm{L}$ de $\mathrm{Al}_{2}\left(\mathrm{SO}_{4}\right)_{3}$ e $1 \mathrm{mg} / \mathrm{L}$ de Magnafloc 1839A (polímero aniônico de média densidade de carga). 
CARDOCH et al. (2000) estudaram o emprego de wetland para o tratamento de efluentes de indústria de processamento de camarão, em comparação com o uso atualmente corrente de flotação por ar dissolvido. Os autores dizem que a FAD é recomendada pela EPA e é um tratamento eficiente para efluentes de processamento de frutos do mar, particularmente para camarões e ostras. A FAD pode acomodar variações sazonais de vazão e operação intermitente. Baseada em operação física de separação sólido-líquido, que pode ser combinada com tratamento químico, sua partida é mais eficiente relativamente aos sistemas biológicos. Finalmente, a baixa necessidade de área faz com que a FAD seja uma opção atraente para o tratamento.

GNIRSS \& PETER-FROLICH (1996) comentam que, para ETEs, tanques de lodos ativados com $10 \mathrm{~m}$ de profundidade são uma alternativa aos tanques convencionais de construção superficial. Resultados de testes pilotos na ETE Berlim mostraram que a remoção biológica de fósforo e os processos de nitrificação e de desnitrificação podem ser implantados com o mesmo sucesso, como nos tanques convencionais de construção superficial. Entretanto, o lodo ativado não sedimenta satisfatoriamente. Desta forma, a flotação foi implantada no processo para clarificação secundária e tem-se mostrado vantajosa. A necessidade total de energia, para ambos os sistemas, foi aproximadamente a mesma. Entretanto, considerando-se apenas as unidades de clarificação secundária, foi observada significativa diferença no consumo de energia. A unidade de flotação consumiu 290 kWh enquanto a unidade de sedimentação consumiu $140 \mathrm{kWh}$. Mas, por causa do lodo em excesso da sedimentação ainda precisar ser adensado, o consumo de energia total, para ambos os sistemas, diferiu pouco (ETE convencional: $1.260 \mathrm{kWh}$; ETE com flotação: 1.370 $\mathrm{kWh}$ ). Um custo estimado em uma unidade preliminar revelou uma vantagem de $10 \%$ a favor da ETE com flotação.

LAINÉ et al. (1998) afirmam que, por um longo tempo, as águas de chuva foram incorretamente consideradas limpas. Entretanto, a carga anual de poluição, trazida para ambientes naturais pelas águas drenadas durante as chuvas, é equivalente às cargas anuais descartadas por ETEs. Algumas vezes, problemas de contaminação microbiológica de certas águas costeiras continuavam a existir após a modernização de ETEs devido à carga microbiológica dessas águas descartadas ao longo da costa. Desta forma, os referidos autores desenvolveram estudo com o emprego da flotação no tratamento de águas drenadas. A unidade de flotação provou ser perfeitamente adaptada ao tratamento de águas de chuva, atingindo máxima eficiência já no primeiro minuto de operação e com concentração residual de sólidos suspensos constante $(45 \mathrm{mg} / \mathrm{L})$, independentemente da variação da carga afluente 
ao processo. Isto é essencial quando se considera a extrema variabilidade da carga durante chuvas.

A flotação por ar dissolvido tem sido empregada com sucesso nas mais diferentes situações, como visto nos exemplos anteriores.

Entretanto, alguns pesquisadores condenam sumariamente o uso do processo físicoquímico em sistemas de tratamento de esgoto sanitário. O principal argumento diz respeito à excessiva produção de lodo químico. De fato, o tratamento primário e secundário de esgoto sanitário, mediante processo físico-químico, tende a produzir grande volume de lodo, em função das altas dosagens de produto químico necessárias. MENNELL et al. (1974), ao investigarem a utilização da flotação por ar dissolvido (FAD) precedida pela coagulação e floculação com cal na remoção de fósforo do esgoto sanitário após tratamento primário, recomendaram o uso de $350 \mathrm{mg} \mathrm{Ca}(\mathrm{OH})_{2} / \mathrm{L}$. STAMBERG et al. (1970) estudaram e recomendaram a pré-precipitação com cal em sistemas de lodos ativados, com dosagem de $150 \mathrm{mg} / \mathrm{L}$ de $\mathrm{Ca}(\mathrm{OH})_{2}$. PEREIRA (1991) estudou o tratamento físico-químico com cal em um sistema piloto composto por unidades de mistura rápida, de sedimentação e de recarbonatação, no tratamento do esgoto sanitário de Campina Grande-PB. Para obtenção de bons resultados, foi necessária dosagem de $960 \mathrm{mg} \mathrm{Ca}(\mathrm{OH})_{2} / \mathrm{L}$.

Altas dosagens de produtos químicos são necessárias no tratamento físico-químico secundário de esgoto, devido à concentração de sólidos elevada. PENETRA (1998), após coleta de amostras horárias de esgoto bruto e de efluente de reator UASB tratando esgoto sanitário de bairro vizinho ao Campus USP-São Carlos, identificou concentrações médias de $502 \mathrm{mgST} / \mathrm{L}$ e de $190 \mathrm{mgSST} / \mathrm{L}$ no esgoto sanitário. Ocorre que, nesse mesmo estudo, foram identificadas concentrações médias de $268 \mathrm{mgST} / \mathrm{L}$ e de $63 \mathrm{mgSST} / \mathrm{L}$ no efluente do reator UASB tratando o referido esgoto sanitário. Desta forma, o tratamento físico-químico de efluentes, com concentrações de sólidos significativamente inferiores àquelas observadas em esgoto sanitário, exigiria dosagens também significativamente inferiores àquelas observadas em tratamentos secundários. A redução das dosagens utilizadas também implicaria na redução da geração de lodo.

\subsubsection{Coagulação e floculação em sistemas de flotação por ar dissolvido}

ZABEL (1984) explica que no tratamento de água em geral o pH de coagulação deve ser investigado para que se obtenha eficiente clarificação do efluente, o que pode ser feito através de adição de um ácido ou de uma base. A recomendação também é válida para os sistemas de flotação por ar dissolvido (FAD). As condições de dosagem adequada de coagulante podem ser determinadas em equipamentos de flotação em escala de laboratório e 
verificadas em escala real, uma vez que os tempos de detenção hidráulica (TDH) nos sistemas de FAD são relativamente curtos (aproximadamente uma hora). Ainda mais importante do que a dosagem de coagulante, são as condições de agitação e a manutenção do valor de $\mathrm{pH}$ de coagulação adequado. A maioria dos sistemas de FAD é equipado com agitadores rápidos $(350 \mathrm{rpm})$ e tanques de mistura rápida com TDH entre 0,5 e $1 \mathrm{~min}$. Em sistemas de grande porte, para garantia de coagulação eficiente, a mistura pode ser realizada ao longo da tubulação afluente com aplicação do coagulante in-line, através de dispositivos adequados.

AMIRTHARAJAH (1989), ao estudar a influência dos valores de gradiente de velocidade para a mistura rápida $\left(\mathrm{G}_{\mathrm{mr}}\right)$, relata que os melhores resultados no tratamento com cloreto férrico de partículas com tamanho médio de $3 \mu \mathrm{m}$ foram conseguidos com $\mathrm{G}_{\mathrm{mr}}$ entre 700 e $1000 \mathrm{~s}^{-1}$ ou acima de $3500 \mathrm{~s}^{-1}$. Quando o tamanho médio das partículas foi aumentado para $6 \mu \mathrm{m}$, os valores ótimos de $\mathrm{G}_{\mathrm{mr}}$ variaram entre 800 e $1000 \mathrm{~s}^{-1}$ e acima de $3000 \mathrm{~s}^{-1}$. Quanto ao uso de polímeros orgânicos, o referido autor explica que os mecanismos de coagulação resultantes da adição desses polímeros são a neutralização de cargas e a formação de pontes entre partículas (ver FIGURA 3.1). Não é necessária, para a coagulação eficiente, a aplicação de valores elevados de gradiente médio de velocidade de mistura rápida quando são utilizados polímeros porque, diferentemente dos coagulantes inorgânicos (sais de ferro ou de alumínio, por exemplo), não ocorrem reações de adsorção dos colóides e de precipitação dos hidróxidos, reações estas que são competitivas entre si. Além disso, valores elevados de gradiente de velocidade podem provocar quebra dos flocos, diminuindo a eficiência da coagulação/floculação. Desta forma, o autor indica valores de gradiente de mistura rápida entre $400 \mathrm{a} 650 \mathrm{~s}^{-1}$ e tempo de mistura rápida entre 30 e $60 \mathrm{~s}$.

Quanto à floculação antecedendo a flotação, ZABEL (1984) comenta que a agitação fornecida deve ser suficiente para promover a colisão das partículas primárias visando o crescimento do floco. As unidades de floculação são constituídas, geralmente, por dois ou mais tanques de volumes iguais, associados a equipamentos de agitação lenta. O tempo de floculação depende das características da água bruta, mas, em geral, assume valores entre 12 a 20 min. Além disso, o grau de agitação também é muito importante e é denominado gradiente médio de velocidade de floculação. O referido autor comenta que o valor otimizado de gradiente médio de velocidade de floculação foi de $70 \mathrm{~s}^{-1}$, em estudo realizado tratando água para abastecimento. Uma alternativa para a agitação mecânica é a agitação hidráulica, realizada na tubulação afluente ao sistema. Com isso, o tempo de floculação poderia ser reduzido para cinco minutos, mas o gradiente médio de velocidade deveria ser elevado para $150 \mathrm{~s}^{-1}$. 


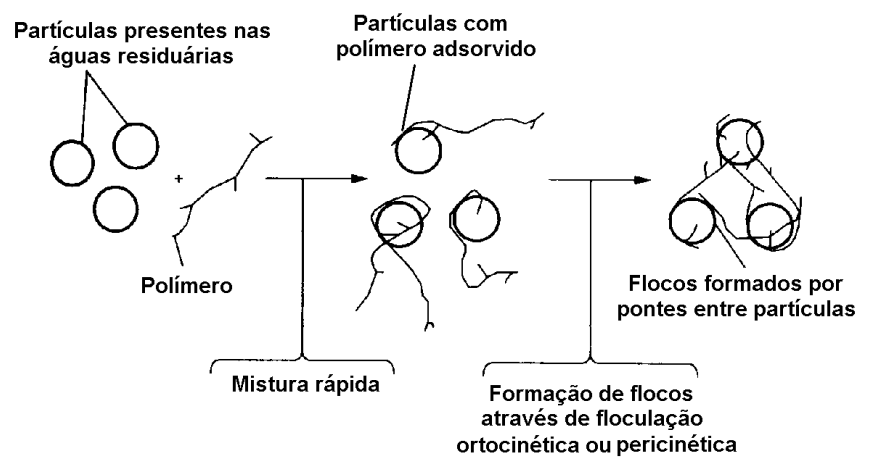

FIGURA 3.1 - Definição esquemática da formação de pontes entre partículas com aplicação de polímeros orgânicos. Fonte: (METCALF \& EDDY, 1991).

Quanto ao uso de polímeros sintéticos no tratamento químico de águas, BOLTO (1995) comenta que os polímeros têm sido usados na purificação da água há mais de três décadas. Numerosos benefícios ao obtidos com o emprego de polímeros, tais como:

- A taxa de separação das fases sólido-líquido é aumentada,

- Um volume menor de lodo é produzido,

- Carreiras de filtração prolongadas são obtidas,

- Uma variedade maior de águas pode ser tratada,

- Resultados menos dependentes do $\mathrm{pH}$,

- Dosagem reduzida de outros produtos químicos utilizados e

- Há uma menor concentração de sais dissolvidos na água final.

Dentre as desvantagens, são citadas:

- Os custos operacionais podem ser maiores,

- Há preocupação de toxicidade sobre monômeros residuais em água potável e sobre polímeros catiônicos em ambientes aquáticos,

- Cada tipo de água pode precisar de um polímero próprio,

- Fornecimento inadequado de produto químico e dados técnicos pelos fabricantes,

- Dosagem excessiva pode reestabilizar a dispersão e afetar outros processos e

- Soluções de polímeros estocadas podem ser biodegradáveis. 
Há numerosos tópicos práticos que necessitam de atenção particular quando do uso de polieletrólitos para tratamento de água e esgoto:

- necessidades para preparação e dosagem do polímero,

- seleção do tipo de polímero e sua dosagem,

- métodos de controle e monitoramento da dosagem,

- análise de polímero residual na água purificada,

- perda de material pela degradação do polímero e

- preocupação sobre a toxicidade do polímero.

Os polímeros aniônicos e não-iônicos, normalmente usados, são geralmente de baixa toxicidade, mas os catiônicos são mais tóxicos, especialmente para organismos aquáticos; os monômeros são geralmente mais tóxicos do que os polímeros. Por causa da preocupação com contaminantes, o Japão e a Suíça não permitem o uso de polieletrólitos no tratamento de água para abastecimento e a Alemanha e a França têm limites bastante severos. Os polímeros catiônicos são acentuadamente mais tóxicos para os organismos aquáticos do que os aniônicos e os não-iônicos, sendo de moderada a alta toxicidade. Eles são prejudiciais para os peixes por causa do entupimento das guelras, que provoca sufocamento. Maiores detalhes sobre as características dos diversos polímeros, sua aplicabilidade nos diferentes processos de tratamento e sua atuação na coagulação e na floculação de águas podem ser encontradas em BOLTO (1995).

SCRIVEN et al. (1999) estudaram o impacto do tratamento físico-químico de água em processo de flotação/filtração. Geralmente a eficiência de FAD é melhor quando é utilizada a floculação mecânica, em vez da floculação hidráulica. Altos valores de gradiente médio de velocidade de floculação (acima de $80 \mathrm{~s}^{-1}$ ) forneceram melhores resultados, em oposição aos valores entre 30 e $60 \mathrm{~s}^{-1}$, utilizados no tratamento convencional por sedimentação. Isto porque o processo de sedimentação requer grandes flocos, da ordem de $100 \mu \mathrm{m}$, em oposição a 20 e $50 \mu \mathrm{m}$ requeridos pela flotação.A prática atual em projetos utiliza de 20 a 30 min de tempo de floculação. Com a flotação, foi verificado que a eficiência do processo, em termos de qualidade da água, não se deterioraria excessivamente para valores de tempo de contato reduzidos até 2 minutos, mas o tempo de carreira de filtração seria proporcional ao tempo de floculação.

Mais especificamente sobre a coagulação e a floculação de efluentes de reatores anaeróbios, PENETRA (1998) investigou as condições de coagulação (dosagem de coagulante) e de floculação (tempo e gradiente médio de velocidade) no pós-tratamento 
físico-químico por flotação por ar dissolvido (FAD) de efluentes de reatores anaeróbios de manta de lodo (UASB), realizando ensaios em escala de laboratório, com equipamento de flotação em escala de laboratório (flotateste). Foram utilizados, separadamente, cloreto férrico e polímero catiônico como coagulantes. Os ensaios realizados em escala de laboratório demonstraram que os melhores resultados foram obtidos com dosagem de 65 $\mathrm{mg} / \mathrm{L}$ de $\mathrm{FeCl}_{3}, 15$ min e $80 \mathrm{~s}^{-1}$ de tempo e de gradiente médio de velocidade de floculação, respectivamente. Para essas condições mais apropriadas, foram observadas remoções de $88 \%$ de DQO (residual de $22 \mathrm{mg} / \mathrm{L}$ de DQO), $96 \%$ de fosfato total (residual de 0,6 mg/L de fosfato total), 94\% de SST (residual de $4 \mathrm{mg} / \mathrm{L}$ de SST), 97\% de turbidez (residual de 2 uT de turbidez), 47\% de NTK (residual de $18 \mathrm{mg} / \mathrm{L}$ de NTK) e não foi detectada a presença de sulfetos no efluente final.

\subsubsection{Aspectos positivos do emprego da coagulação/floculação/flotação como pós- tratamento de efluentes de reatores anaeróbios}

Segundo CAMPOS et. al. (1996), “os reatores anaeróbios têm sido cada vez mais empregados para o tratamento de esgoto sanitário, e, devido à sua natureza, seus efluentes necessitam passar por tratamento complementar".

Quais aspectos qualitativos dos efluentes dos reatores anaeróbios induzem à necessidade de tratamento complementar?

Pode-se citar inicialmente a presença residual de matéria orgânica, geralmente superior àquela permitida pela legislação em vigor, em se tratando de esgoto sanitário. Mesmo em excelentes condições ambientais e operacionais, a obtenção de remoções superiores a $80 \%$ de DBO quando do uso de reatores anaeróbios é rara. As parcelas coloidais e suspensas são susceptíveis ao tratamento químico, com formação de flocos e posterior remoção pela aderência às microbolhas e ascensão à superfície do tanque de flotação. De maneira geral, a parcela dissolvida não é significativamente influenciada pelo tratamento químico.

A remoção de fósforo em reatores anaeróbios é desprezível, tendo em vista que o fósforo é retido pela biomassa apenas para seu próprio crescimento celular. Em consequiência da pequena geração de lodo, a remoção de fósforo em reatores anaeróbios é praticamente nula. A eventual remoção por sedimentação das partículas suspensas também é insignificante pois cerca de $90 \%$ a $95 \%$ do fósforo presente no esgoto sanitário está na forma coloidal ou dissolvida. O tratamento químico com cloreto férrico promove a 
precipitação da parcela dissolvida e a coagulação/floculação da parcela precipitada, coloidal e suspensa. Os flocos contendo fósforo são, então, removidos no tanque de flotação.

Os efluentes de reatores anaeróbios são notoriamente reconhecidos por apresentarem sulfetos em seu meio. Desta forma, o efluente de reatores anaeróbios possui odor característico, facilmente identificável. A aplicação de cloreto férrico neste tipo de efluente resulta na formação de sulfeto de ferro II (FeS) e de sulfeto de ferro III $\left(\mathrm{Fe}_{2} \mathrm{~S}_{3}\right)$, com sua conseqüente incorporação aos flocos químicos e posterior remoção no tanque de flotação. O efluente do flotador final é isento de odor, sobretudo daquele desagradável aos circundantes.

Ainda que dependendo da capacidade de retenção de sólidos do reator anaeróbio e da variação de vazão de esgoto bruto, os efluentes de reatores anaeróbios apresentam concentração de sólidos suspensos e coloidais relativamente elevada, em função do arraste ora de material recalcitrante ora de biomassa desprendida do meio. A presença destes sólidos mantém elevada a turbidez do efluente. O tratamento químico seguido de flotação conduz à coagulação do material suspenso e coloidal, com sua posterior incorporação aos flocos químicos, com produção de efluente final com reduzida turbidez, podendo atingir valores menores do que 1,0 uT.

A partida de reatores anaeróbios demanda período de tempo relativamente elevado. Se não houver inoculação inicial, este período de tempo é bastante elevado, sendo reduzido na medida em que inóculo é introduzido no reator anaeróbio quando do início de sua operação. De maneira geral, o procedimento de partida prevê o aumento gradativo da vazão de esgoto afluente ao reator, com descarte da vazão excedente. O tratamento dessa vazão excedente pelo sistema de flotação permite a emissão de efluente com boa qualidade desde o início da operação da ETE. Para tanto, a dosagem de coagulante deve ser elevada, com conseqüente aumento na geração de lodo. A flexibilidade do sistema permite que os operadores decidam qual situação é mais vantajosa e conveniente técnica e economicamente.

Diversas pesquisas têm relatado que a adição de cloreto férrico, no início de operação de reatores UASB, é benéfica à granulação da biomassa, com conseqüente formação da manta de lodo mais rapidamente. Como alternativa à adição de cloreto férrico comercial, pode-se direcionar parcela do lodo químico flotado ao reator UASB, de forma que o cloreto férrico presente auxilie a granulação da biomassa.

Da mesma forma que o sistema de flotação possui características que complementam excepcionalmente o tratamento inicialmente feito pelo reator anaeróbio, deve-se considerar que o uso de pré-tratamento anaeróbio traz grandes vantagens e 
facilidades na operação de sistemas de flotação. A qualidade do efluente de reatores anaeróbios é mais constante e varia mais lentamente do que a do esgoto bruto ao longo do dia, permitindo que a amplitude de variação e o número de modificações da dosagem de coagulante ao longo do dia sejam menores.

Ainda dependente de maiores investigações, a digestão do lodo flotado no interior de reatores UASB pode tornar-se alternativa para redução do volume de lodo gerado pelo sistema.

\subsection{Alternativas para o pós-tratamento de efluentes anaeróbios}

Diversos pesquisadores ao redor do mundo propõem, estudam e, em caso de sucesso, recomendam diferentes sistemas combinados de tratamento de esgoto visando à obtenção de reduzidos teores de matéria orgânica residual, de nutrientes e de patogênicos. Cada região do globo terrestre apresenta características próprias quanto ao clima, à temperatura média, aos índices pluviométricos, à insolação, a aspectos econômicos, ambientais e sociais. Desta forma e de maneira geral, os pesquisadores tendem a procurar sistemas que atuem eficientemente em determinadas condições específicas. No Brasil, o interesse por sistemas de tratamento de esgoto que atendam as necessidades econômicofinanceiras, técnicas, ambientais e sociais nacionais está em rápido crescimento. Devido a suas peculiaridades, sobretudo no que diz respeito ao clima quente, o Brasil é um país no qual os sistemas anaeróbios apresentam enorme potencial de utilização. Entretanto, dificilmente a qualidade de seus efluentes consegue atender à Legislação vigente.

Procurando acelerar e sistematizar as pesquisas, órgãos federais financiaram rede de pesquisas sobre o tema "Pós-tratamento de efluentes de reatores anaeróbios", através do PROSAB - Programa de Pesquisas em Saneamento Básico.

Diferentes sistemas combinados de tratamento de esgoto sanitário foram estudados, sempre com o emprego inicial de reatores anaeróbios, a saber:

- Reator anaeróbio seguido de aplicação no solo

- Reator anaeróbio seguido de lagoas de polimento

- Reator anaeróbio seguido de reator com biofilme

- Reator anaeróbio seguido de lodos ativados

- Reator anaeróbio seguido de flotação por ar dissolvido

Com a finalidade de contextualizar o emprego da flotação no pós-tratamento de efluentes de reatores anaeróbios, algumas dessas pesquisas são citadas a seguir. 


\section{Reator anaeróbio seguido de aplicação no solo}

CORAUCCI et al. (2000) realizaram trabalho experimental utilizando a disposição no solo de efluentes anaeróbios através do método do escoamento superficial, com o uso de um patamar como reator biológico, com dimensões de $40 \mathrm{~m}$ de comprimento e $4,35 \mathrm{~m}$ de largura e com inclinação média de 3,5\%, coberto com grama Tifton 85 (Cynodon sp), conforme mostrado na FIGURA 3.2. O sistema era abastecido com efluente de filtros anaeróbios lançado na parte superior da rampa. Foram empregadas taxas de 0,10 e 0,20 $\mathrm{m}^{3} / \mathrm{h} / \mathrm{m}$. Para a taxa de $0,10 \mathrm{~m}^{3} / \mathrm{h} / \mathrm{m}$, considerando-se o sistema anaeróbio-aplicação no solo foram observadas remoções de $91 \%$ de DBO, com residuais de $33 \mathrm{mg} / \mathrm{L}$, de $87 \%$ de DQO, com residual em torno de $116 \mathrm{mg} / \mathrm{L}$, de $88 \%$ de SST, com residuais em torno de $40 \mathrm{mg} / \mathrm{L}$, de $91 \%$ de fósforo, com residuais em torno de $0,5 \mathrm{mg} / \mathrm{L}$, e de $74 \%$ de NTK, com residuais em torno de $12,8 \mathrm{mg} / \mathrm{L}$. O método de escoamento superficial foi capaz de remover a matéria orgânica de maneira eficiente, atendendo à Legislação. Além disso, removeu eficazmente fósforo e nitrogênio do efluente, além de permitir sua reoxigenação, tendo em vista concentrações de OD superiores a 4,5 mg/L, com conseqüente melhora da qualidade do líquido. Este método é bastante simples e de baixo custo, tornando-se acessível às comunidades que tenham limitação orçamentária.

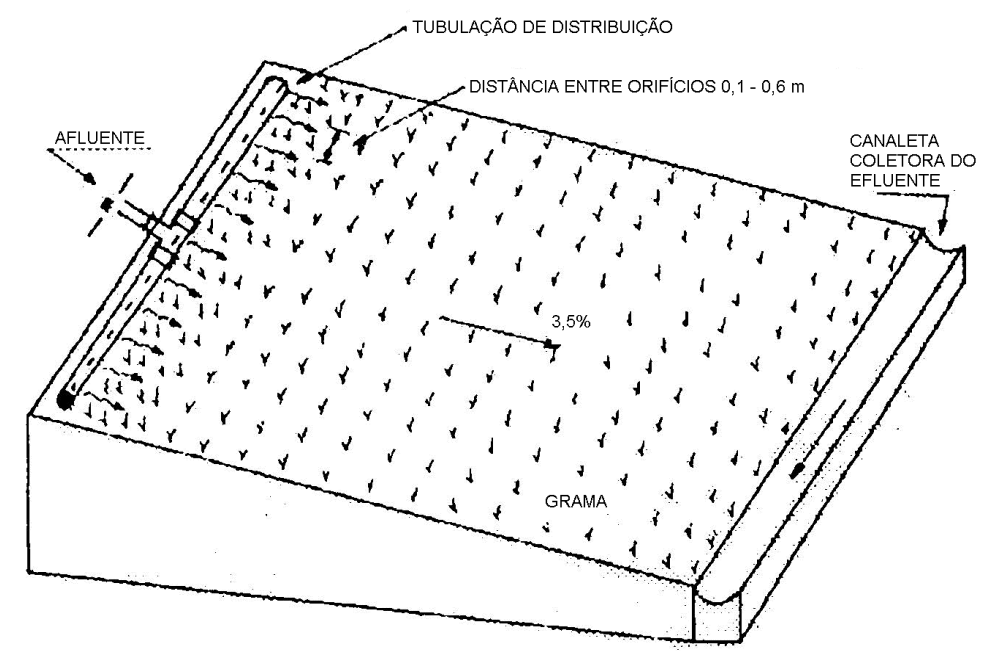

FIGURA 3.2 - Rampa de escoamento superficial. Fonte: Adaptado de CORAUCCI et al. (1999).

Há que se considerar, entretanto, a necessidade de área, a permeabilidade do solo, a topografia do terreno e o clima. Em exemplo apresentado por CORAUCCI et al. (2001), foi calculado que a área necessária para implantação de rampas de escoamento superficial para pós-tratamento de efluente de reator UASB, tratando esgoto sanitário de 10.000 pessoas, era 
de 2,56 ha. Os autores aconselham o uso de solos com permeabilidade de até $15 \mathrm{~mm} / \mathrm{h}$, como os argilosos. Eventualmente, pode-se aceitar solos com permeabilidade de até 50 $\mathrm{mm} / \mathrm{h}$, tendo em vista a sua compactação durante a construção e a colmatação dos vazios pelos sólidos presentes nos efluentes anaeróbios. O terreno deve apresentar declividade mínima de $1 \%$ e não superior a $12 \%$. Clima úmido e/ou temperaturas baixas limitam a aplicação do líquido no solo, sendo necessária a construção de tanques de armazenamento para o período em que a aplicação não puder realizar-se.

\section{Reator anaeróbio seguido de lagoas de polimento}

ARANTES et al. (2000) estudaram o desempenho de lagoas chicaneadas em escala piloto como unidades de pós-tratamento, com o objetivo de remover a matéria orgânica remanescente e os coliformes de efluentes de reator UASB tratando esgoto sanitário. Os tempos de detenção hidráulica (TDH) investigados na operação da lagoa foram de 48, 90 , 120 e 240 horas, com profundidades de 30, 60 e $100 \mathrm{~cm}$. Esse sistema foi operado durante 246 dias. Quando atuando como lagoa de polimento, foram observadas remoções na faixa de 15 a $76 \%$ de DQO, para TDH de 120 horas, e na faixa de 35 a 77\% de DQO, para TDH de 240 horas. Em ambos os valores de TDH e para profundidade de 1,0 m, os valores de DQO residual situaram-se em torno de $52 \mathrm{mg} / \mathrm{L}$. Os autores não apresentaram dados de remoção de nutrientes.

FEITOSA et al. (2001) exemplificaram o uso de lagoa de polimento tratando efluente de reator UASB. Para uma população servida de 10.000 habitantes, os autores calcularam a necessidade de 1,38 ha para implantação da lagoa. Também afirmam que, em função da grande necessidade de área, o terreno disponível pode ser insuficiente, em determinados casos de projetos, sobretudo em grandes centros urbanos, onde a demanda por área é grande e o custo do terreno é elevado. Nestes casos, deve-se recorrer a sistemas de pós-tratamento que ocupem menor área per capita. Os autores ainda afirmam que as condições em lagoas não são propícias para remoção biológica de nutrientes. Em se tratando de fósforo, uma remoção significativa somente é possível mediante a precipitação de sais insolúveis de fosfato, tais como apatita e estruvita. Para tanto, é necessária a presença de íons cálcio ou magnésio, além da presença do íon $\mathrm{PO}_{4}{ }^{3-}$, que somente aparece em concentrações significativas quando a concentração de fósforo é elevada. A remoção de fósforo, na forma de seu íon fosfato, somente começa a ser significativa quando o $\mathrm{pH}$ supera 9. A área necessária para remoção de fósforo depende muito da profundidade. Em lagoas com 1,0 m ou mais de profundidade, praticamente não há remoção de fósforo. 
LUDUVICE et al. (2000) confirmam a dificuldade da remoção de nutrientes em lagoas rasas atuando no pós-tratamento de efluentes de reatores UASB. O estudo em escala real indicou que a alcalinidade do meio líquido exerceu grande influência na remoção de nutrientes das lagoas, em decorrência da capacidade de tamponamento do meio. A limitação da elevação do $\mathrm{pH}$ reduziu a liberação de amônia não ionizável para a atmosfera e a coprecipitação de polifosfatos com sais de cálcio e de magnésio.

CATUNDA et al. (2000) concluíram que o lodo de lagoas de polimento era adequado para uso como fertilizante tendo em vista a presença de $58 \%$ de material volátil, de $0,066 \mathrm{gN} / \mathrm{gSV}$ e de $0,018 \mathrm{gP} / \mathrm{gSV}$ e devido à sua boa estabilidade. Entretanto, sua qualidade higiênica deveria ser melhorada em função da presença de ovos de helmintos presentes no lodo.

\section{Reator anaeróbio seguido de reator com biofilme}

NASCIMENTO et al. (2000) avaliaram um sistema de tratamento de esgoto sanitário, em escala piloto, composto de reator UASB seguido de filtro biológico anaeróbio. O filtro biológico foi operado com taxas de aplicação superficial e orgânica que variaram de 3,4 a $30,6 \mathrm{~m}^{3} / \mathrm{m}^{2} / \mathrm{d}$ e de 0,3 a $3,9 \mathrm{kgDBO} / \mathrm{m}^{3} / \mathrm{d}$, respectivamente. O sistema foi operado por 16 meses. Para taxas de aplicação superficial entre 6,8 e $17,1 \mathrm{~m}^{3} / \mathrm{m}^{2} / \mathrm{d}$, com respectivas taxas de carregamento orgânico entre 1,0 e $2,7 \mathrm{kgDQO} / \mathrm{m}^{3} / \mathrm{d}$ e entre 0,7 e $1,4 \mathrm{kgDBO} / \mathrm{m}^{3} / \mathrm{d}$, o filtro biológico foi capaz de produzir efluente com qualidade final muito boa. Observaramse valores médios de DQO, de DBO e de SST em torno de $90 \mathrm{mgO}_{2} / \mathrm{L}$, de $30 \mathrm{mgO}_{2} / \mathrm{L}$ e de $25 \mathrm{mg} / \mathrm{L}$, respectivamente. Apesar de dados de remoção de nutrientes não terem sido apresentados, supõe-se que não tenham ocorrido remoções significativas de nitrogênio e de fósforo do esgoto, tendo em vista que sistemas primordialmente anaeróbios, mesmo que combinados, não apresentam usualmente eficiência significativa na remoção de nutrientes, nas taxas estudadas.

GONÇALVES et al. (2000) estudaram a associação de um reator UASB e biofiltros aerados submersos para tratamento de esgoto sanitário. O reator UASB e o biofiltro foram operados com tempo de detenção hidráulica de $8,5 \mathrm{~h}$ e $1,3 \mathrm{~h}$, respectivamente. Os valores médios observados foram de $398 \mathrm{mgDQO} / \mathrm{L}$ no esgoto bruto, de $212 \mathrm{mgDQO} / \mathrm{L}$ no efluente do reator UASB e de $90 \mathrm{mgDQO} / \mathrm{L}$ no efluente do biofiltro aerado. Dados de remoção de nutrientes não foram apresentados. 


\section{Reator anaeróbio seguido de lodos ativados}

MARCHETTO et al. (2000) apresentaram o resultado de pesquisa em escala de laboratório em que foram utilizados reator microaerado e reator com aeração intermitente seguidos de flotador por ar dissolvido, para o pós-tratamento de efluentes anaeróbios. O sistema de flotação era responsável pela separação da biomassa aeróbia presente no efluente dos reatores microaerado e com aeração intermitente. Operando em condições de microaeração, com OD entre 0,2 e $0,9 \mathrm{mg} / \mathrm{L}$, e com TDH em torno de $14 \mathrm{~h}$, o reator apresentou eficiência média de DQO de $60 \pm 10 \%$, porém não foram conseguidas remoções significativas de nitrogênio e de fósforo. $\mathrm{O}$ reator com aeração intermitente, com OD entre 2, 0 e 4,0 mg/L, TDH de 6 horas e ciclos alternados de 2 horas com aeração e de 2 horas sem aeração, mostrou-se estável, apresentando elevada remoção média de DQO (92\% de remoção, com residual médio de $35 \mathrm{mg} / \mathrm{L}$ ) e de fósforo ( $90 \%$ de remoção, com residual médio de $1,5 \mathrm{mg} / \mathrm{L}$ ) sem adição de fonte externa de carbono, apenas com recirculação adequada do lodo.

CYBIS \& PICKBRENNER (2000) estudaram o emprego de reator seqüencial em batelada para pós-tratamento de efluentes de tratamento anaeróbio, objetivando a remoção de nutrientes. Para o estudo, foi empregado reator seqüencial em batelada anaeróbio (RSBAn), alimentado por esgoto sintético, com características predominantemente sanitárias, e três reatores sequienciais em batelada (RSB) alimentados com efluente do RSBAn. Os três RSB foram operados com diferentes tempos de enchimento, sendo que dois RSB foram alimentados de forma a suprir a falta de matéria orgânica durante o processo de desnitrificação. Os três RSB foram operados com ciclos operacionais de 12 horas e o RSBAn com ciclos operacionais de 6 horas. De maneira geral, foram observadas remoções de DQO e de sólidos suspensos maiores que $80 \%$ em todos os RSB. A nitrificação ocorreu nos três RSB, com valores entre $80 \%$ e $100 \%$. Entretanto, não foi observada eficiência nos processos de desnitrificação e de remoção biológica de fósforo.

\section{Reator anaeróbio seguido de flotação por ar dissolvido}

O emprego da flotação por ar dissolvido no pós-tratamento físico-químico de efluentes de sistemas biológicos de tratamento de esgoto sanitário foi proposto inicialmente por BRATBY (1982). O referido autor investigou a eficiência da flotação por ar dissolvido aplicada no tratamento secundário de esgoto sanitário mediante precipitação química, na Estação de Tratamento de Esgoto de Brasília - Sul (ETEB-Sul). O sistema de tratamento já existente na ETEB-Sul consistia de gradeamento, caixa de areia, sedimentação primária, aeração dos lodos ativados e sedimentação secundária e o efluente final era encaminhado 
diretamente ao Lago Paranoá, bastante eutrofizado naquele momento. O sistema não era capaz de tratar toda a vazão afluente $\left(0,90 \mathrm{~m}^{3} / \mathrm{s}\right)$ e, desta forma, a vazão excedente $(0,45$ $\mathrm{m}^{3} / \mathrm{s}$ ), após sedimentação primária, era desviada do sistema de lodos ativados e encaminhada diretamente ao Lago Paranoá. Essa operação (by-pass) era realizada durante todo o ano e estava prevista ampliação futura desse sistema, de modo a tratar a vazão total afluente. Os experimentos realizados pelo autor visavam testar a possibilidade de instalação de um sistema de flotação por ar dissolvido para tratamento da vazão excedente, enquanto o sistema existente não fosse ampliado. Após a ampliação, o sistema de FAD poderia ser utilizado no tratamento físico-químico terciário, como polimento final. Além disso, o sistema de FAD poderia atuar como tratamento convencional em caso de vazão afluente extremamente elevada e não suportada pela ETEB-Sul. Durante os ensaios, com o efluente do decantador primário e após adição de $80 \mathrm{mg} / \mathrm{L}$ de sulfato de alumínio, o sistema de FAD removeu $97 \%$ de sólidos suspensos totais, $84 \%$ de DQO e $92 \%$ de fosfato total. Apesar de haver proposto o sistema combinado, aparentemente o referido autor não investigou o emprego da FAD no tratamento terciário dos efluentes aeróbios provenientes do sistema de lodos ativados da ETEB-Sul, pois não foram encontrados trabalhos publicados de sua autoria.

O Departamento de Hidráulica e Saneamento da Escola de Engenharia de São Carlos da Universidade de São Paulo (SHS-EESC-USP) estabeleceu linha de pesquisa visando o estudo e o aperfeiçoamento de sistemas de flotação por ar dissolvido aplicados no tratamento complementar de efluentes de reatores anaeróbios. Em vista das vantagens da FAD já mencionadas, pesquisadores do SHS-EESC-USP já vinham desenvolvendo estudos desde 1978, visando determinar e adequar os parâmetros influentes no processo, sobretudo no tratamento de água de abastecimento, e descobrir novas aplicações na área de saneamento, nas quais a flotação efetivamente apresentasse eficiência comprovada.

Os primeiros resultados da combinação reator anaeróbio-FAD obtidos pelo SHSEESC-USP foram apresentados por CAMPOS et al. (1996), a partir de estudos em escala de laboratório com o objetivo de avaliar a potencialidade do emprego deste sistema combinado, conforme mostrado na FIGURA 3.3. Além de elevada remoção de matéria orgânica, foi avaliada a remoção de sólidos suspensos, de nutrientes e de patógenos. O trabalho não apresentava muito rigor metodológico no que se referia à otimização dos parâmetros de coagulação (melhor tipo de coagulante, tempo e gradiente médio de velocidade de coagulação, dosagens ótimas e valor ótimo de $\mathrm{pH}$ ), de floculação (tempo e gradiente médio de velocidade de floculação) e de flotação (quantidade ótima de ar, taxas, etc.), tendo sido 
avaliadas apenas algumas dosagens de cal hidratada, de sulfato de alumínio e de cloreto férrico como coagulantes. Desta forma, a quantidade necessária de produtos químicos ainda era elevada para obtenção de altos valores de remoção de matéria orgânica, fósforo, sólidos suspensos e patógenos. Os melhores resultados foram observados com dosagens de 150 $\mathrm{mg} / \mathrm{L}$ de cal hidratada, isoladamente, e de $50 \mathrm{mg} / \mathrm{L}$ de cal hidratada associada a $100 \mathrm{mg} / \mathrm{L}$ de cloreto férrico. A partir da constatação da potencialidade deste sistema combinado, um estudo mais aprofundado, em nível de mestrado, foi programado e executado.

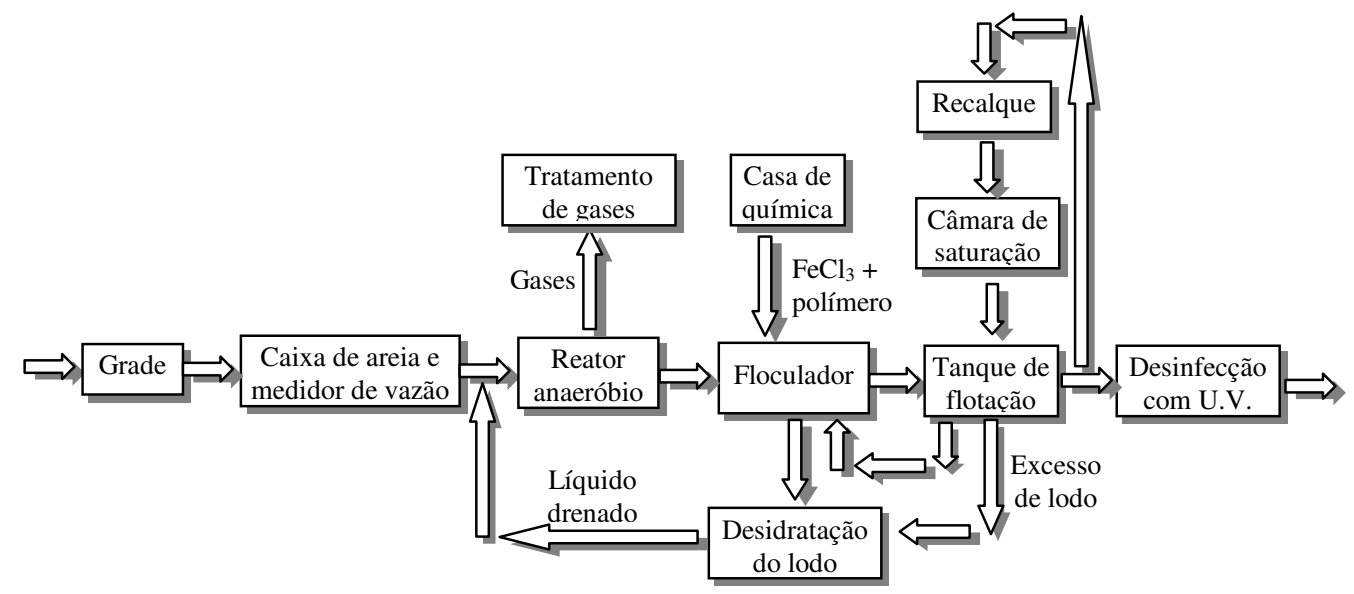

FIGURA 3.3 - Fluxograma do tratamento de esgoto sanitário empregando reator anaeróbio seguido por sistema de flotação. Fonte: CAMPOS et al. (1996).

Sendo assim, PENETRA (1998) estudou, em escala de laboratório, o emprego da FAD tratando o efluente anaeróbio de um reator UASB, com $18 \mathrm{~m}^{3}$ de volume, localizado no setor nordeste do Campus USP-São Carlos e tratando esgoto sanitário de um bairro vizinho ao Campus. Os ensaios em uma unidade de laboratório denominada flotateste foram realizados utilizando diferentes dosagens de cloreto férrico, entre 30 e $110 \mathrm{mg} / \mathrm{L}$, e de polímero catiônico, entre 1,0 e 16,0 mg/L, ambos dosados isoladamente e atuando como coagulantes primários. Também foram estudadas as condições de floculação, com variação dos valores de tempo e de gradiente médio de velocidade de floculação, e diferentes valores de quantidade de ar fornecida ao processo. Em todos os ensaios, as amostras do efluente do flotador eram coletadas em diferentes velocidades de flotação, permitindo, desta maneira, a verificação do comportamento do processo diante de diferentes taxas de aplicação superficial.

PENETRA et al. (1999a) apresentaram o estudo compreendendo dosagens de cloreto férrico entre 30 e $110 \mathrm{mg} / \mathrm{L}$ e concluíram que os melhores resultados observados na FAD foram obtidos quando da dosagem de $65 \mathrm{mg} / \mathrm{L}$ cloreto férrico e em pH entre 5,3 e 6,1. 
Nessas dosagens, elevadas remoções de fósforo (95\%), de sólidos suspensos (94\%), de turbidez (96\%) e de cor aparente (90\%) foram alcançadas pela unidade de flotação. Se considerado o sistema combinado UASB-FAD, as remoções globais observadas foram de 98\% de DQO, com residual menor do que $25 \mathrm{mg} / \mathrm{L}$, de $98 \%$ de fosfato total, com residual de 0,6 mg/L, de 98,4\% de sólidos suspensos, com residual de $4 \mathrm{mg} / \mathrm{L}$, de 99,3\% de turbidez, com residual de 2,0 uT, de $98 \%$ de cor aparente, com residual de $32 \mathrm{uC}$, e não foi detectada a presença de sulfetos no efluente final.

REALI et al. (1998), por sua vez, apresentaram os dados da investigação da influência da floculação na flotação de efluentes anaeróbios de reator UASB. Foram estudados tempos de floculação de 15 e de 25 min associados a gradientes médios de

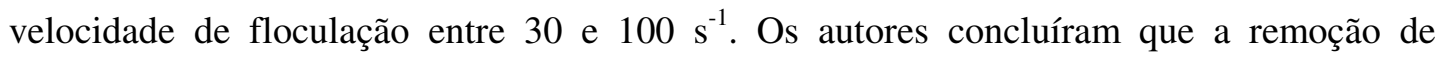
turbidez e de matéria orgânica não era significativamente influenciada pelo tempo e pelo gradiente médio de floculação, dentro das faixas de valores estudadas. Entretanto, a remoção de fosfato foi elevada e positivamente influenciada pelo aumento do gradiente médio de floculação para valores entre 80 e $100 \mathrm{~s}^{-1}$.

A influência da quantidade de ar na qualidade do efluente anaeróbio tratado em unidade de flotação foi apresentada por PENETRA et al. (1999b). Foram investigados onze valores de quantidade de ar fornecida, mediante variação da fração de recirculação (entre $5 \%$ e $30 \%$, em volume), fixando a pressão de saturação (450 $\pm 10 \mathrm{kPa})$. Os testes de laboratório indicaram que a variação da quantidade de ar não interferia significativamente na remoção de DQO, fosfato, turbidez e cor aparente quando taxas de aplicação superficiais usuais eram empregadas. Em todos os ensaios foram observados valores residuais de DQO total menores que $38 \mathrm{mg} / \mathrm{L}$, com eficiência de remoção superior a $71 \%$. A remoção de fosfatos foi superior a $92 \%$, com residual máximo de $0,98 \mathrm{mg} / \mathrm{L}$. Valores de turbidez entre 1,3 e 4,1 uT do efluente final foram observados para todos os valores de quantidade de ar testados, apresentando eficiência entre $94 \%$ e $98 \%$. Entretanto, para taxas maiores, a variação da quantidade de ar foi determinante na turbidez final da amostra. Ainda assim, foi possível observar boa qualidade da amostra final em termos de turbidez, com valor de 3,2 uT. Para as condições de coagulação/floculação estudadas (dosagem de $65 \mathrm{mg} / \mathrm{L}$ de cloreto férrico com 15 min e Gf de $80 \mathrm{~s}^{-1}$ na floculação), as curvas de flotação mostraram que, quando foi simulada operação com taxas mais elevadas (associadas a velocidades de flotação na faixa acima de $20 \mathrm{~cm} / \mathrm{min}$ ), o sistema de flotação exigiu maiores quantidades de ar dissolvido (entre 16 a $19 \mathrm{~g}$ de $\mathrm{ar} / \mathrm{m}^{3}$ de esgoto) para manutenção de níveis de eficiência de remoção de turbidez próximos aos obtidos com taxas menores (abaixo de $20 \mathrm{~cm} / \mathrm{min}$ ), quando foi requerido cerca de $12 \mathrm{~g}$ de $\mathrm{ar} / \mathrm{m}^{3}$ de esgoto para obtenção de eficiência de remoção de turbidez em torno de $96 \%$ (turbidez no efluente em torno de 2,0 uT). A 
aplicação de quantidades de ar dissolvido na faixa de 16 a $19 \mathrm{~g} \mathrm{de} \mathrm{ar} / \mathrm{m}^{3}$ de esgoto permitiu a obtenção de eficiências de remoção por flotação de $95 \%$ de SST, $85 \%$ DQO e 95\% de fosfato total. Considerando-se a eficiência global do Sistema "UASB seguido de unidade de flotação", obteve-se até 97\% de remoção de DQO (concentração efluente na faixa de 20 a 30 $\mathrm{mg} / \mathrm{L}$ ), até $98 \%$ de remoção de fosfato total (concentração efluente na faixa de 0,5 a 0,6 $\mathrm{mg} / \mathrm{L}$ ) e até $99 \%$ de remoção de SST (concentração efluente em torno de $2 \mathrm{mg} / \mathrm{L}$ ).

Visando o aperfeiçoamento da flotação, MARCHIORETTO \& REALI (2001) estudaram o emprego de ozonização e da FAD no pós-tratamento de efluentes anaeróbios com objetivo de investigar a influência da ozonização prévia do efluente na redução da quantidade necessária de coagulante para o posterior tratamento químico. O estudo foi realizado com a ozonização prévia do efluente anaeróbio e seu posterior tratamento físicoquímico por coagulação/floculação/flotação. Diferentes dosagens de ozônio foram estudadas conjuntamente com diversas dosagens de cloreto férrico. Os autores concluíram que a aplicação prévia de ozônio proporcionava eficiências de remoção de DQO, de fosfato total, de cor aparente e de turbidez bastante semelhantes entre si em velocidades de flotação elevadas ou reduzidas, garantindo excelente estabilidade ao processo mediante a variação das taxas de aplicação superficial. E, considerando-se as remoções de DQO, de DBO, de cor aparente e de turbidez (porém não de fosfato total), a aplicação de $6 \mathrm{mg} / \mathrm{L}$ de ozônio permitiu a redução na dosagem de cloreto férrico de $65 \mathrm{mg} / \mathrm{L}$ para $45 \mathrm{mg} / \mathrm{L}$, com conseqüente redução na geração de lodo.

A partir das recomendações de dosagem de cloreto férrico feitas por PENETRA et al. (1999a), AISSE et al. (2001) apresentaram resultados do monitoramento da ETE Cambuí (Campo Largo - PR), unidade que emprega o sistema UASB+FAD, construída pela SANEPAR, para uma vazão de $360 \mathrm{~m} / \mathrm{h}$ e com adição de $65 \mathrm{mg} / \mathrm{L}$ de cloreto férrico para tratamento químico dos efluentes anaeróbios. O efluente final apresentou valores de $71 \pm 12$ $\mathrm{mg} / \mathrm{L}, 5 \pm 2 \mathrm{mg} / \mathrm{L}$ e $30 \pm 1 \mathrm{mg} / \mathrm{L}$, respectivamente para DQO, DBO e SST. A turbidez apresentou valores de 4,1 $\pm 2,7 \mathrm{uT}$. A concentração de fosfato total foi de 1,6 $\pm 0,6 \mathrm{mg} / \mathrm{L}$, alcançando eficiência de remoção de $64 \%$. Os referidos autores também apresentaram os resultados do monitoramento de uma instalação piloto, operando com efluente anaeróbio, construída junto a ETE Ronda (Ponta Grossa - PR). O efluente do flotador apresentou valores de $37 \pm 17 \mathrm{mg} / \mathrm{L}, 9 \pm 4 \mathrm{mg} / \mathrm{L}$ e 4,4 uT, respectivamente para DQO, DBO e turbidez. $\mathrm{O}$ fosfato apresentou concentrações no efluente da ordem de $0,07 \pm 0,06 \mathrm{mg} / \mathrm{L}$.

A partir do conhecimento dos bons resultados obtidos nas pesquisas realizadas no Depto. de Hidráulica e Saneamento da EESC-USP, acerca do emprego da flotação no póstratamento de efluentes anaeróbios, PINTO FILHO \& BRANDÃO (2001) realizaram estudo, em escala de laboratório, para avaliar a aplicabilidade da flotação por ar dissolvido 
no pós-tratamento de efluentes de três tipos de sistemas de tratamento de esgoto localizados em Brasília/DF: lodos ativados, reator UASB e lagoa de estabilização de alta taxa. O sulfato de alumínio foi escolhido para o tratamento químico dos efluentes. Para o efluente do reator UASB foram necessárias dosagens entre 160 e $240 \mathrm{mg} / \mathrm{L}$ de sulfato de alumínio para obtenção de valores de turbidez em torno de $3 \mathrm{uT}$, de DQO de $49 \mathrm{mg} / \mathrm{L}$, de sólidos suspensos de $13 \mathrm{mg} / \mathrm{L}$ e de fosfato total de $0,1 \mathrm{mg} / \mathrm{L}$.

\subsection{Remoção e recuperação de fósforo no esgoto sanitário}

MORSE et al. (1998) fizeram uma revisão das tecnologias para remoção e recuperação de fósforo de esgoto e suas respectivas potencialidades e sustentabilidade na reciclagem de fósforo. Uma ampla gama de tecnologias foi identificada, incluindo a precipitação química, a remoção biológica de fósforo, a cristalização, abordagens modernas de precipitação química e outros métodos baseados na utilização de esgoto e de lodo (ver TABELAS 3.1 e 3.2). O fósforo presente no esgoto representa fonte renovável significativa e não há razão ambiental ou tecnológica para que ele não seja reciclado. De fato, há muitos potenciais benefícios ambientais resultantes da redução da dependência de rochas fosfáticas e de suas impurezas associadas na obtenção de fosfatos, uma prática atualmente insustentável. O desenvolvimento de tecnologias para remoção de fósforo começou na década de 50 na Suíça em resposta à origem da eutrofização e à necessidade de reduzir os níveis de P lançados nas águas superficiais. Segundo ESTEVES (1988), a importância do fósforo nos sistemas biológicos deve-se à sua participação em processos fundamentais do metabolismo dos seres vivos, tais como: armazenamento de energia (fração essencial da molécula de ATP) e estruturação da membrana celular (através de fosfolipídeos).

$\mathrm{O}$ fósforo é o principal fator limitante da produtividade da maioria das águas continentais e tem sido apontado como o principal responsável pela eutrofização artificial destes ecossistemas. O bloom de algas decorrente do processo de eutrofização tende a ocorrer quando a concentração de nitrogênio e fósforo inorgânicos excede, respectivamente, 0,3 mg/L e 0,01 mg/L (SAWYER ${ }^{1}$ apud METCALF \& EDDY, 1991). MITSCH et al. ${ }^{2}$ afirmam que a assimilação do fósforo total é proporcional ao crescimento líquido da biomassa a partir de uma concentração de fósforo total de $0,8 \mathrm{mg} / \mathrm{g}$ de algas (WANG \& MITSCH, 2000).

\footnotetext{
${ }^{1}$ SAWYER, C.N. (1947). "Fertilization of lakes by agricultural and urban drainages". Journal of the New England Waterworks Association, vol. 51, p. 109-127.

${ }^{2}$ MITSCH, W.J., FENNESSY, M.S. E CRONK, J.K. (1990). Ecosystem studies of the Des Plaines River experimental Wetlands-1989-90. Wetlands Research, Chicago, IL, p.48.
} 
TABELA 3.1 - Tecnologias de remoção e de recuperação de fósforo - resumo dos processos. Fonte: MORSE et al. (1998).

\begin{tabular}{|c|c|c|c|c|c|c|}
\hline Tecnologia & Objetivo & Resumo do processo & Afluente principal & Produtos auxiliares & Resíduos & Forma e teor de $P$ \\
\hline $\begin{array}{l}\text { Precipitação } \\
\text { química }\end{array}$ & Remoção de fósforo & $\begin{array}{l}\text { Adição de sal de metal para precipitar } \\
\text { fosfato metálico removido no lodo }\end{array}$ & $\begin{array}{l}\text { Esgoto (primário, } \\
\text { secundário, terciário } \\
\text { ou recirculação) }\end{array}$ & $\begin{array}{l}\mathrm{Fe}, \mathrm{Al}, \mathrm{Ca} \text {. } \\
\text { Polímero aniônico } \\
\text { pode ser utilizado }\end{array}$ & Lodo químico & $\begin{array}{l}\text { Principalmente } \\
\text { compostos químicos } \\
\text { como fosfatos } \\
\text { metálicos }\end{array}$ \\
\hline $\begin{array}{l}\text { Remoção } \\
\text { biológica de } \\
\text { fósforo }\end{array}$ & $\begin{array}{l}\text { Remoção de fósforo } \\
\text { (remoção de } \\
\text { nitrogênio também } \\
\text { pode ser incluída) }\end{array}$ & $\begin{array}{l}\text { Assimilação de P pelas bactérias em } \\
\text { fase aeróbia seguida de fase } \\
\text { anaeróbia }\end{array}$ & $\begin{array}{l}\text { Esgoto (efluente } \\
\text { primário) }\end{array}$ & $\begin{array}{l}\text { Pode requerer fonte } \\
\text { externa de carbono } \\
\text { (por exemplo, } \\
\text { metanol) }\end{array}$ & Lodo biológico & $\begin{array}{l}\text { Compostos } \\
\text { biológicos de } \\
\text { fósforo }\end{array}$ \\
\hline $\begin{array}{l}\text { Cristalização } \\
\text { (DHV } \\
\text { Crystalactor) }\end{array}$ & $\begin{array}{l}\text { Remoção e } \\
\text { recuperação de P }\end{array}$ & $\begin{array}{l}\text { Cristalização de fosfato de cálcio } \\
\text { usando areia }\end{array}$ & $\begin{array}{l}\text { Esgoto (efluente } \\
\text { secundário ou de } \\
\text { recirculação) }\end{array}$ & $\begin{array}{l}\text { Soda cáustica/ solução } \\
\text { de cal, areia; ácido } \\
\text { sulfúrico pode ser } \\
\text { necessário }\end{array}$ & $\begin{array}{l}\text { Fosfato de } \\
\text { cálcio e areia }\end{array}$ & $\begin{array}{l}\text { Fosfato de cálcio } \\
(40 \% \text { a } 50 \%)\end{array}$ \\
\hline $\begin{array}{l}\text { Precipitação } \\
\text { química avançada }\end{array}$ & $\begin{array}{l}\text { Remoção de } \\
\text { nitrogênio e de fósforo }\end{array}$ & $\begin{array}{l}\text { Cristalização de fósforo/matéria } \\
\text { orgânica e hidrólise para fornecer } \\
\text { fonte de carbono para remoção de } \mathrm{N}\end{array}$ & $\begin{array}{l}\text { Esgoto (afluente } \\
\text { primário) }\end{array}$ & $\begin{array}{l}\text { Cloreto de } \\
\text { polialumínio (PAC) }\end{array}$ & Lodo químico & Lodo químico \\
\hline Troca iônica & $\begin{array}{l}\text { Produção de } \\
\text { fertilizante (estruvita) }\end{array}$ & $\begin{array}{l}\text { A troca iônica remove amônia e } \\
\text { fosfato que estão precipitados }\end{array}$ & $\begin{array}{l}\text { Esgoto (efluente } \\
\text { secundário) }\end{array}$ & $\begin{array}{l}\mathrm{H}_{3} \mathrm{PO}_{4}, \mathrm{MgCl}, \mathrm{NaCl} \\
\mathrm{NaCO}_{3}, \mathrm{NaOH}\end{array}$ & $\begin{array}{l}\text { Estruvita } \\
\left(\mathrm{MgNH}_{4} \mathrm{PO}_{4}\right)\end{array}$ & Fosfato diluído \\
\hline $\begin{array}{l}\text { Magnética (Smit- } \\
\text { Nymegen) }\end{array}$ & Remoção de P & $\begin{array}{l}\text { Precipitação, agregação à magnetita, } \\
\text { separação e recuperação }\end{array}$ & $\begin{array}{l}\text { Esgoto (efluente } \\
\text { secundário) }\end{array}$ & Cal, magnetita & $\begin{array}{l}\text { Fosfato de } \\
\text { cálcio }\end{array}$ & Fosfato de cálcio \\
\hline $\begin{array}{l}\text { Adsorventes de } \\
\text { fósforo }\end{array}$ & Remoção de fósforo & Adsorção e separação & Esgoto & Não informado & $\begin{array}{l}\text { Sem } \\
\text { informação }\end{array}$ & Fosfato de cálcio \\
\hline Filtração terciária & Polimento do efluente & Filtração & Efluente secundário & Leito de areia & Lodo terciário & Fosfato insolúvel \\
\hline $\begin{array}{l}\text { Tratamento de } \\
\text { lodo }\end{array}$ & $\begin{array}{l}\text { Disposição final de } \\
\text { lodo }\end{array}$ & Secagem do lodo & Lodo & $\begin{array}{l}\text { Dependente do } \\
\text { processo }\end{array}$ & $\begin{array}{l}\text { Condicionante } \\
\text { de solos }\end{array}$ & $\begin{array}{l}\text { Grânulos secos, } \\
\text { baixo teor de } \mathrm{P}\end{array}$ \\
\hline $\begin{array}{l}\text { Recuperação de } \\
\text { cinzas de lodo }\end{array}$ & Recuperação de P & Extração a partir das cinzas de lodo & $\begin{array}{l}\text { Cinzas de lodo de } \\
\text { remoção biológica }\end{array}$ & Sem informação & $\begin{array}{l}\text { Sem } \\
\text { informação }\end{array}$ & Sem informação \\
\hline
\end{tabular}


TABELA 3.2 - Tecnologias de remoção e de recuperação de fósforo - contexto. Fonte: MORSE et al. (1998).

\begin{tabular}{|c|c|c|c|c|c|}
\hline \multirow[t]{2}{*}{ Tecnologia } & \multirow[t]{2}{*}{ Aplicação } & \multicolumn{2}{|c|}{ Valor do recuperado } & \multirow{2}{*}{$\begin{array}{c}\text { Vantagens } \\
\text { da tecnologia }\end{array}$} & \multirow{2}{*}{$\begin{array}{l}\text { Desvantagens } \\
\text { da tecnologia }\end{array}$} \\
\hline & & Indústria & Agricultura & & \\
\hline $\begin{array}{l}\text { Precipitação } \\
\text { química }\end{array}$ & $\begin{array}{l}\text { Tratamento primário, } \\
\text { secundário, terciário ou } \\
\text { recirculação de lodo }\end{array}$ & $\begin{array}{l}\text { Baixo: composto } \\
\text { metálico de } \mathrm{P} \text { dificulta } \\
\text { a reciclagem }\end{array}$ & $\begin{array}{l}\text { Moderado: } \\
\text { disponibilidade de P } \\
\text { variável }\end{array}$ & $\begin{array}{l}\text { Tecnologia simples e conhecida. } \\
\text { Fácil de instalar e de operar. } \\
\text { Remoção de P pode ser elevada }\end{array}$ & $\begin{array}{l}\text { Requer produtos químicos. } \\
\text { Aumento na produção de lodo. } \\
\text { Reciclabilidade de } \mathrm{P} \text { variável. }\end{array}$ \\
\hline $\begin{array}{l}\text { Remoção } \\
\text { biológica de } \\
\text { fósforo }\end{array}$ & $\begin{array}{l}\text { Tratamento secundário ou } \\
\text { recirculação de lodo } \\
\text { ativado }\end{array}$ & $\begin{array}{l}\text { Moderado: compostos } \\
\text { biológicos de } \mathrm{P} \text { mais } \\
\text { recicláveis }\end{array}$ & $\begin{array}{l}\text { Moderado: compostos } \\
\text { biológicos de } \mathrm{P} \text { mais } \\
\text { disponíveis }\end{array}$ & $\begin{array}{l}\text { Tecnologia conhecida. } \\
\text { Sem necessidade de produtos } \\
\text { químicos. } \\
\text { Remoção de N e P possíveis. } \\
\text { P mais reciclável. }\end{array}$ & $\begin{array}{l}\text { Tecnologia mais complexa para } \\
\text { instalar e operar. Manipulação do } \\
\text { lodo pode ser mais difícil. }\end{array}$ \\
\hline $\begin{array}{l}\text { Cristalização } \\
\text { (DHV } \\
\text { Crystalactor) }\end{array}$ & $\begin{array}{l}\text { Tratamento secundário ou } \\
\text { recirculação de efluente }\end{array}$ & $\begin{array}{l}\text { Muito alto: facilmente } \\
\text { reciclado pela } \\
\text { indústria }\end{array}$ & $\begin{array}{l}\text { Moderado: } \\
\text { disponibilidade de } \mathrm{P} \\
\text { variável }\end{array}$ & $\begin{array}{l}\text { Tecnologia provada. } \\
\text { Pode ser aperfeiçoada. } \\
\text { Produto reciclável. }\end{array}$ & $\begin{array}{l}\text { Requer produtos químicos. } \\
\text { Requer operação especializada. }\end{array}$ \\
\hline $\begin{array}{l}\text { Precipitação } \\
\text { química avançada }\end{array}$ & $\begin{array}{l}\text { Primário (precipitação), } \\
\text { secundário (remoção de } \\
\text { N) }\end{array}$ & $\begin{array}{l}\text { Baixo: composto } \\
\text { metálico de } \mathrm{P} \text { dificulta } \\
\text { a reciclagem }\end{array}$ & $\begin{array}{l}\text { Moderado: } \\
\text { disponibilidade de } \mathrm{P} \\
\text { variável }\end{array}$ & $\begin{array}{l}\text { Tecnologia provada (piloto). } \\
\text { Remoção elevada de N e P. Parte } \\
\text { de um conceito completo de } \\
\text { reciclagem }\end{array}$ & $\begin{array}{l}\text { Requer produtos químicos. } \\
\text { Tecnologia complexa. } \\
\text { P pode não estar em uma forma } \\
\text { conveniente para reciclagem. }\end{array}$ \\
\hline Troca iônica & Tratamento terciário & $\begin{array}{l}\text { Moderado: } \\
\text { modificações são } \\
\text { necessárias }\end{array}$ & $\begin{array}{l}\text { Alto: estruvita é um } \\
\text { bom fertilizante }\end{array}$ & $\begin{array}{l}\text { Alta remoção de P. A estruvita } \\
\text { tem alto potencial de reciclagem } \\
\text { na agricultura. }\end{array}$ & $\begin{array}{l}\text { Requer produtos químicos. } \\
\text { Tecnologia complexa. } \\
\text { Lodo resultante. }\end{array}$ \\
\hline $\begin{array}{l}\text { Magnética } \\
\text { (Smit-Nymegen) }\end{array}$ & Tratamento terciário & $\begin{array}{l}\text { Moderado: } \\
\text { modificações são } \\
\text { necessárias }\end{array}$ & $\begin{array}{l}\text { Baixo: adequabilidade } \\
\text { na agricultura } \\
\text { desconhecida }\end{array}$ & Alta remoção de $\mathrm{P}$. & $\begin{array}{l}\text { Tecnologia complexa } \\
\text { desnecessariamente. Requer } \\
\text { produtos químicos. }\end{array}$ \\
\hline $\begin{array}{l}\text { Adsorventes de } \\
\text { fósforo }\end{array}$ & $\begin{array}{l}\text { Não suficientemente } \\
\text { desenvolvido }\end{array}$ & Baixo: desconhecido & Baixo: desconhecido & $\begin{array}{l}\text { Potencial para recuperação de } \mathrm{P} \\
\text { com poucos produtos químicos. }\end{array}$ & Tecnologia não provada. \\
\hline Filtração terciária & Tratamento terciário & $\begin{array}{l}\text { Nenhum: sem } \\
\text { potencial }\end{array}$ & Nenhum: sem potencial & $\begin{array}{l}\text { Tecnologia conhecida. } \\
\text { Fácil de implantar e usar. }\end{array}$ & $\begin{array}{l}\text { Não é uma tecnologia de } \\
\text { recuperação (produto inútil). }\end{array}$ \\
\hline $\begin{array}{l}\text { Tratamento de } \\
\text { lodo }\end{array}$ & Disposição de lodo & $\begin{array}{l}\text { Baixo: dificuldade de } \\
\text { reciclar }\end{array}$ & Alto: alto reuso de $\mathrm{P}$ & Aumenta o valor do lodo & $\begin{array}{l}\text { Tecnologia mais complexa. } \\
\text { Requer produtos químicos. }\end{array}$ \\
\hline $\begin{array}{l}\text { Recuperação de } \\
\text { cinzas de lodo }\end{array}$ & Após incineração do lodo & $\begin{array}{l}\text { Alto: P prontamente } \\
\text { lixiviado }\end{array}$ & $\begin{array}{l}\text { Moderado: reuso de } \mathrm{P} \\
\text { possível }\end{array}$ & $\begin{array}{l}\text { Potencial para recuperação do P } \\
\text { em altas concentrações. }\end{array}$ & $\begin{array}{l}\text { Tecnologia não desenvolvida. } \\
\text { Somente possível se a } \\
\text { incineração já for utilizada. }\end{array}$ \\
\hline
\end{tabular}


A remoção do fosfato das águas residuárias envolve a incorporação do fosfato em uma forma particulada (sólidos suspensos) e, na seqüência, a remoção dos sólidos suspensos. Os tipos de sólidos suspensos nos quais os fosfatos podem ser incorporados são biológicos (microrganismos) ou químicos (fosfatos de metal precipitados pouco solúveis). A precipitação química do fosfato é necessária quando os limites de emissão de fósforo são menores do que aqueles alcançados pelo tratamento biológico. A precipitação do fosfato é conseguida pela adição de um metal, o que acarreta a formação dos fosfatos precipitados pouco solúveis. Este metal pode ser o cálcio $\left(\mathrm{Ca}^{+2}\right)$, o ferro $\left(\mathrm{Fe}^{+2}\right.$ ou $\left.\mathrm{Fe}^{+3}\right)$ ou o alumínio $\left(\mathrm{Al}^{+3}\right)$. Os sais normalmente empregados são a cal $\left(\mathrm{Ca}(\mathrm{OH})_{2}\right)$, o sulfato de alumínio $\left(\mathrm{Al}_{2}\left(\mathrm{SO}_{4}\right)_{3} \cdot 18 \mathrm{H}_{2} \mathrm{O}\right)$, o aluminato de sódio $\left(\mathrm{NaAlO}_{2}\right)$, o cloreto férrico $\left(\mathrm{FeCl}_{3}\right)$, o sulfato férrico $\left(\mathrm{Fe}_{2}\left(\mathrm{SO}_{4}\right)_{3}\right)$, o sulfato ferroso $\left(\mathrm{FeSO}_{4}\right)$ e o cloreto ferroso $\left(\mathrm{FeCl}_{2}\right)$ (JENKINS \& HERMANOWICZ, 1991).

Por razões cinéticas, $\mathrm{Fe}^{+2}, \mathrm{Fe}^{+3}$ e $\mathrm{Al}^{+3}$ são mais freqüentemente usados no tratamento de esgoto porque são capazes de formar flocos facilmente sedimentáveis, em curto período de tempo. Para $\mathrm{Fe}^{+2}$, isto vale somente se o composto químico é adicionado em água aerada, onde os precipitantes são transformados em complexos hidrolizados de $\mathrm{Fe}^{+3}$, que apresentam características consideravelmente melhores de floculação do que os precipitados $\mathrm{de} \mathrm{Fe}^{+2}$. Os precipitados de $\mathrm{Fe}^{+2}$ aparecem freqüentemente como colóides finamente dispersos e que podem ser parcialmente carreados com o efluente (MAURER \& BOLLER, 1998).

Os fatores que afetam a escolha de determinado produto químico visando a remoção de fósforo são: (i) concentração de fósforo afluente, (ii) concentração de sólidos suspensos na água residuária, (iii) alcalinidade, (iv) custos do produto químico (incluso o transporte), (v) fornecimento garantido do produto, (vi) unidades para manipulação do lodo, (vii) meios adequados para disposição final e (viii) compatibilidade com outros processos. Quando sais de ferro são adicionados às águas residuárias brutas, eles reagem com o ortofosfato solúvel e produzem um precipitado, segundo as reações:

$$
\begin{aligned}
& \mathrm{Fe}^{3+}+\mathrm{PO}_{4}{ }^{3-} \rightleftarrows \mathrm{FePO}_{4} \\
& \mathrm{Fe}^{3+}+3 \mathrm{OH}^{-} \rightleftarrows \mathrm{Fe}(\mathrm{OH})_{3}
\end{aligned}
$$

Em águas com baixa alcalinidade, devido ao consumo de $\mathrm{OH}^{-}$, a adição de uma base ocasionalmente pode ser necessária para manter o pH entre 5 e 7 . Os sais de ferro são geralmente utilizados em uma razão molar na faixa entre 1 a 3 íons de metal para 1 íon de fósforo. A razão molar exata de aplicação é determinada através de ensaios e depende das características da água residuária e da remoção desejada de fósforo (METCALF \& EDDY, 1991). 
A curva de solubilidade de $\mathrm{FePO}_{4}$ (s) é apresentada na FIGURA 3.4. A solubilidade mínima do $\mathrm{FePO}_{4}(\mathrm{~s})$ está ao redor de $\mathrm{pH}$ 5,3. Essa curva foi desenvolvida a partir do precipitado formado pela adição gradual do $\mathrm{FePO}_{4}(\mathrm{~s})$ à água destilada, em laboratório.

Ainda segundo esses autores, quando os sais de ferro são adicionados às águas residuárias para precipitação do fosfato, é obtida uma curva de dosagem química em função do ortofosfato residual solúvel e semelhante àquela mostrada na FIGURA 3.5. Essa curva é característica para valores moderados de $\mathrm{pH}(<7,5)$ e para valores moderados a baixos de alcalinidade (aproximadamente $100 \mathrm{mg} / \mathrm{L} \mathrm{CaCO}_{3}$ ) da água residuária. A curva indica que baixas concentrações residuais de ortofosfato podem ser conseguidas, mas somente com a adição de altas dosagens de $\mathrm{Fe}^{+3}$. A forma dessa curva é confirmada pelos dados operacionais obtidos em várias unidades de lodos ativados localizadas na Baía de Chesapeake, EUA.

Duas regiões predominantes podem ser identificadas na curva: uma região "estequiométrica", com altas concentrações efluentes de fósforo, e uma região de "equilíbrio", com baixas concentrações efluentes de fósforo (ver FIGURA 3.6). Na região estequiométrica, a remoção de ortofosfato solúvel é estequiometricamente proporcional à adição de sal de metal, enquanto na região de equilíbrio são necessários incrementos cada vez maiores na dosagem química para remoções cada vez menores de ortofosfato solúvel.

PENETRA (1998), ao estudar a remoção de fosfato de efluentes de reatores anaeróbios através da coagulação química com cloreto férrico e posterior separação dos flocos pelo uso da flotação por ar dissolvido, observou comportamento da remoção de fosfato bastante semelhante àquele divulgado por JENKINS \& HERMANOWICZ (1991), conforme observado na FIGURA 3.7. O autor também constatou que dosagens acima de 65 $\mathrm{mg} / \mathrm{L}$ de cloreto férrico $(22,4 \mathrm{mg} \mathrm{Fe} / \mathrm{L})$ resultaram em remoção de pequenas frações adicionais de fosfato total.

A precipitação química é muito flexível para remoção de $\mathrm{P}$ e pode ser aplicada em diversos estágios durante o tratamento de esgoto. Quando disposto na agricultura, apresenta valor em potencial, apesar das pesquisas não conclusivas (MORSE et al., 1998).

A remoção específica de fósforo pela adição de produto químico pertence ao estado da arte do tratamento de esgoto há muitos anos. A simplicidade de sua aplicação e a possibilidade de alcançar concentrações de fósforo muito baixas no efluente faz desta tecnologia amplamente utilizada e atende a necessidades de restrição legal para concentração de P no efluente (MAURER \& BOLLER, 1998). 


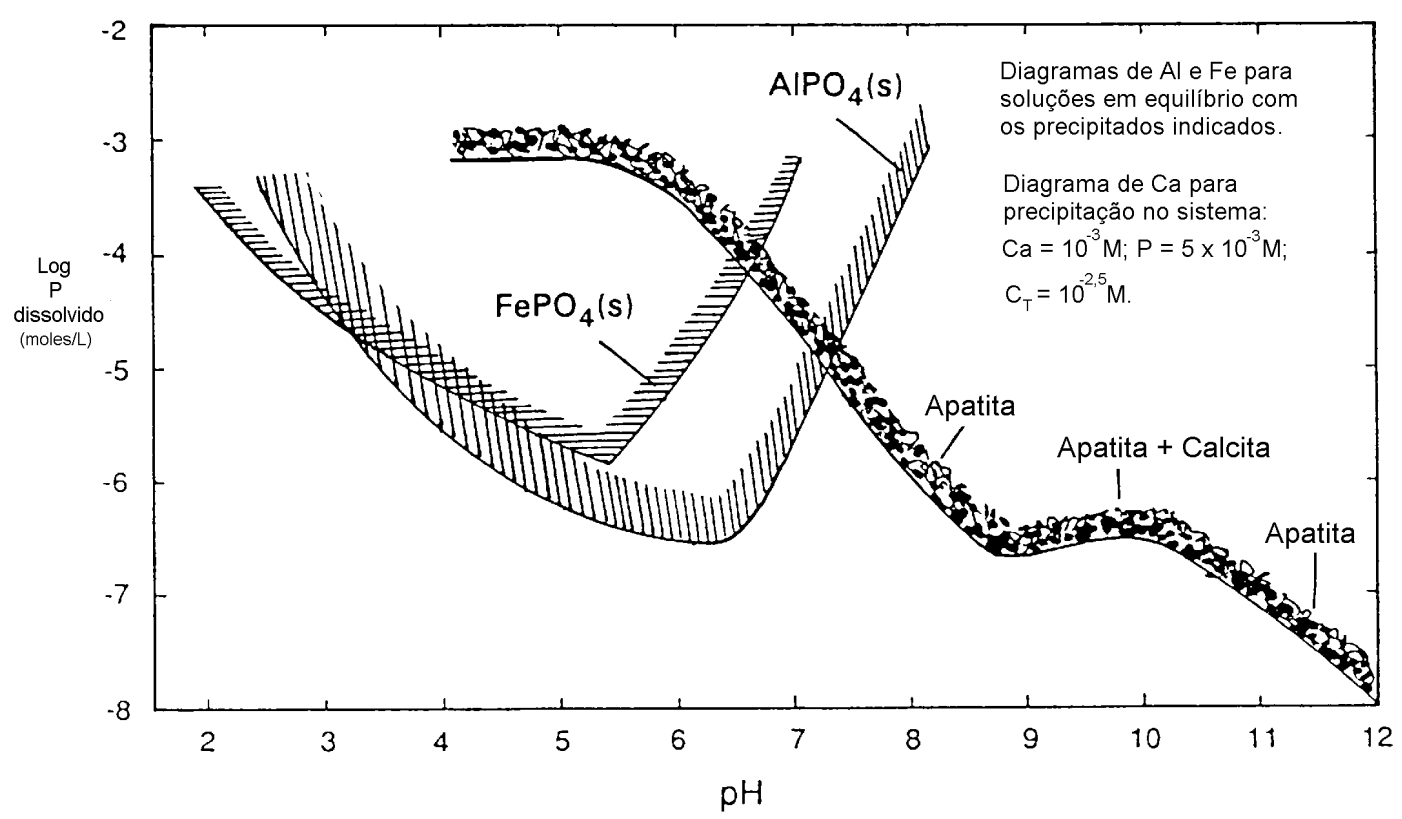

FIGURA 3.4 - Diagramas de equilíbrio de solubilidade para fosfatos de $\mathrm{Fe}$, $\mathrm{Al}$ e $\mathrm{Ca}$. Fonte: JENKINS \& HERMANOWICZ (1991).

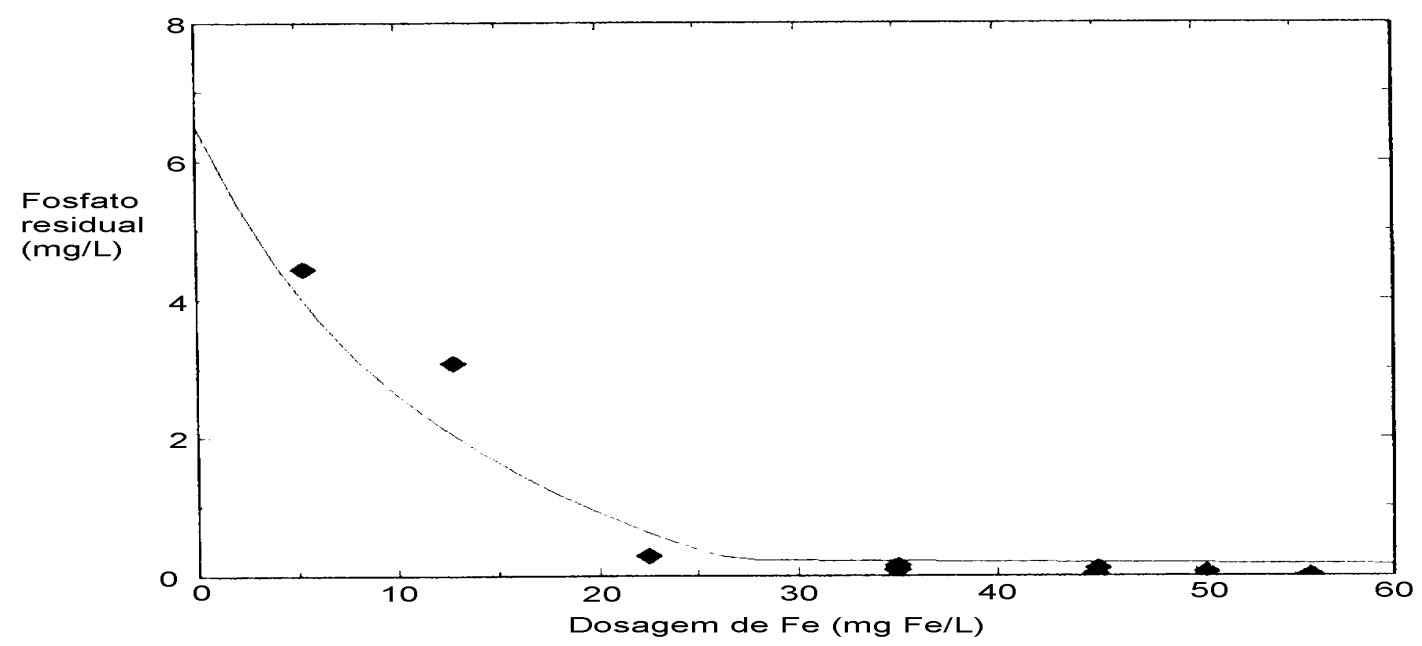

FIGURA 3.5 - Concentração de ortofosfato residual em função da dosagem de $\mathrm{Fe}^{3+}$ (pH não controlado e concentração de ortofosfato afluente entre 6 e $7 \mathrm{mg} / \mathrm{L}$ ). Fonte: (JENKINS \& HERMANOWICZ, 1991).

A remoção biológica de $\mathrm{P}$ tem a vantagem de evitar o uso de produtos químicos e a produção excessiva de lodo, quando comparada ao tratamento físico-químico primário. Entretanto, requer um sistema com configuração e regimes operacionais mais complexos. A remoção biológica de $\mathrm{P}$ alcança valores de $80 \%$ a $90 \%$, entretanto, a remoção é variável e, na prática, o enquadramento em padrões mais restritivos pode requerer precipitação química 
complementar (simultânea). Na teoria, o lodo da remoção biológica de P deveria ser mais biodisponível do que aquele da precipitação química, mas ainda são insuficientes as pesquisas realizadas para avaliar sua adequabilidade na agricultura (MORSE et al., 1998).

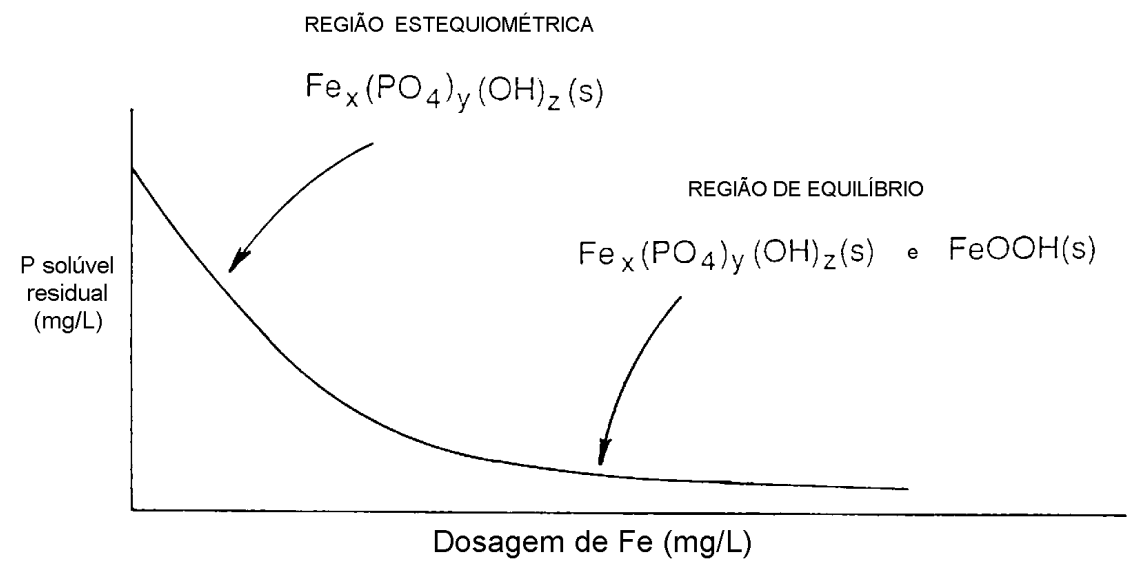

FIGURA 3.6 - Curva característica da concentração de ortofosfato residual em função da dosagem de Fe. Fonte: (JENKINS \& HERMANOWICZ, 1991).

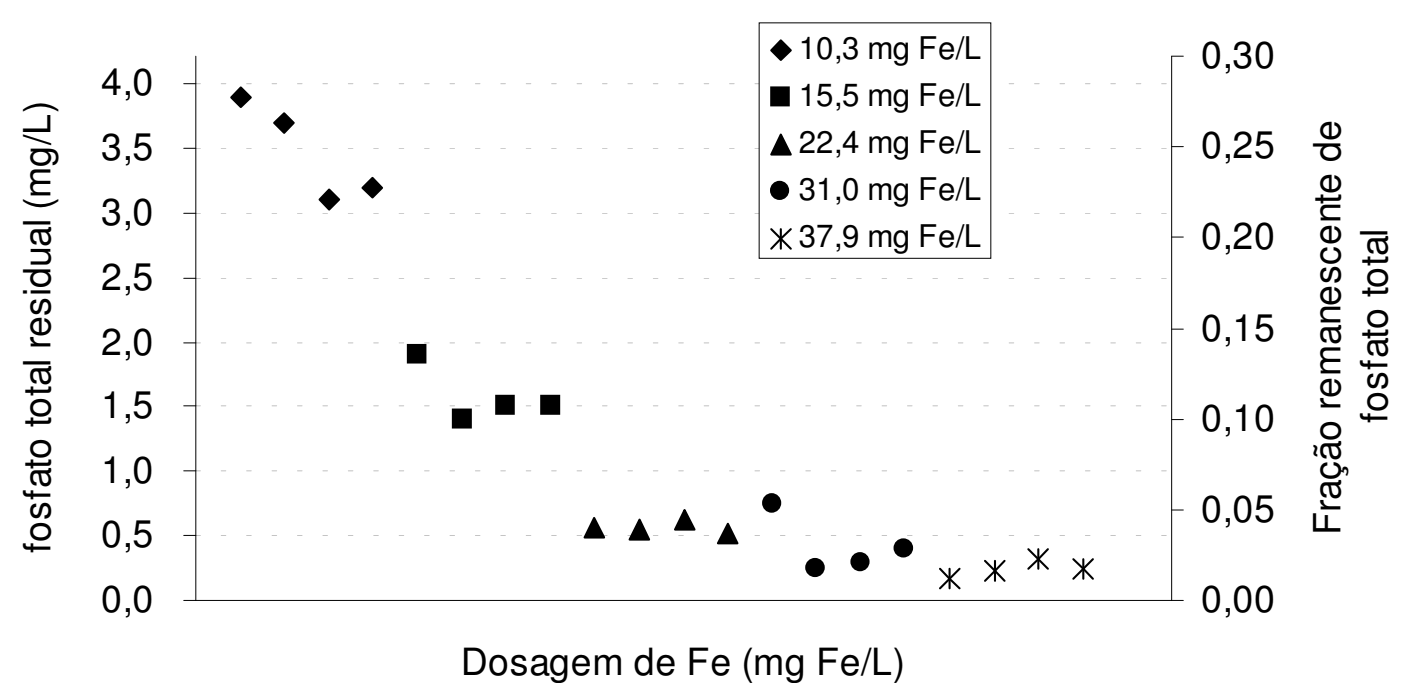

FIGURA 3.7 - Comportamento característico da concentração de fosfato total residual em função da dosagem de Fe, observado em ensaios de flotação de efluentes de reatores anaeróbios. Fonte: Adaptado de PENETRA (1998).

MAURER \& BOLLER (1998) concluem que um modelo geral e válido para a remoção biológica de $\mathrm{P}$ não pode ser formulado porque os parâmetros do modelo dependem da composição do esgoto, isto é, dos constituintes particulados e dissolvidos na água, mais do que das espécies de fósforo. A remoção biológica de fósforo é capaz de diminuir 
significativamente a quantidade de produtos químicos para precipitação ou mesmo eliminála. Entretanto, a natureza biológica da remoção de $\mathrm{P}$ e sua sensibilidade a variações do esgoto podem influenciar a capacidade de remoção de P. Estão documentados diversos exemplos de alta concentração de P no efluente final de ETEs após períodos de baixa carga afluente, tais como em fins de semana ou em dias chuvosos (PITMAN et al. ${ }^{3}$; MEGANCK et $a{ }^{4}{ }^{4}$ ). Há, desta forma, necessidade de precipitação química adicional para a redução da concentração de P no efluente final. TIEHM et al. (1999), estudando a distribuição de tamanho dos sólidos constituintes da matéria orgânica e do fósforo em esgoto sanitário, comentam que as quatro estações de tratamento de esgoto estudadas apresentavam a remoção biológica de fósforo. Entretanto, todas necessitam de precipitação química de $\mathrm{P}$ para atingir qualidade exigida para lançamento no corpo d’água.

ODEGAARD \& SKROVSETH (1997) fizeram uma investigação utilizando dados de monitoramento do tratamento e de sua respectiva estabilidade em 356 estações de tratamento de esgoto da Noruega, com diferentes processos adotados. Basicamente, três sistemas de tratamento foram estudados: unidades químicas, unidades biológicas e unidades biológicas/químicas. Dentre as unidades químicas, diferenciavam-se as unidades com precipitação primária (sem decantador primário) e unidades de precipitação secundária (com decantador primário). Dentre as unidades biológicas, diferenciavam-se unidades de lodos ativados e unidades com presença de biofilme. Dentre as unidades biológicas/químicas, observavam-se unidades de pré-precipitação (unidade química antes da unidade biológica), unidades de precipitação simultânea (precipitação química no tanque de aeração da unidade de lodos ativados), unidades de precipitação combinada (precipitação química depois do reator biológico com presença de biofilme) e pós-precipitação (precipitação química do efluente clarificado do sistema do biológico, normalmente lodos ativados). Os autores demonstraram que o sistema biológico/químico (com 87,3\% de remoção de DQO e 90,9\% de remoção de DBO) era superior ao biológico (com 81,3\% de remoção de DQO e 84,4\% de remoção de DBO) e ao químico (com 77,2\% de remoção de DQO e 73,7\% de remoção de DBO), com respeito à remoção de matéria orgânica. Com respeito a remoção de fósforo, a média dos sistemas químicos $(92,1 \%)$ foi idêntica à média dos sistemas biológicos/químicos $(92,1 \%)$ e muito superior ao biológico $(53,9 \%)$. Com relação aos sólidos suspensos, os diferentes sistemas apresentaram desempenho parecido (entre $87 \%$ e $91 \%$ ). A diferença

\footnotetext{
${ }^{3}$ PITMAN, A.R.; VENTER, S.L.V. \& NICHOLLS, H.A. (1983). Practical experience with biological phosphorus removal plants in Johannesburg. Water Science \& Technology, v.15, n.3-4, p.233-259.
} 
primária entre as unidades químicas e biológicas foi demonstrada pela superioridade da unidade química em remover fósforo. O teor médio do efluente da unidade química é impressionante e de somente $0,42 \mathrm{mgP} / \mathrm{L}$. As unidades biológicas removeram $50 \%$ do fósforo pelo efeito combinado da anaerobiose causada pelo volumoso tanque séptico, para o qual o lodo biológico é retornado, resultando em assimilação biológica de fósforo e pelo fato de que a fração particulada do fósforo é alta na Noruega. Os autores também concluíram que dentre os sistemas biológicos/químicos, as unidades de pós-precipitação (tratamento químico do efluente do sistema de lodos ativados) apresentaram melhores resultados do que as unidades de precipitação combinada (reator de biofilme seguido de tratamento químico). A precipitação simultânea (adição química na unidade de lodos ativados) apresentou os piores resultados de tratamento e foi considerado o sistema menos estável. Desta forma, baseados nos dados de 396 estações de tratamento de esgoto, os autores concluíram que as unidades biológicas/químicas apresentavam melhor estabilidade do que as unidades químicas e estas, por sua vez, apresentavam melhor estabilidade em relação às unidades biológicas.

KIURU \& RAUTIAINEN (1998) relatam o caso de uma ETE que foi construída originariamente (1978) com uma unidade de lodos ativados de baixa carga com precipitação simultânea de fósforo. Seis anos depois, a unidade foi complementada com um terceiro estágio de filtros flotantes para melhorar a remoção de sólidos suspensos e de fósforo. A nitrificação foi introduzida no processo de lodos ativados da unidade em 1987. O processo de lodos ativados da ETE foi modificado entre 1991 e 1993 para remoção de nitrogênio e entre 1994 e 1995 para remoção biológica de nitrogênio e de fósforo. A desnitrificação foi introduzida no processo e a precipitação simultânea de fósforo foi substituída pela remoção biológica deste. Na ocasião, a unidade estava operando há mais de 4 anos com remoção biológica de nitrogênio, aproveitando-se dos compostos orgânicos carbonáceos do esgoto. Uma pequena adição de precipitante ainda era utilizada para melhorar a remoção biológica de fósforo, que é geralmente menor que $0,3 \mathrm{mg} / \mathrm{L}$ e sempre menor do que $0,5 \mathrm{mg} / \mathrm{L}$.

Outro exemplo de como sistemas biológicos de remoção de fósforo são dependentes de tratamento químico complementar pode ser visto no trabalho de MÜNCH \& BARR (2001). Os autores comentam que a remoção biológica de fósforo (EBPR) é a tecnologia preferida para remover fósforo do esgoto em diversos casos. Entretanto, para unidades EBPR que usam digestores anaeróbios para tratamento do lodo, a dificuldade surge de como

\footnotetext{
${ }^{4}$ MEGANCK, M.; MALNOU, D.; LE FLOHIC, P.; FAUP, G.M. \& ROVEL, J.M. (1985). The importance of acidogenic microflora in biological phosphorus removal process. Water Science \& Technology, v.17, n.11-12, p.199-212.
} 
recircular o líquido remanescente da digestão, com alta concentração de fósforo e que contribui com uma carga significativa de fósforo para a unidade receptora. Essa recirculação de líquido remanescente da digestão origina-se de equipamentos de desaguamento de lodo digerido, tal como centrífugas e filtros-prensas. O líquido drenado ou filtrado desses equipamentos possui alta concentração de amônia e de fósforo porque estes compostos são liberados no processo de digestão anaeróbia. O fósforo que é incorporado na massa microbiana no processo EBPR é re-solubilizado sob as condições de um digestor anaeróbio. Se o líquido da digestão do lodo retorna para o início do tratamento, a maioria do P somente é recirculada e não removida. Para que o $\mathrm{P}$ fique no lodo, os autores sugerem a adição de hidróxido de magnésio $\left(\mathrm{Mg}(\mathrm{OH})_{2}\right)$ ou cloreto de magnésio $\left(\mathrm{MgCl}_{2}\right)$, caracterizando o processo de cristalização por estruvita.

SCHÖNBORN et al. (2001) estudaram a estabilidade de sistema de remoção biológica de fósforo (EBPR) com e sem dosagem adicional de metais. Durante o período experimental sem dosagem adicional de metais, o processo de eliminação de $\mathrm{P}$ foi totalmente instável. A média aritmética da eficiência de remoção de $\mathrm{P}$ foi de $84,9 \%$. O desvio padrão atingiu 19,7\%. A concentração efluente de $\mathrm{P}$ foi maior que $2 \mathrm{mg} / \mathrm{L}$ em $28 \%$ de todas as amostras e maior que $1 \mathrm{mg} / \mathrm{L}$ em $36 \%$ de todas as amostras. Durante a dosagem adicional de cálcio, a média aritmética da eficiência de eliminação de P foi de $89,9 \%$, o que significa 5\% mais do que sem adição de metais. Mas o alto desvio padrão de $15,1 \%$ torna evidente o fato de que o processo EBPR não era estável suficiente para garantir valores de $\mathrm{P}$ no efluente menores que 1 ou $2 \mathrm{mg} / \mathrm{L}$ continuamente. Durante a dosagem adicional de magnésio no afluente, a eficiência de remoção de $\mathrm{P}$ excedeu $80 \%$ em quase todos os casos. A média aritmética subiu para $97 \%$. O baixo desvio padrão, de somente $4 \%$, foi uma confirmação da alta estabilidade do processo EBPR mediante adição de magnésio. Os autores afirmam não ser razoável concluir que a alta estabilidade do EBPR foi causada pela precipitação química do fosfato de magnésio $\left(\mathrm{Mg}\left(\mathrm{NH}_{4}\right) \mathrm{PO}_{6} \cdot 6 \mathrm{H}_{2} \mathrm{O}\right)$. Devido a diferenças na solubilidade, a supersaturação da solução foi muito maior para compostos de fosfato de cálcio $\left(\mathrm{Ca}_{5}\left(\mathrm{PO}_{4}\right) \mathrm{OH}\right.$ e $\left.\mathrm{Ca}_{3}\left(\mathrm{PO}_{4}\right)_{2}\right)$ do que para os compostos de fosfato de magnésio. Isto significa que durante a adição de cálcio a eliminação de $\mathrm{P}$ deveria ser maior e mais estável do que durante a adição de magnésio, se a precipitação química fosse o mecanismo predominante. Os autores consideram que a introdução de magnésio auxiliou a fase biológica da remoção de $\mathrm{P}$.

Quando o efluente tratado de uma ETE possui um fim relativamente mais nobre do que seu lançamento em corpos d’água, a preocupação por parte dos projetistas em garantir 
efluentes com baixa concentração de fósforo pode ser visto no exemplo apresentado por LAW (1996). O referido autor apresenta o caso de um sistema de reuso de efluentes sanitários para áreas residenciais com fins não potáveis, mas somente para descarga em banheiros, para lavagem de carros, para irrigação de jardins e parques e para outros espaços abertos. O sistema atende 300 mil pessoas na Austrália. O sistema é composto por tratamento primário convencional, reator biológico projetado para remoção biológica de nitrogênio e fósforo, tratamento terciário composto de mistura rápida com adição de produto químico (alumínio, soda cáustica e polieletrólito), de floculação em 3 estágios com gradiente médio decrescente, clarificação e filtração e desinfecção com cloração e descloração. Um sistema de controle e aquisição de dados foi incorporado para monitoramento e controle da ETE. Um analisador de orto-P foi instalado na tubulação do efluente filtrado para controlar a dosagem de alumínio e assegurar a obediência aos padrões de $\mathrm{P}$ de $0,3 \mathrm{mg} / \mathrm{L}$ em $90 \%$ do tempo.

CALLADO \& FORESTI (2001) estudaram a eficiência de sistema em escala de laboratório composto de dois reatores seqüenciais em batelada, caracterizando um sistema anaeróbio/aeróbio de tratamento de esgoto. Ambos os reatores, com 12,5 L de volume útil cada, foram operados em ciclos de 12 horas recebendo 8,0 L de substrato (esgoto sintético) em cada ciclo, em temperatura controlada e constante de $28^{\circ} \mathrm{C} \pm 1{ }^{\circ} \mathrm{C}$. O primeiro reator (anaeróbio) era responsável por remover grande parte da matéria carbonácea e de promover a amonificação do substrato. O segundo reator (aeróbio) era operado alternadamente em condições aeróbias e anóxicas para o estabelecimento de condições para obtenção da nitrificação. A desnitrificação e a remoção biológica de fósforo ocorriam no mesmo ciclo. Entretanto, para a efetiva remoção biológica de fósforo, era necessária a adição de acetato de sódio, produto químico utilizado como fonte de carbono para os microrganismos, na dosagem de $500 \mathrm{mg} / \mathrm{L}$.

A estabilidade da remoção biológica de fósforo ainda é fortemente dependente da variabilidade das características físico-químicas do esgoto. Espera-se que o avanço da microbiologia e da biologia molecular na área de saneamento, sobretudo no tratamento de esgoto, consiga fornecer alternativas eficientes e estáveis para a remoção biológica de fósforo. A remoção estável de fósforo é fundamental para a viabilização da sua recuperação em larga escala, fornecendo alternativa ambientalmente sustentável à extração de $\mathrm{P}$ de rochas fosfáticas.

A breve história da tecnologia de remoção e de recuperação de $\mathrm{P}$ e sua referida legislação é baseada na premissa de que o fósforo é necessariamente um problema 
ambiental. Entretanto, uma nova visão acerca do assunto está em desenvolvimento. A remoção e, sobretudo, a recuperação do fósforo a partir de esgoto e de lodos apresentam-se como uma oportunidade ambiental ainda maior. A obtenção de fósforo em estações de tratamento de esgoto pode gradativamente substituir a atual tecnologia de obtenção de fosfatos a partir de rochas fosfáticas (MORSE et al., 1998).

YEOMAN et al. (1993) relatam que as autoridades têm implementado restrições ao uso de fósforo na composição química dos detergentes. Entretanto, o êxito de tais medidas tem sido limitado e o fósforo ainda continua sendo largamente utilizado na fabricação de detergentes.

SCHMID \& McKINNEY (1969), para demonstrar o aumento da concentração de fósforo no esgoto decorrente do advento dos detergentes, dizem que, em 1940, cada norteamericano era, em média, responsável pela eliminação diária de $0,75 \mathrm{~g}$ de fósforo. Já em 1960, após o advento dos detergentes, esta média passou para 3,2 g diárias, dos quais 2,2 g provinham de produtos de limpeza. ESTEVES (1988) comenta que em 1978 um habitante da Europa Central eliminava diariamente 4,2 $\mathrm{g}$ de $\mathrm{P}$, dos quais 2,7 g provinham de produtos de limpeza. MORSE et al. (1998) relatam que diariamente acima de $2 \mathrm{~g}$ de $\mathrm{P}$ são descarregados no esgoto por cada indivíduo. Liberado no ambiente aquático, pode contribuir para um problema ambiental (eutrofização) e seu potencial de reciclagem é perdido. Entretanto, o fósforo presente no esgoto representa uma considerável fonte renovável prontamente disponível para exploração, resultando em torno de 250 mil toneladas anuais na Europa Ocidental, comparável com as necessidades da indústria de fosfato.

No presente, a produção comercial de $\mathrm{P}$ é baseada quase que exclusivamente na exploração da rocha fosfática - composta de fosfato de cálcio em várias formas e combinada com uma ampla gama de impurezas. A produção primária pode usar o processo termal para obter o P elementar mas este procedimento é pouco usado atualmente por causa das desvantagens ambientais e do aumento dos custos da energia. A rota de produção dominante utiliza o chamado "processo molhado" onde a rocha fosfática reage com o ácido sulfúrico para produção de ácido fosfórico impuro (freqüentemente chamado "ácido verde") e resíduos de sulfato de cálcio e fosfato. $\mathrm{O}$ sulfato de cálcio é geralmente enterrado ou descartado no mar. Mas o ácido verde ainda contém a maior parte das impurezas da rocha, incluindo traços de metais pesados, tais como cádmio, zinco, urânio e outros, além de algumas substâncias húmicas, arsênicos e fluoretos. O ácido verde intermediário é transportado e processado posteriormente dependendo de seu uso final (MORSE et al., 1998). Visando recuperar o fosfato perdido nos resíduos, ABDEL-AAL (1999) estudou a recuperação do ácido fosfórico presente nos resíduos finais gerados na obtenção de fosfatos 
a partir de rochas fosfáticas, com utilização de ácido clorídrico, em substituição ao ácido sulfúrico. Desta forma, cerca de $99 \%$ do fosfato que seria descartado como resíduo pode ser recuperado.

O uso do ácido fosfórico, extraído das rochas pelas fábricas produtoras, pode ser dividido em fertilizantes e em fosfatos industriais. Para produção de fertilizantes, há relativamente baixo nível de processamento posterior para converter o $\mathrm{P}$ em mais uma forma mais solúvel e, então, em forma mais biodisponível. Como exemplo, pode-se citar a adição de ácido fosfórico a rochas fosfáticas para conversão de fosfato de tricálcio insolúvel a fosfato monocálcio relativamente solúvel. Entretanto, a fabricação de fertilizantes não prevê remoção significativa das impurezas retidas no ácido verde. Desta forma, essas impurezas são introduzidas no ambiente agriculturável quando o fertilizante é empregado. As aplicações industriais do P cobrem uma ampla gama de variedades de produtos, incluindo aqueles utilizados no tratamento de água, detergentes, inibidores de corrosão, tintas, comidas e bebidas, farmacêuticos e muitos outros. Ao contrário dos fertilizantes, os padrões de qualidade são muito maiores, requerendo purificação posterior do ácido verde intermediário a um nível onde todas ou quase todas as impurezas são removidas. Remoções maiores de $99 \%$ das impurezas são necessárias e especificamente para aplicações alimentares as impurezas são reduzidas a menos de $1 \mathrm{ppm}$. A indústria atual é baseada na utilização do fosfato de cálcio como material bruto e, apesar de não haver carência imediata, as reservas de alta qualidade de rocha são finitas e a prática de extração e processamento dos fosfatos é insustentável. O uso de fontes renováveis oferece a vantagem imediata de evitar os impactos ambientais associados com a exploração primária de rocha fosfática. E de grande interesse é a certeza de que muitos lodos de estações de tratamento de esgoto apresentam teores de impureza consideravelmente menores do que as rochas fosfáticas, oferecendo a vantagem de um material bruto mais limpo e renovável. Os benefícios ambientais resultantes são decorrentes da eliminação do lançamento das impurezas das rochas fosfáticas no ambiente terrestre (MORSE et al., 1998).

Os pesquisadores têm buscado novas técnicas para recuperação do fósforo a partir de lodo gerado no tratamento de esgoto. TAKAHASHI et al. (2001) desenvolveram estudo sobre técnica de recuperação de fósforo a partir de cinzas oriundas de lodo incinerado gerado no tratamento de esgoto. A recuperação era obtida pela adição de ácido sulfúrico às cinzas para extração do fósforo. O estudo determinou que, após um álcali ser adicionado para ajustar o pH da extração para 4,0, o fósforo era posteriormente recuperado por 
filtração.Além disso, quando o álcali era adicionado para ajuste do $\mathrm{pH}$ em 10,0, a recuperação de vários metais pesados era observada.

Idealmente, os materiais recuperados usando tecnologia de remoção e de recuperação de fosfatos deveriam estar prontamente disponíveis para reuso, dependendo de limitado processamento posterior. Para uso como fertilizante, a mais simples forma de reciclagem é a prática presente de espalhar estercos ou lodo de esgoto na terra agriculturável. Entretanto, por causa da ampla variação na concentração de $\mathrm{P}$ e sua biodisponibilidade nos lodos, o valor econômico do P é pequeno e incerto, quando há, para os fazendeiros. As futuras pesquisas tecnológicas necessitam complementação através de pesquisas ambientais para investigar mais detalhadamente os benefícios ambientais, econômicos e sociais. Atualmente, a indústria do fósforo é altamente concentrada e eficiente, enquanto os serviços de tratamento de esgoto são mais distribuídos. Entretanto, é possível contemplar unidades de processamento menores e mais simples em ETEs, responsáveis pelo fosfato recuperado para satisfazer a demanda da horticultura e da agricultura. Também pode-se produzir um material bruto concentrado para transporte para unidades distantes onde os materiais de maior pureza são fabricados. É necessária a cooperação entre diversos organismos, tendo o Governo na liderança. A cooperação e a liderança do Governo são necessárias para o avanço nas questões relativas ao fósforo em direção à sua produção ambientalmente sustentável (MORSE et al., 1998).

Considerando os aspectos físico-químicos e biológicos, vários pesquisadores, além daqueles já citados, têm procurado aprofundar o entendimento dos mecanismos de remoção química e biológica do fósforo e sua inter-relação com os demais constituintes das águas residuárias, bem como o desenvolvimento de novos sistemas de tratamento de águas residuárias visando a remoção de fósforo. Dentre eles, pode-se citar FERGUSON \& HORRES (1979), ANTE et al. (1994), PRIHA (1994), RÖSKE \& SCHÖNBORN (1994), TAYLOR et al. (1994), XIE et al. (1994), ARSOV et al. (1995), CARUCCI et al. (1995), HEINRICH (1995), NGO \& VIGNESWARAN (1996), UPTON et al. (1996).

\subsection{Reatores anaeróbios de leito expandido (RALEx)}

CAMPOS \& PEREIRA (1999) comentam que, de maneira geral, os reatores anaeróbios ainda não apresentam concepção otimizada quando se consideram as condições hidrodinâmicas, muito embora apresentem boas condições de funcionamento quando dimensionados segundo os critérios atuais de projeto. Dentre os reatores anaeróbios, os de leito expandido, por sua vez, seriam aqueles que oferecem as melhores condições hidrodinâmicas. Por este motivo, os projetos desses tipos de reator adotam tempos de 
detenção hidráulica menores do que aqueles utilizados em outros reatores conhecidos. No reator anaeróbio de leito expandido (RALEx), os microrganismos crescem aderidos ao leito suporte, mantido em suspensão pelo movimento ascendente do líquido. Em comparação com reatores UASB, as velocidades ascensionais do líquido empregadas em reatores RALEx são muito maiores em decorrência da maior densidade das biopartículas observadas no RALEx (material suporte + biofilme) em comparação com aquela observada no reator UASB (grânulos biológicos). O reator RALEx é um reator vertical, com fluxo ascendente em velocidade adequada para manter a suspensão das partículas do leito suporte (usualmente com tamanho entre 0,2 e 2,0 mm). A pequena dimensão das partículas proporciona grande superfície específica para fixação dos microrganismos. Considera-se que os reatores de leito expandido são classificados como reatores de leito móvel e filme fixo. Os reatores de leito expandido são constituídos por região de reação, região de retenção de sólidos em suspensão, dispositivo de coleta de biogás e sistema de recirculação, conforme esquematizado na FIGURA 3.8. A degradação do substrato ocorre primordialmente na região de reação. Para evitar o carreamento de partículas suspensas no efluente tratado e a perda de biopartículas, a região de retenção de sólidos suspensos é construída no próprio reator ou pode-se adotar uma unidade independente. A flexibilidade e a segurança durante a operação do reator são proporcionadas pelo emprego do sistema de recirculação de parcela do efluente, de modo a se alcançar velocidades ascensionais do líquido que proporcionem melhores condições de transferência de massa. Como todas as demais unidades de tratamento, os reatores RALEx apresentam aspectos positivos e negativos. Dentre os positivos, destacam-se:

1. A alta concentração de biomassa ativa aderida ao leito suporte permite significativa retenção de microrganismos e elevada eficiência na conversão de substratos orgânicos biodegradáveis.

2. Os custos de implantação tendem a serem menores em relação aos de outros reatores, em função da redução da área necessária e do menor volume do reator, para tratamento da mesma vazão afluente.

3. A pequena espessura do biofilme facilita a difusão do substrato.

4. A movimentação do leito suporte evita problemas de colmatação.

5. A grande área específica da biopartícula ocasiona boas condições de transferência de massa.

6. A facilidade para introduzir material novo ao leito e para remoção de sólidos gerados (lodo). 
Dentre os aspectos negativos, destacam-se:

1. O pequeno número de reatores operando em escala real que possa servir de base para novos projetos.

2. O consumo de energia elétrica maior do que o de outros tipos mais simples de reatores anaeróbios.

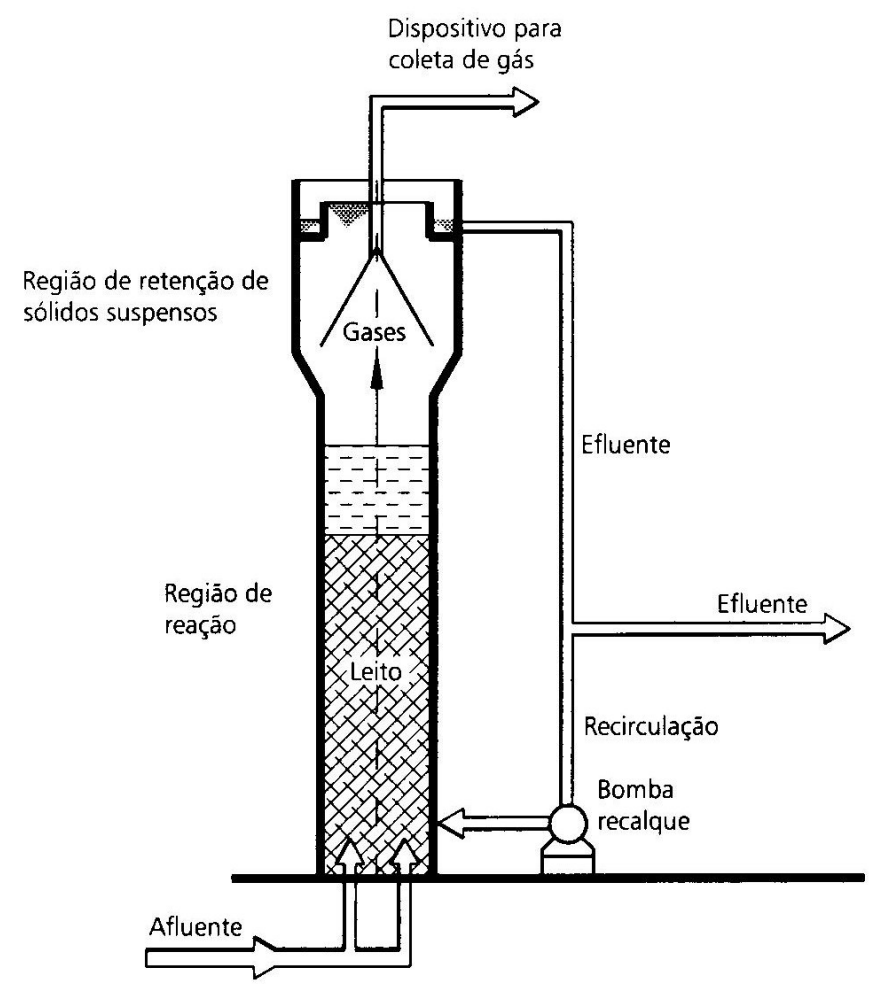

FIGURA 3.8 - Esquema do reator anaeróbio de leito expandido. Fonte: Campos \& Pereira (1999).

Com relação à aplicabilidade de reatores anaeróbios de leito expandido, CAMPOS \& PEREIRA (1999) afirmam que os resultados de trabalhos experimentais já demonstraram que os reatores RALEx podem ser utilizados para tratamento anaeróbio e aeróbio de efluentes líquidos industriais e de esgoto sanitário, com excelentes resultados. Evidentemente, as condições que definem a eficiência dos reatores dependem da concepção de configuração da unidade, das características do material suporte, da composição do esgoto (presença de materiais tóxicos ou de óleos e graxas) e dos controles operacionais (velocidade ascensional, tempo de detenção hidráulico, temperatura de operação etc.). Contudo, há reatores, alimentados por esgoto sanitário, que, com tempo de detenção hidráulica total de aproximadamente 3 horas, estão apresentando eficiência média de 
remoção de DQO próxima de 80\%, conforme relatado por PEREIRA et al. (1999). Os referidos autores realizaram experimento utilizando reator anaeróbio de leito expandido, com 1,5 m de diâmetro na base e 14,9 m de altura, instalado no Campus da Escola de Engenharia de São Carlos para tratamento de $10,5 \mathrm{~m}^{3} / \mathrm{h}$ de esgoto sanitário de 1535 habitantes. A operação de partida do reator foi realizada sem inoculação prévia e com leito formado por $1500 \mathrm{~kg}$ de partículas de Carvão Ativado Granular (CAG), com tamanho médio de 2,0 mm, porosidade inicial de 0,564 e altura estática de $1,70 \mathrm{~m}$. O reator apresentou eficiência média de 78\% de remoção de Demanda Química de Oxigênio (DQO) nos 18 meses de funcionamento, para amostras coletadas no horário das 8:30.

A opção por modulação dos reatores e a reduzida área necessária para sua construção reduzem os custos de desapropriação de áreas urbanas, contribuindo para consolidação da concepção alternativa de sistemas de esgotamento sanitário descentralizados. Essa descentralização das ETEs é significativamente importante em razão de o crescimento das áreas urbanas não ser acompanhado pela infra-estrutura. Há também que se considerar os elevados custos para construção de redes coletoras de grandes dimensões, de estações elevatórias de esgoto na chegada das ETEs e de estações de tratamento de grande porte. É possível concluir que a pequena área para implantação, a eficiência do tratamento e o investimento com custo reduzido despertará cada vez mais o interesse de pesquisadores e usuários para esse tipo de reator, fazendo com que aumente sensivelmente o número de unidades para tratamento de esgoto sanitário em regiões urbanas brasileiras (CAMPOS \& PEREIRA, 1999).

Notadamente, a reduzida necessidade de área para implantação é um aspecto positivo e já reconhecido dos reatores RALEx. A flotação por ar dissolvido também caracteriza-se pela reduzida necessidade de área, tendo em vista a adoção de elevadas taxas de aplicação superficial em seu dimensionamento. Sendo assim, a associação destas duas tecnologias resulta em configurações de estações de tratamento de esgoto extremamente compactas, oferecendo suporte para adoção desse sistema combinado quando há escassez de área ou quando se opta pelo tratamento descentralizado do esgoto. 


\section{MATERIAIS E MÉTODOS}

\subsection{Considerações iniciais}

Conforme descrito no capítulo 2, o propósito principal deste trabalho foi testar e quantificar os principais parâmetros envolvidos no pós-tratamento físico-químico por flotação por ar dissolvido (FAD) de efluente de reator anaeróbio de leito expandido (RALEx), quando tratando esgoto sanitário. Para promover a coagulação do efluente do reator RALEx, foram utilizados, isoladamente ou associados, cloreto férrico e polímeros sintéticos. A soda cáustica foi empregada para promover a elevação do $\mathrm{pH}$ de coagulação, bem como o ácido sulfúrico foi utilizado para a redução do $\mathrm{pH}$ quando o cloreto férrico era utilizado. Os parâmetros testados e quantificados foram: características dos polímeros sintéticos, dosagem de produto químico (DCF e/ou DP), pH de coagulação (pHcoag), gradiente médio de velocidade de floculação (Gf), tempo total de floculação (Tf), tempo de floculação do polímero (Tfpol), horário de coleta do efluente do reator anaeróbio utilizado nos ensaios de laboratório, quantidade de ar fornecida ( $\left.S^{*}\right)$ e taxa de aplicação superficial (TAS). O trabalho foi desenvolvido em duas fases distintas: ensaios em escala de laboratório (flotateste) e ensaios em unidade piloto (flotador) (conforme mostrado nas FIGURAS 4.1 a 4.4).

As características físico-químicas e biológicas do efluente do reator RALEx variam ao longo do dia, do mês e do ano. Por este motivo, foi adotado um procedimento padrão, descrito no item 4.4, para coleta e armazenamento das amostras do esgoto bruto e do efluente do reator RALEx utilizadas nos ensaios de laboratório.

Nesses ensaios, foi utilizado equipamento de floculação/flotação, em escala de laboratório (flotateste). Para os ensaios em escala piloto, foi utilizada uma unidade de coagulação/floculação/flotação por ar dissolvido com escoamento contínuo (flotador), projetada e construída para ser utilizada inicialmente nesta pesquisa e posteriormente na Estação de Tratamento de Esgotos do Campus USP-São Carlos.

Nos ensaios de laboratório foi avaliada a influência dos seguintes parâmetros na eficiência da flotação: 
1. Capacidade dos polímeros sintéticos na remoção de DQO, de fósforo e de turbidez dos efluentes do reator anaeróbio,

2. Dosagem de produto químico na coagulação do efluente do reator anaeróbio (DCF e/ou DP),

3. $\mathrm{pH}$ de coagulação (pHcoag),

4. Gradiente médio de velocidade de floculação (Gf) e tempo total de floculação (Tf),

5. Tempo de floculação do polímero (Tfpol),

6. Efeito da variação horária das características do afluente ao flotador utilizado nos ensaios de laboratório,

7. Quantidade de ar fornecida $\left(\mathrm{S}^{*}\right) \mathrm{e}$

8. Velocidade de flotação (Vf).

Os valores encontrados em laboratório foram posteriormente utilizados nos ensaios em escala piloto, quando, então, foram reavaliados os parâmetros DCF, DP, Gf, Tf, S* e TAS.

O tempo de detenção hidráulica do efluente do reator RALEx no flotador era de aproximadamente quarenta minutos, o que possibilitava a determinação da eficiência do processo de FAD a partir dos resultados puntuais, ou seja, a partir de amostras coletadas simultaneamente. Entretanto, por se tratar de um sistema composto (RALEx + FAD), julgou-se interessante a avaliação da eficiência global do sistema. Ocorre que o tempo de detenção hidráulica do esgoto bruto dentro do RALEx era de três horas, aproximadamente, o que inviabilizava a determinação da eficiência do sistema a partir de resultados puntuais. A partir dessa constatação, surgiu a necessidade de conhecer algumas características físicoquímicas do esgoto bruto afluente e do efluente do RALEx ao longo do dia (8:00 às 20:00) e da noite (20:00 às 8:00). Portanto, além dos ensaios já previstos, foi acrescentada uma etapa adicional onde foi realizada uma caracterização físico-química simplificada destes dois líquidos, abrangendo os dois períodos.

\subsection{Programação dos ensaios}

\subsubsection{Ensaios de laboratório utilizando o equipamento Flotateste}

A primeira e a segunda etapa de ensaios foram realizadas em laboratório, utilizando o equipamento Flotateste. 
Na primeira etapa de ensaios, procurou-se, inicialmente, identificar qual polímero, dentre os testados e atuando como coagulante primário, apresentava a maior eficiência de remoção de DQO, de fósforo e de turbidez dos efluentes do reator anaeróbio após a coagulação/floculação/flotação. A partir da escolha de alguns destes polímeros, foi investigada a sua atuação como auxiliar de floculação, mediante prévia coagulação com cloreto férrico. A influência da variação da qualidade do efluente do reator anaeróbio, na eficiência de tratamento, também foi investigada na primeira etapa. Da mesma forma, diferentes valores de pH de coagulação foram testados para determinar sua influência na eficiência de tratamento. O fluxograma auto-explicativo de ensaios desta etapa é mostrado na FIGURA 4.1.

$\mathrm{Na}$ segunda etapa de ensaios, estudou-se a associação de produtos químicos no tratamento físico-químico, com o emprego de diferentes dosagens de cloreto férrico, atuando como coagulante primário, e de polímero sintético, atuando como auxiliar de floculação. Nessa etapa, também foram investigados aspectos da floculação dos efluentes do reator anaeróbio e da quantidade de ar fornecida à flotação. O fluxograma auto-explicativo de ensaios desta etapa é mostrado na FIGURA 4.2.

\subsubsection{Ensaios de campo utilizando unidade de flotação em escala piloto}

A terceira e a quarta etapa de ensaios foram realizadas em campo, utilizando a unidade de flotação em escala piloto.

$\mathrm{Na}$ terceira etapa de ensaios, a unidade de flotação foi operada continuamente para que sua eficiência de tratamento fosse testada com diferentes valores de taxa de aplicação superficial e de quantidade de ar fornecida ao processo, com diferentes tempos e gradientes médios de velocidade de floculação e com variação da dosagem de cloreto férrico. $O$ fluxograma auto-explicativo de ensaios desta etapa é mostrado na FIGURA 4.3.

$\mathrm{Na}$ quarta etapa de ensaios, a unidade de flotação continuou a ser operada continuamente para que sua eficiência de tratamento fosse testada mediante a variação da dosagem combinada de cloreto férrico e de polímero sintético. Para essa nova condição de coagulação, também foram investigados diferentes valores de taxa de aplicação superficial, de quantidade de ar fornecida ao processo e de tempo de floculação. O fluxograma autoexplicativo de ensaios desta etapa é mostrado na FIGURA 4.4. 


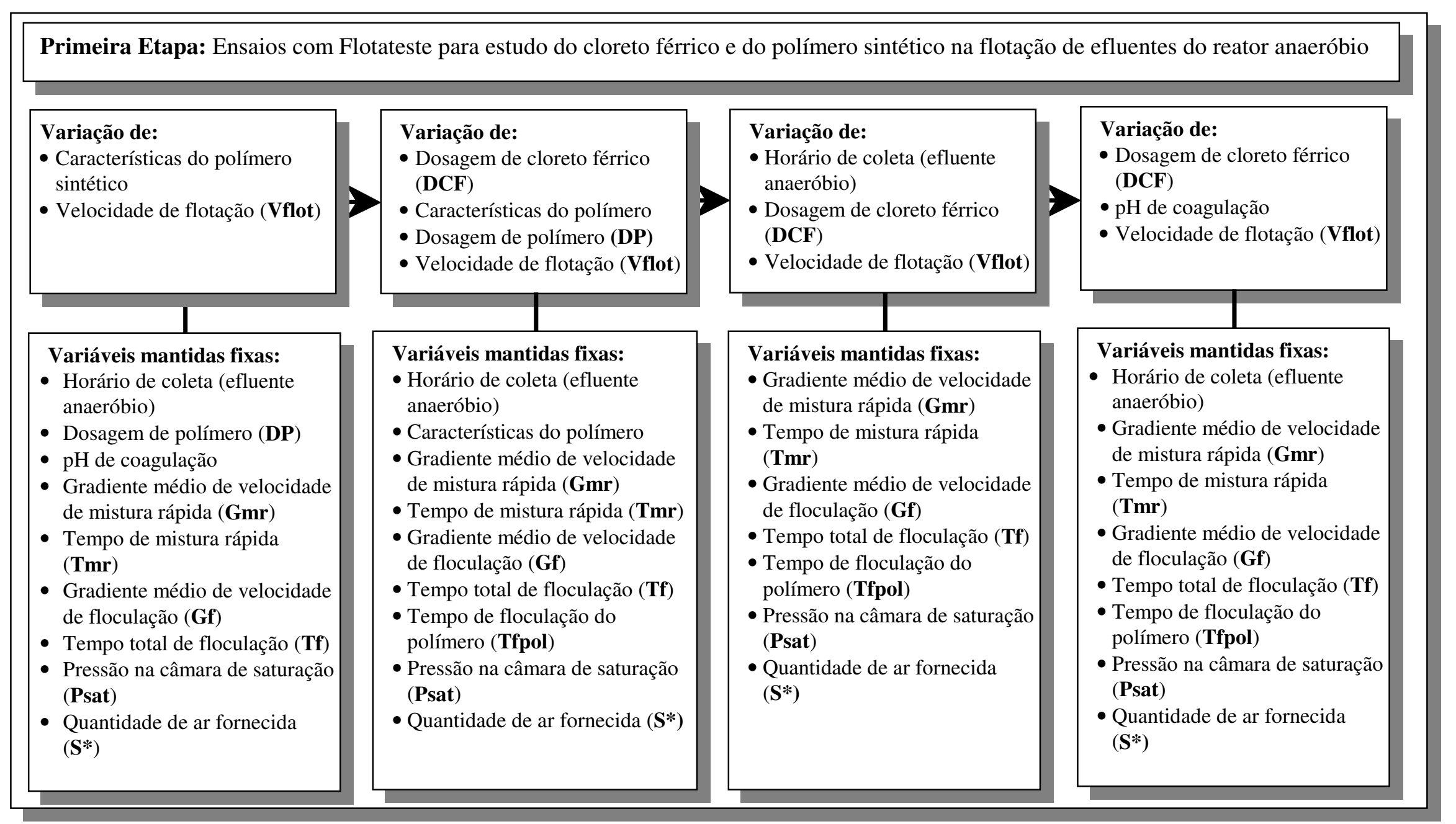

FIGURA 4.1 - Fluxograma do método adotado para ensaios preliminares de coagulação-floculação-flotação utilizando cloreto férrico e polímero sintético no pós-tratamento físico-químico de efluentes de reator RALEx. 


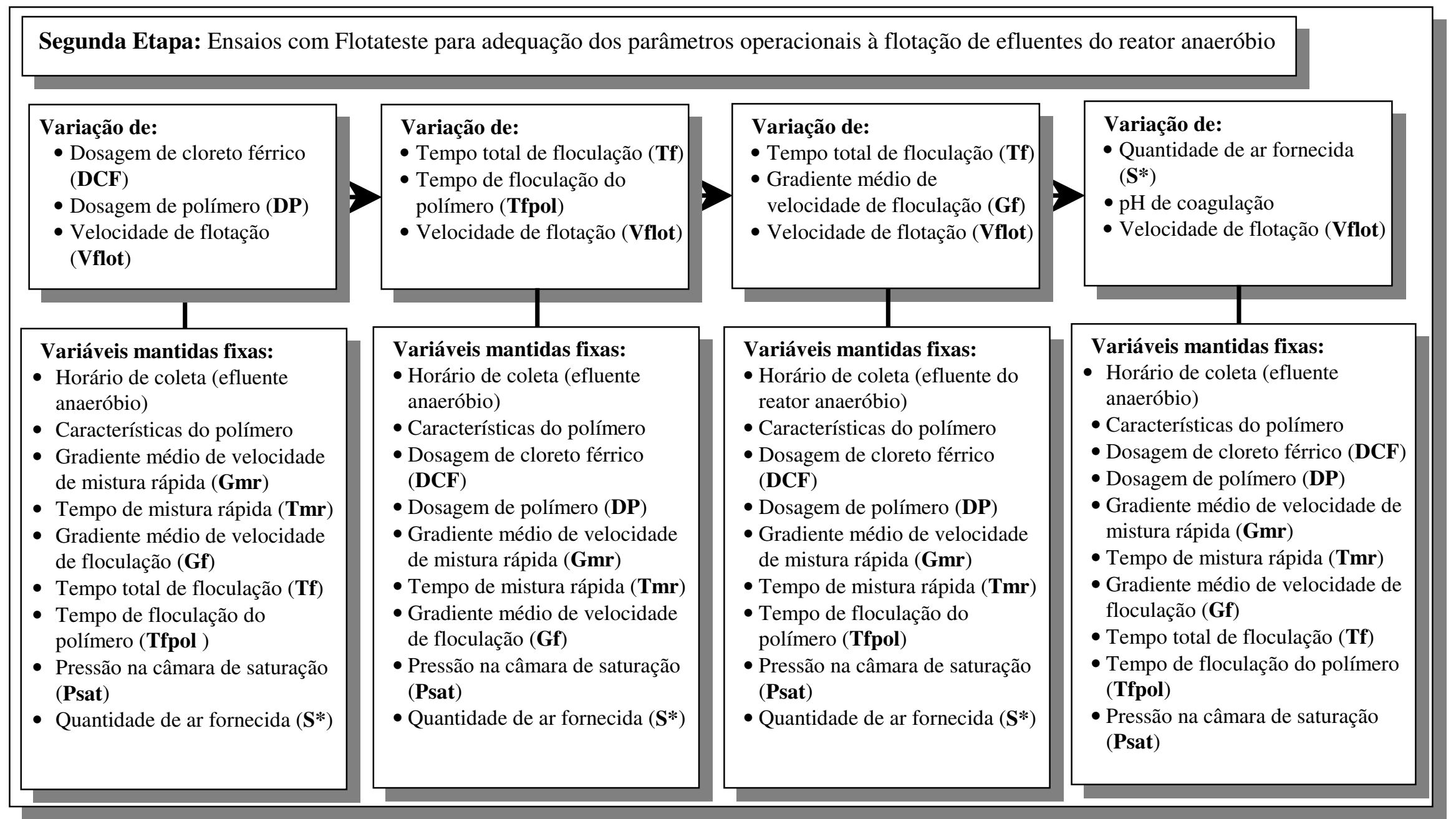

FIGURA 4.2 - Fluxograma do método adotado para ensaios de coagulação-floculação-flotação utilizando cloreto férrico e polímero sintético no póstratamento físico-químico de efluentes de reator RALEx. 


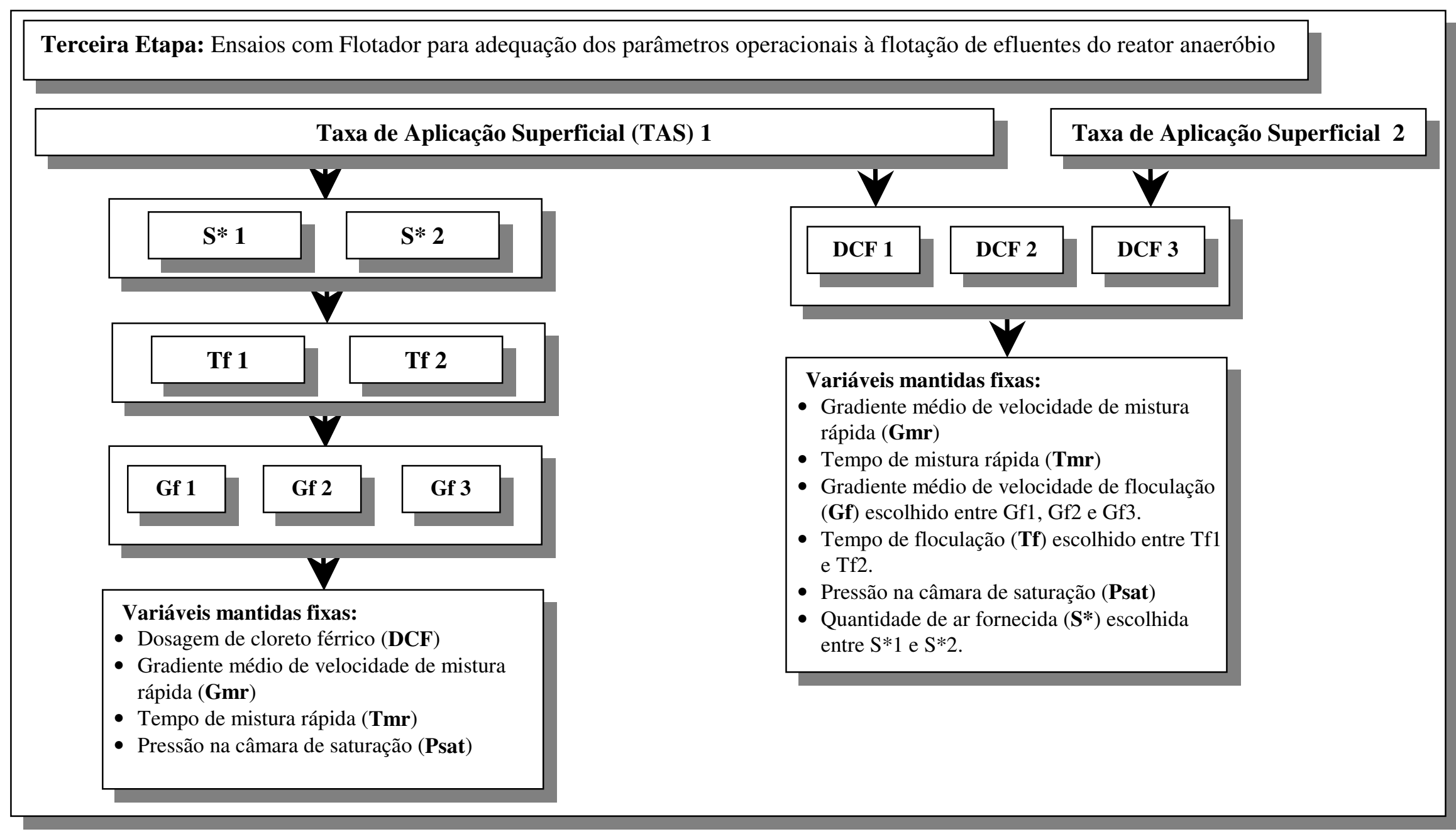

FIGURA 4.3 - Fluxograma do método adotado para ensaios de coagulação-floculação-flotação utilizando cloreto férrico no pós-tratamento físicoquímico de efluentes de reator RALEx, utilizando unidade piloto com escoamento contínuo (flotador). 


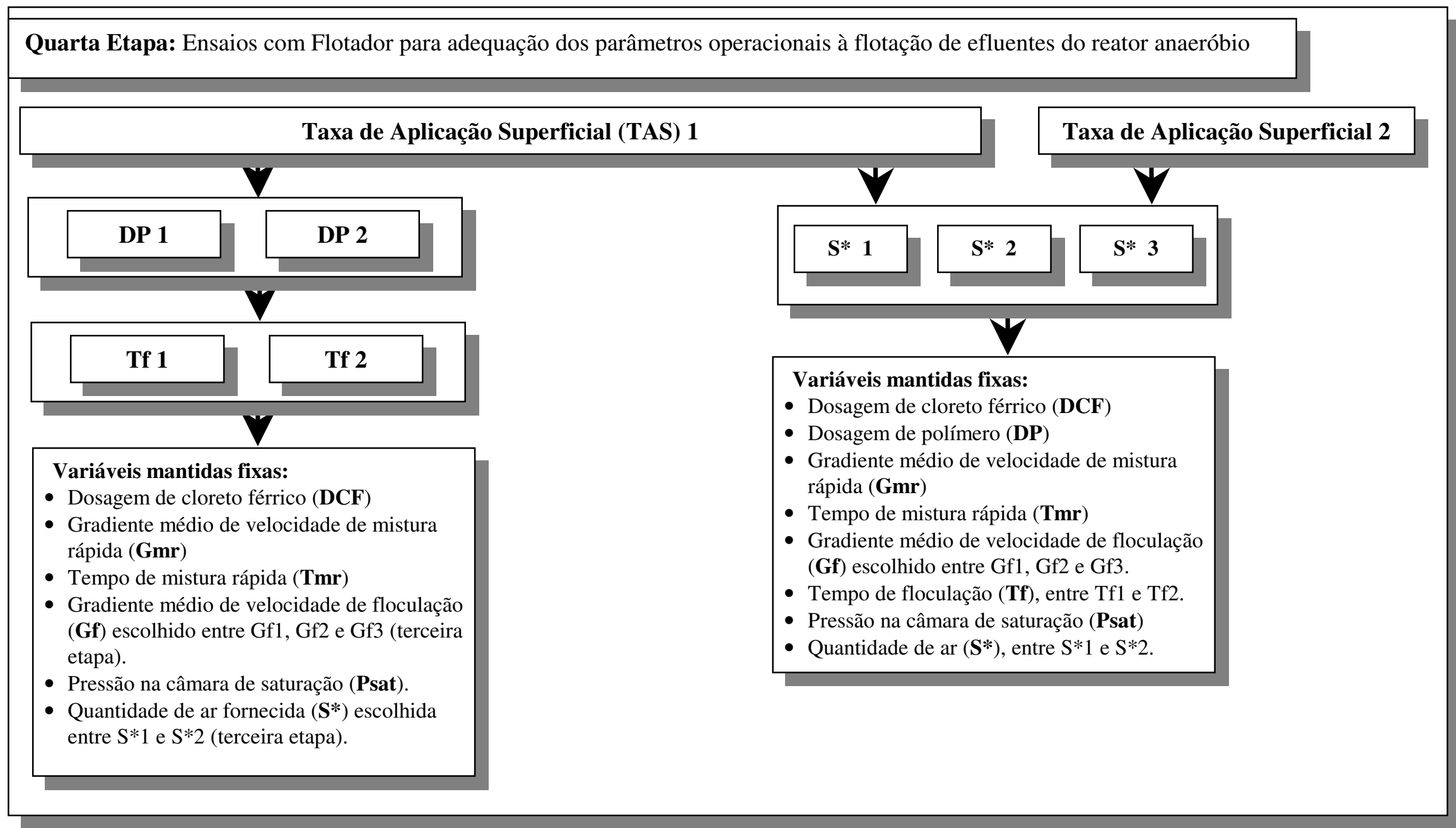

FIGURA 4.4 - Fluxograma do método adotado para ensaios de coagulação-floculação-flotação utilizando cloreto férrico e polímero sintético no póstratamento físico-químico de efluentes de reator RALEx, utilizando unidade piloto com escoamento contínuo (flotador). 


\subsection{Descrição das instalações}

\subsubsection{Equipamento de floculação/flotação em escala de laboratório (flotateste)}

O equipamento, mostrado na FIGURA 4.5 e na FIGURA 4.6, foi desenvolvido no Departamento de Hidráulica e Saneamento da EESC-USP. Especificamente, durante a presente investigação, essa unidade foi construída para ser utilizada nos ensaios de flotação de águas residuárias. O flotateste é composto por quatro colunas cilíndricas independentes entre si e interligadas a uma câmara de saturação. Cada coluna possuía $60 \mathrm{~mm}$ de diâmetro interno, $900 \mathrm{~mm}$ de altura, $5 \mathrm{~mm}$ de parede de acrílico e capacidade útil de 2,5 litros.

Para efetuar a floculação, cada coluna possuía agitador próprio (tipo eixo vertical, paletas paralelas ao eixo, dois braços e uma paleta por braço) impulsionado por meio de um conjunto moto-redutor e ligado a um regulador de tensão para controle da energia fornecida para a floculação (rotação do agitador).

Para efetuar a flotação, cada coluna foi interligada a uma câmara de saturação construída a partir de tubo acrílico com $10 \mathrm{~mm}$ de espessura de parede, $105 \mathrm{~mm}$ de diâmetro interno, $1000 \mathrm{~mm}$ de altura e 7 litros de volume útil. Para sua operação e controle, a câmara de saturação possuía manômetro, válvula de segurança, entrada de ar comprimido e entrada de água proveniente da rede de abastecimento público. O ar comprimido era fornecido por compressor de ar marca Shultz, modelo MSI-2.6 VL40, C56 JZ, 1² CV, 850 rpm. A entrada da água saturada nas colunas de flotação era controlada por registros de agulha.

Para coleta de amostra líquida, cada coluna possuía pequenos orifícios ao longo de sua altura. A partir da caracterização dessas amostras coletadas, foram construídas as 'curvas de flotação', conforme método proposto por REALI (1991). Tais curvas possibilitam uma melhor comparação do desempenho da flotação nas diferentes condições de estudo.

\subsubsection{Instalação piloto de coagulação/floculação/flotação por ar dissolvido com escoamento contínuo (flotador)}

Na FIGURA 4.7 é mostrado um esquema simplificado do flotador utilizado durante a pesquisa. Na FIGURA 4.8 podem ser observadas as dimensões de cada unidade constituinte do sistema de FAD. Em particular, as dimensões e características do sistema de floculação são mostradas na FIGURA 4.9. Fotografias do flotador e do sistema (RALEx e flotador) são mostradas, respectivamente, na FIGURA 4.10 e na FIGURA 4.11. Mais especificamente, são mostrados detalhes de alguns componentes do sistema piloto nas FIGURAS 4.12 a 4.13. 


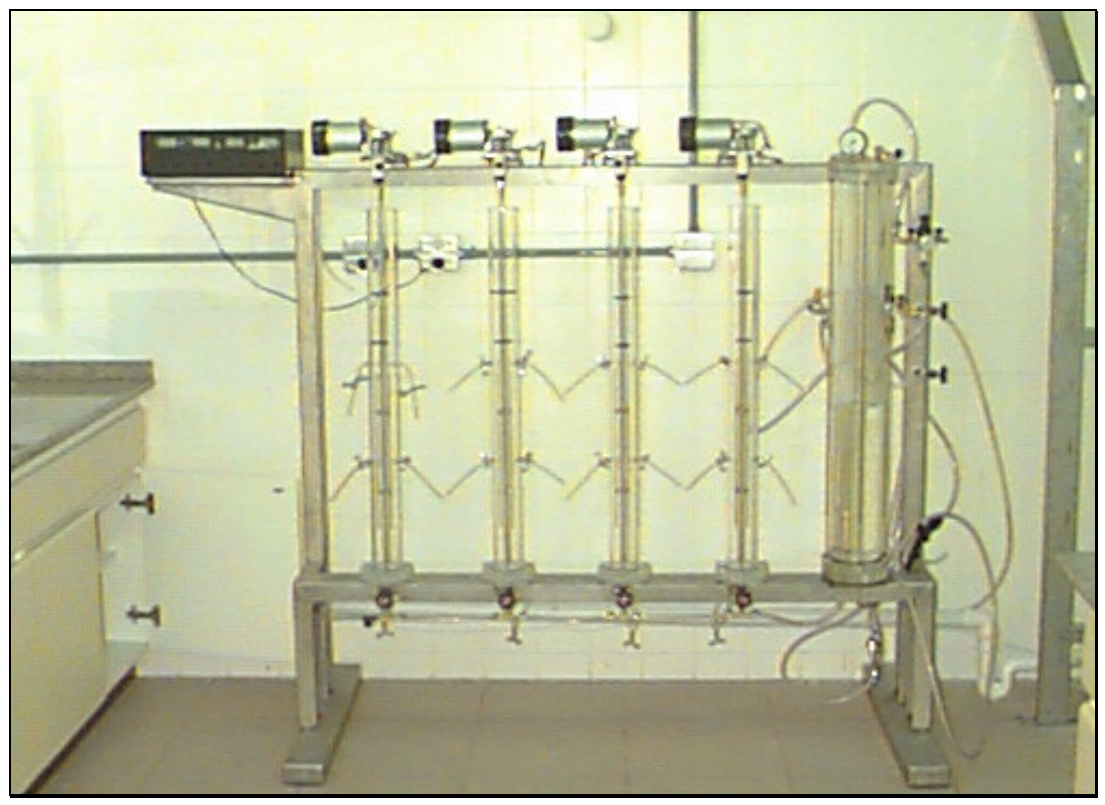

FIGURA 4.5 - Fotografia do equipamento de floculação/flotação em escala de laboratório (flotateste).

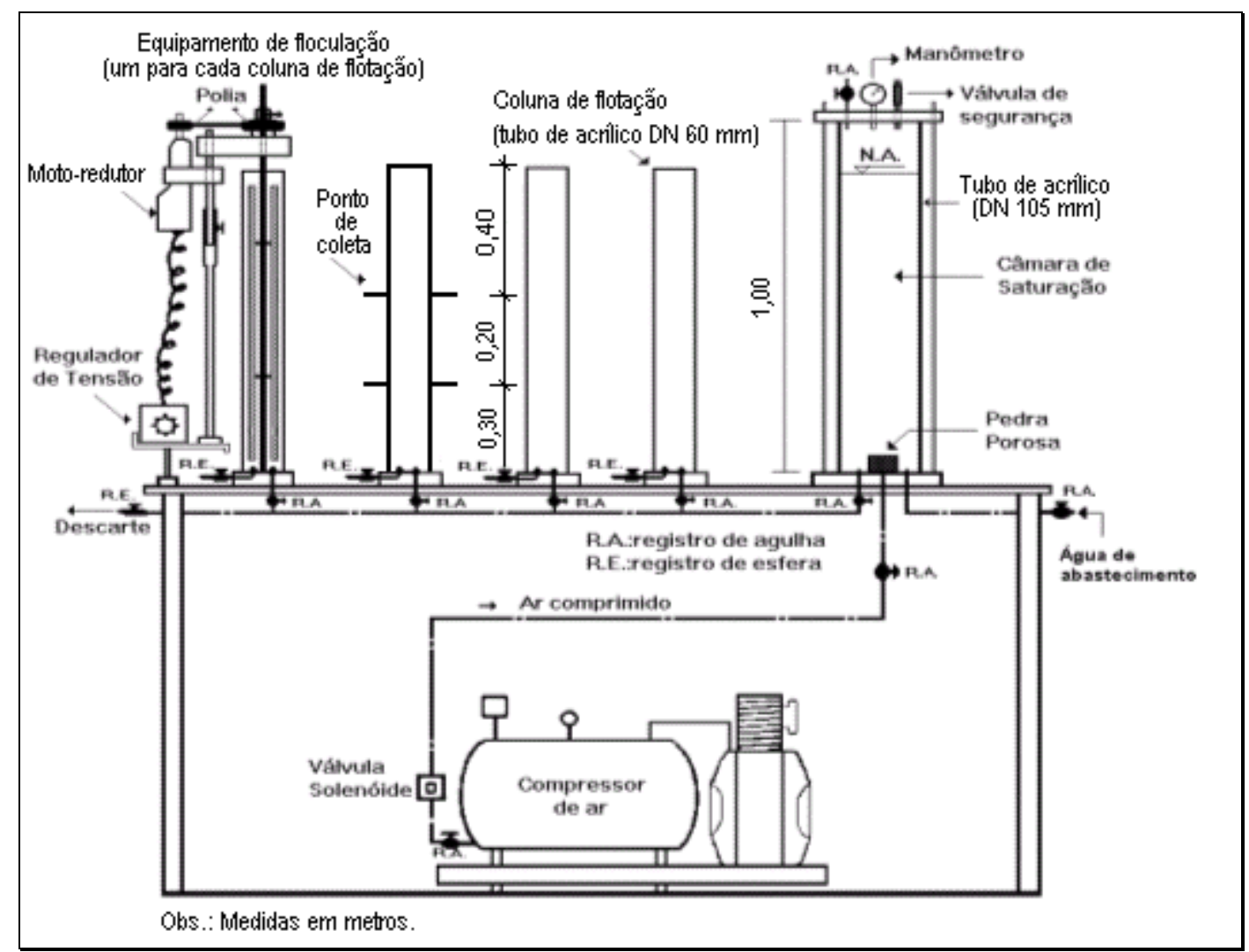

FIGURA 4.6 - Esquema geral do flotateste. Fonte: adaptado de REALI, 1994. 
O sistema de coagulação/floculação/flotação era constituído, inicialmente, por um medidor eletromagnético da vazão afluente (efluente do reator anaeróbio) ao sistema (FIGURA 4.12 - 1).

Na seqüência, havia um dispositivo de mistura de cloreto férrico na tubulação de recalque do efluente do reator anaeróbio (FIGURA 4.12 - 2), dimensionado e construído para promover a mistura rápida do coagulante com o efluente do reator RALEx.

Depois da mistura rápida, havia o sistema de controle de vazão para cada uma das três primeiras câmaras de floculação (FIGURA 4.12 - 3). Esse sistema permitiu a utilização de duas, três ou quatro câmaras de floculação, proporcionando flexibilidade em estudos de tempo de floculação. O sistema de floculação era composto por quatro câmaras em série, contendo agitadores lentos mecanizados com eixo vertical e paletas paralelas ao eixo (FIGURA 4.12 - 4). Entre a terceira e a última câmara de floculação, situava-se o ponto de dosagem de polímero sintético (FIGURA 4.12 - 5). Na última câmara de floculação havia um ponto de descarte de líquido floculado (FIGURA 4.12 - 6). Esse descarte possibilitava o estudo de diferentes taxas de aplicação superficial da câmara de flotação sem alteração do tempo de floculação. Para controle da vazão descartada, havia um medidor eletromagnético de vazão (FIGURA 4.13 - 7).

Após as câmaras de floculação, o líquido floculado era introduzido na câmara de flotação por ar dissolvido, onde era misturado ao líquido recirculado saturado com ar dissolvido, proveniente da câmara de saturação (FIGURA 4.13 - 8). Essa mistura ocorria na zona de contato (FIGURA 4.13 - 9), propiciando a colisão e a aderência das microbolhas aos flocos, resultando em um fluxo ascensional dos flocos em direção à superfície, formando uma camada de lodo flotado, continuamente removido por raspador superficial (FIGURA 4.13 - 10) e encaminhado para a Rede Coletora de Esgotos do Campus USP-São Carlos (FIGURA 4.13 - 11).

Após sua clarificação, o líquido passava por vertedor controlador do nível d’água (FIGURA 4.13 - 12) e era despejado em uma câmara acumuladora. Essa unidade destinavase à manutenção do volume de líquido a ser bombeado para a câmara de saturação. A vazão excedente era, então, enviada a Rede Municipal de Esgotos (FIGURA 4.13 - 13). A parcela bombeada para a câmara de saturação foi denominada vazão de recirculação do sistema (FIGURA 4.13 - 14). 


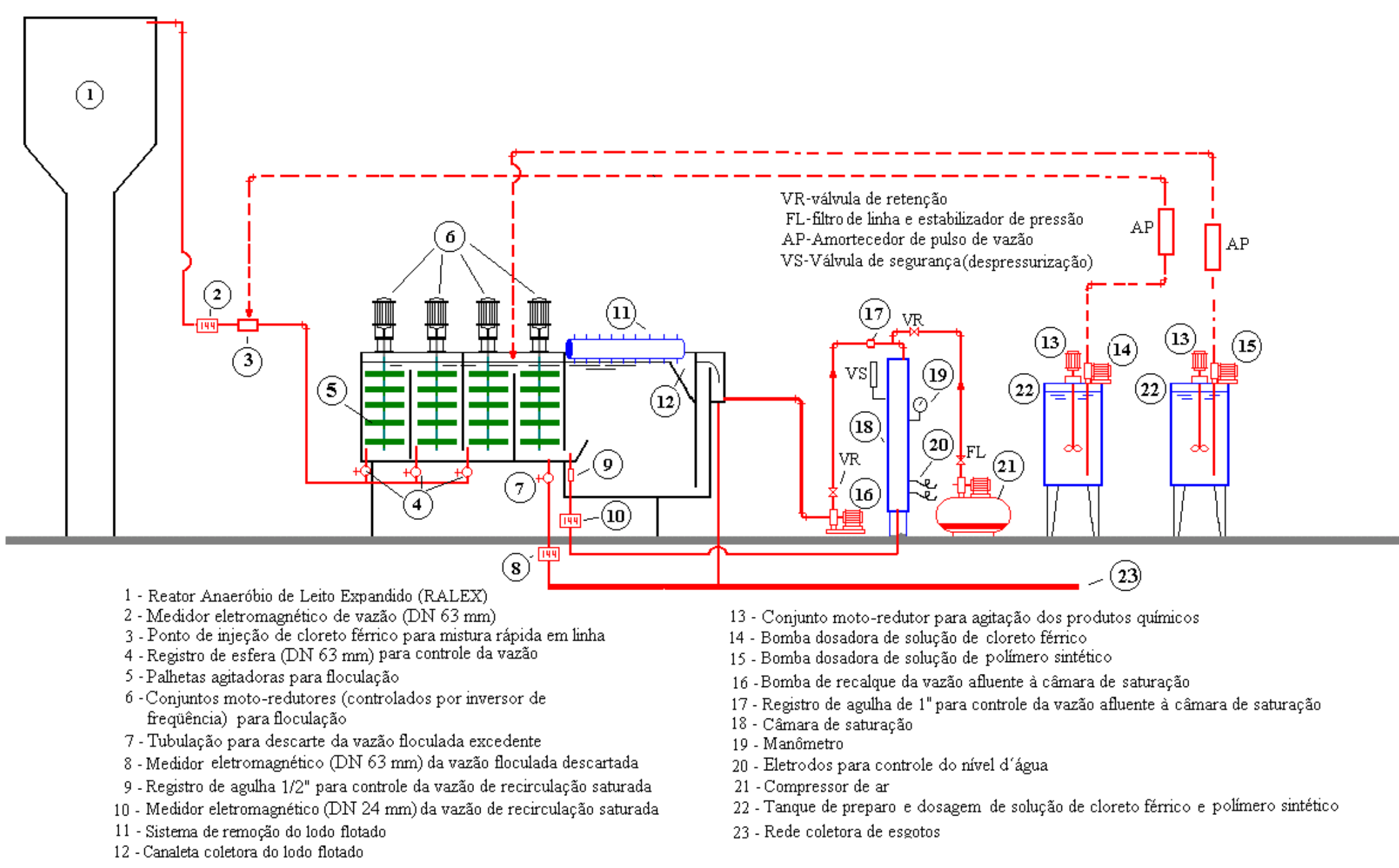

FIGURA 4.7 - Esquema simplificado da instalação piloto de coagulação/floculação/flotação por ar dissolvido com escoamento contínuo (flotador). 


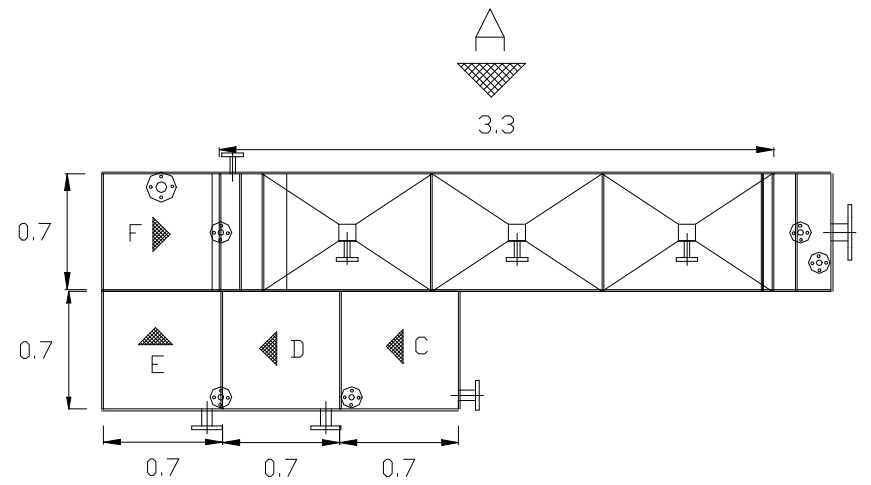

Vista Superior
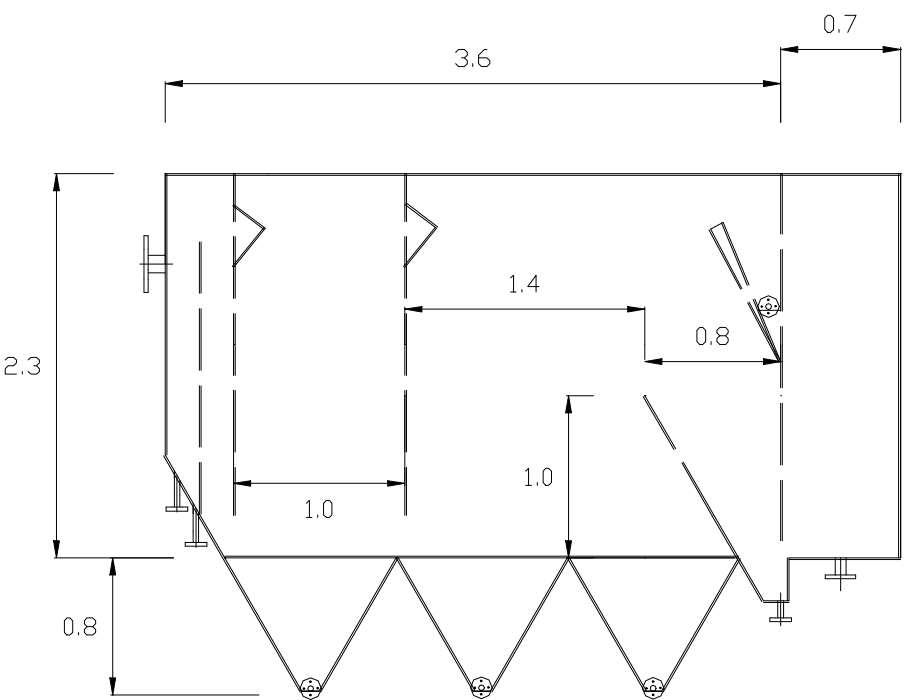

Vista A
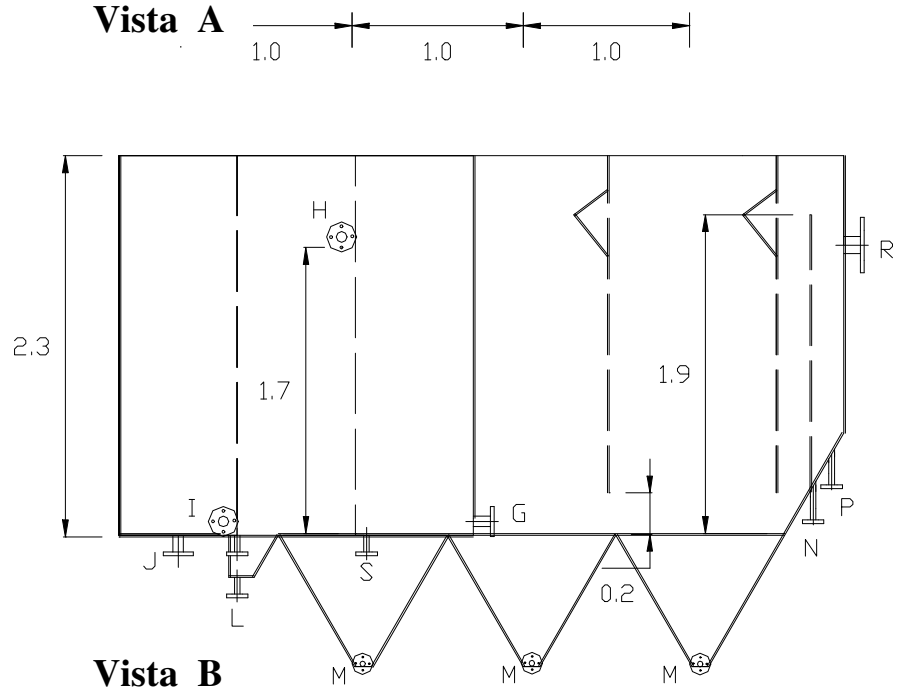

G - flange para tubulação de entrada da primeira câmara de floculação.

H - flange para tubulação de entrada da segunda câmara de floculação.

I - flange para tubulação de entrada da terceira câmara de floculação.

$\mathbf{J}$ - flange para tubulação de descarte de vazão floculada excedente.

$\mathbf{L}, \mathbf{M}, \mathbf{N}$ e $\mathbf{S}$ - flange para tubulação de esvaziamento do flotador.

$\mathbf{N}$ - flange para tubulação de sucção de parcela do efluente clarificado para recirculação pressurizada.

$\mathbf{R}$ - flange para tubulação de descarte do efluente clarificado.

FIGURA 4.8 - Vistas superior e laterais da instalação piloto de coagulação/floculação/ flotação por ar dissolvido com escoamento contínuo (flotador). Medidas em metro. 

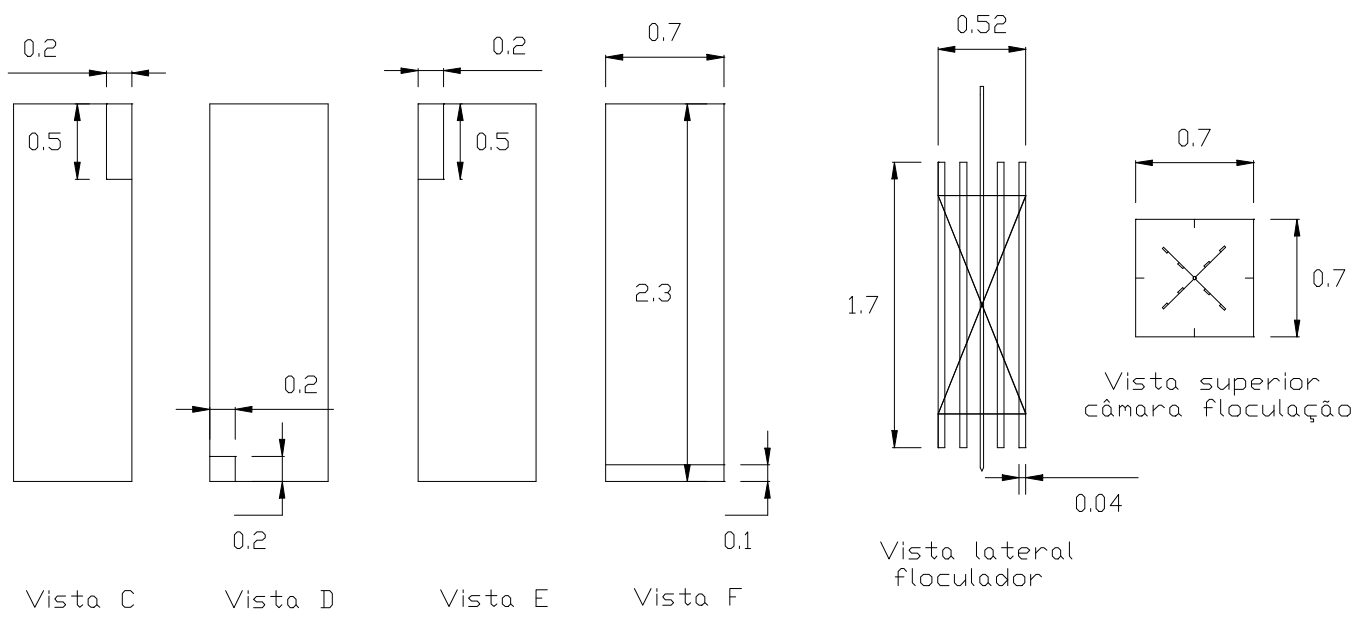

FIGURA 4.9 - Vistas do sistema de floculação da unidade piloto de coagulação-floculaçãoflotação. Medidas em metro.

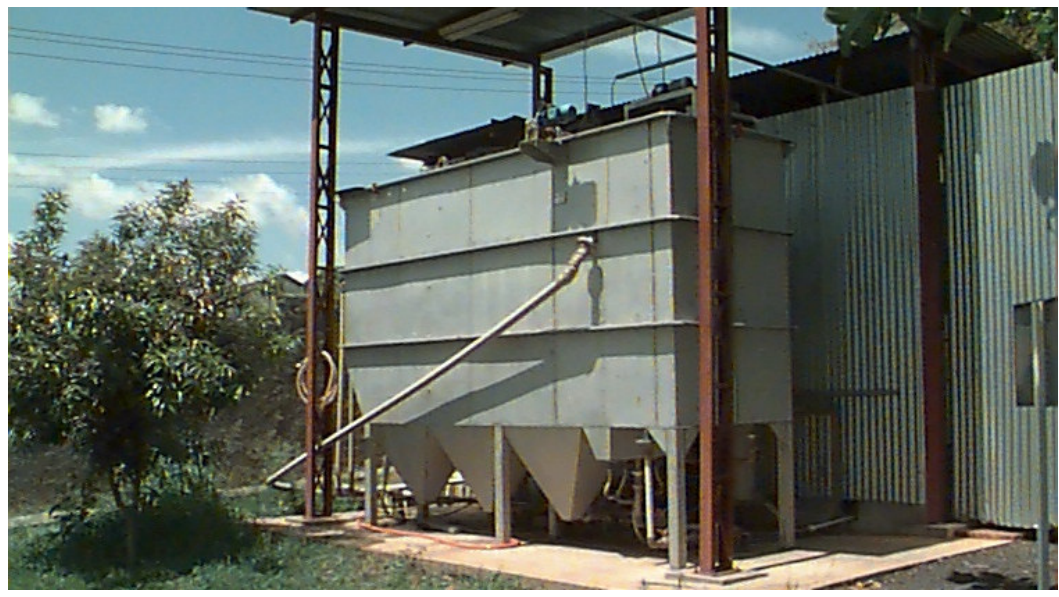

FIGURA 4.10 - Fotografia da instalação piloto de coagulação/floculação/flotação por ar dissolvido com escoamento contínuo (flotador).

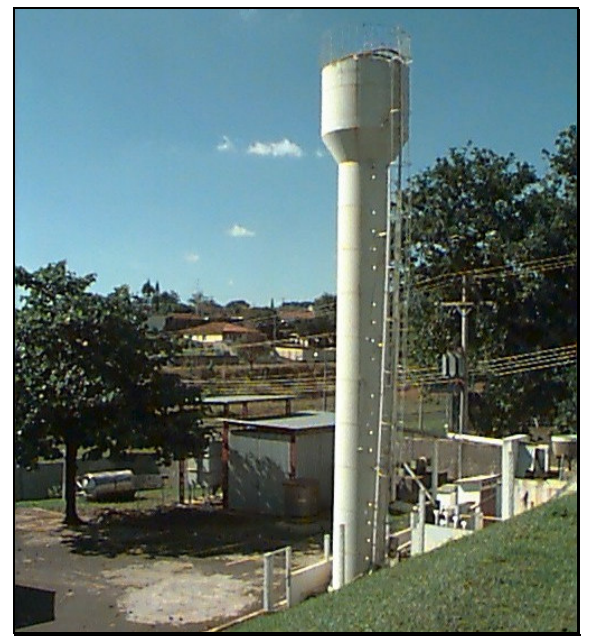

FIGURA 4.11 - Fotografia do sistema de tratamento composto por reator RALEx e flotador. 


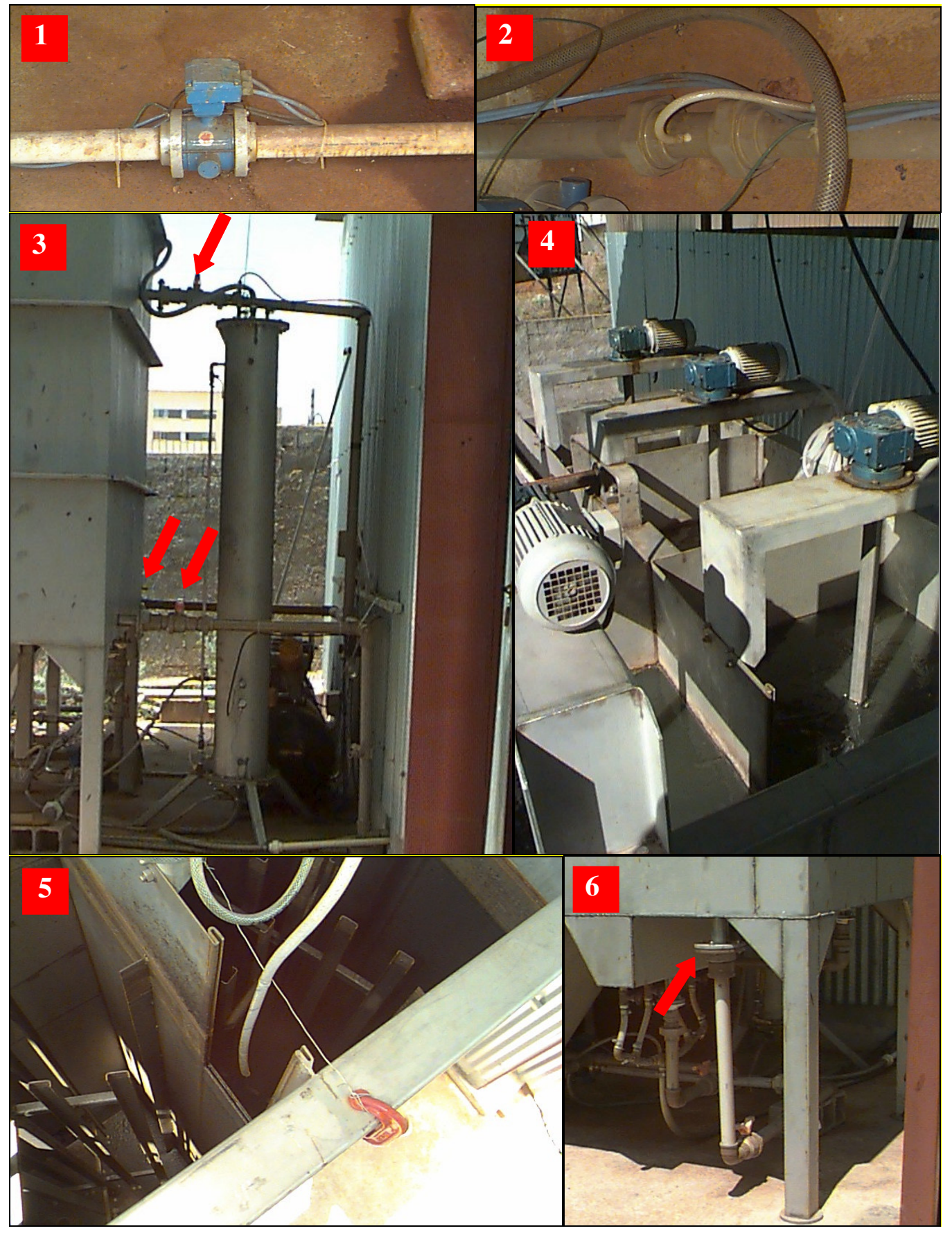

FIGURA 4.12 - Unidades constituintes do sistema de coagulação-floculação-flotação em escala piloto. (1) Medidor eletromagnético de vazão afluente ao sistema (efluente do reator anaeróbio); (2) Unidade para dosagem do cloreto férrico diretamente na tubulação (mistura rápida em linha); (3) Controle de vazão para as diferentes câmaras de floculação; (4) Sistema de floculação, composto por quatro câmaras de floculação com moto-redutores e agitadores; (5) Ponto de dosagem de polímero sintético durante a floculação; (6) Sistema para remoção da vazão floculada excedente. 


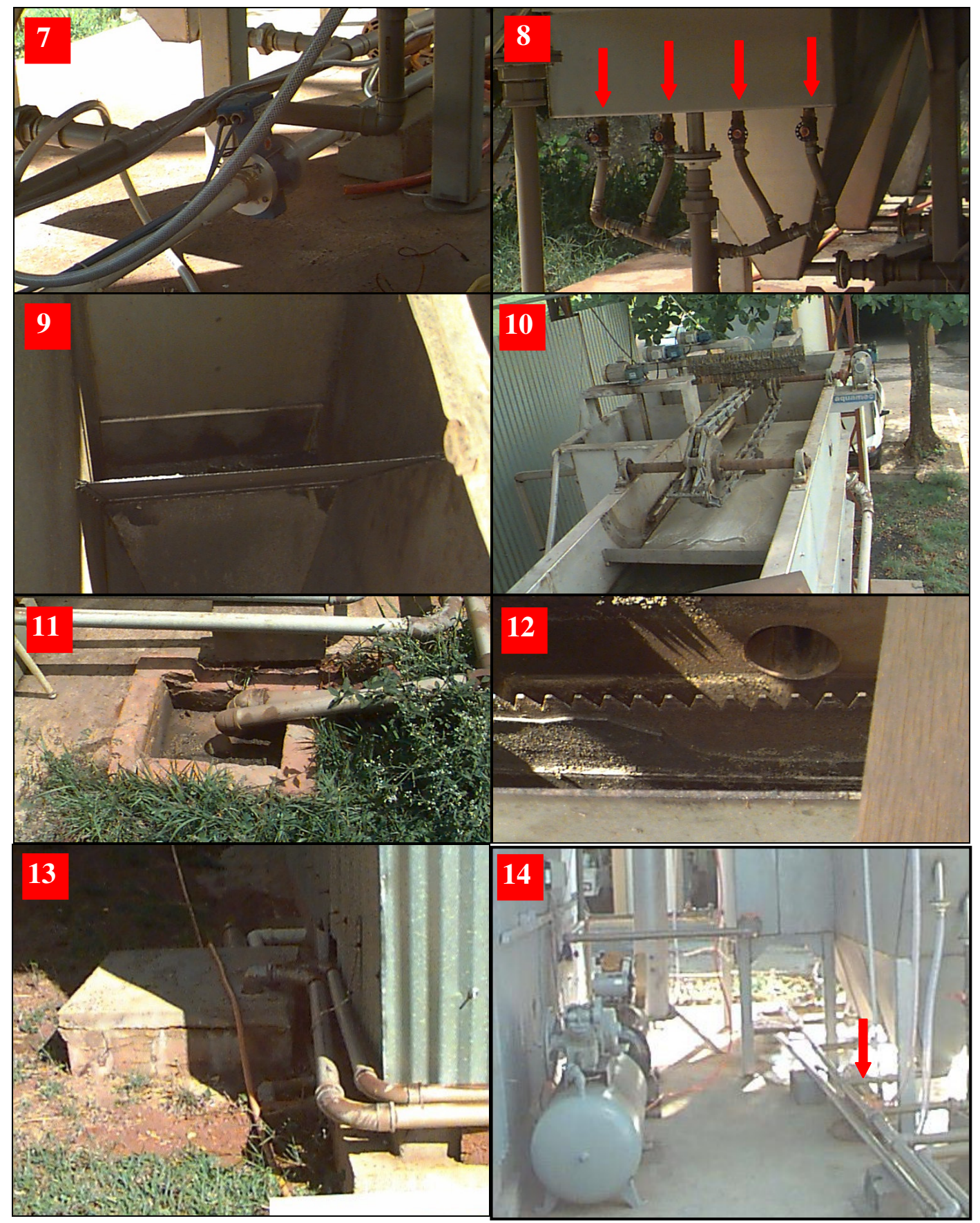

FIGURA 4.13 - Unidades constituintes do sistema de coagulação-floculação-flotação em escala piloto. (7) Medidor eletromagnético de vazão floculada excedente; (8) Sistema de injeção de líquido pressurizado; (9) Zona de contato do líquido floculado com o líquido pressurizado (contato bolha e floco); (10) Raspador superficial de lodo flotado; (11) Local de descarte do lodo flotado removido do sistema; (12) Vertedor para controle do nível d’água no interior do flotador; (13) Local de descarte do efluente líquido clarificado e da vazão floculada excedente; (14) Sistema de pressurização e de saturação de parcela do efluente clarificado, para geração de microbolhas. 


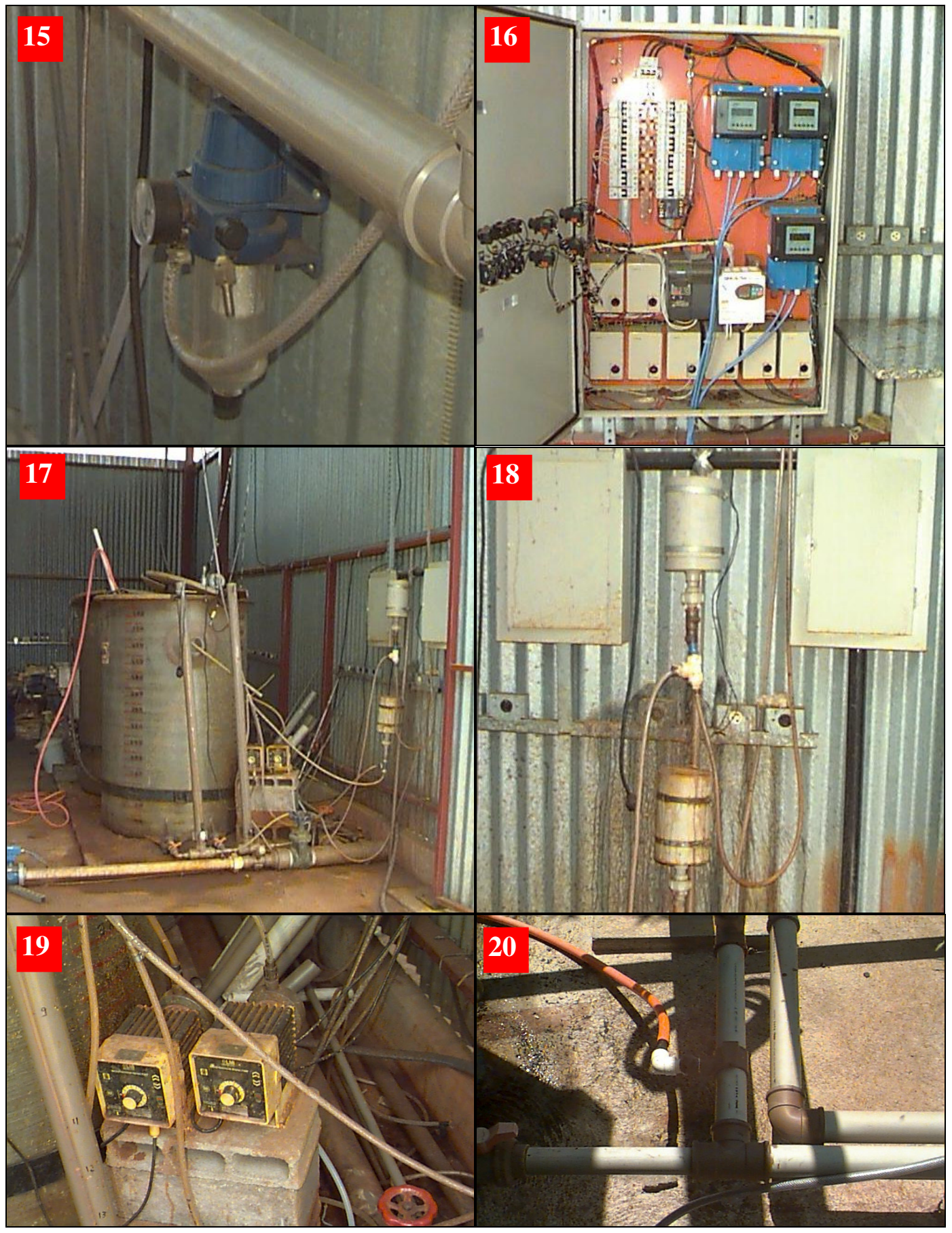

FIGURA 4.14 - Unidades constituintes do sistema de coagulação-floculação-flotação em escala piloto. (15) Filtro de linha de ar e controlador da pressão fornecida à câmara de saturação; (16) Quadro de comando das diferentes unidades eletro-eletrônicas do sistema; (17) Sistema de dosagem de produtos químicos, com destaque para o tanque de preparo e dosagem de soluções químicas; (18) Amortecedores de pulso de vazão, responsáveis pela dosagem contínua dos produtos químicos; (19) Bombas dosadoras de soluções de produtos químicos (cloreto férrico e polímero sintético); (20) Ponto de coleta de amostras do efluente clarificado. 
A câmara de saturação utilizada possuía recheio, composto de tubos de PVC DN 50 $\mathrm{mm}$ divididos em peças de $50 \mathrm{~mm}$ de altura. Na parte superior da câmara de saturação era introduzido o ar comprimido com o objetivo de manter um colchão de ar dentro desta câmara, sob pressão constante (FIGURA 4.14 - 15), necessário para o bom funcionamento da unidade.

Em seguida, o líquido saturado era enviado ao dispositivo de despressurização (quatro registros de agulha, conforme FIGURA 4.13 - 8), localizado na parte inferior da câmara de flotação, que o libera na zona de contato, onde era misturado ao líquido floculado. A vazão desse líquido saturado era quantificada por medidor de vazão eletromagnético.

Todas as unidades constituintes do sistema de coagulação-floculação-flotação eram operadas a partir de quadro de comando eletro-eletrônico (FIGURA 4.14 - 16).

O sistema de dosagem de produtos químicos era constituído por tanques de preparo e dosagem de produtos químicos (FIGURA 4.14 - 17), providos de medidores volumétricos de vazão, por duas bombas dosadoras (FIGURA 4.14 - 19) e por amortecedores de pulso de vazão, responsáveis pela dosagem contínua dos produtos químicos (FIGURA 4.14 - 18).

A coleta de amostras do efluente clarificado para envio ao laboratório era feita na tubulação de descarte do respectivo efluente (FIGURA 4.14 - 20).

A seguir, algumas unidades constituintes do sistema de flotação são detalhadas.

\section{Unidade de mistura rápida em linha}

A mistura rápida do coagulante era realizada através da introdução do cloreto férrico na canalização de efluente do reator anaeróbio (proveniente do reator RALEx), num ponto situado imediatamente a montante de um misturador tipo injetor instalado em um reator tubular, construído de acordo com as recomendações feitas por HESPANHOL ${ }^{1}$ apud REALI (1991). As características construtivas do mesmo encontram-se apresentadas na FIGURA 4.15 , onde pode-se observar que o reator tubular é constituído da própria canalização de efluente do reator anaeróbio, com diâmetro igual a $50 \mathrm{~mm}$ e comprimento igual a $8 \mathrm{~m}$, contados a partir da unidade de mistura rápida até a entrada dos floculadores. Tal unidade

${ }^{11}$ HESPANHOL, I. (1982). Cinética de floculação de suspensões coloidais com polieletrólitos naturais. São Paulo. 232p.. Tese (Livre Docência) - Escola Politécnica, Universidade de São Paulo. 
foi projetada de forma a fornecer gradiente médio de velocidade na mistura rápida na faixa de 3.000 a $9.000 \mathrm{~s}^{-1}$ aproximadamente (para vazões entre 0,9 e $1,9 \mathrm{~L} / \mathrm{s}$ ).

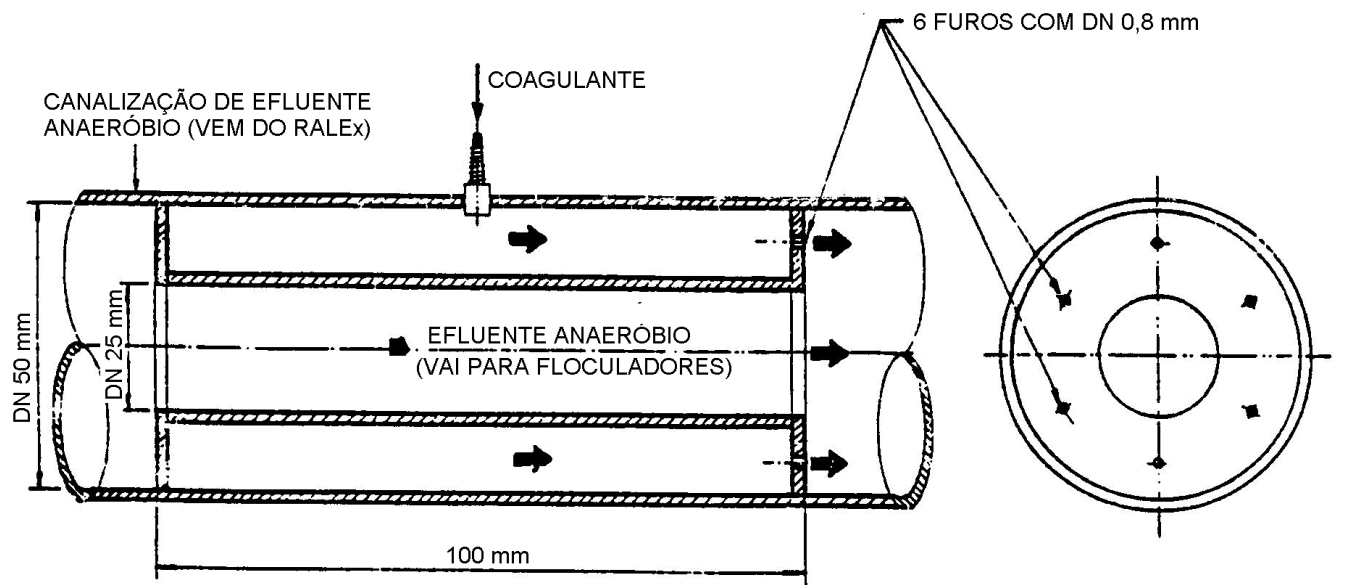

FIGURA 4.15. Características e dimensões da unidade de mistura rápida. Fonte: Reali (1991).

\section{Unidade de floculação}

A unidade de floculação era composta por quatro câmaras em série contendo agitadores mecanizados, com controle de rotação por meio de inversor de freqüência. Os agitadores possuíam eixo vertical com paletas paralelas ao eixo. Na FIGURA 4.9 são apresentadas as dimensões e as características geométricas dos agitadores.

Os moto-redutores dos agitadores estavam ligados a um microprocessadorcontrolador de tamanho e freqüência de onda marca SIEMENS, modelo Micromaster. Este equipamento permitia que a velocidade de rotação do motor fosse modificada através da variação da sua frequiência (de 0 a $60 \mathrm{~Hz}$ ) de funcionamento. Desta forma, durante os ensaios com o flotador, foi possível adotar os gradientes médios de velocidade na floculação já obtidos nos ensaios de laboratório utilizando, cloreto férrico e/ou polímero catiônico. Desta forma, nos ensaios de campo foi utilizado Gf entre $60 \mathrm{~s}^{-1}$ e $100 \mathrm{~s}^{-1}$.

No roteiro de ensaios realizados com o flotador, foram previstas as variações da fração de recirculação (R) e da taxa de aplicação superficial (TAS) na câmara de flotação. Em função da dificuldade de mudança nas dimensões da câmara de flotação (A), a alternativa era restrita à mudança da vazão floculada afluente $(\mathrm{Q})$, conforme pode ser verificado na EQUAÇÃO 4-1. 
$T A S=\frac{Q \times(1+R)}{A}$

Onde:

TAS: taxa de aplicação superficial $\left(\mathrm{m}^{3} / \mathrm{m}^{2} / \mathrm{d}\right)$;

Q: vazão floculada afluente à câmara de flotação $\left(\mathrm{m}^{3} / \mathrm{d}\right)$;

$\mathrm{R}$ : fração de recirculação (adimensional) e

A: área em planta da câmara de flotação.

Ocorre que há necessidade de que o tempo de floculação (Tf) seja igual nos ensaios em que se deseja estudar a influência da taxa de aplicação superficial ou da quantidade de ar fornecida sobre a qualidade do efluente clarificado, de forma a garantir que qualquer variação na eficiência do processo seja conseqüência da variação de TAS ou de R. A possibilidade de poder adotar duas, três ou quatro câmaras de floculação propiciava uma variação descontínua no volume das câmaras de flotação. Quando eram necessárias variações menores do que o volume relativo a uma câmara de floculação, caracterizava-se uma situação de impossibilidade de obtenção do volume desejado para a floculação. Como Tf deve ser constante e o volume do sistema de floculação não pode variar continuamente, então a vazão afluente à unidade de floculação (Qafl) não pode ser variada, conforme pode ser verificado na EQUAÇÃO 4-2.

$$
T f=\frac{V}{Q a f l}
$$

Onde:

Tf: tempo de floculação (s);

V: volume total da unidade de floculação $\left(\mathrm{m}^{3}\right) \mathrm{e}$

Qafl: vazão afluente à unidade de floculação $\left(\mathrm{m}^{3} / \mathrm{s}\right)$.

Diante da necessidade de variação de Q e da impossibilidade de mudança em Qafl (para manutenção das mesmas condições de floculação nos diversos ensaios), a solução adotada previa descarte de uma parcela de Q imediatamente antes de sua entrada na câmara de flotação. Desta forma, foi instalada uma tomada de líquido próxima à saída da unidade de floculação (última câmara) e, através de um medidor eletromagnético de vazão e de uma válvula de esfera, a parcela descartada era mensurada e controlada. 


\section{Unidade de flotação por ar dissolvido}

A unidade de flotação por ar dissolvido era do tipo convencional e retangular. Possui em seu interior uma zona de contato limitada por um defletor com inclinação de $60^{\circ}$ com a horizontal. Como esta unidade foi projetada para tratar até $300 \mathrm{~m}^{3} / \mathrm{d}$, operando com TAS de $180 \mathrm{~m}^{3} / \mathrm{m}^{2} / \mathrm{d}$, e o RALEx fornece até $240 \mathrm{~m}^{3} / \mathrm{d}$, foi preciso reduzir a área em planta e o volume da zona de clarificação desta unidade para que pudesse estudar valores de TAS de até $250 \mathrm{~m}^{3} / \mathrm{m}^{2} / \mathrm{d}$. Para tanto, foi introduzida uma parede removível transversalmente, limitando a área superficial da câmara de flotação a $0,98 \mathrm{~m}^{2}$ (ver FIGURA 4.8). Havia, em seu interior, uma canaleta para coleta do lodo flotado e removido por raspador superficial. O líquido clarificado era enviado para câmara acumuladora através de comporta ajustável.

Para os estudos aqui desenvolvidos, a TAS foi definida como sendo a razão entre a vazão total afluente à câmara de flotação $\left(\mathrm{Q}_{\text {total }}\right)$ e a área onde o líquido apresentava sentido de fluxo descendente (A). Desta forma, $\mathrm{Q}_{\text {total }}$ é calculada pela EQUAÇÃO 4-3.

$$
Q_{\text {total }}=Q_{R A L E X}+Q_{\text {coag }}+Q_{R}-Q_{\text {descarte }}
$$

Onde:

QRALEX: vazão efluente do reator RALEx e afluente à instalação piloto;

$\mathrm{Q}_{\text {coag }}$ : vazão referente à dosagem de coagulante;

$\mathrm{Q}_{\mathrm{R}}$ : vazão de recirculação;

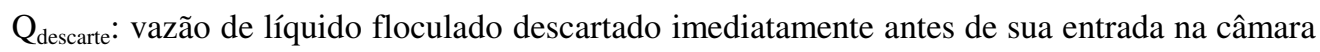
de flotação

\section{Sistema de pressurização e saturação da vazão de recirculação}

A unidade piloto previa recirculação pressurizada. Sendo assim, o sistema de pressurização e saturação da vazão de recirculação era composto por bomba de pressurização, câmara de saturação, compressor de ar, medidor eletromagnético de vazão, dispositivo de despressurização e tubulações. A pressurização da câmara de saturação era realizada por uma bomba centrífuga multi-estágio Jacuzzi Hidroflex 15H4D10. O fornecimento de ar era efetuado por compressor de ar SCHULZ MSL 10 ML/175, diretamente na parte superior da câmara de saturação. Para que a pressão no interior da câmara se mantivesse constante, foi instalada uma válvula reguladora de pressão, com filtro de ar, na tubulação de fornecimento de ar. Havia a necessidade de manter um colchão de ar dentro da câmara de saturação, essencial para o bom funcionamento da unidade. O controle do nível de água era realizado por eletrodos de nível mínimo/máximo ligados à válvula 
solenóide, responsável pela liberação do excesso de ar. Todo o ar em excesso fornecido pelo compressor era eliminado pela válvula solenóide, o que permitia a formação do colchão de ar e mantinha o nível d'água fixo. Para controle da vazão de ar fornecida pelo compressor foi instalado um registro de agulha $\left(\phi^{1 / 4}\right)$ na linha.

A câmara de saturação apresentava dimensões de $1,80 \mathrm{~m}$ de altura e $0,28 \mathrm{~m}$ de diâmetro e continha recheio, composto de tubos de PVC DN $50 \mathrm{~mm}$ divididos em peças de $50 \mathrm{~mm}$ de altura. A altura da camada de recheio era de 1,2 $\mathrm{m}$. Optou-se pela adoção de recheio tendo em vista o esperado aumento da eficiência de dissolução do ar no líquido em relação a câmaras sem recheio.

\section{Tanque de preparo e dosagem de produto químico}

Foram utilizados dois produtos químicos diferentes: (i) cloreto férrico e (ii) polímero catiônico. Para o preparo das soluções de cloreto férrico (entre 3\% e 10\%) e de polímero catiônico $(0,1 \%)$ foi instalado agitador mecânico no interior do tanque em fibra de vidro de $600 \mathrm{~L}$ cada, sendo utilizado motor de 0,5 HP de potência. Na saída dos tanques foram instalados medidores volumétricos de vazão, constituídos por uma tubulação de PVC (DN $50 \mathrm{~mm}$ ) com visor transparente e graduado para leitura do nível da solução no interior do tubo. A altura deste tubo era igual à do tanque e possuía extremidade superior aberta (operando como vasos comunicantes). Entre o tubo e o tanque foi instalada uma válvula de esfera, de forma que, durante a operação de dosagem, a válvula era fechada e o intervalo de tempo necessário para consumir o volume de solução no interior do tubo era cronometrado. A partir destes dois dados, a vazão de dosagem era calculada. O controle da vazão de dosagem era realizado por meio de uma bomba dosadora instalada na linha de fornecimento de solução de produto químico. O cloreto férrico era injetado na unidade de mistura rápida em linha e o polímero catiônico na abertura da ligação entre a terceira e a última câmara de floculação.

\section{Quantidade de ar fornecida para a flotação}

Para verificação da eficiência de saturação de ar da câmara de saturação utilizada neste estudo, foi utilizado método desenvolvido e proposto por REALI (1991). O método prevê a realização de ensaios específicos visando a verificação da eficiência de saturação do ar (em peso) na água (em volume) em função da pressão na própria câmara e da temperatura da água. 


\subsubsection{Descrição do Reator Anaeróbio de Leito Expandido (RALEx)}

O trabalho proposto utilizou o reator anaeróbio de leito expandido (sistema piloto), objeto de estudo da pesquisa de doutorado do Eng. José Almir Rodrigues Pereira, intitulada 'Concepção de um Reator Anaeróbio de Flexibilidade Operacional, para Crescimento de Microrganismos em Consórcios Suspensos ou em Consórcios Aderidos, com Aplicação no Tratamento de Esgoto Sanitário", sob orientação do Prof. Tit. José Roberto Campos.

$\mathrm{O}$ reator anaeróbio de leito expandido está implantado na Escola de Engenharia de São Carlos (EESC) da Universidade de São Paulo (USP).

De acordo com PEREIRA (2000), o reator foi fabricado em aço carbono zincado a quente, com 14,9 m de altura útil e volume útil de $32 \mathrm{~m}^{3}$ e está dividido em uma câmara de reação e uma câmara de sedimentação. A câmara de reação é cilíndrica, com altura útil de 12 m e diâmetro de $1,5 \mathrm{~m}$. A câmara de sedimentação apresenta o formato de uma taça, com 2,9 m de altura, 1,5 m de diâmetro menor e 2,5 m de diâmetro maior.

O reator apresenta, no seu interior, dispositivo perfurado, com $400 \mathrm{~mm}$ de diâmetro e 7,0 m de altura, com formato cônico, destinado à mistura da massa líquida, à coleta de gás resultante da degradação do substrato e à separação do material sólido de densidade maior que a da massa líquida.

O esgoto sanitário produzido em um bairro vizinho ao campus da EESC-USP é utilizado para alimentação do reator e é coletado de um interceptor de CA de $\varnothing=800 \mathrm{~mm}$. A FIGURA 4.16 e a FIGURA 4.17 mostram o reator anaeróbio implantado na EESC-USP.

O reator é parte integrante do sistema experimental de tratamento de esgoto sanitário construído em aproximadamente $300 \mathrm{~m}^{2}$ da área Nordeste do campus da EESC-USP. A FIGURA 4.18 esquematiza o sistema anaeróbio experimental.

Além do reator, o sistema experimental é constituído pelas seguintes unidades, dispositivos e equipamentos:

- Caixa coletora em concreto armado $\left(2,5 \mathrm{~m}^{3}\right)$;

- Grade com 2,5 cm de espaçamento entre barras;

- Poço de sucção em concreto armado $\left(2,70 \mathrm{~m}^{3}\right)$;

- Dois motores tipo elétrico, marca WEG IV, com potência de $5 \mathrm{CV}$ e frequiência de $60 \mathrm{~Hz}$;

- Duas bombas helicoidais, marca Geremia, modelo HF-60L com pressão máxima de $6 \mathrm{kgf} / \mathrm{cm}^{2}$ e sucção máxima de 8 m.c.a.;

- Poço em concreto armado para recirculação do efluente $\left(3,78 \mathrm{~m}^{3}\right)$; 
- Tanque de peneiramento, em concreto armado, com peneira de aço inoxidável $\left(1,44 \mathrm{~m}^{2}\right.$ com abertura de $\left.1 \mathrm{~mm}\right)$;

- Painel eletrônico com dois indicadores de pressão digitais na faixa de 0/32 m.c.a., botoeira de controle dos conjuntos moto-bombas e indicadores de operação (tempo de funcionamento das bombas, rotação dos motores, voltagem e amperagem);

- Dois transmissores eletrônicos de pressão com selo e amortecedor de pulsação na faixa de 0/45 psi e

- Medidor de volume de gás TECNOBRÁS, modelo Gallus 2000-G4.

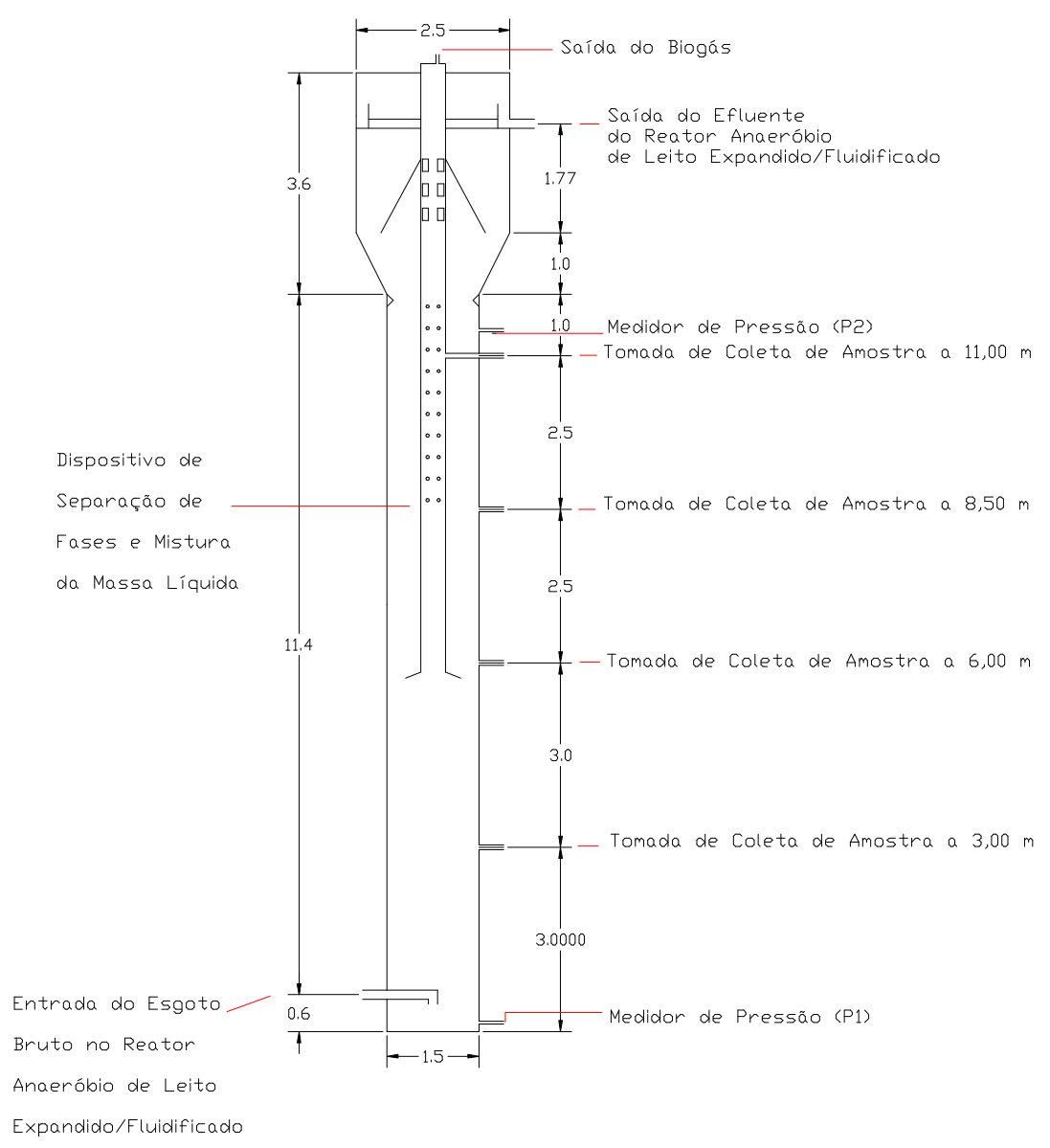

FIGURA 4.16 - Corte esquemático do Reator Anaeróbio de Leito Expandido. Medidas em metro. Fonte: MENDONÇA (1998). 


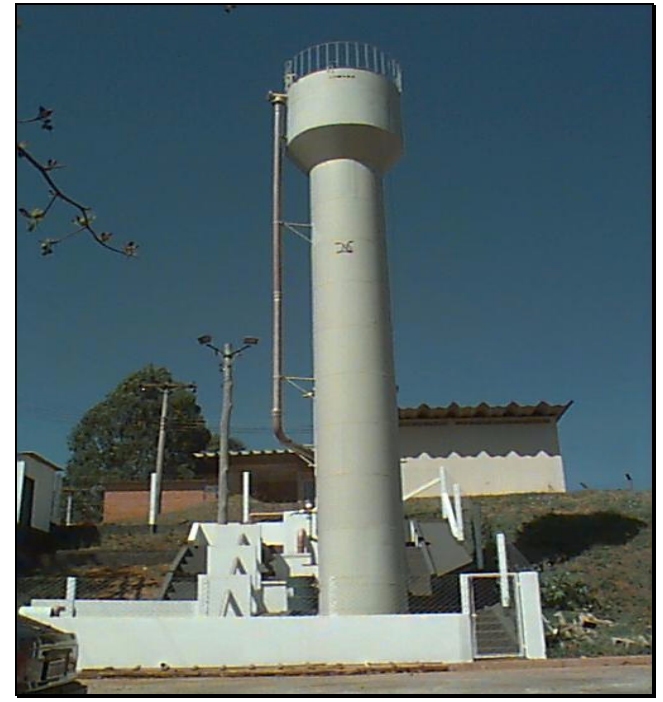

FIGURA 4.17 - Fotografia do Reator Anaeróbio de Leito Expandido. Fonte: PEREIRA (2000).

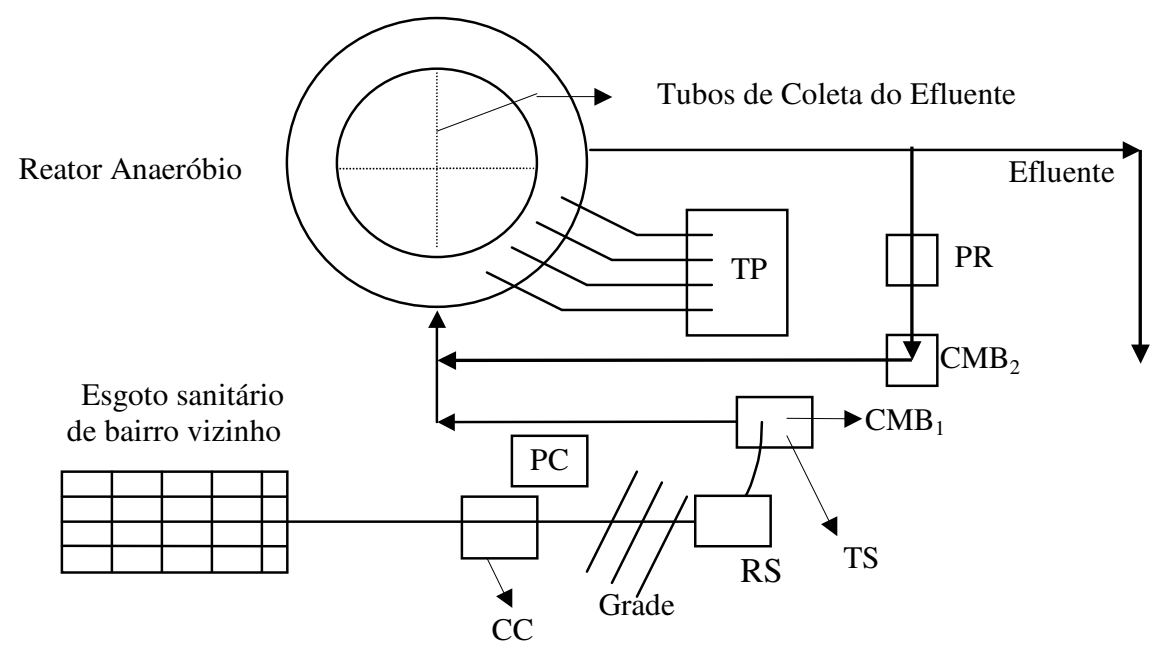

LEGENDAS:

CC-Caixa Coletora de Esgoto Bruto; PC-Painel de Controle; TS-Tanque de Sução TP-Tanque de Peneiramento; $\mathbf{C M B}_{1}$-Conjunto Moto Bomba; $\mathbf{C M B}_{2}$-Conjunto Moto Bomba; RS-Tanque de retenção de sólidos grosseiros e PR-Poço de Recirculação.

FIGURA 4.18 - Esquema do sistema experimental no desenvolvimento do estudo da partida do reator anaeróbio de leito expandido. Fonte: PEREIRA (2000).

\subsection{Efluente do reator RALEx}

As características físico-químicas e biológicas do efluente do reator RALEx variavam ao longo do dia, do mês e do ano. Por este motivo, foi adotado um procedimento 
padrão para coleta e armazenamento das amostras do esgoto bruto e do efluente do reator RALEx utilizadas nos ensaios com o flotateste. Para os ensaios de laboratório, as amostras eram coletadas sempre às 08:00, exceto nos ensaios em que se estudou a influência da qualidade do efluente do reator anaeróbio, através de sua coleta em horários diferentes ao longo do dia. Vale ressaltar que não foram efetuadas coletas nos sábados, domingos, segundas-feiras, feriados e seus respectivos dias seguintes, tendo em vista a possibilidade de que as características do esgoto sanitário não fossem representativas. Da mesma forma, para evitar a interferência da diluição do esgoto sanitário decorrente de chuvas, não era realizada coleta se houvesse chovido nas $24 \mathrm{~h}$ anteriores. Do esgoto bruto afluente era coletada uma amostra de 1 L. Em relação ao efluente do reator RALEx, era coletado volume de amostra suficiente para os ensaios diários. Durante a coleta, eram medidos o pH, a turbidez e a temperatura das amostras. A amostra de esgoto bruto e a parcela da amostra do efluente do reator anaeróbio eram conservadas sob refrigeração para posterior caracterização no Laboratório de Tratamento Avançado e Reuso de Águas do Departamento de Hidráulica e Saneamento da Escola de Engenharia de São Carlos-USP. A outra parcela do efluente do reator anaeróbio era utilizada para os ensaios com flotateste.

\subsection{Produtos químicos empregados}

Ao longo dos ensaios, foram empregados três diferentes produtos químicos, a seguir listados.

1. Solução de cloreto férrico: do tipo comercial, com as seguintes características (de acordo com o fabricante):

- Densidade:

- $\mathrm{FeCl}_{3}$ :

- Material insolúvel:

- Ferro II (Fe II/Fe total)

- $\mathrm{pH}$ :

- Acidez livre ( $\mathrm{HCl}$ livre):
$1,410 \mathrm{~g} / \mathrm{cm}^{3}$;

$38 \%$ a $40 \%$;

máx. $0,10 \%$

máx. 2,5\%

$<1,0$

$1,21 \%$.

2. Ácido sulfúrico: do tipo PA para uso em laboratório.

3. Soda cáustica: do tipo PA para uso em laboratório.

4. Polímeros sintéticos: do tipo comercial, marcas ADESOL e NALCO, com as características apresentadas (de acordo com o fabricante) na TABELA 4.1. 
TABELA 4.1 - Características dos polímeros sintéticos utilizados no estudo.

\begin{tabular}{|c|c|c|c|c|c|c|}
\hline Marca & Denominação & Carga & $\begin{array}{c}\text { Intensidade } \\
\text { de carga }\end{array}$ & $\begin{array}{c}\text { Peso } \\
\text { molecular }\end{array}$ & Forma & pH \\
\hline Adesol & W 320 & catiônica & alta & alto & emulsão & 4,0 \\
\hline Adesol & W 341 & catiônica & Média & alto & emulsão & 4,0 \\
\hline Adesol & W 360 & catiônica & média & alto & emulsão & 4,0 \\
\hline Adesol & G 991 & catiônica & média & alto & granulado & - \\
\hline Adesol & G 992 & catiônica & média & alto & granulado & - \\
\hline Adesol & G 9046 & catiônica & alta & alto & granulado & - \\
\hline Adesol & G 9047 & catiônica & alta & alto & granulado & - \\
\hline Adesol & G 9048 & catiônica & baixa & alto & granulado & - \\
\hline Adesol & G 9049 & catiônica & média & baixo & emulsão & 5,5 \\
\hline Nalco & N 7750 & catiônica & NI & NI & emulsão & NI \\
\hline Nalco & N 7751 & catiônica & NI & NI & emulsão & NI \\
\hline Adesol & W 301 & aniônica & alta & alto & emulsão & 8,0 \\
\hline Adesol & W 302 & aniônica & baixa & alto & emulsão & 6,8 \\
\hline Adesol & G 997 & aniônica & baixa & alto & granulado & - \\
\hline Adesol & G 998 & aniônica & alta & alto & granulado & - \\
\hline Adesol & G 9050 & aniônica & alta & altíssimo & granulado & - \\
\hline Adesol & G 9052 & aniônica & média & alto & granulado & - \\
\hline Nalco & N 4016 & aniônica & NI & NI & emulsão & NI \\
\hline Nalco & N 4032 & aniônica & NI & NI & emulsão & $\mathrm{NI}$ \\
\hline Adesol & W 303 & não iônica & NI & alto & emulsão & 8,0 \\
\hline Adesol & G 999 & não iônica & NI & alto & granulado & - \\
\hline Adesol & W $360 \mathrm{C}$ & NI & NI & NI & emulsão & $\mathrm{NI}$ \\
\hline Adesol & W 3076 & NI & NI & NI & emulsão & $\mathrm{NI}$ \\
\hline Adesol & W 3081 & NI & NI & NI & emulsão & NI \\
\hline Adesol & G 3055 & $\mathrm{NI}$ & NI & NI & emulsão & $\mathrm{NI}$ \\
\hline Nalco & N 2835 & \multicolumn{5}{|c|}{ Policloreto de alumínio + emulsion break } \\
\hline
\end{tabular}

(-) Sem valor de $\mathrm{pH}$ por ser sólido. (NI) não informado pelo fabricante.

4.6 Ensaios preliminares em escala de laboratório, utilizando o flotateste e com aplicação de polímeros sintéticos, isoladamente ou associados ao cloreto férrico

Essa fase da pesquisa foi dividida em duas etapas distintas, ilustradas na TABELA 4.2. A descrição detalhada de cada etapa é encontrada nos itens 4.6.1 e 4.6.2. O objetivo dessas duas etapas foi verificar quais polímeros, dentre aqueles testados, adaptar-se-iam melhor ao tratamento químico do efluente do reator anaeróbio. 


\subsubsection{Ensaios com variação do tipo de polímero sintético, dosado isoladamente}

O objetivo dessa etapa foi a escolha de alguns polímeros, dentre os testados, que melhor se adaptariam ao tratamento de efluentes do reator anaeróbio, quando dosados isoladamente. Essa adaptabilidade adviria da capacidade do polímero, durante a floculação, de produzir flocos mais susceptíveis à aderência das microbolhas. Baseado em PENETRA (1998), optou-se pela dosagem de $4 \mathrm{mg} / \mathrm{L}$ de cada um dos diferentes polímeros testados. Foram testados os seguintes polímeros: W303; G9049; W360C; W3076; W320; W360; W301; W341; W3081; G3055; G991; G9046; G9052; G999; G992; G9047; G997; G9050; G998 e G9048.

Os valores de $\mathrm{pH}$ de coagulação resultantes da dosagem de diferentes polímeros variaram entre 6,5 e 6,8. Os demais parâmetros operacionais foram mantidos com valores em torno de: $\mathrm{Tmr}=30 \mathrm{~s} ; \mathrm{Gmr}=600 \mathrm{~s}^{-1} ; \mathrm{Tf}=20 \mathrm{~min} ; \mathrm{Gf}=60 \mathrm{~s}^{-1} ; \mathrm{R}=20 \%$ (em volume); a pressão de saturação (Psat) foi fixada em $450 \pm 10 \mathrm{kPa}$ e as velocidades de flotação estudadas foram: Vf1 $=5,0 \mathrm{~cm} / \mathrm{min} ; \mathrm{Vf} 2=10,0 \mathrm{~cm} / \mathrm{min} ; \mathrm{Vf3}=15,0 \mathrm{~cm} / \mathrm{min} ; \mathrm{Vf} 4=20,0 \mathrm{~cm} / \mathrm{min}$; Vf5 $=25,2 \mathrm{~cm} / \mathrm{min}$. Na TABELA 4.2 esta etapa é apresentada dentro da seqüência de ensaios realizados com o flotateste e com aplicação de polímero sintético.

\subsubsection{Ensaios com variação do tipo de polímero sintético, dosado conjuntamente com cloreto férrico}

Embora a verificação da adaptabilidade de diferentes polímeros, adicionados isoladamente, ao tratamento do efluente do reator anaeróbio fosse importante, seria fundamental estudar a aplicação dos polímeros durante a floculação do efluente do reator anaeróbio, já previamente misturado com cloreto férrico, e sua eficiência na formação de flocos mais susceptíveis à aderência das microbolhas. Dentre os vinte diferentes polímeros testados na etapa anterior, foram escolhidos onze deles para esta etapa. Além desses onze, mais cinco polímeros, obtidos posteriormente, foram testados. Desta forma, foram estudadas associações de diferentes dosagens de cloreto férrico e de diversos polímeros. Para dosagens de $15 \mathrm{mg} / \mathrm{L}$ e de $30 \mathrm{mg} / \mathrm{L}$ de cloreto férrico foram associadas dosagens de $0,4 \mathrm{mg} / \mathrm{L}$ e de 1,0 $\mathrm{mg} / \mathrm{L}$ de polímero sintético.

Os demais parâmetros operacionais foram mantidos com valores em torno de: $\mathrm{Tmr}=$

$10 \mathrm{~s} ; \mathrm{Gmr}=1000 \mathrm{~s}^{-1} ; \mathrm{Tf}=20 \mathrm{~min} ; \mathrm{Tfpol}=5 \mathrm{~min} ; \mathrm{Gf}=80 \mathrm{~s}^{-1} ; \mathrm{R}=20 \%$ (em volume); a pressão de saturação (Psat) foi fixada em $450 \pm 10 \mathrm{kPa}$ e as velocidades de flotação estudadas foram: $\mathrm{Vf} 1=5,0 \mathrm{~cm} / \mathrm{min} ; \mathrm{Vf} 2=10,0 \mathrm{~cm} / \mathrm{min} ; \mathrm{Vf} 3=15,0 \mathrm{~cm} / \mathrm{min} ; \mathrm{Vf} 4=20,0 \mathrm{~cm} / \mathrm{min} ; \mathrm{Vf} 5=25,2$ $\mathrm{cm} /$ min. Na TABELA 4.2, essa etapa é apresentada dentro da seqüência de ensaios realizados com o flotateste e com aplicação de polímero sintético. 
TABELA 4.2 - Seqüência das etapas de ensaios realizados em laboratório com uso do flotateste.

\begin{tabular}{|c|c|c|}
\hline Objetivo da etapa & Variáveis mantidas fixas & Variáveis estudadas \\
\hline $\begin{array}{c}\text { Investigação da } \\
\text { adaptabilidade do } \\
\text { polímero ao } \\
\text { tratamento químico } \\
\text { do efluente do } \\
\text { reator anaeróbio } \\
\text { (4.6.1) }\end{array}$ & $\begin{array}{l}\mathrm{DP}=4 \mathrm{mg} / \mathrm{L} ; \mathrm{Gmr}=600 \mathrm{~s}^{-1} ; \mathrm{Tmr}= \\
30 \mathrm{~s} ; \mathrm{Gf}=60 \mathrm{~s}^{-1} ; \mathrm{Tf}=20 \mathrm{~min} ; \mathrm{R}=20 \% \\
(\mathrm{em} \text { volume}) ; \mathrm{Psat}=450 \mathrm{kPa} ; \mathrm{Vf} 1= \\
5,0 \mathrm{~cm} / \mathrm{min} ; \mathrm{Vf} 2=10,0 \mathrm{~cm} / \mathrm{min} ; \mathrm{Vf} 3= \\
15,0 \mathrm{~cm} / \mathrm{min} ; \mathrm{Vf} 4=20,0 \mathrm{~cm} / \mathrm{min} ; \mathrm{Vf} 5 \\
=25,2 \mathrm{~cm} / \mathrm{min} .\end{array}$ & $\begin{array}{l}\text { Tipo de polímero sintético: } \\
\text { W303; G9049; W360C; } \\
\text { W3076; W320; W360; W301; } \\
\text { W341; W3081; G3055; G991; } \\
\text { G9046; G9052; G999; G992; } \\
\text { G9047; G997; G9050; G998 e } \\
\text { G9048. }\end{array}$ \\
\hline $\begin{array}{c}\text { Investigação da } \\
\text { adaptabilidade do } \\
\text { polímero, associado } \\
\text { ao cloreto férrico, } \\
\text { ao tratamento } \\
\text { químico do efluente } \\
\text { do reator anaeróbio } \\
(\mathbf{4 . 6 . 2 )}\end{array}$ & $\begin{array}{l}\mathrm{Gmr}=1000 \mathrm{~s}^{-1} ; \mathrm{Tmr}=10 \mathrm{~s} ; \mathrm{Gf}=80 \mathrm{~s}^{-} \\
{ }^{-} ; \mathrm{Tf}=20 \mathrm{~min} ; \mathrm{Tfpol}=5 \mathrm{~min} ; \mathrm{R}=20 \% \\
(\mathrm{em} \text { volume }) ; \text { Psat }=450 \mathrm{kPa} ; \mathrm{Vf} 1= \\
5,0 \mathrm{~cm} / \mathrm{min} ; \mathrm{Vf} 2=10,0 \mathrm{~cm} / \mathrm{min} ; \mathrm{Vf} 3= \\
15,0 \mathrm{~cm} / \mathrm{min} ; \mathrm{Vf} 4=20,0 \mathrm{~cm} / \mathrm{min} ; \mathrm{Vf} 5 \\
=25,2 \mathrm{~cm} / \mathrm{min} .\end{array}$ & $\begin{array}{l}\text { Tipo de polímero sintético: } \\
\text { N4032; N7751; N4016; N2835; } \\
\text { N7750; W303; G9049; W302; } \\
\text { W301; G9046; G9052; G999; } \\
\text { G992; G998; G9047 e G9048. } \\
\text { DCF/DP: } \\
(15 / 0,4) ;(15 / 1,0) ;(30 / 0,4) ; \\
(30 / 1,0)\end{array}$ \\
\hline
\end{tabular}

4.7 Ensaios em escala de laboratório, utilizando o flotateste e com aplicação de cloreto férrico e polímero sintético (escolhido no item 4.6), durante período de partida do RALEx.

Em junho de 2000, durante a operação do reator anaeróbio de leito expandido, houve rompimento da tubulação de recalque do esgoto bruto, com conseqüente perda definitiva de 50\% do leito suporte (carvão ativado) e colapso biológico total da biomassa aderida à parcela de 50\% de leito suporte recuperada. Para retomada de sua operação, novo lote de carvão ativado foi adquirido, visando restabelecer as condições iniciais de operação. Reposto o leito suporte, foi iniciada operação de partida do reator, com gradativo aumento da vazão afluente e controle de pH.

Os ensaios descritos neste item abrangem o período em que o reator estava em condições de readaptação e recuperação da biomassa, funcionando ininterruptamente há cerca de trinta dias, após a renovação do carvão ativado do leito expandido.

O objetivo desses ensaios foi estudar o comportamento do flotador durante a partida do reator anaeróbio, verificando se as dosagens de produtos químicos rotineiramente empregadas eram suficientes para manter o efluente final com boa qualidade, atendendo limites restritos de lançamento.

Esta fase da pesquisa foi dividida em quatro etapas distintas e ilustradas na TABELA 4.3. A descrição detalhada de cada etapa é encontrada nos itens 4.7.1, 4.7.2, 4.7.3 e 4.7.4. 


\subsubsection{Ensaios com variação da dosagem de cloreto férrico associada a diferentes dosagens de polímero sintético}

O objetivo desta etapa foi a obtenção de dosagem adequada de cloreto férrico associada à dosagem de polímero sintético (escolhido no item 4.6), para tratamento físicoquímico do efluente do RALEx. Foram testadas dosagens de cloreto férrico (DCF) entre zero e $40 \mathrm{mg} / \mathrm{L}$, associadas a dosagens de polímeros entre zero e 1,25 mg/L (ver TABELA $4.3)$.

Os demais parâmetros operacionais foram mantidos com valores em torno de: Tmr= $10 \mathrm{~s} ; \mathrm{Gmr}=1000 \mathrm{~s}^{-1} ; \mathrm{Tf}=20 \mathrm{~min}$; Tfpol= $15 \mathrm{~min} ; \mathrm{Gf}=80 \mathrm{~s}^{-1} ; \mathrm{R}=20 \%$ (em volume) $\mathrm{a}$ pressão de saturação (Psat) foi fixada em $450 \pm 10 \mathrm{kPa}$ e as velocidades de flotação estudadas foram: Vf1 $=5,0 \mathrm{~cm} / \mathrm{min} ; \mathrm{Vf} 2=10,0 \mathrm{~cm} / \mathrm{min} ; \mathrm{Vf3}=15,0 \mathrm{~cm} / \mathrm{min} ; \mathrm{Vf} 4=20,0 \mathrm{~cm} / \mathrm{min}$; Vf5 $=25,2 \mathrm{~cm} / \mathrm{min}$.

\subsubsection{Ensaios com variação do tempo total de floculação associado a diferentes valores de tempo de floculação do polímero sintético}

Em função das dimensões das câmaras de floculação da unidade piloto de flotação e da vazão efluente do RALEx, foram adotados valores de tempo de floculação múltiplos de seis. Desta forma, nos ensaios realizados nesta etapa foram testados quatro valores de tempo total de floculação (Tf): 24, 18, 12 e 6 min. Para cada tempo total de floculação, foram investigados diferentes valores de tempo de floculação do polímero (Tfpol): 24, 18, 12 e 6 min (ver TABELA 4.3).

Os demais parâmetros operacionais foram mantidos com valores em torno de: $\mathrm{DCF}=$ $40 \mathrm{mg} / \mathrm{L}$ e DP= $1,25 \mathrm{mg} / \mathrm{L}$, obtidos na etapa 4.6.1; Tmr= $10 \mathrm{~s} ; \mathrm{Gmr}=1000 \mathrm{~s}^{-1} ; \mathrm{Gf}=80 \mathrm{~s}^{-1} ; \mathrm{R}=$ $20 \%$ (em volume); a pressão de saturação (Psat) foi fixada em $450 \pm 10 \mathrm{kPa}$ e as velocidades de flotação estudadas foram: Vf1 $=5,0 \mathrm{~cm} / \mathrm{min} ; \mathrm{Vf} 2=10,0 \mathrm{~cm} / \mathrm{min} ; \mathrm{Vf} 3=15,0 \mathrm{~cm} / \mathrm{min}$; $\mathrm{Vf} 4=20,0 \mathrm{~cm} / \mathrm{min} ; \mathrm{Vf5}=25,2 \mathrm{~cm} / \mathrm{min}$.

\subsubsection{Ensaios com variação do tempo total de floculação associado a diferentes valores de gradiente médio de velocidade de floculação}

Nos ensaios realizados nesta etapa foram testados três valores de tempo total de floculação (Tf): 24, 18 e 12 min. Para cada tempo total de floculação, foram investigados diferentes valores de gradiente médio de velocidade de floculação (Gf): 40, 60, 80 e $100 \mathrm{~s}^{-1}$ (ver TABELA 4.3). Além disso, foi realizado ensaio sem período de floculação, ou seja, tempo de floculação igual a zero. 
TABELA 4.3 - Seqüência das etapas de ensaios realizados com flotateste e cloreto férrico associado a polímero sintético (4.7.1 a 4.7.4).

\begin{tabular}{|c|c|c|}
\hline Objetivo da etapa & Variáveis mantidas fixas & Variáveis estudadas \\
\hline $\begin{array}{c}\text { Investigação da } \\
\text { dosagem de cloreto } \\
\text { férrico associada a } \\
\text { diferentes dosagens } \\
\text { de polímero sintético } \\
(4.7 .1)\end{array}$ & $\begin{array}{l}\mathrm{Gmr}=1000 \mathrm{~s}^{-1} ; \mathrm{Tmr}=10 \mathrm{~s} ; \\
\mathrm{Gf}=80 \mathrm{~s}^{-1} ; \mathrm{Tf}=20 \mathrm{~min} ; \mathrm{Tfpol} \\
=15 \mathrm{~min} ; \mathrm{R}=20 \% \quad(\mathrm{em} \\
\text { volume }) \text { Psat }=450 \mathrm{kPa} ; \mathrm{Vf} 1 \\
=5,0 \mathrm{~cm} / \mathrm{min} ; \mathrm{Vf} 2=10,0 \\
\mathrm{~cm} / \mathrm{min} ; \mathrm{Vf} 3=15,0 \mathrm{~cm} / \mathrm{min} ; \\
\mathrm{Vf} 4=20,0 \mathrm{~cm} / \mathrm{min} ; \mathrm{Vf} 5=25,2 \\
\mathrm{~cm} / \mathrm{min} .\end{array}$ & 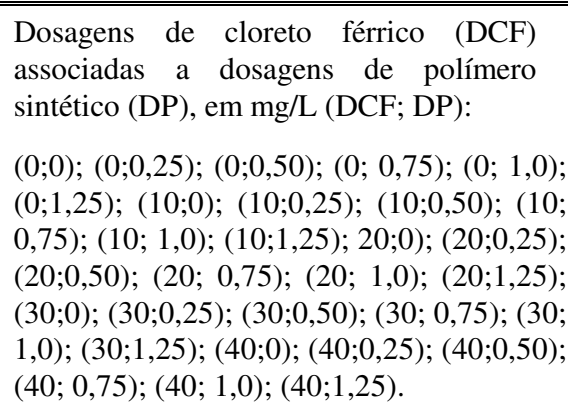 \\
\hline $\begin{array}{c}\text { Investigação de } \\
\text { diferentes valores de } \\
\text { tempo total de } \\
\text { floculação } \\
\text { associados a } \\
\text { diferentes valores de } \\
\text { tempo de floculação } \\
\text { do polímero } \\
\text { (4.7.2) }\end{array}$ & $\begin{array}{l}\mathrm{DCF}=40 \mathrm{mg} / \mathrm{L} \text { e } \mathrm{DP}=1,25 \\
\mathrm{mg} / \mathrm{L} \quad(\text { escolhidos na etapa } \\
4.6 .1) ; \mathrm{Gmr}=1000 \mathrm{~s}^{-1} ; \mathrm{Tmr}= \\
10 \mathrm{~s} ; \mathrm{Gf}=80 \mathrm{~s}^{-1} ; \mathrm{R}=20 \%(\mathrm{em} \\
\text { volume}) ; \mathrm{Psat}=450 \mathrm{kPa} ; \mathrm{Vf} 1 \\
=5,0 \mathrm{~cm} / \mathrm{min} ; \mathrm{Vf} 2=10,0 \\
\mathrm{~cm} / \mathrm{min} ; \mathrm{Vf} 3=15,0 \mathrm{~cm} / \mathrm{min} ; \\
\mathrm{Vf} 4=20,0 \mathrm{~cm} / \mathrm{min} ; \mathrm{Vf} 5=25,2 \\
\mathrm{~cm} / \mathrm{min} .\end{array}$ & $\begin{array}{l}\text { Valores de tempo total de floculação } \\
\text { (Tf) associados a valores de tempo } \\
\text { de floculação do polímero (Tfpol), } \\
\text { em min (Tf; Tfpol): } \\
(24 ; 24) ;(24 ; 18) ;(24 ; 12) ;(24 ; 6) ; \\
(18 ; 18) ;(18 ; 12) ;(18 ; 6) ;(12 ; 12) ; \\
(12 ; 6) ;(6 ; 6) \text {. }\end{array}$ \\
\hline $\begin{array}{l}\text { Investigação do } \\
\text { tempo total de } \\
\text { floculação e do } \\
\text { gradiente médio de } \\
\text { velocidade de } \\
\text { floculação } \\
\text { (4.7.3) }\end{array}$ & $\begin{array}{l}\mathrm{DCF}=40 \mathrm{mg} / \mathrm{L} \text { e } \mathrm{DP}=1,25 \\
\mathrm{mg} / \mathrm{L} \quad(\text { escolhidos na etapa } \\
4.6 .1) ; \mathrm{Gmr}=1000 \mathrm{~s}^{-1} ; \mathrm{Tmr}= \\
10 \mathrm{~s} ; \text { Intervalo entre a dosagem } \\
\text { de cloreto férrico e a dosagem } \\
\text { de polímero }=6 \mathrm{~min}(\text { obtido na } \\
\text { etapa } 4.6 .2) ; \mathrm{R}=20 \% \quad(\mathrm{em} \\
\text { volume); Psat }=450 \mathrm{kPa} ; \mathrm{Vf} 1 \\
=5,0 \mathrm{~cm} / \mathrm{min} ; \mathrm{Vf} 2=10,0 \\
\mathrm{~cm} / \mathrm{min} ; \mathrm{Vf} 3=15,0 \mathrm{~cm} / \mathrm{min} ; \\
\mathrm{Vf} 4=20,0 \mathrm{~cm} / \mathrm{min} ; \mathrm{Vf} 5=25,2 \\
\mathrm{~cm} / \mathrm{min} .\end{array}$ & $\begin{array}{l}\text { Valores de tempo total de floculação } \\
\text { (Tf) associados a valores de tempo de } \\
\text { floculação do polímero (Tfpol), em } \\
\text { min, sob a ação de diferentes valores de } \\
\text { gradiente médio de velocidade de } \\
\text { floculação (Gf), em s }{ }^{-1} \text {, (Tf; Tfpol; Gf): } \\
(0 ; 0 ; 0) ;(12 ; 6 ; 40) ;(12 ; 6 ; 60) ;(12 ; \\
6 ; 80) ;(12 ; 6 ; 100) ;(18 ; 12 ; 40) ;(18 ; \\
12 ; 60) ;(18 ; 12 ; 80) ;(18 ; 12 ; 100) ; \\
(24 ; 18 ; 40) ;(24 ; 18 ; 60) ;(24 ; 18 ; 80) ; \\
(24 ; 18 ; 100) \text {. }\end{array}$ \\
\hline $\begin{array}{c}\text { Investigação da } \\
\text { quantidade de ar } \\
\text { fornecida } \\
\text { (4.7.4) }\end{array}$ & $\begin{array}{l}\mathrm{DCF}=40 \mathrm{mg} / \mathrm{L} \text { e } \mathrm{DP}=1,25 \\
\mathrm{mg} / \mathrm{L} \quad(\text { escolhidos na etapa } \\
4.6 .1) ; \mathrm{Gmr}=1000 \mathrm{~s}^{-1} ; \mathrm{Tmr}= \\
10 \mathrm{~s} \text {; Intervalo entre a dosagem } \\
\text { de cloreto férrico e a dosagem } \\
\text { de polímero }=6 \mathrm{~min} \text { (obtido na } \\
\text { etapa } 4.6 .2) ; \mathrm{Tf}=24 \mathrm{~min} \text {, Tfpol } \\
=18 \mathrm{~min} \text { e } \mathrm{Gf}=100 \mathrm{~s}^{-1} \text { (obtidos } \\
\text { na etapa } 4.6 .3) ; \mathrm{R}=20 \%(\mathrm{em} \\
\text { volume); Psat }=450 \mathrm{kPa} ; \mathrm{Vf} 1 \\
=5,0 \mathrm{~cm} / \mathrm{min} ; \mathrm{Vf} 2=10,0 \\
\mathrm{~cm} / \mathrm{min} ; \mathrm{Vf} 3=15,0 \mathrm{~cm} / \mathrm{min} ; \\
\mathrm{Vf} 4=20,0 \mathrm{~cm} / \mathrm{min} ; \mathrm{Vf} 5=25,2 \\
\mathrm{~cm} / \mathrm{min} .\end{array}$ & $\begin{array}{l}\text { Fração de recirculação (R), em volume: } \\
3 \% ; 6 \% ; 9 \% ; 12 \% ; 15 \% ; 15 \% ; 18 \% \text {; } \\
21 \% ; 24 \% ; 27 \%, 30 \% \text {. }\end{array}$ \\
\hline
\end{tabular}

Os demais parâmetros operacionais foram mantidos com valores em torno de: $\mathrm{DCF}=$ $40 \mathrm{mg} / \mathrm{L}$ e DP= $1,25 \mathrm{mg} / \mathrm{L}$, obtidos na etapa 4.6.1; Tmr= $10 \mathrm{~s} ; \mathrm{Gmr}=1000 \mathrm{~s}^{-1}$; intervalo entre 
a aplicação do cloreto férrico e a do polímero sintético $=6$ min, obtido na etapa 4.6.2; R= $20 \%$ (em volume); a pressão de saturação (Psat) foi fixada em $450 \pm 10 \mathrm{kPa}$ e as velocidades de flotação estudadas foram: Vf1 $=5,0 \mathrm{~cm} / \mathrm{min} ; \mathrm{Vf} 2=10,0 \mathrm{~cm} / \mathrm{min} ; \mathrm{Vf} 3=15,0 \mathrm{~cm} / \mathrm{min}$; $\mathrm{Vf} 4=20,0 \mathrm{~cm} / \mathrm{min} ; \mathrm{Vf} 5=25,2 \mathrm{~cm} / \mathrm{min}$.

\subsubsection{Ensaios com variação da quantidade de ar fornecida ao processo}

A variação da quantidade de ar fornecida ao processo $\left(\mathrm{S}^{*}\right)$ foi conseguida através da variação da fração de recirculação $(R)$ de água saturada introduzida na coluna de flotação e medida em fração percentual do volume da amostra a ser tratada contida na coluna, mantendo-se constante a pressão de saturação $(450 \pm 10 \mathrm{kPa})$. Foram testadas as frações de recirculação (R) iguais a 3,0;6,0;9,0;12,0;15,0;18,0;21,0;24,0;27,0 e 30,0\% (ver TABELA 4.3).

Os demais parâmetros operacionais foram mantidos com valores em torno de: $\mathrm{DCF}=$ $40 \mathrm{mg} / \mathrm{L}$ e DP= 1,25 mg/L, obtidos na etapa 4.6.1; Tmr= $10 \mathrm{~s} ; \mathrm{Gmr}=1000 \mathrm{~s}^{-1}$; intervalo entre a aplicação do cloreto férrico e a do polímero sintético $=6 \mathrm{~min}$, obtido na etapa 4.6.2; $\mathrm{Tf}=$ $24 \mathrm{~min}$, Tfpol= $18 \mathrm{~min}$ e $\mathrm{Gf}=100 \mathrm{~s}^{-1}$, obtidos na etapa 4.6.3; $\mathrm{R}=20 \%$ (em volume); a pressão de saturação (Psat) foi fixada em $450 \pm 10 \mathrm{kPa}$ e as velocidades de flotação estudadas foram: Vf1 $=5,0 \mathrm{~cm} / \mathrm{min} ; \mathrm{Vf} 2=10,0 \mathrm{~cm} / \mathrm{min} ; \mathrm{Vf3}=15,0 \mathrm{~cm} / \mathrm{min} ; \mathrm{Vf} 4=20,0 \mathrm{~cm} / \mathrm{min}$; Vf5 $=25,2 \mathrm{~cm} / \mathrm{min}$.

\subsubsection{Ensaios com variação da dosagem de cloreto férrico, da dosagem de polímero sintético (dosado isoladamente), do tipo de polímero sintético e da dosagem de polímero (dosado conjuntamente com cloreto férrico)}

Foram estudadas diferentes adições de cloreto férrico e de polímeros sintéticos (catiônico, aniônico e não iônico) isoladamente e associações de diferentes dosagens de cloreto férrico e de polímeros. As dosagens de cloreto férrico variaram entre 0 e $65 \mathrm{mg} / \mathrm{L}$. As dosagens de polímero variaram entre 1 e $7 \mathrm{mg} / \mathrm{L}$. Para dosagens de $15 \mathrm{mg} / \mathrm{L}$ e de 30 $\mathrm{mg} / \mathrm{L}$ de cloreto férrico foram associadas dosagens de $0,4 \mathrm{mg} / \mathrm{L}$ e de $1,0 \mathrm{mg} / \mathrm{L}$ de polímeros sintéticos.

Os demais parâmetros operacionais foram mantidos com valores em torno de: Tmr= $10 \mathrm{~s} ; \mathrm{Gmr}=1000 \mathrm{~s}^{-1} ; \mathrm{Tf}=20 \mathrm{~min} ; \mathrm{Gf}=80 \mathrm{~s}^{-1} ; \mathrm{R}=20 \%$ (em volume); a pressão de saturação (Psat) foi fixada em $450 \pm 10 \mathrm{kPa}$ e as velocidades de flotação estudadas foram: Vf1 = 5,0 $\mathrm{cm} / \mathrm{min} ; \mathrm{Vf} 2=10,0 \mathrm{~cm} / \mathrm{min} ; \mathrm{Vf} 3=15,0 \mathrm{~cm} / \mathrm{min} ; \mathrm{Vf} 4=20,0 \mathrm{~cm} / \mathrm{min} ; \mathrm{Vf} 5=25,2 \mathrm{~cm} / \mathrm{min}$. Na TABELA 4.4 essa etapa é apresentada dentro da seqüência de ensaios realizados com o flotateste, durante a partida do RALEx. 


\subsubsection{Ensaios com variação da dosagem de cloreto férrico e da qualidade do efluente do reator RALEx, mediante coleta de amostras em diferentes horários do dia}

Nas etapas anteriores, os ensaios eram realizados com amostras do efluente do RALEx coletadas às 08:00. Apesar de a qualidade do efluente de reatores anaeróbios possuir amplitude de variação diária menor do que aquela observada em esgoto sanitário bruto, foi necessário verificar a eficiência de tratamento com FAD em função da variação da qualidade do efluente do RALEx ao longo do dia, quando submetido a diferentes dosagens de cloreto férrico. As dosagens de cloreto férrico variaram entre 0 e $85 \mathrm{mg} / \mathrm{L}$. Diferentes amostras de efluente do RALEx foram coletadas ao longo do dia, nos horários de 08:00, 11:00, 14:00, 17:00 e 20:00, para realização dos ensaios de flotação.

Os demais parâmetros operacionais foram mantidos com valores em torno de: $\mathrm{Tmr}=$ $10 \mathrm{~s} ; \mathrm{Gmr}=1000 \mathrm{~s}^{-1} ; \mathrm{Tf}=20 \mathrm{~min} ; \mathrm{Gf}=80 \mathrm{~s}^{-1} ; \mathrm{R}=20 \%$ (em volume); a pressão de saturação (Psat) foi fixada em $450 \pm 10 \mathrm{kPa}$ e as velocidades de flotação estudadas foram: Vf1 = 5,0 $\mathrm{cm} / \mathrm{min} ; \mathrm{Vf2}=10,0 \mathrm{~cm} / \mathrm{min} ; \mathrm{Vf} 3=15,0 \mathrm{~cm} / \mathrm{min} ; \mathrm{Vf} 4=20,0 \mathrm{~cm} / \mathrm{min} ; \mathrm{Vf5}=25,2 \mathrm{~cm} / \mathrm{min}$. Na TABELA 4.4 essa etapa é apresentada dentro da seqüência de ensaios realizados com o flotateste durante a partida do RALEx.

TABELA 4.4 - Sequiência das etapas de ensaios realizados com flotateste e cloreto férrico associado a polímero sintético.

\begin{tabular}{|c|c|c|}
\hline Objetivo da etapa & Variáveis mantidas fixas & Variáveis estudadas \\
\hline $\begin{array}{c}\text { Investigação do } \\
\text { comportamento da } \\
\text { flotação durante } \\
\text { partida do RALEx, } \\
\text { com diferentes } \\
\text { valores de DCF, DP } \\
\text { e DCF+DP } \\
(\mathbf{4 . 7 . 5 )} \\
\end{array}$ & $\begin{array}{l}\mathrm{Gmr}=1000 \mathrm{~s}^{-1} ; \mathrm{Tmr}=10 \mathrm{~s} ; \mathrm{Gf} \\
=80 \mathrm{~s}^{-1} ; \mathrm{Tf}=20 \mathrm{~min} ; \mathrm{R}=20 \% \\
(\mathrm{em} \text { volume }) ; \text { Psat }=450 \mathrm{kPa} \\
\mathrm{Vf} 1=5,0 \mathrm{~cm} / \mathrm{min} ; \mathrm{Vf} 2=10,0 \\
\mathrm{~cm} / \mathrm{min} ; \mathrm{Vf} 3=15,0 \mathrm{~cm} / \mathrm{min} ; \\
\mathrm{Vf} 4=20,0 \mathrm{~cm} / \mathrm{min} ; \mathrm{Vf} 5=25,2 \\
\mathrm{~cm} / \mathrm{min} .\end{array}$ & $\begin{array}{l}\mathrm{DCF}=0 ; 15 ; 30 ; 45 \text { e } 65 \mathrm{mg} / \mathrm{L} . \\
\text { DP= 1; } 2 ; 4 \text { e } 7 \mathrm{mg} / \mathrm{L} . \\
\text { Tipo de polímero sintético: } \\
\text { G999; G998 e G9047. } \\
\text { DCF/DP: }(15 / 0,4) ;(15 / 1,0) ;(30 / 0,4) ; \\
(30 / 1,0)\end{array}$ \\
\hline $\begin{array}{l}\text { Investigação da } \\
\text { variação da } \\
\text { dosagem de cloreto } \\
\text { férrico e da } \\
\text { qualidade do } \\
\text { efluente do reator } \\
\text { RALEx (4.7.6) }\end{array}$ & $\begin{array}{l}\mathrm{Gmr}=1000 \mathrm{~s}^{-1} ; \mathrm{Tmr}=10 \mathrm{~s} ; \mathrm{Gf} \\
=80 \mathrm{~s}^{-1} ; \mathrm{Tf}=20 \mathrm{~min} ; \mathrm{R}=20 \% \\
(\mathrm{em} \text { volume }) ; \text { Psat }=450 \mathrm{kPa} ; \\
\mathrm{Vf} 1=5,0 \mathrm{~cm} / \mathrm{min} ; \mathrm{Vf} 2=10,0 \\
\mathrm{~cm} / \mathrm{min} ; \mathrm{Vf} 3=15,0 \mathrm{~cm} / \mathrm{min} ; \\
\mathrm{Vf} 4=20,0 \mathrm{~cm} / \mathrm{min} ; \mathrm{Vf} 5=25,2 \\
\mathrm{~cm} / \mathrm{min} .\end{array}$ & $\begin{array}{l}\text { Horário de coleta das amostras de } \\
\text { efluente do RALEx: 08:00, 11:00, } \\
\text { 14:00, 17:00 e 20:00. } \\
\text { DCF=0; } 15 ; 30 ; 45,65 \text { e } 85 \mathrm{mg} / \mathrm{L} \text {. }\end{array}$ \\
\hline $\begin{array}{c}\text { Ensaios com } \\
\text { variação do valor do } \\
\text { pH de coagulação } \\
\text { associada a } \\
\text { diferentes dosagens } \\
\text { de cloreto férrico } \\
(4.7 .7)\end{array}$ & $\begin{array}{l}\mathrm{Gmr}=1000 \mathrm{~s}^{-1} ; \mathrm{Tmr}=10 \mathrm{~s} ; \mathrm{Gf} \\
=80 \mathrm{~s}^{-1} ; \mathrm{Tf}=20 \mathrm{~min} ; \mathrm{R}=20 \% \\
(\mathrm{em} \text { volume }) ; \text { Psat }=450 \mathrm{kPa} ; \\
\mathrm{Vf} 1=5,0 \mathrm{~cm} / \mathrm{min} ; \mathrm{Vf} 2=10,0 \\
\mathrm{~cm} / \mathrm{min} ; \mathrm{Vf} 3=15,0 \mathrm{~cm} / \mathrm{min} ; \\
\mathrm{Vf} 4=20,0 \mathrm{~cm} / \mathrm{min} ; \mathrm{Vf} 5=25,2 \\
\mathrm{~cm} / \mathrm{min} .\end{array}$ & $\begin{array}{l}\mathrm{DCF}=0 ; 15 ; 30 ; 45,65 \text { e } 85 \mathrm{mg} / \mathrm{L} . \\
\text { pH de coagulação: entre } 4,4 \text { e } 6,4 .\end{array}$ \\
\hline
\end{tabular}




\subsubsection{Ensaios com variação do valor do $\mathrm{pH}$ de coagulação associada a diferentes dosagens de cloreto férrico}

Nas etapas anteriores, os ensaios eram realizados sem variação adicional de $\mathrm{pH}$, além daquela produzida pela adição de cloreto férrico. Conforme já discutido na Revisão Bibliográfica, a qualidade na formação dos flocos químicos é dependente do $\mathrm{pH}$ de coagulação do efluente. Sendo assim, é necessário verificar a eficiência de tratamento com FAD diante da variação do $\mathrm{pH}$ de coagulação do efluente do RALEx, quando submetido a diferentes dosagens de cloreto férrico. As dosagens de cloreto férrico variaram entre 0 e 85 $\mathrm{mg} / \mathrm{L}$ associadas a valores de $\mathrm{pH}$ entre 4,4 e 6,4.

Os demais parâmetros operacionais foram mantidos com valores em torno de: Tmr= $10 \mathrm{~s} ; \mathrm{Gmr}=1000 \mathrm{~s}^{-1} ; \mathrm{Tf}=20 \mathrm{~min} ; \mathrm{Gf}=80 \mathrm{~s}^{-1} ; \mathrm{R}=20 \%$ (em volume); a pressão de saturação (Psat) foi fixada em $450 \pm 10 \mathrm{kPa}$ e as velocidades de flotação estudadas foram: Vf1 = 5,0 $\mathrm{cm} / \mathrm{min} ; \mathrm{Vf} 2=10,0 \mathrm{~cm} / \mathrm{min} ; \mathrm{Vf} 3=15,0 \mathrm{~cm} / \mathrm{min} ; \mathrm{Vf} 4=20,0 \mathrm{~cm} / \mathrm{min} ; \mathrm{Vf} 5=25,2 \mathrm{~cm} / \mathrm{min} . \mathrm{Na}$ TABELA 4.4 essa etapa é apresentada dentro da seqüência de ensaios realizados com o flotateste durante a partida do RALEx.

\subsection{Caracterização físico-química das amostras obtidas durante os ensaios com o flotateste}

Em todos os ensaios foram coletadas cinco amostras relativas às cinco diferentes velocidades de flotação (Vf1, Vf2, Vf3, Vf4 e Vf5). O volume de cada amostra foi de 30 $\mathrm{mL}$, com exceção daquela relativa a Vf2, com volume de $150 \mathrm{~mL}$. Foram efetuadas leituras de turbidez em cada amostra coletada, a partir das quais foram calculadas as eficiências teóricas de turbidez para cada velocidade de flotação. Somente a amostra relativa a Vf2 foi conservada para posterior caracterização físico-química simplificada no Laboratório de Tratamento Avançado e Reuso de Águas da Escola de Engenharia de São Carlos - USP. Essa caracterização é constituída pela determinação de DQO e de fosfato.

Dentre os ensaios de algumas etapas, aquele que apresentava as maiores eficiências teóricas de turbidez foi repetido em duas colunas do flotateste e somente a amostra relativa a Vf2 foi coletada em ambos, de forma a obter $500 \mathrm{~mL}$ de amostra. A partir dessa amostra, foi realizada caracterização complementar composta com a determinação de sólidos suspensos.

Todos os parâmetros caracterizados obedeceram à padronização de ensaios descrita no AWWA-APHA \&WPCF (1999). 


\subsection{Ensaios realizados na instalação piloto de flotação por ar dissolvido}

Nesta fase da pesquisa, foram executadas a construção, a montagem e a calibração de todas as unidades e equipamentos necessários à operação da instalação piloto de flotação com escoamento contínuo.

Os ensaios de laboratório com o flotateste forneceram valores de dosagem de coagulante, tempo de floculação, gradiente médio de velocidade de floculação e quantidade de ar fornecida ao processo para os dois produtos químicos testados: cloreto férrico e polímero catiônico. Esses parâmetros foram diretamente utilizados na operação da instalação piloto. Ainda assim, os valores de tempo de floculação, de gradiente médio de velocidade de floculação e de quantidade de ar fornecido foram novamente investigados, de forma a verificar a influência do aumento de escala.

Quanto ao tempo de floculação, foram testados dois valores: 13 e 20 min, durante os ensaios na instalação piloto.

Com relação à quantidade de ar fornecida, foram testados valores de $12 \%, 15 \% \mathrm{e}$ 18\%. Foram utilizadas as mesmas frações de recirculação (R) observadas em laboratório pois era esperado que a eficiência da câmara de saturação se aproximasse de $96 \%$ de saturação teórica de ar, em função da presença de recheio.

Quanto ao gradiente médio de velocidade de floculação, foram testados valores

entre 60 e $100 \mathrm{~s}^{-1}$, tendo em vista que valores menores que estes não apresentaram bons resultados na remoção de fósforo.

A partir destes valores, a instalação piloto (flotador) foi posta em operação.

\subsubsection{Procedimento e monitoramento dos ensaios na instalação piloto de flotação}

A operação da instalação piloto de flotação durante os ensaios é descrita a seguir.

- Verificação da vazão efluente do reator RALEx para confirmar o tempo de detenção hidráulico (TDH $= \pm 3$ horas) na unidade e, portanto, sua disponibilidade para abastecer a instalação de flotação com as vazões desejadas.

- Preparação da solução de produto químico utilizado no ensaio (cloreto férrico e/ou polímero catiônico), em seus respectivos tanques. Durante os ensaios com cloreto férrico, a agitação era ocasionalmente acionada, com a finalidade de manter a solução homogênea. $\mathrm{O}$ uso de polímero catiônico exigia agitação constante para que sua solução pudesse ser mantida homogênea. 
- Ajuste da dosagem de solução de produto químico através da respectiva bomba dosadora.

- Início, em seguida, da alimentação da instalação piloto com efluente do reator RALEx. A vazão em todos os ensaios foi mantida entre 6,4 e $8,5 \mathrm{~m}^{3} / \mathrm{h}$, conforme a necessidade de vazão para estudos de tempo de floculação e de taxa de aplicação superficial. A vazão era conferida em medidor eletromagnético e controlada através de válvulas de esfera presentes na linha de alimentação do flotador. Dependendo do tempo de floculação desejado, era escolhida uma das três primeiras câmaras de floculação para a entrada do efluente do reator anaeróbio previamente coagulado. As demais válvulas de esferas eram mantidas fechadas.

- Acionamento dos motores das unidades de floculação, da(s) bomba(s) dosadora(s) e do raspador superficial de lodo.

- Preenchimento gradual de cada unidade pelo efluente do reator RALEx coagulado.

- Ajuste a vazão de descarte de líquido floculado após o flotador estar totalmente preenchido, de forma a obter o valor de TAS previsto nos ensaios.

- Fornecimento de parcela do líquido clarificado para a câmara de saturação, através do acionamento da bomba de recirculação pressurizada do sistema de saturação de água, no momento em que a instalação piloto começava a fornecer o efluente já clarificado.

- Ajuste da bomba de recirculação pressurizada e do compressor de ar de forma a manter uma pressão em torno de $450 \mathrm{kPa}$ no interior da câmara e a vazão de recirculação desejada no ensaio. Os ajustes eram efetuados através das quatro válvulas de agulha presentes no equipamento.

- Realização de descartes de material eventualmente sedimentado nos troncos piramidais da câmara de flotação após a estabilização da operação da câmara de saturação e o início da flotação dos flocos químicos. Este material sedimentava, pois, até o momento em que a câmara de saturação iniciava o fornecimento de microbolhas ao sistema, o tanque de flotação funcionava como um pseudodecantador.

- Acompanhamento minucioso do funcionamento da instalação piloto por doze horas pois (i) era necessário que todos os equipamentos estivessem funcionando corretamente e de acordo com os ajustes iniciais e (ii) era suposto que, após esse 
período, não mais haveria influência de resquícios do material eventualmente sedimentado na câmara de flotação.

- Manutenção do sistema em funcionamento após a partida do flotador, enquanto durassem os diferentes ensaios previstos nas respectivas etapas. Como cada ensaio tinha duração de 12 horas, no mínimo, eram coletadas amostras do esgoto bruto, do efluente do reator RALEx e do líquido clarificado a cada três horas, por um período mínimo de doze horas (cinco amostras).

- Determinação dos valores de $\mathrm{pH}$, de turbidez e de temperatura de cada amostra. Além das medidas dessas amostras, também era verificado o $\mathrm{pH}$ do líquido na unidade de coagulação ( $\mathrm{pH}$ de coagulação) para determinados ensaios.

- Ajuste da instalação piloto para operar com novos parâmetros a serem estudados após coletadas as cinco baterias de amostras. A última coleta era feita às 20:00, quando, então, era modificado o parâmetro em estudo, seja gradiente de velocidade de floculação, tempo de floculação, dosagem de produto químico, taxa de aplicação superficial ou quantidade de ar fornecida ao sistema. Até a próxima coleta, às 08:00 do dia seguinte, a unidade piloto já se encontrava estabilizada com seus novos parâmetros de operação.

\subsubsection{Ensaios com a instalação piloto utilizando somente cloreto férrico}

Nos ensaios com a instalação piloto utilizando somente cloreto férrico, foram testadas três dosagens de cloreto férrico (DCF), três gradientes médios de velocidade de floculação (Gf), dois tempos de floculação (Tf), dois valores de fração de recirculação (R) e duas diferentes taxas de aplicação superficial (TAS). A associação entre os diferentes parâmetros e os seus respectivos valores está listada na TABELA 4.5.

\subsubsection{Ensaios com instalação piloto utilizando cloreto férrico associado a polímero sintético}

Nos ensaios com instalação piloto utilizando cloreto férrico associado a polímero sintético, foram testadas duas dosagens de cloreto férrico (DCF) associadas a duas dosagens de polímero sintético (DP), dois tempos de floculação (Tf), três valores de fração de recirculação (R) e duas diferentes taxas de aplicação superficial (TAS). A associação entre os diferentes parâmetros e os seus respectivos valores está listada na TABELA 4.6. 
TABELA 4.5 - Seqüência das etapas de ensaios realizados com aplicação de cloreto férrico no afluente ao sistema de flotação.

\begin{tabular}{ccccccc}
\hline \hline Ensaio & $\begin{array}{c}\text { DCF } \\
(\mathbf{m g} / \mathbf{L})\end{array}$ & $\begin{array}{c}\mathbf{D P} \\
(\mathbf{m g} / \mathbf{L})\end{array}$ & $\begin{array}{c}\mathbf{G f} \\
\left(\mathbf{s}^{\mathbf{- 1}}\right)\end{array}$ & $\begin{array}{c}\mathbf{T f} \\
(\mathbf{m i n})\end{array}$ & $\begin{array}{c}\mathbf{R} \\
(\boldsymbol{\%})\end{array}$ & $\begin{array}{c}\mathbf{T A S} \\
\left(\mathbf{m}^{\mathbf{3}} / \mathbf{m}^{\mathbf{2}} / \mathbf{d}\right)\end{array}$ \\
\hline \hline 1 & 50 & 0 & 60 & 13 & 12 & 180 \\
\hline 2 & 50 & 0 & 80 & 13 & 12 & 180 \\
\hline 3 & 50 & 0 & 100 & 13 & 12 & 180 \\
\hline 4 & 50 & 0 & 60 & 20 & 12 & 180 \\
\hline 5 & 50 & 0 & 80 & 20 & 12 & 180 \\
\hline 6 & 50 & 0 & 100 & 20 & 12 & 180 \\
\hline 7 & 50 & 0 & 60 & 13 & 18 & 180 \\
\hline 8 & 50 & 0 & 80 & 13 & 18 & 180 \\
\hline 9 & 50 & 0 & 100 & 13 & 18 & 180 \\
\hline 10 & 50 & 0 & 60 & 20 & 18 & 180 \\
\hline 11 & 50 & 0 & 80 & 20 & 18 & 180 \\
\hline 12 & 50 & 0 & 100 & 20 & 18 & 180 \\
\hline 13 & 70 & 0 & 80 & 20 & 18 & 180 \\
\hline 14 & 30 & 0 & 80 & 20 & 18 & 180 \\
\hline 15 & 70 & 0 & 80 & 20 & 18 & 250 \\
\hline 16 & 50 & 0 & 80 & 20 & 18 & 250 \\
\hline 17 & 30 & 0 & 80 & 20 & 18 & 250 \\
\hline 18 & 70 & 0 & 80 & 20 & 18 & 180 \\
\hline 19 & 90 & 0 & 80 & 20 & 18 & 180 \\
\hline 20 & Variável & 0 & 80 & 20 & 18 & 180 \\
\hline \hline
\end{tabular}

TABELA 4.6 - Seqüência das etapas de ensaios realizados com aplicação de cloreto férrico associado a polímero sintético no afluente ao sistema de flotação.

\begin{tabular}{ccccccc}
\hline \hline Ensaio & $\begin{array}{c}\text { DCF } \\
(\mathbf{m g} / \mathbf{L})\end{array}$ & $\begin{array}{c}\text { DP } \\
(\mathbf{m g} / \mathbf{L})\end{array}$ & $\begin{array}{c}\mathbf{G f} \\
\left(\mathbf{s}^{-\mathbf{1}}\right)\end{array}$ & $\begin{array}{c}\mathbf{T f} \\
(\mathbf{m i n})\end{array}$ & $\begin{array}{c}\mathbf{R} \\
(\boldsymbol{\%})\end{array}$ & $\begin{array}{c}\mathbf{T A S} \\
\left(\mathbf{m}^{\mathbf{3}} / \mathbf{m}^{\mathbf{2}} / \mathbf{d}\right)\end{array}$ \\
\hline \hline 1 & 30 & 0,40 & 80 & 14 & 20 & 180 \\
\hline 2 & 30 & 0,40 & 80 & 21 & 20 & 180 \\
\hline 3 & 30 & 1,0 & 80 & 14 & 20 & 180 \\
\hline 4 & 30 & 1,0 & 80 & 21 & 20 & 180 \\
\hline 5 & 50 & 0,40 & 80 & 23 & 12 & 180 \\
\hline 6 & 50 & 0,40 & 80 & 23 & 15 & 180 \\
\hline 7 & 50 & 0,40 & 80 & 23 & 18 & 180 \\
\hline 8 & 50 & 0,40 & 80 & 20 & 12 & 250 \\
\hline 9 & 50 & 0,40 & 80 & 20 & 15 & 250 \\
\hline 10 & 50 & 0,40 & 80 & 20 & 18 & 250 \\
\hline \hline
\end{tabular}




\subsubsection{Ensaios com a câmara de saturação visando determinação da quantidade de ar fornecida ao processo}

Foram realizados ensaios com a câmara de saturação para determinação da quantidade de ar fornecida ao processo, quando da pressurização e recirculação do efluente. Somente a partir desses valores, era possível saber a quantidade de ar que esta unidade estava propiciando ao processo. Os procedimentos para a realização dos ensaios estão apresentados em REALI (1991). Os ensaios foram realizados em setembro de 2002 por Marcelo Eustáquio de Carvalho e Renata Cristina Moretti, ambos pós-graduandos do Departamento de Hidráulica e Saneamento da EESC-USP.

Nos ensaios, a pressão no interior da câmara foi mantida em torno de $450 \pm 10 \mathrm{kPa}$. Os parâmetros variados foram temperatura e taxa de aplicação superficial da câmara de saturação $\left(\mathrm{TAS}_{\mathrm{cs}}\right)$. A variação da temperatura não foi controlada pois dependia simplesmente das condições ambientes no momento dos ensaios, que oscilaram em torno de $23,0 \pm 0,5^{\circ} \mathrm{C}$ (água) e $24,0 \pm 0,5^{\circ} \mathrm{C}$ (ar). A variação da $\mathrm{TAS}_{\text {cs }}$ era função das vazões de recirculação utilizadas nos ensaios, de forma que os valores ensaiados eram relativamente reduzidos $\left(342 \leq \mathrm{TAS}_{\mathrm{cs}} \leq 634 \mathrm{~m}^{3} / \mathrm{m}^{2} / \mathrm{d}\right)$ em comparação aos comumente empregados $\left(\right.$ TAS $_{\mathrm{cs}}$ $\geq 600 \mathrm{~m}^{3} / \mathrm{m}^{2} / \mathrm{d}$ ). Vale ressaltar que estes valores de $\mathrm{TAS}_{\mathrm{cs}}$ estão abaixo do comumente utilizado pois o sistema piloto foi projetado para tratar vazões superiores àquelas observadas neste estudo. Os ensaios forneceram os valores de saturação em peso (Sp), expressos em g de $\mathrm{ar} / \mathrm{m}^{3}$ de água, proporcionados pela câmara. A quantidade de ar fornecido ao processo (S*) foi obtida através da EQUAÇÃO 4-1.

$$
S^{*}=S p \times R
$$

Onde:

$\mathrm{S}^{*}$ : massa de ar fornecida ao processo por unidade de volume de líquido afluente $\left(\mathrm{g} / \mathrm{m}^{3}\right)$

Sp: saturação em peso do ar na água $\left(\mathrm{g} / \mathrm{m}^{3}\right)$ e

R: fração de recirculação (adimensional)

\subsubsection{Caracterização físico-química das amostras obtidas durante os ensaios com a instalação piloto}

Ao final de cada dia de ensaio, eram obtidas cinco amostras do esgoto bruto, cinco do efluente do reator RALEx, cinco do líquido clarificado e, em alguns casos, cinco do líquido floculado. As amostras do esgoto bruto, do efluente do reator RALEx e do líquido clarificado foram caracterizadas quanto à temperatura, turbidez, pH, DQO, fosfato e sólidos suspensos. A presença de ferro total e, eventualmente, de alguns outros metais foi determinada nas amostras compostas obtidas a partir das cinco amostras de cada fonte. 
Quando amostras de líquido floculado eram colhidas, o $\mathrm{pH}$ e os sólidos suspensos eram determinados também para estas amostras.

No último ensaio, além das determinações já citadas, também foram efetuadas as determinações de DQO e de fósforo das amostras filtradas, DBO, óleos e graxas, carbono orgânico total, sólidos totais, dureza total, sulfato, sulfeto, cloreto, sódio, NTK, nitrogênio amoniacal, nitrato, nitrito, flúor, fenóis, sílica, coliformes totais e fecais.

Todos os parâmetros caracterizados obedeceram à padronização de ensaios descrita no AWWA-APHA \&WPCF (1999).

\subsection{Caracterização físico-química simplificada do esgoto bruto e do efluente do reator RALEx ao longo de 24 horas}

Esta etapa dos trabalhos foi realizada em parceria com Neyson Martins Mendonça e Margarida Marchetto, alunos do Programa de Doutorado do Departamento de Hidráulica e Saneamento da EESC-USP, Hélio Rodrigues dos Santos, Renata Cristina Moretti, Guilherme Finazzi e Carlos Magno de Souza Vidal, alunos de Mestrado do Departamento de Hidráulica e Saneamento da EESC-USP, Cristiano Luchesi Niciura, Marcelo Eustáquio de Carvalho, Marcos Antônio da Silva, Pedro Ivo de Almeida Santos e Fábio Sebastião de Paula, alunos de Iniciação Científica da EESC-USP, em 7 de outubro de 1999. Em 8 de fevereiro de 2000, os trabalhos foram feitos em parceria com Neyson Martins Mendonça, Hélio Rodrigues dos Santos, Pedro Ivo de Almeida Santos, Renata Cristina Moretti, Cristiano Luchesi Niciura, Marcelo Eustáquio de Carvalho e Marcos Antônio da Silva.

Foram caracterizados o esgoto sanitário bruto e o efluente do Reator Anaeróbio de Leito Expandido (RALEx) utilizados no Tratamento de Esgoto Sanitário. As amostras eram coletadas a cada duas horas de intervalo e encaminhadas imediatamente ao Laboratório de Saneamento e ao Laboratório de Tratamento Avançado e Reuso de Águas da EESC-USP, onde sua caracterização era iniciada. Os trabalhos foram realizados em duas datas, a saber:

1. Das 6:00 do dia 7 de outubro às 6:00 do dia 8 de outubro de 1999 e

2. Das 6:00 do dia 8 de fevereiro às 6:00 do dia 9 de fevereiro de 2000 .

Não houve registro de precipitações pluviométricas na bacia de contribuição da rede de coleta de esgotos nas $24 \mathrm{~h}$ anteriores ao início dos trabalhos, em ambos os dias de coleta.

As determinações realizadas foram alcalinidade parcial e total, alcalinidade a bicarbonato, ácidos voláteis, DQO da amostra não filtrada, DQO da amostra filtrada, turbidez, fósforo total da amostra não filtrada, fósforo da amostra filtrada, nitrogênio orgânico, amoniacal e NTK, sólidos sedimentáveis, sólidos totais e suspensos.

Todos os parâmetros caracterizados obedeceram à padronização de ensaios descrita no AWWA-APHA \&WPCF (1999). 


\section{RESULTADOS E DISCUSSÕES}

Os ensaios com a câmara de saturação, visando determinação da quantidade de ar fornecida ao processo através da recirculação de líquido pressurizado, são relatados no item 5.1.

O item 5.2 apresenta as duas caracterizações físico-químicas simplificadas do esgoto sanitário e do efluente do reator RALEx, realizadas por um período de 24 horas, possibilitando verificar seu comportamento nos períodos diurno e noturno, principalmente em relação à presença de fósforo total, DQO e SST.

Os resultados obtidos durante os ensaios preliminares com o equipamento de floculação/flotação, em escala de laboratório (flotateste), e com aplicação de diversos polímeros sintéticos, isoladamente ou associados ao cloreto férrico, são apresentados no item 5.3.

No item 5.4, após escolha dos polímeros que proporcionaram as melhores eficiências de remoção de turbidez, DQO e de fósforo, são apresentados os resultados obtidos durante os ensaios com o equipamento de floculação/flotação, em escala de laboratório (flotateste), e com aplicação de cloreto férrico, isoladamente ou associado a polímero sintético.

Os resultados dos ensaios com amostras de efluente do reator RALEx coletadas ao longo do dia, utilizando o flotateste e com aplicação de cloreto férrico, visando o estudo do comportamento da unidade de floculação/flotação, diante da variação da qualidade do efluente do reator anaeróbio, são apresentados no item 5.5.

No item 5.6, são apresentados os resultados dos ensaios realizados na instalação piloto de flotação por ar dissolvido, onde foram estudadas faixas mais estreitas de valores de dosagem de coagulante, tempo e gradiente médio de velocidade de floculação, quantidade de ar fornecida ao processo e taxa de aplicação superficial.

A partir do item 5.3, onde se inicia a discussão dos resultados concernentes aos ensaios de flotação, encontram-se destacados os parágrafos considerados mais relevantes, através da inserção de molduras em torno dos mesmos. Tais parágrafos foram considerados mais relevantes devido ao fato de apresentarem discussão de resultados com caráter bastante conclusivo. 


\subsection{Ensaios com a câmara de saturação visando determinação da quantidade de ar fornecida ao processo}

Nessa fase, foram realizados ensaios para avaliar a eficiência de dissolução do ar na água da câmara de saturação, para determinação da quantidade de ar fornecida ao processo. A pressão no interior da câmara de saturação foi mantida estável e igual a $450 \pm 10 \mathrm{kPa}$. O parâmetro variado foi o da taxa de aplicação superficial da câmara de saturação $\left(\right.$ TAS $\left._{\mathrm{cs}}\right)$. A temperatura não foi controlada, pois dependia simplesmente das condições ambientes durante os ensaios. Ainda assim, a variação de temperatura não foi considerável, oscilando em torno de $24,0 \pm 0,5^{\circ} \mathrm{C}$ (ar) e $23,0 \pm 0,5^{\circ} \mathrm{C}$ (água). A variação da $\mathrm{TAS}_{\mathrm{cs}}$ foi proporcional às vazões de recirculação utilizadas nos ensaios, de forma que os valores testados foram relativamente reduzidos $\left(342 \leq \mathrm{TAS}_{\mathrm{cs}} \leq 634 \mathrm{~m}^{3} / \mathrm{m}^{2} / \mathrm{d}\right)$ em comparação aos comumente empregados $\left(\mathrm{TAS}_{\mathrm{cs}} \geq\right.$ $600 \mathrm{~m}^{3} / \mathrm{m}^{2} / \mathrm{d}$ ). Essa fase de ensaios foi imprescindível, pois a quantidade de ar fornecida ao processo depende da fração de recirculação, da pressão de saturação e da eficiência de dissolução do ar na água da câmara de saturação.

Na TABELA 5.1 são apresentados os resultados dos ensaios realizados com o objetivo de determinar a quantidade de ar fornecida ao processo durante os diferentes ensaios deste trabalho. A saturação, em peso, do ar na água variou de $69,4 \mathrm{mg} / \mathrm{L}$ a $117,7 \mathrm{mg} / \mathrm{L}$, para valores de taxa de aplicação superficial da câmara de saturação iguais a 634 e $440 \mathrm{~m}^{3} / \mathrm{m}^{2} / \mathrm{dia}$, respectivamente. Notadamente, o emprego de valores de $\mathrm{TAS}_{\mathrm{CS}}$ menores que $516 \mathrm{~m}^{3} / \mathrm{m}^{2} / \mathrm{dia}$ resultou em maiores concentrações de ar na água, entre 108,4 e 117,7 mg/L. Na medida em que a $\mathrm{TAS}_{\mathrm{CS}}$ foi elevada para valores de até $634 \mathrm{~m}^{3} / \mathrm{m}^{2} /$ dia, a concentração de ar dissolvido na água foi sendo reduzida, de 99,1 a 69,4 mg/L.

TABELA 5.1 - Resultados dos ensaios com a câmara de saturação.

\begin{tabular}{|c|c|c|c|c|c|c|c|c|}
\hline $\begin{array}{l}\text { Temp. } \\
\text { ar } \\
\left({ }^{\circ} \mathrm{C}\right)\end{array}$ & $\begin{array}{l}\text { Temp. } \\
\text { água } \\
\left({ }^{\circ} \mathrm{C}\right)\end{array}$ & $\begin{array}{c}\text { Pressão } \\
\text { de vapor } \\
(\mathrm{mmHg})\end{array}$ & $\begin{array}{c}\text { Vazão de } \\
\text { recirculação } \\
(\mathrm{L} / \mathrm{h})\end{array}$ & $\begin{array}{l}\text { TAS na } \\
\text { câmara de } \\
\text { saturação } \\
\left(\mathrm{m}^{3} / \mathrm{m}^{2} / \mathbf{d}\right)\end{array}$ & $\begin{array}{c}\text { Pressão } \\
\text { Câmara } \\
\text { de } \\
\text { Saturação } \\
\quad(\mathbf{k P a})\end{array}$ & $\begin{array}{c}\text { Pressão } \\
\text { Atmosférica } \\
(\mathbf{m m H g})\end{array}$ & $\begin{array}{c}\text { Saturação } \\
\text { em volume } \\
\text { nas } \\
\text { Condições } \\
\text { Ambientes } \\
(\mathrm{mL} / \mathrm{L})\end{array}$ & $\begin{array}{c}\text { Saturação } \\
\text { em peso } \\
(\mathrm{Sp}) \\
(\mathrm{mg} / \mathrm{L})\end{array}$ \\
\hline $24,0 \pm 0,5$ & $23,0 \pm 0,5$ & 21,94 & $876 \pm 20$ & $342 \pm 8$ & $450 \pm 10$ & 654 & 108,5 & 109,2 \\
\hline $24,0 \pm 0,5$ & $23,0 \pm 0,5$ & 21,94 & $1128 \pm 20$ & $440 \pm 8$ & $450 \pm 10$ & 654 & 117,0 & 117,7 \\
\hline $24,0 \pm 0,5$ & $23,0 \pm 0,5$ & 21,94 & $1324 \pm 20$ & $516 \pm 8$ & $450 \pm 10$ & 654 & 107,7 & 108,4 \\
\hline $24,0 \pm 0,5$ & $23,0 \pm 0,5$ & 21,94 & $1496 \pm 20$ & $583 \pm 8$ & $450 \pm 10$ & 654 & 98,5 & 99,1 \\
\hline $24,0 \pm 0,5$ & $23,0 \pm 0,5$ & 21,94 & $1625 \pm 20$ & $634 \pm 8$ & $450 \pm 10$ & 654 & 69,0 & 69,4 \\
\hline
\end{tabular}




\subsection{Caracterização físico-química simplificada do esgoto bruto e do efluente do reator RALEx ao longo de 24 horas}

Os resultados obtidos durante a caracterização físico-química simplificada do esgoto bruto e do efluente do RALEx ao longo de 24 horas possibilitaram verificar seu comportamento nos períodos diurno e noturno, principalmente em relação à presença de fósforo total, DQO e sólidos suspensos totais.

A primeira caracterização simplificada foi realizada no dia 7 de outubro de 1999 e a segunda caracterização no dia 8 de fevereiro de 2000. As amostras foram coletadas a cada duas horas de intervalo. Como os principais parâmetros de controle em todas as etapas de ensaios são DQO, fósforo total e sólidos suspensos totais, a discussão a seguir contempla somente esses parâmetros.

Na FIGURA 5.1 são apresentados os valores da temperatura do ar, do esgoto bruto e do efluente do reator RALEx, de DQO bruta (amostras não filtradas), de concentração de fósforo total e de sólidos suspensos totais observados no período entre 06:00 de 7 de outubro às 06:00 do dia 8 de outubro de 1999.

Com relação à temperatura, é interessante notar que sua menor amplitude de variação foi observada no esgoto bruto, com valores entre $24,0^{\circ} \mathrm{C}$ e $28,0^{\circ} \mathrm{C}$. O emprego de tubulações enterradas para transporte do esgoto explica a manutenção de temperaturas mais estáveis. Em contraposição, a temperatura do ar apresentou a maior amplitude de variação, com valores entre $19,0^{\circ} \mathrm{C}$ e $34,0^{\circ} \mathrm{C}$. A existência de elevada relação área superficial/volume do reator RALEx e o uso de aço em sua fabricação resultaram na significativa influência da temperatura do ar na temperatura do efluente do reator RALEx. Pode-se observar que nos momentos em que a temperatura do ar é menor do que a do esgoto bruto, entre 06:00 e 12:00 e entre 00:00 e 06:00, o efluente do RALEx apresenta temperatura também menor do que a do esgoto bruto. No momento em que a temperatura do ar é maior do que a do esgoto bruto, entre 12:00 e 00:00, o efluente do RALEx apresenta temperatura também maior do que a do esgoto bruto.

A DQO do esgoto bruto apresentou grande variabilidade ao longo das 24 horas. O menor valor de DQO, $96 \mathrm{mg} / \mathrm{L}$, foi observado às 06:00 do dia 8/10/99 e seu maior valor, 854 $\mathrm{mg} / \mathrm{L}$, às 18:00 do dia 7/10/99. Entretanto, a variabilidade dos valores de DQO do efluente do RALEx foi significativamente menor. Basicamente, a DQO, às 06:00, apresenta os menores valores (140 mg/L, no dia 7/10, e $116 \mathrm{mg} / \mathrm{L}$, no dia 8/10) observados ao longo das 24 horas. A partir deste horário, há uma tendência de aumento da DQO, até às 10:00. Entre 10:00 e 22:00, os valores de DQO apresentaram média de $287 \mathrm{mg} / \mathrm{L}$, com desvio padrão de $16 \mathrm{mg} / \mathrm{L}$. A partir das 00:00, a DQO tendeu a reduzir-se gradativamente, até às 06:00. 
O comportamento da variação da concentração de fósforo total no esgoto bruto está bastante definido. Sua concentração $(8,7 \mathrm{mgP} / \mathrm{L})$ apresentou-se bastante elevada às 08:00 e tendeu a reduzir-se ao longo do dia e da noite, atingindo valores mínimos às 06:00 (2,3 mgP/L, no dia 7/10, e 1,5 mgP/L, no dia 8/10/99). Como esperado, as concentrações de fósforo total observadas no efluente do RALEx apresentaram menor amplitude de variação. Os valores de fósforo observados durante as 24 horas apresentaram concentração entre 2,7 e 5,2 mgP/L.

A concentração de sólidos suspensos totais no esgoto bruto apresentava oscilações entre 08:00, do dia 7/10, e 4:00, do dia 8/10, com valores entre 220 e $497 \mathrm{mg} / \mathrm{L}$. O teor de SST da amostra coletada às 2:00 do dia 8/10 não está disponível pois houve perda da amostra no laboratório. Às 06:00 do dia 8/10, a concentração de SST no esgoto bruto foi bastante baixa, com valor de $30 \mathrm{mg} / \mathrm{L}$. A variação de SST no efluente do RALEx foi pequena, com valores entre 60 e $188 \mathrm{mg} / \mathrm{L}$.

Na FIGURA 5.2 são apresentados os valores da temperatura do ar, do esgoto bruto e do efluente do reator RALEx, de DQO bruta (amostras não filtradas), de concentração de fósforo total e de sólidos suspensos totais observados no período entre 06:00 de 8 de fevereiro às 06:00 do dia 09 de fevereiro de 2000.

Com relação à temperatura, é interessante notar que sua menor amplitude de variação foi observada no efluente do reator RALEx, com valores entre $25,0^{\circ} \mathrm{C}$ e $28,5^{\circ} \mathrm{C}$. A amplitude de variação do esgoto bruto foi de $23,5^{\circ} \mathrm{C}$ a $29,0^{\circ} \mathrm{C}$. A menor amplitude de variação da temperatura observada no efluente do reator RALEx pode ser decorrente da nebulosidade predominante no período da caracterização simplificada. Sem a incidência direta da luz solar sobre a área superficial do reator, a temperatura em seu interior apresentou tendência de relativa estabilidade, não sofrendo influência significativa da variação da temperatura do ar, entre 22,0 e $33,0^{\circ} \mathrm{C}$.

A DQO do esgoto bruto apresentou grande variabilidade ao longo das 24 horas. O menor valor de DQO (38 mg/L) foi observado às 06:00 do dia 09/2/2000 e seu maior valor (873 $\mathrm{mg} / \mathrm{L}$ ) às 08:00 do dia 8/2/2000. Entretanto, a DQO do efluente do RALEx não variou significativamente, apresentando valores baixos (106 mg/L, às 06:00 do dia 8/2 e $38 \mathrm{mg} / \mathrm{L}$, às 06:00 do dia 09/2) no começo do dia. A DQO do efluente do reator anaeróbio apresentou tendência de elevação de valor até às 14:00. Entre as 14:00 e as 20:00, os valores de DQO apresentam média de $253 \mathrm{mg} / \mathrm{L}$, com desvio padrão de 37,4 mg/L. A partir das 20:00, sua DQO tende a reduzir-se gradativamente, até às 06:00. 
Temperatura das amostras nos dias 7 e 8 de outubro de 1999

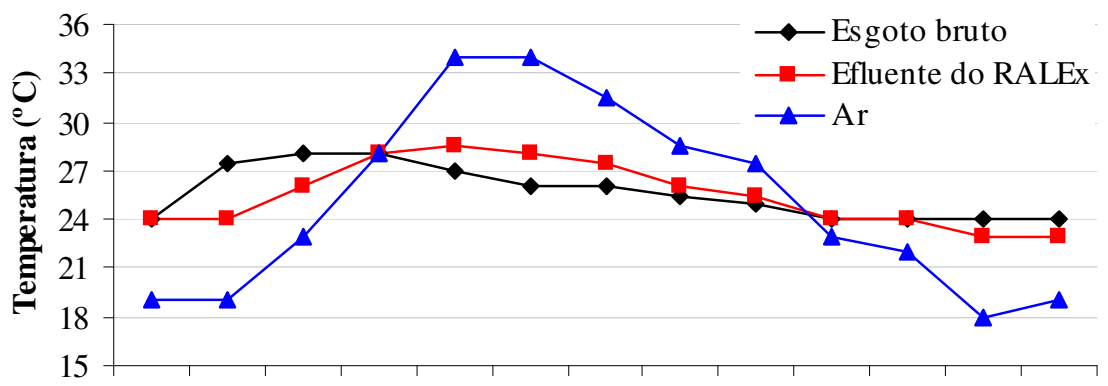

DQO das amostras não filtradas (7 e 8 de outubro de 1999)

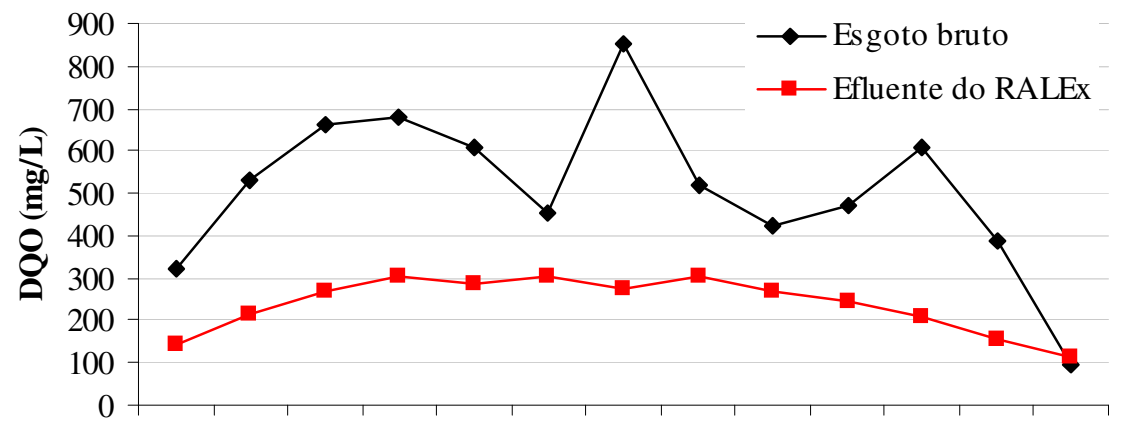

Fósforo das amostras não filtradas (7 e 8 de outubro de 1999)

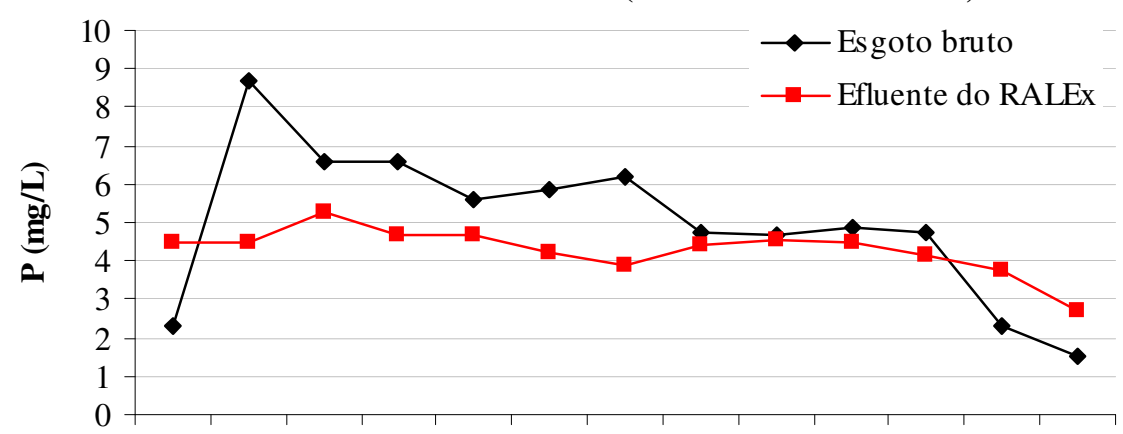

SST das amostras (7 e 8 de outubro de 1999)

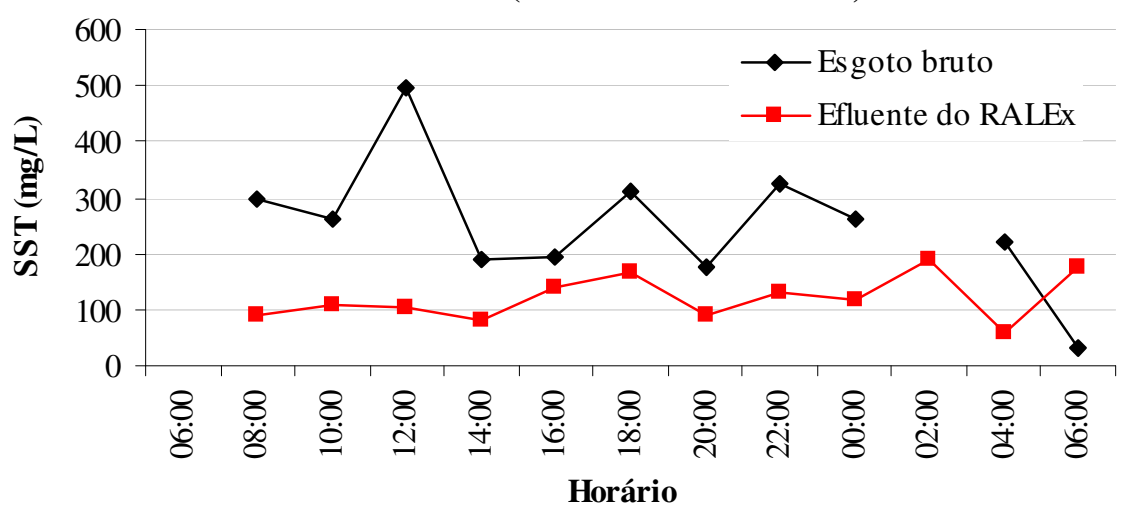

FIGURA 5.1 - Valores de temperatura do ar, do esgoto bruto e do efluente do reator RALEx, de DQO bruta (amostras não filtradas), de concentração de fósforo total e de sólidos suspensos totais observados durante a primeira caracterização físicoquímica, no período entre 06:00 de 7 de outubro e 06:00 do dia 8 de outubro de 1999. 
A concentração de fósforo $(11,1 \mathrm{mgP} / \mathrm{L})$ estava consideravelmente elevada às 10:00 do dia 8 de fevereiro e apresentou tendência de redução ao longo do dia, atingindo valores mínimos às 20:00 do dia 8/2 (1,6 mgP/L), e às 06:00 do dia 09/2/2000 (1,0 mgP/L). Entretanto, as concentrações de fósforo observadas no efluente do RALEx apresentam menor variabilidade. Das 10:00 até as 22:00 os valores de fósforo observados apresentaram concentração entre 3,9 e $4,9 \mathrm{mgP} / \mathrm{L}$. A concentração de fósforo voltou a diminuir a partir das 22:00, permanecendo entre 1,6 e 2,3 mg/L até as 06:00 do dia 09/2/2000.

A concentração de sólidos suspensos totais no esgoto bruto apresentou rápida elevação entre 06:00, com $36 \mathrm{mgSST} / \mathrm{L}$, e 08:00, com $500 \mathrm{mgSST} / \mathrm{L}$. Entre 10:00 e 22:00, a concentração de SST oscilou entre 70 e $235 \mathrm{mg} / \mathrm{L}$. A partir das 22:00 até 06:00, a presença de SST no esgoto bruto reduziu-se gradativamente até alcançar $13 \mathrm{mg} / \mathrm{L}$. A variação de SST no efluente do RALEx foi pequena, com valores entre 14 e $92 \mathrm{mg} / \mathrm{L}$ ao longo das 24 horas observadas.

Na TABELA 5.2, estão apresentados os dados de carga de diferentes parâmetros de qualidade observados em amostras de esgoto bruto e de efluente de reator RALEx, coletadas em outubro de 1999 e em fevereiro de 2000, e de efluente de reator UASB, coletada em outubro de 1997 (PENETRA, 1998), durante caracterização simplificada de efluentes ao longo de 24 horas.

O reator UASB utilizado por PENETRA (1998) era construído em fibra de vidro e estava implantado na área nordeste do Campus de São Carlos, da Universidade de São Paulo. O reator possuía volume de $18 \mathrm{~m}^{3}$, sendo $4,0 \mathrm{~m}^{2}$ de área e $4,5 \mathrm{~m}$ de altura. Na FIGURA 5.3 está apresentada a fotografia do reator UASB. O esgoto sanitário tratado era proveniente da rede coletora pública da sub-bacia do Córrego Tijuco Preto, que atravessa o Campus de São Carlos, o mesmo atualmente utilizado como afluente do reator RALEx. Sua operação foi iniciada em 29 de setembro de 1995. Em maio de 1996, o reator foi continuamente operado com tempo de detenção hidráulico (TDH) igual a $8 \mathrm{~h}$, equivalente a uma vazão efluente tratada de $0,61 \mathrm{~L} / \mathrm{s}$. Em 2000, a operação do reator foi interrompida e em 2002 foi completamente removido do local.

A carga dos diferentes parâmetros de qualidade das amostras de esgoto bruto, afluente aos reatores anaeróbios, entre 08:00 e 20:00 é substancialmente maior do que aquela observada entre 20:00 e 08:00, conforme dados coletados entre 1997 e 2000. Como exemplo, pode-se citar os valores de DQO de amostras não filtradas $\left(\mathrm{DQO}_{\text {bruta }}\right)$ de esgoto bruto. Em 1997, a carga de DQO $_{\text {bruta }}$ entre 08:00 e 20:00 foi de 28,4 $\mathrm{kgO}_{2}$ e entre 20:00 e 08:00 foi de 11,1 $\mathrm{kgO}_{2}$, correspondente à vazão de 0,61 L/s. Em 1999, o valor ao longo do dia foi de 73,9 $\mathrm{kgO}_{2} \mathrm{e}$ durante a noite foi de $48,5 \mathrm{kgO}_{2}$, correspondente à vazão de $10 \mathrm{~m}^{3} / \mathrm{h}$. Em 2000, a carga de $\mathrm{DQO}_{\text {bruta }}$ entre 08:00 e 20:00 foi de 68,1 $\mathrm{kgO}_{2}$ e entre 20:00 e 08:00 foi de 15,4 $\mathrm{kgO}_{2}$. De maneira geral, esse comportamento é semelhante entre os demais parâmetros de qualidade. 
Temperatura das amostras nos dias 8 e 9 de fevereiro de 2000

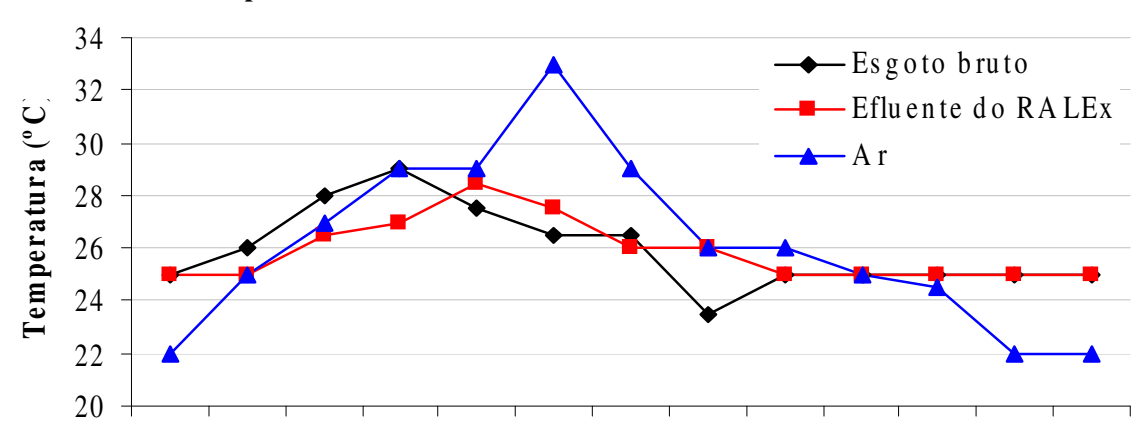

DQO das amostras não filtradas (8 e 9 de fevereiro de 2000 )

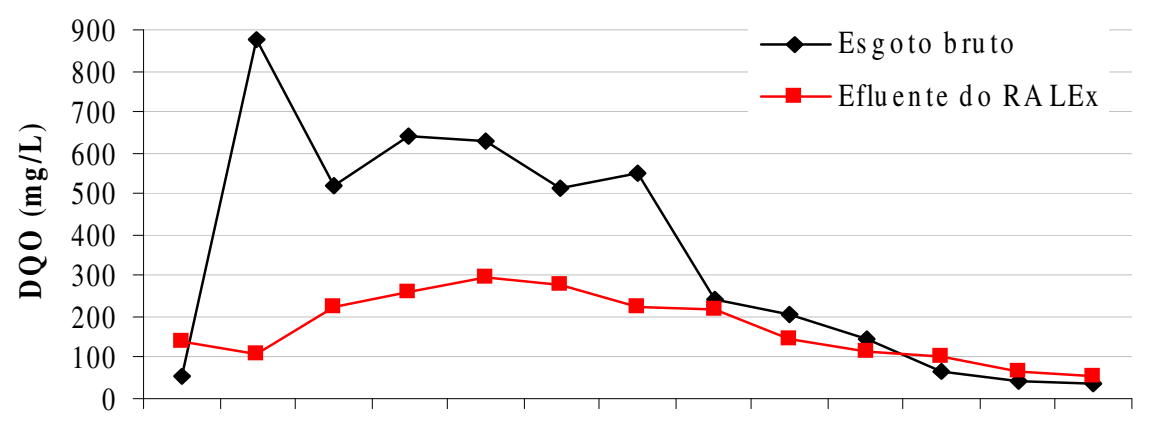

Fósforo das amostras não filtradas (8 e 9 de fevereiro de 2000 )

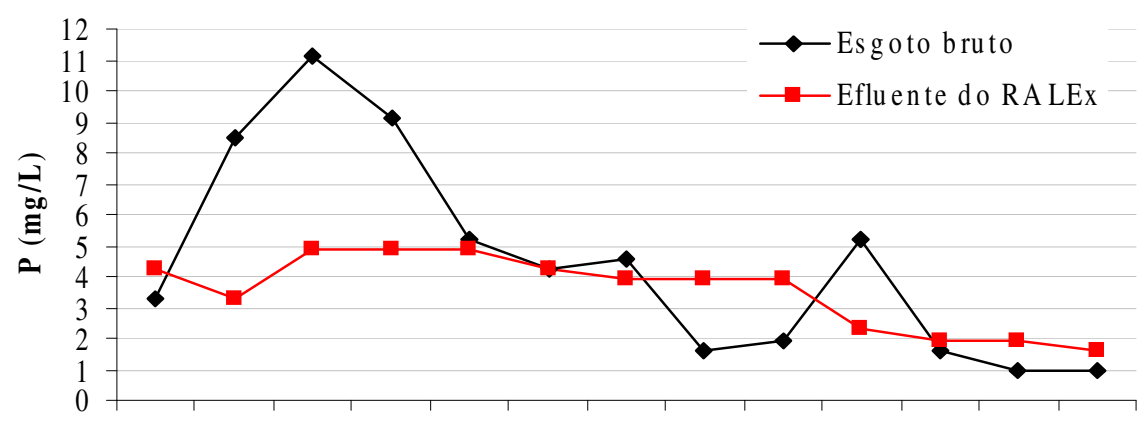

SST das amostras (8 e 9 de fevereiro de 2000$)$

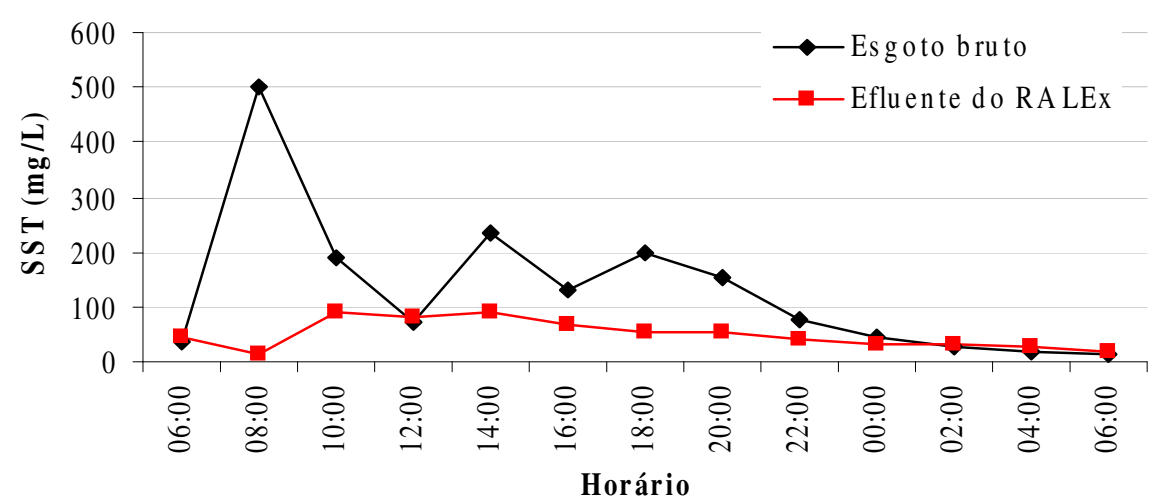

FIGURA 5.2 - Valores de temperatura do ar, do esgoto bruto e do efluente do reator RALEx, de DQO bruta (amostras não filtradas) e de concentração de fósforo total observados durante a primeira caracterização físico-química, no período entre 06:00 de 8 de fevereiro e 06:00 do dia 09 de fevereiro de 1999. 


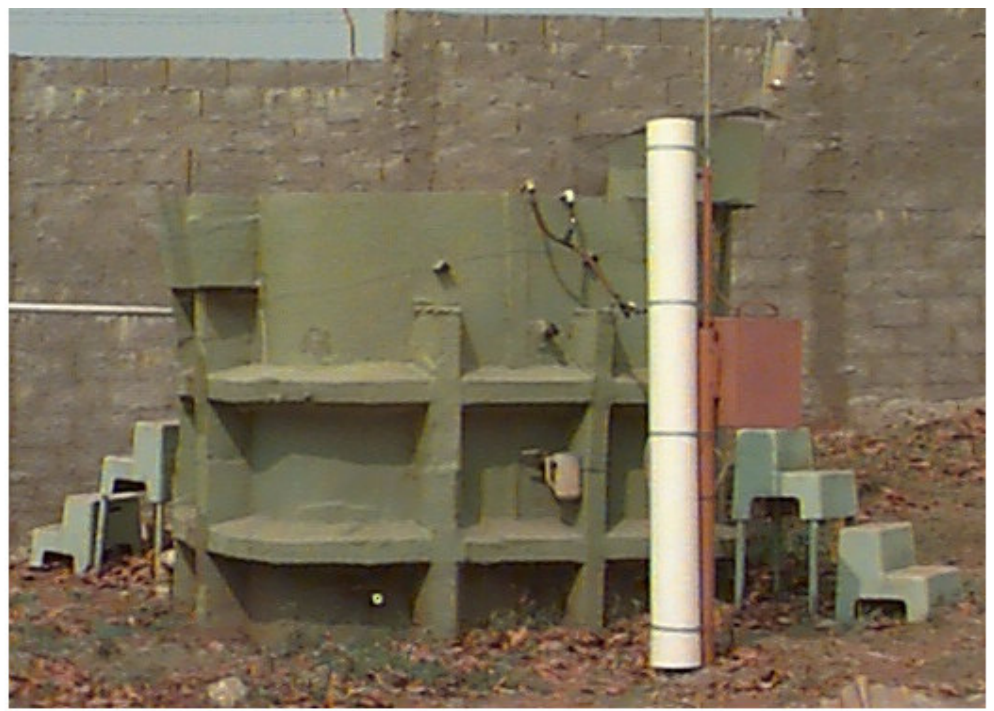

FIGURA 5.3 - Fotografia do reator UASB. Fonte: PENETRA (1998).

Desenvolvendo o mesmo raciocínio para os efluentes dos reatores anaeróbios, verificase que a diferença de carga entre os períodos diurnos e noturnos é menor do que aquela observada para o esgoto bruto. Ainda como exemplo, pode-se citar os valores de DQO de amostras não filtradas $\left(\mathrm{DQO}_{\text {bruta }}\right)$ dos efluentes dos reatores anaeróbios. Em 1997, a carga de DQO $_{\text {bruta }}$ entre 08:00 e 20:00 foi de 7,9 $\mathrm{kgO}_{2}$ e entre 20:00 e 08:00 foi de 7,0 $\mathrm{kgO}_{2}$. Em 1999, o valor ao longo do dia foi de $33,5 \mathrm{kgO}_{2}$ e durante a noite foi de $23,5 \mathrm{kgO}_{2}$. Em 2000, a carga de $\mathrm{DQO}_{\text {bruta }}$ entre 08:00 e 20:00 foi de 27,5 $\mathrm{kgO}_{2}$ e entre 20:00 e 08:00 foi de 13,5 $\mathrm{kgO}_{2}$. De maneira geral, esse comportamento é semelhante entre os demais parâmetros de qualidade.

A conseqüência dessa diferença de comportamento entre os períodos diurnos e noturnos é a diferença "aparente" entre as efici ências de remoção de carga pelo reator anaeróbio entre os referidos turnos. Novamente utilizando a DQO bruta como exemplo, observa-se que, em 1997, a remoção de carga de $\mathrm{DQO}_{\text {bruta }}$ entre 08:00 e 20:00 foi de 72\% e entre 20:00 e 08:00 foi de 37\%. Em 1999, o valor ao longo do dia foi de 55\% e durante a noite foi de 52\%. Em 2000, a remoção de carga de $\mathrm{DQO}_{\text {bruta }}$ entre 08:00 e 20:00 foi de 60\% e entre 20:00 e 08:00 foi de 12\%. Além disso, a eficiência "real" do reator anaeróbio, ao longo de 24 horas corridas, é a in termediária entre os referidos períodos. Em 1997 foi de 62\%, em 1999 foi de 53\% e em 2000 foi de 51\%.

A remoção de fósforo pelo reator anaeróbio também é influenciada pelos períodos de coleta de amostra. Desta forma, aparentemente há "remoção" de até $32 \%$ d e fósforo ao longo do dia. Entretanto, à noite, a concentração de fósforo no efluente do reator anaeróbio é maior que a do esgoto bruto, com "acréscimo" de até $20 \%$ (TABELA 5.2).

A remoção de $\mathrm{DQO}_{\text {filtr }}$ é um aspecto relevante a ser observado, ao comparar o reator RALEx e o reator UASB. O reator UASB, em 1997, apresentou 70\% de eficiência de remoção de $\mathrm{DQO}_{\text {filtr }}$ e 62\% de remoção de $\mathrm{DQO}_{\text {bruta. }}$ O reator RALEx, em 1999 e em 2000, apresentou 
eficiência de remoção de $\mathrm{DQO}_{\text {filtr }}$ entre $34 \%$ e $37 \%$ e remoção de $\mathrm{DQO}_{\text {bruta }}$ entre $51 \%$ e $53 \%$. Aparentemente, a biomassa do reator UASB era mais eficiente na remoção de material dissolvido e finamente particulado.

TABELA 5.2 - Dados de carga de diferentes parâmetros observados em amostras de esgoto bruto, de efluente de reator RALEx e de reator UASB (PENETRA, 1998), coletadas durante caracterização simplificada de efluentes ao longo de 24 horas.

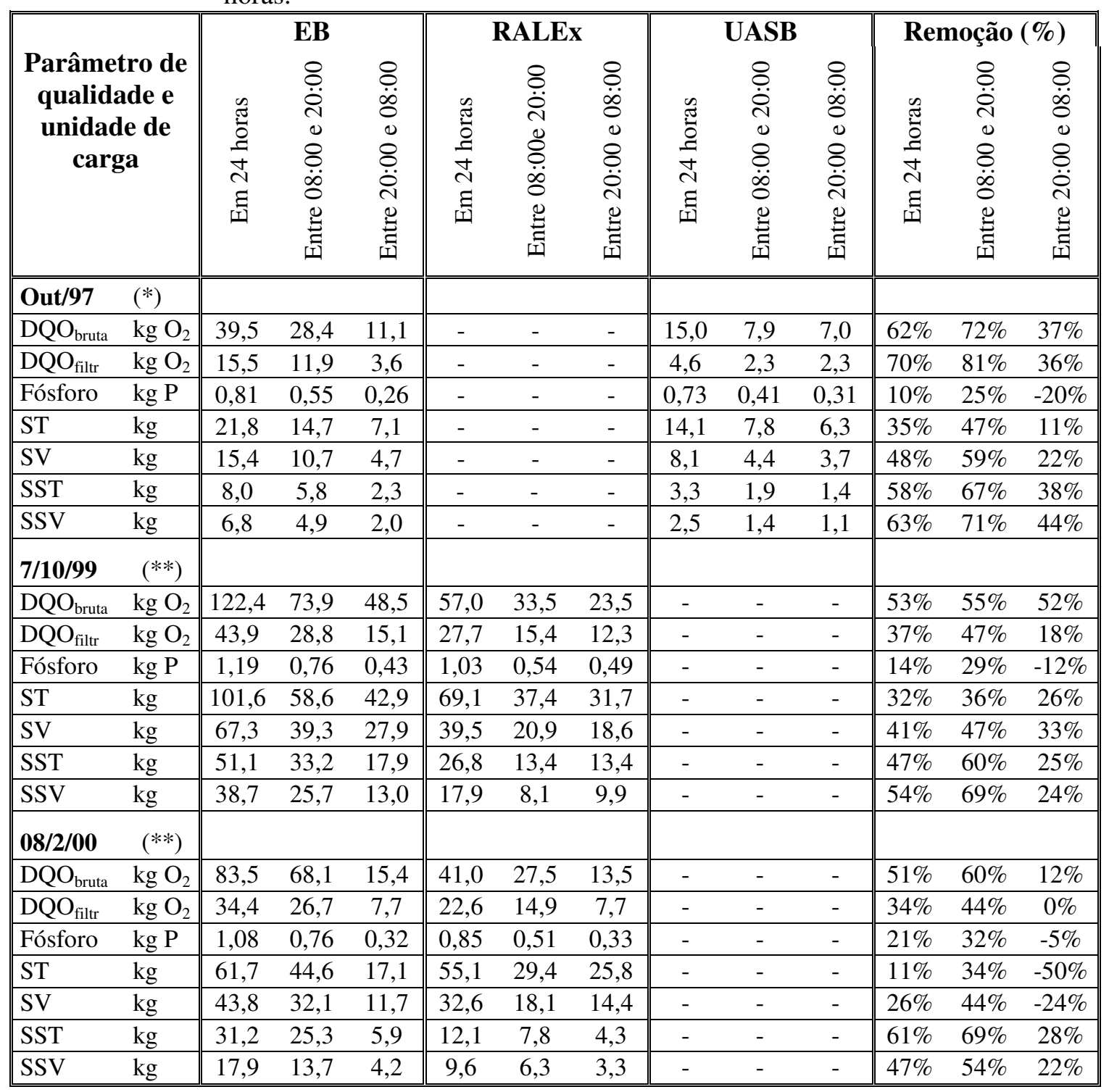

(*) Considerando vazão de $0,61 \mathrm{~L} / \mathrm{s}$.

(**) Considerando vazão de $10 \mathrm{~m}^{3} / \mathrm{h}$.

Como já relatado no item 4.7, em junho de 2000, o rompimento da tubulação de recalque do esgoto bruto para o reator RALEx resultou na perda definitiva de 50\% do leito suporte (carvão ativado) e colapso biológico total da biomassa aderida à parcela de 50\% de leito suporte recuperada. A partir de então, nova operação de partida foi necessária. Para melhor 
compreensão do comportamento do reator após esse período, foram agrupados os dados de DQO das amostras de esgoto bruto e do efluente do reator, observados durante as etapas de trabalho descritas nos itens 4.9.2 e 4.9.3.

Na FIGURA 5.4, são apresentados os dados de DQO das amostras de esgoto bruto coletadas entre março e setembro de 2001, durante as etapas de trabalho descritas nos itens 4.9.2 e 4.9.3, entre 08:00 e 20:00. Na FIGURA 5.5, são apresentados os dados de DQO das amostras de efluente do reator RALEx coletadas entre março e setembro de 2001, após operação de partida, entre 08:00 e 20:00. Na FIGURA 5.6, são apresentadas as eficiências de remoção de carga diária/diurna de DQO alcançadas pelo RALEx no referido período. Na TABELA 5.3, estão apresentados os valores mínimos, médios e máximos de DQO e respectivos desviospadrões das amostras de esgoto bruto e de efluente de reator anaeróbio entre os meses de março e setembro de 2001.

Apesar de apresentar elevada amplitude de variação de valores, desde $390 \mathrm{mg} / \mathrm{L}$ às 08:00 até $1584 \mathrm{mg} / \mathrm{L}$ às 11:00 (TABELA 5.3), a DQO das amostras do esgoto bruto apresentou oscilação aleatória ao longo dos meses nos diferentes horários, com elevação mediana nos meses de junho, julho e agosto, como visto na FIGURA 5.4.

Em se tratando do efluente do reator RALEx, os valores de DQO apresentaram significativa elevação entre março e final de julho/início de agosto (FIGURA 5.5). Às 08:00, a DQO da amostra de efluente era de $199 \mathrm{mg} / \mathrm{L}$ em 8/3/01 e de $594 \mathrm{mg} / \mathrm{L}$ em 26/7/01. A partir de então, reduziram-se até atingir $183 \mathrm{mg} / \mathrm{L}$ em 25/09/01. Comportamentos semelhantes são observados nos demais horários de coleta de amostras.

O forte aumento da DQO das amostras de efluentes do reator RALEx, associado à elevação mediana nos valores de DQO do esgoto bruto, resultou na queda da eficiência de remoção de carga orgânica pelo RALEx nos meses de junho, julho e agosto (FIGURA 5.6). Dentre os 14 ensaios realizados entre 1/junho e 06/agosto, 12 deles apresentaram eficiência de remoção de matéria orgânica abaixo de 46\%, entre 08:00 e 20:00. Vale recordar, conforme discutido anteriormente, que, no período diurno, a eficiência parcial relativa é maior que a efetiva eficiência alcançada em 24 horas. Ao longo de todos os ensaios, entre março e setembro de 2001, a remoção média de carga orgânica entre 08:00 e 20:00 foi de 49,3\%. Notadamente, a biomassa presente no reator RALEx não estava atuando eficientemente, de acordo com a potencialidade de reatores anaeróbios.

Por tratar-se de unidade experimental, em escala de pequeno porte, o reator RALEx foi projetado e construído para propiciar estudos mais aprofundados do seu funcionamento fora de laboratório, visando aperfeiçoar, também, aspectos operacionais. Desta forma, seu projeto original e efetivamente implantado apresenta certas deficiências, já corrigidas nas novas unidades projetadas:

1. A recirculação do esgoto, promovida com o objetivo de manter velocidade ascensional do líquido no interior da zona de reação, com diâmetro de 1,5 m (ver FIGURA 4.16), 
suficientemente elevada para expansão do leito suporte, era efetuada mediante recalque do efluente tratado a partir do poço de recirculação (ver FIGURA 4.18). O ideal seria que a recirculação fosse efetuada em circuito fechado, com retirada do efluente no topo da zona de reação. No RALEx, o efluente encaminhado ao poço de recirculação é descartado no topo da zona de sedimentação (diâmetro=2,5 m, FIGURA 4.16). Dessa forma, torna-se limitada a possibilidade de variação da vazão de recirculação (e conseqüente variação da velocidade ascensional na zona de reação) pois há correspondente variação da eficiência da zona de sedimentação com a mudança da velocidade ascensional nesta zona.

2. O tanque de retenção de sólidos grosseiros foi construído de acordo com as limitadas possibilidades topográficas e físicas do local. Sua configuração é baseada na presença de chicanas. Dessa forma, sua eficiência de remoção de sólidos grosseiros é limitada, acarretando o arraste de parcela destes sólidos para o interior do reator anaeróbio. Como sólidos grosseiros e/ou inertes não são eficientemente tratáveis pela biomassa, há elevada presença de sólidos no efluente final e/ou sua acumulação nas demais caixas (poços) existentes no conjunto.

3. A entrada do esgoto bruto no reator anaeróbio é feita por tubulação (FIGURA 4.16) emborcada para baixo através de uma curva de $90^{\circ}$. A distribuição do esgoto ao longo de toda a seção transversal do início da zona de reação é prejudicada pois o fluxo de esgoto fica limitado às proximidades da curva de $90^{\circ}$. O ideal seria o aumento dos pontos de distribuição do esgoto no início da zona de reação de forma que não haja volume morto.

As limitações operacionais deste reator anaeróbio provavelmente influenciaram o desenvolvimento e atuação da biomassa, limitando a capacidade de remoção de matéria orgânica e de sólidos presentes no esgoto sanitário.

TABELA 5.3 - Valores mínimos, médios e máximos de DQO e respectivos desvios-padrões das amostras de esgoto bruto e de efluente de reator anaeróbio entre os meses de março e setembro de 2001.

\begin{tabular}{|c|c|c|c|c|c|c|c|c|}
\hline \multirow{2}{*}{$\begin{array}{l}\text { Hora } \\
\text { do dia }\end{array}$} & \multicolumn{4}{|c|}{ DQO (mg/L) no esgoto bruto } & \multicolumn{4}{|c|}{ DQO (mg/L) no efluente do RALEx } \\
\hline & Mín. & Média & Máx. & $\begin{array}{l}\text { Desvio- } \\
\text { padrão }\end{array}$ & Mín. & Média & Máx. & $\begin{array}{l}\text { Desvio- } \\
\text { padrão }\end{array}$ \\
\hline 08:00 & 390 & 729 & 1116 & 171 & 126 & 337 & 594 & 135 \\
\hline 11:00 & 538 & 916 & 1584 & 210 & 199 & 365 & 547 & 82 \\
\hline $14: 00$ & 613 & 857 & 1119 & 127 & 253 & 399 & 605 & 94 \\
\hline $17: 00$ & 506 & 683 & 961 & 117 & 242 & 425 & 674 & 113 \\
\hline 20:00 & 446 & 595 & 850 & 85 & 225 & 389 & 567 & 89 \\
\hline
\end{tabular}




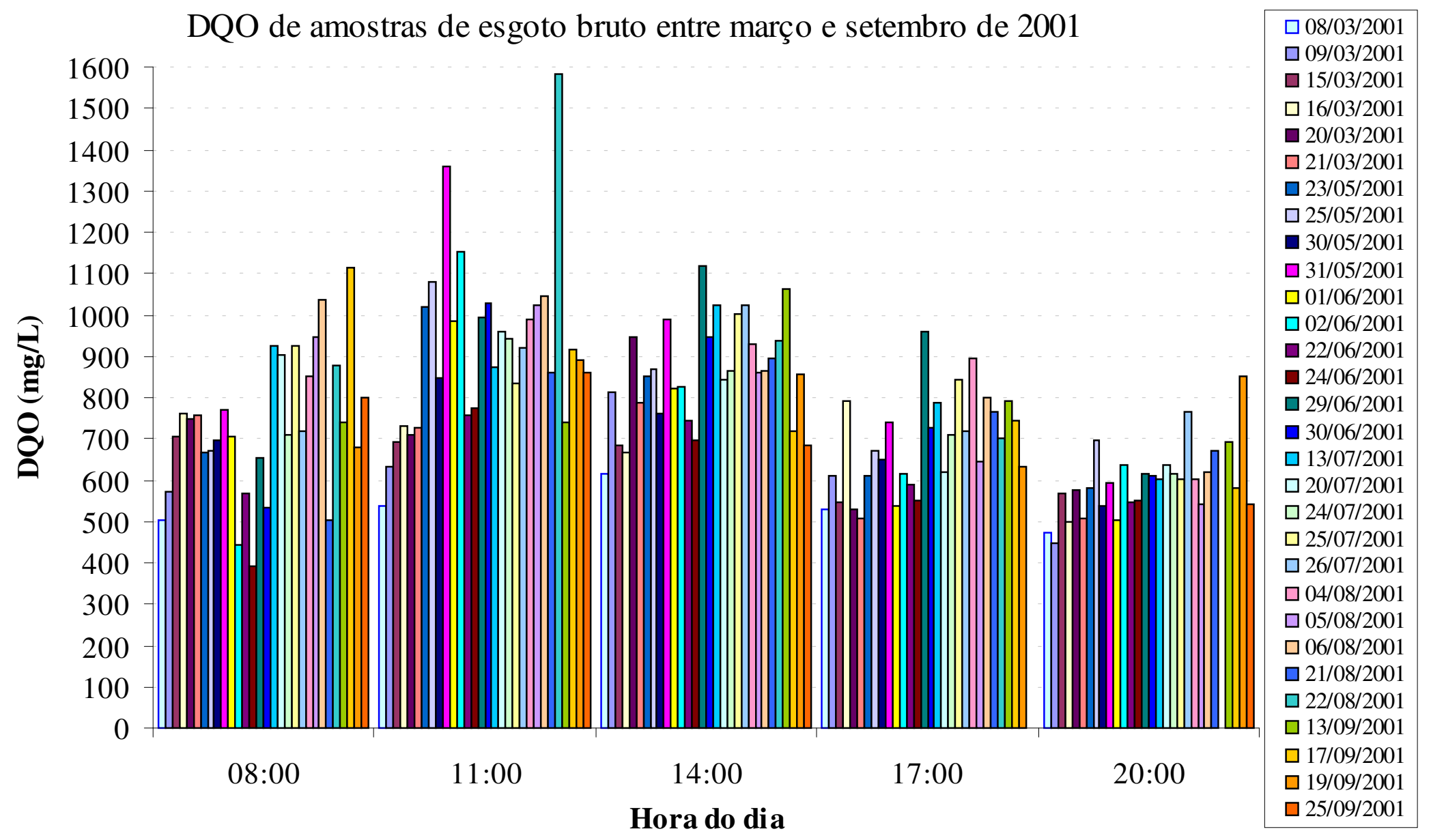

FIGURA 5.4 - Dados de DQO das amostras de esgoto bruto coletadas entre março e setembro de 2001, durante as etapas de trabalho descritas nos itens 4.9.2 e 4.9.3, entre 08:00 e 20:00. 
DQO de amostras de efluente do reator RALEx entre março e setembro de 2001

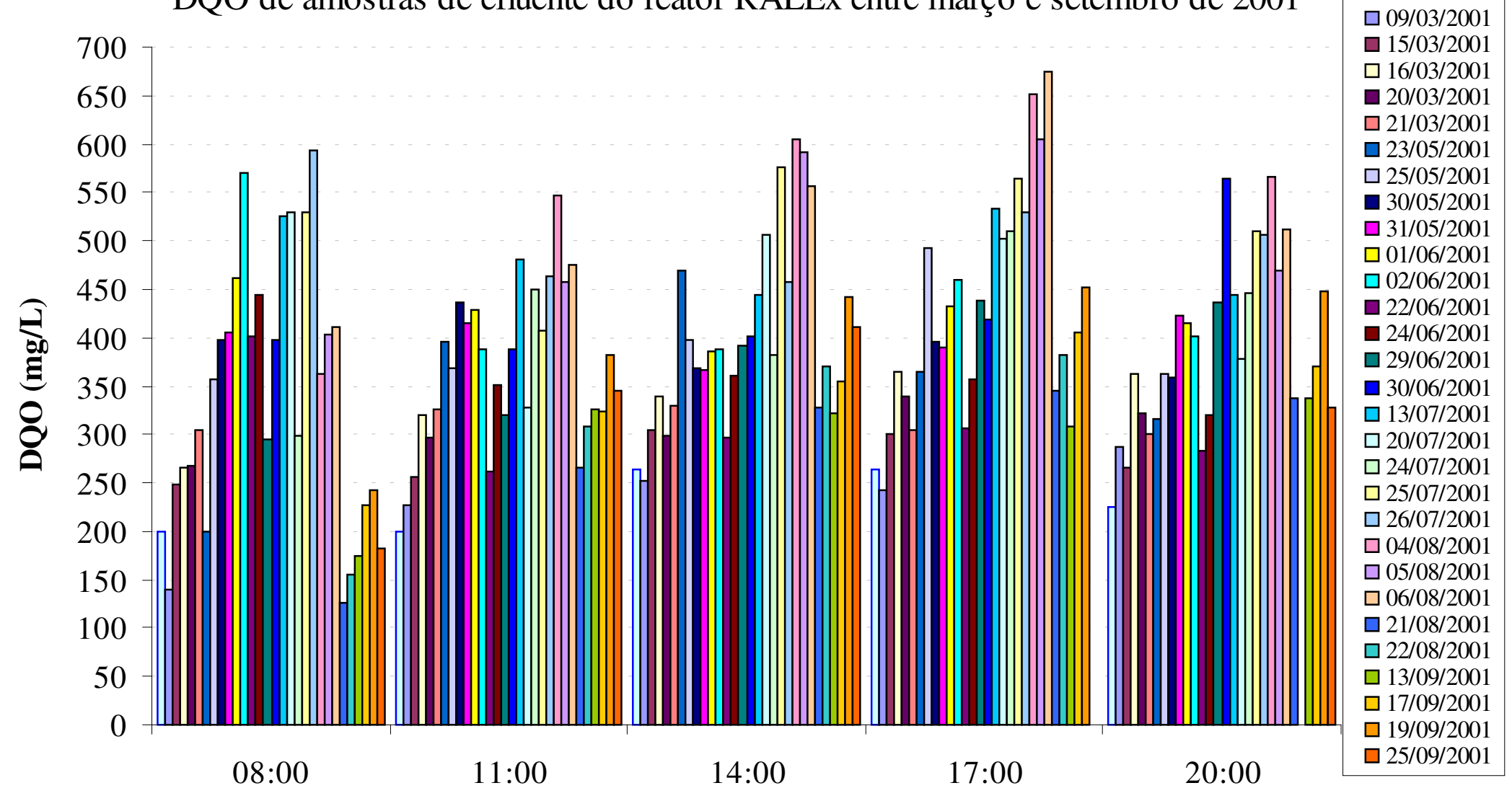

Hora do dia

FIGURA 5.5 - Dados de DQO das amostras de efluente do reator RALEx coletadas entre março e setembro de 2001, após operação de partida, entre 08:00 e 20:00. 
Eficiência de remoção de carga orgânica pelo RALEx, entre março e setembro de 2001

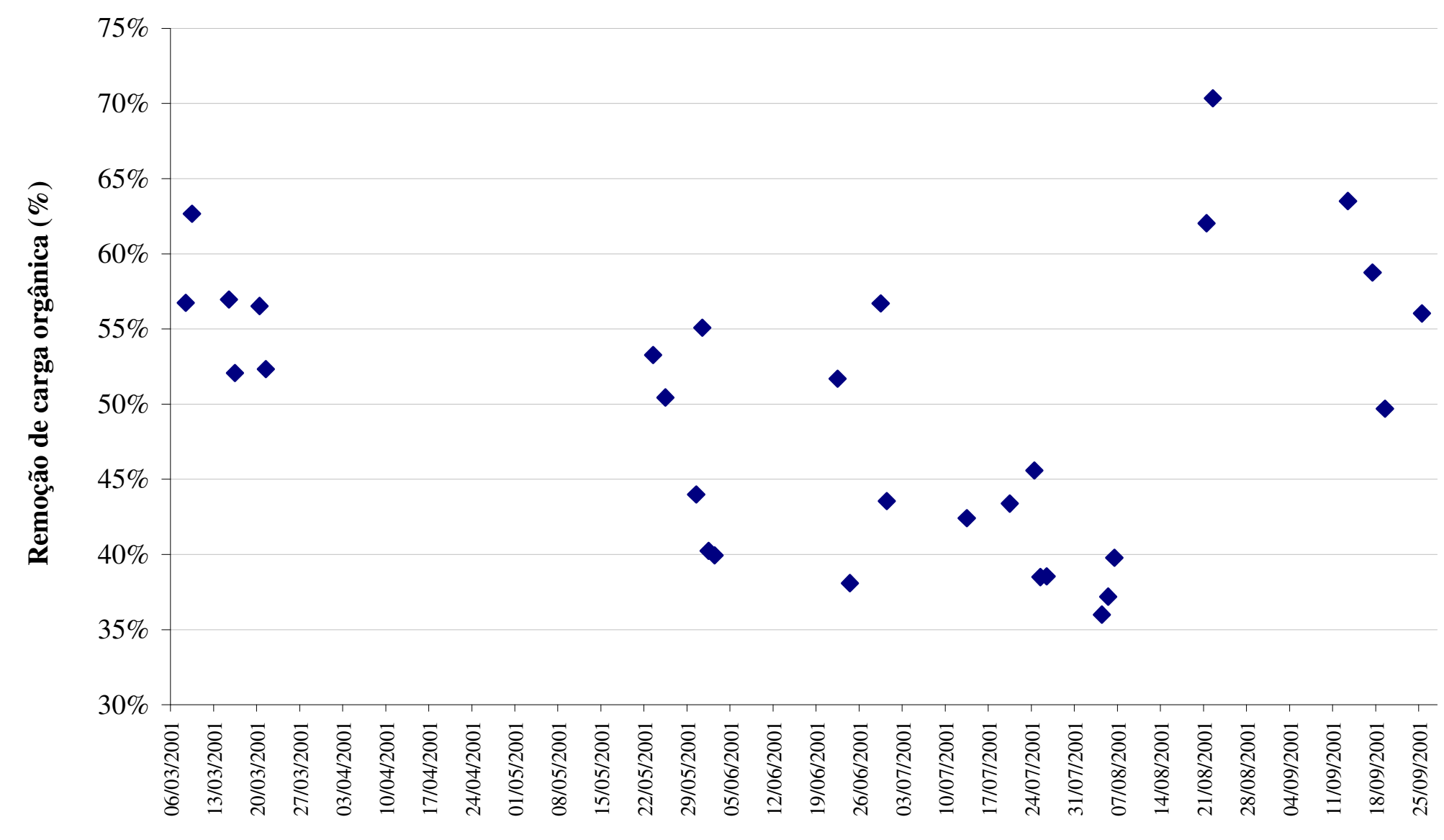

Data

FIGURA 5.6 - Eficiências de remoção de carga diária/diurna de DQO alcançadas pelo RALEx entre março e setembro de 2002. 


\subsection{Resultados dos ensaios preliminares de pós-tratamento do efluente do reator RALEx em escala de laboratório, utilizando o flotateste e com aplicação de polímeros sintéticos, isoladamente ou associados ao cloreto férrico}

Os resultados dos ensaios com variação do tipo de polímero sintético, dosado isoladamente, são apresentados no item 5.3.1.

No item 5.3.2, são apresentados os resultados obtidos durante os ensaios com variação do tipo de polímero sintético, agora dosado conjuntamente com cloreto férrico.

Todos os ensaios realizados nessa fase tiveram por objetivo escolher, dentre os diversos polímeros à disposição e com diferentes características químicas, aqueles que melhor se adaptam ao tratamento químico seguido de flotação dos efluentes de reator anaeróbio.

\subsubsection{Ensaios com variação do tipo de polímero sintético, dosado isoladamente}

São relatados os resultados obtidos nos ensaios descritos no item 4.6.1. A discussão desses resultados fornece elementos para a escolha de alguns polímeros, dentre os testados, que melhor se adaptam ao tratamento de efluentes anaeróbios, quando dosados isoladamente. Essa adaptabilidade adviria da capacidade do polímero, durante a floculação, de produzir flocos mais susceptíveis à aderência das microbolhas. A discussão baseia-se na eficiência de remoção de turbidez e de DQO das amostras não filtradas $\left(\mathrm{DQO}_{\text {bruta }}\right)$ e filtradas $\left(\mathrm{DQO}_{\text {filtr }}\right)$ coletadas nos ensaios com os polímeros.

Em função do grande número de polímeros testados, os ensaios foram realizados em duas fases. Na primeira fase foram testados 10 diferentes polímeros, a saber: W303, G9049, W360C, W3076, W320, W302, W360, W301, W341 e W3081. Todos estes polímeros apresentam diferentes características entre si, tais como carga iônica, peso molecular e densidade de carga.

As curvas de flotação (FIGURA 5.7) estão individualmente identificadas por legendas, especificando o polímero testado, a velocidade de flotação e o valor da DQO da amostra coletada. As curvas de flotação apresentam os valores de fração de turbidez remanescente, ou seja, a razão entre a turbidez da amostra tratada e a turbidez do efluente do reator RALEx, em função da velocidade de flotação. De acordo com REALI (1991), as curvas de flotação permitem avaliar a velocidade ascensional dos flocos formados em diferentes condições de coagulação e floculação. Quanto maior a velocidade de flotação, maior poderá ser a taxa de aplicação superficial em uma unidade de flotação em escala real (menor o tamanho da unidade de flotação), para manutenção de determinada eficiência de remoção. Desta forma, consideramse melhores as curvas de flotação que resultam em curvas com os menores valores de "fração de 
turbidez com velocidade menor que a estabelecida" (eixo das ordenadas). A coleta das amostras em cinco diferentes velocidades de flotação permite a construção e análise aproximada do comportamento hipotético do tratamento em diferentes taxas de aplicação superficial. Deve-se ressaltar que não é válida a correlação direta dos valores absolutos de velocidades de flotação no Flotateste com valores de taxa de aplicação superficial em unidade de flotação em escala real. As amostras foram coletadas em cinco diferentes velocidades de flotação: Vflot $1=5 \mathrm{~cm} / \mathrm{min}$, Vflot $2=10 \mathrm{~cm} / \mathrm{min}$, Vflot $3=15 \mathrm{~cm} / \mathrm{min}$, Vflot $4=20,1 \mathrm{~cm} / \min$ e Vflot $5=25,1 \mathrm{~cm} / \mathrm{min}$.

Da mesma forma, a FIGURA 5.8 apresenta as diferentes frações remanescentes de $\mathrm{DQO}_{\text {bruta }}$ e de $\mathrm{DQO}_{\text {filtr }}$, observadas nas amostras coletadas na velocidade de flotação de 10 $\mathrm{cm} / \mathrm{min}$ nos diferentes ensaios.

Investigando a FIGURA 5.7, verifica-se que os polímeros podem ser divididos em três grupos, de acordo com sua eficiência de remoção de turbidez. O primeiro grupo, composto pelos que produziram efluentes com as menores frações remanescentes de turbidez, é formado pelos polímeros G9049, W360, W360C, W341 e W3081. O segundo grupo é constituído pelos polímeros W303, W320, W302 e W301, que apresentaram os piores resultados quanto à remoção de turbidez. O terceiro grupo é composto por somente um polímero (W3076) e apresenta eficiência intermediária entre os dois primeiros grupos.

Os polímeros do primeiro grupo, G9049, W360, W360C, W341 e W3081, apresentaram os melhores resultados, com remoções de turbidez na faixa entre $78 \%$ e $83 \%$ para velocidade de flotação de $10 \mathrm{~cm} / \mathrm{min}$ e entre $71 \%$ e $77 \%$ para velocidade de flotação de $25 \mathrm{~cm} / \mathrm{min}$. Particularmente, para velocidades de flotação iguais ou inferiores a $20 \mathrm{~cm} / \mathrm{min}$, o polímero G9049 apresentou o melhor desempenho, com eficiências de remoção de turbidez de $84 \%$ para velocidades de flotação até $15 \mathrm{~cm} / \mathrm{min}$ e $81 \%$ para velocidade de flotação de $20 \mathrm{~cm} / \mathrm{min}$.

O segundo grupo de polímeros, composto por W303, W320, W302 e W301, proporcionou remoções de turbidez entre $61 \%$ e $64 \%$, para velocidade de flotação de 10 $\mathrm{cm} / \mathrm{min}$, e entre $50 \%$ e $57 \%$, para velocidade de flotação de $25 \mathrm{~cm} / \mathrm{min}$.

O polímero W3076, do terceiro grupo, apresentou eficiência de remoção de turbidez de $70 \%$, para velocidade de flotação de $10 \mathrm{~cm} / \mathrm{min}$, e de $67 \%$, para velocidade de flotação de 25 $\mathrm{cm} / \mathrm{min}$.

Os resultados de fração remanescente de $\mathrm{DQO}_{\text {bruta }}$ e $\mathrm{DQO}_{\text {filtr }}$ das amostras coletadas nos diferentes ensaios são apresentados na FIGURA 5.8.

Somente a amostra coletada no ensaio com o polímero G9049 apresentou eficiência de remoção de $\mathrm{DQO}_{\text {bruta }}$ superior a 70\%. O emprego dos polímeros W360C, W3076, W360, W341 
e W3081 proporcionou remoções de DQO $_{\text {bruta }}$ entre $60 \%$ e 70\%. Remoções abaixo de $60 \%$ foram observadas quando do emprego dos polímeros W303, W320, W302 e W301.
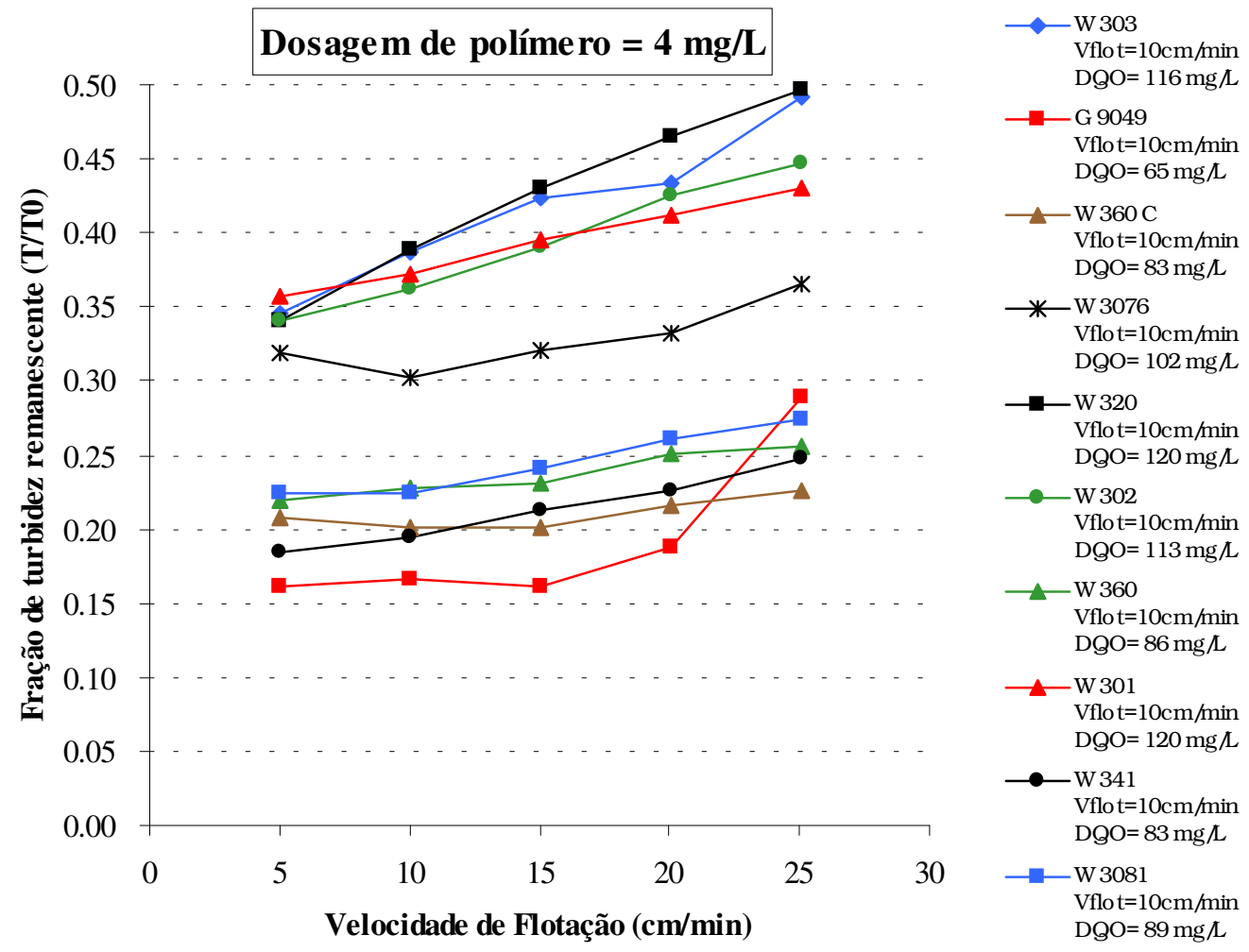

FIGURA 5.7 - Fração remanescente de turbidez (T/T0) nas amostras coletadas em função da velocidade de flotação para ensaios empregando diferentes polímeros e com dosagem de $4 \mathrm{mg} / \mathrm{L}$.

Ensaios realizados com o equipamento de flotateste e efluente do reator RALEx. Gmr: $600 \mathrm{~s}^{-1}$, Tmr: $30 \mathrm{~s}$; Gf: $60 \mathrm{~s}^{-1}$; Tf: $20 \mathrm{~min}$; R: $20 \%$ (em volume); $\mathrm{S}^{*}: 19,0 \mathrm{~g} / \mathrm{m}^{3}$; Psat: $450 \mathrm{kPa}$. Características do efluente do reator RALEx: turbidez: 95,3 uT; DQO da amostra não filtrada: $261 \mathrm{mg} / \mathrm{L}$; temperatura: $22,0 \pm 0,5^{\circ} \mathrm{C}$.

Em relação à remoção de DQO $_{\text {filtr, }}$ o polímero G9049 apresentou o melhor desempenho, com eficiência de 50\%. É plausível afirmar que a parcela de $\mathrm{DQO}_{\text {filtr }}$ removida pelo polímero era constituída por sólidos coloidais e não dissolvidos. Aparentemente, dentre os polímeros inicialmente testados, o G9049 apresenta características químicas mais apropriadas à agregação dos sólidos coloidais e não dissolvidos e sua posterior remoção pela flotação.

Partindo da premissa de que era o mais apropriado ao uso proposto, o polímero G9049 foi utilizado na investigação dos demais polímeros, atuando como elemento de comparação.

O segundo grupo a ser testado era constituído por 11 polímeros diferentes, a saber: G3055, G991, G9046, G9052, G999, G992, G997, G9050, G998, G9047 e G9048. Todos estes 
polímeros apresentam diferentes características entre si, tais como peso molecular e densidade de carga. Para poder haver elemento de comparação de atuação entre os polímeros do primeiro e do segundo grupo, optou-se por acrescentar o polímero do primeiro grupo com o melhor desempenho, G9049, a este segmento de ensaios.

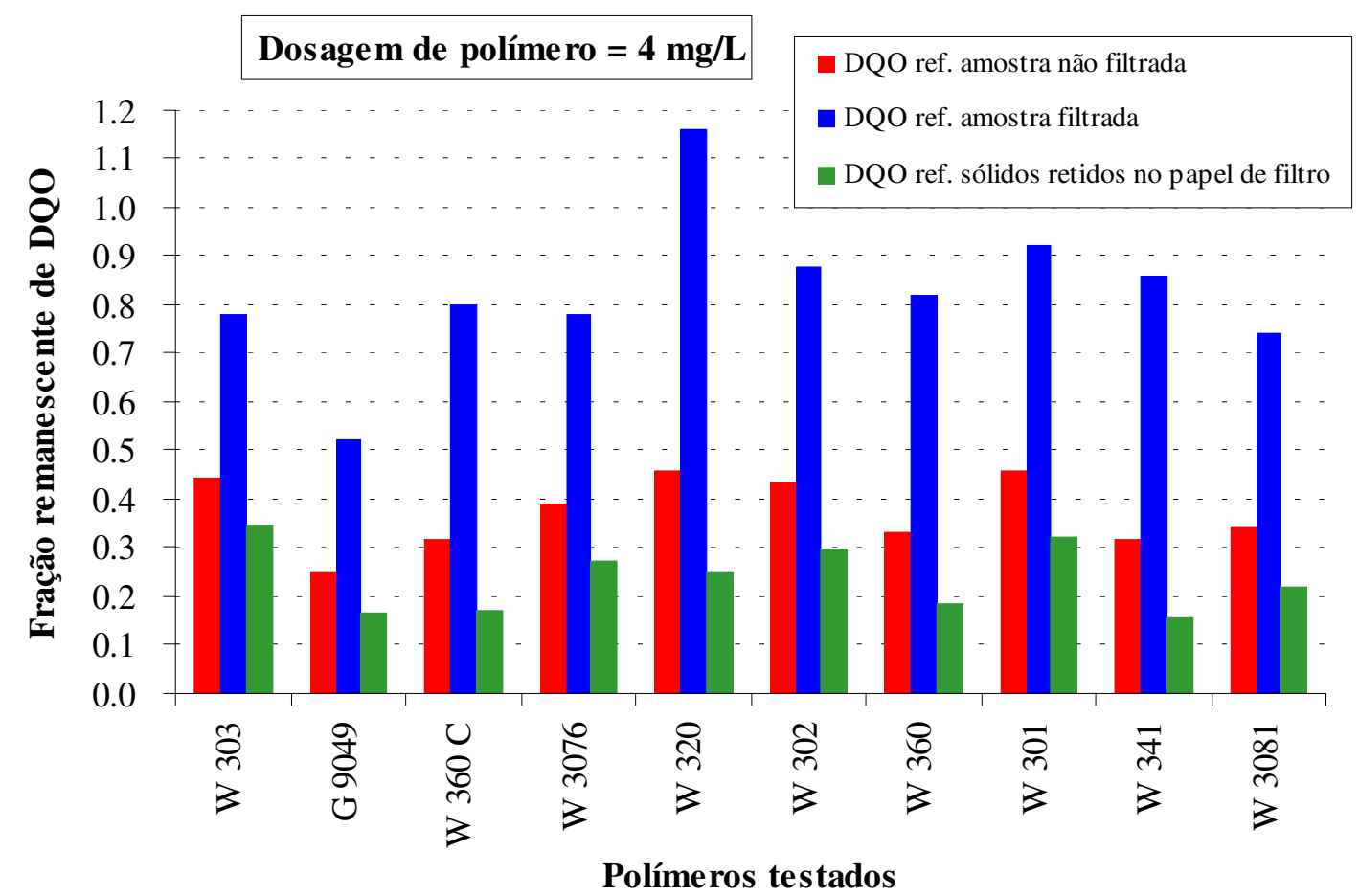

FIGURA 5.8 - Fração remanescente de DQO nas amostras coletadas em função da velocidade de flotação para ensaios empregando diferentes polímeros e com dosagem de $4 \mathrm{mg} / \mathrm{L}$.

Ensaios realizados com o equipamento de flotateste e efluente do reator RALEx. Gmr: $600 \mathrm{~s}^{-1}$, Tmr: $30 \mathrm{~s}$; Gf: $60 \mathrm{~s}^{-1}$; Tf: $20 \mathrm{~min}$; R: $20 \%$ (em volume); S*: 19,0 g/m³ ; Psat: $450 \mathrm{kPa}$. Características do efluente do reator RALEx: turbidez: 95,3 uT; DQO da amostra não filtrada: $261 \mathrm{mg} / \mathrm{L}$; DQO da amostra filtrada: $60 \mathrm{mg} / \mathrm{L}$; temperatura: $22,0 \pm 0,5^{\circ} \mathrm{C}$.

Igualmente aos ensaios anteriores, foram realizados mais 12 ensaios para verificar a eficiência média de remoção de cada um dos polímeros do segundo grupo, utilizando-se dosagem de polímero igual a $4 \mathrm{mg} / \mathrm{L}$. As curvas de flotação destes novos ensaios estão apresentadas na FIGURA 5.9. Na FIGURA 5.4 são apresentadas as diferentes frações remanescentes de $\mathrm{DQO}_{\text {bruta }}$ e de $\mathrm{DQO}_{\text {filtr }}$ observadas nas amostras coletadas na velocidade de flotação de $10 \mathrm{~cm} / \mathrm{min}$.

Pode-se observar na FIGURA 5.9 que os polímeros G992, G9046, G9047, G9048 apresentaram os melhores resultados, proporcionando eficiências de remoção de turbidez muito próximas e praticamente constantes para as diferentes velocidades de flotação, na faixa entre 
$85 \%$ e $87 \%$ para velocidade de flotação de $10 \mathrm{~cm} / \mathrm{min}$ e entre $81 \%$ e $83 \%$ para velocidade de flotação de $25 \mathrm{~cm} / \mathrm{min}$.

O polímero G9049 apresentou eficiência de remoção de turbidez intermediária entre os polímeros de melhor desempenho e aqueles de pior desempenho. Para velocidade de flotação de $10 \mathrm{~cm} / \mathrm{min}$, o polímero G9049 apresentou 53\% de remoção de turbidez. Para velocidade de flotação de $25 \mathrm{~cm} / \mathrm{min}$, a remoção foi de $51 \%$.

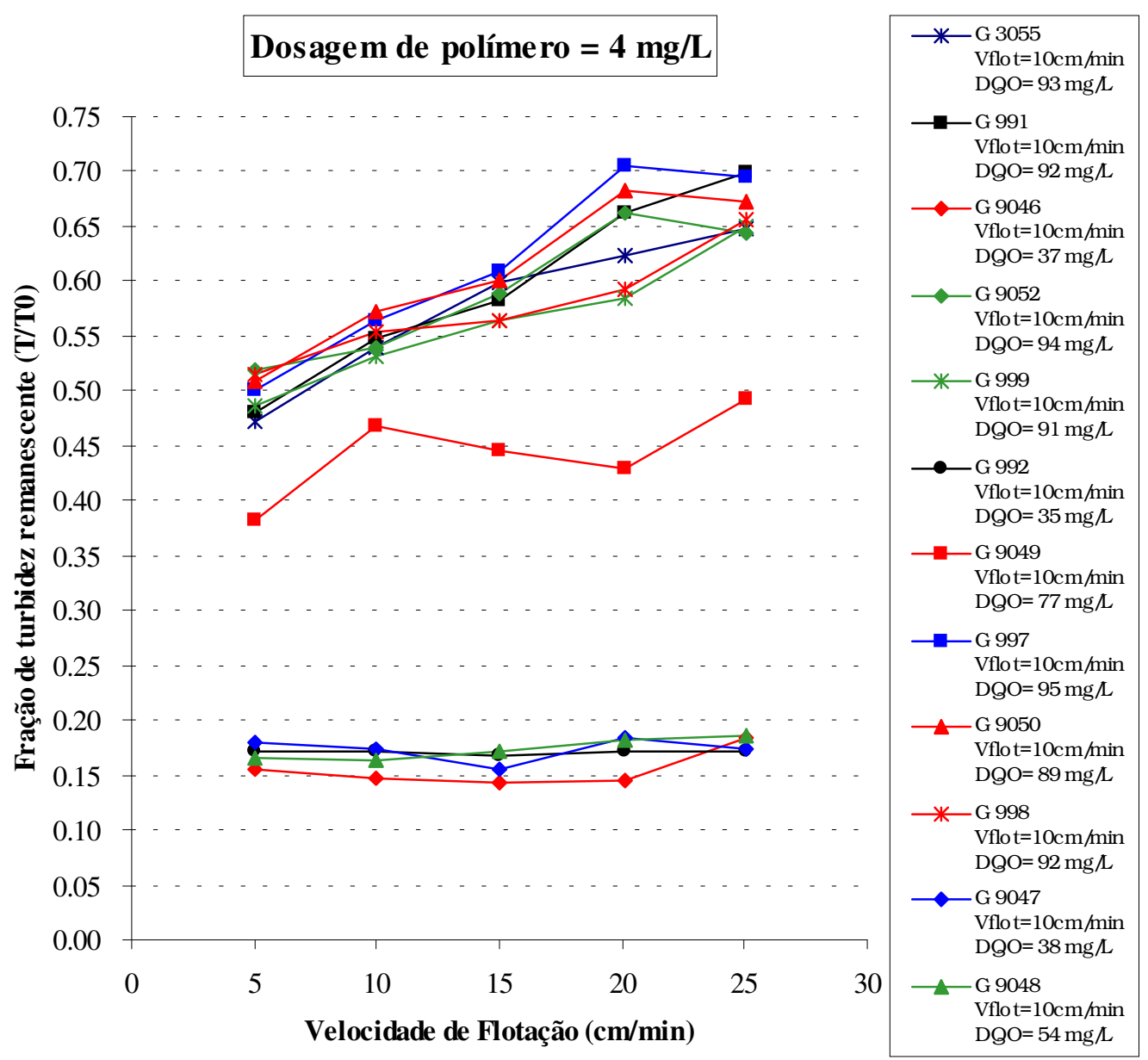

FIGURA 5.9 - Fração remanescente de turbidez (T/T0) nas amostras coletadas em função da velocidade de flotação para ensaios empregando diferentes polímeros e com dosagem de $4 \mathrm{mg} / \mathrm{L}$.

Ensaios realizados com o equipamento de flotateste e efluente do reator RALEx. Gmr: $600 \mathrm{~s}^{-1}$, Tmr: $30 \mathrm{~s}$; Gf: $60 \mathrm{~s}^{-1}$; Tf: $20 \mathrm{~min}$; R: $20 \%$ (em volume); S*: 19,0 g/m³ ; Psat: $450 \mathrm{kPa}$. Características do efluente do reator RALEx: turbidez: 62,3 uT; DQO da amostra não filtrada: $132 \mathrm{mg} / \mathrm{L}$; temperatura: $24,2 \pm 0,3^{\circ} \mathrm{C}$.

O grupo de polímeros que apresentou o pior desempenho foi composto por G3055, G991, G9052, G999, G997, G9050 e G998. A faixa de remoção de turbidez, para velocidade de 
flotação de $10 \mathrm{~cm} / \mathrm{min}$, variou entre $43 \%$ e $47 \%$ e para velocidade de flotação de $25 \mathrm{~cm} / \mathrm{min}$ a remoção de turbidez variou entre $30 \%$ e $36 \%$.

Os resultados de fração remanescente de $\mathrm{DQO}_{\text {bruta }}$ e $\mathrm{DQO}_{\text {filtr }}$ das amostras coletadas nos diferentes ensaios são apresentados na FIGURA 5.10.

Os polímeros G992, G9046, G9047 e G9048 foram aqueles que apresentaram as melhores eficiências de remoção de $\mathrm{DQO}_{\text {bruta }}$, variando entre $60 \%$ e $74 \%$.

O uso do polímero G9049 proporcionou eficiência de remoção de $\mathrm{DQO}_{\text {bruta }}$ igual a $41 \%$.

O uso dos demais polímeros resultou em remoção de $\mathrm{DQO}_{\text {bruta }}$ entre $28 \%$ e $32 \%$.

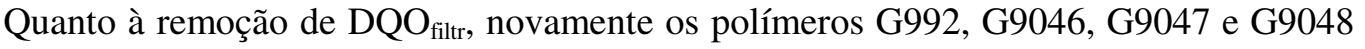
apresentaram os melhores desempenhos, com eficiência variando de $12 \%$ a $45 \%$. É plausível afirmar, portanto, que a parcela de $\mathrm{DQO}_{\text {filtr }}$ removida pelos polímeros era constituída preponderantemente por sólidos coloidais e não dissolvidos.

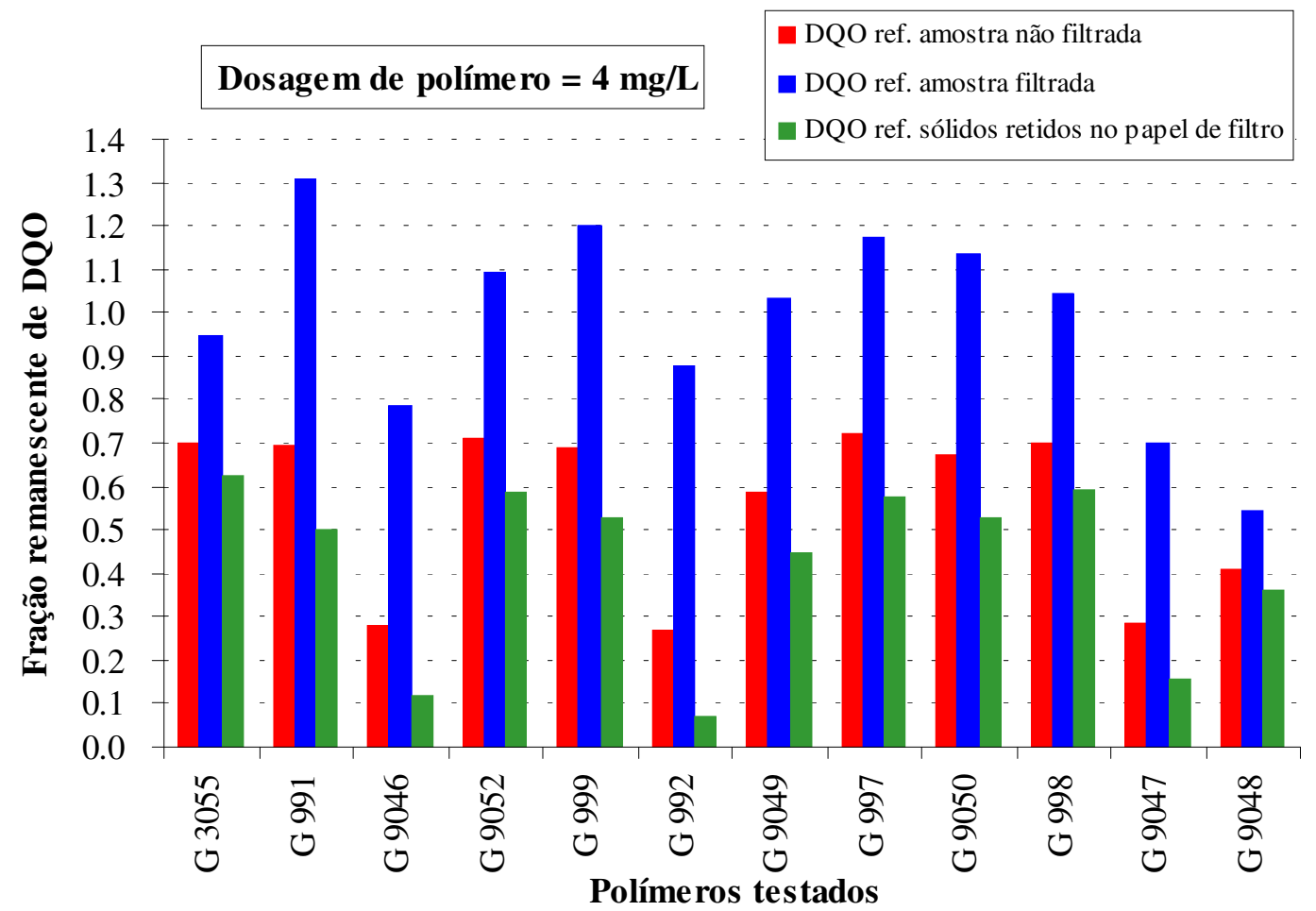

FIGURA 5.10 - Fração remanescente de DQO nas amostras coletadas em ensaios empregando diferentes polímeros e com dosagem de $4 \mathrm{mg} / \mathrm{L}$.

Ensaios realizados com o equipamento de flotateste e efluente do reator RALEx. Gmr: $600 \mathrm{~s}^{-1}$, Tmr: $30 \mathrm{~s}$; Gf: $60 \mathrm{~s}^{-1}$; Tf: $20 \mathrm{~min}$; R: $20 \%$ (em volume); S*: 19,0 g/m³ ; Psat: $450 \mathrm{kPa}$. Características do efluente do reator RALEx: turbidez: 62,3 uT; DQO da amostra não filtrada: $132 \mathrm{mg} / \mathrm{L}$; DQO da amostra filtrada: $32 \mathrm{mg} / \mathrm{L}$; temperatura: 24,2 \pm $0,3^{\circ} \mathrm{C}$. 
De acordo com os resultados obtidos dos ensaios de flotação realizados, visando a investigação da eficiência de remoção de turbidez e DQO dos 21 diferentes tipos de polímeros, pode-se concluir que o uso dos polímeros G992, G9046, G9047, G9048 e G9049 resultaram nas melhores eficiências de remoção de turbidez e de DQO. Desta forma, estes polímeros foram investigados mais profundamente, conforme descrito no item 4.6.2, desta vez atuando como auxiliares de floculação após a coagulação com cloreto férrico.

\subsubsection{Ensaios com variação do tipo de polímero sintético, dosado conjuntamente com cloreto férrico}

Nesta etapa de estudos foram analisados dezesseis polímeros: onze polímeros da marca ADESOL (W301, W302, W303, G992, G998, G999, G9046, G9047, G9048, G9049, G9052), selecionados na etapa anterior e mais cinco polímeros da marca NALCO (N4032, N4016, N2835, N7750 e N7751). Para efeito de apresentação dos resultados e de discussão, os polímeros foram agrupados de acordo com a carga iônica. Os polímeros G992, G9046, G9047, G9048, G9049, N7750 e N7751 são catiônicos. Os polímeros W301, W302, G998, G9052, N4032, N4016 são aniônicos. Os polímeros W303 e G999 são não iônicos. O polímero N2835 é um policloreto de alumínio e será discutido juntamente com os não iônicos.

As FIGURAS 5.11 a 5.14 apresentam os valores de fração de turbidez remanescente, ou seja, a razão entre a turbidez da amostra tratada e a turbidez do efluente do reator RALEx, em função da velocidade de flotação para as dosagens de cloreto férrico (DCF) de 15 e de $30 \mathrm{mg} / \mathrm{L}$ combinadas com dosagens de polímero (DP) de 0,4 e 1,0 mg/L. Para efeito de comparação, foram realizados mais dois ensaios: no primeiro, não houve adição de cloreto férrico nem de polímero e a amostra de efluente foi submetida apenas à flotação; no segundo, houve adição de cloreto férrico e a posterior flotação da amostra floculada de efluente. Em todos os ensaios foram coletadas cinco amostras relativas a cinco diferentes velocidades de flotação: Vflot1 $=5$ $\mathrm{cm} / \mathrm{min}$, Vflot $2=10 \mathrm{~cm} / \mathrm{min}$, Vflot $3=15 \mathrm{~cm} / \mathrm{min}$, Vflot $4=20,1 \mathrm{~cm} / \mathrm{min}$ e Vflot5 $=25,1$ $\mathrm{cm} / \mathrm{min}$.

\section{Polímeros catiônicos}

Observando-se a FIGURA 5.11A, verifica-se que, considerando a combinação das dosagens de $15 \mathrm{mg} / \mathrm{L}$ de cloreto férrico (DCF) e $0,4 \mathrm{mg} / \mathrm{L}$ de polímero catiônico (DP), todo o grupo de polímeros apresentou ação semelhante, proporcionando eficiências de remoção de turbidez muito próximas e praticamente constantes para as velocidades de flotação de 5, 10 e 15 $\mathrm{cm} / \mathrm{min}$, na faixa entre $91 \%$ e $94 \%$. Desta forma, é importante ressaltar que o uso de polímero não elevou a eficiência de remoção de turbidez em velocidades iguais e inferiores a $15 \mathrm{~cm} / \mathrm{min}$. A adição de $15 \mathrm{mg} / \mathrm{L}$ de cloreto férrico, isoladamente, produziu resultados semelhantes àqueles 
observados com dosagem adicional de $0,4 \mathrm{mg} / \mathrm{L}$ de polímero. O polímero somente atuou positivamente para velocidades de flotação maiores que $15 \mathrm{~cm} / \mathrm{min}$. De maneira geral, todos os polímeros catiônicos testados produziram resultados de turbidez bastante semelhantes também na faixa de velocidade de flotação entre 20 e $25 \mathrm{~cm} / \mathrm{min}$. Excelentes resultados de remoção de DQO foram observados para todos os polímeros catiônicos testados. Cabe destacar o desempenho do polímero G9047, em cujo ensaio foi obtido efluente do flotateste com valores de DQO inferiores a $25 \mathrm{mg} / \mathrm{L}$, tanto para médias e altas velocidades de flotação (TABELA 5.4). Com relação à remoção de fosfato total, todos os polímeros catiônicos testados apresentaram desempenho semelhante, porém apenas razoáveis, com concentrações variando entre 1,67 e 2,28 $\mathrm{mgPO}_{4}{ }^{-} / \mathrm{L}$, para $\mathrm{Vf}=10 \mathrm{~cm} / \mathrm{min}$, e 2,35 e $3,12 \mathrm{mgPO}_{4}{ }^{-} / \mathrm{L}$, para $\mathrm{Vf}=25 \mathrm{~cm} / \mathrm{min}$.

Observando-se a FIGURA 5.12A, verifica-se que, considerando a combinação das dosagens de $15 \mathrm{mg} / \mathrm{L}$ de cloreto férrico (DCF) e 1,0 mg/L de polímero catiônico (DP), todo o grupo de polímeros apresentou ação semelhante, proporcionando eficiências de remoção de turbidez muito próximas e praticamente constantes para as velocidades de flotação de 5, 10 e 15 $\mathrm{cm} / \mathrm{min}$, na faixa entre $93 \%$ e $97 \%$. A adição de $15 \mathrm{mg} / \mathrm{L}$ de cloreto férrico, isoladamente, produziu resultados ligeiramente inferiores ( $93 \%$ de remoção de turbidez) àqueles observados com dosagem adicional de $1,0 \mathrm{mg} / \mathrm{L}$ de polímero. A dosagem de $1,0 \mathrm{mg} / \mathrm{L}$ de polímero catiônico elevou levemente a eficiência de remoção de turbidez em velocidades iguais e inferiores a $15 \mathrm{~cm} / \mathrm{min}$. O polímero atuou ainda mais positivamente para velocidades de flotação maiores que $15 \mathrm{~cm} / \mathrm{min}$. De maneira geral, todos os polímeros catiônicos testados produziram resultados bastante semelhantes também na faixa de velocidade de flotação entre 20 e 25 $\mathrm{cm} / \mathrm{min}$, com remoções de turbidez acima de $92 \%$. Também para a dosagem de $1,0 \mathrm{mg} / \mathrm{L} \mathrm{de}$ polímero, excelentes resultados de remoção de DQO foram observados para todos os polímeros catiônicos testados. Cabe destacar o desempenho dos polímeros G9049 e N7751, em cujos ensaios foram obtidos efluentes flotados com valores de DQO inferiores a $27 \mathrm{mg} / \mathrm{L}$, tanto para médias e altas velocidades de flotação. Com relação à remoção de fosfato total, todos os polímeros catiônicos testados apresentaram desempenho semelhante, porém apenas razoável, com concentrações variando entre 1,63 e $2,09 \mathrm{mgPO}_{4}{ }^{-} / \mathrm{L}$, para $\mathrm{Vf}=10 \mathrm{~cm} / \mathrm{min}$, e 1,83 e 2,84 $\mathrm{mgPO}_{4}{ }^{-} / \mathrm{L}$, para $\mathrm{Vf}=25 \mathrm{~cm} / \mathrm{min}$.

Observando-se a FIGURA 5.13A, verifica-se que, considerando a combinação das dosagens de $30 \mathrm{mg} / \mathrm{L}$ de cloreto férrico (DCF) e 0,4 mg/L de polímero catiônico (DP), todo o grupo de polímeros apresentou ação semelhante, proporcionando eficiências de remoção de turbidez muito próximas e praticamente constantes para as velocidades de flotação de 5, 10 e 15 $\mathrm{cm} / \mathrm{min}$, na faixa entre $95 \%$ e $97 \%$. Desta forma, é importante ressaltar que o uso de polímero não elevou a eficiência de remoção de turbidez em velocidades iguais e inferiores a $15 \mathrm{~cm} / \mathrm{min}$. 
A adição de $30 \mathrm{mg} / \mathrm{L}$ de cloreto férrico, isoladamente, produziu resultados melhores do que aqueles observados com dosagem adicional de $0,4 \mathrm{mg} / \mathrm{L}$ de polímero. O polímero somente atuou positivamente para velocidades de flotação maiores que $20 \mathrm{~cm} / \mathrm{min}$. De maneira geral, todos os polímeros catiônicos testados produziram resultados de turbidez bastante semelhantes também na faixa de velocidade de flotação de $20 \mathrm{~cm} / \mathrm{min}$. Particularmente, o polímero G9047 apresentou excelente efeito para velocidade de flotação de $25 \mathrm{~cm} / \mathrm{min}$, com remoção de $96 \%$ de turbidez. Excelentes resultados de remoção de DQO foram observados para todos os polímeros catiônicos testados, com valores residuais de DQO menores que $42 \mathrm{mg} / \mathrm{L}$, mesmo em velocidades altas de flotação. Com relação à remoção de fosfato total, todos os polímeros catiônicos testados apresentaram efeito semelhante, com concentrações variando entre $0,72 \mathrm{e}$ $0,98 \mathrm{mgPO}_{4}^{-} / \mathrm{L}$, para $\mathrm{Vf}=10 \mathrm{~cm} / \mathrm{min}$, e 0,77 e $1,88 \mathrm{mgPO}_{4}{ }^{-} / \mathrm{L}$, para $\mathrm{Vf}=25 \mathrm{~cm} / \mathrm{min}$. Cabe destacar o desempenho do polímero G9047, em cujo ensaio foi obtido efluente do flotateste com concentração 0,72 e $0,77 \mathrm{mgPO}_{4}{ }^{-} / \mathrm{L}$, tanto para médias e altas velocidades de flotação (TABELA 5.4).

Observando-se a FIGURA 5.14A, verifica-se que, considerando a combinação das dosagens de $30 \mathrm{mg} / \mathrm{L}$ de cloreto férrico (DCF) e 1,0 mg/L de polímero catiônico (DP), todo o grupo de polímeros apresentou ação semelhante, proporcionando eficiências de remoção de turbidez muito próximas e praticamente constantes para as velocidades de flotação entre 5 e 15 $\mathrm{cm} / \mathrm{min}$, na faixa entre $95 \%$ e $98 \%$. A adição de $30 \mathrm{mg} / \mathrm{L}$ de cloreto férrico isoladamente produziu resultados semelhantes (97\% de remoção de turbidez) àqueles observados com dosagem adicional de 1,0 mg/L de polímero. A dosagem de 1,0 mg/L de polímero catiônico elevou a eficiência de remoção de turbidez em velocidades em torno de $25 \mathrm{~cm} / \mathrm{min}$. De maneira geral, todos os polímeros catiônicos testados produziram resultados bastante semelhantes também na faixa de velocidade de flotação entre 20 e $25 \mathrm{~cm} / \mathrm{min}$, com remoções de turbidez acima de $90 \%$. Particularmente, o polímero G9047 apresentou excelente ação para velocidade de flotação de $25 \mathrm{~cm} / \mathrm{min}$, com remoção de $98 \%$ de turbidez. Também para a dosagem de 1,0 $\mathrm{mg} / \mathrm{L}$ de polímero, excelentes resultados de remoção de DQO foram observados para todos os polímeros catiônicos testados, com valores residuais de DQO no efluente do flotateste entre 26 e $47 \mathrm{mg} / \mathrm{L}$ em médias e altas velocidades de flotação. Com relação à remoção de fosfato total, todos os polímeros catiônicos testados apresentaram efeito semelhante, com concentrações variando entre 0,44 e $0,83 \mathrm{mgPO}_{4}{ }^{-} / \mathrm{L}$, para $\mathrm{Vf}=10 \mathrm{~cm} / \mathrm{min}$, e 0,59 e $1,75 \mathrm{mgPO}_{4}{ }^{-} / \mathrm{L}$, para $\mathrm{Vf}=25$ cm/min. Novamente, cabe destacar a ação do polímero G9047, em cujo ensaio foi obtido efluente do flotateste com concentração 0,44 e $0,59 \mathrm{mgPO}_{4}{ }^{-} / \mathrm{L}$, para médias e altas velocidades de flotação (TABELA 5.4). 


\section{Polímeros aniônicos}

Observando-se a FIGURA 5.11B, verifica-se que, com exceção dos polímeros N4032 e W301, o grupo de polímeros apresentou ação semelhante, proporcionando eficiências de remoção de turbidez muito próximas e praticamente constantes para as velocidades de flotação de 5,10 e $15 \mathrm{~cm} / \mathrm{min}$, na faixa entre $91 \%$ e $94 \%$. Novamente, a exemplo dos polímeros catiônicos, é importante ressaltar que o uso de polímero não elevou a eficiência de remoção de turbidez em velocidades iguais e inferiores a $15 \mathrm{~cm} / \mathrm{min}$. A adição de $15 \mathrm{mg} / \mathrm{L}$ de cloreto férrico isoladamente produziu resultados semelhantes, mas ligeiramente melhores, àqueles observados com dosagem adicional de $0,4 \mathrm{mg} / \mathrm{L}$ de polímero. O polímero somente atuou positivamente para velocidades de flotação maiores que $15 \mathrm{~cm} / \mathrm{min}$. Com exceção dos polímeros N4032 e W301, os polímeros aniônicos testados produziram resultados bastante semelhantes e superiores a $85 \%$ de remoção de turbidez também na faixa de velocidade de flotação entre 20 e $25 \mathrm{~cm} / \mathrm{min}$. Excelentes resultados de remoção de DQO foram observados para todos os polímeros aniônicos testados. Cabe destacar a ação do polímero N4032, em cujo ensaio foi obtido efluente do flotateste com valores de DQO inferiores a $29 \mathrm{mg} / \mathrm{L}$, tanto para médias e altas velocidades de flotação (TABELA 5.4). Com relação à remoção de fosfato total, todos os polímeros aniônicos testados apresentaram efeito semelhante, porém apenas razoáveis, com concentrações variando entre 2,23 e 2,81 $\mathrm{mgPO}_{4}{ }^{-} / \mathrm{L}$, para $\mathrm{Vf}=10 \mathrm{~cm} / \mathrm{min}$, e 2,67 e 3,98 $\mathrm{mgPO}_{4}{ }^{-} / \mathrm{L}$, para $\mathrm{Vf}=25 \mathrm{~cm} / \mathrm{min}$.

Observando-se a FIGURA 5.12B, verifica-se que, considerando a combinação das dosagens de $15 \mathrm{mg} / \mathrm{L}$ de cloreto férrico (DCF) e 1,0 mg/L de polímero aniônico (DP), todo o grupo de polímeros apresentou ação semelhante, proporcionando eficiências de remoção de turbidez muito próximas e praticamente constantes para as velocidades de flotação de 5, 10 e 15 $\mathrm{cm} / \mathrm{min}$, na faixa entre $93 \%$ e $95 \%$. A adição de $15 \mathrm{mg} / \mathrm{L}$ de cloreto férrico isoladamente produziu resultados semelhantes (94\% de remoção de turbidez) àqueles observados com dosagem adicional de 1,0 mg/L de polímero. A dosagem de 1,0 mg/L de polímero aniônico não influenciou na eficiência de remoção de turbidez em velocidades iguais e inferiores a 15 $\mathrm{cm} / \mathrm{min}$. O polímero somente atuou positivamente para velocidades de flotação maiores que 15 cm/min. Em especial, os polímeros G998 e G9052 apresentaram os melhores resultados para velocidade de flotação de $25 \mathrm{~cm} / \mathrm{min}$, com remoções superiores a $93 \%$ de turbidez. Excelentes resultados de remoção de DQO foram observados para todos os polímeros aniônicos testados. Cabe destacar o efeito dos polímeros W302 e G998, em cujos ensaios foram obtidos efluentes flotados com valores de DQO inferiores a $25 \mathrm{mg} / \mathrm{L}$, tanto para médias e altas velocidades de flotação (TABELA 5.4). Com relação à remoção de fosfato total, todos os polímeros aniônicos testados apresentaram ação semelhante, porém apenas razoáveis, com concentrações variando entre 2,12 e 2,67 $\mathrm{mgPO}_{4}{ }^{-} / \mathrm{L}$, para $\mathrm{Vf}=10 \mathrm{~cm} / \mathrm{min}$, e 2,16 e 3,66 $\mathrm{mgPO}_{4}{ }^{-} / \mathrm{L}$, para $\mathrm{Vf}=25 \mathrm{~cm} / \mathrm{min}$. 
Observando-se a FIGURA 5.13B, verifica-se que, considerando a combinação das dosagens de $30 \mathrm{mg} / \mathrm{L}$ de cloreto férrico (DCF) e $0,4 \mathrm{mg} / \mathrm{L}$ de polímero aniônico (DP), todo o grupo de polímeros apresentou efeito semelhante, proporcionando eficiências de remoção de turbidez muito próximas e praticamente constantes para as velocidades de flotação entre 5 e 20 $\mathrm{cm} / \mathrm{min}$, na faixa entre $95 \%$ e $97 \%$. Desta forma, é importante ressaltar que o uso de polímero não elevou a eficiência de remoção de turbidez em velocidades iguais e inferiores a $20 \mathrm{~cm} / \mathrm{min}$. A adição de $30 \mathrm{mg} / \mathrm{L}$ de cloreto férrico isoladamente produziu resultados semelhantes, e até melhores, àqueles observados com dosagem adicional de $0,4 \mathrm{mg} / \mathrm{L}$ de polímero. $\mathrm{O}$ polímero somente atuou positivamente para velocidades de flotação maiores que $20 \mathrm{~cm} / \mathrm{min}$. De maneira geral, todos os polímeros aniônicos testados resultaram em elevada remoção de turbidez também na faixa de velocidade de flotação de $25 \mathrm{~cm} / \mathrm{min}$, com valores acima de $87 \%$. Particularmente, o polímero N4032 apresentou excelente ação para velocidade de flotação de 25 $\mathrm{cm} / \mathrm{min}$, com remoção de $95 \%$ de turbidez. Excelentes resultados de remoção de DQO foram observados para quase todos os polímeros aniônicos testados, com valores residuais de DQO menores que $35 \mathrm{mg} / \mathrm{L}$, mesmo em velocidades altas de flotação. Somente o uso do polímero G9052 resultou em $60 \mathrm{mg} / \mathrm{L}$ de DQO para $\mathrm{Vf}=25 \mathrm{~cm} / \mathrm{min}$. Com relação à remoção de fosfato total, todos os polímeros aniônicos testados apresentaram efeito semelhante, com concentrações variando entre 0,69 e $1,16 \mathrm{mgPO}_{4}{ }^{-} / \mathrm{L}$, para $\mathrm{Vf}=10 \mathrm{~cm} / \mathrm{min}$, e 1,24 e $1,63 \mathrm{mgPO}_{4}{ }^{-} / \mathrm{L}$, para $\mathrm{Vf}=25$ $\mathrm{cm} / \mathrm{min}$.

Observando-se a FIGURA 5.14B, verifica-se que, considerando a combinação das dosagens de $30 \mathrm{mg} / \mathrm{L}$ de cloreto férrico (DCF) e 1,0 mg/L de polímero aniônico (DP), todo o grupo de polímeros apresentou efeito semelhante, proporcionando eficiências de remoção de turbidez muito próximas e praticamente constantes para as velocidades de flotação entre 5 e 15 $\mathrm{cm} / \mathrm{min}$, na faixa entre $94 \%$ e $97 \%$. A adição de $30 \mathrm{mg} / \mathrm{L}$ de cloreto férrico, isoladamente, produziu resultados semelhantes ( $97 \%$ de remoção de turbidez) àqueles observados com dosagem adicional de 1,0 mg/L de polímero. A dosagem de $1,0 \mathrm{mg} / \mathrm{L}$ de polímero catiônico elevou a eficiência de remoção de turbidez em velocidades em torno de $25 \mathrm{~cm} / \mathrm{min}$. De maneira geral, todos os polímeros aniônicos testados produziram resultados bastante semelhantes também na faixa de velocidade de flotação entre 20 e $25 \mathrm{~cm} / \mathrm{min}$, com remoções de turbidez acima de $91 \%$. Particularmente, o polímero G998 apresentou excelente efeito para velocidade de flotação de $25 \mathrm{~cm} / \mathrm{min}$, com remoção de $97 \%$ de turbidez. Também para dosagem de 1,0 $\mathrm{mg} / \mathrm{L}$ de polímero, resultados muito bons de remoção de DQO foram observados para todos os polímeros aniônicos testados, com valores residuais de DQO no efluente do flotateste abaixo de 70 mg/L em médias e altas velocidades de flotação. Com relação à remoção de fosfato total, os polímeros aniônicos testados apresentaram efeitos diferentes entre si, com concentrações 
variando entre 0,79 e $1,30 \mathrm{mgPO}_{4}{ }^{-} / \mathrm{L}$, para $\mathrm{Vf}=10 \mathrm{~cm} / \mathrm{min}$, e 0,79 e $1,65 \mathrm{mgPO}_{4}{ }^{-} / \mathrm{L}$, para $\mathrm{Vf}=25$ $\mathrm{cm} / \mathrm{min}$. Novamente, cabe destacar a ação do polímero G998, em cujo ensaio foi obtido efluente do flotateste com concentração em torno de $0,79 \mathrm{mgPO}_{4}{ }^{-} / \mathrm{L}$, para médias e altas velocidades de flotação (TABELA 5.4).

\section{Polímeros não iônicos e policloreto de alumínio}

Observando-se a FIGURA 5.11C, verifica-se que os dois polímeros não iônicos apresentaram ação semelhante, proporcionando eficiências de remoção de turbidez muito próximas e praticamente constantes para as velocidades de flotação entre 5 e $20 \mathrm{~cm} / \mathrm{min}$, em torno de 93\%. Novamente, a exemplo dos polímeros catiônicos e aniônicos, é importante ressaltar que o uso de polímero não elevou a eficiência de remoção de turbidez em velocidades inferiores a $15 \mathrm{~cm} / \mathrm{min}$. A adição de $15 \mathrm{mg} / \mathrm{L}$ de cloreto férrico, isoladamente, produziu resultados semelhantes (94\% de remoção de turbidez) àqueles observados com dosagem adicional de $0,4 \mathrm{mg} / \mathrm{L}$ de polímero. O polímero somente atuou positivamente para velocidades de flotação maiores que $15 \mathrm{~cm} / \mathrm{min}$. Os polímeros não iônicos testados produziram resultados bastante semelhantes e superiores a $90 \%$ de remoção de turbidez na faixa de velocidade de flotação entre 20 e $25 \mathrm{~cm} / \mathrm{min}$. A adição de policloreto de alumínio (N2835) influenciou negativamente a remoção de turbidez, tanto em baixas como em altas velocidades de flotação. Excelentes resultados de remoção de DQO foram observados para todos os polímeros não iônicos testados, em cujos ensaios foi obtido efluente do flotateste com valores de DQO inferiores a $26 \mathrm{mg} / \mathrm{L}$, tanto para médias e altas velocidades de flotação (TABELA 5.4). O policloreto de alumínio N2835 apresentou excelente remoção de DQO para $\mathrm{Vf}=10 \mathrm{~cm} / \mathrm{min}$, entretanto, para $\mathrm{Vf}=25 \mathrm{~cm} / \mathrm{min}$, a remoção foi mínima. Com relação à remoção de fosfato total, os polímeros não iônicos testados apresentaram efeito semelhante, porém apenas razoáveis, com concentrações em torno de 2,2 $\mathrm{mgPO}_{4}^{-} / \mathrm{L}$, para $\mathrm{Vf}=10 \mathrm{~cm} / \mathrm{min}$, e 2,41 e 2,94 $\mathrm{mgPO}_{4}{ }^{-} / \mathrm{L}$, para $\mathrm{Vf}=25 \mathrm{~cm} / \mathrm{min}$. O policloreto de alumínio N2835 apresentou remoção de fosfato total semelhante aos não iônicos, para $\mathrm{Vf}=10 \mathrm{~cm} / \mathrm{min}$, mas, para $\mathrm{Vf}=25 \mathrm{~cm} / \mathrm{min}$, a remoção foi mínima.

Observando-se a FIGURA 5.12C, verifica-se que os dois polímeros não iônicos, na dosagem de 1,0 mg/L, apresentaram ação semelhante, proporcionando eficiências de remoção de turbidez muito próximas e praticamente constantes para as velocidades de flotação de 5, 10 e $15 \mathrm{~cm} / \mathrm{min}$, em torno de $94 \%$. A adição de $15 \mathrm{mg} / \mathrm{L}$ de cloreto férrico, isoladamente, produziu resultados semelhantes (94\% de remoção de turbidez) àqueles observados com dosagem adicional de 1,0 mg/L de polímero. Desta forma, a dosagem adicional de 1,0 mg/L de polímero não iônico não influenciou na eficiência de remoção de turbidez em velocidades iguais e 
inferiores a $15 \mathrm{~cm} / \mathrm{min}$. O polímero somente atuou positivamente para velocidades de flotação maiores que $15 \mathrm{~cm} / \mathrm{min}$. Cabe destacar o efeito do polímero G999, em cujo ensaio foram observadas remoções de turbidez em torno de $95 \%$, tanto para médias e altas velocidades de flotação. O policloreto de alumínio produziu resultados bastante semelhantes ao G999 e superiores a $92 \%$ de remoção de turbidez na faixa de velocidade de flotação entre 20 e 25 $\mathrm{cm} /$ min. Bons resultados de remoção de DQO foram observados para os polímeros não iônicos testados, em cujos ensaios foram obtidos efluentes flotados com valores de DQO inferiores a 39 $\mathrm{mg} / \mathrm{L}$, tanto para médias e altas velocidades de flotação (TABELA 5.4). O aumento da dosagem de 0,4 para 1,0 mg/L de polímero resultou em piora na remoção de carga orgânica. Com relação à remoção de fosfato total, os polímeros não iônicos e o policloreto de alumínio testados apresentaram efeito semelhante, porém apenas razoáveis, com concentrações variando entre 1,98 e $2,38 \mathrm{mgPO}_{4}^{-} / \mathrm{L}$, para $\mathrm{Vf}=10 \mathrm{~cm} / \mathrm{min}$, e 2,15 e $3,66 \mathrm{mgO}_{4}^{-} / \mathrm{L}$, para $\mathrm{Vf}=25 \mathrm{~cm} / \mathrm{min}$.

Observando-se a FIGURA 5.13C, verifica-se que, considerando a combinação das dosagens de $30 \mathrm{mg} / \mathrm{L}$ de cloreto férrico (DCF) e $0,4 \mathrm{mg} / \mathrm{L}$ de polímero não iônico ou policloreto de alumínio, todo o grupo apresentou ação semelhante, proporcionando eficiências de remoção de turbidez muito próximas e praticamente constantes para as velocidades de flotação entre 5 e $20 \mathrm{~cm} / \mathrm{min}$, na faixa entre $96 \%$ e $97 \%$. Desta forma, é importante ressaltar que o uso de polímero não elevou a eficiência de remoção de turbidez em velocidades iguais e inferiores a 20 $\mathrm{cm} / \mathrm{min}$. A adição de $30 \mathrm{mg} / \mathrm{L}$ de cloreto férrico isoladamente produziu resultados semelhantes, e até melhores, àqueles observados com dosagem adicional de $0,4 \mathrm{mg} / \mathrm{L}$ de polímero. De maneira geral, os polímeros não iônicos e o policloreto de alumínio testados resultaram em elevada remoção de turbidez também na faixa de velocidade de flotação de $25 \mathrm{~cm} / \mathrm{min}$, com valores acima de $86 \%$. Bons resultados de remoção de DQO foram observados para os polímeros não iônicos e o policloreto de alumínio testados, com valores residuais de DQO entre 30 e $48 \mathrm{mg} / \mathrm{L}$, em velocidades médias e altas de flotação. Com relação à remoção de fosfato total, todos os polímeros não iônicos testados apresentaram efeito semelhante, com concentrações variando entre 0,86 e $1,05 \mathrm{mgPO}_{4}{ }^{-} / \mathrm{L}$, para $\mathrm{Vf}=10 \mathrm{~cm} / \mathrm{min}$, e 1,40 e $1,84 \mathrm{mgPO}_{4}{ }^{-}$ $/ \mathrm{L}$, para $\mathrm{Vf}=25 \mathrm{~cm} / \mathrm{min}$.

Observando-se a FIGURA 5.14C, verifica-se que, considerando a combinação das dosagens de $30 \mathrm{mg} / \mathrm{L}$ de cloreto férrico (DCF) e 1,0 mg/L de polímero não iônico ou policloreto de alumínio, todo o grupo apresentou ação semelhante, proporcionando eficiências de remoção de turbidez muito próximas e praticamente constantes para as velocidades de flotação entre 5 e $15 \mathrm{~cm} / \mathrm{min}$, na faixa entre $95 \%$ e $97 \%$. A adição de $30 \mathrm{mg} / \mathrm{L}$ de cloreto férrico isoladamente produziu resultados semelhantes (98\% de remoção de turbidez) àqueles observados com dosagem adicional de $1,0 \mathrm{mg} / \mathrm{L}$ de polímero. A dosagem de $1,0 \mathrm{mg} / \mathrm{L}$ de polímero não iônico 
G999 elevou a eficiência de remoção de turbidez em velocidades em torno de $25 \mathrm{~cm} / \mathrm{min}$, apresentando excelente desempenho, com remoção de 97\% de turbidez. Também para dosagem de 1,0 mg/L de polímero, resultados muito bons de remoção de DQO foram observados para os polímeros testados, com valores residuais de DQO no efluente do flotateste abaixo de $54 \mathrm{mg} / \mathrm{L}$ em médias e altas velocidades de flotação. Com relação à remoção de fosfato total, os polímeros testados apresentaram efeitos semelhantes, com concentrações variando entre 0,86 e 0,95 $\mathrm{mgPO}_{4}{ }^{-} / \mathrm{L}$, para $\mathrm{Vf}=10 \mathrm{~cm} / \mathrm{min}$, e 0,84 e $1,44 \mathrm{mgPO}_{4}{ }^{-} / \mathrm{L}$, para $\mathrm{Vf}=25 \mathrm{~cm} / \mathrm{min}$. Cabe destacar a ação do polímero G999, em cujo ensaio foi obtido efluente do flotateste com concentração em torno de $0,85 \mathrm{mgPO}_{4}{ }^{-} / \mathrm{L}$, para médias e altas velocidades de flotação (TABELA 5.4).

Considerando-se que:

1. Para andamento dos trabalhos, é necessária a escolha de somente um dos polímeros testados;

2. Para dosagens de $15 \mathrm{mgFeCl}_{3} / \mathrm{L}$, o uso de $0,4 \mathrm{mg} / \mathrm{L}$ de polímero $\mathrm{G} 9047$ resultou em valores de DQO na amostra do flotateste abaixo de $25 \mathrm{mg} / \mathrm{L}$ em médias e altas velocidades de flotação;

3. Para dosagens de $30 \mathrm{mgFeCl} / 3 / \mathrm{L}$, o uso de $0,4 \mathrm{mg} / \mathrm{L}$ de polímero $\mathrm{G} 9047$ resultou em $96 \%$ de remoção de turbidez, para $25 \mathrm{~cm} / \mathrm{min}$ de velocidade de flotação, e amostra do flotateste com concentração de fosfato total entre 0,72 e $0,77 \mathrm{mg} / \mathrm{L} \mathrm{em}$ médias e altas velocidades de flotação;

4. Para dosagens de $30 \mathrm{mgFeCl} / 3 / \mathrm{L}$, o uso de $1,0 \mathrm{mg} / \mathrm{L}$ de polímero $\mathrm{G} 9047$ resultou em $98 \%$ de remoção de turbidez, para $25 \mathrm{~cm} / \mathrm{min}$ de velocidade de flotação, e amostra do flotateste com concentração de fosfato total entre 0,44 e $0,59 \mathrm{mg} / \mathrm{L}$ em médias e altas velocidades de flotação;

5. Na maior parte dos ensaios, o emprego de polímeros aniônicos e não-iônicos resultou em eficiências de remoção inferiores àquelas observadas para o polímero G9047. Somente em alguns casos isolados, os resultados observados nos ensaios com os polímeros aniônicos e não-iônicos foram semelhantes àqueles observados com o uso do polímero G9047;

O polímero G9047 foi escolhido para a realização dos ensaios das fases seguintes.

Procurando apresentar síntese dos resultados e das conclusões parciais desta etapa, na FIGURA 5.15 está apresentado um fluxograma simplificado da Primeira Etapa de Ensaios em laboratório, para investigação do emprego de polímeros sintéticos no pós-tratamento físicoquímico por flotação, descrita nos itens 4.6.1 e 4.6.2. 

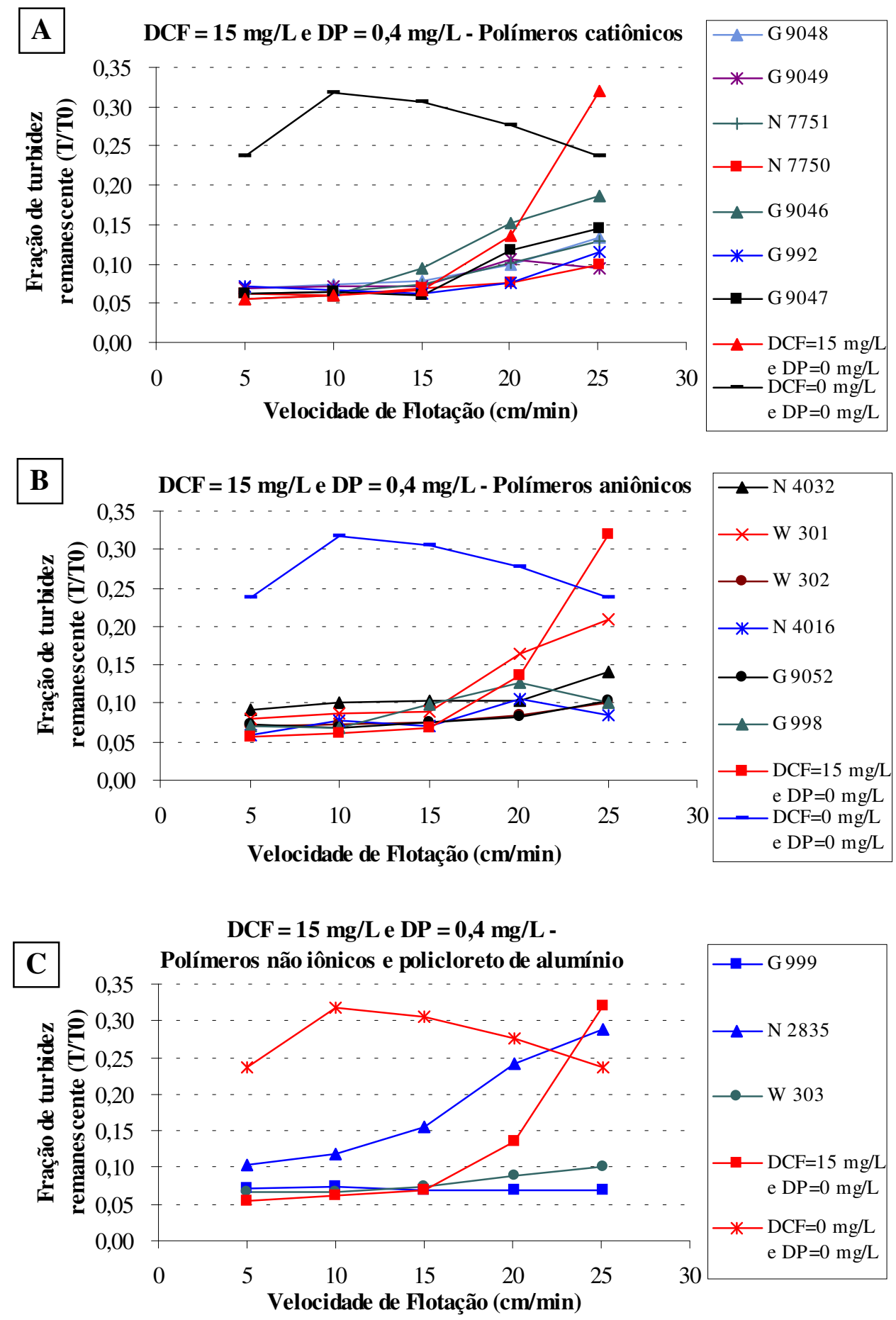

FIGURA 5.11 - Fração remanescente de turbidez (T/T0) em função da velocidade de flotação para dosagem de cloreto férrico (DCF) $=15 \mathrm{mg} / \mathrm{L}$ e dosagem de polímeros $(\mathrm{DP})=0,4 \mathrm{mg} / \mathrm{L}$. Polímeros catiônicos (A), aniônicos $(\mathbf{B})$ e não iônicos e policloreto de alumínio $(\mathbf{C})$.

Ensaios realizados com o equipamento de flotateste e efluente do reator RALEx. Gmr: $800 \mathrm{~s}^{-1}$, Tmr: $30 \mathrm{~s}$; Gf: $60 \mathrm{~s}^{-1}$; Tf: $20 \mathrm{~min}$; R: $20 \%$ (em volume); $\mathrm{S}^{*}: 19,0 \mathrm{~g} / \mathrm{m}^{3}$; Psat: $450 \mathrm{kPa}$. Características do efluente do reator RALEx: turbidez: 69,1 uT; DQO da amostra não filtrada: $106 \mathrm{mg} / \mathrm{L}$; fosfato total da amostra não filtrada: $6,40 \mathrm{mg} / \mathrm{L}$; temperatura: $24,0 \pm 0,3^{\circ} \mathrm{C}$. 

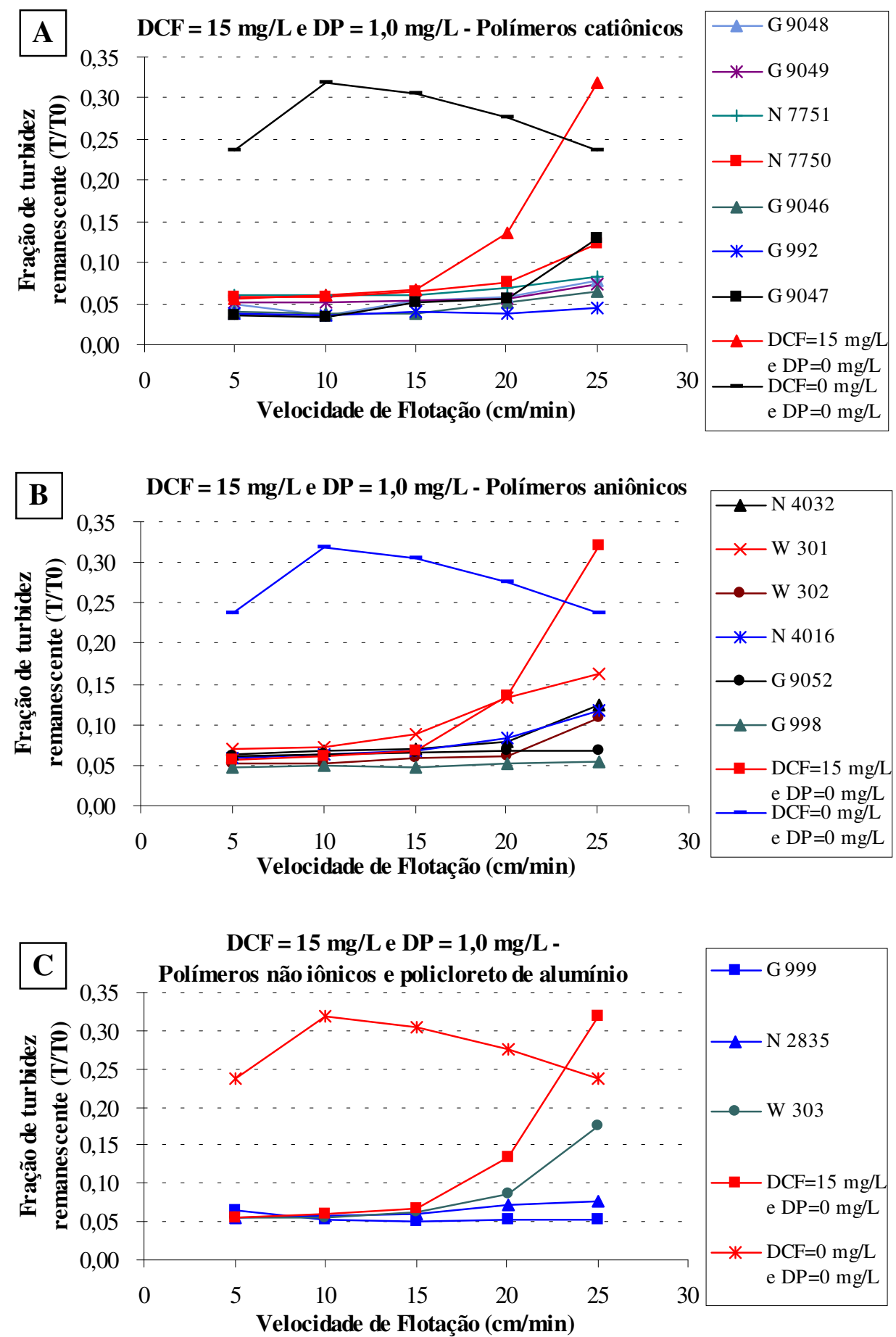

FIGURA 5.12 - Fração remanescente de turbidez (T/T0) em função da velocidade de flotação para dosagem de cloreto férrico $(\mathrm{DCF})=15 \mathrm{mg} / \mathrm{L}$ e dosagem de polímeros $(\mathrm{DP})=1,0 \mathrm{mg} / \mathrm{L}$. Polímeros catiônicos $(\mathbf{A})$, aniônicos $(\mathbf{B})$ e não iônicos e policloreto de alumínio (C).

Ensaios realizados com o equipamento de flotateste e efluente do reator RALEx. Gmr: $800 \mathrm{~s} \mathrm{~s}^{-1}$, Tmr: 30s; Gf: $60 \mathrm{~s}^{-1}$; Tf: $20 \mathrm{~min}$; R: $20 \%$ (em volume); $\mathrm{S}^{*}: 19,0 \mathrm{~g} / \mathrm{m}^{3}$; Psat: 450 $\mathrm{kPa}$. Características do efluente do reator RALEx: turbidez: 69,1 uT; DQO da amostra não filtrada: $106 \mathrm{mg} / \mathrm{L}$; fosfato total da amostra não filtrada: $6,40 \mathrm{mg} / \mathrm{L}$; temperatura: $24,0 \pm 0,3^{\circ} \mathrm{C}$. 

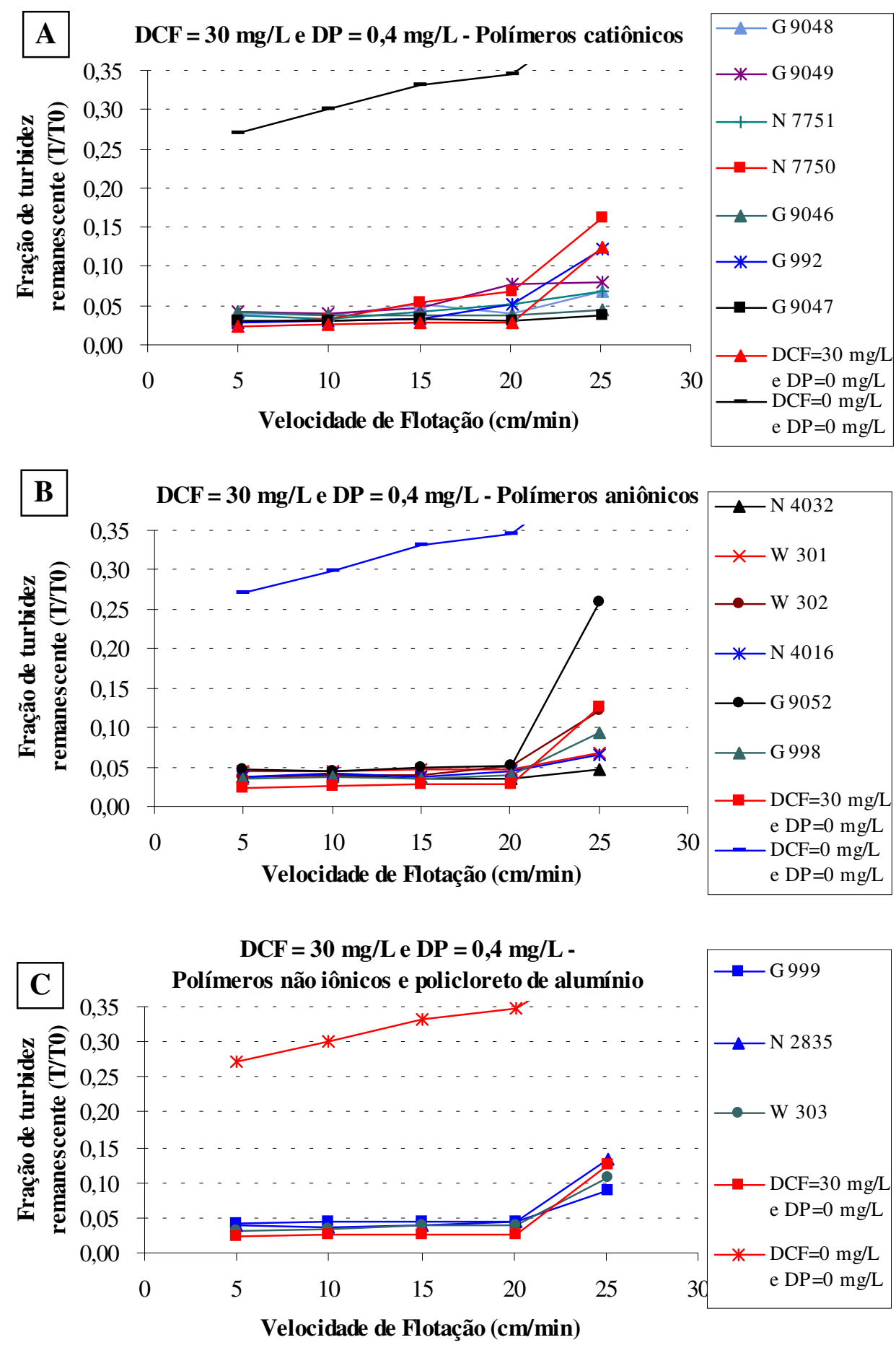

FIGURA 5.13 - Fração remanescente de turbidez (T/T0) em função da velocidade de flotação para dosagem de cloreto férrico $(\mathrm{DCF})=30 \mathrm{mg} / \mathrm{L}$ e dosagem de polímeros $(\mathrm{DP})=0,4 \mathrm{mg} / \mathrm{L}$. Polímeros catiônicos $(\mathbf{A})$, aniônicos $(\mathbf{B})$ e não iônicos e policloreto de alumínio $(\mathbf{C})$.

Ensaios realizados com o equipamento de flotateste e efluente do reator RALEx. Gmr: $800 \mathrm{~s}^{-1}$, Tmr: $30 \mathrm{~s}$; Gf: $60 \mathrm{~s}^{-1}$; Tf: $20 \mathrm{~min}$; R: $20 \%$ (em volume); $\mathrm{S}^{*}: 19,0 \mathrm{~g} / \mathrm{m}^{3}$; Psat: $450 \mathrm{kPa}$. Características do efluente do reator RALEx: turbidez: 71,7 uT; DQO da amostra não filtrada: $99 \mathrm{mg} / \mathrm{L}$; fosfato total da amostra não filtrada: $5,80 \mathrm{mg} / \mathrm{L}$; temperatura: $24,0 \pm 0,3{ }^{\circ} \mathrm{C}$. 

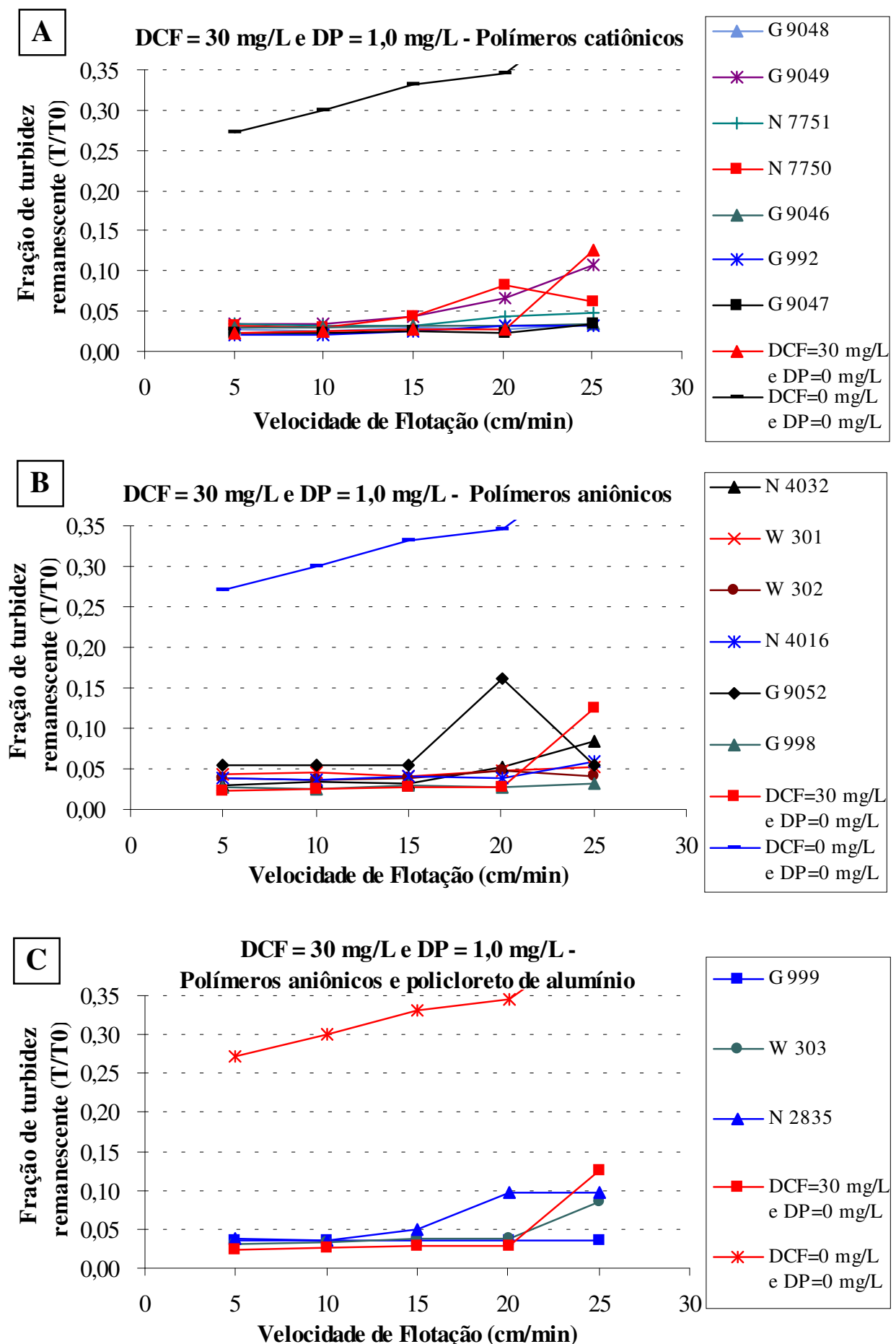

FIGURA 5.14 - Fração remanescente de turbidez (T/T0) em função da velocidade de flotação para dosagem de cloreto férrico $(\mathrm{DCF})=30 \mathrm{mg} / \mathrm{L}$ e dosagem de polímeros $(\mathrm{DP})=1,0 \mathrm{mg} / \mathrm{L}$. Polímeros catiônicos (A), aniônicos $(\mathbf{B})$ e não iônicos e policloreto de alumínio $(\mathbf{C})$.

Ensaios realizados com o equipamento de flotateste e efluente do reator RALEx. Gmr: $800 \mathrm{~s}^{-1}$, Tmr: 30s; Gf: $60 \mathrm{~s}^{-1}$; Tf: $20 \mathrm{~min}$; R: 20\% (em volume); $\mathrm{S}^{*}: 19,0 \mathrm{~g} / \mathrm{m}^{3}$; Psat: 450 $\mathrm{kPa}$. Características do efluente do reator RALEx: turbidez: 71,7 uT; DQO da amostra não filtrada: $99 \mathrm{mg} / \mathrm{L}$; fosfato total da amostra não filtrada: $5,80 \mathrm{mg} / \mathrm{L}$; temperatura: $24,0 \pm 0,3{ }^{\circ} \mathrm{C}$. 
TABELA 5.4 - Valores de Demanda Química de Oxigênio (DQO) e de Fosfato Total $\left(\mathrm{PO}_{4}{ }^{-}\right)$em função da velocidade de flotação para dosagem de cloreto férrico (DCF) de 15 e de $30 \mathrm{mg} / \mathrm{L}$ associada à dosagem de polímeros (DP) de 0,4 e 1,0 mg/L.

Ensaios realizados com o equipamento de flotateste e efluente do reator RALEx. Gmr: $800 \mathrm{~s}^{-1}$, Tmr: 30s; Gf: $60 \mathrm{~s}^{-1}$; Tf: $20 \mathrm{~min}$; R: $20 \%$ (em volume); $\mathrm{S}^{*}: 19,0 \mathrm{~g} / \mathrm{m}^{3}$; Psat: 450 $\mathrm{kPa}$. Características do efluente do reator RALEx: turbidez: 71,7 uT; DQO da amostra não filtrada: $99 \mathrm{mg} / \mathrm{L}$; fosfato total da amostra não filtrada: $5,80 \mathrm{mg} / \mathrm{L}$; temperatura: $24,0 \pm 0,3{ }^{\circ} \mathrm{C}$.

\begin{tabular}{|c|c|c|c|c|c|c|c|c|c|c|c|c|c|c|c|c|}
\hline \multirow[b]{4}{*}{$\begin{array}{l}\stackrel{0}{0} \\
\stackrel{0}{0} \\
\stackrel{0}{0}\end{array}$} & \multicolumn{8}{|c|}{ DQO (mg/L) } & \multicolumn{8}{|c|}{ Fosfato total $\left(\mathrm{mg} \mathrm{PO}_{4}^{-} / \mathrm{L}\right)$} \\
\hline & \multicolumn{4}{|c|}{$\mathrm{DCF}=15 \mathrm{mg} / \mathrm{L}$} & \multicolumn{4}{|c|}{$D C F=30 \mathrm{mg} / \mathrm{L}$} & \multicolumn{4}{|c|}{$\mathrm{DCF}=15 \mathrm{mg} / \mathrm{L}$} & \multicolumn{4}{|c|}{$\mathrm{DCF}=30 \mathrm{mg} / \mathrm{L}$} \\
\hline & \multicolumn{2}{|c|}{ 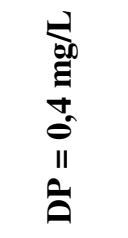 } & \multicolumn{2}{|c|}{ 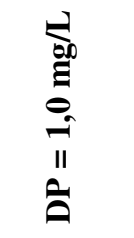 } & \multicolumn{2}{|c|}{ 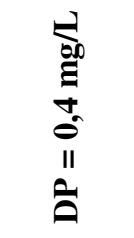 } & \multicolumn{2}{|c|}{ 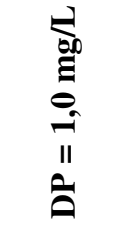 } & \multicolumn{2}{|c|}{ 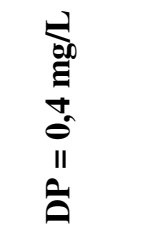 } & \multicolumn{2}{|c|}{ 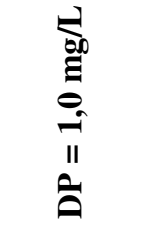 } & \multicolumn{2}{|c|}{ 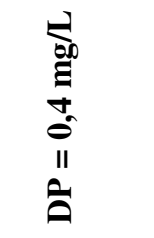 } & \multicolumn{2}{|c|}{ 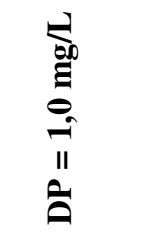 } \\
\hline & 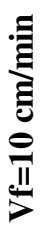 & 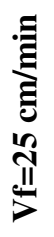 & 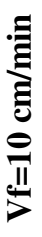 & 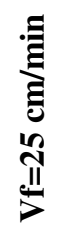 & 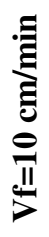 & 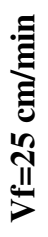 & 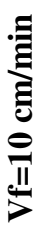 & 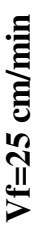 & 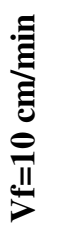 & 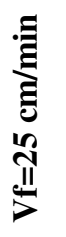 & 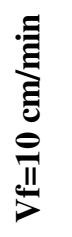 & 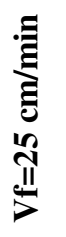 & 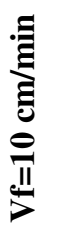 & 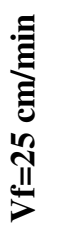 & 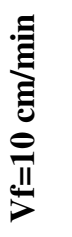 & 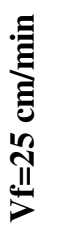 \\
\hline G 992 & 48 & 52 & 15 & 29 & 32 & 29 & 32 & 43 & 2,09 & 2,35 & 1,77 & 1,83 & 0,72 & 1,37 & 0,56 & 0,92 \\
\hline G 9046 & 18 & 58 & 21 & 35 & 27 & 31 & 30 & 28 & 1,67 & 3,12 & 1,66 & 2,84 & 0,74 & 0,80 & 0,51 & 0,65 \\
\hline G 9047 & 19 & 20 & 24 & 38 & 30 & 31 & 29 & 40 & 2,00 & 2,73 & 1,63 & 2,47 & 0,72 & 0,77 & 0,44 & 0,59 \\
\hline G 9048 & 21 & 31 & 47 & 26 & 32 & 27 & 47 & 32 & 2,33 & 2,99 & 1,91 & 2,50 & 0,86 & 0,97 & 0,56 & 0,65 \\
\hline G 9049 & 24 & 28 & 14 & 27 & 31 & 37 & 36 & 37 & 2,28 & 3,05 & 2,09 & 2,41 & 0,89 & 1,27 & 0,74 & 1,33 \\
\hline N 7750 & 21 & 26 & 36 & 48 & 42 & 36 & 35 & 36 & 2,23 & 2,77 & 2,14 & 2,77 & 0,91 & 1,88 & 0,83 & 1,75 \\
\hline N 7751 & 30 & 50 & 15 & 27 & 24 & 41 & 26 & 38 & 2,09 & 2,65 & 2,12 & 2,62 & 0,98 & 1,21 & - & 1,04 \\
\hline W 301 & 25 & 49 & 31 & 26 & 34 & 35 & 24 & 70 & 2,63 & 3,98 & 2,67 & 3,66 & 1,16 & 1,58 & 1,30 & 1,38 \\
\hline W 302 & 38 & 49 & 24 & 24 & 35 & 31 & 41 & 31 & 2,42 & 2,93 & 2,38 & 3,05 & 1,01 & 1,63 & 1,04 & 1,14 \\
\hline G 998 & 26 & 32 & 22 & 23 & 23 & 34 & 39 & 38 & 2,49 & 2,67 & 2,15 & 2,27 & 0,93 & 1,30 & 0,79 & 0,79 \\
\hline G 9052 & 42 & 36 & 29 & 49 & 30 & 60 & 26 & 39 & 2,81 & 2,81 & 2,44 & 2,62 & 1,26 & 0,69 & 1,72 & 1,65 \\
\hline N 4032 & 26 & 29 & 26 & 35 & 24 & 34 & 25 & 36 & 2,70 & 3,30 & 2,37 & 2,49 & 0,98 & 1,24 & 0,88 & 1,30 \\
\hline N 4016 & 41 & 50 & 25 & 33 & 29 & 32 & 54 & 38 & 2,23 & 2,84 & 2,12 & 2,16 & 0,99 & 1,27 & 1,21 & 1,33 \\
\hline W 303 & 24 & 26 & 18 & 39 & 38 & 43 & 30 & 54 & 2,26 & 2,94 & 2,38 & 3,66 & 0,86 & 1,49 & 0,95 & 1,44 \\
\hline G 999 & 25 & 25 & 23 & 35 & 48 & 45 & 23 & 38 & 2,21 & 2,41 & 1,98 & 2,15 & 1,05 & 1,40 & 0,86 & 0,84 \\
\hline N 2835 & 22 & 84 & 46 & 145 & 30 & 47 & 27 & 24 & 2,65 & 4,28 & 2,12 & 2,35 & 0,88 & 1,84 & 0,92 & 1,30 \\
\hline $\mathrm{DP}=0$ & 20 & 54 & 20 & 54 & 27 & 33 & 27 & 33 & 3,52 & 4,36 & 3,52 & 4,36 & 0,86 & 1,63 & 0,86 & 1,63 \\
\hline $\begin{array}{l}\mathrm{DP}=0 \mathrm{e} \\
\mathrm{DCF}=0\end{array}$ & 41 & 56 & 41 & 56 & 63 & 93 & 63 & 93 & 5,47 & 5,84 & 5,47 & 5,84 & 5,60 & 5,65 & 5,60 & 5,65 \\
\hline
\end{tabular}


Primeira Etapa: Ensaio em laboratório para investigação do desempenho de polímeros

\begin{tabular}{|c|c|}
\hline $\begin{array}{l}\text { Parâmetros } \\
\text { mantidos fixos: } \\
\text { \& Coleta às 08:00 }\end{array}$ & $\begin{array}{l}\text { Parâmetros variados: } \\
\text { *Características dos polímeros sintéticos } \\
\text { *Vflot entre } 5 \text { e } 25 \mathrm{~cm} / \mathrm{min}\end{array}$ \\
\hline * $\mathrm{DP}=4 \mathrm{mg} / \mathrm{L}$ & 7 \\
\hline $\begin{array}{l}\text { * } \mathrm{Gmr}=600 \mathrm{~s}^{-1} \\
\text { * } \mathrm{Tmr}=30 \mathrm{~s} \\
\text { \& } \mathrm{Tf}=60 \mathrm{~s}^{-1} \\
\text { \& }=20 \mathrm{~min}\end{array}$ & $\begin{array}{l}\text { Quando os polímeros catiônicos e com alto peso molecular G992, } \\
\text { G9046, G9047 e G9048 foram usados e Vflot }=\mathbf{1 0} \mathbf{~ c m} / \mathbf{m i n} \text { : } \\
\text { \&Remoção entre } 83 \% \text { e } 85 \% \text { de turbidez, e residuais entre } 12,6 \text { e } 14,2 \mathrm{uT} \text {; } \\
\text { \&Remoção entre } 59 \% \text { e } 73 \% \text { de } D_{\text {bruta }} \text {, e residuais entre } 35 \text { e } 54 \mathrm{mg} / \mathrm{L} \text {; } \\
\text { \& Remoção entre } 12 \% \text { e } 45 \% \text { de } \text { DQO }_{\text {filtr }} \text {, e residuais menores de } 28 \mathrm{mg} / \mathrm{L} \text {. }\end{array}$ \\
\hline
\end{tabular}

Aspectos observados:

* Nessa etapa, dentre os 21 polímeros testados, 10 polímeros apresentaram bons resultados. Entre estes, 6 eram catiônicos com alto peso molecular, 1 era catiônico com baixo peso molecular e os demais não tiveram suas características informadas pelo fabricante.

* 11 polímeros apresentaram baixo desempenho. Entre eles, 2 eram catiônicos com alto peso molecular, 6 eram aniônicos com alto peso molecular, 2 eram não-iônicos e 1 não teve suas características informadas pelo fabricante.

*Os polímeros G992, G9046, G9047 e G9048 apresentaram desempenho semelhante em todas as velocidades de flotação estudadas (até $25 \mathrm{~cm} / \mathrm{min}$ ).

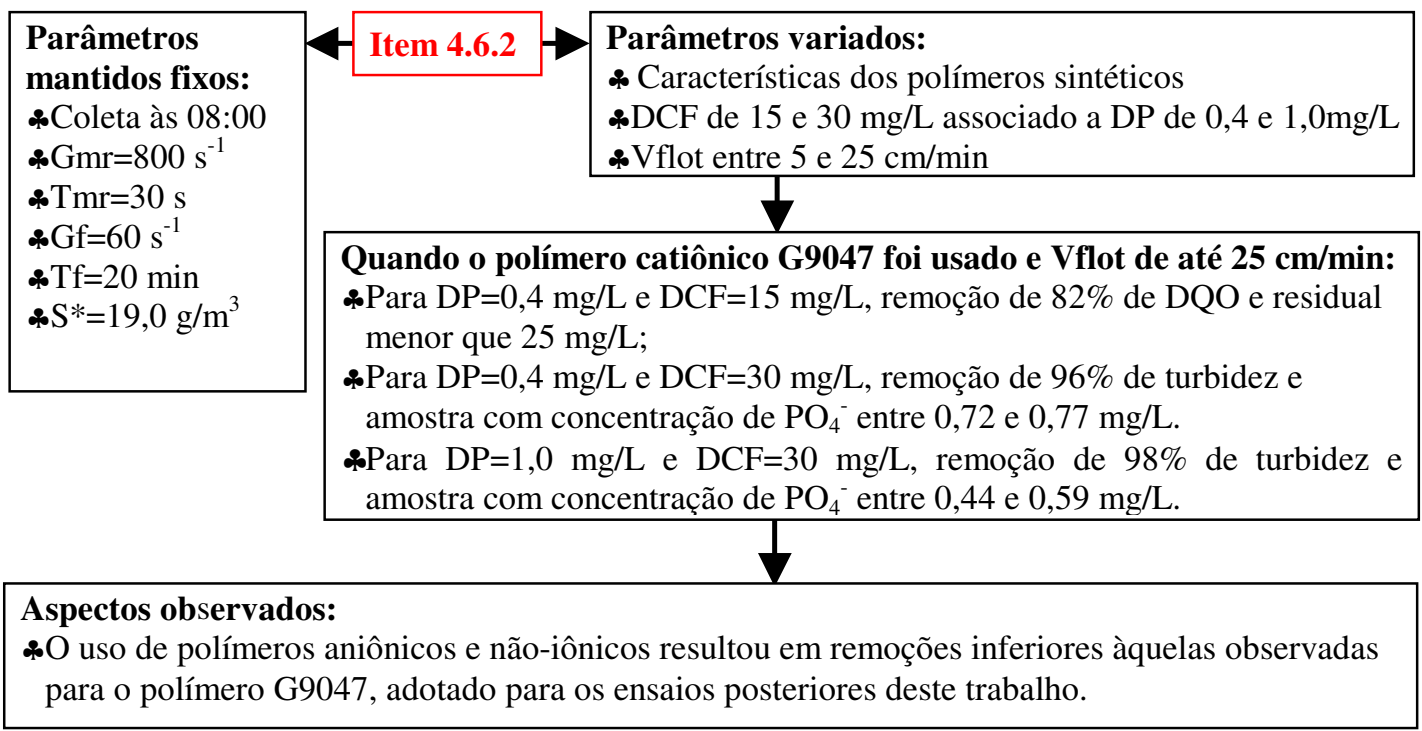

FIGURA 5.15 - Fluxograma simplificado da Primeira Etapa de Ensaios em laboratório, para investigação do emprego de polímeros sintéticos no pós-tratamento físicoquímico por flotação, descrita nos itens 4.6.1 e 4.6.2. 


\subsection{Ensaios em escala de laboratório, utilizando o flotateste e com aplicação de cloreto férrico e polímero sintético, durante período de partida do RALEx}

Como já mencionado, os ensaios descritos neste item abrangem o período em que o reator estava em condições de readaptação e recuperação da biomassa, funcionando ininterruptamente há cerca de trinta dias, após a renovação do carvão ativado do leito expandido.

O objetivo desses ensaios foi estudar o comportamento do flotador durante a partida do reator anaeróbio, verificando se as dosagens de produtos químicos rotineiramente empregadas eram suficientes para manter o efluente final com boa qualidade, atendendo limites restritos de lançamento.

Os resultados dos ensaios com variação da dosagem de cloreto férrico associada a diferentes dosagens de polímero sintético são apresentados no item 5.4.1.

No item 5.4.2, são apresentados os resultados obtidos durante os ensaios com variação do tempo total de floculação associado a diferentes valores de tempo de floculação do polímero sintético.

Os resultados dos ensaios com variação do tempo total de floculação associado a diferentes valores de gradiente médio de velocidade de floculação são apresentados no item 5.4.3.

No item 5.4.4, são apresentados os resultados obtidos durante os ensaios com variação da quantidade de ar fornecida ao processo, através da recirculação de líquido pressurizado.

E, finalmente, no item 5.4.5, os resultados dos ensaios com utilização dos valores mais adequados dos parâmetros discutidos nos itens 5.4.1 a 5.4.4 são apresentados.

Os resultados dos ensaios com variação da dosagem de cloreto férrico, da dosagem de polímero sintético (dosado isoladamente), do tipo de polímero sintético e da dosagem de polímero (dosado conjuntamente com cloreto férrico), durante partida de reator RALEx, são apresentados no item 5.4.6.

Nesta fase, faixas de valores mais amplas de cada parâmetro foram estudadas. Todos os ensaios realizados tiveram por objetivo escolher, entre os diversos parâmetros de operação do floculador e do flotador, faixas de valores mais adequadas ao tratamento químico seguido de flotação dos efluentes de reator anaeróbio. Essas faixas de valores mais adequadas foram posteriormente investigadas também na unidade piloto de floculação/flotação com escoamento contínuo. 


\subsubsection{Ensaios com variação da dosagem de cloreto férrico associada a diferentes dosagens de polímero sintético}

São relatados os resultados obtidos nos ensaios descritos no item 4.7.1. Na discussão desses resultados é analisada a influência da dosagem de cloreto férrico associada à de polímero catiônico, dentre as testadas, e as que melhor se adaptam ao tratamento de efluentes de reatores anaeróbios. A discussão baseia-se na eficiência de remoção de turbidez, entre velocidades de flotação de 5 a $25 \mathrm{~cm} / \mathrm{min}$, e de DQO e de fósforo (P) das amostras não filtradas coletadas nos ensaios em velocidades de flotação de 10 e de $25 \mathrm{~cm} / \mathrm{min}$.

As FIGURAS 5.16 e 5.17 apresentam os valores de fração de turbidez remanescente, ou seja, a razão entre a turbidez da amostra tratada e a turbidez do efluente do reator RALEx, em função da velocidade de flotação para as dosagens de cloreto férrico (DCF) de 0; 10; 20; 30 e 40 $\mathrm{mg} / \mathrm{L}$ associadas a dosagens de polímero catiônico G9047 (DPC) de 0; 0,25; 0,50;0,75; 1,0 e $1,25 \mathrm{mg} / \mathrm{L}$.

O aumento da dosagem de polímero catiônico e suas conseqüências na remoção de turbidez

Sem adição de cloreto férrico $(\mathrm{DCF}=0 \mathrm{mg} / \mathrm{L})$, foram investigadas seis dosagens de polímero catiônico G9047 (DPC): 0;0,25;0,50;0,75; 1,0 e 1,25 mg/L. Observando-se a FIGURA 5.17A, verifica-se que, de maneira geral, o aumento da dosagem de polímero pouco influenciou a qualidade do efluente em termos de turbidez, entre 28,3 uT e 29,8 uT, para velocidade de flotação de $10 \mathrm{~cm} / \mathrm{min}$ e sem adição de cloreto férrico. Verificou-se ligeira melhora da qualidade do efluente somente quando a dosagem de polímero foi de 1,25 mg/L, produzindo amostra com turbidez de $25,1 \mathrm{uT}$ para $\mathrm{Vf}=10 \mathrm{~cm} / \mathrm{min}$.

Para dosagens de cloreto férrico de $10 \mathrm{mg} / \mathrm{L}$, os resultados de turbidez estão mostrados na FIGURA 5.17B. O aumento da dosagem de polímero não determinou o aumento da remoção de turbidez. De maneira geral, as amostras apresentaram valores de turbidez bastante próximos, entre 28,4 uT e $31,3 \mathrm{uT}$, para Vf $=10 \mathrm{~cm} / \mathrm{min}$, com exceção do ensaio com dosagem de 1,0 $\mathrm{mg} / \mathrm{L}$ de polímero, onde a turbidez da amostra foi de $36,4 \mathrm{uT}$.

A FIGURA 5.16C mostra os resultados de turbidez das amostras obtidas nos ensaios com dosagem de $20 \mathrm{mg} / \mathrm{L}$ de cloreto férrico associada a diferentes dosagens de polímero catiônico. O aumento da dosagem de polímero não resultou em aumento da remoção de turbidez. De maneira geral, as amostras apresentaram valores de turbidez bastante próximos, entre $25,8 \mathrm{uT}$ e $28,7 \mathrm{uT}$, para $\mathrm{Vf}=10 \mathrm{~cm} / \mathrm{min}$.

Observando-se a FIGURA 5.17A, verifica-se que, de maneira geral, o aumento da dosagem de polímero não influenciou a qualidade do efluente em termos de turbidez, entre 21,8 uT e 24,4 uT, para velocidade de flotação de $10 \mathrm{~cm} / \mathrm{min}$ e com adição de $30 \mathrm{mg} / \mathrm{L}$ de cloreto 
férrico. As amostras apresentaram valores de turbidez bastante próximos, com exceção do ensaio com dosagem de $0,5 \mathrm{mg} / \mathrm{L}$ de polímero, onde a turbidez da amostra foi de 27,7 uT.

Observando-se a FIGURA 5.17B, verifica-se que o aumento da dosagem de polímero pouco influenciou a qualidade do efluente em termos de turbidez, entre 13,2 uT e 15,5 uT, para $\mathrm{Vf}=10 \mathrm{~cm} / \mathrm{min}$ e $\mathrm{DCF}=40 \mathrm{mg} / \mathrm{L}$. Verificou-se ligeira melhora da qualidade do efluente somente quando a dosagem de polímero foi de $1,25 \mathrm{mg} / \mathrm{L}$, produzindo amostra com turbidez de $9,2 \mathrm{uT}$ para $\mathrm{Vf}=10 \mathrm{~cm} / \mathrm{min}$. Essa combinação de dosagem produziu efluente com excelentes valores de turbidez, mesmo para velocidades de flotação mais altas. A amostra coletada quando $\mathrm{Vf}=25 \mathrm{~cm} / \mathrm{min}$ apresentou turbidez de 14,0 uT, com correspondente remoção de turbidez de $70,7 \%$.

Nas faixas de dosagens de cloreto férrico e de polímero catiônico investigadas, o aumento de DP não proporcionou elevação da eficiência de remoção de turbidez.

\section{O aumento da dosagem de cloreto férrico e suas conseqüências na remoção de} turbidez

O aumento da dosagem de cloreto férrico (FIGURAS 5.16 e 5.17), entre zero e 40 $\mathrm{mg} / \mathrm{L}$, produziu resultados com diferentes comportamentos de acordo com a velocidade de flotação estudada.

Considerando-se as amostras coletadas na $\mathrm{Vf}=10 \mathrm{~cm} / \mathrm{min}$, quando $\mathrm{DCF}=0 \mathrm{mg} / \mathrm{L}$, os valores de turbidez das amostras variaram entre 28,3 uT e 29,8 uT. Com DCF $=10 \mathrm{mg} / \mathrm{L}$, os valores de turbidez variaram entre 28,4 uT e $31,3 \mathrm{uT}$. Para DCF $=20 \mathrm{mg} / \mathrm{L}$, os valores de turbidez variaram entre 25,8 uT e $28,7 \mathrm{uT}$. Considerando $\mathrm{DCF}=30 \mathrm{mg} / \mathrm{L}$, os valores de turbidez variaram entre $21,8 \mathrm{uT}$ e $24,4 \mathrm{uT}$. E, finalmente, para DCF $=40 \mathrm{mg} / \mathrm{L}$, os valores de turbidez variaram entre 9,2 uT e 15,5 uT.

Sendo assim, para baixas velocidades, menores que $15 \mathrm{~cm} / \mathrm{min}$, o aumento da dosagem de cloreto férrico resultou em redução nos valores de turbidez das amostras.

No entanto, considerando-se as amostras coletadas na $\mathrm{Vf}=25 \mathrm{~cm} / \mathrm{min}$, quando $\mathrm{DCF}=0$ $\mathrm{mg} / \mathrm{L}$, os valores de turbidez das amostras variaram entre 28,0 uT e 33,6 uT. Com DCF $=10$ $\mathrm{mg} / \mathrm{L}$, os valores de turbidez variaram entre 28,9 uT e $36,6 \mathrm{uT}$. Para DCF $=20 \mathrm{mg} / \mathrm{L}$, os valores de turbidez variaram entre 29,4 uT e 36,4 uT. Considerando DCF $=30 \mathrm{mg} / \mathrm{L}$, os valores de turbidez variaram entre 40,9 uT e 51,8 uT. E, finalmente, para DCF $=40 \mathrm{mg} / \mathrm{L}$, os valores de turbidez variaram entre 42,0 uT e 62,2 uT, com exceção de quando a DPC era de 1,25 mg/L, com amostra apresentando turbidez de 14,0 uT.

Desta forma, para altas velocidades de flotação (acima de $15 \mathrm{~cm} / \mathrm{min}$ ), o aumento da dosagem de cloreto férrico produziu amostras com valores de turbidez maiores, em decorrência da redução da eficiência de remoção. 

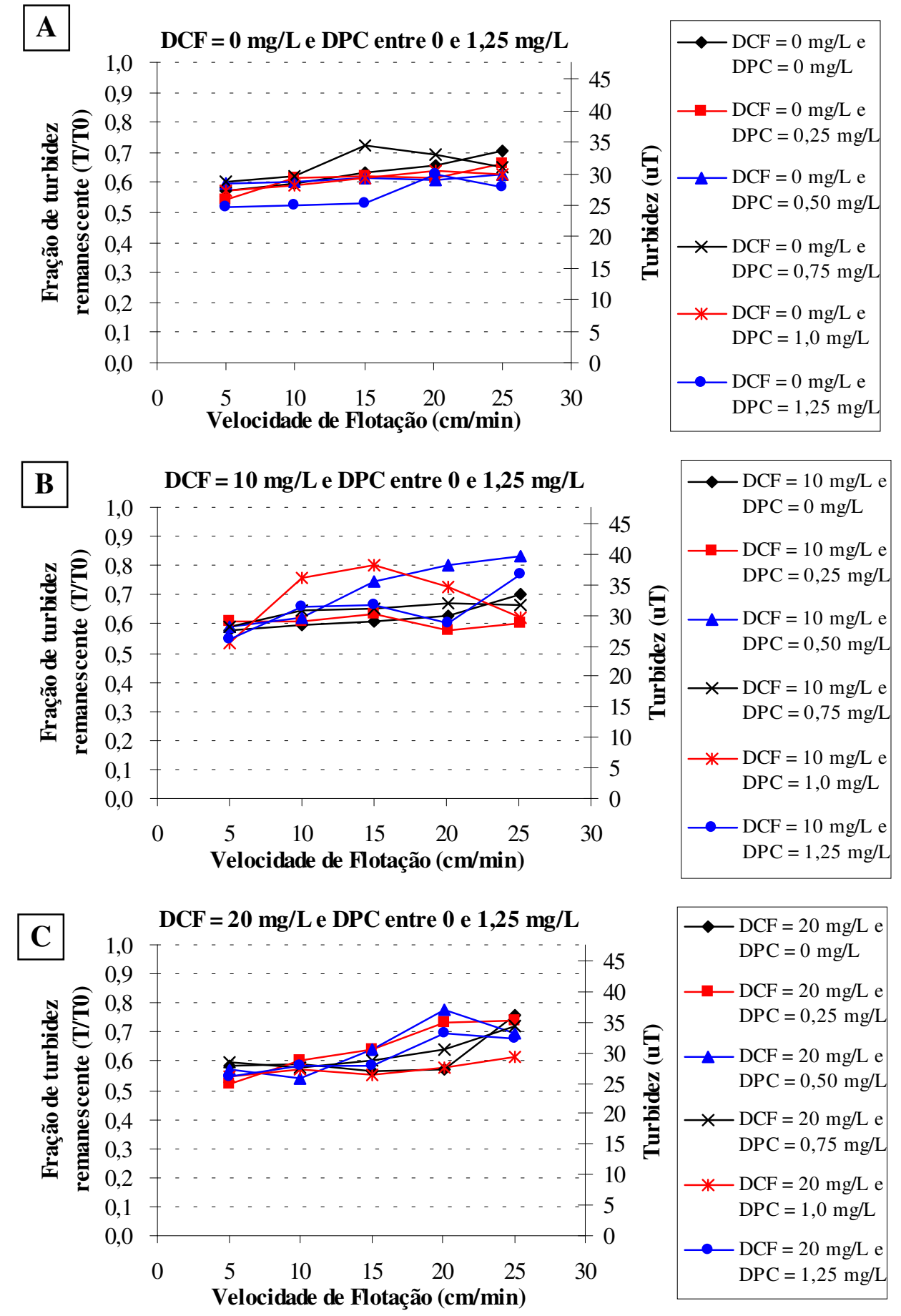

FIGURA 5.16 - Fração remanescente de turbidez (T/T0) em função da velocidade de flotação para dosagem de cloreto férrico (DCF) entre 0 e $20 \mathrm{mg} / \mathrm{L}$ e dosagem de polímero catiônico (DPC) entre 0 e $1,25 \mathrm{mg} / \mathrm{L} . \mathrm{DCF}=0 \mathrm{mg} / \mathrm{L}(\mathbf{A}), \mathrm{DCF}=10$ $\mathrm{mg} / \mathrm{L}(\mathbf{B})$ e $\mathrm{DCF}=20 \mathrm{mg} / \mathrm{L}(\mathbf{C})$.

Ensaios realizados com o equipamento de flotateste e efluente do reator RALEx. Gmr: $1000 \mathrm{~s}^{-1}$, Tmr: 10s; Gf: $80 \mathrm{~s}^{-1}$; Tf: $20 \mathrm{~min}$; R: $20 \%$ (em volume); $\mathrm{S}^{*}: 19,0 \mathrm{~g} / \mathrm{m}^{3}$; Psat: $450 \mathrm{kPa}$. Características do efluente do reator RALEx: turbidez: 47,7 uT; DQO da amostra não filtrada: $249 \mathrm{mg} / \mathrm{L}$; fósforo da amostra não filtrada: $5,15 \mathrm{mg} / \mathrm{L}$; temperatura: $21,0 \pm 0,3^{\circ} \mathrm{C}$. 

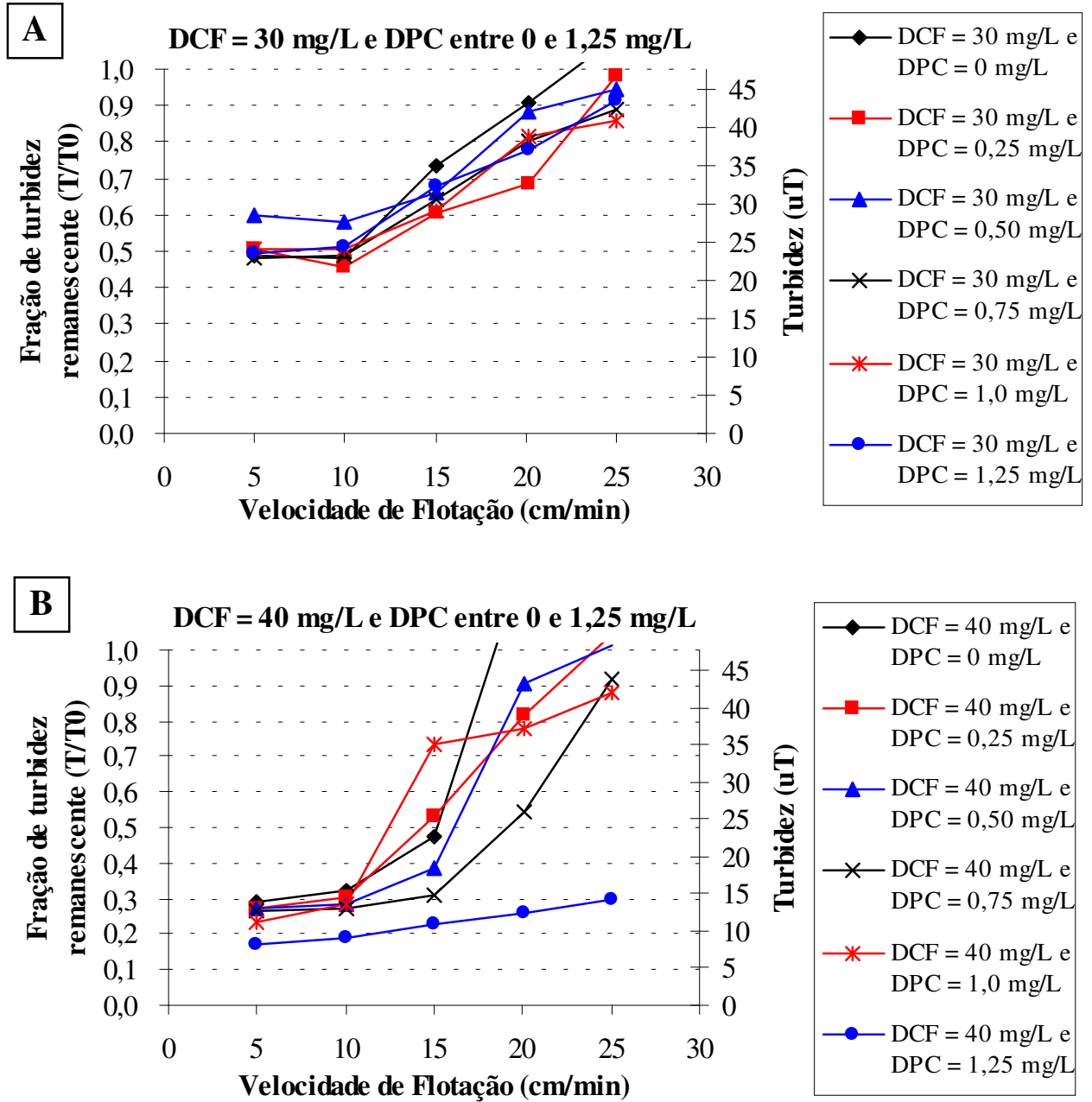

FIGURA 5.17 - Fração remanescente de turbidez (T/T0) em função da velocidade de flotação para dosagem de cloreto férrico (DCF) entre 30 e $40 \mathrm{mg} / \mathrm{L}$ e dosagem de polímero catiônico (DPC) entre 0 e $1,25 \mathrm{mg} / \mathrm{L} . \mathrm{DCF}=30 \mathrm{mg} / \mathrm{L}$ (A) e DCF $=40$ $\mathrm{mg} / \mathrm{L}(\mathbf{B})$.

Ensaios realizados com o equipamento de flotateste e efluente do reator RALEx. Gmr: $1000 \mathrm{~s}^{-1}$, Tmr: 10s; Gf: $80 \mathrm{~s}^{-1}$; Tf: $20 \mathrm{~min}$; R: $20 \%$ (em volume); $\mathrm{S}^{*}: 19,0 \mathrm{~g} / \mathrm{m}^{3}$; Psat: $450 \mathrm{kPa}$. Características do efluente do reator RALEx: turbidez: 47,7 uT; DQO da amostra não filtrada: $249 \mathrm{mg} / \mathrm{L}$; fósforo da amostra não filtrada: $5,15 \mathrm{mg} / \mathrm{L}$; temperatura: $21,0 \pm 0,3^{\circ} \mathrm{C}$.

Observando a FIGURA 5.18A, pode-se concluir que o aumento da dosagem de polímero também não afetou significativamente a qualidade das amostras coletadas na $\mathrm{Vf}=10$ $\mathrm{cm} /$ min em termos de concentração de fósforo do efluente, para dosagens de cloreto férrico entre 0 e $30 \mathrm{mg} / \mathrm{L}$. Nessas condições, as concentrações de fósforo das amostras variaram entre $3,15 \mathrm{mg} / \mathrm{L}$ e 3,60 mg/L. Para DCF = $40 \mathrm{mg} / \mathrm{L}$, houve aumento na remoção de fósforo a partir de dosagens de $0,75 \mathrm{mg} / \mathrm{L}$ de polímero, atingindo seu melhor desempenho quando $\mathrm{DPC}=1,25$ $\mathrm{mg} / \mathrm{L}$, com concentração de fósforo de $1,98 \mathrm{mg} / \mathrm{L}$. O mesmo comportamento pode ser 
observado para velocidades mais altas de flotação. Para $\mathrm{Vf}=25 \mathrm{~cm} / \mathrm{min}$ e DCF entre 0 e 30 $\mathrm{mg} / \mathrm{L}$, as concentrações de fósforo das amostras variaram entre $3,10 \mathrm{mg} / \mathrm{L}$ e $3,72 \mathrm{mg} / \mathrm{L}$. Para $\mathrm{DCF}=40 \mathrm{mg} / \mathrm{L}$, houve aumento na remoção de fósforo com o aumento da dosagem de polímero, atingindo seu melhor desempenho quando $\mathrm{DPC}=1,25 \mathrm{mg} / \mathrm{L}$, com concentração de fósforo de 2,40 mg/L.
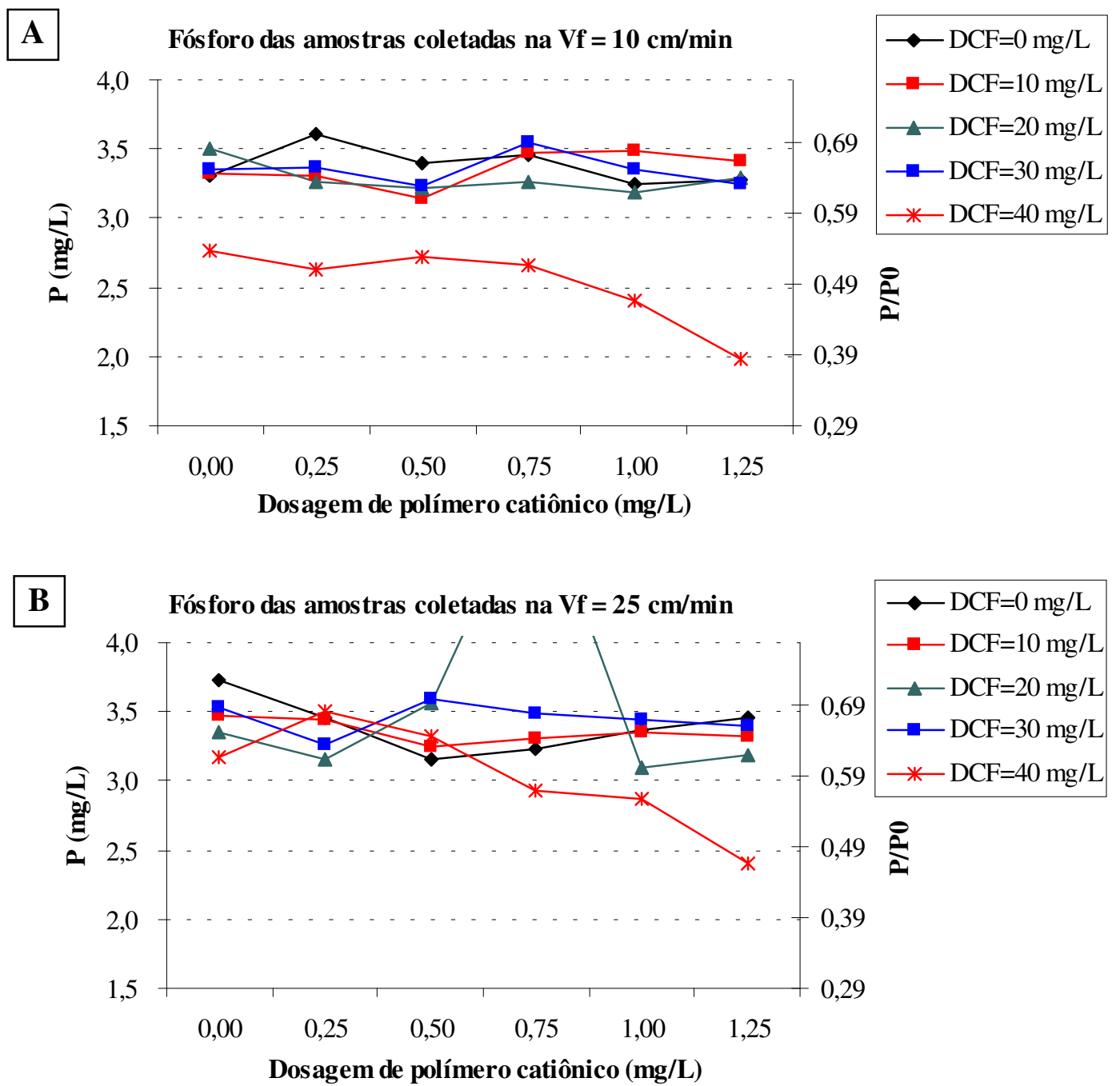

FIGURA 5.18 - Concentração de fósforo $(\mathrm{P})$ das amostras coletadas nos ensaios com dosagem de cloreto férrico (DCF) entre 0 e $40 \mathrm{mg} / \mathrm{L}$ e dosagem de polímero catiônico (DPC) entre 0 e $1,25 \mathrm{mg} / \mathrm{L} . \mathrm{Vf}=10 \mathrm{~cm} / \mathrm{min}(\mathbf{A})$ e $\mathrm{Vf}=25 \mathrm{~cm} / \mathrm{min}(\mathbf{B})$.

Ensaios realizados com o equipamento de flotateste e efluente do reator RALEx. Gmr: $1000 \mathrm{~s}^{-1}$, Tmr: 10s; Gf: $80 \mathrm{~s}^{-1}$; Tf: $20 \mathrm{~min}$; R: $20 \%$ (em volume); S*: 19,0 g/m³ ; Psat: $450 \mathrm{kPa}$. Características do efluente do reator RALEx: turbidez: 47,7 uT; DQO da amostra não filtrada: $249 \mathrm{mg} / \mathrm{L}$; fósforo da amostra não filtrada: $5,15 \mathrm{mg} / \mathrm{L}$; temperatura: $21,0 \pm 0,3^{\circ} \mathrm{C}$. 


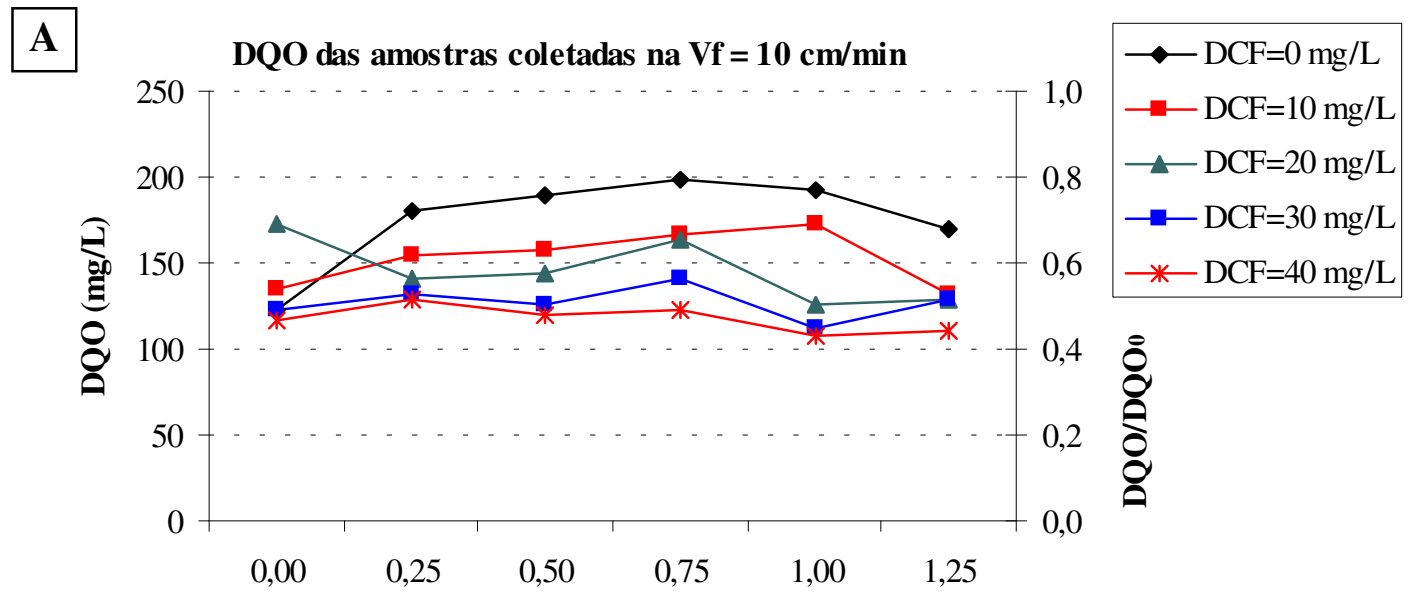

Dosagem de polímero catiônico $(\mathrm{mg} / \mathrm{L})$

B

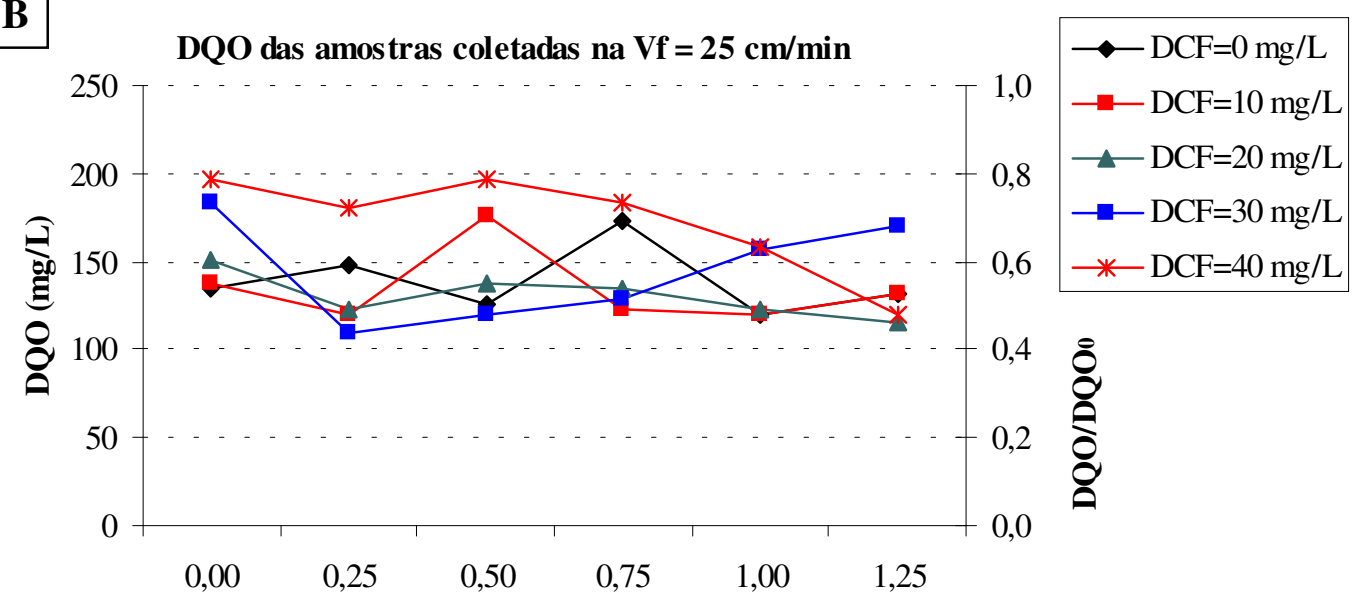

Dosagem de polímero catiônico $(\mathrm{mg} / \mathrm{L})$

FIGURA 5.19 - Demanda química de oxigênio (DQO) das amostras coletadas nos ensaios com dosagem de cloreto férrico (DCF) entre 0 e $40 \mathrm{mg} / \mathrm{L}$ e dosagem de polímero catiônico (DPC) entre 0 e $1,25 \mathrm{mg} / \mathrm{L}$. Vf $=10 \mathrm{~cm} / \mathrm{min}(\mathbf{A})$ e Vf $=25 \mathrm{~cm} / \mathrm{min}$ (B).

Ensaios realizados com o equipamento de flotateste e efluente do reator RALEx. Gmr: $1000 \mathrm{~s}^{-1}$, Tmr: 10s; Gf: $80 \mathrm{~s}^{-1}$; Tf: $20 \mathrm{~min}$; R: $20 \%$ (em volume); $\mathrm{S}^{*}: 19,0 \mathrm{~g} / \mathrm{m}^{3}$; Psat: $450 \mathrm{kPa}$. Características do efluente do reator RALEx: turbidez: 47,7 uT; DQO da amostra não filtrada: $249 \mathrm{mg} / \mathrm{L}$; fósforo da amostra não filtrada: $5,15 \mathrm{mg} / \mathrm{L}$; temperatura: $21,0 \pm 0,3^{\circ} \mathrm{C}$.

Observando a FIGURA 5.19A, pode-se concluir que o aumento da dosagem de polímero não afetou significativamente a qualidade das amostras coletadas na $\mathrm{Vf}=10 \mathrm{~cm} / \mathrm{min}$ em termos de DQO. Entretanto, o aumento da dosagem de cloreto férrico proporcionou ligeira redução nos valores de DQO das amostras. Quando não houve adição de cloreto férrico, os valores de DQO das amostras variaram entre 170 e $199 \mathrm{mg} / \mathrm{L}$. Quando foram adicionados 40 $\mathrm{mg} / \mathrm{L}$ de cloreto férrico esses valores variaram entre 106 e $129 \mathrm{mg} / \mathrm{L}$. Para velocidades mais altas de flotação $(25 \mathrm{~cm} / \mathrm{min})$, conforme visto na FIGURA 5.19B, os valores de DQO das 
amostras não apresentaram comportamento definido em função da variação das dosagens de cloreto férrico e de polímero.

\subsubsection{Ensaios com variação do tempo total de floculação associado a diferentes valores de tempo de floculação do polímero sintético}

São relatados os resultados obtidos nos ensaios descritos no item 4.7.2. Na discussão desses resultados é analisada a influência na qualidade do efluente do flotateste do tempo total de floculação do efluente do reator anaeróbio mediante adição de cloreto férrico e do melhor momento para adição do polímero, proporcionando tempo de floculação com presença simultânea de cloreto férrico e de polímero.

A discussão baseia-se na eficiência de remoção de turbidez, entre velocidades de flotação de 5 a 25 cm/min, e de DQO e de fósforo (P) das amostras não filtradas coletadas nos ensaios em velocidades de flotação de 10 e de $25 \mathrm{~cm} / \mathrm{min}$.

A FIGURA 5.20 apresenta os valores de fração de turbidez remanescente em função da velocidade de flotação para tempos totais de floculação (Tf) entre 6 e 24 minutos e tempo de floculação do polímero (Tfpol) entre 6 e 24 minutos.

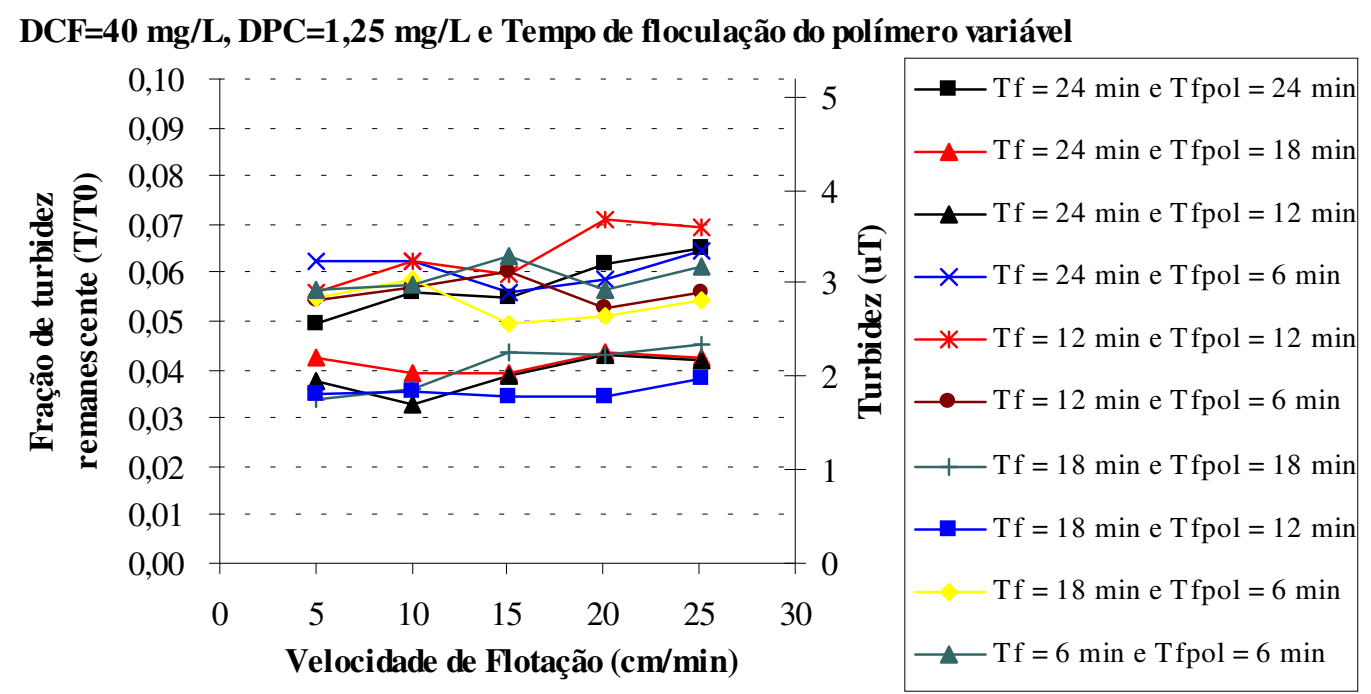

FIGURA 5.20 - Fração remanescente de turbidez (T/T0) em função da velocidade de flotação para diferentes valores de tempo total de floculação associado a diferentes valores de tempo de floculação do polímero.

Ensaios realizados com o equipamento de flotateste e efluente do reator RALEx. Gmr: $1000 \mathrm{~s}^{-1}$, Tmr: 10s; DCF = $40 \mathrm{mg} / \mathrm{L} ; \mathrm{DPC}=1,25 \mathrm{mg} / \mathrm{L} ; \mathrm{Gf}: 80 \mathrm{~s}^{-1}$; R: $20 \%(\mathrm{em}$ volume); $\mathrm{S}^{*}: 19,0 \mathrm{~g} / \mathrm{m}^{3}$; Psat: $450 \mathrm{kPa}$. Características do efluente do reator RALEx: turbidez: 51,9 uT; DQO da amostra não filtrada: $244 \mathrm{mg} / \mathrm{L}$; fósforo da amostra não filtrada: $3,67 \mathrm{mg} / \mathrm{L}$; temperatura: $20,7 \pm 0,3^{\circ} \mathrm{C}$. 
As FIGURAS 5.21 e 5.22 apresentam, respectivamente, as concentrações de fósforo e de DQO, para velocidade de flotação de 10 e de $25 \mathrm{~cm} / \mathrm{min}$, para tempos totais de floculação (Tf) entre 6 e 24 minutos e tempo de floculação do polímero (Tfpol) entre 6 e 24 minutos.
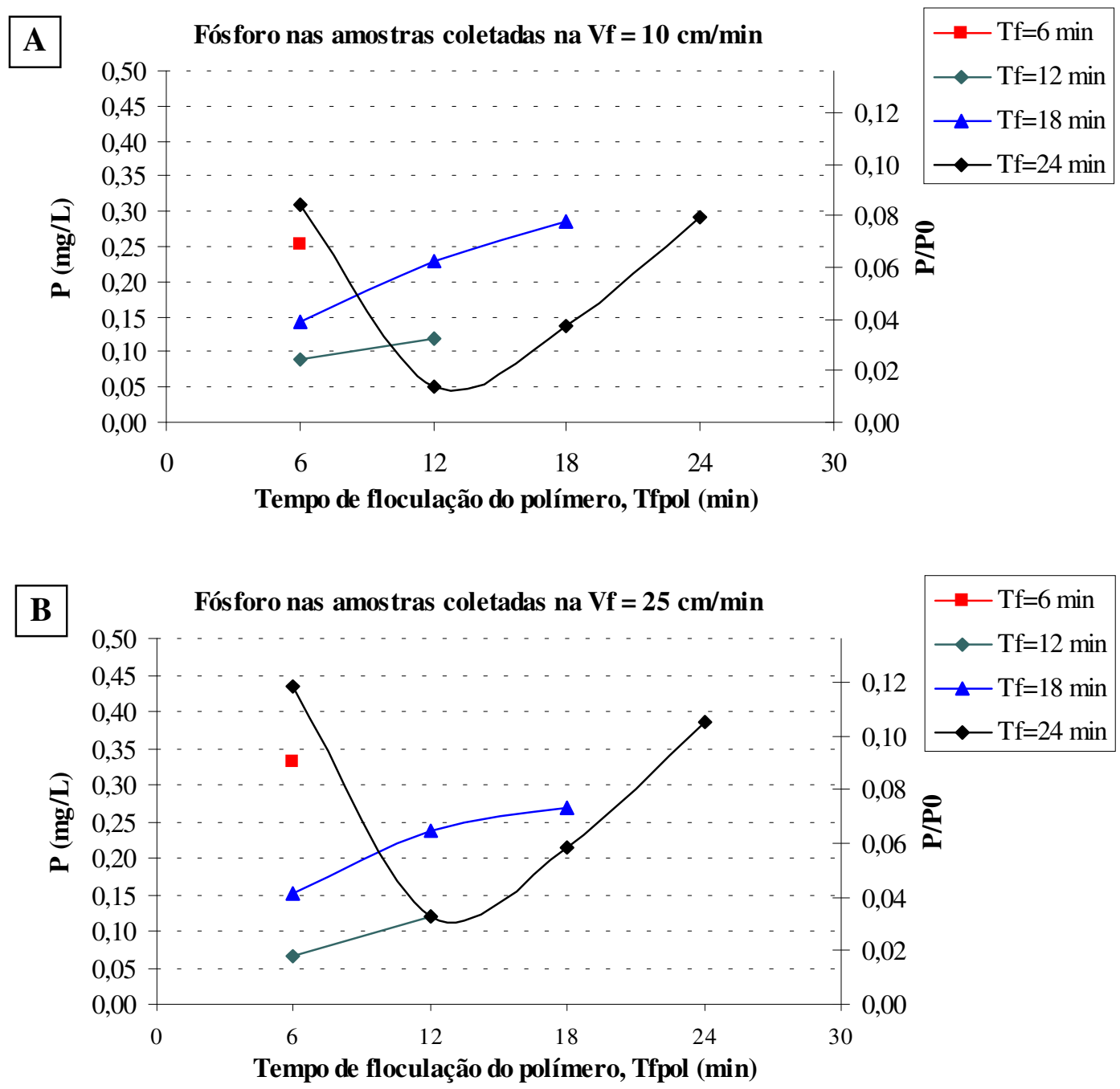

FIGURA 5.21 - Concentração de fósforo (P) das amostras coletadas nos ensaios com diferentes valores de tempo total de floculação associado a diferentes valores de tempo de floculação do polímero. $\mathrm{Vf}=10 \mathrm{~cm} / \mathrm{min}(\mathbf{A})$ e $\mathrm{Vf}=25 \mathrm{~cm} / \mathrm{min}(\mathbf{B})$.

Ensaios realizados com o equipamento de flotateste e efluente do reator RALEx. Gmr: $1000 \mathrm{~s}^{-1}$, Tmr: $10 \mathrm{~s} ; \mathrm{DCF}=40 \mathrm{mg} / \mathrm{L} ; \mathrm{DPC}=1,25 \mathrm{mg} / \mathrm{L} ; \mathrm{Gf}: 80 \mathrm{~s}^{-1}$; R: $20 \%$ (em volume); $\mathrm{S}^{*}: 19,0 \mathrm{~g} / \mathrm{m}^{3}$; Psat: $450 \mathrm{kPa}$. Características do efluente do reator RALEx: turbidez: 51,9 uT; DQO da amostra não filtrada: $244 \mathrm{mg} / \mathrm{L}$; fósforo da amostra não filtrada: $3,67 \mathrm{mg} / \mathrm{L}$; temperatura: $20,7 \pm 0,3{ }^{\circ} \mathrm{C}$. 

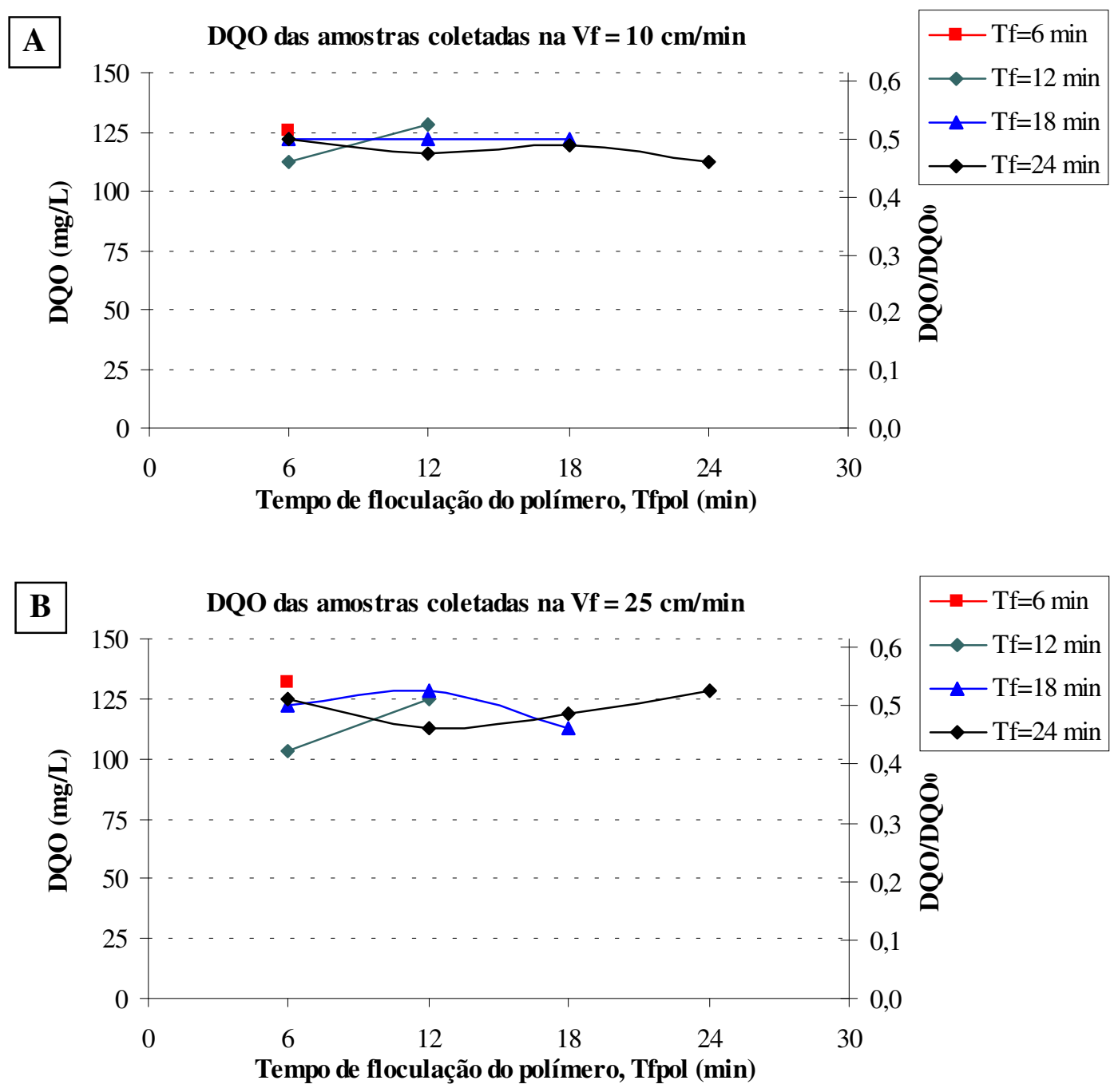

FIGURA 5.22 - Demanda química de oxigênio (DQO) das amostras coletadas nos ensaios com diferentes valores de tempo total de floculação associado a diferentes valores de tempo de floculação do polímero. Vf $=10 \mathrm{~cm} / \mathrm{min}(\mathbf{A})$ e $\mathrm{Vf}=25 \mathrm{~cm} / \mathrm{min}$ (B).

Ensaios realizados com o equipamento de flotateste e efluente do reator RALEx. Gmr: $1000 \mathrm{~s}^{-1}$, Tmr: 10s; DCF $=40 \mathrm{mg} / \mathrm{L} ; \mathrm{DPC}=1,25 \mathrm{mg} / \mathrm{L} ; \mathrm{Gf}: 80 \mathrm{~s}^{-1} ; \mathrm{R}: 20 \%(\mathrm{em}$ volume); $\mathrm{S}^{*}: 19,0 \mathrm{~g} / \mathrm{m}^{3}$; Psat: $450 \mathrm{kPa}$. Características do efluente do reator RALEx: turbidez: 51,9 uT; DQO da amostra não filtrada: $244 \mathrm{mg} / \mathrm{L}$; fósforo da amostra não filtrada: $3,67 \mathrm{mg} / \mathrm{L}$; temperatura: $20,7 \pm 0,3{ }^{\circ} \mathrm{C}$.

Observando as curvas de flotação da FIGURA 5.20, verifica-se que os seguintes pares de valores (Tf; Tfpol) produziram amostras com valores mais elevados de turbidez: (24 min; 24 min); (24 min; $6 \mathrm{~min})$; (18 min; $6 \mathrm{~min})$; (12 $\mathrm{min} ; 12 \mathrm{~min})$; (12 min; $6 \mathrm{~min})$ e (6 min; $6 \mathrm{~min})$. Estes pares de valores produziram amostras com turbidez entre 2,6 uT e 3,6 uT, para as diferentes velocidades de flotação testadas. 
Observando novamente a FIGURA 5.20, verifica-se que os seguintes pares de valores (Tf; Tfpol) produziram amostras com os menores valores de turbidez: (24 min; $18 \mathrm{~min}$ ); (24 min; $12 \mathrm{~min})$; (18 min; $18 \mathrm{~min})$ e (18 $\mathrm{min} ; 12 \mathrm{~min})$. Estes pares de valores produziram amostras com turbidez entre 1,7 uT e 2,4 uT, para as diferentes velocidades de flotação testadas.

Pode-se inferir que tempos totais de floculação entre 18 e 24 min, associados a tempos de floculação após a adição do polímero entre 12 e 18 min, formam combinação mais adequada para a etapa posterior de flotação.

Durante os ensaios, a análise visual permitia verificar que a adição de polímero, após decorrido certo período de floculação com cloreto férrico, era benéfica, de forma que o polímero atuasse sobre flocos previamente formados a partir da hidrólise do cloreto férrico. A formação desses flocos era acompanhada pelo aumento da transparência da amostra líquida, indicando que grande parcela dos sólidos suspensos e coloidais já estava agregada aos flocos formados a partir de hidróxido metálico. O intervalo de tempo mais adequado para adição do polímero era de até $12 \mathrm{~min}$, muito embora intervalos com cerca de 6 min já eram suficientes para produzir a aglomeração dos sólidos aos flocos.

Para a velocidade de flotação de $10 \mathrm{~cm} / \mathrm{min}$, os ensaios forneceram resultados de eficiência de remoção de DQO entre $47 \%$ a 54\%, com residuais entre 112 e 128 mg/L (FIGURA 5.22), e resultados de eficiência de remoção de fósforo entre $92 \%$ e 98\%, com residuais entre 0,05 e $0,31 \mathrm{mg} / \mathrm{L}$ (FIGURA 5.21). Para a velocidade de flotação de $25 \mathrm{~cm} / \mathrm{min}$ os resultados de eficiência de remoção de DQO se situam entre $47 \%$ a $58 \%$, com residuais entre 112 e $131 \mathrm{mg} / \mathrm{L}$, e de eficiência de remoção de fósforo entre $88 \%$ e $98 \%$, com residuais entre 0,06 e $0,42 \mathrm{mg} / \mathrm{L}$.

De maneira geral, todos os valores testados de tempo total e tempo de floculação após a adição do polímero produziram bons resultados em termos de remoção de DQO e de fósforo.

Particularmente, verifica-se que o emprego de 24 min de tempo total de floculação aliado a 12 min e a 18 min de tempo de floculação após a adição do polímero resultou em excelentes condições de remoção de turbidez, de DQO e de fósforo.

\subsubsection{Ensaios com variação do tempo total de floculação associado a diferentes valores de gradiente médio de velocidade de floculação}

São relatados os resultados obtidos nos ensaios descritos no item 4.7.3. Na discussão desses resultados é analisada a influência da variação do gradiente médio de velocidade de floculação, associado a diferentes tempos totais de floculação, na qualidade do efluente do flotateste. 
A discussão baseia-se na eficiência de remoção de turbidez, entre velocidades de flotação de 5 a $25 \mathrm{~cm} / \mathrm{min}$, de DQO e de fósforo (P) das amostras não filtradas coletadas nos ensaios em velocidades de flotação de 10 e de $25 \mathrm{~cm} / \mathrm{min}$.

A FIGURA 5.23 apresenta os valores de fração de turbidez remanescente em função da velocidade de flotação para tempos totais de floculação (Tf), entre 12 e 24 minutos, associados a gradientes médios de velocidade de floculação entre 40 e $100 \mathrm{~s}^{-1}$. Para efeito de comparação, também são apresentados os resultados de ensaio realizado sem a etapa de floculação, ou seja, mediante coagulação (mistura rápida) seguida de flotação do efluente do reator RALEx.

Observando as curvas de flotação da FIGURA 5.23, verifica-se que o aumento do tempo total de floculação de 12 para 24 min resultou em melhoria significativa na remoção de turbidez, independentemente do gradiente médio de velocidade de floculação considerado. Na FIGURA 5.23A, o menor valor de turbidez do efluente do flotateste foi igual a 2,2 uT, para Tf igual a $12 \mathrm{~min}$ e Gf igual a $80 \mathrm{~s}^{-1}$, na Vf de $10 \mathrm{~cm} / \mathrm{min}$. Já na FIGURA 5.23C, o menor valor de turbidez do efluente do flotateste foi igual a 1,3 uT, para Tf igual a 24 min e Gf igual a $80 \mathrm{~s}^{-1}$, na Vf de $10 \mathrm{~cm} / \mathrm{min}$.

O emprego de 12 min de tempo total de floculação produziu amostras com concentração de fósforo entre 0,14 e $0,42 \mathrm{mg} / \mathrm{L}$, para valores de Gf entre 40 e $100 \mathrm{~s}^{-1}$, na velocidade de flotação de $10 \mathrm{~cm} / \mathrm{min}$. Para esta mesma faixa de valores de Gf, o uso de $18 \mathrm{~min}$ de tempo total de floculação produziu amostras com concentração de fósforo entre 0,06 e $0,16 \mathrm{mg} / \mathrm{L}$. Já para Tf de 24 min e dentro da mesma faixa de valores de Gf, foram obtidas amostras com concentração de fósforo entre 0,01 e $0,10 \mathrm{mg} / \mathrm{L}$ (FIGURA 5.24).

Desta forma, verifica-se que a remoção de fósforo também foi positivamente influenciada pelo aumento do tempo total de floculação, independentemente do gradiente médio de velocidade de floculação considerado. Cabe ainda ressaltar que, para os diferentes valores de Tf, o emprego de Gf entre 60 e $100 \mathrm{~s}^{-1}$ proporcionou as maiores remoções de fósforo.

As amostras coletadas nos diferentes ensaios com variação de Tf e de Gf apresentaram valores de DQO entre 129 e $142 \mathrm{mg} / \mathrm{L}$ (FIGURA 5.25). Verifica-se, então, que a variação do tempo total e do gradiente médio de velocidade de floculação praticamente não influenciou a remoção de DQO, para a faixa de valores testados. 

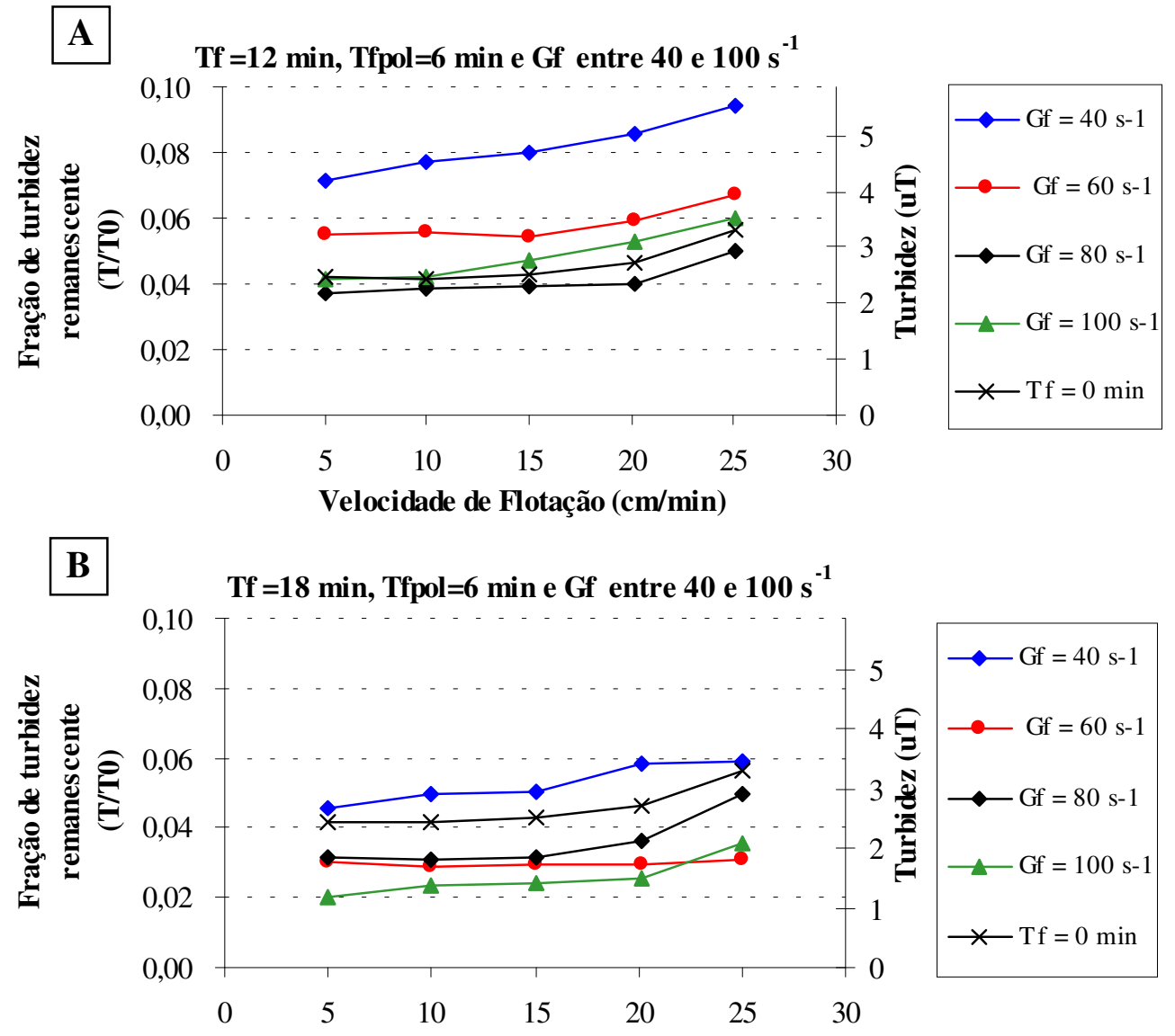

C Tf $=24 \mathrm{~min}$, Tfpol=6 min e Gf entre 40 e $100 \mathrm{~s}^{-1}$

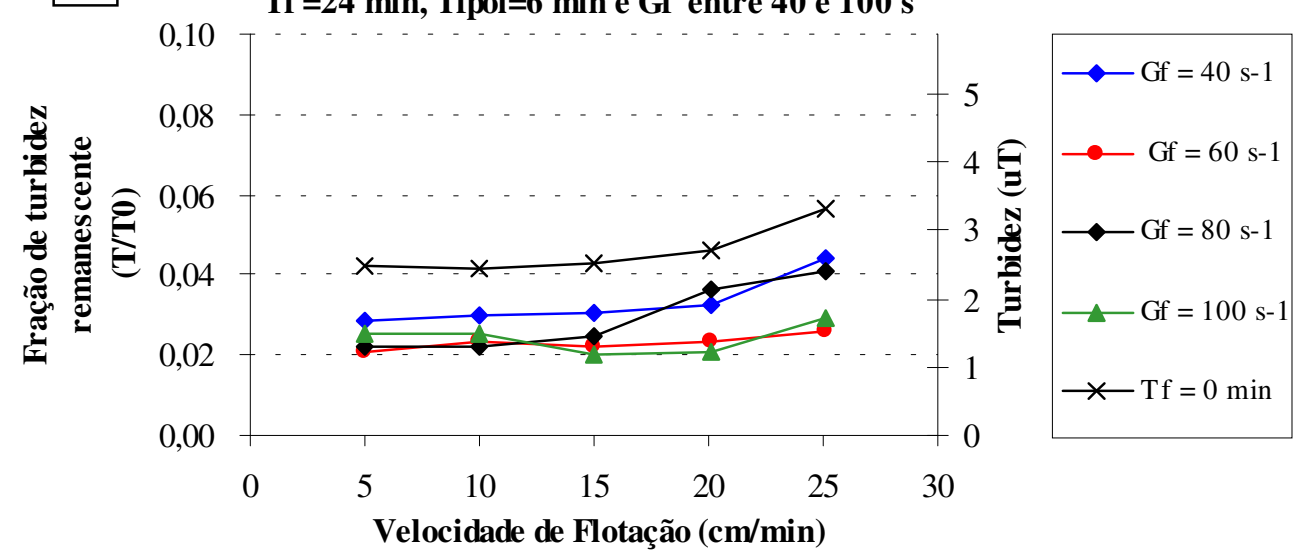

FIGURA 5.23 - Fração remanescente de turbidez (T/T0) em função da velocidade de flotação para diferentes valores de tempo total de floculação (Tf) associado a diferentes valores de gradiente médio de floculação (Gf). $\mathrm{Tf}=12 \min (\mathbf{A})$; $\mathrm{Tf}=18 \min (\mathbf{B})$ e $\mathrm{Tf}=24 \min (\mathbf{C})$.

Ensaios realizados com o equipamento de flotateste e efluente do reator RALEx. Gmr: $1000 \mathrm{~s}^{-1}$, Tmr: $10 \mathrm{~s} ; \mathrm{DCF}=40 \mathrm{mg} / \mathrm{L} ; \mathrm{DPC}=1,25 \mathrm{mg} / \mathrm{L} ; \mathrm{R}: 20 \%$ (em volume); $\mathrm{S}^{*}: 19,0 \mathrm{~g} / \mathrm{m}^{3}$; Psat: $450 \mathrm{kPa}$. Características do efluente do reator RALEx: turbidez: 58,7 uT; DQO da amostra não filtrada: $301 \mathrm{mg} / \mathrm{L}$; fósforo da amostra não filtrada: $3,46 \mathrm{mg} / \mathrm{L}$; temperatura: $21,0 \pm 0,5^{\circ} \mathrm{C}$. 

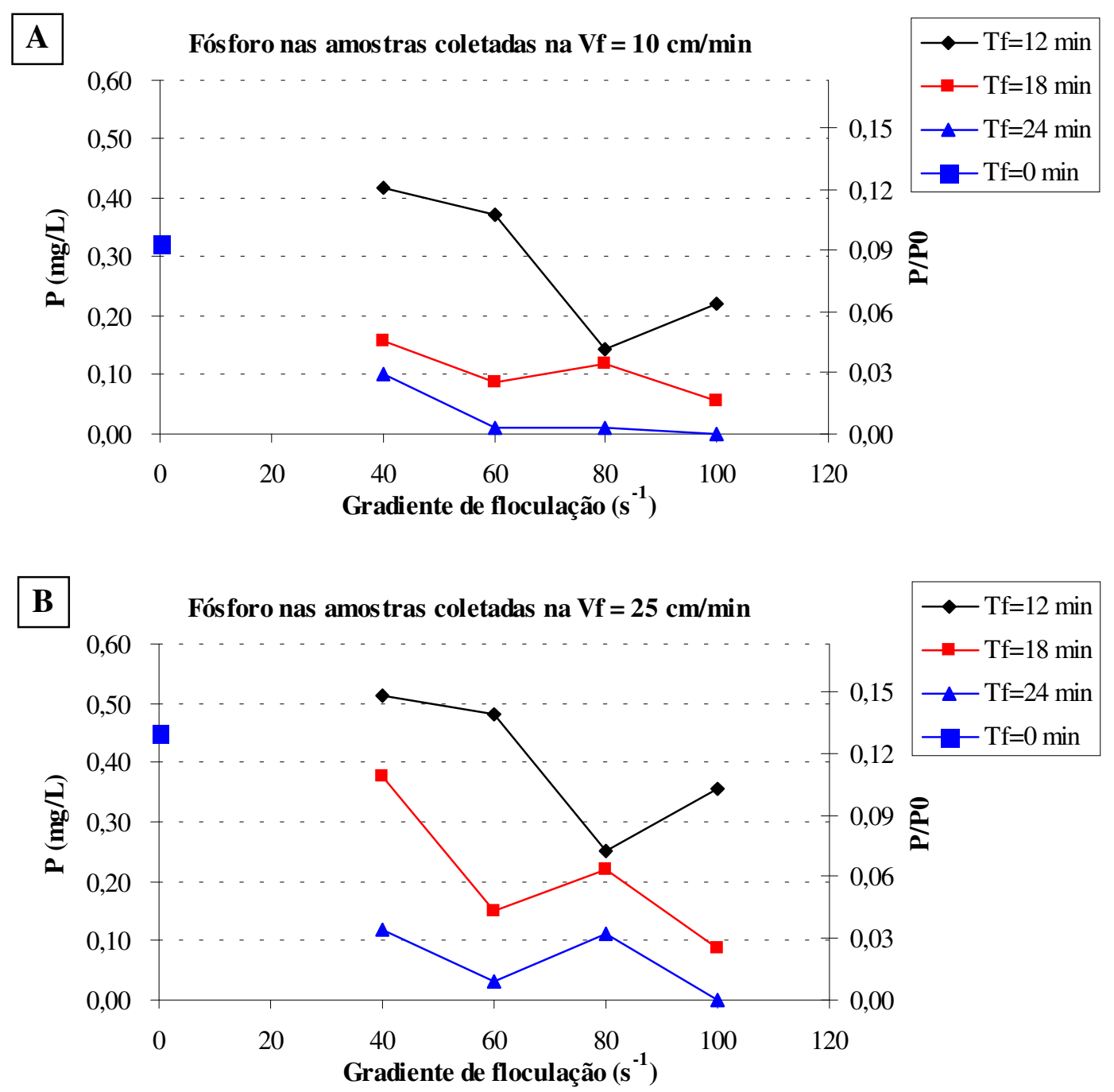

FIGURA 5.24 - Concentração de fósforo $(\mathrm{P})$ das amostras coletadas nos ensaios com diferentes valores de tempo total de floculação associado a diferentes valores de gradiente médio de floculação. Vf $=10 \mathrm{~cm} / \min (\mathbf{A})$ e $\mathrm{Vf}=25 \mathrm{~cm} / \mathrm{min}(\mathbf{B})$.

Ensaios realizados com o equipamento de flotateste e efluente do reator RALEx. Gmr: $1000 \mathrm{~s}^{-1}$, Tmr: 10s; DCF $=40 \mathrm{mg} / \mathrm{L} ; \mathrm{DPC}=1,25 \mathrm{mg} / \mathrm{L} ; \mathrm{Tfpol}=6 \mathrm{~min} ; \mathrm{R}: 20 \%$ (em volume); $\mathrm{S}^{*}: 19,0 \mathrm{~g} / \mathrm{m}^{3}$; Psat: $450 \mathrm{kPa}$. Características do efluente do reator RALEx: turbidez: 58,7 uT; DQO da amostra não filtrada: $301 \mathrm{mg} / \mathrm{L}$; fósforo da amostra não filtrada: $3,46 \mathrm{mg} / \mathrm{L}$; temperatura: $21,0 \pm 0,5^{\circ} \mathrm{C}$.

Considerando-se a remoção de turbidez e de fósforo, o emprego de gradientes médios de velocidade de floculação entre 60 e $100 \mathrm{~s}^{-1}$ produziu efluente do flotateste com excelente qualidade. O uso de Gf de $40 \mathrm{~s}^{-1}$ mostrou-se desfavorável em todos os ensaios realizados em diferentes tempos de floculação. 

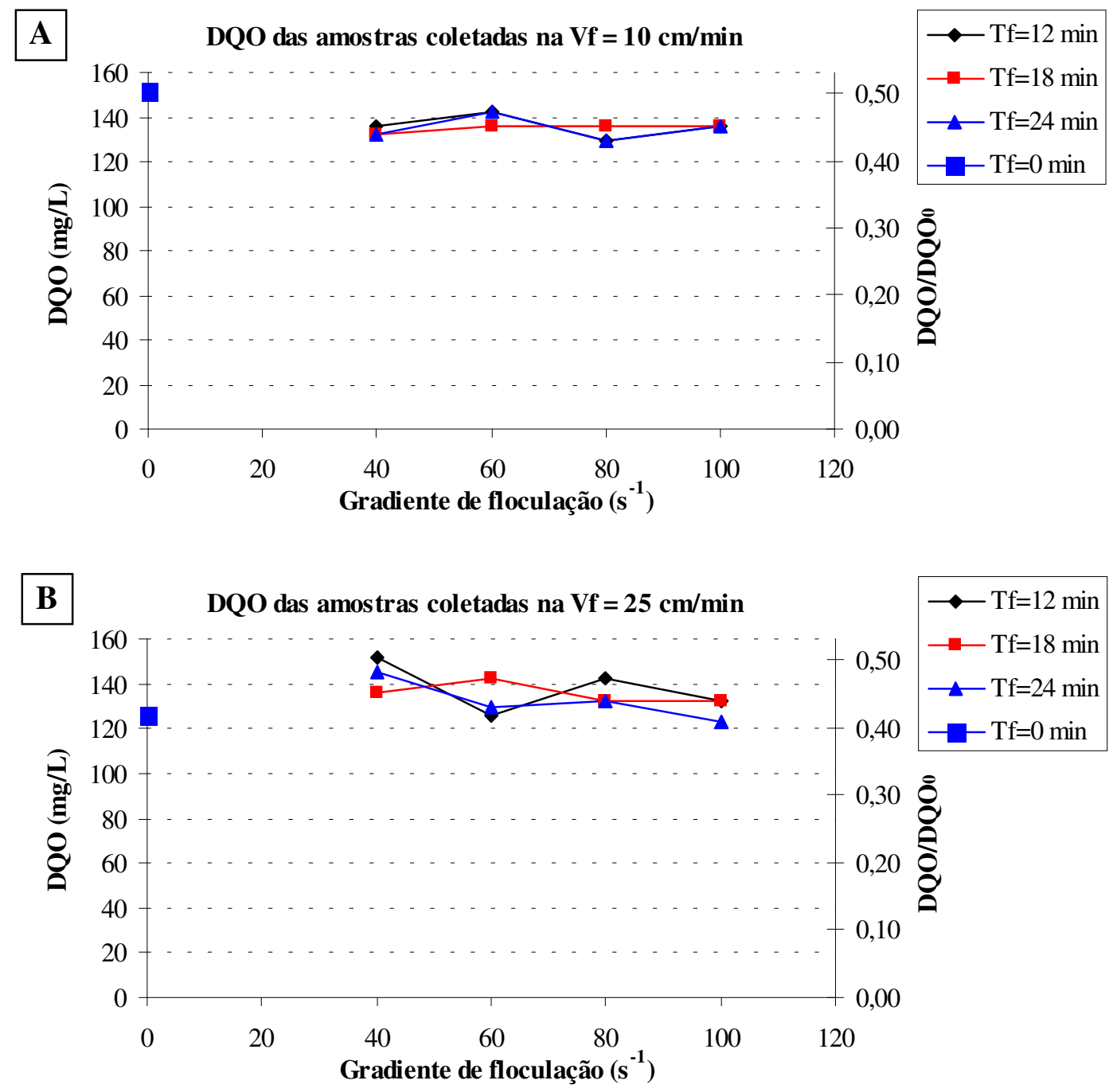

FIGURA 5.25 - Demanda química de oxigênio (DQO) das amostras coletadas nos ensaios com diferentes valores de tempo total de floculação associado a diferentes valores de gradiente médio de floculação. $\mathrm{Vf}=10 \mathrm{~cm} / \mathrm{min}(\mathbf{A})$ e $\mathrm{Vf}=25 \mathrm{~cm} / \mathrm{min}(\mathbf{B})$.

Ensaios realizados com o equipamento de flotateste e efluente do reator RALEx. Gmr: $1000 \mathrm{~s}^{-1}$, Tmr: $10 \mathrm{~s} ; \mathrm{DCF}=40 \mathrm{mg} / \mathrm{L} ; \mathrm{DPC}=1,25 \mathrm{mg} / \mathrm{L} ; \mathrm{Tfpol}=6 \mathrm{~min} ; \mathrm{R}: 20 \%(\mathrm{em}$ volume); $\mathrm{S}^{*}: 19,0 \mathrm{~g} / \mathrm{m}^{3}$; Psat: $450 \mathrm{kPa}$. Características do efluente do reator RALEx: turbidez: $58,7 \mathrm{uT}$; DQO da amostra não filtrada: $301 \mathrm{mg} / \mathrm{L}$; fósforo da amostra não filtrada: $3,46 \mathrm{mg} / \mathrm{L}$; temperatura: $21,0 \pm 0,5^{\circ} \mathrm{C}$.

\subsubsection{Ensaios com variação da quantidade de ar fornecida ao processo}

São relatados os resultados obtidos nos ensaios descritos no item 4.7.4. Na discussão desses resultados é analisada a influência da quantidade de ar fornecida ao processo, mediante variação da fração de recirculação do efluente pressurizado $(\mathrm{R})$, na qualidade do efluente do flotateste. 
A discussão baseia-se na eficiência de remoção de turbidez, entre velocidades de flotação de 5 a $25 \mathrm{~cm} / \mathrm{min}$, e de DQO e de fósforo (P) das amostras não filtradas coletadas nos ensaios em velocidades de flotação de 10 e de $25 \mathrm{~cm} / \mathrm{min}$.

A FIGURA 5.26 apresenta os valores de fração de turbidez remanescente, ou seja, a razão entre a turbidez da amostra tratada e a turbidez do efluente do reator RALEx, em função da velocidade de flotação para frações de recirculação do efluente pressurizado $(\mathrm{R})$ entre $3 \%$ e $30 \%$, mantendo-se constante a pressão de saturação utilizada (Psat $=450 \pm 10 \mathrm{kPa})$.

Considerando-se as amostras coletadas na Vf de $10 \mathrm{~cm} / \mathrm{min}$, os valores de turbidez observados variaram entre 8,9 e 11,2 uT para as diferentes frações de recirculação testadas.

Analisando as curvas da FIGURA 5.26, observa-se que os valores de R de $12 \%$ e de
$18 \%$, para as velocidades de flotação $5,10,15$ e $20 \mathrm{~cm} / \mathrm{min}$, forneceram os melhores resultados
de eficiência de remoção de turbidez por flotação, com eficiências bastante próximas entre si
(entre $83 \%$ e $86 \%$ ).

Nota-se que, para praticamente todas as frações de recirculação (R) investigadas, as respectivas curvas de flotação apresentam-se quase horizontais para as velocidades de flotação citadas. Para a velocidade de flotação de $25 \mathrm{~cm} / \mathrm{min}$, observa-se uma eficiência de remoção de turbidez de $71 \%$ para o valor de $\mathrm{R}=12 \%$, e remoções de turbidez menores que $69 \%$ para os demais valores de $\mathrm{R}$.

No que se refere à eficiência de remoção de DQO, verifica-se, analisando a FIGURA 5.28 , para a velocidade de flotação de $10 \mathrm{~cm} / \mathrm{min}$, que todos os valores de R proporcionaram remoções entre $41 \%$ e $51 \%$, sendo que o melhor resultado foi obtido com $\mathrm{R}$ de $18 \%$.

Para a velocidade de flotação de $25 \mathrm{~cm} / \mathrm{min}$, os valores de R de $6 \%$ e $12 \%$ forneceram os melhores resultados, apresentando respectivamente $49 \%$ e $47 \%$ de remoção de DQO.

Em relação à eficiência de remoção de fósforo, verifica-se, analisando a FIGURA 5.27,
para a velocidade de flotação de $10 \mathrm{~cm} /$ min, que os valores de R entre $9 \%$ e $27 \%$ (com exceção
de R de $21 \%$ ) foram mais eficientes, com remoções entre $58 \%$ e $62 \%$. Dentre esses valores de
R, o de $18 \%$ forneceu resultados ligeiramente melhores que os demais, embora extremamente
próximos.

Para a velocidade de flotação de $25 \mathrm{~cm} / \mathrm{min}$, o valor de R de $18 \%$ apresentou o melhor resultado, com eficiência de remoção de $68 \%$ de fósforo. 


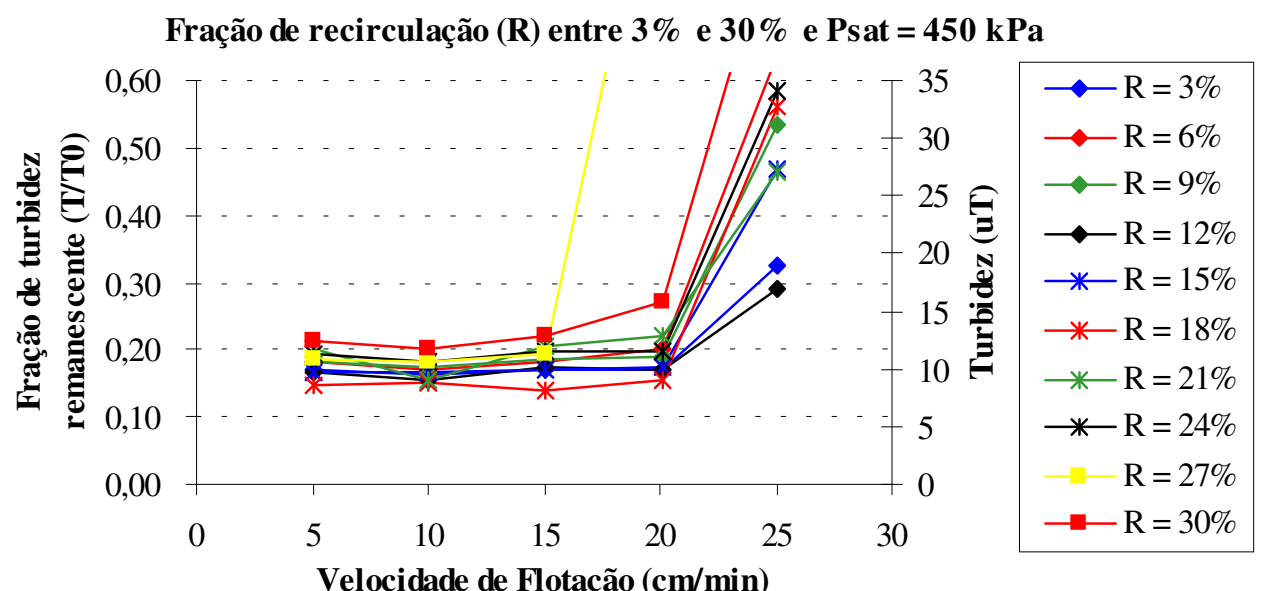

FIGURA 5.26 - Fração remanescente de turbidez (T/T0) em função da velocidade de flotação para diferentes valores de fração de recirculação (R).

Ensaios realizados com o equipamento de flotateste e efluente do reator RALEx. Gmr: $1000 \mathrm{~s}^{-1}$, Tmr: $10 \mathrm{~s} ; \mathrm{DCF}=40 \mathrm{mg} / \mathrm{L} ; \mathrm{DPC}=1,25 \mathrm{mg} / \mathrm{L} ; \mathrm{Tf}=24 \mathrm{~min} ; \mathrm{Tfpol}=$ $18 \mathrm{~min}$; Gf $=80 \mathrm{~s}^{-1}$; Psat: $450 \mathrm{kPa}$. Características do efluente do reator RALEx: turbidez: 58,3 uT; DQO da amostra não filtrada: $288 \mathrm{mg} / \mathrm{L}$; fósforo da amostra não filtrada: $4,58 \mathrm{mg} / \mathrm{L}$; temperatura: $21,0 \pm 0,5^{\circ} \mathrm{C}$.

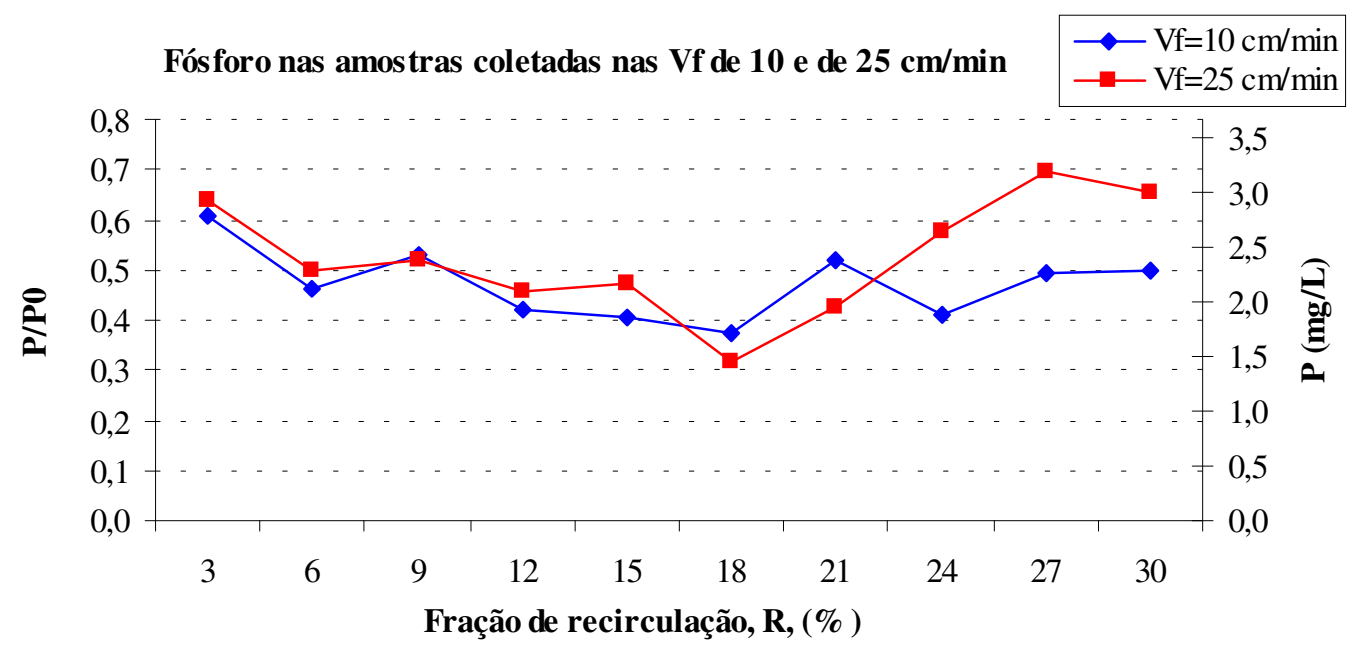

FIGURA 5.27 - Concentração de fósforo $(\mathrm{P})$ das amostras coletadas nos ensaios com diferentes valores de fração de recirculação $(\mathrm{R})$.

Ensaios realizados com o equipamento de flotateste e efluente do reator RALEx. Gmr: $1000 \mathrm{~s}^{-1}, \mathrm{Tmr}: 10 \mathrm{~s} ; \mathrm{DCF}=40 \mathrm{mg} / \mathrm{L} ; \mathrm{DPC}=1,25 \mathrm{mg} / \mathrm{L} ; \mathrm{Tf}=24 \mathrm{~min} ; \mathrm{Tfpol}=$ $18 \mathrm{~min}$; Gf $=80 \mathrm{~s}^{-1}$; Psat: $450 \mathrm{kPa}$. Características do efluente do reator RALEx: turbidez: 58,3 uT; DQO da amostra não filtrada: $288 \mathrm{mg} / \mathrm{L}$; fósforo da amostra não filtrada: $4,58 \mathrm{mg} / \mathrm{L}$; temperatura: $21,0 \pm 0,5^{\circ} \mathrm{C}$. 


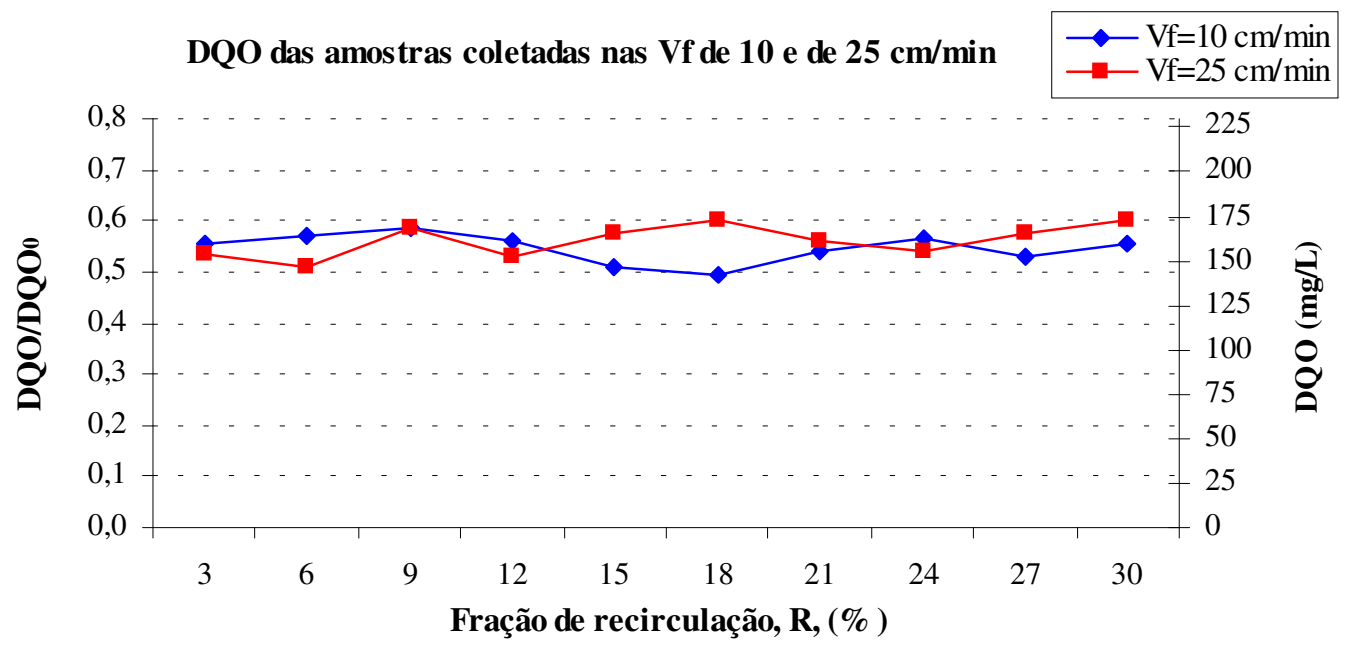

FIGURA 5.28 - Demanda química de oxigênio (DQO) das amostras coletadas nos ensaios com diferentes valores de fração de recirculação $(R)$.

Ensaios realizados com o equipamento de flotateste e efluente do reator RALEx. Gmr: $1000 \mathrm{~s}^{-1}, \mathrm{Tmr}: 10 \mathrm{~s} ; \mathrm{DCF}=40 \mathrm{mg} / \mathrm{L} ; \mathrm{DPC}=1,25 \mathrm{mg} / \mathrm{L} ; \mathrm{Tf}=24 \mathrm{~min} ; \mathrm{Tfpol}=$ $18 \mathrm{~min}$; Gf $=80 \mathrm{~s}^{-1}$; Psat: $450 \mathrm{kPa}$. Características do efluente do reator RALEx: turbidez: 58,3 uT; DQO da amostra não filtrada: $288 \mathrm{mg} / \mathrm{L}$; fósforo da amostra não filtrada: $4,58 \mathrm{mg} / \mathrm{L}$; temperatura: $21,0 \pm 0,5^{\circ} \mathrm{C}$.

\subsubsection{Ensaios com utilização dos valores mais adequados dos parâmetros discutidos nos itens 5.2.1 a 5.2.4.}

Nesta etapa da pesquisa, foram realizados ensaios com o objetivo de testar as melhores condições de dosagem de produto químico, de floculação e de quantidade de ar fornecida ao processo, determinadas nas fases anteriores.

A FIGURA 5.29 apresenta os valores de turbidez, de DQO, de fósforo e de SST para velocidade de flotação de $10 \mathrm{~cm} / \mathrm{min}$ para as dosagens de cloreto férrico (DCF) de 10; 20; $30 \mathrm{e}$ $40 \mathrm{mg} / \mathrm{L}$. Os demais parâmetros operacionais foram mantidos fixos: dosagem de polímero catiônico G9047 $(\mathrm{DPC})=1,25 \mathrm{mg} / \mathrm{L} ; \mathrm{R}=12 \%$ (em volume); Gmr=1000 s${ }^{-1} ; \mathrm{Tmr}=10 \mathrm{~s} ; \mathrm{Gf}=80$ $\mathrm{s}^{-1} ; \mathrm{Tf}=24$ min e pressão de saturação (Psat) $=450 \mathrm{kPa}$.

Analisando a FIGURA 5.29A, observa-se que a dosagem de $40 \mathrm{mg} / \mathrm{L}$ de cloreto férrico proporcionou 95\% de remoção de turbidez (turbidez residual de 2,8 uT), a maior dentre os demais ensaios, como esperado. Pode-se observar também que a dosagem de $40 \mathrm{mg} / \mathrm{L} \mathrm{de}$ cloreto férrico proporcionou a maior eficiência de remoção de DQO, com cerca de 40\% (DQO residual de $149 \mathrm{mg} / \mathrm{L}$ ), para a amostra não filtrada. Para as amostras filtradas coletadas, verificase que a eficiência de remoção de DQO se situa na faixa entre $43 \%$ e $48 \%$ (DQO residual de 128 e $141 \mathrm{mg} / \mathrm{L}$ ), não apresentando diferenças significativas de desempenho entre as diferentes dosagens (FIGURA 5.29B). 
Baseado nestes resultados, verifica-se que, com o aumento da dosagem de cloreto férrico, praticamente não houve melhora na eficiência de remoção da fração solúvel de DQO. Entretanto, em relação à remoção da fração de DQO não dissolvida, verifica-se uma significativa melhora. $\mathrm{O}$ aumento da dosagem de cloreto férrico melhorou a flotabilidade dos flocos formados a partir do material coloidal e em suspensão presentes no efluente do reator RALEx, mas não interferiu na parcela dissolvida da matéria orgânica.
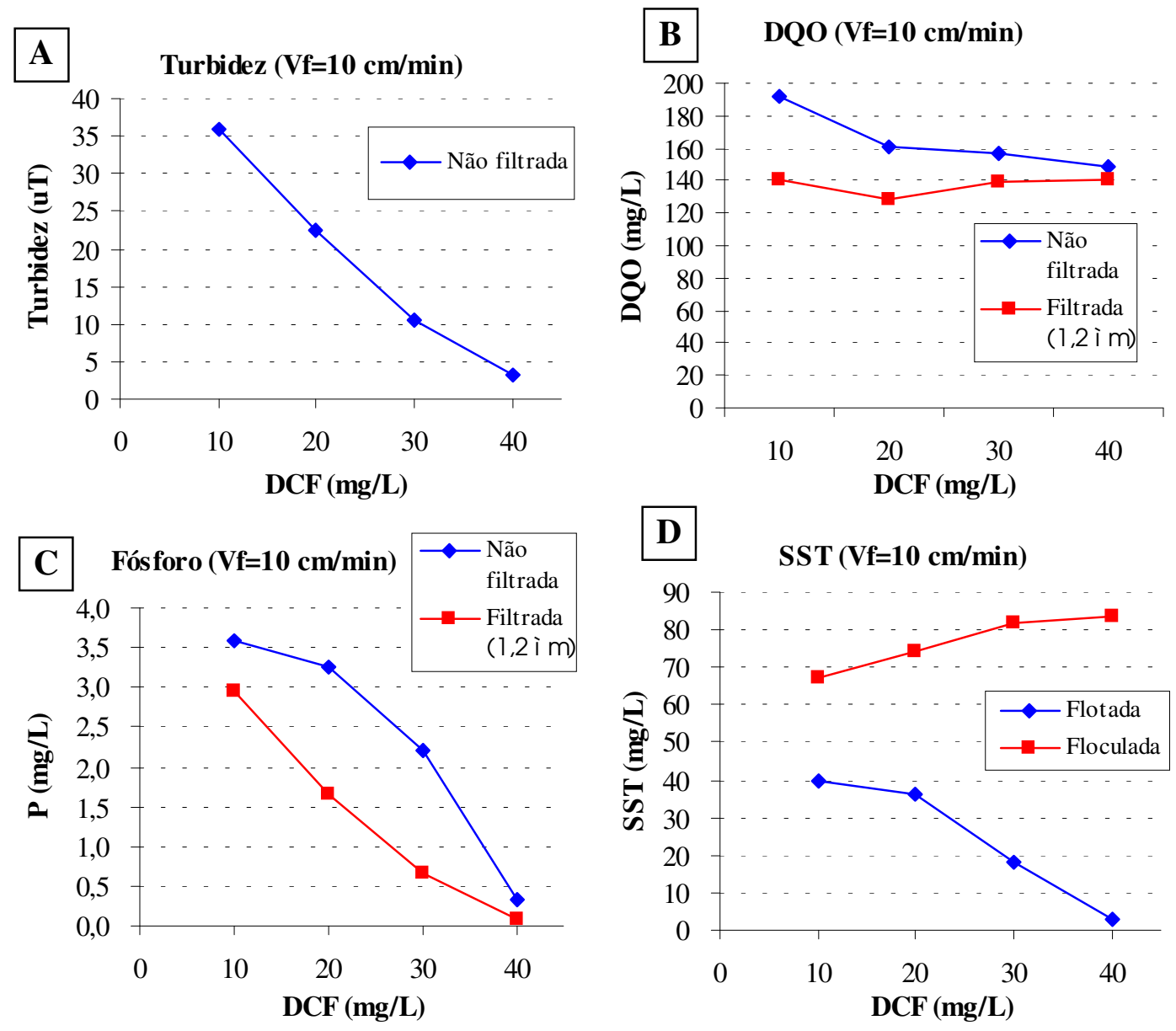

FIGURA 5.29 - Turbidez (A), DQO (B), fósforo (C) e sólidos suspensos totais (D) das amostras coletadas nos ensaios com utilização dos valores mais adequados dos parâmetros discutidos nos itens 5.2.1 a 5.2.4.

Ensaios realizados com o equipamento de flotateste e efluente do reator RALEx. Gmr: $1000 \mathrm{~s}^{-1}$, Tmr: $10 \mathrm{~s} ; \mathrm{DPC}=1,25 \mathrm{mg} / \mathrm{L} ; \mathrm{Tf}=24 \mathrm{~min} ; \mathrm{Tfpol}=18 \mathrm{~min} ; \mathrm{Gf}=80 \mathrm{~s}^{-}$ ${ }^{1} ; \mathrm{R}=12 \%$; Psat: $450 \mathrm{kPa}$; amostras coletadas na Vf $=10 \mathrm{~cm} / \mathrm{min}$. Características do efluente do reator RALEx: turbidez: 53,3 uT; DQO da amostra não filtrada: 247 $\mathrm{mg} / \mathrm{L}$; DQO da amostra filtrada: $173 \mathrm{mg} / \mathrm{L}$; fósforo da amostra não filtrada: 4,89 $\mathrm{mg} / \mathrm{L}$; fósforo da amostra filtrada: $3,91 \mathrm{mg} / \mathrm{L}$; sólidos suspensos totais: $41 \mathrm{mg} / \mathrm{L}$; temperatura: $21,0 \pm 0,5^{\circ} \mathrm{C}$. 
No que se refere à eficiência de remoção de fósforo, verifica-se que a dosagem de 40 $\mathrm{mg} / \mathrm{L}$ de cloreto férrico apresentou o melhor desempenho, tanto para a amostra não filtrada quanto para a amostra filtrada, proporcionando eficiência de remoção de 93\% e de 98\% (concentração residual de fósforo igual a 0,36 e $0,08 \mathrm{mg} / \mathrm{L}$, respectivamente). Da mesma forma, para a velocidade de flotação de $10 \mathrm{~cm} / \mathrm{min}$, o emprego de $40 \mathrm{mg} / \mathrm{L}$ de cloreto férrico foi o mais eficiente no que se refere à remoção de sólidos suspensos totais, cerca de 90\%, com residual de 3,5 mg/L (FIGURA 5.29C).

Observa-se melhora na eficiência de remoção, tanto para a fração solúvel, quanto para a fração não dissolvida de fósforo. $\mathrm{O}$ aumento da dosagem foi fundamental para a obtenção de baixos residuais de fósforo. Além disso, os flocos formados com a aplicação de $40 \mathrm{mg} / \mathrm{L}$ também apresentaram boas condições de flotabilidade, como demonstrado pela pequena diferença de valor existente entre a concentração de fósforo total e de fósforo solúvel (FIGURA 5.29C).

O aumento da dosagem de cloreto férrico elevou significativamente a remoção de SST (FIGURA 5.29D). Quando $10 \mathrm{mgFeCl}_{3} / \mathrm{L}$ foram usados, a remoção de SST foi mínima, de $4,9 \%$. Houve gradativo aumento da remoção à medida que havia a elevação da dosagem de cloreto férrico, atingindo $92,7 \%$ quando $\mathrm{DCF}=40 \mathrm{mg} / \mathrm{L}$. Nota-se, também, que o aumento da dosagem de cloreto férrico elevou a presença de SST no efluente do floculador, como esperado. Utilizando a hipótese simplificada de que o lodo flotado é constituído somente por sólidos suspensos totais, pode-se estimar o peso seco de lodo resultante das diferentes dosagens de cloreto férrico. Para $10 \mathrm{mgFeCl}_{3} / \mathrm{L}$, o valor de SST removido foi de $28 \mathrm{mg} / \mathrm{L}$. Para 20 $\mathrm{mgFeCl}_{3} / \mathrm{L}$, o valor de SST removido foi de $38 \mathrm{mg} / \mathrm{L}$. Para $30 \mathrm{mgFeCl} / 3 / \mathrm{L}$, o valor de SST removido foi de $64 \mathrm{mg} / \mathrm{L}$. Para $40 \mathrm{mgFeCl}_{3} / \mathrm{L}$, o valor de SST removido foi de $81 \mathrm{mg} / \mathrm{L}$. Utilizando a vazão tratada pelo RALEx $\left(10 \mathrm{~m}^{3} / \mathrm{h}\right)$ como referência para cálculo do peso seco estimado, é esperada a remoção de $810 \mathrm{~g} / \mathrm{h}$ de lodo flotado.

Visando máxima eficiência de remoção de turbidez, DQO, fósforo e SST, o emprego de $40 \mathrm{mg} / \mathrm{L}$ de cloreto férrico foi julgado o mais apropriado para os ensaios realizados.

Procurando apresentar síntese dos resultados e das conclusões parciais desta etapa, na FIGURA 5.30 está apresentado um fluxograma simplificado da Segunda Etapa de Ensaios em laboratório, para investigação do emprego de polímeros sintéticos no pós-tratamento físicoquímico por flotação, descrita nos itens 4.7.1 e 4.7.5. 
Segunda Etapa: Ensaios em laboratório para investigação do desempenho de polímeros associados a cloreto férrico

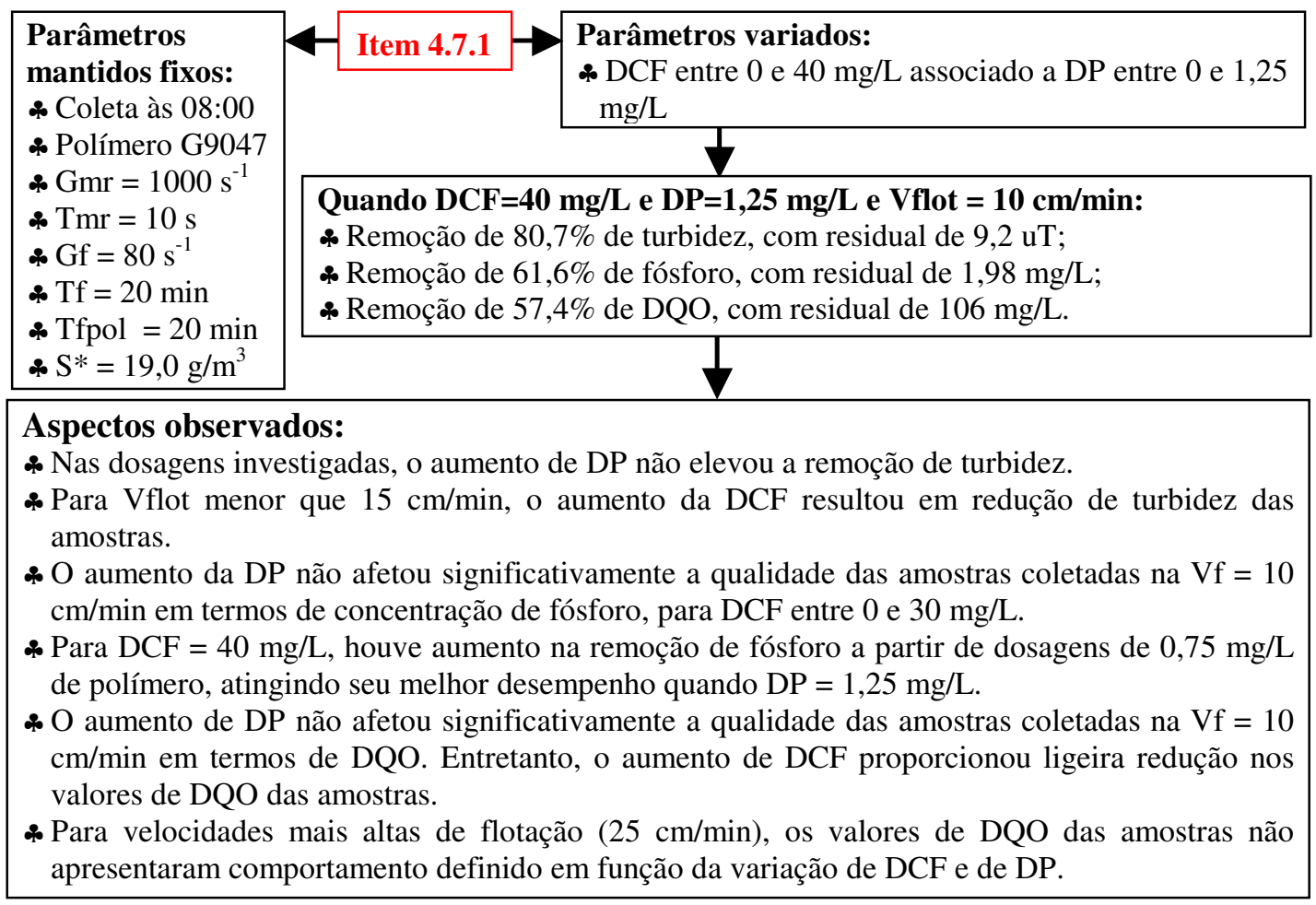

\begin{tabular}{|l|}
\hline Parâmetros \\
mantidos fixos: \\
* Coleta às 08:00 \\
* Polímero $\mathrm{G} 9047$ \\
* $\mathrm{Gmr}=1000 \mathrm{~s}^{-1}$ \\
* Tmr $=10 \mathrm{~s}$ \\
* $\mathrm{DCF}=40 \mathrm{mg} / \mathrm{L}$ \\
* $\mathrm{DP}=1,25 \mathrm{mg} / \mathrm{L}$ \\
* $\mathrm{Gf}=80 \mathrm{~s}^{-1}$ \\
* $\mathrm{S}^{*}=19,0 \mathrm{~g} / \mathrm{m}^{3}$
\end{tabular}

Item 4.7.2

\section{Parâmetros variados:}

* Tf entre 6 e 24 min associado a Tfpol entre 6 e 24 min

*Vflot entre 5 e $25 \mathrm{~cm} / \mathrm{min}$

Quando $T f=24 \min$ associado a $T$ Tpol entre 12 e 18 min e Vflot=10 cm/min:

* Remoção em torno de 96,4\% de turbidez e residuais em torno de 1,9 uT;

* Remoção em torno de $97,5 \%$ de fósforo e residuais em torno de 0,16 $\mathrm{mg} / \mathrm{L}$;

* Remoção em torno de 52\% de DQO e residuais em torno de 117 mg/L.

\section{Aspectos observados:}

- Tempos totais de floculação entre 18 e 24 min associados a tempos de floculação do polímero entre 12 e 18 min formaram a combinação mais adequada em termos de remoção de turbidez, de $\mathrm{DQO}$ e de fósforo.

* De maneira geral, todos os valores testados de tempo total e tempo de floculação do polímero produziram bons resultados em termos de remoção de DQO e de fósforo.

\section{Item 4.7.3}

FIGURA 5.30 - Fluxograma com o resumo dos resultados mais conclusivos da Segunda Etapa de Ensaios em laboratório, para investigação do emprego de polímeros sintéticos associado a cloreto férrico no pós-tratamento físico-químico por flotação, descrita nos itens 4.7.1 a 4.7.5. 


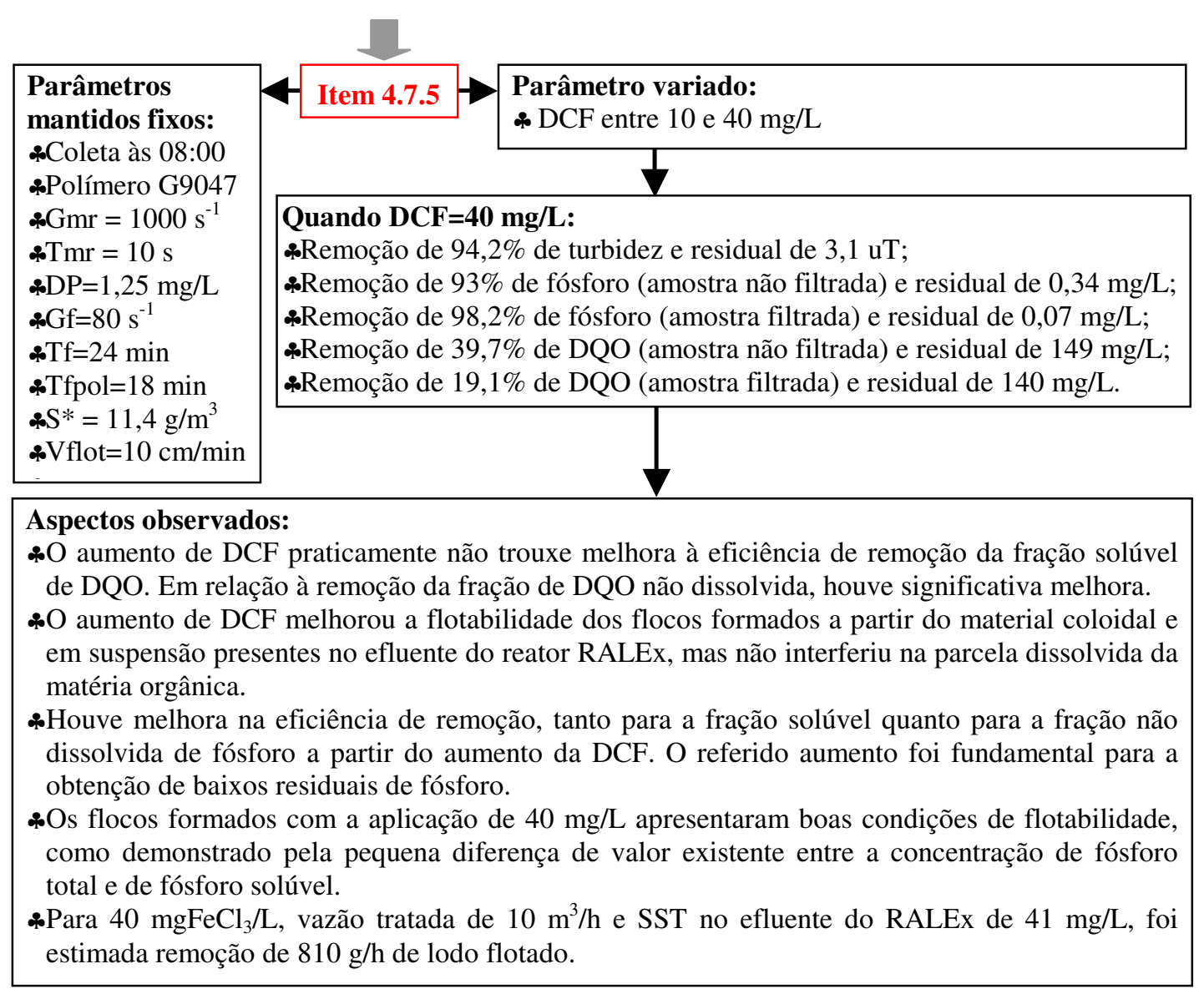

FIGURA 5.30 (cont.) - Fluxograma com o resumo dos resultados mais conclusivos da Segunda Etapa de Ensaios em laboratório, para investigação do emprego de polímeros sintéticos associado a cloreto férrico no pós-tratamento físico-químico por flotação, descrita nos itens 4.7.1 a 4.7.5.

\subsubsection{Ensaios com variação da dosagem de cloreto férrico, da dosagem de polímero sintético (dosado isoladamente), do tipo de polímero sintético e da dosagem de polímero (dosado conjuntamente com cloreto férrico), durante partida de reator RALEx}

Tendo em vista que os ensaios discutidos no item 5.3 foram realizados em data anterior à perda do leito suporte e biomassa aderida do reator RALEx e servem de referência para a realização desta nova etapa de trabalho, foi necessária a realização de novos ensaios, semelhantes àqueles discutidos no item 5.3.2. Os resultados destes ensaios fornecem parâmetros de comparação entre o comportamento do tratamento físico-químico diante de duas qualidades de efluente do reator anaeróbio: efluente de reator em equilíbrio dinâmico com três anos de operação ininterrupta e efluente de reator durante partida. 


\subsubsection{Flotação sem aplicação de produtos químicos durante partida do reator RALEx}

A grande concentração de microbolhas de ar (com diâmetro médio da ordem de $50 \mu \mathrm{m}$ ) presentes na entrada do flotador (zona de contato entre microbolhas e flocos) cria condições satisfatórias para a colisão e aderência dessas microbolhas à superfície dos flocos formados na etapa anterior de coagulação química.

Mesmo sem a aplicação de coagulante, para velocidade de flotação de $10 \mathrm{~cm} / \mathrm{min}$, observou-se remoção significativa dos pequenos flocos biológicos presentes no efluente anaeróbio, tendo sido verificadas remoções de DQO próxima a 37\% (residual de 94,5 mg/L) com $50 \%$ de remoção de fosfato total (residual de $6,3 \mathrm{mg} / \mathrm{L}$ ) e turbidez em torno de $19 \mathrm{uT}$ (TABELA 5.5).

\subsubsection{Flotação com aplicação somente de cloreto férrico durante partida do reator RALEx}

Durante a operação do RALEx em situação de equilíbrio dinâmico aparente, os resultados apresentados no item 5.3.2 mostram que a aplicação de pequenas dosagens de coagulante (entre 15 e $30 \mathrm{mg} / \mathrm{L}$ de cloreto férrico) promoveu a coagulação de colóides e pequenas partículas em suspensão, conduzindo à formação de flocos com características de superfície (grau de hidrofobicidade) bastante favoráveis à flotação, produzindo efluente de excelente qualidade (TABELA 5.4 e FIGURAS 5.11 a 5.14, para $\mathrm{DP}=0 \mathrm{mg} / \mathrm{L}$ ). No entanto, durante a partida do reator RALEx, a modificação da qualidade do efluente anaeróbio influenciou fortemente a qualidade final do efluente do flotateste, diante de diferentes dosagens de cloreto férrico. A aplicação de $15 \mathrm{mg} / \mathrm{L}$ de cloreto férrico, sem adição de polímeros, promoveu redução no desempenho do tratamento em termos de remoção de DQO (residual de $118 \mathrm{mg} / \mathrm{L}$ ). Em termos de remoção de fosfato e de turbidez, houve apenas ligeira melhora no efluente do flotateste: residuais de 5,5 $\mathrm{mgPO}_{4}{ }^{-} / \mathrm{L}$ de fosfato e de 18,1 uT de turbidez (FIGURA 5.31A). Com o aumento da dosagem de cloreto férrico para $30 \mathrm{mg} / \mathrm{L}$, ainda sem adição de polímeros, verificou-se modificação significativa na remoção de DQO (residual de 77,4 mg/L), mas não se constatou melhora significativa na remoção de fosfato (residual de 5,2 $\mathrm{mgPO}_{4}{ }^{-} / \mathrm{L}$ ) e de turbidez (residual de 14,4 uT). O aumento da dosagem de cloreto férrico para a faixa de 45 a $65 \mathrm{mg} / \mathrm{L}$ resultou em aumento na remoção de DQO (residuais em torno de $59 \mathrm{mg} / \mathrm{L}$ ).

Particularmente, a adição de $65 \mathrm{mg} / \mathrm{L}$ de cloreto férrico resultou em amostras com excepcional qualidade: turbidez de 1,4 uT, 0,3 $\mathrm{mgPO}_{4}{ }^{-} / \mathrm{L}$ e $0,4 \mathrm{mg} / \mathrm{L}$ de SST. Portanto, de 
maneira geral, verificou-se que a remoção de fosfato foi fortemente dependente da dosagem de cloreto férrico utilizada.

Para obtenção de níveis satisfatórios de remoção de fosfato foram necessárias dosagens de $30 \mathrm{mg} / \mathrm{L}$ para o efluente do reator RALEx em equilíbrio dinâmico (TABELA 5.4), sendo que para o efluente durante a partida foram requeridas dosagens na faixa de 45 a $65 \mathrm{mg} / \mathrm{L}$ (TABELA $5.5)$.

\subsubsection{Flotação com aplicação somente de polímeros durante partida do reator RALEx}

Nessa fase, foi estudada a potencialidade de aplicação de polímeros sintéticos, em substituição do cloreto férrico, como auxiliar de coagulação/flotação. As dosagens de polímero sintético requeridas para a floculação de águas e águas residuárias são usualmente bem menores que aquelas utilizadas quando se usa somente cloreto férrico. Assim, o uso de polímero foi investigado com vistas à minimização da geração de lodo durante o processo de flotação através da aplicação de menores dosagens de produto químico. Os resultados obtidos nessa fase do estudo indicaram que dosagens de polímero catiônico (G9047) na faixa de 1 a $7 \mathrm{mg} / \mathrm{L}$ proporcionaram bom desempenho da flotação em relação à remoção de turbidez e de carga orgânica, sendo que as maiores eficiências foram obtidas com aplicação de valores mais próximos ao limite superior da faixa indicada $(7 \mathrm{mg} / \mathrm{L})$. Nesta situação, obteve-se cerca de $60 \%$ de remoção de DQO (residuais em torno de $61 \mathrm{mg} / \mathrm{L}$ ), $42 \%$ de remoção de fosfato (residual em torno de 7,3 $\mathrm{mgPO}_{4}{ }^{-} / \mathrm{L}$ ) e $81 \%$ de remoção de turbidez (residuais em torno de 10,5 uT), como visto na FIGURA 5.31B.

De maneira geral, tais resultados demonstram que o emprego de polímero catiônico como auxiliar de flotação forneceu resultados satisfatórios no que se refere à remoção de turbidez e de DQO, embora não tão bons quanto aqueles obtidos com aplicação de cloreto férrico. Com relação à remoção de fósforo, como era de se esperar, o emprego de polímero catiônico não foi capaz de fornecer remoção satisfatória da fração solúvel desse elemento. De maneira geral, tais resultados demonstram que o emprego de polímero catiônico resultou na produção de flocos com elevada velocidade ascensional, conforme pode ser determinado através das curvas de flotação. Este fato é extremamente positivo pois indicam a possibilidade de se operar unidades de flotação em escala real com taxas bastante elevadas. Em outras palavras, permitiria a adoção de unidades mais compactas e, portanto, mais econômicas. 


\subsubsection{Flotação com aplicação de cloreto férrico associado a polímero sintético durante partida do reator RALEx}

Para estudo da associação de cloreto férrico e polímero durante a partida do reator RALEx, foram testados 3 tipos de polímeros sintéticos com diferentes características quanto à natureza das cargas (G9047, catiônico; G998, aniônico e G999, não iônico). Esses polímeros foram selecionados pois apresentaram o melhor desempenho nos ensaios discutidos no item 5.3.2. Os resultados estão apresentados na TABELA 5.5.

A aplicação combinada de apenas $15 \mathrm{mg} / \mathrm{L}$ de cloreto férrico com $0,4 \mathrm{mg} / \mathrm{L}$ de qualquer um dos três polímeros selecionados resultou em boa eficiência de remoção de turbidez do efluente do reator anaeróbio de leito expandido (FIGURA 5.31C), aliado a uma remoção da DQO remanescente na faixa de $40 \%$ a $47 \%$ (residuais na faixa de 80 a $90 \mathrm{mg} / \mathrm{L}$ ) e a uma remoção de fosfato total na faixa de $50 \%$ a $59 \%$ (residuais na faixa de 5,2 a 6,3 $\mathrm{mgPO}_{4}{ }^{-} / \mathrm{L}$ ), considerando velocidade de flotação de $10 \mathrm{~cm} / \mathrm{min}$. Nessas condições de dosagem, o polímero não iônico apresentou as maiores eficiências.

$\mathrm{O}$ aumento da dosagem de polímeros para $1,0 \mathrm{mg} / \mathrm{L}$, mantendo-se a dosagem de 15 $\mathrm{mg} / \mathrm{L}$ de cloreto férrico, acarretou ligeira melhora na eficiência de remoção de turbidez (de $67 \%$ para 70\%), visto na FIGURA 5.31D, mantendo-se os mesmos níveis de remoção de DQO e de fosfato total, para Vf de $10 \mathrm{~cm} / \mathrm{min}$. A elevação da dosagem de cloreto férrico para $30 \mathrm{mg} / \mathrm{L}$, associada a dosagens de cada um dos polímeros iguais a $0,4 \mathrm{mg} / \mathrm{L}$, resultou em pequena melhoria da eficiência de remoção de fosfato total (58\% a 66\%, com residuais na faixa de 4,3 a $5,3 \mathrm{mgPO}_{4}{ }^{-} / \mathrm{L}$ ) e de DQO (46\% a 53\%, com residuais na faixa de 70 a $75 \mathrm{mg} / \mathrm{L}$ ), para velocidade de flotação de $10 \mathrm{~cm} / \mathrm{min}$.

Quanto à remoção de turbidez (FIGURA 5.31E), observou-se a manutenção dos valores obtidos anteriormente (com $15 \mathrm{mg} / \mathrm{L}$ de cloreto férrico), com piora nos ensaios com polímero catiônico. Finalmente, nos ensaios em que foram aplicadas dosagens de $30 \mathrm{mg} / \mathrm{L}$ de cloreto férrico associada a 1,0 mg/L de polímeros, verificou-se ligeira melhora na eficiência de remoção de turbidez (em torno de 76\%), como mostrado na FIGURA 5.31F. Observou-se a manutenção da remoção de fosfato total $(60 \%)$, mesmo em velocidades elevadas de flotação (até 25 $\mathrm{cm} / \mathrm{min}$ ). Sendo que as maiores eficiências de remoção de DQO foram obtidas com os polímeros aniônico e não iônico (53\% a 63\%), observando-se ligeira queda de eficiência para o polímero catiônico $(46 \%)$.

Assim, durante a operação de partida do reator anaeróbio, observou-se que a aplicação de pequenas dosagens de polímero catiônico (com alto peso molecular e alta densidade de carga) ou de polímero não iônico (de alto peso molecular) não permitiu a obtenção da mesma qualidade de efluente final observada nos ensaios anteriores (efluente do reator em equilíbrio 
dinâmico). Para tanto, maiores dosagens de cloreto férrico (variando entre 45 e $65 \mathrm{mg} / \mathrm{L}$ ) seriam necessárias para atingir a qualidade desejada.

TABELA 5.5 - Valores de Temperatura, pH, Turbidez, Demanda Química de Oxigênio (DQO), de Fosfato Total $\left(\mathrm{PO}_{4}^{-}\right)$e de SST em função da velocidade de flotação para dosagem de cloreto férrico (DCF) de 15 e de $30 \mathrm{mg} / \mathrm{L}$ associada à dosagem de polímeros (DP) de 0,4 e 1,0 mg/L, quando da partida do reator RALEx.

Ensaios realizados com o equipamento de flotateste e efluente do reator RALEx. Gmr: 1000 $\mathrm{s}^{-1}$, Tmr: 10s; Gf: $80 \mathrm{~s}^{-1}$; Tf: $20 \mathrm{~min}$; R: 20\% (em volume); $\mathrm{S}^{*}:$ 19,0 g/m $\mathrm{m}^{3}$; Psat: $450 \mathrm{kPa}$. Características do efluente do reator RALEx: turbidez: 54,8 uT; pH: 6,5; DQO: $150 \mathrm{mg} / \mathrm{L}$; fosfato total: $12,6 \mathrm{mg} / \mathrm{L}$; temperatura: $22,0 \pm 0,5^{\circ} \mathrm{C}$.

\begin{tabular}{|c|c|c|c|c|c|c|c|c|c|c|c|c|c|c|}
\hline \multirow[b]{2}{*}{ 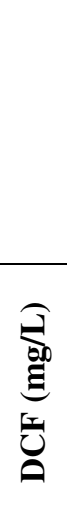 } & \multirow[b]{2}{*}{$\begin{array}{l}\widehat{\vec{\theta}} \\
\stackrel{\theta 0}{\Xi} \\
\hat{\vec{\theta}}\end{array}$} & \multirow[b]{2}{*}{ 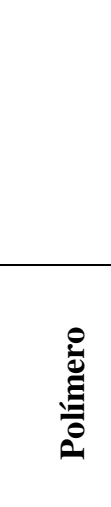 } & \multirow[b]{2}{*}{ 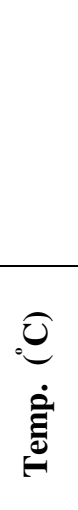 } & \multirow[b]{2}{*}{ pH } & \multirow{2}{*}{ 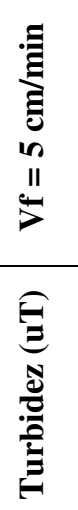 } & \multicolumn{4}{|c|}{ 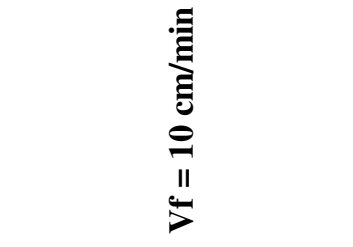 } & \multirow{2}{*}{ 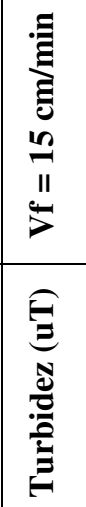 } & \multirow{2}{*}{ 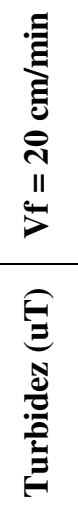 } & \multicolumn{3}{|c|}{ 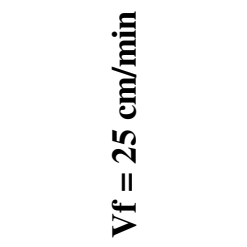 } \\
\hline & & & & & & 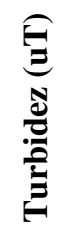 & 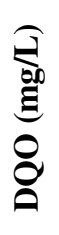 & 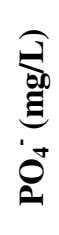 & 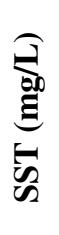 & & & 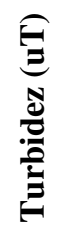 & 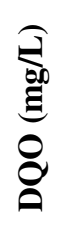 & 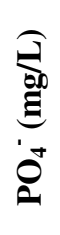 \\
\hline 0 & 0 & - & 22,0 & 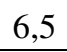 & 19,0 & 18,8 & 95 & 6,3 & 26 & 17,7 & 19,2 & 20,2 & 116 & 7,9 \\
\hline 15 & 0 & - & 22,0 & 6,4 & 18,2 & 18,1 & 118 & 5,5 & 35 & 17,8 & 19,3 & 27,2 & 113 & 5,6 \\
\hline 30 & 0 & - & 22,0 & 6,3 & 15,2 & 14,4 & 77 & 5 & 17 & 13,8 & 16,0 & 32,0 & 117 & 5,7 \\
\hline 45 & 0 & - & 22,0 & 6,2 & 5,6 & 6,0 & 58 & 2,8 & 12 & 6,1 & 6,3 & 13,6 & 73 & 4,2 \\
\hline 65 & 0 & - & 22,0 & 6,0 & 1,4 & 1,4 & 60 & 0,3 & 1 & 1,6 & 3,3 & 5,5 & 62 & 1,4 \\
\hline 0 & 1 & G9047 & 22,0 & 6,5 & 16,6 & 15,8 & 78 & 6,8 & 20 & 15,8 & 15,8 & 16,9 & 99 & 7,0 \\
\hline 0 & 2 & G9047 & 22,0 & & 13,2 & 13,0 & 7. & 7,6 & 16 & 12,9 & 12,9 & 14,1 & 78 & 7,6 \\
\hline 0 & 4 & G9047 & 22,0 & 6,5 & 12,3 & 12,1 & 72 & 7,3 & 11 & 11,8 & 12,0 & 13,5 & 70 & 6,9 \\
\hline 0 & 7 & G9047 & 22,0 & 6,5 & 10,4 & 10,5 & 61 & 7,3 & 7 & 10,6 & 10,4 & 11,6 & 63 & 7,3 \\
\hline 15 & 0,4 & G9047 & 22,0 & 6,4 & 18,2 & 18,2 & 90 & 6,0 & 33 & 18,3 & 19,6 & 21,8 & 140 & 5,9 \\
\hline 15 & 1,0 & G9047 & 22,0 & 6,4 & 17,1 & 17,0 & 8 & 5 & 35 & 17,0 & 23,4 & 22,6 & 156 & 5,8 \\
\hline 30 & 0,4 & G9047 & 22,0 & 6,3 & 13,9 & 18,3 & 76 & 5,3 & 26 & 21,2 & 23,4 & 30,0 & 93 & 4,9 \\
\hline 30 & 1,0 & G9047 & 22,0 & 6,3 & 14,5 & 14,1 & 80 & 5,0 & 28 & 14,0 & 18,2 & 23,8 & 91 & 5,2 \\
\hline 15 & 0,4 & G998 & 22,0 & 6,4 & 17,1 & 17,4 & 86 & 6,3 & 26 & 17,5 & 17,6 & 25,0 & 88 & 5,8 \\
\hline 15 & 1,0 & G998 & 22,0 & 6,4 & 16,6 & 16,9 & 85 & 5,9 & 27 & 16,9 & 17,2 & 19,8 & 85 & 5,1 \\
\hline 30 & 0,4 & G998 & 22,0 & 6,3 & 13,5 & 13,8 & 70 & 5,0 & 24 & 13,9 & 19,3 & 23,6 & 82 & 5,5 \\
\hline 30 & 1,0 & G998 & 22,0 & 6,3 & 13,8 & 13,9 & 70 & 5,1 & 26 & 12,8 & 14,0 & 18,7 & 79 & 5,2 \\
\hline 15 & 0,4 & G999 & 22,0 & 6,4 & 17,1 & 18,0 & 80 & 5,2 & 26 & 15,8 & 18,1 & 17,1 & 74 & 5,6 \\
\hline 15 & 1,0 & G999 & 22,0 & 6,4 & 15,9 & 15,9 & 84 & 6,0 & 25 & 16,0 & 16,3 & 18,4 & 84 & 6,2 \\
\hline 30 & 0,4 & G999 & 22,0 & 6,3 & 12,0 & 12,2 & 72 & 4,3 & 19 & 12,3 & 12,7 & 14,0 & 83 & 4,6 \\
\hline 30 & 1,0 & G999 & 22,0 & 6,3 & 12,6 & 12,7 & 66 & 5,1 & 25 & 11,8 & 12,1 & 12,1 & 77 & 4,7 \\
\hline
\end{tabular}



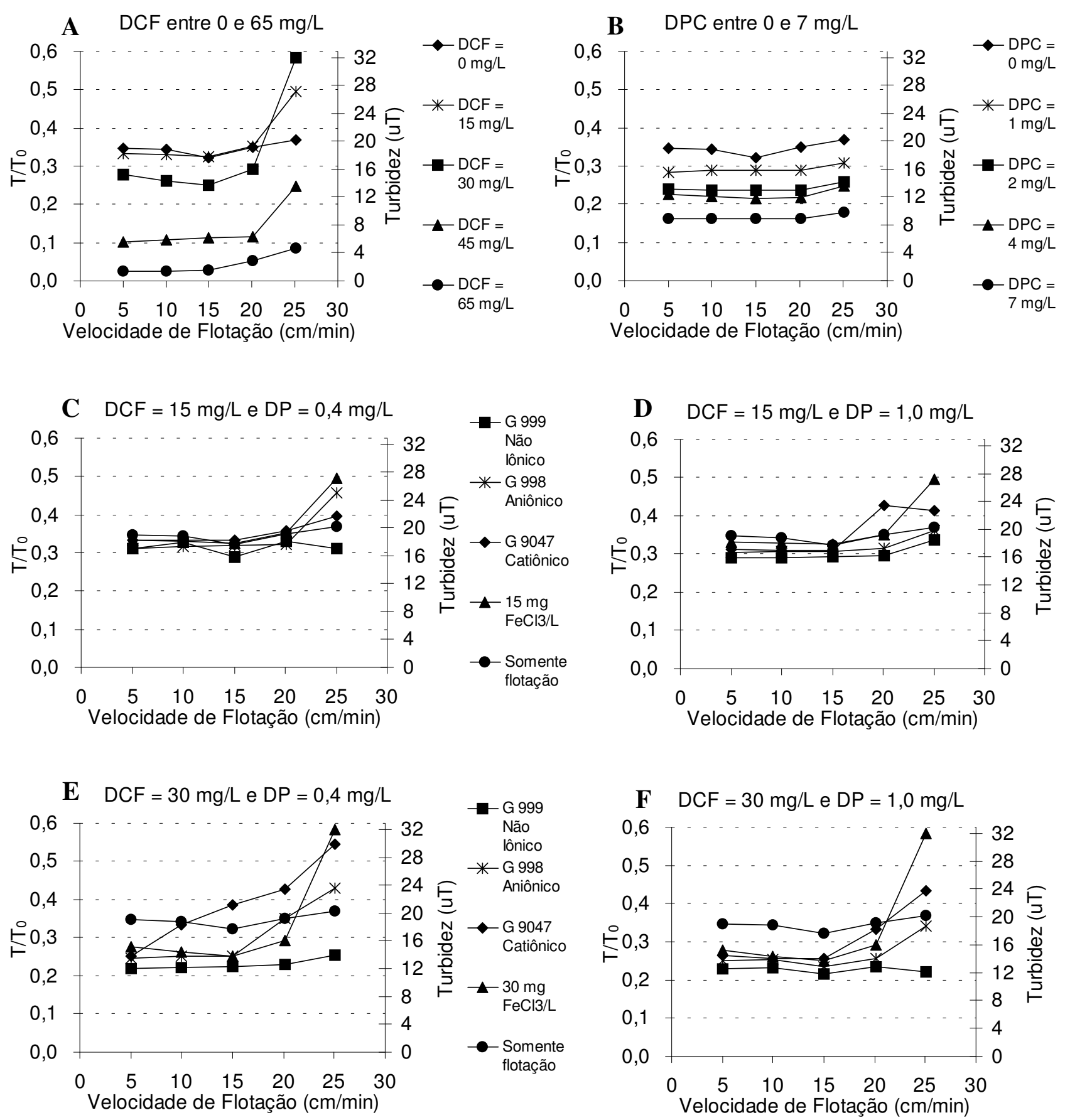

FIGURA 5.31 - Resultados de remoção e de residual de turbidez nos ensaios de coagulação/ floculação/flotação com aplicação de cloreto férrico (DCF) e/ou polímeros (DP).

Ensaios realizados com o equipamento de flotateste e efluente do reator RALEx. Gmr: $1000 \mathrm{~s}^{-1}$, Tmr: $10 \mathrm{~s}$; Tf $=20 \mathrm{~min}$; Gf $=80 \mathrm{~s}^{-1} ; \mathrm{R}=20 \%$; Psat: $450 \mathrm{kPa}$. Características do efluente do reator RALEx: turbidez: 54,8 uT; DQO da amostra não filtrada: $150 \mathrm{mg} / \mathrm{L}$; fosfato total da amostra não filtrada: $12,6 \mathrm{mg} / \mathrm{L}$; sólidos suspensos totais: $37 \mathrm{mg} / \mathrm{L}$; temperatura: $22,0 \pm 0,5^{\circ} \mathrm{C}$. 
Primeira Etapa durante partida do RALEx: Ensaio em laboratório para investigação do desempenho de polímeros e/ou cloreto férrico

\begin{tabular}{|c|c|c|}
\hline Item 4.7.5 & \multicolumn{2}{|c|}{$\begin{array}{l}\text { Parâmetros variados: } \\
* \quad \text { DCF entre } 0 \text { e } 65 \mathrm{mg} / \mathrm{L} \\
\end{array}$} \\
\hline $\begin{array}{l}\text { Parâmetros } \\
\text { mantidos fixos: } \\
\text { \& Coleta às } 08: 00 \\
\& \mathrm{Gmr}=1000 \mathrm{~s}^{-1} \\
\& \mathrm{Tmr}=10 \mathrm{~s} \\
\& \mathrm{Gf}=80 \mathrm{~s}^{-1} \\
\& \mathrm{Tf}=20 \mathrm{~min} \\
\& \mathrm{~S}^{*}=19,0 \mathrm{~g} / \mathrm{m}^{3}\end{array}$ & \multicolumn{2}{|c|}{$\begin{array}{l}\text { Quando DCF entre } \mathbf{4 5} \text { e } \mathbf{6 5} \text { mg/L: } \\
\text { * Remoções de } 89,1 \% \text { a } 98,2 \% \text { de turbidez com residuais entre } 1,4 \text { e } 6,0 \mathrm{uT} \text {. } \\
\text { * Remoção de cerca de } 60,7 \% \text { de DQO com residuais em torno de } 59 \mathrm{mg} / \mathrm{L} \text {. } \\
\text { * Remoções entre } 77,8 \% \text { e } 97,6 \% \text { de fosfato total com residuais entre } 0,3 \text { e } \\
\text { 2,8 mg/L. } \\
\text { *Remoções entre } 67,6 \% \text { e } 97,3 \% \text { de SST com residuais entre } 1 \text { e } 12 \text { mg/L. }\end{array}$} \\
\hline \multicolumn{3}{|c|}{$\begin{array}{l}\text { Aspectos observados: } \\
\text { * Mesmo sem a aplicação de cloreto férrico, para Vflot de } 10 \mathrm{~cm} / \mathrm{min} \text {, observaram-se } \\
\text { remoções de DQO próxima a } 37 \% \text { (residual de } 94,5 \mathrm{mg} / \mathrm{L} \text { ), de } 50 \% \text { de fosfato total } \\
\text { (residual de } 6,3 \mathrm{mg} / \mathrm{L} \text { ) e turbidez em torno de } 19 \mathrm{uT} \text {. } \\
\text { * Para obtenção de níveis satisfatórios de remoção de fosfato foram necessárias dosagens } \\
\text { de } 30 \mathrm{mg} / \mathrm{L} \text { para o efluente do reator RALEx em equilíbrio dinâmico, sendo que para o } \\
\text { efluente durante a partida foram requeridas dosagens na faixa de } 45 \text { a } 65 \mathrm{mg} / \mathrm{L} \text {. }\end{array}$} \\
\hline $\begin{array}{l}\text { Parâmetros va } \\
\text { \& DP entre } 1,0 \\
\text { * Vflot entre } 5 \\
\end{array}$ & $\begin{array}{l}\text { dos: } \\
0 \mathrm{mg} / \mathrm{L} \\
5 \mathrm{~cm} / \mathrm{min} \\
\end{array}$ & $\begin{array}{l}\text { uando DP=7,0 mg/L e Vflot }=\mathbf{1 0} \mathbf{~ c m} / \mathbf{m i n}: \\
\text { Remoção de } 81 \% \text { de turbidez com residual de } 10,5 \mathrm{uT} \text {. } \\
\text { Remoção de } 60 \% \text { de DQO, com residual de } 61 \mathrm{mg} / \mathrm{L} \text {. } \\
42 \% \text { de remoção de fosfato,com residual de } 7,3 \mathrm{mgPO}_{4}{ }^{-} / \mathrm{L} \text {. }\end{array}$ \\
\hline \multicolumn{3}{|c|}{$\begin{array}{l}\text { Aspectos observados: } \\
\text { * O emprego de polímero catiônico como auxiliar de flotação, em menores dosagens que as } \\
\text { utilizadas nos ensaios com cloreto férrico, forneceu resultados satisfatórios de remoção de } \\
\text { turbidez e de DQO, embora não tão bons quanto aqueles obtidos com aplicação de } \mathrm{FeCl}_{3} \text {. } \\
\text { * Com relação à remoção de fósforo, como era de se esperar, o emprego de polímero catiônico } \\
\text { não foi capaz de fornecer remoção satisfatória da fração solúvel desse elemento. } \\
\text { * O uso de polímero catiônico resultou na produção de flocos com elevada velocidade } \\
\text { ascensional, acenando com a possibilidade de se operar unidades de flotação em escala real } \\
\text { com taxas bastante elevadas. }\end{array}$} \\
\hline
\end{tabular}

Parâmetros variados:

* Carga iônica dos polímeros sintéticos

\& DCF de 15 e 30 $\mathrm{mg} / \mathrm{L}$ associado a DP de 0,4 e $1,0 \mathrm{mg} / \mathrm{L}$

* Vflot entre 5 e 25 $\mathrm{cm} / \mathrm{min}$
Quando DCF=30 mg/L e DP=1,0 mg/L e Vflot=10 cm/min:

* Remoções entre $74,3 \%$ e $76,8 \%$ de turbidez com residuais entre 12,7 e 14,1 uT.

* Remoções entre $46,7 \%$ e 56,0\% de DQO, com residuais entre 66 e $80 \mathrm{mg} / \mathrm{L}$.

* $60 \%$ de remoção de fosfato, com residuais em torno de 5,0 mg/L.

* Remoções entre $24,3 \%$ e $32,4 \%$ de SST, com residuais entre 25 e $28 \mathrm{mg} / \mathrm{L}$.

\section{Aspectos observados:}

*Durante a partida do RALEx, observou-se que o uso de pequenas dosagens de polímero catiônico (com alto peso molecular e alta densidade de carga) ou de polímero não iônico (de alto peso molecular) não permitiu a obtenção da mesma qualidade de efluente final observada nos ensaios anteriores (efluente do reator em equilíbrio dinâmico). Para tanto, valores de DCF entre 45 e $65 \mathrm{mg} / \mathrm{L}$ seriam necessários para atingir a qualidade desejada.

FIGURA 5.32 - Fluxograma simplificado da Primeira Etapa de Ensaios em laboratório, durante partida do reator RALEx, para investigação do emprego de polímeros sintéticos e/ou cloreto férrico no pós-tratamento físico-químico por flotação, descrita no item 4.7.6. 


\subsection{Ensaios em escala de laboratório, utilizando o flotateste e com aplicação de cloreto férrico para amostras coletadas ao longo do dia}

Essa etapa de estudos foi fundamental para verificação do comportamento da variação da qualidade do efluente do flotateste decorrente da variação na qualidade do efluente do reator RALEx, mediante coleta de amostras ao longo do dia, em ensaios com as mesmas condições operacionais.

Os resultados obtidos durante os ensaios com variação da dosagem de cloreto férrico para coagulação/floculação/flotação de amostras de efluente do reator anaeróbio coletadas ao longo do dia são apresentados no item 5.5.1.

No item 5.5.2, são apresentados os resultados obtidos durante os ensaios com variação da dosagem de cloreto férrico e do pH de coagulação para coagulação/floculação/ flotação de amostras de efluente de reator anaeróbio coletadas em data diferente daquelas mostradas no item 5.5.1.

\subsubsection{Ensaios com variação da dosagem de cloreto férrico para coagulação/}

floculação/flotação de amostras de efluente anaeróbio coletadas ao longo do dia.

São relatados os resultados obtidos nos ensaios descritos no item 4.7.6. Nessa etapa da pesquisa, foram realizados ensaios com o objetivo de investigar a variação da qualidade do efluente do flotateste ao longo do dia (entre 08:00 e 20:00) mediante adição de diferentes dosagens de cloreto férrico (entre 0 e $85 \mathrm{mg} / \mathrm{L}$ ). Os demais parâmetros operacionais foram mantidos fixos: $\mathrm{Gmr}=1000 \mathrm{~s}^{-1} ; \mathrm{Tmr}=10 \mathrm{~s} ; \mathrm{Gf}=80 \mathrm{~s}^{-1} ; \mathrm{Tf}=20 \mathrm{~min} ; \mathrm{R}=20 \%$; Psat=450 $\pm 10 \mathrm{kPa}$.

A discussão baseia-se na eficiência de remoção de turbidez, entre velocidades de flotação de 5 a $25 \mathrm{~cm} / \mathrm{min}$, e de DQO e de fósforo (P) das amostras não filtradas e das amostras filtradas em membranas com abertura média de $1,2 \mu \mathrm{m}$ e $0,45 \mu \mathrm{m}$, coletadas nos ensaios em velocidade de flotação de $10 \mathrm{~cm} / \mathrm{min}$.

Convém lembrar que, durante o período desses ensaios, a carga orgânica, em termos de DQO, presente no efluente do reator RALEx estava acima dos valores comumente observados. Os valores de DQO do efluente do reator RALEx variavam entre $180 \mathrm{mg} / \mathrm{L} \mathrm{e}$ $270 \mathrm{mg} / \mathrm{L}$, no período compreendido entre as 8:00 e as 20:00.

As FIGURAS 5.33A a 5.33E apresentam, na ordenada esquerda, os valores de fração de turbidez remanescente e, na ordenada direita, os respectivos valores de turbidez do efluente do flotateste em função da velocidade de flotação para diferentes dosagens de cloreto férrico, entre 0 e $85 \mathrm{mg} / \mathrm{L}$, em diferentes horários de coleta de amostras do efluente do reator anaeróbio. 
Às 08:00 (FIGURA 5.33A), para $\mathrm{Vf}=10 \mathrm{~cm} / \mathrm{min}$, a flotação direta $(\mathrm{DCF}=0 \mathrm{mg} / \mathrm{L})$ do efluente do reator anaeróbio produziu amostra com turbidez de 34,8 uT (eficiência de remoção de $61,1 \%$ de turbidez). Com adição de $15 \mathrm{mg} / \mathrm{L}$ de cloreto férrico, na coagulação/floculação/flotação de efluente de reator anaeróbio, a amostra produzida foi ligeiramente menos turva, com 32,2 uT e respectiva eficiência de remoção de $64,1 \%$. Houve melhora significativa da qualidade do efluente do flotateste, com turbidez de 20,8 uT e $76,8 \%$ de remoção, quando foram adicionados $30 \mathrm{mg} / \mathrm{L}$ de cloreto férrico. $\mathrm{O}$ aumento de DCF para 45 mg/L resultou em eficiência de remoção de turbidez de 90,4\% (turbidez remanescente de 8,7 uT). Quando do uso de $65 \mathrm{mg} / \mathrm{L}$ de cloreto férrico, observou-se elevada eficiência de remoção de turbidez, de 96,9\%, com residual de 2,8 uT. Para DCF de 85 mg/L, a turbidez do efluente do flotateste foi de 1,0 uT, com respectiva eficiência de remoção de 98,9\%.

Às 11:00 (FIGURA 5.33B), para Vf=10 cm/min, a flotação direta (DCF=0 mg/L) do efluente do reator anaeróbio produziu amostra com turbidez de 68,8 uT (eficiência de remoção de $11,9 \%$ de turbidez). Com adição de $15 \mathrm{mg} / \mathrm{L}$ de cloreto férrico, na coagulação/floculação/flotação de efluente de reator anaeróbio, a amostra produzida foi ligeiramente menos turva, com 65,9 uT e respectiva eficiência de remoção de 15,6\%. Houve relativa melhora da qualidade do efluente do flotateste, com turbidez de 54,1 uT e 30,7\% de remoção, quando foram adicionados $30 \mathrm{mg} / \mathrm{L}$ de cloreto férrico. O aumento de DCF para 45 $\mathrm{mg} / \mathrm{L}$ resultou em eficiência de remoção de turbidez de 59,6\% (turbidez remanescente de $31,6 \mathrm{uT}$ ). Quando do uso de $65 \mathrm{mg} / \mathrm{L}$ de cloreto férrico, observou-se significativa eficiência de remoção de turbidez, de 84,2\%, com residual de 12,4 uT. Para DCF de $85 \mathrm{mg} / \mathrm{L}$, a turbidez do efluente do flotateste foi de $1,7 \mathrm{uT}$, com respectiva eficiência de remoção de $97,9 \%$.

Às 14:00 (FIGURA 5.33C), para $\mathrm{Vf}=10 \mathrm{~cm} / \mathrm{min}$, a flotação direta $(\mathrm{DCF}=0 \mathrm{mg} / \mathrm{L})$ do efluente do reator anaeróbio produziu amostra com turbidez de 78,2 uT (eficiência de remoção de 22,6\% de turbidez). Com adição de $15 \mathrm{mg} / \mathrm{L}$ de cloreto férrico, na coagulação/floculação/flotação de efluente de reator anaeróbio, a amostra obtida foi ligeiramente melhor, com 73,9 uT e respectiva eficiência de remoção de $26,9 \%$. Houve melhora da qualidade do efluente do flotateste, com turbidez de 63,7 uT e 37,0\% de eficiência de remoção, quando foram adicionados $30 \mathrm{mg} / \mathrm{L}$ de cloreto férrico. $\mathrm{O}$ aumento de DCF para $45 \mathrm{mg} / \mathrm{L}$ resultou em eficiência de remoção de turbidez de 61,8\% (turbidez remanescente de 38,6 uT). Quando do uso de $65 \mathrm{mg} / \mathrm{L}$ de cloreto férrico, observou-se elevada eficiência de remoção de turbidez, de 89,5\%, com residual de 10,7 uT. Para DCF de $85 \mathrm{mg} / \mathrm{L}$, a turbidez do efluente do flotateste foi de 2,3 uT, com respectiva eficiência de remoção de $97,8 \%$. 
Às 17:00 (FIGURA 5.33D), para Vf=10 cm/min, a flotação direta (DCF=0 mg/L) do efluente do reator anaeróbio produziu amostra com turbidez de 112,4 uT (eficiência de remoção de 4,8\% de turbidez). Com adição de $15 \mathrm{mg} / \mathrm{L}$ de cloreto férrico, na coagulação/floculação/flotação de efluente de reator anaeróbio, a amostra produzida foi ligeiramente menos turva, com 101,9 uT e respectiva eficiência de remoção de $13,7 \%$. Houve pequena melhora da qualidade do efluente do flotateste, com turbidez de 88,8 uT e $24,8 \%$ de eficiência de remoção, quando foram adicionados $30 \mathrm{mg} / \mathrm{L}$ de cloreto férrico. $\mathrm{O}$ aumento de DCF para $45 \mathrm{mg} / \mathrm{L}$ resultou em eficiência de remoção de turbidez de 52,6\% (turbidez remanescente de 56,0 uT). Quando do uso de $65 \mathrm{mg} / \mathrm{L}$ de cloreto férrico, observouse elevada eficiência de remoção de turbidez, de 90,8\%, com residual de 10,9 uT. Para DCF de $85 \mathrm{mg} / \mathrm{L}$, a turbidez do efluente do flotateste foi de 1,3 uT, com respectiva eficiência de remoção de $99,0 \%$.

Às 20:00 (FIGURA 5.33E), para $\mathrm{Vf}=10 \mathrm{~cm} / \mathrm{min}$, a flotação direta ( $\mathrm{DCF}=0 \mathrm{mg} / \mathrm{L})$ do efluente do reator anaeróbio produziu amostra com turbidez de 116,5 uT (eficiência de remoção de 2,1\% de turbidez). Com adição de $15 \mathrm{mg} / \mathrm{L}$ de cloreto férrico, na coagulação/floculação/flotação de efluente de reator anaeróbio, a amostra produzida foi ligeiramente menos turva, com 10,38 uT e respectiva eficiência de remoção de 12,8\%. Houve melhora significativa da qualidade do efluente do flotateste, com turbidez de 90,0 uT e $24,4 \%$ de eficiência de remoção, quando foram adicionados $30 \mathrm{mg} / \mathrm{L}$ de cloreto férrico. $\mathrm{O}$ aumento de DCF para $45 \mathrm{mg} / \mathrm{L}$ resultou em eficiência de remoção de turbidez de 60,3\% (turbidez remanescente de 47,3 uT). Quando do uso de $65 \mathrm{mg} / \mathrm{L}$ de cloreto férrico, observouse elevada eficiência de remoção de turbidez, de 95,1\%, com residual de 5,9 uT. Para DCF de $85 \mathrm{mg} / \mathrm{L}$, a turbidez do efluente do flotateste foi de 1,3 uT, com respectiva eficiência de remoção de $99,0 \%$.

\footnotetext{
Investigando a FIGURA 5.33, para Vflot $=10 \mathrm{~cm} / \mathrm{min}$, nota-se que o uso de 6 dosagens de cloreto férrico resultou em 3 grupos com comportamentos distintos. O primeiro grupo é composto pelos ensaios com DCF entre 0 e $30 \mathrm{mg} / \mathrm{L}$. Às 08:00, a eficiência de eficiência de remoção de turbidez deste grupo variou entre 61,1 e 76,8\%. Às 11:00, esses valores oscilaram entre 11,9 e 30,7\%. Às 14:00, variações entre 22,6 e 37,0\% foram observadas. Às 17:00, variaram entre 4,8 e 24,8\% e às 20:00 oscilaram entre 2,1 e 24,4\%. Desta forma, a capacidade de remoção de turbidez com o uso de dosagens entre 0 e $30 \mathrm{mg} / \mathrm{L}$ de cloreto férrico é totalmente diferente para amostras coletadas às 08:00 e para aquelas coletadas nos demais horários. A deterioração da qualidade do efluente do reator RALEx influenciou, sobremaneira, a qualidade da amostra coletada no flotateste quando dosagens iguais e menores que $30 \mathrm{mgFeCl}_{3} / \mathrm{L}$ foram aplicadas.
} 
O segundo grupo é composto unicamente pela DCF de $45 \mathrm{mg} / \mathrm{L}$. Às 08:00, a eficiência de eficiência de remoção de turbidez foi de 90,4\%. Entre 11:00 e 18:00, as eficiências de remoção oscilaram entre 52,6 e $61,8 \%$. Muito embora a capacidade de remoção de turbidez tenha sido reduzida entre 08:00 e os demais horários, a redução foi menos significativa se comparada ao primeiro grupo de dosagens de cloreto férrico.

O terceiro grupo constitui-se das dosagens de 65 e 85 mg/L. Às 08:00, a eficiência de remoção de turbidez variou entre 96,9 e $98,9 \%$. Entre 11:00 e 18:00, as remoções oscilaram entre 84,2 e $99 \%$. Praticamente não houve influência da qualidade do efluente do RALEx na capacidade de remoção de turbidez quando do uso de DCF entre 65 e $85 \mathrm{mg} / \mathrm{L}$. Desta forma, quando do uso isolado do cloreto férrico na coagulação e floculação de efluente do reator RALEx, dosagens iguais ou superiores a $65 \mathrm{mg} / \mathrm{L}$ são necessárias para manutenção da qualidade do efluente final do flotador, com valores de turbidez inferiores a $15 \mathrm{uT}$ e com remoções superiores a $84 \%$, ao longo do dia.

As FIGURAS 5.34A a 5.34F apresentam, na ordenada esquerda, os valores de DQO remanescente do efluente do flotateste em função do horário de coleta de amostras do efluente do reator anaeróbio para realização de ensaios com aplicação de diferentes dosagens de cloreto férrico, entre 0 e $85 \mathrm{mg} / \mathrm{L}$, para velocidade de flotação igual a $10 \mathrm{~cm} / \mathrm{min}$.

Às 08:00 (FIGURA 5.34A), a flotação direta ( $\mathrm{DCF}=0 \mathrm{mg} / \mathrm{L})$ do efluente do reator anaeróbio produziu amostra com DQO de $138 \mathrm{mg} / \mathrm{L}$ (eficiência de remoção de 23,3\%). Com adição de $15 \mathrm{mg} / \mathrm{L}$ de cloreto férrico, na coagulação/floculação/flotação de efluente de reator anaeróbio, a amostra produzida apresentou DQO de $107 \mathrm{mg} / \mathrm{L}$ e respectiva eficiência de remoção de 40,6\%. Houve melhora da qualidade do efluente do flotateste, com DQO de 76 $\mathrm{mg} / \mathrm{L}$ e $57,8 \%$ de remoção, quando foram adicionados $30 \mathrm{mg} / \mathrm{L}$ de cloreto férrico. $\mathrm{O}$ aumento de DCF para $45 \mathrm{mg} / \mathrm{L}$ resultou em eficiência de remoção de DQO de 67,8\% (DQO remanescente de $58 \mathrm{mg} / \mathrm{L}$ ). Quando do uso de $65 \mathrm{mg} / \mathrm{L}$ de cloreto férrico, observou-se eficiência de remoção de DQO de 70,6\%, com residual de $53 \mathrm{mg} / \mathrm{L}$. Para DCF de $85 \mathrm{mg} / \mathrm{L}$, a DQO do efluente do flotateste foi de $39 \mathrm{mg} / \mathrm{L}$, com respectiva eficiência de remoção de $78,3 \%$.

Às 08:00, o uso de dosagens maiores de $45 \mathrm{mgFeCl}_{3} / \mathrm{L}$ não afetou significativamente a remoção de DQO, indicando que dosagens de cloreto férrico da ordem de $45 \mathrm{mg} / \mathrm{L}$ são suficientes pra manutenção de efluente do flotateste com reduzida concentração de matéria orgânica devido à elevada remoção global de DQO no sistema RALEx/flotador, da ordem de $90,2 \%$.

Às 11:00, a flotação direta ( $\mathrm{DCF}=0 \mathrm{mg} / \mathrm{L}$ ) do efluente do reator anaeróbio produziu amostra com DQO de $246 \mathrm{mg} / \mathrm{L}$ (eficiência de remoção de 0,8\%). Com adição de $15 \mathrm{mg} / \mathrm{L}$ 
de cloreto férrico, na coagulação/floculação/flotação de efluente de reator anaeróbio, a amostra produzida apresentou DQO de $208 \mathrm{mg} / \mathrm{L}$ e respectiva eficiência de remoção de 16,1\%. Houve melhora da qualidade do efluente do flotateste, com DQO de $203 \mathrm{mg} / \mathrm{L} \mathrm{e}$ $18,1 \%$ de eficiência de remoção, quando foram adicionados $30 \mathrm{mg} / \mathrm{L}$ de cloreto férrico. $\mathrm{O}$ aumento de DCF para 45 mg/L resultou em eficiência de remoção de DQO de 39,1\% (DQO remanescente de $151 \mathrm{mg} / \mathrm{L}$ ). Quando do uso de $65 \mathrm{mg} / \mathrm{L}$ de cloreto férrico, observou-se eficiência de remoção de DQO, de 61,7\%, com residual de 95 mg/L. Para DCF de 85 mg/L, a DQO do efluente do flotateste foi de $90 \mathrm{mg} / \mathrm{L}$, com respectiva eficiência de remoção de $63,7 \%$.

Às 11:00, a aplicação de valores maiores de $65 \quad \mathrm{mgFeCl}_{3} / \mathrm{L}$ não afetou significativamente a remoção de DQO, indicando que dosagens de cloreto férrico da ordem de $65 \mathrm{mg} / \mathrm{L}$ são suficientes pra manutenção de efluente do flotateste com reduzida concentração de matéria orgânica e elevada remoção global de DQO no sistema RALEx/flotador, da ordem de $88,6 \%$.

Âs 14:00, a flotação direta $(\mathrm{DCF}=0 \mathrm{mg} / \mathrm{L})$ do efluente do reator anaeróbio produziu amostra com DQO de $246 \mathrm{mg} / \mathrm{L}$ (eficiência de remoção de 2,8\%). Com adição de $15 \mathrm{mg} / \mathrm{L}$ de cloreto férrico, na coagulação/floculação/flotação de efluente de reator anaeróbio, a amostra produzida apresentou DQO de $226 \mathrm{mg} / \mathrm{L}$ e respectiva eficiência de remoção de 10,7\%. Houve melhora da qualidade do efluente do flotateste, com DQO de $213 \mathrm{mg} / \mathrm{L} \mathrm{e}$ $15,8 \%$ de remoção, quando foram adicionados $30 \mathrm{mg} / \mathrm{L}$ de cloreto férrico. $\mathrm{O}$ aumento de DCF para $45 \mathrm{mg} / \mathrm{L}$ resultou em eficiência de remoção de DQO de 34,8\% (DQO remanescente de $165 \mathrm{mg} / \mathrm{L}$ ). Quando do uso de $65 \mathrm{mg} / \mathrm{L}$ de cloreto férrico, observou-se eficiência de remoção de DQO, de 35,2\%, com residual de 164 mg/L. Para DCF de 85 mg/L, a DQO do efluente do flotateste foi de $187 \mathrm{mg} / \mathrm{L}$, com respectiva eficiência de remoção de $26,1 \%$.

Às 14:00, nem a aplicação de valores de até $85 \mathrm{mgFeCl}_{3} / \mathrm{L}$ logrou produzir efluentes com eficiência de remoção global de DQO no sistema RALEx/flotador superior a 80\%.

Âs 17:00, a flotação direta $(\mathrm{DCF}=0 \mathrm{mg} / \mathrm{L})$ do efluente do reator anaeróbio produziu amostra com DQO de $261 \mathrm{mg} / \mathrm{L}$ (eficiência de remoção de 3,3\%). Com adição de $15 \mathrm{mg} / \mathrm{L}$ de cloreto férrico, na coagulação/floculação/flotação de efluente de reator anaeróbio, a amostra produzida apresentou DQO de $248 \mathrm{mg} / \mathrm{L}$ e respectiva eficiência de remoção de $8,1 \%$. Houve melhora da qualidade do efluente do flotateste, com DQO de $232 \mathrm{mg} / \mathrm{L} \mathrm{e}$ $14,1 \%$ de remoção, quando foram adicionados $30 \mathrm{mg} / \mathrm{L}$ de cloreto férrico. $\mathrm{O}$ aumento de DCF para $45 \mathrm{mg} / \mathrm{L}$ resultou em eficiência de remoção de DQO de 30,4\% (DQO remanescente de $188 \mathrm{mg} / \mathrm{L}$ ). Quando do uso de $65 \mathrm{mg} / \mathrm{L}$ de cloreto férrico, observou-se 
eficiência de remoção de DQO, de 65,6\%, com residual de 93 mg/L. Para DCF de 85 mg/L, a DQO do efluente do flotateste foi de $103 \mathrm{mg} / \mathrm{L}$, com respectiva eficiência de remoção de $61,9 \%$.

Às 17:00, o uso de dosagens em torno de $65 \mathrm{mgFeCl}_{3} / \mathrm{L}$ foi suficiente pra manutenção de efluente do flotateste com concentração de matéria orgânica aceitável e remoção global de DQO no sistema RALEx/flotador da ordem de 80,7\%.

Âs 20:00, a flotação direta ( $\mathrm{DCF}=0 \mathrm{mg} / \mathrm{L}$ ) do efluente do reator anaeróbio produziu amostra com DQO de 197 uT (eficiência de remoção de 17,6\%). Com adição de $15 \mathrm{mg} / \mathrm{L}$ de cloreto férrico, na coagulação/floculação/flotação de efluente de reator anaeróbio, a amostra produzida apresentou DQO de $157 \mathrm{mg} / \mathrm{L}$ e respectiva eficiência de remoção de 34,3\%. Houve melhora da qualidade do efluente do flotateste, com DQO de $156 \mathrm{mg} / \mathrm{L}$ e 34,7\% de remoção, quando foram adicionados $30 \mathrm{mg} / \mathrm{L}$ de cloreto férrico. O aumento de DCF para 45 mg/L resultou em eficiência de remoção de DQO de 53,6\% (DQO remanescente de 111 $\mathrm{mg} / \mathrm{L}$ ). Quando do uso de $65 \mathrm{mg} / \mathrm{L}$ de cloreto férrico, observou-se eficiência de remoção de DQO, de 78,7\%, com residual de $51 \mathrm{mg} / \mathrm{L}$. Para DCF de $85 \mathrm{mg} / \mathrm{L}$, a DQO do efluente do flotateste foi de $40 \mathrm{mg} / \mathrm{L}$, com respectiva eficiência de remoção de 83,3\%.

Às 20:00, a aplicação de valores maiores de $65 \mathrm{mgFeCl}_{3} / \mathrm{L}$ não afetou significativamente a remoção de DQO, indicando que dosagens de cloreto férrico da ordem de $65 \mathrm{mg} / \mathrm{L}$ são suficientes pra manutenção de efluente do flotateste com reduzida concentração de matéria orgânica e elevada remoção global de DQO no sistema RALEx/flotador, da ordem de 91,4\%.

Verifica-se, então, que a remoção de DQO foi significativamente influenciada pela qualidade do efluente do reator RALEx. Às 8:00, $45 \mathrm{mgFeCl}_{3} / \mathrm{L}$ eram suficientes para promover eficiência de 90,2\% de remoção global de DQO no sistema RALEx/flotador. Para obtenção de eficiência de remoção global de $88,6 \%$ de DQO às 11:00, já foram necessários $65 \mathrm{mgFeCl} 3 / \mathrm{L}$. Às 14:00, nenhuma dosagem de cloreto férrico testada foi suficiente para promover eficiência de remoção global de DQO no sistema RALEx/flotador superior a $80 \%$. Às 17:00, dosagem de $65 \mathrm{mgFeCl} 3 / \mathrm{L}$ foi necessária para eficiência de remoção global de 80,7\% de DQO. Essa mesma dosagem, às 20:00, foi suficiente para eficiência de remoção global de $91,4 \%$ de DQO.

Analisando as FIGURAS 5.34D a 5.34F, pode-se tecer algumas considerações sobre a influência do aumento de dosagem de cloreto férrico na eficiência de remoção de partículas que geram DQO, com diferentes tamanhos médios. A FIGURA 5.34D mostra que o aumento da dosagem de cloreto férrico resultou em significativa redução da presença de partículas 
que geram DQO de diferentes tamanhos nos efluentes flotados ao longo do dia. A FIGURA 5.34E mostra que o aumento da dosagem de cloreto férrico acarretou pequena diferença na redução da presença de partículas que geram DQO de tamanho inferior a 1,2 $\mu \mathrm{m}$ nos efluentes flotados ao longo do dia. Vale destacar que a aplicação de dosagens iguais ou superiores a $65 \mathrm{mgFeCl}_{3} / \mathrm{L}$ possibilitou a quase completa remoção de partículas que geram DQO com tamanhos médios acima de $1,2 \mu \mathrm{m}$. A FIGURA 5.34F mostra que o aumento da dosagem de cloreto férrico particularmente não acarretou elevação da eficiência de remoção de partículas que geram DQO de tamanho inferior a $0,45 \mu \mathrm{m}$ nos efluentes flotados ao longo do dia. Desta forma, vale ressaltar que a flotação, com dosagens de cloreto férrico acima de $30 \mathrm{mg} / \mathrm{L}$, apresentou boa eficiência para remoção de partículas que geram DQO com tamanhos superiores a 1,2 $\mu \mathrm{m}$. Entretanto a maior eficiência de remoção das partículas com tamanho superior a $1,2 \mu \mathrm{m}$ foi obtida com dosagens de $65 \mathrm{mgFeCl}_{3} / \mathrm{L}$ ou superiores.

As FIGURAS 5.35A a 5.35F apresentam os valores de concentração de fósforo (P) remanescente do efluente do flotateste em função do horário de coleta de amostras do efluente do reator anaeróbio para realização de ensaios com aplicação de diferentes dosagens de cloreto férrico, entre 0 e $85 \mathrm{mg} / \mathrm{L}$, para velocidade de flotação igual a $10 \mathrm{~cm} / \mathrm{min}$.

Às 08:00 (FIGURA 5.35A), a flotação direta $(\mathrm{DCF}=0 \mathrm{mg} / \mathrm{L})$ do efluente do reator anaeróbio produziu amostra com 4,36 mgP/L (eficiência de remoção de 22,7\%). Com adição de $15 \mathrm{mg} / \mathrm{L}$ de cloreto férrico, na coagulação/floculação/flotação de efluente de reator anaeróbio, a amostra produzida apresentou $4,49 \mathrm{mgP} / \mathrm{L}$ e respectiva eficiência de remoção de $20,4 \%$. Houve pequena melhora na remoção de fósforo do efluente do flotateste, com 3,16 $\mathrm{mgP} / \mathrm{L}$ e $44,0 \%$ de eficiência de remoção, quando foram adicionados $30 \mathrm{mg} / \mathrm{L}$ de cloreto férrico. O aumento de DCF para $45 \mathrm{mg} / \mathrm{L}$ resultou em eficiência de remoção de $\mathrm{P}$ de 76,6\% (remanescente de 1,32 mgP/L). Quando do uso de $65 \mathrm{mg} / \mathrm{L}$ de cloreto férrico, observou-se eficiência de remoção de 94,1\%, com residual de 0,33 mgP/L. Para DCF de $85 \mathrm{mg} / \mathrm{L}$, a concentração de fósforo do efluente do flotateste foi de $0,09 \mathrm{mgP} / \mathrm{L}$, com respectiva eficiência de remoção de 98,4\%.

Às 11:00, a flotação direta $(\mathrm{DCF}=0 \mathrm{mg} / \mathrm{L})$ do efluente do reator anaeróbio produziu amostra com 4,71 mgP/L (eficiência de remoção de 21,0\%). Com adição de $15 \mathrm{mg} / \mathrm{L}$ de cloreto férrico, na coagulação/floculação/flotação de efluente de reator anaeróbio, a amostra produzida apresentou 4,74 mgP/L e respectiva eficiência de remoção de $20,5 \%$. Houve melhora da qualidade do efluente do flotateste, com 3,53 $\mathrm{mgP} / \mathrm{L}$ e $40,8 \%$ de remoção, quando foram adicionados $30 \mathrm{mg} / \mathrm{L}$ de cloreto férrico. O aumento de DCF para $45 \mathrm{mg} / \mathrm{L}$ resultou em eficiência de remoção de 64,8\% (remanescente de 2,10 mgP/L). Quando do uso de $65 \mathrm{mg} / \mathrm{L}$ de cloreto férrico, observou-se eficiência de remoção de 83,7\%, com residual de 
0,97 mgP/L. Para DCF de $85 \mathrm{mg} / \mathrm{L}$, a concentração de fósforo do efluente do flotateste foi de $0,17 \mathrm{mg} / \mathrm{L}$, com respectiva eficiência de remoção de $97,1 \%$.

Às 14:00, a flotação direta $(\mathrm{DCF}=0 \mathrm{mg} / \mathrm{L})$ do efluente do reator anaeróbio produziu amostra com 4,86 mgP/L (eficiência de remoção de 16,2\%). Com adição de $15 \mathrm{mg} / \mathrm{L}$ de cloreto férrico, na coagulação/floculação/flotação de efluente de reator anaeróbio, a amostra produzida apresentou 4,40 mgP/L e respectiva eficiência de remoção de $24,1 \%$. Houve melhora da qualidade do efluente do flotateste, com 3,30 mgP/L e 43,1\% de eficiência de remoção, quando foram adicionados $30 \mathrm{mg} / \mathrm{L}$ de cloreto férrico. O aumento de DCF para 45 $\mathrm{mg} / \mathrm{L}$ resultou em eficiência de remoção de 61,0\% (remanescente de 2,26 mgP/L). Quando do uso de $65 \mathrm{mg} / \mathrm{L}$ de cloreto férrico, observou-se eficiência de remoção de 85,0\%, com residual de $0,87 \mathrm{mgP} / \mathrm{L}$. Para $\mathrm{DCF}$ de $85 \mathrm{mg} / \mathrm{L}$, a concentração de fósforo do efluente do flotateste foi de $0,12 \mathrm{mg} / \mathrm{L}$, com respectiva eficiência de remoção de $97,9 \%$.

Às 17:00, a flotação direta $(\mathrm{DCF}=0 \mathrm{mg} / \mathrm{L})$ do efluente do reator anaeróbio produziu amostra com 4,57 mgP/L (eficiência de remoção de 20,7\%). Com adição de $15 \mathrm{mg} / \mathrm{L}$ de cloreto férrico, na coagulação/floculação/flotação de efluente de reator anaeróbio, a amostra produzida apresentou 4,53 $\mathrm{mgP} / \mathrm{L}$ e respectiva eficiência de remoção de $21,4 \%$. Houve melhora da qualidade do efluente do flotateste, com 3,66 $\mathrm{mgP} / \mathrm{L}$ e $36,5 \%$ de remoção, quando foram adicionados $30 \mathrm{mg} / \mathrm{L}$ de cloreto férrico. O aumento de DCF para $45 \mathrm{mg} / \mathrm{L}$ resultou em remoção de 61,6\% (remanescente de 2,21 mgP/L). Quando do uso de $65 \mathrm{mg} / \mathrm{L}$ de cloreto férrico, observou-se eficiência de remoção de 89,2\%, com residual de 0,62 mgP/L. Para DCF de $85 \mathrm{mg} / \mathrm{L}$, não foi detectada a presença de fósforo no efluente do flotateste.

Às 20:00, a flotação direta $(\mathrm{DCF}=0 \mathrm{mg} / \mathrm{L})$ do efluente do reator anaeróbio produziu amostra com 4,42 mgP/L (eficiência de remoção de 3,5\%). Com adição de $15 \mathrm{mg} / \mathrm{L}$ de cloreto férrico, na coagulação/floculação/flotação de efluente de reator anaeróbio, a amostra produzida apresentou 4,37 $\mathrm{mgP} / \mathrm{L}$ e respectiva eficiência de remoção de 4,6\%. Houve melhora da qualidade do efluente do flotateste, com 3,64 mgP/L e 20,5\% de remoção, quando foram adicionados $30 \mathrm{mg} / \mathrm{L}$ de cloreto férrico. O aumento de DCF para $45 \mathrm{mg} / \mathrm{L}$ resultou em eficiência de remoção de 58,7\% (remanescente de 1,89 $\mathrm{mgP} / \mathrm{L}$ ). Quando do uso de $65 \mathrm{mg} / \mathrm{L}$ de cloreto férrico, observou-se eficiência de remoção de 93,4\%, com residual de $0,30 \mathrm{mgP} / \mathrm{L}$. Para DCF de $85 \mathrm{mg} / \mathrm{L}$, a concentração de fósforo do efluente do flotateste foi de $0,04 \mathrm{mg} / \mathrm{L}$, com respectiva eficiência de remoção de $99,1 \%$.

Sendo assim, a aplicação de dosagens gradativamente maiores de cloreto férrico afetou significativamente a remoção de fósforo, até sua quase completa remoção, a partir do uso de $85 \mathrm{mgFeCl}_{3} / \mathrm{L}$. 

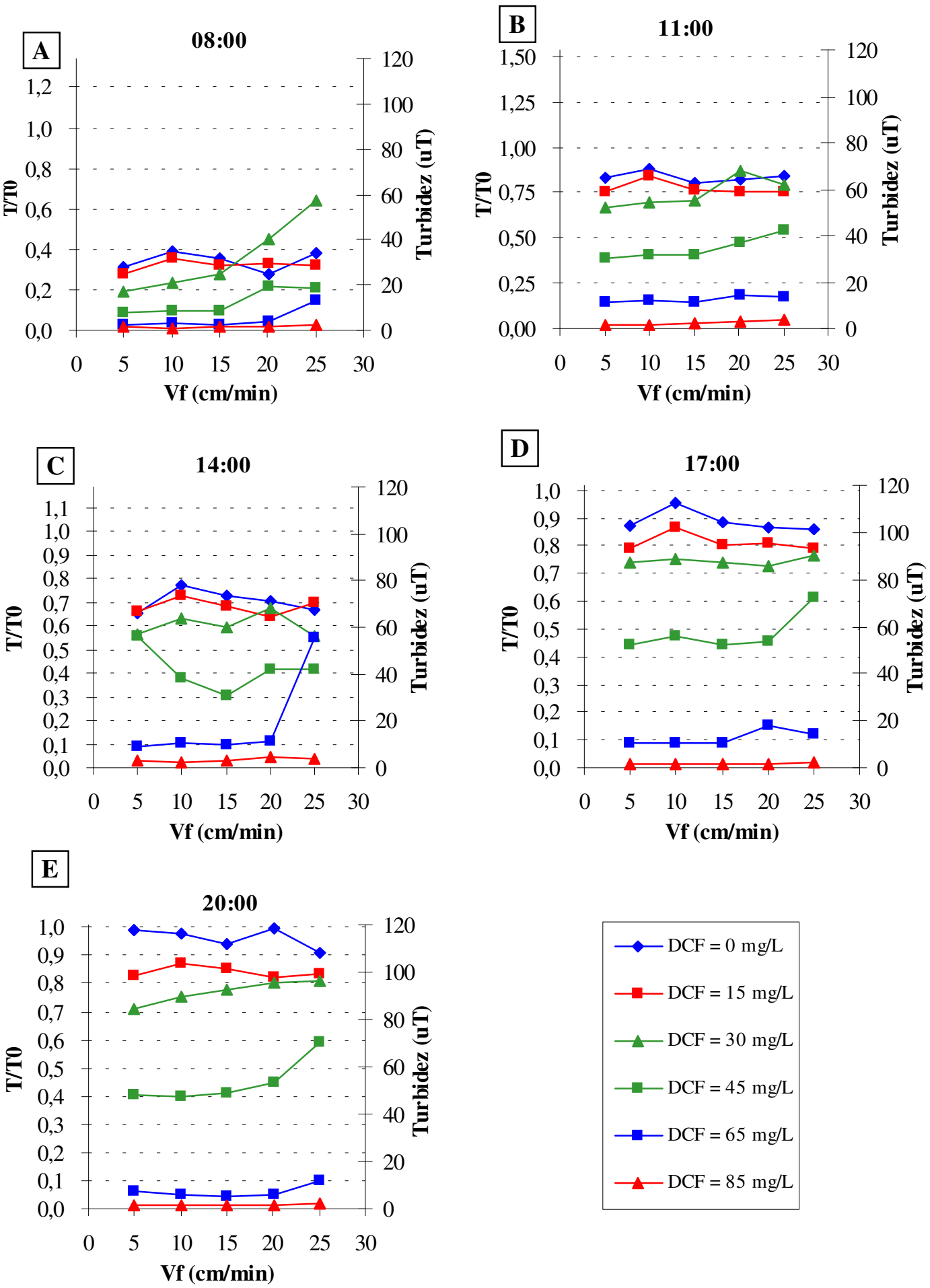

FIGURA 5.33 - Fração remanescente de turbidez (T/T0) e turbidez das amostras coletadas nos ensaios com variação da dosagem de cloreto férrico para coagulação/ floculação/flotação de amostras de efluente do reator anaeróbio coletadas ao longo do dia.Horários de coleta: 08:00 (A); 11:00 (B); 14:00 (C); 17:00 (D) e 20:00 (E).

Ensaios realizados com o equipamento de flotateste e efluente do reator RALEx. $\mathrm{Gmr}=1000 \mathrm{~s}^{-1}$; Tmr=10 s; Gf=80 s $; \mathrm{Tf}=20 \mathrm{~min} ; \mathrm{R}=20 \%$; Psat=450 kPa. Características do efluente do reator RALEx: turbidez: 233 uT (8:00); 303 uT (11:00); 289 uT (14:00); 219 uT (17:00) e 208 uT (20:00) 


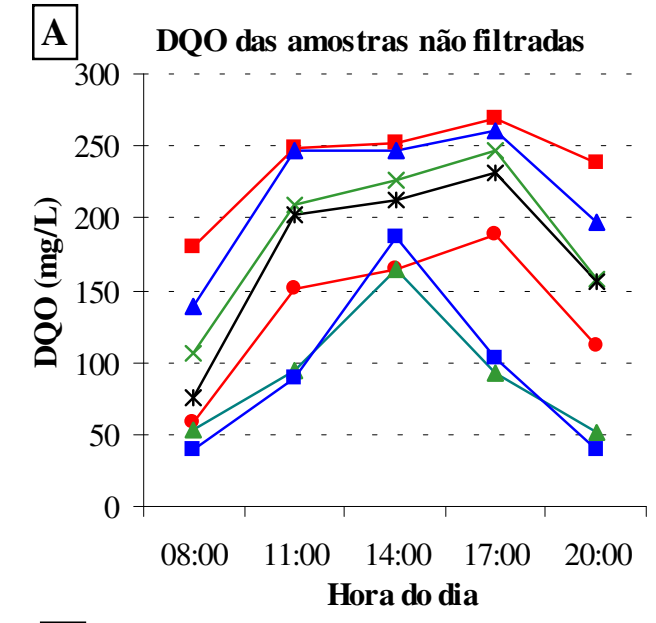

D DQO das amostras não filtradas

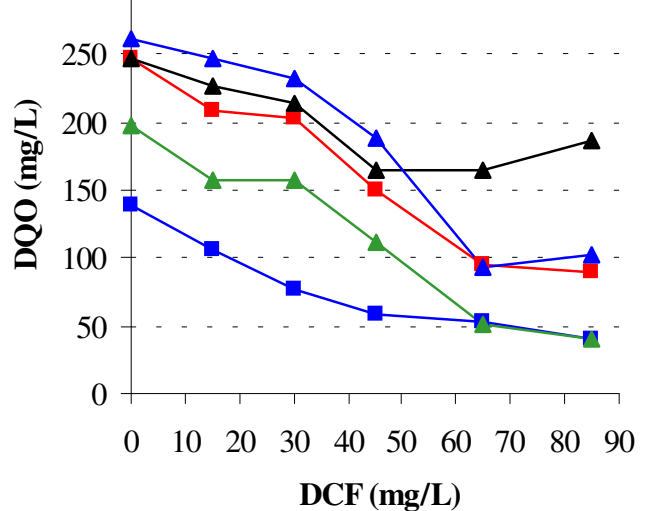

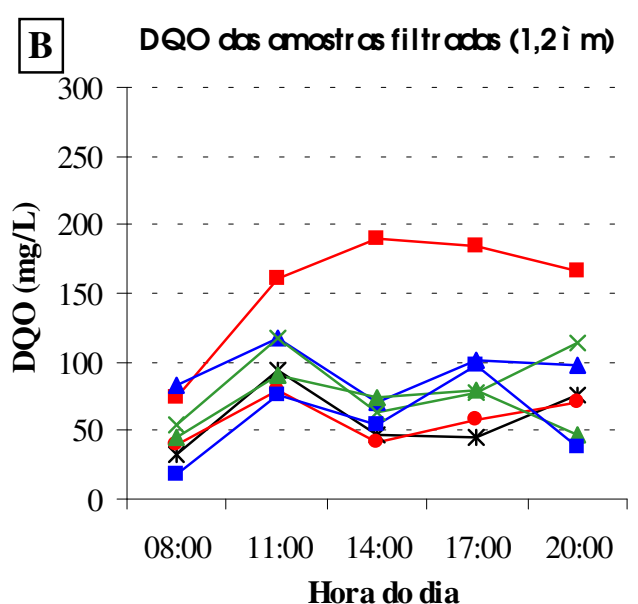

E DQO dos amostr os filtr adbs $(1,2$ i m)

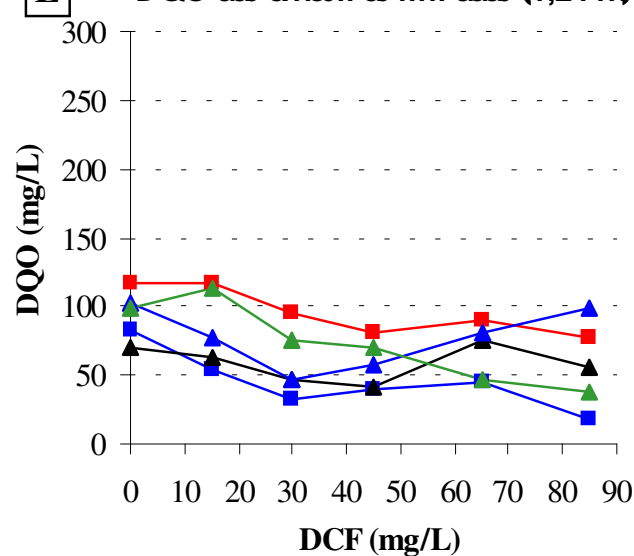

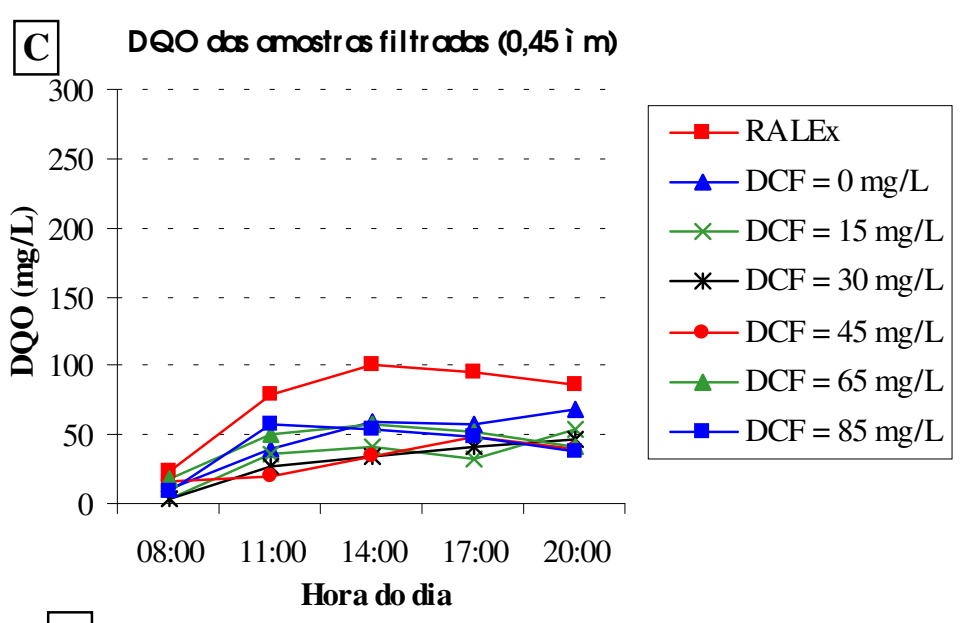
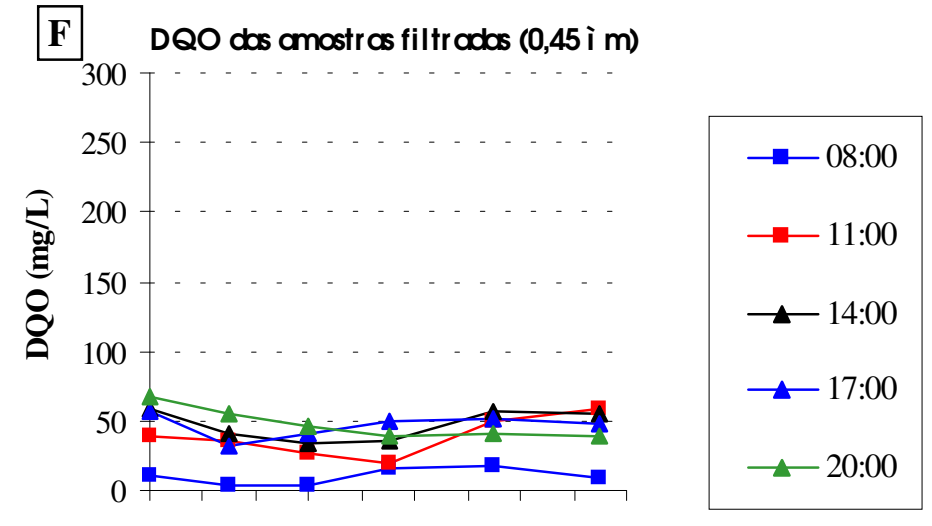

$\begin{array}{llllllllll}0 & 10 & 20 & 30 & 40 & 50 & 60 & 70 & 80 & 90\end{array}$ $\mathrm{DCF}(\mathrm{mg} / \mathrm{L})$

FIGURA 5.34 - Demanda química de oxigênio (DQO) das amostras coletadas nos ensaios com variação da dosagem de cloreto férrico para coagulação/floculação/flotação de amostras de efluente do reator anaeróbio coletadas ao longo do dia. Ensaios realizados com o equipamento de flotateste e efluente do reator RALEx. Gmr=1000 s ${ }^{-1}$; Tmr=10 s; Gf=80 s ${ }^{-1}$ Tf $=20 \mathrm{~min} ; \mathrm{R}=20 \%$; Psat=450 kPa e Vf=10 cm/min. 
A remoção de fósforo do meio líquido é dependente de dois fatores distintos: i) a precipitação do fósforo na forma dissolvida, com geração de material particulado e ii) a atuação de sistema capaz de promover a separação das fases líquida e sólida. Ou seja, caso parcela do fósforo esteja na forma particulada, sua remoção somente depende de sistema eficiente na separação das fases. Entretanto, caso parcela do fósforo esteja na forma dissolvida, sua remoção depende de sua completa precipitação, gerando material particulado, e, somente então, de sistema eficiente na separação das fases.

Como se pode observar nas FIGURAS 5.35D a 5.35F, grande parcela (entre $87 \%$ e 92\%) de fósforo presente no efluente do reator RALEx está constituída por sólidos com tamanho médio inferior a $0,45 \mu \mathrm{m}$ (material dissolvido e finamente coloidal). Entre 2,2\% e $5,0 \%$ estavam presentes na forma de sólidos com tamanho médio entre $0,45 \mu \mathrm{m}$ e 1,2 $\mu \mathrm{m}$ (material coloidal) e entre $2,6 \%$ e $8,4 \%$ em sólidos com tamanho médio superior a $1,2 \mu \mathrm{m}$ (material particulado). Desta forma, a eficiente remoção de fósforo depende inicialmente da precipitação da parcela dissolvida e/ou finamente coloidal. Considerando os atuais níveis de concentração de fósforo no efluente do reator anaeróbio, dosagens iguais ou acima de 45 $\mathrm{mgFeCl}_{3} / \mathrm{L}$ são suficientes para precipitação de mais de $88 \%$ da carga de fósforo com tamanho médio inferior a $0,45 \mu \mathrm{m}$, resultando em concentrações de fósforo inferiores a 0,50 $\mathrm{mg} / \mathrm{L}$ no efluente do flotateste filtrado em membrana com $\phi=0,45 \mu \mathrm{m}$ (FIGURA 5.35F). Entretanto, o material particulado formado a partir da adição de $45 \mathrm{mgFeCl}_{3} / \mathrm{L}$ não resultou em flocos com boas características de flotabilidade. A FIGURA 5.35D mostra que, para a referida dosagem, a concentração de fósforo total no efluente do flotateste esteve entre 1,32 e $2,26 \mathrm{mg} / \mathrm{L}$, com remoções entre $59 \%$ e $76 \%$. Na situação de aplicação de $65 \mathrm{mgFeCl} / 3 / \mathrm{L}$, o material particulado formado resultou em flocos com razoável flotabilidade. A FIGURA 5.35D mostra que, para a referida dosagem, a concentração de fósforo total no efluente do flotateste foi entre 0,30 e $0,97 \mathrm{mg} / \mathrm{L}$, com remoções entre $84 \%$ e $94 \%$. Somente com aplicação de $85 \mathrm{mgFeCl}_{3} / \mathrm{L}$, o material particulado formado resultou em flocos com boa flotabilidade. A FIGURA 5.35D mostra que, para a referida dosagem, a concentração de fósforo total no efluente do flotateste oscilou entre praticamente ausente (não detectado) e $0,17 \mathrm{mg} / \mathrm{L}$, com remoções acima de $97 \%$.

Desta forma, a elevada remoção de fósforo depende, a partir de dosagens de 45 $\mathrm{mgFeCl}_{3} / \mathrm{L}$, das características de flotabilidade dos flocos formados, tendo em vista que grande parcela do material dissolvido foi precipitada. As características de flotabilidade podem ser modificadas pela variação de $\mathrm{pH}$ de coagulação ou pela adição de polímeros sintéticos, possibilitando a manutenção de elevadas remoções de fósforo e baixa adição de cloreto férrico. 
A FIGURA 5.36 mostra um fluxograma-resumo dos ensaios realizados com amostra do efluente do RALEx coletada às 11:00, com $\mathrm{DQO}=248 \mathrm{mg} / \mathrm{L}$, turbidez=78,0 uT, $\mathrm{P}=5,96$ $\mathrm{mg} / \mathrm{L}$ e com aplicação de dosagens de cloreto férrico entre 0 e $85 \mathrm{mg} / \mathrm{L}$ e Vflot=10 cm/min.

$\mathrm{O}$ aumento da dosagem de cloreto férrico elevou gradativamente a eficiência de remoção de turbidez, desde $11,8 \%$ até $97,8 \%$, respectivamente para DCF entre 0 e $85 \mathrm{mg} / \mathrm{L}$. Todos os aumentos de dosagem de cloreto férrico implicaram em elevação da remoção de turbidez para toda a faixa de DCF testada.

A remoção de DQO da amostra não filtrada, entretanto, não apresentou o mesmo comportamento. A eficiência de remoção elevou-se gradualmente, entre $0,8 \%$ e $61,7 \%$, para valores entre 0 e $65 \mathrm{mgFeCl}_{3} / \mathrm{L}$. Entre 65 e $85 \mathrm{mgFeCl}_{3} / \mathrm{L}$, praticamente não houve melhoria na remoção de DQO. Através da análise das amostras filtradas em membranas com $\phi=1,2$ $\mu \mathrm{m}$, pode-se perceber que o uso de DCF entre 65 e $85 \mathrm{mg} / \mathrm{L}$ proporcionou excelente remoção de sólidos suspensos, visto que a "DQO retida" variou entre 5 e $14 \mathrm{mg} / \mathrm{L}$, valores bastante reduzidos.

$\mathrm{O}$ uso de dosagens entre 30 e $85 \mathrm{mgFeCl}_{3} / \mathrm{L}$ resultou em DQO das amostras filtradas em membrana com $\phi=1,2 \mu \mathrm{m}$ com valores entre 76 e $94 \mathrm{mg} / \mathrm{L}$, ou seja, valores muito próximos entre si, indicando que $30 \mathrm{mgFeCl}_{3} / \mathrm{L}$ já foram suficientes para coagular parte considerável do material finamente particulado presente na amostra de efluente do RALEx. Ainda que sendo suficiente para tal, não o foi para proporcionar boa flotabilidade aos sólidos formados. As melhores condições de flotabilidade somente foram alcançadas para dosagens acima de $45 \mathrm{mgFeCl}_{3} / \mathrm{L}$. Através da análise das amostras filtradas em membranas com $\phi=0,45 \mu \mathrm{m}$, observa-se que o efluente apresentou DQO oscilando entre 20 e $58 \mathrm{mg} / \mathrm{L}$, valores bastante próximos e sem comportamento definido em função do aumento da dosagem de cloreto férrico. Verifica-se, então, que a adição ou a ausência de cloreto férrico não influenciou na remoção de sólidos da amostra na referida faixa de tamanho.

$\mathrm{O}$ aumento da dosagem de cloreto férrico elevou gradativamente a eficiência de remoção de fósforo, desde $21,0 \%$ até $97,1 \%$, respectivamente para DCF entre 0 e $85 \mathrm{mg} / \mathrm{L}$. Todos os aumentos de dosagem de cloreto férrico implicaram em elevação da remoção de fósforo para toda a faixa de DCF testada. Vale lembrar que, em função da padronização dos procedimentos de ensaio e embora a amostra de efluente do RALEx não tenha recebido cloreto férrico quando $\mathrm{DCF}=0 \mathrm{mg} / \mathrm{L}$, em todos os ensaios houve a fase de "mistura rápida" de "floculação".

A remoção de fósforo quando $\mathrm{DCF}=0 \mathrm{mg} / \mathrm{L}$ pode ser resultante da agregação de polímeros naturais, ainda presentes na superfície dos sólidos, e da intercolisão, promovida durante a agitação mecânica, com conseqüente remoção dos flocos durante a flotação. 

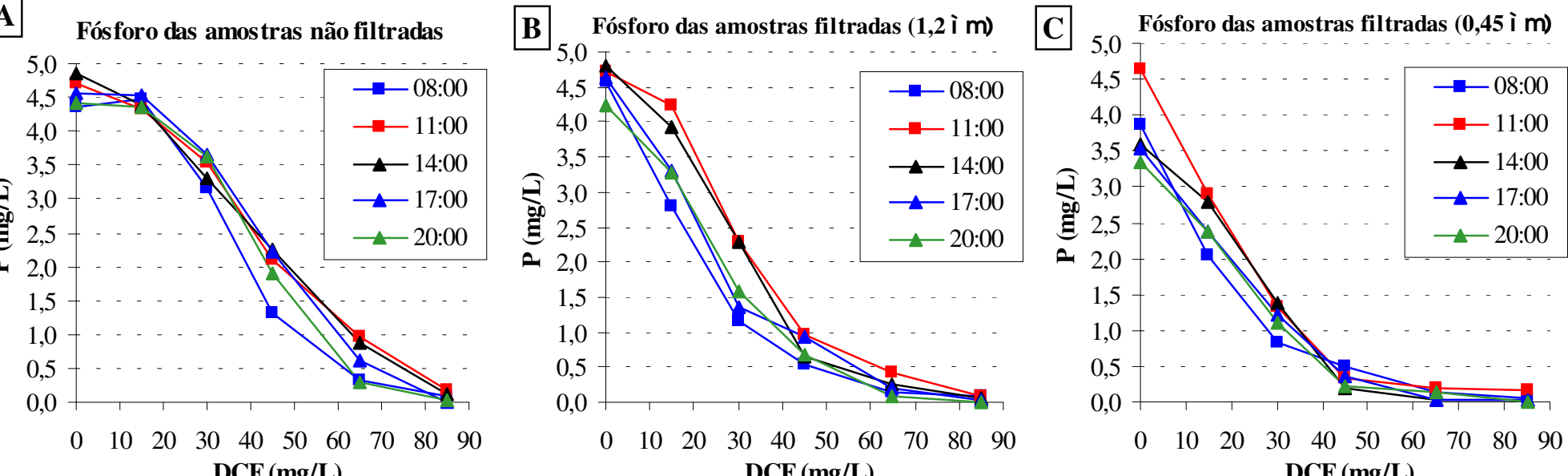

D Fósforo das amostras não filtradas
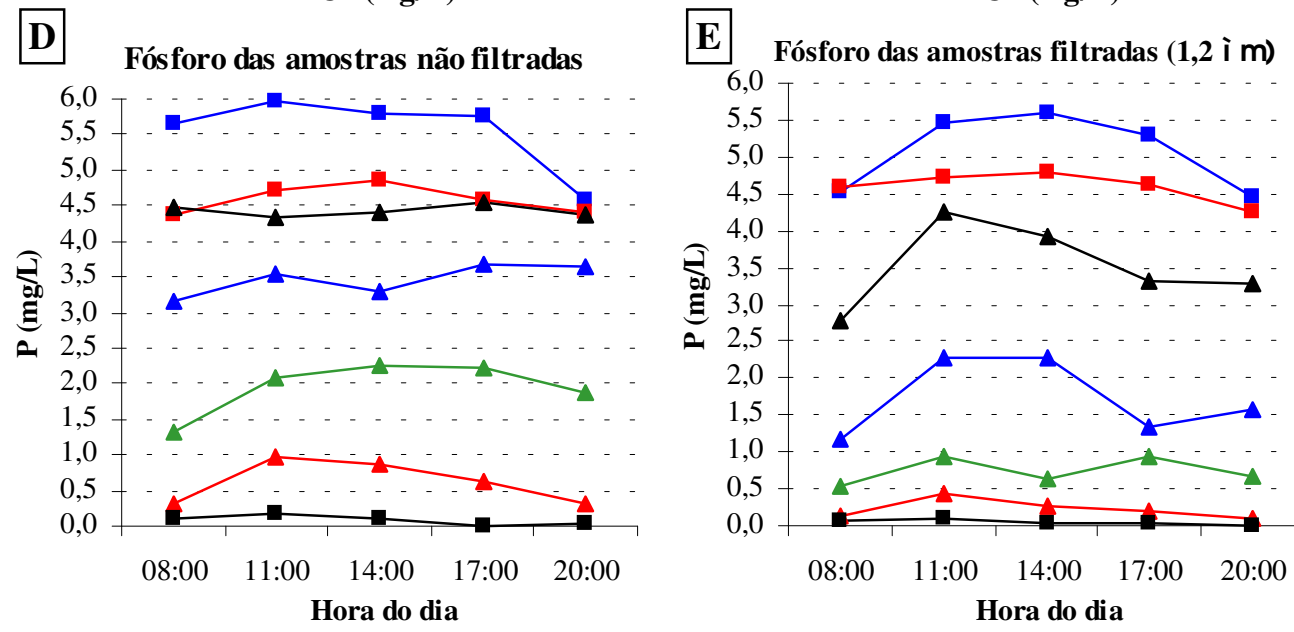

$\mathbf{F}$

$$
\text { DCF }(\mathbf{m g} / \mathbf{L})
$$
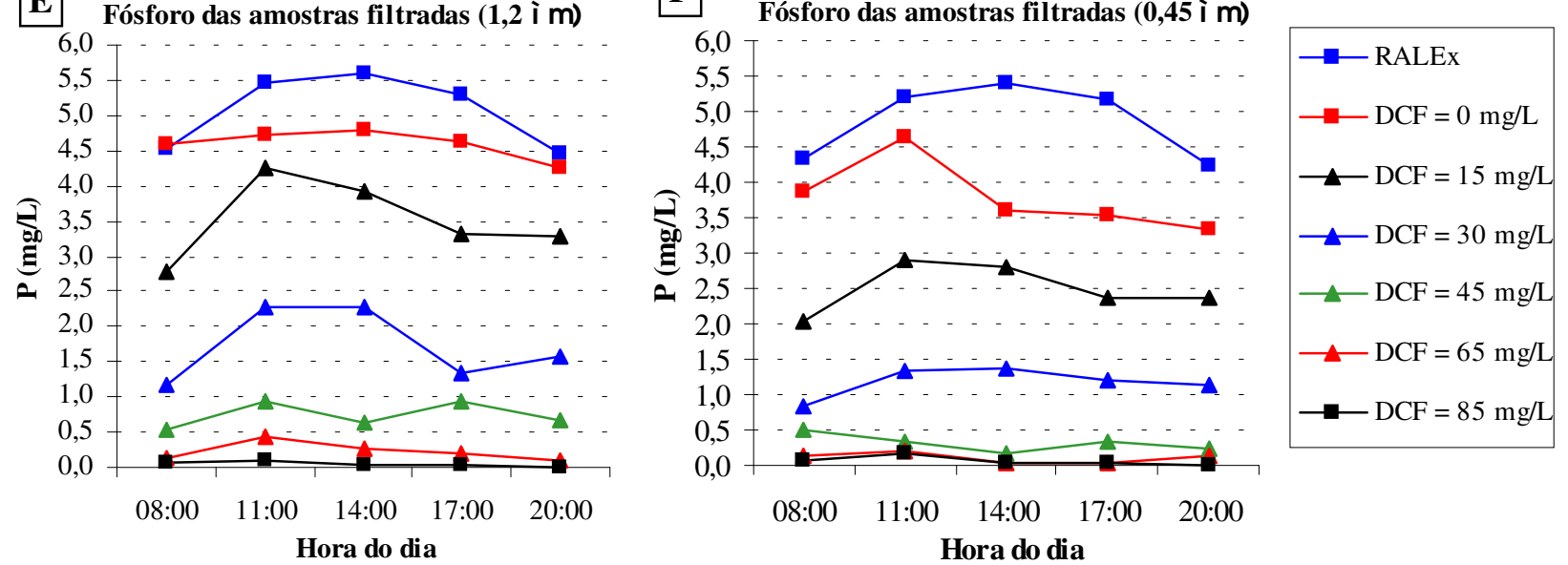

FIGURA 5.35 - Concentração de fósforo $(\mathrm{P})$ das amostras coletadas nos ensaios com variação da dosagem de cloreto férrico para coagulação/ floculação/flotação de amostras de efluente do reator anaeróbio coletadas ao longo do dia. Ensaios realizados com o equipamento de flotateste e efluente do reator RALEx. $\mathrm{Gmr}=1000 \mathrm{~s}^{-1} ; \mathrm{Tmr}=10 \mathrm{~s} ; \mathrm{Gf}=80 \mathrm{~s}^{-1} ; \mathrm{Tf}=20 \mathrm{~min} ; \mathrm{R}=20 \%$; Psat=450 $\mathrm{kPa}$. 


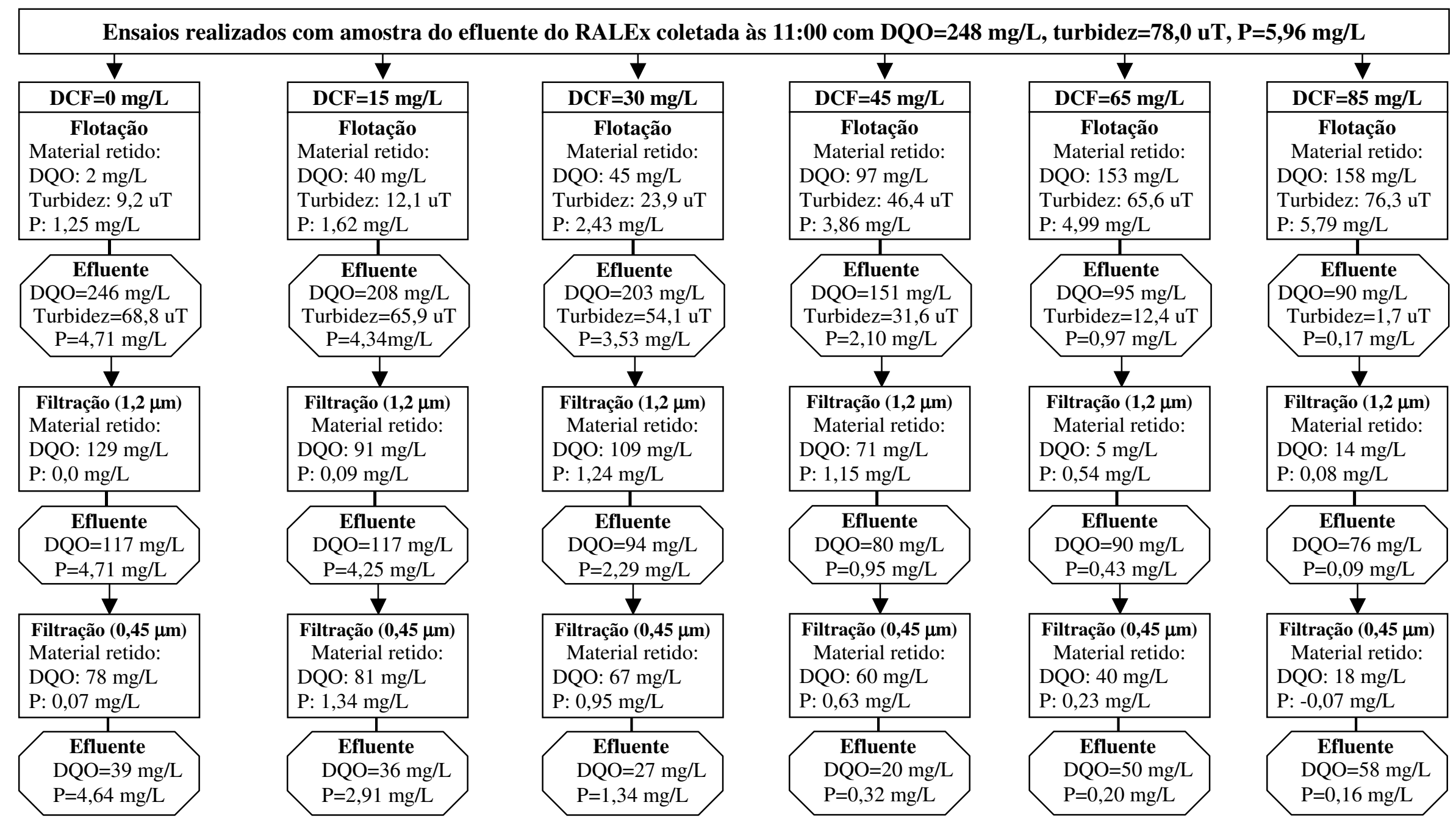

FIGURA 5.36 - Fluxograma-resumo dos ensaios realizados com amostra do efluente do RALEx coletada às 11:00, com DQO=248 mg/L, turbidez=78,0 uT, P=5,96 mg/L e com aplicação de dosagens de cloreto férrico entre 0 e $85 \mathrm{mg} / \mathrm{L}$ e Vflot=10 cm/min. 
Quando DCF=0 mg/L, cerca de 98,5\% do fósforo existente na amostra não filtrada também estava presente na amostra filtrada em membrana com $\phi=0,45 \mu \mathrm{m}$, demonstrando que praticamente todo o fósforo residual presente estava na forma coloidal ou dissolvida. À medida que a dosagem de cloreto férrico era elevada, reduzia-se a presença de fósforo, em amostra filtrada com membrana de $\phi=0,45 \mu \mathrm{m}$. A redução era decorrente da precipitação do fósforo, com geração de sólidos com tamanho superior a $0,45 \mu \mathrm{m}$. A redução de "fósforo retido" em membrana de $\phi=0,45 \mu \mathrm{m}$ indicou que a elevação de DCF resultou em aumento do tamanho médio das partículas, para valores superiores a $1,2 \mu \mathrm{m}$, tornando-as passíveis, então, de serem eficientemente removidas pela flotação.

\subsubsection{Ensaios com variação da dosagem de cloreto férrico e do pH de coagulação para coagulação/floculação/flotação de amostras de efluente anaeróbio.}

São relatados os resultados obtidos nos ensaios descritos no item 4.7.7. Nessa etapa da pesquisa foram realizados ensaios com o objetivo de investigar a variação da qualidade do efluente do flotateste mediante variação do pH de coagulação quando da adição de diferentes dosagens de cloreto férrico (entre 0 e $85 \mathrm{mg} / \mathrm{L}$ ). Os demais parâmetros operacionais foram mantidos fixos: $\mathrm{Gmr}=1000 \mathrm{~s}^{-1}$; Tmr=10 s; $\mathrm{Gf}=80 \mathrm{~s}^{-1} ; \mathrm{Tf}=20 \mathrm{~min} ; \mathrm{R}=20 \%$; Psat=450 $\pm 10 \mathrm{kPa}$.

A discussão baseia-se na eficiência de remoção de turbidez, entre velocidades de flotação de 5 a $25 \mathrm{~cm} / \mathrm{min}$, e de DQO e de fósforo (P) das amostras não filtradas e das amostras filtradas em membranas com abertura média de $1,2 \mu \mathrm{m}$ e $0,45 \mu \mathrm{m}$, coletadas nos ensaios em velocidade de flotação de $10 \mathrm{~cm} / \mathrm{min}$.

As FIGURAS 5.37A a 5.37E apresentam, na ordenada esquerda, os valores de fração de turbidez remanescente e, na ordenada direita, os respectivos valores de turbidez do efluente do flotateste em função da velocidade de flotação para diferentes dosagens de cloreto férrico, entre 15 e $85 \mathrm{mg} / \mathrm{L}$, e diferentes valores de $\mathrm{pH}$ de coagulação. Para facilitar a comparação entre as diversas curvas de flotação, os valores de turbidez observados nas amostras coletadas no ensaio sem adição de cloreto férrico ( $\mathrm{DCF}=0 \mathrm{mg} / \mathrm{L}$ e pH=6,4) estão presentes em todos os gráficos. Para $\mathrm{Vf}=10 \mathrm{~cm} / \mathrm{min}$, a flotação direta do efluente do reator RALEx produziu amostra com 8,7 uT (89,6\% de eficiência de remoção).

$\mathrm{Na}$ FIGURA 5.37A, pode-se observar que a adição de $15 \mathrm{mgFeCl}_{3} / \mathrm{L}$, em valores de pH de coagulação maiores de 5,2, resultou em qualidade do efluente do flotateste inferior àquela observada em ensaio sem adição de cloreto férrico. $O$ efluente do flotateste somente apresentou qualidade superior quando o pH de coagulação foi de 4,6, com turbidez de 4,4 uT para $\mathrm{Vf}=10 \mathrm{~cm} / \mathrm{min}$. 
Na FIGURA 5.37B, pode-se observar que a adição de $30 \mathrm{mgFeCl}_{3} / \mathrm{L}$, em valores de $\mathrm{pH}$ de coagulação gradativamente menores, resultou em qualidade do efluente do flotateste gradativamente melhor do que aquela observada em ensaio sem adição de cloreto férrico. $\mathrm{O}$ efluente do flotateste apresentou turbidez de 8,5 uT para $\mathrm{pH}$ de 6,3 e, à medida que o pH diminuía, a turbidez das amostras também era reduzida. No pH de 5,0, a turbidez da amostra foi de $0,9 \mathrm{uT}$, com respectiva eficiência de remoção de $99,0 \%$, para $\mathrm{Vf}=10 \mathrm{~cm} / \mathrm{min}$.

Na FIGURA 5.37C, pode-se observar que a adição de $45 \mathrm{mgFeCl}_{3} / \mathrm{L}$, em valores de pH de coagulação gradativamente menores, resultou em qualidade do efluente do flotateste gradativamente melhor e bastante inferior àquela observada em ensaio sem adição de cloreto férrico, ainda que a melhora da qualidade das amostras tenha sido relativamente pequena. $\mathrm{O}$ efluente do flotateste apresentou turbidez de 4,1 uT para $\mathrm{pH}$ de 6,2 e, à medida que o pH diminuía, a turbidez das amostras também era reduzida. No pH de 4,4, a turbidez da amostra foi de $0,6 \mathrm{uT}$, com respectiva eficiência de remoção de $99,4 \%$, para $\mathrm{Vf}=10 \mathrm{~cm} / \mathrm{min}$.

Na FIGURA 5.37D, pode-se observar que a adição de $65 \mathrm{mgFeCl}_{3} / \mathrm{L}$, em valores de $\mathrm{pH}$ de coagulação entre 5,4 e 6,0 e em $\mathrm{Vf}=10 \mathrm{~cm} / \mathrm{min}$, resultou em qualidade do efluente do flotateste praticamente constante, com turbidez em torno de 1,9 uT, e bastante inferior àquela observada em ensaio sem adição de cloreto férrico. Entretanto, para valores de $\mathrm{pH}$ menores de 5,4, a turbidez das amostras apresentou tendência de elevação. Com pH de 5,0 a turbidez foi de 2,8 uT e com pH de 4,7 observou-se turbidez de 5,8 uT.

Na FIGURA 5.37E, pode-se observar que a adição de $85 \mathrm{mgFeCl}_{3} / \mathrm{L}$, em valores de pH de coagulação entre 5,0 e 6,0, resultou em valores de turbidez entre 3,0 e 4,1 uT, para $\mathrm{Vf}=10 \mathrm{~cm} / \mathrm{min}$, apresentando qualidade inferior àquela observada em ensaio com adição de $65 \mathrm{mg} / \mathrm{L}$ de cloreto férrico.

Basicamente, houve duas alternativas para obtenção de amostra coletada após ensaio com turbidez abaixo de 4 uT, em Vflot=10 cm/min. Para DCF entre 15 e $30 \mathrm{mg} / \mathrm{L}$, a redução do $\mathrm{pH}$ para valores entre 4,5 e 5,0 foi fundamental para coleta de amostra com baixa turbidez. Para $\mathrm{DCF}=45 \mathrm{mg} / \mathrm{L}$, toda a faixa de $\mathrm{pH}$ de coagulação testada, entre 4,3 e 6,2, resultou em amostra com turbidez abaixo de $4 \mathrm{uT}$. Porém, quanto menor o $\mathrm{pH}$, menor a turbidez das amostras, indicando que a redução dos valores de $\mathrm{pH}$ foi benéfica ao desempenho da flotação. Para DCF entre 65 e $85 \mathrm{mg} / \mathrm{L}$, o uso de $\mathrm{pH}$ acima de 5,0 resultou em amostras com menores valores de turbidez do que aquelas com $\mathrm{pH}$ menor que 5,0.

Desta forma, a aplicação isolada de DCF entre 15 e $30 \mathrm{mg} / \mathrm{L}$ não foi alternativa recomendável para obtenção de efluente com elevada qualidade em termos de turbidez, tendo em vista os baixos valores de pH. Já para DCF entre 45 e $85 \mathrm{mg} / \mathrm{L}$, tendo em vista que a qualidade do efluente não dependia de baixos valores de $\mathrm{pH}$, seu uso foi recomendável, com a vantagem adicional de que elimina a necessidade de correção de $\mathrm{pH}$. 

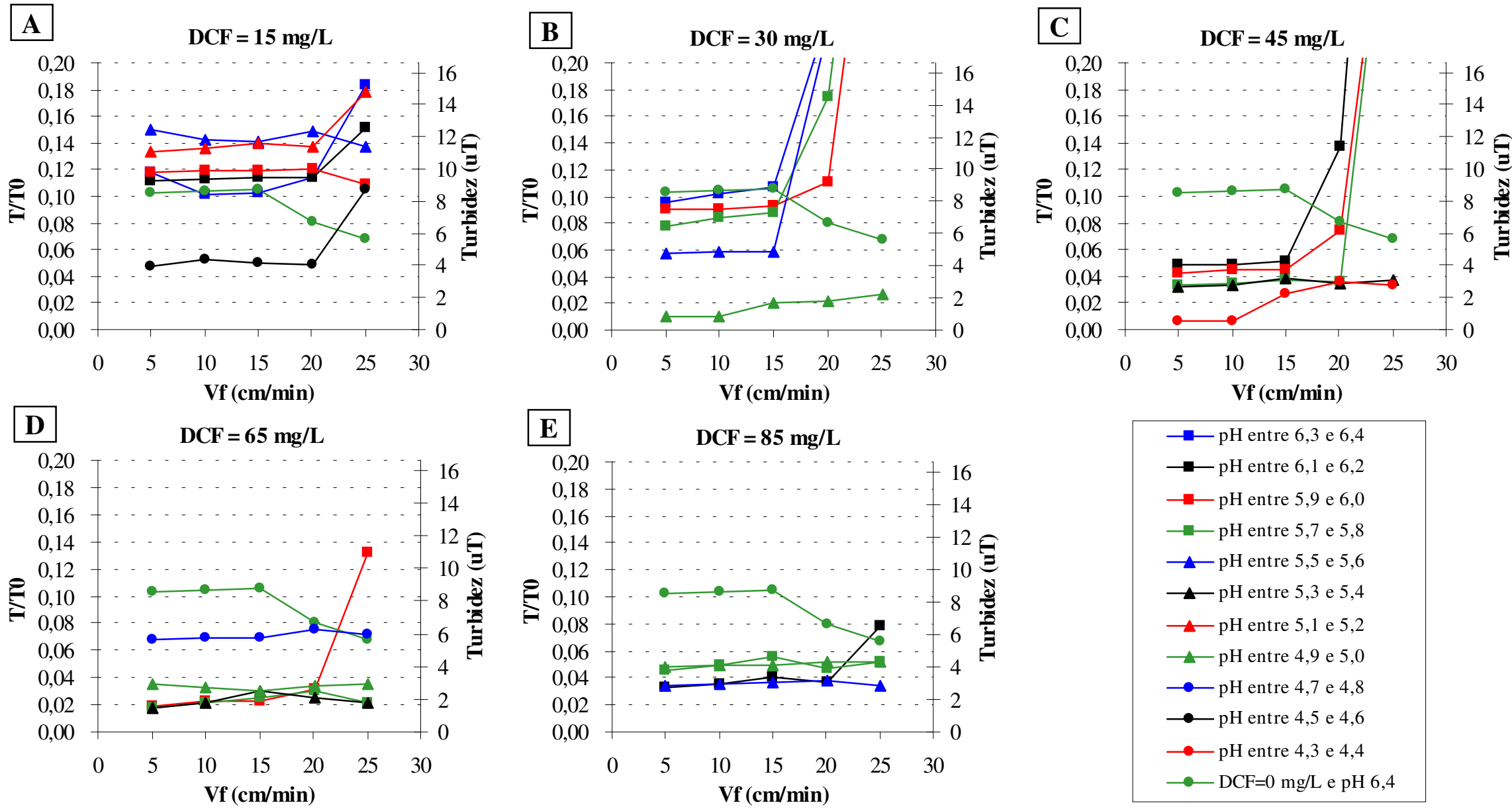

FIGURA 5.37 - Fração remanescente de turbidez (T/T0) e turbidez das amostras coletadas nos ensaios com variação da dosagem de cloreto férrico e do $\mathrm{pH}$ de coagulação para coagulação/floculação/flotação de amostras de efluente do reator anaeróbio. Ensaios realizados com o equipamento de flotateste e efluente do reator RALEx. Horário de coleta: 08:00; Gmr=1000 s ${ }^{-1}$ Tmr=10 s; Gf=80 s${ }^{-1} ; \mathrm{Tf}=20 \mathrm{~min}$; R=20\%; Psat $=450 \mathrm{kPa}$. 
As FIGURAS 5.38A a 5.38C apresentam, na ordenada esquerda, os valores de DQO das amostras flotadas e, na ordenada direita, os respectivos valores de fração remanescente de DQO em função da velocidade de flotação para diferentes dosagens de cloreto férrico, entre 0 e $85 \mathrm{mg} / \mathrm{L}$, e diferentes valores de pH de coagulação. Na FIGURA 5.38A, os valores de DQO apresentados são referentes a amostras não filtradas. Na FIGURA 5.38B, os valores de DQO apresentados são referentes a amostras filtradas em membranas com abertura média de 1,2 $\mu \mathrm{m}$. Na FIGURA 5.38C, os valores de DQO apresentados são referentes a amostras filtradas em membranas com abertura média de $0,45 \mu \mathrm{m}$.

Observando a FIGURA 5.38A, verifica-se que a flotação direta, sem adição de cloreto férrico, produziu efluente com $104 \mathrm{mg} / \mathrm{L}$ de DQO. Para $15 \mathrm{mgFeCl}_{3} / \mathrm{L} \mathrm{e} \mathrm{pH}$ de 6,4, a DQO observada na amostra do flotateste foi de $76 \mathrm{mg} / \mathrm{L}$, enquanto no $\mathrm{pH}$ de 4,6, a DQO da amostra do flotateste foi de $36 \mathrm{mg} / \mathrm{L}$.

A redução do $\mathrm{pH}$ de coagulação proporcionou significativo aumento na remoção de DQO das amostras para $15 \mathrm{mgFeCl}_{3} / \mathrm{L}$.

Para $30 \mathrm{mgFeCl}_{3} / \mathrm{L}$ e pH de 6,3, a DQO observada na amostra do flotateste foi de 43 $\mathrm{mg} / \mathrm{L}$, enquanto no $\mathrm{pH}$ de 5,0, a DQO da amostra do flotateste foi de $27 \mathrm{mg} / \mathrm{L}$.

A redução do $\mathrm{pH}$ de coagulação proporcionou ligeiro aumento na remoção de DQO das amostras para $30 \mathrm{mgFeCl}_{3} / \mathrm{L}$.

Para dosagens entre 45 e $85 \mathrm{mgFeCl}_{3} / \mathrm{L}$ e valores de $\mathrm{pH}$ entre 4,4 e 6,2, a DQO observada nas amostras flotadas variou entre 25 e $40 \mathrm{mg} / \mathrm{L}$, sem padrão de comportamento definido. Para essa faixa de valores, a redução de pH de coagulação não elevou a remoção de DQO.

Analisando a FIGURA 5.38B, observa-se que a flotação direta, sem adição de cloreto férrico, produziu efluente com $48 \mathrm{mg} / \mathrm{L}$ de DQO. Para $15 \mathrm{mgFeCl}_{3} / \mathrm{L}$ e pH entre 4,6 e 6,4, a DQO observada nas amostras do flotateste variou entre 37 e $54 \mathrm{mg} / \mathrm{L}$, sem padrão de comportamento definido. Para dosagens entre 30 e $85 \mathrm{mgFeCl}_{3} / \mathrm{L}$ e valores de $\mathrm{pH}$ entre $4,4 \mathrm{e}$ 6,3 , a DQO observada nas amostras flotadas variou entre 25 e $41 \mathrm{mg} / \mathrm{L}$, sem padrão de comportamento definido.

Desta forma, a redução do $\mathrm{pH}$ não apresentou influência na remoção de matéria orgânica correspondente a sólidos com tamanho médio abaixo de 1,2 $\mu \mathrm{m}$.

Estudando a FIGURA 5.38C, vê-se que a flotação direta, sem adição de cloreto férrico, produziu efluente com $42 \mathrm{mg} / \mathrm{L}$ de DQO. Para dosagens entre 15 e $85 \mathrm{mgFeCl}_{3} / \mathrm{L}$ e valores de $\mathrm{pH}$ entre 4,4 e 6,4, a DQO observada nas amostras flotadas variou entre 25 e 45 $\mathrm{mg} / \mathrm{L}$, sem padrão de comportamento definido. 
Sendo assim, nem a adição de cloreto férrico e nem a redução do $\mathrm{pH}$ apresentou influência na remoção de matéria orgânica correspondente a sólidos com tamanho médio abaixo de $0,45 \mu \mathrm{m}$.

Observando a FIGURA 5.39A, verifica-se que a flotação direta, sem adição de cloreto férrico, produziu efluente com 4,75 mgP/L. Para $15 \mathrm{mgFeCl}_{3} / \mathrm{L}$ e $\mathrm{pH}$ de 6,4 , observou-se na amostra do flotateste 4,80 mgP/L, enquanto no $\mathrm{pH}$ de 4,6 a amostra do flotateste apresentava 3,02 $\mathrm{mgP} / \mathrm{L}$.

A redução do $\mathrm{pH}$ de coagulação proporcionou aumento na remoção de fósforo das amostras para dosagem de $15 \mathrm{mgFeCl}_{3} / \mathrm{L}$, sobretudo ao considerar que no $\mathrm{pH}$ de 6,4 não houve remoção de fósforo. Ainda assim, a concentração final de fósforo nas amostras flotadas é relativamente elevada.

Para $30 \mathrm{mgFeCl}_{3} / \mathrm{L}$ e pH de 6,3, observou-se na amostra do flotateste $2,38 \mathrm{mgP} / \mathrm{L}$, enquanto no $\mathrm{pH}$ de 5,0 a amostra do flotateste apresentou $0,71 \mathrm{mgP} / \mathrm{L}$.

A redução do $\mathrm{pH}$ de coagulação proporcionou aumento na remoção de fósforo das amostras para $30 \mathrm{mgFeCl}_{3} / \mathrm{L}$.

Para $45 \mathrm{mgFeCl}_{3} / \mathrm{L}$ e $\mathrm{pH}$ de 6,2 , observou-se na amostra do flotateste $1,17 \mathrm{mgP} / \mathrm{L}$, enquanto no $\mathrm{pH}$ de 4,4 a amostra do flotateste apresentou $0,11 \mathrm{mgP} / \mathrm{L}$.

Desta vez, a redução do pH de coagulação proporcionou aumento na remoção de fósforo das amostras para $45 \mathrm{mgFeCl}_{3} / \mathrm{L}$, alcançado concentrações remanescentes de fósforo muito reduzidas.

Para $65 \mathrm{mgFeCl}_{3} / \mathrm{L}$ e $\mathrm{pH}$ de 6,0 , observou-se na amostra do flotateste $0,27 \mathrm{mgP} / \mathrm{L}$, enquanto no $\mathrm{pH}$ de 4,7 a amostra do flotateste apresentou 0,07 mgP/L.

Novamente, a redução do $\mathrm{pH}$ de coagulação proporcionou aumento na remoção de
fósforo das amostras para $65 \mathrm{mgFeCl}_{3} / \mathrm{L}$, alcançado concentrações remanescentes de fósforo
muito reduzidas.

Para dosagens de $85 \mathrm{mgFeCl}_{3} / \mathrm{L}$ e valores de $\mathrm{pH}$ entre 5,0 e 6,0, foi observada nas amostras flotadas variação entre 0,06 e $0,13 \mathrm{mgP} / \mathrm{L}$, sem padrão de comportamento definido.

Para dosagens de $85 \mathrm{mgFeCl}_{3} / \mathrm{L}$, a redução de $\mathrm{pH}$ de coagulação não elevou a
remoção de fósforo, porém continuou alcançado concentrações remanescentes de fósforo
muito reduzidas.

Observando as FIGURAS 5.39B e 5.39C, pode-se verificar que redução do pH de coagulação não elevou significativamente a remoção de fósforo em amostras filtradas em membranas com tamanhos de $1,2 \mu \mathrm{m}$ e de $0,45 \mu \mathrm{m}$, respectivamente, ou seja, a precipitação de fósforo não foi substancialmente influenciada pela variação do $\mathrm{pH}$. Entretanto, como esperado, a remoção de fósforo foi significativamente influenciada pela dosagem de cloreto férrico, em todas as faixas de tamanhos de partículas investigadas. 
A DQO das amostras não filtradas para diferentes dosagens de cloreto férrico em diferentes valores de $\mathbf{p H}$ de coagulação
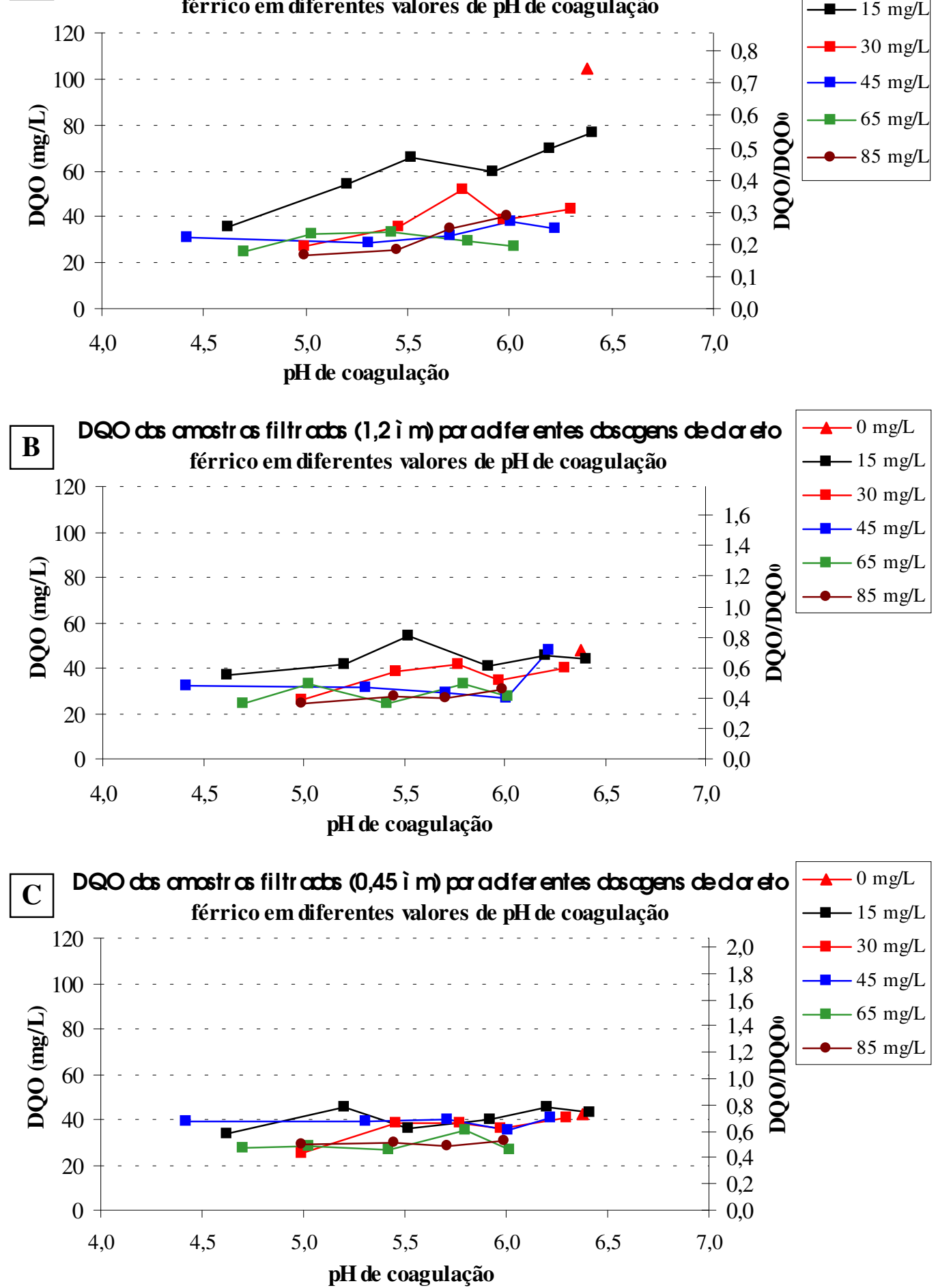

FIGURA 5.38 - Demanda química de oxigênio (DQO) das amostras coletadas nos ensaios com variação da dosagem de cloreto férrico e do $\mathrm{pH}$ de coagulação para coagulação/floculação/flotação de amostras de efluente do reator anaeróbio.

Ensaios realizados com o equipamento de flotateste e efluente do reator RALEx. Horário de coleta: 08:00; $\mathrm{Gmr}=1000 \mathrm{~s}^{-1} ; \mathrm{Tmr}=10 \mathrm{~s} ; \mathrm{Gf}=80 \mathrm{~s}^{-1} ; \mathrm{Tf}=20 \mathrm{~min}$; $\mathrm{R}=20 \%$; Psat=450 $\mathrm{kPa}$. 
A Fósforo das amostras não filtradas para diferentes dosagens de cloreto férrico em diferentes valores de $\mathrm{pH}$ de coagulação

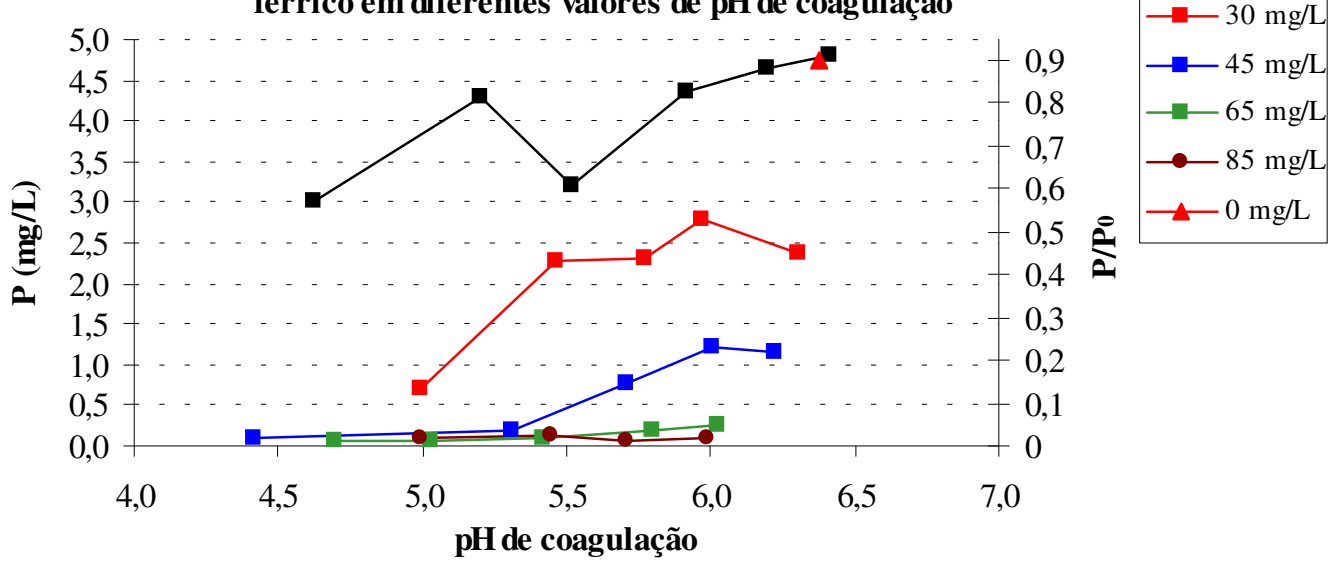

B Fósforo das amostras filtradas (1,2 ì m) por adfer entes doscagens de cloreto férrico em diferentes valores de $\mathrm{pH}$ de coagulação

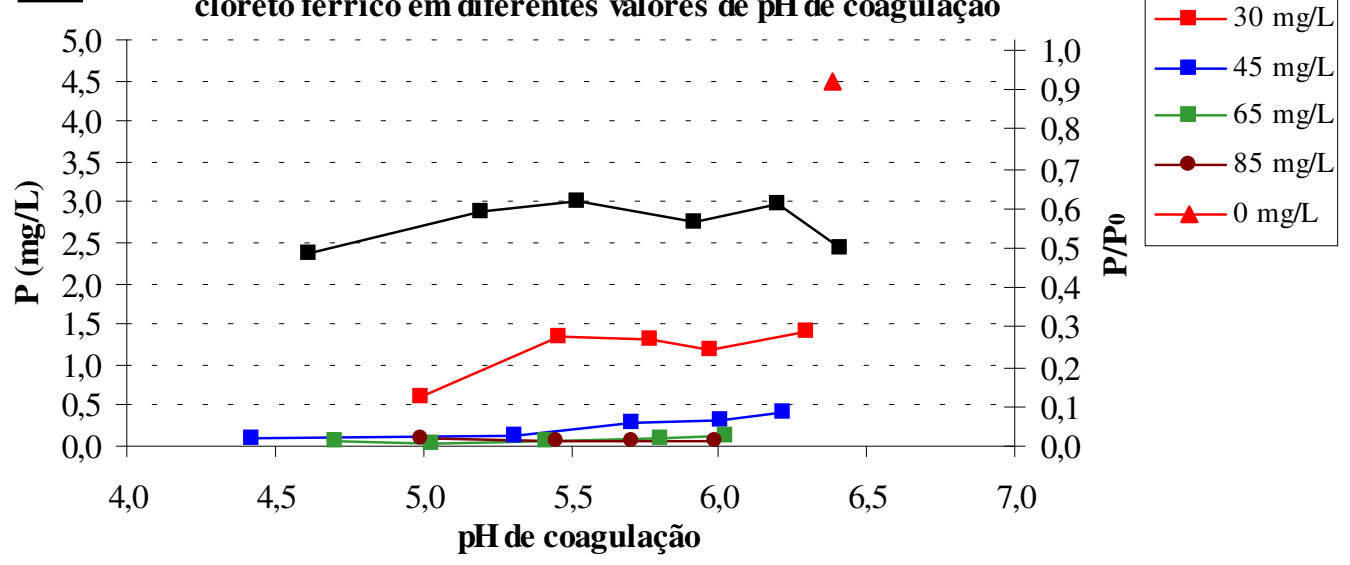

C Fósforo das amostras filtradas $(0,45$ ì m) por adfer entes dbscagens de cloreto férrico em diferentes valores de $\mathrm{pH}$ de coagulação

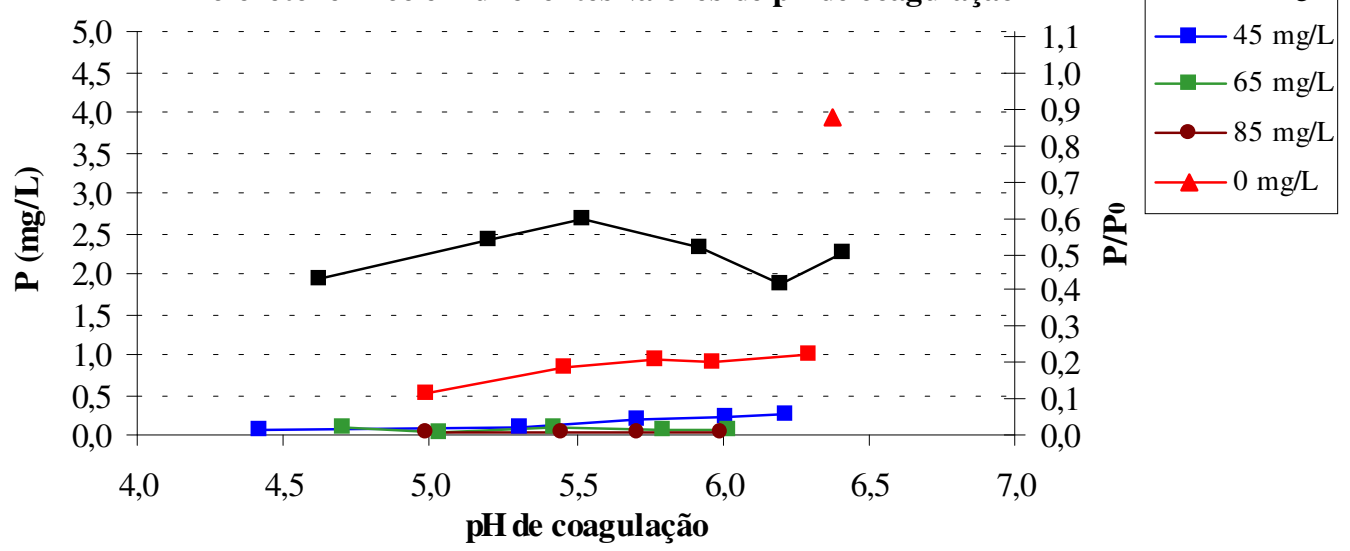

FIGURA 5.39 - Concentração de fósforo (P) das amostras coletadas nos ensaios com variação da dosagem de cloreto férrico e do $\mathrm{pH}$ de coagulação para coagulação/floculação/flotação de amostras de efluente do reator anaeróbio.

Ensaios realizados com o equipamento de flotateste e efluente do reator RALEx. Horário de coleta: 08:00; $\mathrm{Gmr}=1000 \mathrm{~s}^{-1} ; \mathrm{Tmr}=10 \mathrm{~s} ; \mathrm{Gf}=80 \mathrm{~s}^{-1} ; \mathrm{Tf}=20 \mathrm{~min}$; $\mathrm{R}=20 \%$; Psat $=450 \mathrm{kPa}$. 


\subsection{Ensaios realizados na instalação piloto de flotação por ar dissolvido}

Os ensaios de laboratório com o flotateste forneceram valores de dosagem de coagulante, tempo de floculação, gradiente médio de velocidade de floculação e quantidade de ar fornecida ao processo para os dois produtos químicos testados: cloreto férrico e polímero sintético. Esses parâmetros foram diretamente utilizados na operação da instalação piloto. Ainda assim, os valores de tempo de floculação, de gradiente médio de velocidade de floculação e de quantidade de ar fornecido foram novamente investigados, de forma a verificar a sua influência quando do aumento de escala.

Os resultados obtidos durante os ensaios com a instalação piloto de flotação utilizando somente cloreto férrico são apresentados no item 5.6.1.

No item 5.6.2, são apresentados os resultados obtidos durante os ensaios com a instalação piloto de flotação utilizando cloreto férrico associado a polímero catiônico.

\subsubsection{Ensaios com a instalação piloto de flotação utilizando somente cloreto férrico.}

São relatados os resultados obtidos nos ensaios descritos no item 4.9.2. Nessa etapa da pesquisa, foram realizados ensaios com o objetivo de investigar a variação da qualidade do efluente do flotateste ao longo do dia (entre 08:00 e 20:00) mediante adoção de diferentes parâmetros operacionais do flotador, tais como dosagem de cloreto férrico (DCF), gradiente médio de velocidade de floculação (Gf), tempo de floculação (Tf), quantidade de ar fornecida ao processo ( $\mathrm{S}^{*}$ ) e taxa de aplicação superficial (TAS). Convém lembrar que os parâmetros operacionais adotados apresentam menor amplitude de variação do que aqueles utilizados em laboratório, tendo em vista que os ensaios com o flotateste forneceram dados conclusivos que permitiram estreitar a gama de valores a serem testadas em escala piloto.

Foram utilizadas dosagens de cloreto férrico de 30; 50; 70 e $90 \mathrm{mg} / \mathrm{L}$. Os valores de gradiente médio de velocidade de floculação foram iguais a 60,80 e $100 \mathrm{~s}^{-1}$. Adotaram-se dois valores de tempo de floculação, 13 e 20 min. Frações de recirculação de $12 \%$ e $18 \%$

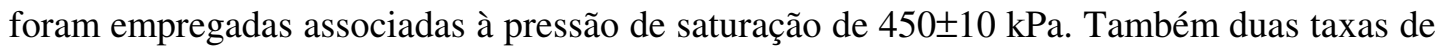
aplicação superficial foram estudadas: 180 e $250 \mathrm{~m}^{3} / \mathrm{m}^{2} / \mathrm{d}$.

A discussão baseia-se na eficiência de remoção de turbidez, de DQO, de fósforo e de sólidos suspensos totais das amostras não filtradas.

\subsubsection{Ensaios com a instalação piloto de flotação operada com $T A S=180 \mathrm{~m}^{3} / \mathrm{m}^{2} / \mathrm{d}$.}

São relatados os ensaios com a instalação piloto de flotação operada com 180 $\mathrm{m}^{3} / \mathrm{m}^{2} / \mathrm{d}$ de taxa de aplicação superficial. Nesses ensaios, foram investigados dois valores de fração de recirculação (R de $12 \%$ e de $18 \%$ e $450 \mathrm{kPa}$ ). 


\subsection{Ensaios com a instalação piloto de flotação operada com $R=12 \%$.}

São relatados os ensaios com a instalação piloto de flotação operada com $12 \%$ de recirculação e pressão de saturação de $450 \mathrm{kPa}$. Nesses ensaios, foram investigados dois

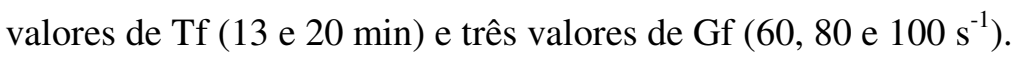

A FIGURA 5.40 apresenta os valores de temperatura, de pH, de turbidez, de DQO, de fósforo e de sólidos suspensos totais do efluente do flotateste em função do horário de coleta das amostras quando os seguintes parâmetros operacionais foram adotados: $\mathrm{DCF}=50$ $\mathrm{mg} / \mathrm{L}, \mathrm{Gf}=60 \mathrm{~s}^{-1}, \mathrm{Tf}=13 \mathrm{~min}, \mathrm{R}=12 \%$, Psat $=450 \mathrm{kPa}$ e TAS $=180 \mathrm{~m}^{3} / \mathrm{m}^{2} / \mathrm{dia}$.

A temperatura do esgoto bruto variou entre $22,5^{\circ} \mathrm{C}$; às $08: 00$, e $24,5^{\circ} \mathrm{C}$, às $14: 00$. $\mathrm{O}$ efluente do reator anaeróbio apresentou temperaturas entre $21,0^{\circ} \mathrm{C}$ e $25,0^{\circ} \mathrm{C}$ e o efluente do flotador entre $21,2^{\circ} \mathrm{C}$ e $25,7^{\circ} \mathrm{C}$. Em todos os ensaios, as menores temperaturas foram observadas nas amostras coletadas às 08:00 enquanto as maiores temperaturas foram às 14:00. Da mesma forma, o esgoto bruto apresentou a menor amplitude de variação de temperatura, tendo em vista suas características de produção e de transporte, e o efluente do flotador apresentou a maior amplitude de variação de temperatura em função das pequenas dimensões da unidade.

$\mathrm{O}$ pH do esgoto bruto variou entre 6,6 e 7,2, demonstrando que a correção de pH na entrada do RALEx era desnecessária, e por isso mesmo, não foi adotada. O efluente do RALEx apresentou pH entre 6,6 e 6,8 enquanto o $\mathrm{pH}$ do efluente do flotador variou entre 6,4 e 6,7. A redução do pH do líquido ao passar pelo flotador foi decorrente da adição de cloreto férrico.

A turbidez do esgoto bruto apresentou forte variação, com valores entre 235 e 822 uT. O efluente do reator anaeróbio não sofreu forte variação de sua turbidez ao longo do dia, variando entre 187 e 242 uT. A turbidez do efluente do flotador elevou-se gradativamente, de 22,3 uT, às 08:00, a 140 uT, às 17:00. Às 20:00, a turbidez sofreu redução em seu valor para $95,3 \mathrm{uT}$.

O esgoto bruto, ao longo de todos os ensaios, apresentou forte oscilação nos valores de DQO. Neste ensaio, foram observados valores de DQO entre 592 e 1360 mg/L. O RALEx contribuiu eficientemente para redução da carga orgânica, fornecendo efluente com DQO entre 366 e 423 mg/L, com eficiência de remoção média de carga orgânica de 55,1\% entre às 08:00 e às 20:00. A DQO do efluente do flotador elevou-se gradativamente, de $67 \mathrm{mg} / \mathrm{L}$, às 08:00, a $271 \mathrm{mg} / \mathrm{L}$, às 17:00. Às 20:00, a DQO do efluente do flotador sofreu redução em seu valor para 197 mg/L. A eficiência de remoção de carga orgânica promovida pelo flotador 
entre as 08:00 e as 20:00 foi de 53,0\%. A eficiência de remoção global de carga orgânica alcançada pelo sistema RALEx-flotador foi de 78,9\%.

O esgoto bruto, ao longo deste ensaio, também apresentou forte oscilação nos valores de fósforo. Foram observados valores de P entre 5,9 e 12,6 mg/L. O RALEx contribuiu eficientemente para equalização da concentração de fósforo no seu efluente, resultando em valores de $\mathrm{P}$ entre 6,6 e 7,4 mg/L. A concentração de $\mathrm{P}$ do efluente do flotador elevou-se gradativamente, de 1,57 mg/L, às 08:00, a 6,9 mg/L, às 14:00. A partir das 17:00, a concentração de $\mathrm{P}$ do efluente do flotador sofreu gradativa redução em seu valor para até 3,6 mg/L. A eficiência de remoção de carga de fósforo promovida pelo flotador entre as 08:00 e as 20:00 foi de 31,0\%.

O esgoto bruto, ao longo de todos os ensaios, também apresentou forte oscilação nos valores de SST. Neste ensaio, foram observados valores de SST entre 186 e $613 \mathrm{mg} / \mathrm{L}$. O RALEx contribuiu eficientemente para redução da carga de sólidos suspensos, fornecendo efluente com SST entre 111 e 206 mg/L, com eficiência de remoção média de carga de sólidos de 56,4\% entre às 08:00 e às 20:00. A concentração de SST do efluente do flotador elevou-se bruscamente, de $21 \mathrm{mg} / \mathrm{L}$, às 08:00, a $72 \mathrm{mg} / \mathrm{L}$, às 11:00 e daí em diante mantevese oscilando em torno deste valor. A eficiência de remoção de carga de SST promovida pelo flotador entre as 08:00 e as 20:00 foi de 61,1\%. A eficiência de remoção global de carga de SST alcançada pelo sistema RALEx-flotador foi de $83,0 \%$. 

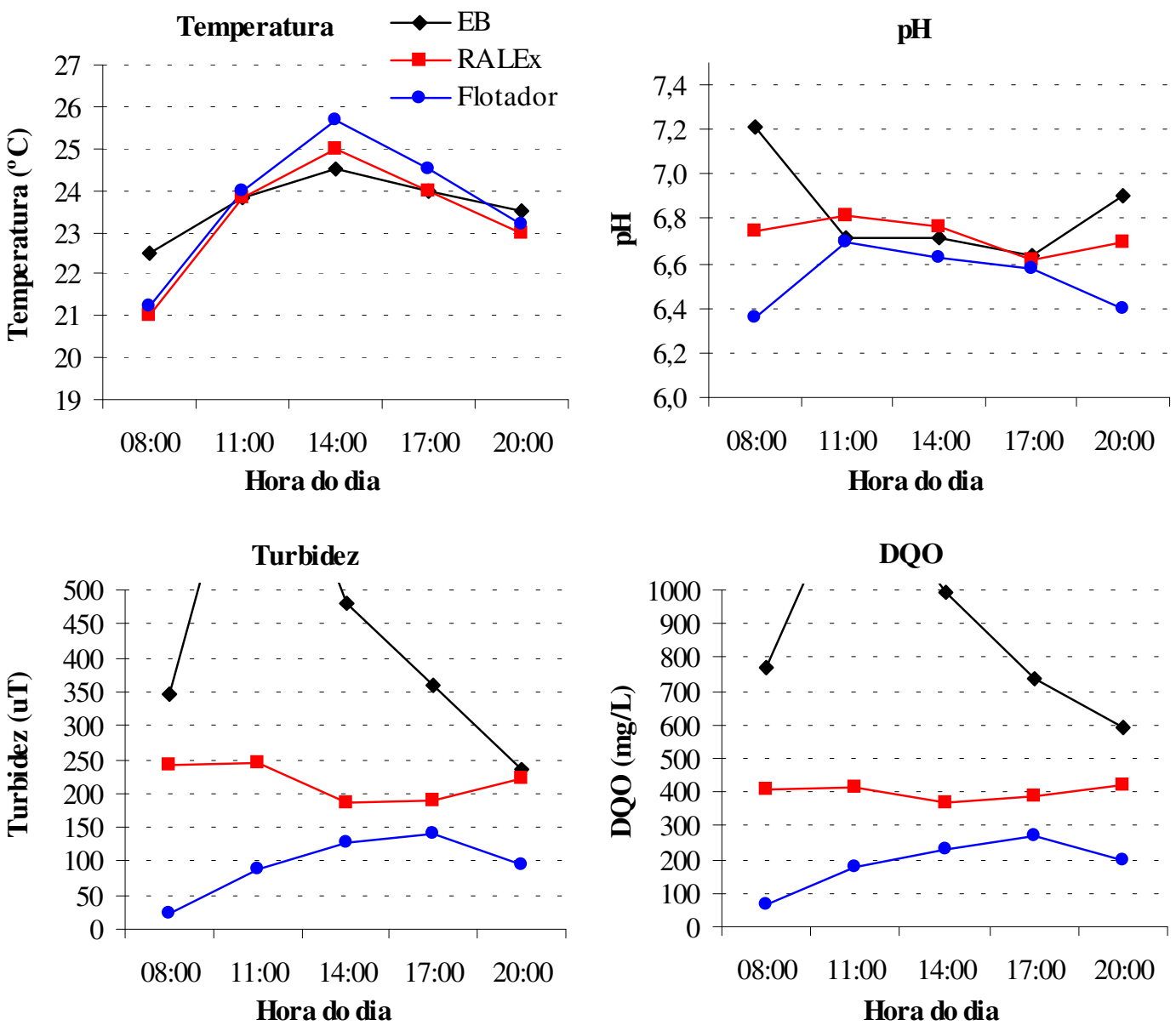

Fósforo
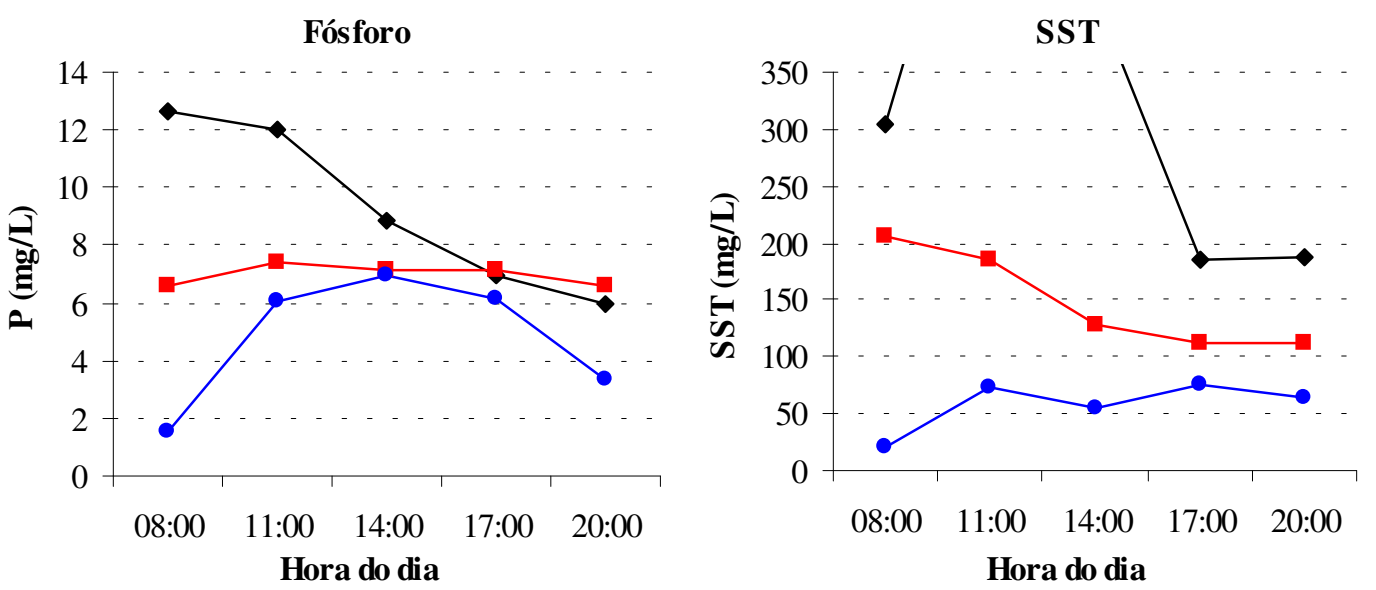

FIGURA 5.40 - Temperatura, pH, turbidez, demanda química de oxigênio, fósforo e sólidos suspensos totais das amostras de esgoto bruto, de efluente do reator RALEx e de efluente do flotador coletadas ao longo do dia de ensaio (31/05/2001).

Ensaios realizados em instalação piloto de coagulação/floculação/flotação por ar dissolvido com escoamento contínuo e efluente do reator RALEx. Data do ensaio: 31/05/2001; DCF=50 mg/L; Gf=60 $\mathrm{s}^{-1} ; \mathrm{Tf}=13 \mathrm{~min} ; \mathrm{R}=12 \%$; Psat=450 kPa; $\mathrm{S} *=13,1 \mathrm{~g} / \mathrm{m}^{3} ;$ TAS $=180 \mathrm{~m}^{3} / \mathrm{m}^{2} /$ dia. 
A FIGURA 5.41 apresenta os valores de temperatura, de $\mathrm{pH}$, de turbidez, de DQO, de fósforo e de sólidos suspensos totais do efluente do flotador em função do horário de coleta das amostras quando os seguintes parâmetros operacionais foram adotados: $\mathrm{DCF}=50$ $\mathrm{mg} / \mathrm{L}, \mathrm{Gf}=80 \mathrm{~s}^{-1}, \mathrm{Tf}=13 \mathrm{~min}, \mathrm{R}=12 \%$, Psat $=450 \mathrm{kPa}$ e TAS $=180 \mathrm{~m}^{3} / \mathrm{m}^{2} / \mathrm{dia}$.

A temperatura do esgoto bruto variou entre $23,0^{\circ} \mathrm{C}$; às $08: 00$, e $25,0^{\circ} \mathrm{C}$, às $14: 00$. O efluente do reator anaeróbio RALEx apresentou temperaturas entre $22,8^{\circ} \mathrm{C}$ e $25,2^{\circ} \mathrm{C}$ e o efluente do flotador entre $22,5^{\circ} \mathrm{C}$ e $25,8^{\circ} \mathrm{C}$. $\mathrm{O} \mathrm{pH}$ do esgoto bruto variou entre 6,8 e 7,1 . O efluente do RALEx apresentou $\mathrm{pH}$ entre 6,6 e 6,9 enquanto o $\mathrm{pH}$ do efluente do flotador variou entre 6,5 e 6,8. A redução do pH do líquido ao passar pelo flotador é decorrente da adição de cloreto férrico. A turbidez do esgoto bruto apresentou razoável variação, com valores entre 201 e 460 uT. O efluente do reator anaeróbio não sofreu forte variação de sua turbidez ao longo do dia, variando entre 189 e $323 \mathrm{uT}$. A turbidez do efluente do flotador elevou-se gradativamente, de 30,0 uT, às 08:00, a 143 uT, às 17:00. Às 20:00, a turbidez sofreu pequena redução em seu valor para $125 \mathrm{uT}$.

O esgoto bruto apresentou forte oscilação nos valores de DQO. Neste ensaio, foram observados valores de DQO entre 503 e $934 \mathrm{mg} / \mathrm{L}$. O reator anaeróbio contribuiu apenas razoavelmente para redução da carga orgânica, fornecendo efluente com DQO entre 386 e $462 \mathrm{mg} / \mathrm{L}$, com eficiência de remoção de carga orgânica de 40,2\% entre às 08:00 e às 20:00. A DQO do efluente do flotador elevou-se gradativamente, de $69 \mathrm{mg} / \mathrm{L}$, às 08:00, a $303 \mathrm{mg} / \mathrm{L}$, às 17:00. Às 20:00, a DQO do efluente do flotador sofreu redução em seu valor para 268 $\mathrm{mg} / \mathrm{L}$. A eficiência de remoção de carga orgânica promovida pelo flotador entre as 08:00 e as 20:00 foi de 49,6\%. A eficiência de remoção global de carga orgânica alcançada pelo sistema RALEx-flotador foi de 70,0\%

Neste ensaio, foram observados valores de P entre 5,9 e 13,6 mg/L. O RALEx contribuiu eficientemente para equalização da concentração de fósforo no seu efluente, resultando em valores de $\mathrm{P}$ entre 6,3 e 7,6 mg/L. A concentração de $\mathrm{P}$ do efluente do flotador elevou-se gradativamente, de 2,72 mg/L, às 08:00, a 6,9 mg/L, às 14:00. A partir das 17:00, a concentração de $\mathrm{P}$ do efluente do flotador sofreu gradativa redução em seu valor para até $5,4 \mathrm{mg} / \mathrm{L}$. A eficiência de remoção de carga de fósforo promovida pelo flotador entre as 08:00 e as 20:00 foi de 21,1\%.

Neste ensaio, foram observados valores de SST entre 154 e 309 mg/L. O RALEx contribuiu moderadamente para redução da carga de sólidos suspensos, fornecendo efluente com SST entre 121e $230 \mathrm{mg} / \mathrm{L}$, com eficiência de remoção média de carga de sólidos de 32,7\% entre às 08:00 e às 20:00. A concentração de SST do efluente do flotador elevou-se bruscamente, de $34 \mathrm{mg} / \mathrm{L}$, às 08:00, a $75 \mathrm{mg} / \mathrm{L}$, às 11:00 e daí em diante manteve-se oscilando em torno deste valor. A eficiência de remoção de carga de SST promovida pelo flotador entre as 08:00 e as 20:00 foi de 55,6\%. A eficiência de remoção global de sólidos suspensos alcançada pelo sistema RALEx-flotador foi de 70,1\%. 

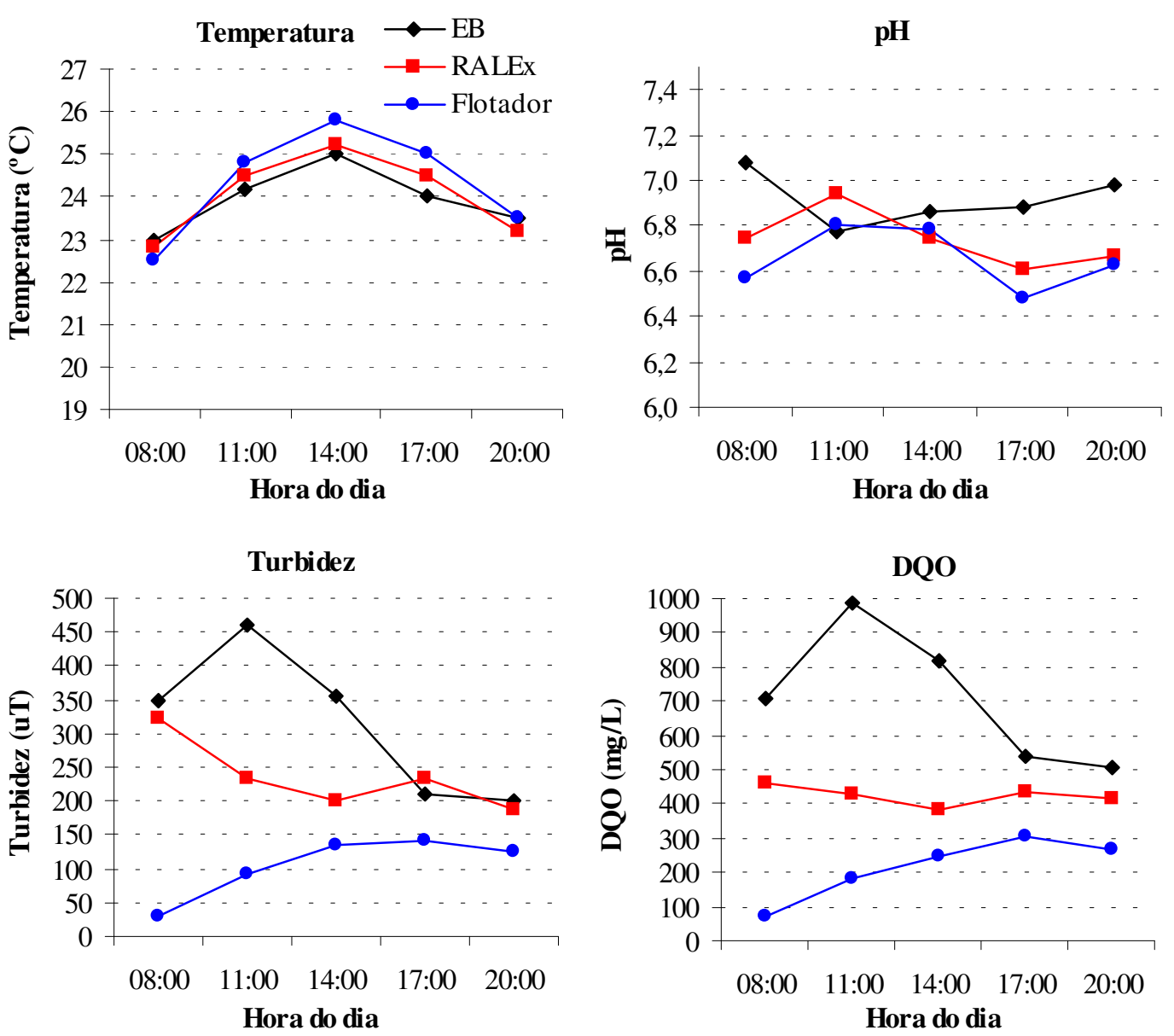

Fósforo
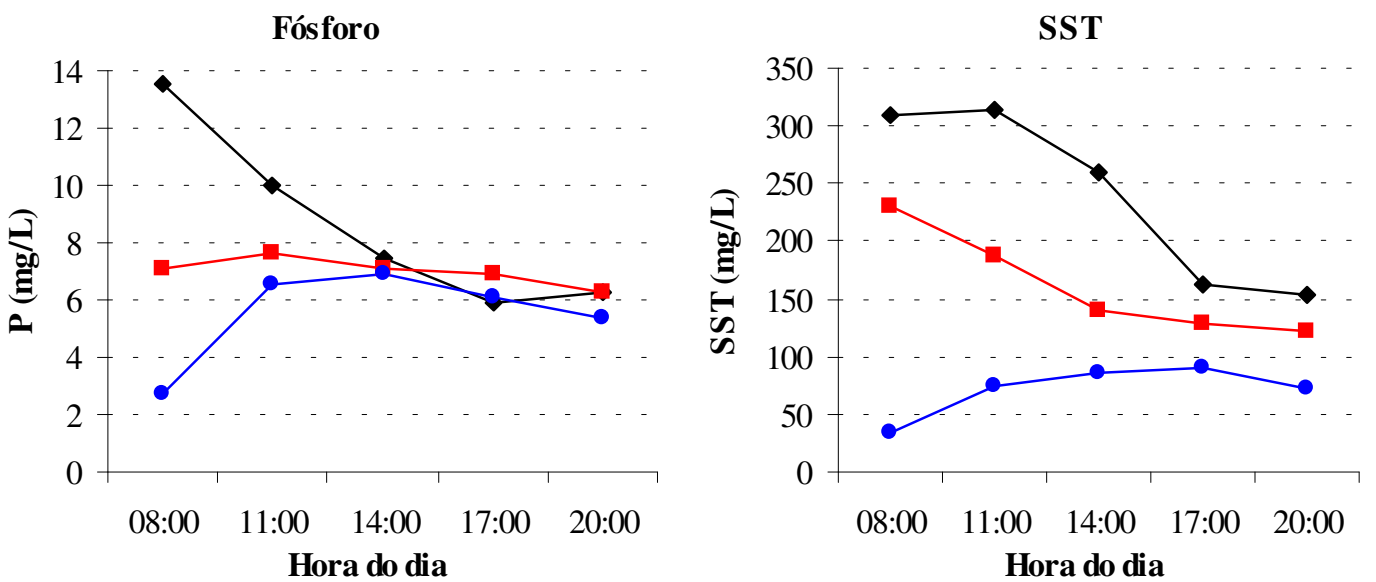

FIGURA 5.41 - Temperatura, pH, turbidez, demanda química de oxigênio, fósforo e sólidos suspensos totais das amostras de esgoto bruto, de efluente do reator RALEx e de efluente do flotador coletadas ao longo do dia de ensaio (01/06/2001). Ensaios realizados em instalação piloto de coagulação/floculação/flotação por ar dissolvido com escoamento contínuo e efluente do reator RALEx. Data do ensaio: 01/06/2001; DCF=50 mg/L; Gf=80 s-1. Tf=13 min; R=12\%; Psat=450 kPa; $\mathrm{S} *=13,1 \mathrm{~g} / \mathrm{m}^{3} ;$ TAS $=180 \mathrm{~m}^{3} / \mathrm{m}^{2} /$ dia. 
A FIGURA 5.42 apresenta os valores de temperatura, de pH, de turbidez, de DQO, de fósforo e de sólidos suspensos totais do efluente do flotador em função do horário de coleta das amostras quando os seguintes parâmetros operacionais foram adotados: $\mathrm{DCF}=50$ $\mathrm{mg} / \mathrm{L}, \mathrm{Gf}=100 \mathrm{~s}^{-1}, \mathrm{Tf}=13 \mathrm{~min}, \mathrm{R}=12 \%$, Psat $=450 \mathrm{kPa}$ e TAS $=180 \mathrm{~m}^{3} / \mathrm{m}^{2} / \mathrm{dia}$.

A temperatura do esgoto bruto variou entre $23,0^{\circ} \mathrm{C}$; às $08: 00$, e $24,5^{\circ} \mathrm{C}$, às $14: 00$. O efluente do reator anaeróbio apresentou temperaturas entre $22,3^{\circ} \mathrm{C}$ e $25,2^{\circ} \mathrm{C}$ e o efluente do flotador entre $22,5^{\circ} \mathrm{C}$ e $26,0^{\circ} \mathrm{C}$.

$\mathrm{O} \mathrm{pH}$ do esgoto bruto variou entre 6,8 e 7,1. O efluente do RALEx apresentou $\mathrm{pH}$ entre 6,7 e 6,9 enquanto o $\mathrm{pH}$ do efluente do flotador variou entre 6,5 e 6,8.

A turbidez do esgoto bruto apresentou razoável variação, com valores entre 179 e 520 uT. O efluente do reator anaeróbio não sofreu forte variação de sua turbidez entre as 08:00 e as 20:00, variando entre 198 e $247 \mathrm{uT}$. A turbidez do efluente do flotador elevou-se gradativamente, de 20,3 uT, às 08:00, a 147 uT, às 17:00. Às 20:00, a turbidez sofreu pequena redução em seu valor para 119 uT.

O esgoto bruto apresentou forte oscilação nos valores de DQO. Neste ensaio, foram observados valores de DQO entre 443 e $1151 \mathrm{mg} / \mathrm{L}$. O RALEx contribuiu apenas razoavelmente para redução da carga orgânica, fornecendo efluente com DQO entre 387 e $570 \mathrm{mg} / \mathrm{L}$, com eficiência de remoção de carga orgânica de 40,0\% entre às 08:00 e às 20:00. A DQO do efluente do flotador elevou-se gradativamente, de $71 \mathrm{mg} / \mathrm{L}$, às 08:00, a $258 \mathrm{mg} / \mathrm{L}$, às 17:00. Às 20:00, a DQO do efluente do flotador sofreu redução em seu valor para 228 $\mathrm{mg} / \mathrm{L}$. A eficiência de remoção de carga orgânica promovida pelo flotador entre as 08:00 e as 20:00 foi de 56,6\%. A eficiência de remoção global de carga orgânica alcançada pelo sistema RALEx-flotador foi de $74,0 \%$.

O esgoto bruto também apresentou forte oscilação nos valores de fósforo. Neste ensaio, foram observados valores de $\mathrm{P}$ entre 5,5 e 12,1 mg/L. O RALEx contribuiu eficientemente para equalização da concentração de fósforo no seu efluente, resultando em valores de $\mathrm{P}$ entre 6,5 e $7,9 \mathrm{mg} / \mathrm{L}$. A concentração de $\mathrm{P}$ do efluente do flotador elevou-se gradativamente, de 1,8 mg/L, às 08:00, a $6,9 \mathrm{mg} / \mathrm{L}$, às 14:00. A partir das 17:00, a concentração de $\mathrm{P}$ do efluente do flotador sofreu gradativa redução em seu valor para até 5,6 $\mathrm{mg} / \mathrm{L}$. A eficiência de remoção de carga de fósforo promovida pelo flotador entre as 08:00 e as 20:00 foi de apenas $28,4 \%$.

O esgoto bruto também apresentou forte oscilação nos valores de SST. Neste ensaio, foram observados valores de SST entre 193 e 416 mg/L. O RALEx contribuiu moderadamente para redução da carga de sólidos suspensos, fornecendo efluente com SST entre 122 e $328 \mathrm{mg} / \mathrm{L}$, com eficiência de remoção média de carga de sólidos de 29,3\% entre às 08:00 e às 20:00. A concentração de SST do efluente do flotador elevou-se gradativamente, de $26 \mathrm{mg} / \mathrm{L}$, às 08:00, a $94 \mathrm{mg} / \mathrm{L}$, às 17:00, diminuindo às 20:00 para 75 $\mathrm{mg} / \mathrm{L}$. A eficiência de remoção de carga de SST promovida pelo flotador entre as 08:00 e as 20:00 foi de $64,0 \%$. A eficiência de remoção global de sólidos suspensos alcançada pelo sistema RALEx-flotador foi de $74,5 \%$. 

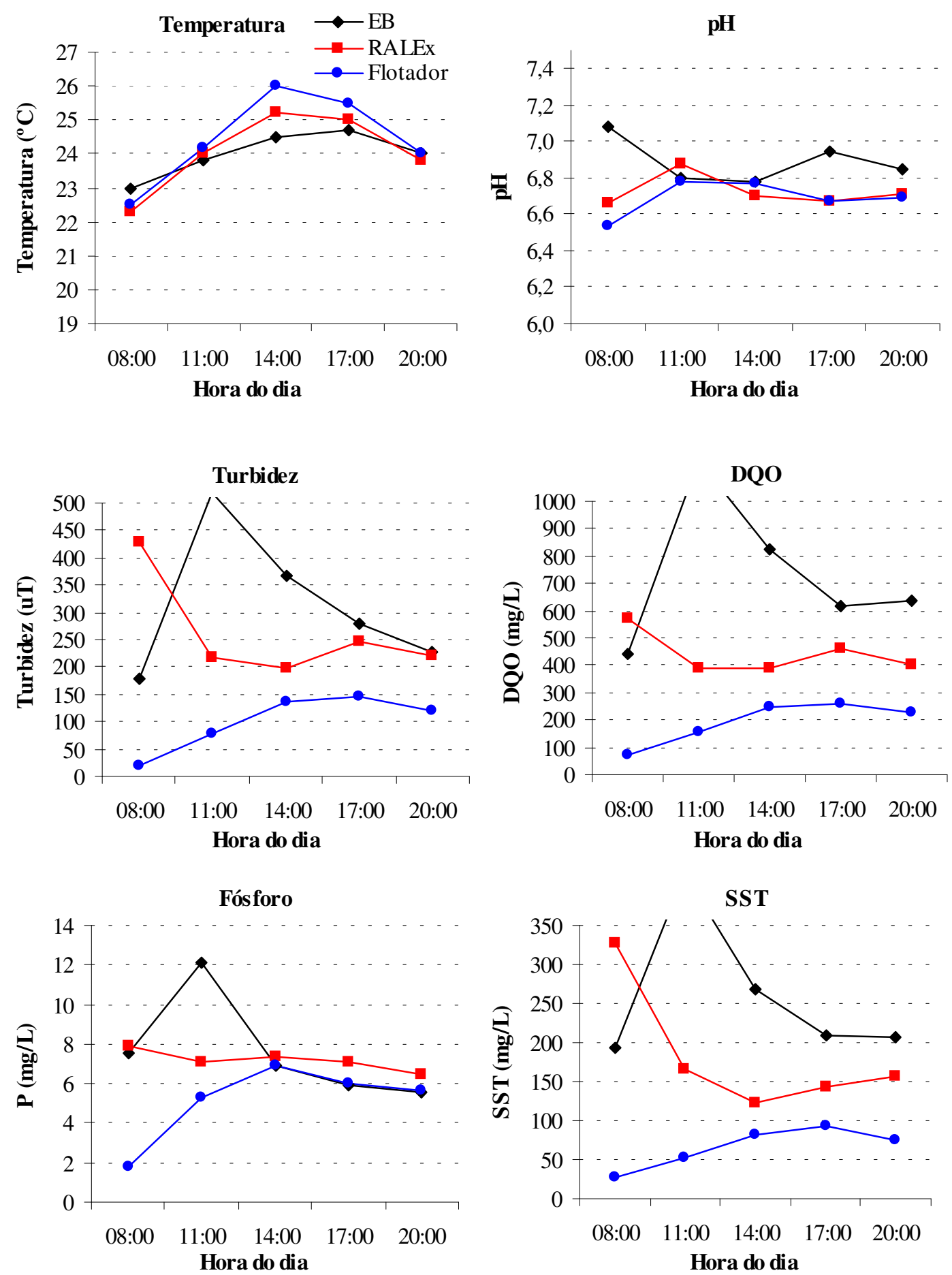

FIGURA 5.42 - Temperatura, pH, turbidez, demanda química de oxigênio, fósforo e sólidos suspensos totais das amostras de esgoto bruto, de efluente do reator RALEx e de efluente do flotador coletadas ao longo do dia de ensaio (02/06/2001).

Ensaios realizados em instalação piloto de coagulação/floculação/flotação por ar dissolvido com escoamento contínuo e efluente do reator RALEx. Data do ensaio: 02/06/2001; DCF=50 mg/L; Gf=100 $\mathrm{s}^{-1} ; \mathrm{Tf}=13 \mathrm{~min} ; \mathrm{R}=12 \%$; Psat=450 kPa; $\mathrm{S}^{*}=13,1 \mathrm{~g} / \mathrm{m}^{3} ;$ TAS $=180 \mathrm{~m}^{3} / \mathrm{m}^{2} / \mathrm{dia}$. 
A FIGURA 5.43 apresenta os valores de temperatura, de $\mathrm{pH}$, de turbidez, de DQO, de fósforo e de sólidos suspensos totais do efluente do flotador em função do horário de coleta das amostras quando os seguintes parâmetros operacionais foram adotados: $\mathrm{DCF}=50$ $\mathrm{mg} / \mathrm{L}, \mathrm{Gf}=60 \mathrm{~s}^{-1}, \mathrm{Tf}=20 \mathrm{~min}, \mathrm{R}=12 \%$, Psat $=450 \mathrm{kPa}$ e TAS $=180 \mathrm{~m}^{3} / \mathrm{m}^{2} / \mathrm{dia}$.

A temperatura do esgoto bruto variou entre $21,0^{\circ} \mathrm{C}$; às $08: 00$, e $23,1^{\circ} \mathrm{C}$, às $14: 00$. $\mathrm{O}$ efluente do reator anaeróbio apresentou temperaturas entre $19,8^{\circ} \mathrm{C}$ e $23,0^{\circ} \mathrm{C}$ e o efluente do flotador entre $20,2^{\circ} \mathrm{C}$ e $23,1^{\circ} \mathrm{C}$.

$\mathrm{O} \mathrm{pH}$ do esgoto bruto variou entre 6,8 e 7,2. O efluente do RALEx apresentou pH entre 6,6 e 6,8 enquanto o $\mathrm{pH}$ do efluente do flotador variou entre 6,4 e 6,6.

A turbidez do esgoto bruto apresentou razoável variação, com valores entre $221 \mathrm{e}$ 380 uT. O efluente do reator anaeróbio sofreu forte variação de sua turbidez entre as 08:00 e as 20:00, variando entre 84,2 e 229 uT. A turbidez do efluente do flotador elevou-se gradativamente, de 26,0 uT, às 08:00, a 96 uT, às 17:00. Às 20:00, a turbidez sofreu pequena redução em seu valor para 77,2 uT.

O esgoto bruto apresentou forte oscilação nos valores de DQO. Neste ensaio, foram observados valores de DQO entre 582 e $1021 \mathrm{mg} / \mathrm{L}$. O RALEx contribuiu moderadamente para redução da carga orgânica, fornecendo efluente com DQO entre 167 e $468 \mathrm{mg} / \mathrm{L}$, com eficiência de remoção de carga orgânica de 53,3\% entre às 08:00 e às 20:00. A DQO do efluente do flotador elevou-se gradativamente, de $76 \mathrm{mg} / \mathrm{L}$, às 08:00, a $210 \mathrm{mg} / \mathrm{L}$, às 17:00. Às 20:00, a DQO do efluente do flotador sofreu redução em seu valor para $167 \mathrm{mg} / \mathrm{L}$. A eficiência de remoção de carga orgânica promovida pelo flotador entre as 08:00 e as 20:00 foi de 56,3\%. A eficiência de remoção global de carga orgânica alcançada pelo sistema RALEx-flotador foi de 79,6\%.

O esgoto bruto também apresentou moderada oscilação nos valores de fósforo. Neste ensaio, foram observados valores de $P$ entre 6,0 e $9,3 \mathrm{mg} / \mathrm{L}$. O RALEx contribuiu razoavelmente para equalização da concentração de fósforo no seu efluente, resultando em valores de $\mathrm{P}$ entre 5,5 e $7,5 \mathrm{mg} / \mathrm{L}$. A concentração de $\mathrm{P}$ do efluente do flotador elevou-se gradativamente, de 2,6 mg/L, às 08:00, a 5,6 mg/L, às 14:00. A partir das 17:00, a concentração de $\mathrm{P}$ do efluente do flotador sofreu gradativa redução em seu valor para até 3,4 $\mathrm{mg} / \mathrm{L}$. A eficiência de remoção de carga de fósforo promovida pelo flotador entre as 08:00 e as 20:00 foi de $35,9 \%$.

O esgoto bruto também apresentou forte oscilação nos valores de SST. Neste ensaio, foram observados valores de SST entre 171 e $337 \mathrm{mg} / \mathrm{L}$. O RALEx contribuiu razoavelmente para redução da carga de sólidos suspensos, fornecendo efluente com SST entre 98 e 185 $\mathrm{mg} / \mathrm{L}$, com eficiência de remoção média de carga de sólidos de 44,6\% entre às 08:00 e às 20:00. A concentração de SST do efluente do flotador elevou-se gradativamente, de 30 $\mathrm{mg} / \mathrm{L}$, às 08:00, a $69 \mathrm{mg} / \mathrm{L}$, às 17:00, diminuindo às 20:00 para $60 \mathrm{mg} / \mathrm{L}$. A eficiência de remoção de carga de SST promovida pelo flotador entre as 08:00 e as 20:00 foi de 60,9\%. A eficiência de remoção global de sólidos suspensos alcançada pelo sistema RALEx-flotador foi de $78,3 \%$. 

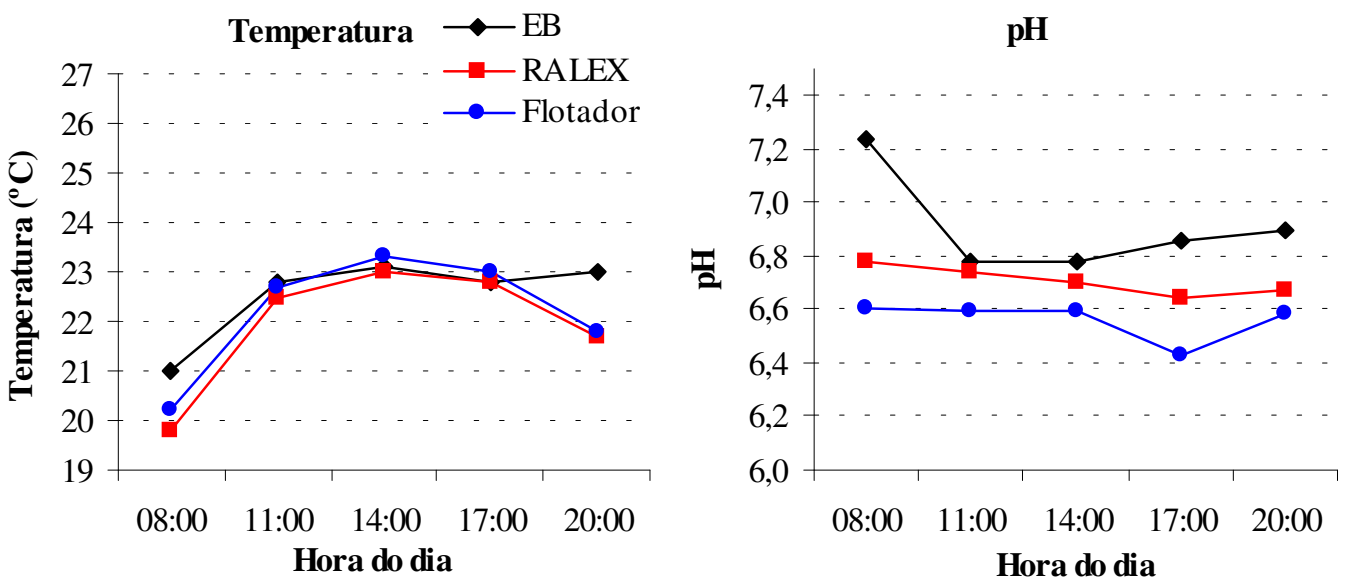

Turbidez
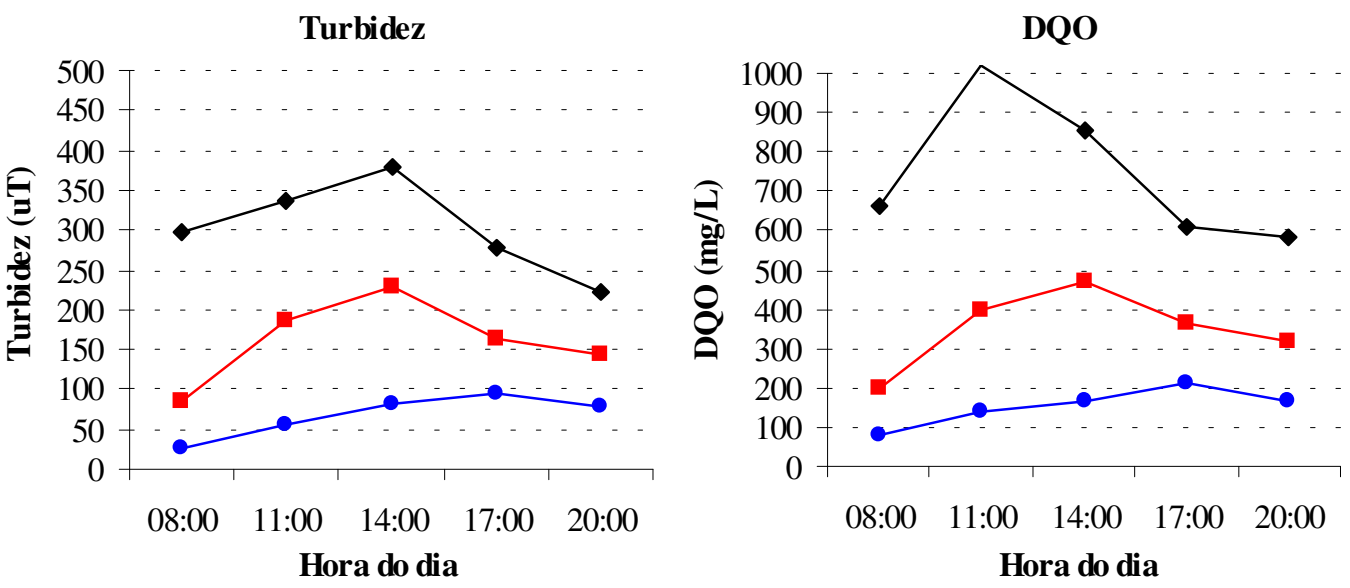

Fósforo
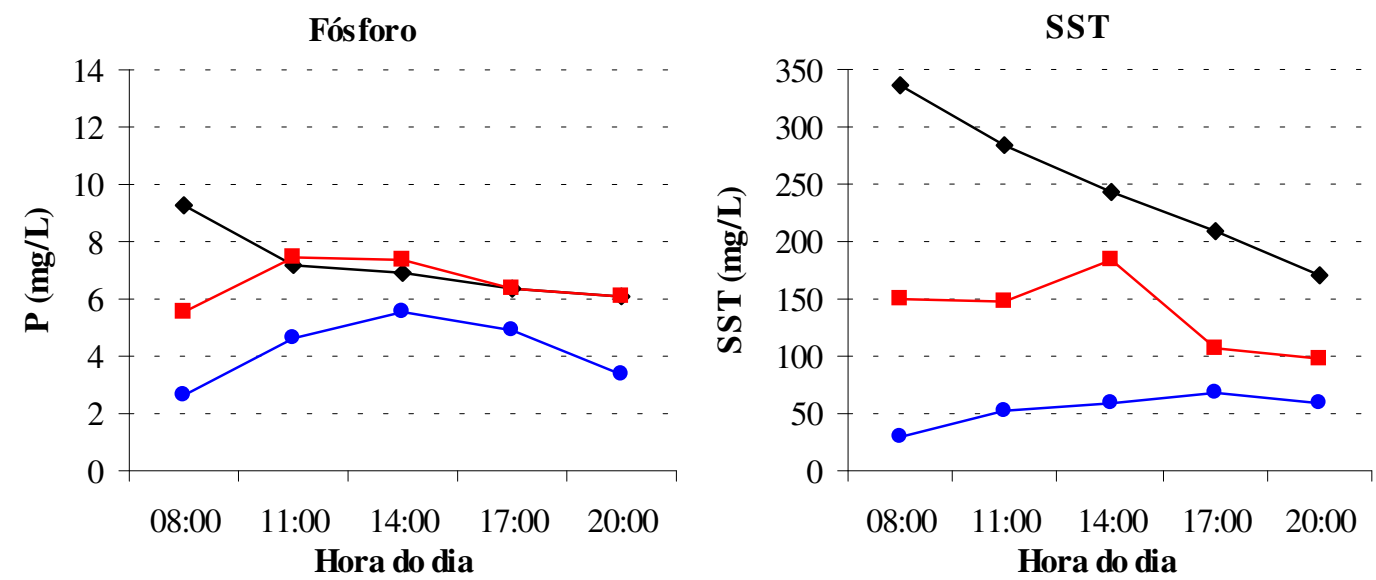

FIGURA 5.43 - Temperatura, pH, turbidez, demanda química de oxigênio, fósforo e sólidos suspensos totais das amostras de esgoto bruto, de efluente do reator RALEx e de efluente do flotador coletadas ao longo do dia de ensaio (23/05/2001).

Ensaios realizados em instalação piloto de coagulação/floculação/flotação por ar dissolvido com escoamento contínuo e efluente do reator RALEx. Data do ensaio: 23/05/2001; DCF=50 mg/L; Gf=60 s-1. Tf=20 min; R=12\%; Psat=450 kPa; $\mathrm{S}^{*}=13,1 \mathrm{~g} / \mathrm{m}^{3} ;$ TAS $=180 \mathrm{~m}^{3} / \mathrm{m}^{2} /$ dia. 
A FIGURA 5.44 apresenta os valores de temperatura, de $\mathrm{pH}$, de turbidez, de DQO, de fósforo e de sólidos suspensos totais do efluente do flotador em função do horário de coleta das amostras quando os seguintes parâmetros operacionais foram adotados: $\mathrm{DCF}=50$ $\mathrm{mg} / \mathrm{L}, \mathrm{Gf}=80 \mathrm{~s}^{-1}, \mathrm{Tf}=20 \mathrm{~min}, \mathrm{R}=12 \%$, Psat $=450 \mathrm{kPa}$ e TAS $=180 \mathrm{~m}^{3} / \mathrm{m}^{2} / \mathrm{dia}$.

A temperatura do esgoto bruto variou entre $22,0^{\circ} \mathrm{C}$; às $08: 00$, e $24,0^{\circ} \mathrm{C}$, às $14: 00$. $\mathrm{O}$ efluente do reator anaeróbio apresentou temperaturas entre $21,0^{\circ} \mathrm{C}$ e $24,0^{\circ} \mathrm{C}$ e o efluene do flotador entre $21,3^{\circ} \mathrm{C}$ e $24,5^{\circ} \mathrm{C}$. $\mathrm{O}$ pH do esgoto bruto variou entre 6,8 e 7,2. O efluente do RALEx apresentou pH entre 6,6 e 6,8 enquanto o $\mathrm{pH}$ do efluente do flotador variou entre 6,4 e 6,6. A turbidez do esgoto bruto apresentou forte variação, com valores entre 230 e 426 uT. O efluente do reator anaeróbio sofreu moderada variação de sua turbidez entre as 08:00 e as 20:00, variando entre 171 e 251 uT. A turbidez do efluente do flotador elevou-se gradativamente, de 18,1 uT, às 08:00, a 106 uT, às 20:00. Às 14:00, a turbidez sofreu significativa redução em seu valor para 4,55 uT, sem razão aparente.

O esgoto bruto apresentou forte oscilação nos valores de DQO. Neste ensaio, foram observados valores de DQO entre 671 e 1079 mg/L. O RALEx contribuiu moderadamente para redução da carga orgânica, fornecendo efluente com DQO entre 356 e $492 \mathrm{mg} / \mathrm{L}$, com eficiência de remoção de carga orgânica de 50,5\% entre às 08:00 e às 20:00. A DQO do efluente do flotador elevou-se gradativamente, de $56 \mathrm{mg} / \mathrm{L}$, às 08:00, a $236 \mathrm{mg} / \mathrm{L}$, às 17:00. A eficiência de remoção de carga orgânica promovida pelo flotador entre as 08:00 e as 20:00 foi de $61,4 \%$. A eficiência de remoção global de carga orgânica alcançada pelo sistema RALEx-flotador foi de 80,9\%.

O esgoto bruto também apresentou moderada oscilação nos valores de fósforo. Neste ensaio, foram observados valores de $\mathrm{P}$ entre 6,0 e 8,9 mg/L. O RALEx contribuiu razoavelmente para equalização da concentração de fósforo no seu efluente, resultando em valores de $\mathrm{P}$ entre 6,2 e 7,5 mg/L. A concentração de $\mathrm{P}$ do efluente do flotador elevou-se gradativamente, de 1,4 mg/L, às 08:00, a 5,6 mg/L, às 20:00. Às 14:00, a concentração de fósforo sofreu significativa redução em seu valor para 0,3 uT, sem razão aparente. A eficiência de remoção de carga de fósforo promovida pelo flotador entre as 08:00 e as 20:00 foi de $58,2 \%$.

O esgoto bruto também apresentou forte oscilação nos valores de SST. Neste ensaio, foram observados valores de SST entre 187 e $325 \mathrm{mg} / \mathrm{L}$. O RALEx contribuiu razoavelmente para redução da carga de sólidos suspensos, fornecendo efluente com SST entre 106 e 227 $\mathrm{mg} / \mathrm{L}$, com eficiência de remoção média de carga de sólidos de 36,9\% entre às 08:00 e às 20:00. A concentração de SST do efluente do flotador elevou-se gradativamente, de 16 $\mathrm{mg} / \mathrm{L}$, às 08:00, a $85 \mathrm{mg} / \mathrm{L}$, às 20:00. Às 14:00, a presença de sólidos suspensos sofreu significativa redução em seu valor para $9 \mathrm{mg} / \mathrm{L}$, sem razão aparente. A eficiência de remoção de carga de SST promovida pelo flotador entre as 08:00 e as 20:00 foi de 68,3\%. A eficiência de remoção global de sólidos suspensos alcançada pelo sistema RALEx-flotador foi de $80,0 \%$. 

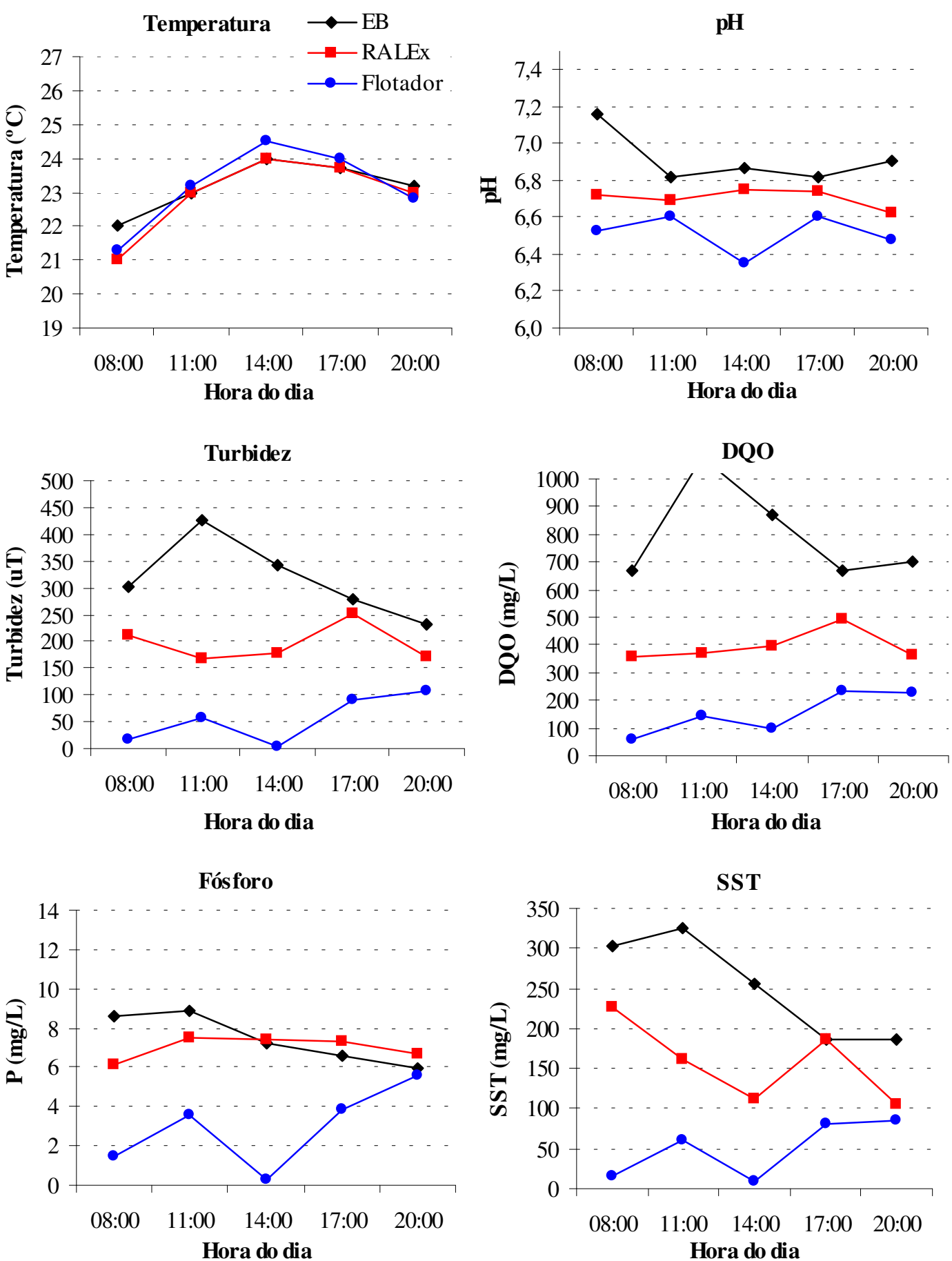

FIGURA 5.44 - Temperatura, pH, turbidez, demanda química de oxigênio, fósforo e sólidos suspensos totais das amostras de esgoto bruto, de efluente do reator RALEx e de efluente do flotador coletadas ao longo do dia de ensaio (25/05/2001). Ensaios realizados em instalação piloto de coagulação/floculação/flotação por ar dissolvido com escoamento contínuo e efluente do reator RALEx. Data do ensaio: 25/05/2001; DCF=50 mg/L; Gf=80 s-1; $\mathrm{Tf}=20 \mathrm{~min} ; \mathrm{R}=12 \%$; Psat=450 kPa; $\mathrm{S}^{*}=13,1 \mathrm{~g} / \mathrm{m}^{3} ;$ TAS $=180 \mathrm{~m}^{3} / \mathrm{m}^{2} / \mathrm{dia}$. 
A FIGURA 5.45 apresenta os valores de temperatura, de pH, de turbidez, de DQO, de fósforo e de sólidos suspensos totais do efluente do flotador em função do horário de coleta das amostras quando os seguintes parâmetros operacionais foram adotados: $\mathrm{DCF}=50$ $\mathrm{mg} / \mathrm{L}, \mathrm{Gf}=100 \mathrm{~s}^{-1}, \mathrm{Tf}=20 \mathrm{~min}, \mathrm{R}=12 \%$, Psat $=450 \mathrm{kPa}$ e TAS $=180 \mathrm{~m}^{3} / \mathrm{m}^{2} / \mathrm{dia}$.

A temperatura do esgoto bruto variou entre $23,0^{\circ} \mathrm{C}$; às $08: 00$, e $25,2^{\circ} \mathrm{C}$, às $14: 00$. O efluente do reator anaeróbio apresentou temperaturas entre $22,2^{\circ} \mathrm{C}$ e $25,5^{\circ} \mathrm{C}$ e o efluente do flotador entre $22,0^{\circ} \mathrm{C}$ e $26,0^{\circ} \mathrm{C}$. O pH do esgoto bruto variou entre 6,6 e 7,0. O efluente do RALEx apresentou $\mathrm{pH}$ entre 6,7 e 6,8 enquanto o $\mathrm{pH}$ do efluente do flotador variou entre 6,4 e 6,7. A turbidez do esgoto bruto apresentou razoável variação, com valores entre 204 e 378 uT. O efluente do reator anaeróbio sofreu forte variação de sua turbidez entre as 08:00 e as 20:00, variando entre 182 e 266 uT. A turbidez do efluente do flotador elevou-se gradativamente, de 19,7 uT, às 08:00, a 128 uT, às 14:00. A partir das 17:00, a turbidez sofreu pequena redução em seu valor até atingir $113 \mathrm{uT}$.

O esgoto bruto apresentou moderada oscilação nos valores de DQO. Neste ensaio, foram observados valores de DQO entre 537 e $846 \mathrm{mg} / \mathrm{L}$. O RALEx contribuiu moderadamente para redução da carga orgânica, fornecendo efluente com DQO entre 358 e $437 \mathrm{mg} / \mathrm{L}$, com eficiência de remoção de carga orgânica de 44,0\% entre às 08:00 e às 20:00. A DQO do efluente do flotador elevou-se gradativamente, de $67 \mathrm{mg} / \mathrm{L}$, às 08:00, a $227 \mathrm{mg} / \mathrm{L}$, às 14:00. A partir das 17:00, a DQO do efluente do flotador sofreu redução em seu valor para 197 mg/L. A eficiência de remoção de carga orgânica promovida pelo flotador entre as 08:00 e as 20:00 foi de 55,4\%. A eficiência de remoção global de carga orgânica alcançada pelo sistema RALEx-flotador foi de $75,0 \%$.

O esgoto bruto também apresentou forte oscilação nos valores de fósforo. Neste ensaio, foram observados valores de $\mathrm{P}$ entre 5,9 e 12,2 $\mathrm{mg} / \mathrm{L}$. O RALEx contribuiu fortemente para equalização da concentração de fósforo no seu efluente, resultando em valores de $\mathrm{P}$ entre 6,6 e 7,6 mg/L. A concentração de $\mathrm{P}$ do efluente do flotador elevou-se gradativamente, de 1,4 mg/L, às 08:00, a $6,8 \mathrm{mg} / \mathrm{L}$, às 14:00. A partir das 17:00, a concentração de $\mathrm{P}$ do efluente do flotador sofreu gradativa redução em seu valor para até 4,7 $\mathrm{mg} / \mathrm{L}$. A eficiência de remoção de carga de fósforo promovida pelo flotador entre as 08:00 e as 20:00 foi de $35,4 \%$.

O esgoto bruto também apresentou moderada oscilação nos valores de SST. Neste ensaio, foram observados valores de SST entre 163 e $284 \mathrm{mg} / \mathrm{L}$. O RALEx contribuiu reduzidamente para redução da carga de sólidos suspensos, fornecendo efluente com SST entre 114 e $195 \mathrm{mg} / \mathrm{L}$, com eficiência de remoção média de carga de sólidos de 29,2\% entre as 08:00 e as 20:00. A concentração de SST do efluente do flotador elevou-se gradativamente, de $19 \mathrm{mg} / \mathrm{L}$, às 08:00, a $84 \mathrm{mg} / \mathrm{L}$, às 14:00, diminuindo para $68 \mathrm{mg} / \mathrm{L}$ às 20:00. A eficiência de remoção de carga de SST promovida pelo flotador entre as 08:00 e as 
20:00 foi de $60,6 \%$. A eficiência de remoção global de sólidos suspensos alcançada pelo sistema RALEx-flotador foi de $72,1 \%$.
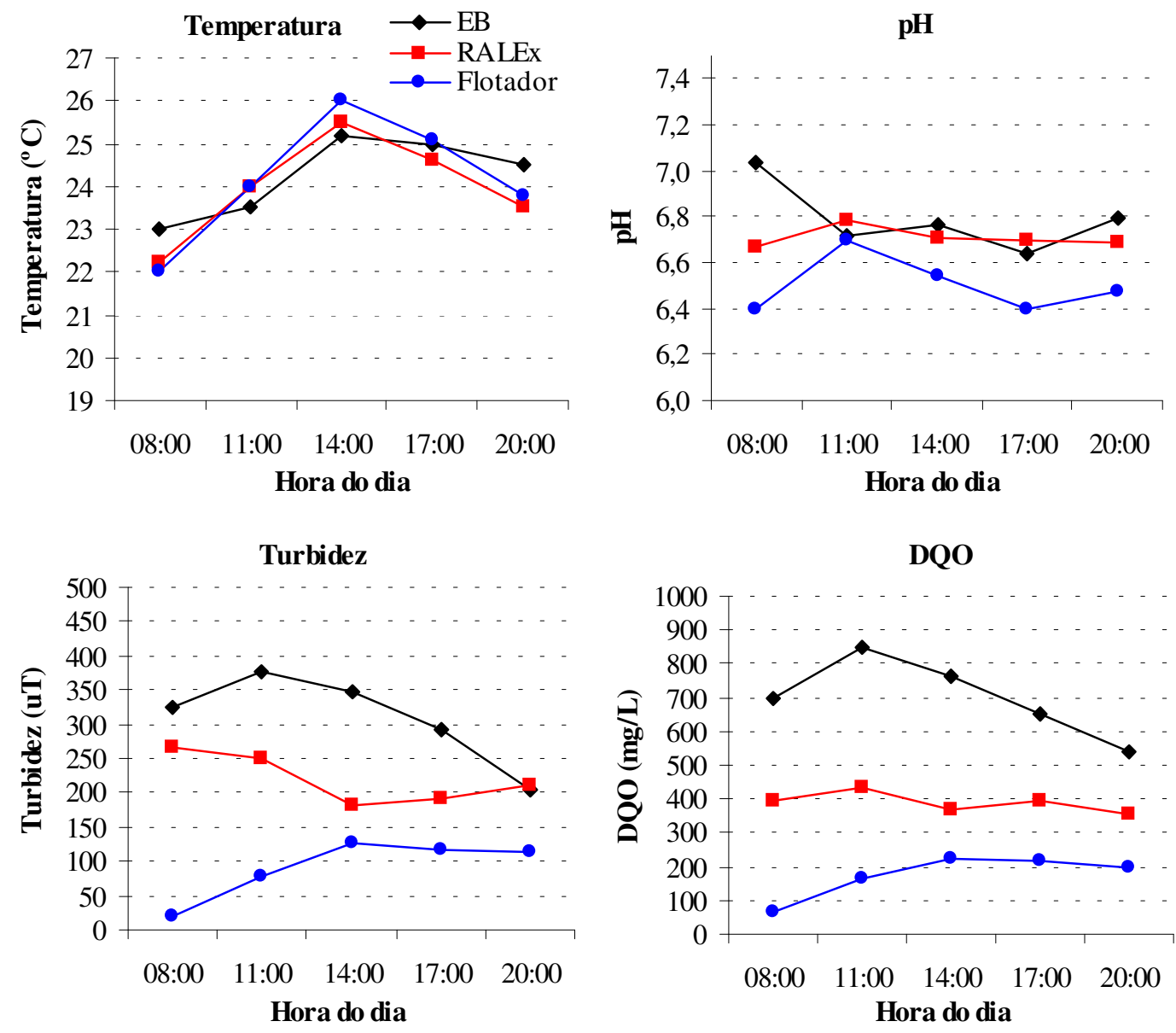

Fósforo
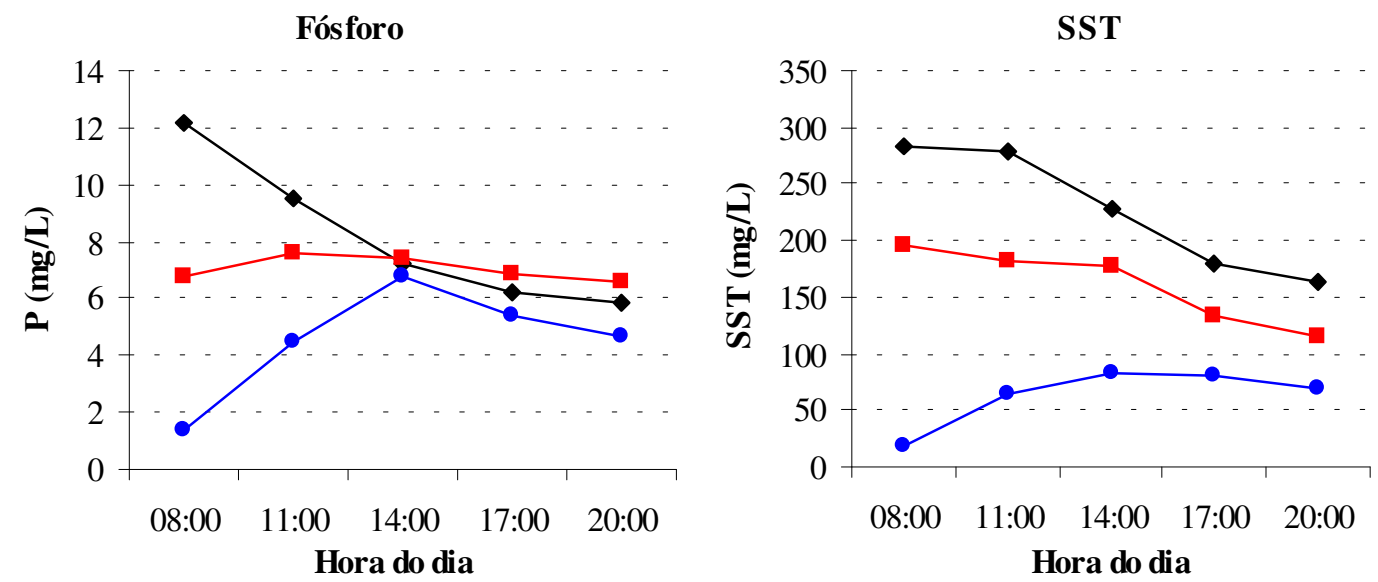

FIGURA 5.45 - Temperatura, pH, turbidez, demanda química de oxigênio, fósforo e sólidos suspensos totais das amostras de esgoto bruto, de efluente do reator RALEx e de efluente do flotador coletadas ao longo do dia de ensaio (30/05/2001).

Ensaios realizados em instalação piloto de coagulação/floculação/flotação por ar dissolvido com escoamento contínuo e efluente do reator RALEx. Data do ensaio: 30/05/2001; DCF=50 mg/L; Gf=100 $\mathrm{s}^{-1} ; \mathrm{Tf}=20 \mathrm{~min} ; \mathrm{R}=12 \%$; Psat=450 kPa; $\mathrm{S} *=13,1 \mathrm{~g} / \mathrm{m}^{3} ;$ TAS $=180 \mathrm{~m}^{3} / \mathrm{m}^{2} /$ dia. 
Durante os ensaios dessa etapa, o sistema de flotação apresentou operação fácil, comportamento mecânico estável, porém desempenho insatisfatório devido à baixa quantidade de ar fornecido ao processo.

A análise e discussão dos resultados através da comparação entre as diferentes eficiências de eficiência de remoção média de turbidez e de carga de DQO, de fósforo e de SST observadas em cada ensaio dessa etapa é relativa em função da variabilidade horária e diária da qualidade do esgoto bruto e da significativa influência da qualidade do efluente do reator RALEx pela qualidade do esgoto bruto, o que não é desejável.

Ainda assim, alguns comportamentos puderam ser observados quando da variação do tempo e do gradiente médio de velocidade de floculação, conforme dados da TABELA 5.6, para $\mathrm{R}=12 \%$.

A qualidade do efluente do RALEx, em termos de turbidez média e de carga de DQO, de fósforo e de SST entre 08:00 e 20:00, durante os ensaios com $\mathrm{Tf}=13 \mathrm{~min}$ associados a Gf de 60 a $100 \mathrm{~s}^{-1}$ foi relativamente semelhante. Comparando os dados dos respectivos ensaios, observa-se que a qualidade do efluente do flotador nos diferentes ensaios não foi significativamente diferente para indicar qual valor de Gf era o mais apropriado. De maneira geral, o desempenho do flotador nestes ensaios foi insatisfatório, com remoções entre $49,6 \%$ e $56,6 \%$ de carga de DQO, entre $21,1 \%$ e $31,0 \%$ de carga de fósforo e entre 55,6\% e 63,9\% de carga de SST. Em nenhum dos ensaios foi alcançado $80 \%$ de eficiência de remoção de DQO pelo sistema RALEx+flotador.

Durante os ensaios com $\mathrm{Tf}=20 \mathrm{~min}$, a qualidade do efluente do RALEx, em termos de turbidez média e de carga de DQO, de fósforo e de SST entre 08:00 e 20:00, era relativamente diferente entre os três ensaios, dificultando a comparação. Ainda assim, comparando-os, observa-se que a qualidade do efluente do flotador quando $\mathrm{Gf}=80 \mathrm{~s}^{-1}$ era semelhante a quando $\mathrm{Gf}=60 \mathrm{~s}^{-1}$ e relativamente melhor do que quando $\mathrm{Gf}=100 \mathrm{~s}^{-1}$.

Em termos de remoção de carga de DQO, de fósforo e de SST, os valores observados quando $\mathrm{Gf}=60 \mathrm{~s}^{-1}$ eram semelhantes àqueles quando $\mathrm{Gf}=100 \mathrm{~s}^{-1}$, porém significativamente inferiores à remoção alcançada quando $\mathrm{Gf}=80 \mathrm{~s}^{-1}$. Ainda assim, o desempenho do flotador nesses ensaios foi insatisfatório. Somente quando utilizado Gf=80 s${ }^{1}$, foi alcançado $80 \%$ de remoção de DQO pelo sistema RALEx+flotador.

Verifica-se, também, que o uso de $\mathrm{Tf}=20 \mathrm{~min}$ resultou em efluente do flotador com qualidade melhor e com maior remoção de turbidez, DQO, fósforo e SST do que quando $\mathrm{Tf}=13 \mathrm{~min}$ foi empregado.

Tendo em vista que o reator RALEx não estava apresentando o desempenho esperado e uma das conseqüências era o elevador teor de SST em seu efluente, com carga 
entre 10,8 e $14,4 \mathrm{~kg} / 12 \mathrm{~h}$, o fornecimento de $13,1 \mathrm{~g} \mathrm{de} \mathrm{ar} / \mathrm{m}^{3}$ de efluente ( $\mathrm{R}=12 \%$ ) foi insuficiente para proporcionar boa qualidade ao efluente final, mediante remoção dos flocos. Para obtenção de remoção mais eficiente dos flocos foi necessário maior fornecimento de ar para a flotação, com emprego de mais de $12 \%$ de recirculação.

TABELA 5.6 - Valores de turbidez média e de carga de DQO, de fósforo e de SST para as amostras de esgoto bruto, de efluente do RALEx e de efluente do flotador, entre 08:00 e 20:00, e respectivas remoções observadas no reator RALEx, no flotador e no sistema conjugado, de acordo com a etapa 5.6.1.1.1.

\begin{tabular}{|c|c|c|c|c|c|c|c|}
\hline & \multicolumn{6}{|c|}{ DCF $=50 \mathrm{mg} / \mathrm{L} ; \mathrm{R}=12 \%, \mathrm{~S}^{*}=13,1 \mathrm{~g} / \mathrm{m}^{3}, \mathrm{TAS}=180 \mathrm{~m}^{3} / \mathrm{m}^{2} / \mathrm{d}$} \\
\hline & & \multicolumn{3}{|c|}{$T f=13 \min$} & \multicolumn{3}{|c|}{$\mathbf{T f}=\mathbf{2 0} \mathrm{min}$} \\
\hline & & $60 \mathrm{~s}^{-1}$ & $80 \mathrm{~s}^{-1}$ & $100 \mathrm{~s}^{-1}$ & $60 \mathrm{~s}^{-1}$ & $80 \mathrm{~s}^{-1}$ & $100 \mathrm{~s}^{-1}$ \\
\hline \multirow{4}{*}{ 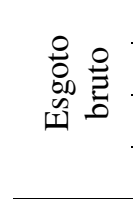 } & Turbidez média (uT) & 449 & 315 & 314 & 303 & 315 & 309 \\
\hline & $\mathrm{DQO}(\mathrm{kg} / 12 \mathrm{~h})$ & 70,1 & 55,9 & 57,9 & 58,8 & 62,8 & 55,0 \\
\hline & $\mathrm{P}(\mathrm{kg} / 12 \mathrm{~h})$ & 0,73 & 0,68 & 0,60 & 0,56 & 0,59 & 0,65 \\
\hline & SST $(\mathrm{kg} / 12 \mathrm{~h})$ & 26,9 & 18,9 & 20,4 & 19,6 & 19,8 & 17,8 \\
\hline \multirow{4}{*}{ 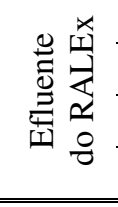 } & Turbidez média (uT) & 217 & 237 & 262 & 162 & 196 & 220 \\
\hline & DQO $(\mathrm{kg} / 12 \mathrm{~h})$ & 31,5 & 33,4 & 34,8 & 27,5 & 31,1 & 30,8 \\
\hline & $\mathrm{P}(\mathrm{kg} / 12 \mathrm{~h})$ & 0,55 & 0,55 & 0,56 & 0,52 & 0,55 & 0,56 \\
\hline & SST $(\mathrm{kg} / 12 \mathrm{~h})$ & 11,7 & 12,7 & 14,4 & 10,8 & 12,5 & 12,6 \\
\hline \multirow{4}{*}{ 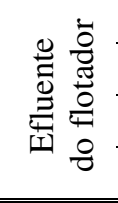 } & Turbidez média (uT) & 94,2 & 105 & 100 & 67,6 & 55,6 & 91,2 \\
\hline & DQO $(\mathrm{kg} / 12 \mathrm{~h})$ & 14,8 & 16,8 & 15,1 & 12,0 & 12,0 & 13,7 \\
\hline & $\mathrm{P}(\mathrm{kg} / 12 \mathrm{~h})$ & 0,38 & 0,44 & 0,40 & 0,33 & 0,23 & 0,36 \\
\hline & SST $(\mathrm{kg} / 12 \mathrm{~h})$ & 4,6 & 5,7 & 5,2 & 4,2 & 4,0 & 5,0 \\
\hline \multirow{3}{*}{ 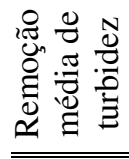 } & RALEx $(\%)$ & 51,6 & 24,9 & 16,7 & 46,6 & 37,7 & 28,7 \\
\hline & FAD $(\%)$ & 56,6 & 55,5 & 61,7 & 58,2 & 71,7 & 58,6 \\
\hline & Sistema (\%) & 79,0 & 66,6 & 68,1 & 77,7 & 82,3 & 70,5 \\
\hline \multirow{3}{*}{ 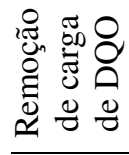 } & RALEx $(\%)$ & 55,1 & 40,2 & 39,9 & 53,3 & 50,5 & 44,0 \\
\hline & FAD $(\%)$ & 53,0 & 49,6 & 56,6 & 56,3 & 61,4 & 55,4 \\
\hline & Sistema $(\%)$ & 78,9 & 69,9 & 73,9 & 79,6 & 80,9 & 75,0 \\
\hline \multirow{3}{*}{ 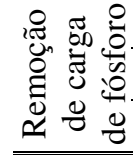 } & RALEx $(\%)$ & 24,8 & 19,0 & 5,6 & 8,1 & 5,6 & 14,1 \\
\hline & FAD $(\%)$ & 31,0 & 21,1 & 28,4 & 35,9 & 58,2 & 35,4 \\
\hline & Sistema (\%) & 48,1 & 36,1 & 32,4 & 41,1 & 60,6 & 44,5 \\
\hline \multirow{3}{*}{ 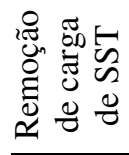 } & RALEx $(\%)$ & 56,4 & 32,7 & 29,3 & 44,6 & 36,9 & 29,2 \\
\hline & FAD $(\%)$ & 61,1 & 55,6 & 63,9 & 60,9 & 68,3 & 60,6 \\
\hline & Sistema (\%) & 83,0 & 70,1 & 74,5 & 78,3 & 80,0 & 72,1 \\
\hline
\end{tabular}

\subsection{Ensaios com a instalação piloto de flotação operada com $R=18 \%$.}

São relatados os ensaios com a instalação piloto de flotação operada com $18 \%$ de recirculação e pressão de saturação de $450 \mathrm{kPa}$. Nesses ensaios, foram investigados dois

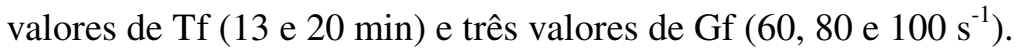


A FIGURA 5.46 apresenta os valores de temperatura, de pH, de turbidez, de DQO, de fósforo e de sólidos suspensos totais do efluente do flotador em função do horário de coleta das amostras quando os seguintes parâmetros operacionais foram adotados: $\mathrm{DCF}=50$ $\mathrm{mg} / \mathrm{L}, \mathrm{Gf}=60 \mathrm{~s}^{-1}, \mathrm{Tf}=13 \mathrm{~min}, \mathrm{R}=18 \%$, Psat $=450 \mathrm{kPa}$ e TAS $=180 \mathrm{~m}^{3} / \mathrm{m}^{2} / \mathrm{dia}$.

A temperatura do esgoto bruto variou entre $24,0^{\circ} \mathrm{C}$; às $08: 00$, e $26,3^{\circ} \mathrm{C}$, às $17: 00 . \mathrm{O}$ efluente do reator anaeróbio apresentou temperaturas entre $23,9^{\circ} \mathrm{C}$ e $26,5^{\circ} \mathrm{C}$ e o efluente do flotador entre $23,8^{\circ} \mathrm{C}$ e $26,5^{\circ} \mathrm{C}$. $\mathrm{O} \mathrm{pH}$ do esgoto bruto variou entre 6,8 e 7,2. O efluente do RALEx apresentou pH entre 6,6 e 6,9 enquanto o pH do efluente do flotador variou entre 6,4 e 6,8. A turbidez do esgoto bruto apresentou razoável variação, com valores entre 180 e 245 uT. O efluente do reator anaeróbio sofreu moderada variação de sua turbidez entre as 08:00 e as 20:00, variando entre 91 e 119 uT. A turbidez do efluente do flotador elevou-se gradativamente, de 13,2 uT, às 08:00, a 0,4 uT, às 17:00. Às 20:00, a turbidez sofreu forte redução em seu valor para 21,3 uT.

O esgoto bruto apresentou pequena oscilação nos valores de DQO. Neste ensaio, foram observados valores de DQO entre 473 e 613 mg/L. O RALEx contribuiu eficientemente para redução da carga orgânica, fornecendo efluente com DQO entre 199 e $263 \mathrm{mg} / \mathrm{L}$, com eficiência de remoção de carga orgânica de 56,8\% entre às 08:00 e às 20:00. A DQO do efluente do flotador elevou-se gradativamente, de $64 \mathrm{mg} / \mathrm{L}$, às 08:00, a 174 mg/L, às 17:00. A partir das 20:00, a DQO do efluente do flotador sofreu redução em seu valor para $68 \mathrm{mg} / \mathrm{L}$. A eficiência de remoção de carga orgânica promovida pelo flotador entre as 08:00 e as 20:00 foi de 54,7\%. A eficiência de remoção global de carga orgânica alcançada pelo sistema RALEx-flotador foi de $80,4 \%$.

O esgoto bruto também apresentou pequena oscilação nos valores de fósforo. Neste ensaio, foram observados valores de $\mathrm{P}$ entre 5,0 e 5,9 mg/L. O RALEx contribuiu fortemente para equalização da concentração de fósforo no seu efluente, resultando em valores de $\mathrm{P}$ entre 4,3 e 5,0 mg/L. A concentração de $P$ do efluente do flotador elevou-se gradativamente, de $0,9 \mathrm{mg} / \mathrm{L}$, às $08: 00$, a 4,4 mg/L, às 17:00. A partir de então, a concentração de $\mathrm{P}$ do efluente do flotador sofreu gradativa redução em seu valor para até $0,7 \mathrm{mg} / \mathrm{L}$, às 20:00. A eficiência de remoção de carga de fósforo promovida pelo flotador entre as 08:00 e as 20:00 foi de $47,9 \%$.

O esgoto bruto também apresentou moderada oscilação nos valores de SST. Neste ensaio, foram observados valores de SST entre 111 e $181 \mathrm{mg} / \mathrm{L}$. O RALEx contribuiu eficientemente para redução da carga de sólidos suspensos, fornecendo efluente com SST entre 50 e $67 \mathrm{mg} / \mathrm{L}$, com eficiência de remoção média de carga de sólidos de 59,6\% entre as 08:00 e as 20:00. A concentração de SST do efluente do flotador elevou-se gradativamente, de $8 \mathrm{mg} / \mathrm{L}$, às 08:00, a $63 \mathrm{mg} / \mathrm{L}$, às 17:00, diminuindo para $15 \mathrm{mg} / \mathrm{L}$ às 20:00. A eficiência de remoção de carga de SST promovida pelo flotador entre as 08:00 e as 20:00 foi de 49,0\%. A eficiência de remoção global de sólidos suspensos alcançada pelo sistema RALEx-flotador foi de $79,4 \%$. 
Temperatura

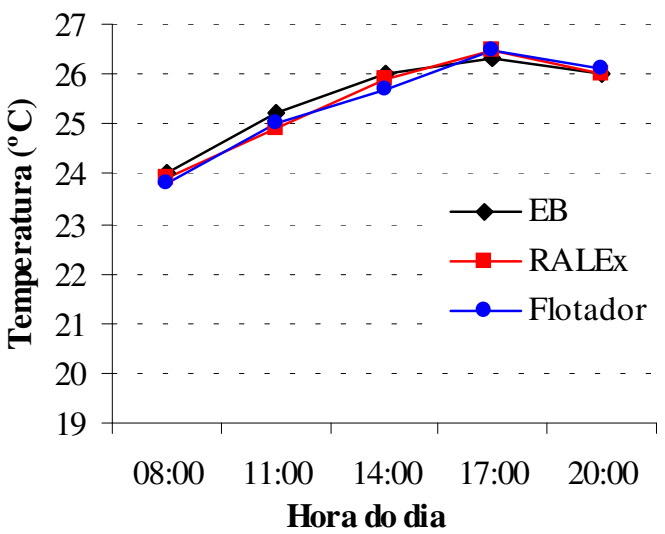

Turbidez

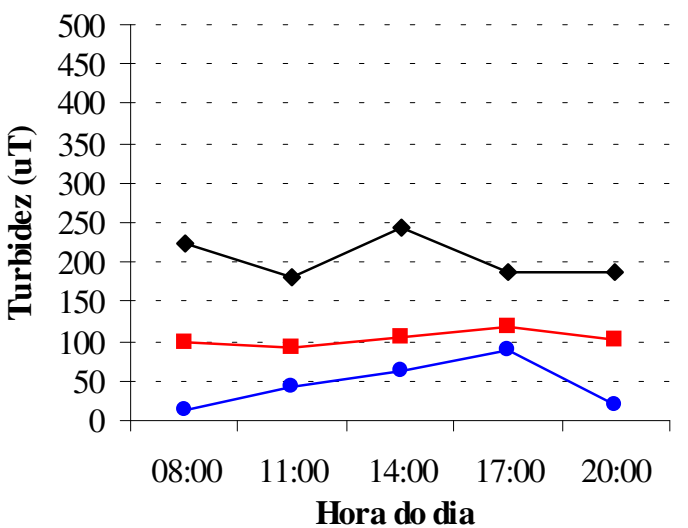

Fósforo

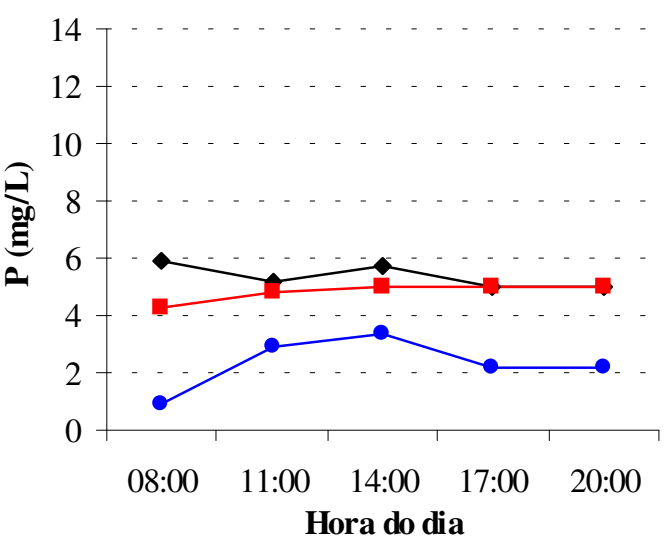

pH

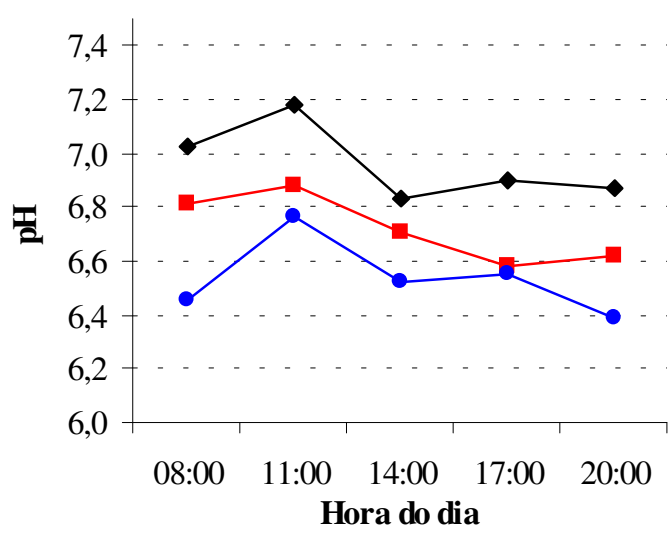

DQO

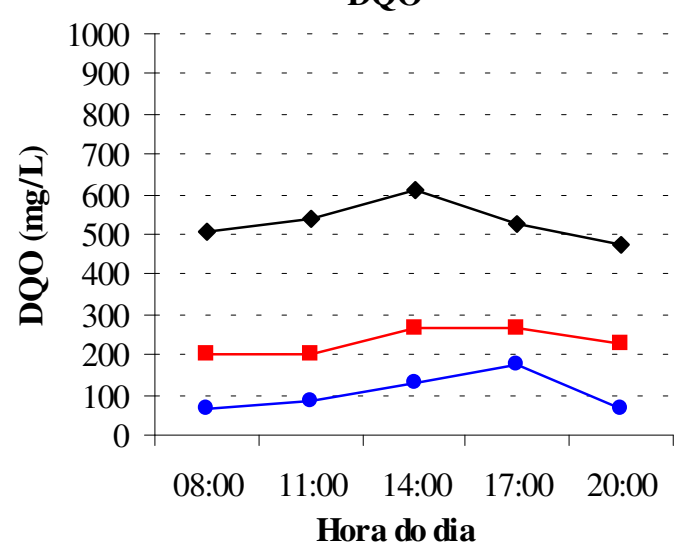

SST

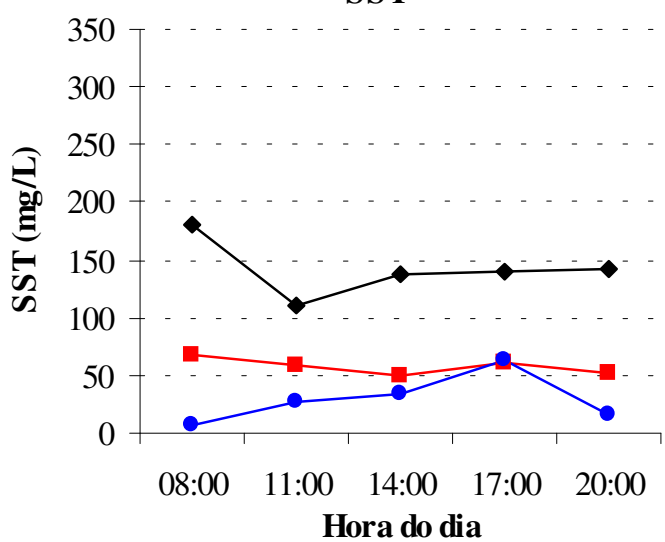

FIGURA 5.46 - Temperatura, pH, turbidez, demanda química de oxigênio, fósforo e sólidos suspensos totais das amostras de esgoto bruto, de efluente do reator RALEx e de efluente do flotador coletadas ao longo do dia de ensaio (08/03/2001). Ensaios realizados em instalação piloto de coagulação/floculação/flotação por ar dissolvido com escoamento contínuo e efluente do reator RALEx. Data do ensaio: 08/03/2001; DCF=50 mg/L; Gf=60 s ${ }^{-1}$; $\mathrm{Tf}=13 \mathrm{~min} ; \mathrm{R}=18 \%$; Psat=450 kPa; $\mathrm{S} *=19,7 \mathrm{~g} / \mathrm{m}^{3} ;$ TAS $=180 \mathrm{~m}^{3} / \mathrm{m}^{2} /$ dia. 
A FIGURA 5.47 apresenta os valores de temperatura, de pH, de turbidez, de DQO, de fósforo e de sólidos suspensos totais do efluente do flotador em função do horário de coleta das amostras quando os seguintes parâmetros operacionais foram adotados: $\mathrm{DCF}=50$ $\mathrm{mg} / \mathrm{L}, \mathrm{Gf}=80 \mathrm{~s}^{-1}, \mathrm{Tf}=13 \mathrm{~min}, \mathrm{R}=18 \%$, Psat $=450 \mathrm{kPa}$ e TAS $=180 \mathrm{~m}^{3} / \mathrm{m}^{2} / \mathrm{dia}$.

A temperatura do esgoto bruto variou entre $25,3^{\circ} \mathrm{C}$; às 08:00, e $25,0^{\circ} \mathrm{C}$, às 20:00. $\mathrm{O}$ efluente do reator anaeróbio apresentou temperaturas entre $24,8^{\circ} \mathrm{C}$ e $25,3^{\circ} \mathrm{C}$ e o efluente do flotador entre $24,3^{\circ} \mathrm{C}$ e $25,5^{\circ} \mathrm{C}$. $\mathrm{O} \mathrm{pH}$ do esgoto bruto variou entre $6,6 \mathrm{e} 7,1$. O efluente do RALEx apresentou $\mathrm{pH}$ em torno de 6,7 enquanto o $\mathrm{pH}$ do efluente do flotador variou entre 6,2 e 6,5. A turbidez do esgoto bruto apresentou forte variação, com valores entre 158 e 515 uT. O efluente do reator anaeróbio sofreu moderada variação de sua turbidez entre 08:00 e 20:00, variando entre 61,4 e 154 uT. A turbidez do efluente do flotador elevou-se gradativamente, de 1,00 uT, às 08:00, a 25,8 uT, às 14:00. A partir das 17:00, a turbidez sofreu redução em seu valor, até atingir 7,70 uT, às 20:00.

O esgoto bruto apresentou moderada oscilação nos valores de DQO. Neste ensaio, foram observados valores de DQO entre 446 e $815 \mathrm{mg} / \mathrm{L}$. O RALEx contribuiu de modo mais eficaz que nos ensaios anteriores para redução da carga orgânica, fornecendo efluente com DQO entre 140 e 287 mg/L, com eficiência de remoção de carga orgânica de 62,6\% entre 08:00 e 20:00. A DQO do efluente do flotador elevou-se gradativamente, de $44 \mathrm{mg} / \mathrm{L}$, às 08:00, a $82 \mathrm{mg} / \mathrm{L}$, às 14:00. A partir das 17:00, a DQO do efluente do flotador sofreu redução em seu valor, até atingir $42 \mathrm{mg} / \mathrm{L}$, às 20:00. A eficiência de remoção de carga orgânica promovida pelo flotador entre 08:00 e 20:00 foi de 75,1\%. A eficiência de remoção global de carga orgânica alcançada pelo sistema RALEx-flotador foi de 90,7\%.

O esgoto bruto também apresentou moderada oscilação nos valores de fósforo. Neste ensaio, foram observados valores de P entre 5,1 e 8,6 mg/L. O RALEx contribuiu fortemente para equalização da concentração de fósforo no seu efluente, resultando em valores de $\mathrm{P}$ entre 3,0 e 5,7 mg/L. A concentração de $\mathrm{P}$ do efluente do flotador elevou-se gradativamente, de $0,03 \mathrm{mg} / \mathrm{L}$, às $08: 00$, a $1,20 \mathrm{mg} / \mathrm{L}$, às $14: 00$. A partir das 17:00, a concentração de $\mathrm{P}$ do efluente do flotador sofreu gradativa redução em seu valor para até $0,2 \mathrm{mg} / \mathrm{L}$, às 20:00. A eficiência de remoção de carga de fósforo promovida pelo flotador entre as 08:00 e as 20:00 foi de $85,9 \%$.

O esgoto bruto também apresentou forte oscilação nos valores de SST. Neste ensaio, foram observados valores de SST entre 161 e 316 mg/L. O RALEx contribuiu eficientemente para redução da carga de sólidos suspensos, fornecendo efluente com SST entre 43 e $64 \mathrm{mg} / \mathrm{L}$, com eficiência de remoção média de carga de sólidos de 78,5\% entre 08:00 e 20:00. A concentração de SST do efluente do flotador elevou-se gradativamente, de $3 \mathrm{mg} / \mathrm{L}$, às 08:00, para $14 \mathrm{mg} / \mathrm{L}$, às 14:00, diminuindo para $5 \mathrm{mg} / \mathrm{L}$ às 20:00. A eficiência de remoção de carga de SST promovida pelo flotador entre 08:00 e 20:00 foi de 82,9\%. A eficiência de remoção global de sólidos suspensos alcançada pelo sistema RALEx-flotador foi de $96,3 \%$. 

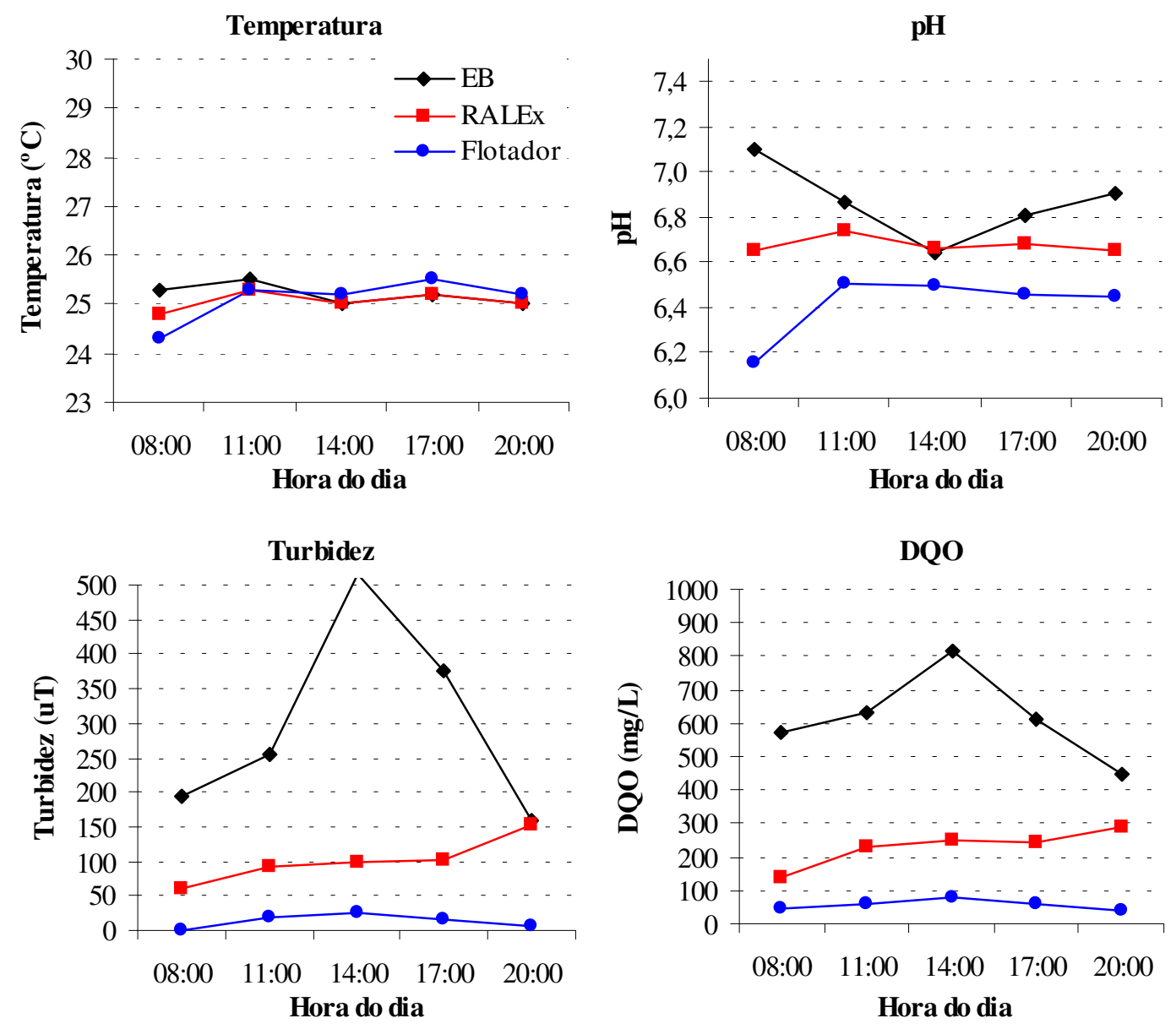

Fósforo
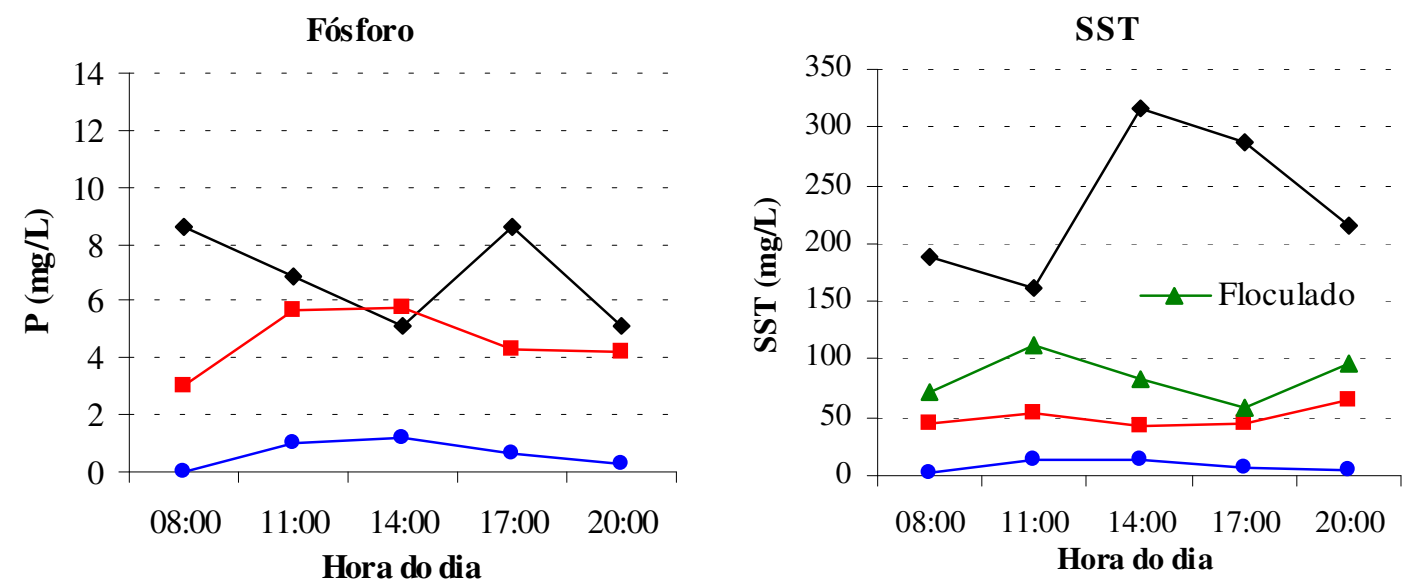

FIGURA 5.47 - Temperatura, pH, turbidez, demanda química de oxigênio, fósforo e sólidos suspensos totais das amostras de esgoto bruto, de efluente do reator RALEx e de efluente do flotador coletadas ao longo do dia de ensaio (09/03/2001).

Ensaios realizados em instalação piloto de coagulação/floculação/flotação por ar dissolvido com escoamento contínuo e efluente do reator RALEx. Data do ensaio: 09/03/2001; DCF=50 mg/L; Gf=80 s-1; $\mathrm{Tf}=13 \mathrm{~min} ; \mathrm{R}=18 \%$; Psat=450 kPa; $\mathrm{S}^{*}=19,7 \mathrm{~g} / \mathrm{m}^{3} ;$ TAS $=180 \mathrm{~m}^{3} / \mathrm{m}^{2} /$ dia. 
A FIGURA 5.48 apresenta os valores de temperatura, de pH, de turbidez, de DQO, de fósforo e de sólidos suspensos totais do efluente do flotador em função do horário de coleta das amostras quando os seguintes parâmetros operacionais foram adotados: $\mathrm{DCF}=50$ $\mathrm{mg} / \mathrm{L}, \mathrm{Gf}=100 \mathrm{~s}^{-1}, \mathrm{Tf}=13 \mathrm{~min}, \mathrm{R}=18 \%$, Psat $=450 \mathrm{kPa}$ e TAS $=180 \mathrm{~m}^{3} / \mathrm{m}^{2} / \mathrm{dia}$.

A temperatura do esgoto bruto variou entre $26,3^{\circ} \mathrm{C}$; às $08: 00$, e $27,5^{\circ} \mathrm{C}$, às $20: 00$. O efluente do reator anaeróbio apresentou temperaturas entre $26,0^{\circ} \mathrm{C}$ e $28,7^{\circ} \mathrm{C}$ e o efluente do flotador entre $26,0^{\circ} \mathrm{C}$ e $28,5^{\circ} \mathrm{C}$.

$\mathrm{O}$ pH do esgoto bruto variou entre 6,8 e 7,1. O efluente do RALEx apresentou pH entre 6,6 e 6,9 enquanto o $\mathrm{pH}$ do efluente do flotador variou entre 6,4 e 6,7.

A turbidez do esgoto bruto apresentou moderada variação, com valores entre $207 \mathrm{e}$ 331 uT. O efluente do reator anaeróbio sofreu pequena variação de sua turbidez entre 08:00 e 20:00, variando entre 117 e $150 \mathrm{uT}$. A turbidez do efluente do flotador elevou-se gradativamente, de 3,10 uT, às 08:00, a 28,2 uT, às 14:00. A partir das 17:00, a turbidez sofreu redução em seu valor, até atingir 23,2 uT, às 20:00.

O esgoto bruto apresentou pequena oscilação nos valores de DQO. Neste ensaio, foram observados valores de DQO entre 546 e 706 mg/L. O RALEx contribuiu eficientemente para redução da carga orgânica, fornecendo efluente com DQO entre 249 e $305 \mathrm{mg} / \mathrm{L}$, com eficiência de remoção de carga orgânica de 57,0\% entre 08:00 e 20:00. A DQO do efluente do flotador elevou-se gradativamente, de $37 \mathrm{mg} / \mathrm{L}$, às 08:00, para $70 \mathrm{mg} / \mathrm{L}$, às 17:00. A partir das 20:00, a DQO do efluente do flotador sofreu redução em seu valor, até atingir $64 \mathrm{mg} / \mathrm{L}$. A eficiência de remoção de carga orgânica promovida pelo flotador entre 08:00 e 20:00 foi de 79,0\%. A eficiência de remoção global de carga orgânica alcançada pelo sistema RALEx-flotador foi de $91,0 \%$.

O esgoto bruto também apresentou forte oscilação nos valores de fósforo. Neste ensaio, foram observados valores de $\mathrm{P}$ entre 4,7 e $9,5 \mathrm{mg} / \mathrm{L}$. O RALEx contribuiu fortemente para equalização da concentração de fósforo no seu efluente, resultando em valores de $\mathrm{P}$ entre 4,8 e $6,7 \mathrm{mg} / \mathrm{L}$. A concentração de $\mathrm{P}$ do efluente do flotador elevou-se gradativamente, de $0,2 \mathrm{mg} / \mathrm{L}$, às $08: 00$, a $1,50 \mathrm{mg} / \mathrm{L}$, às 14:00. A partir das 17:00, a concentração de $\mathrm{P}$ do efluente do flotador sofreu gradativa redução em seu valor para até $0,9 \mathrm{mg} / \mathrm{L}$, às 20:00. A eficiência de remoção de carga de fósforo promovida pelo flotador entre 08:00 e 20:00 foi de $85,1 \%$.

O esgoto bruto também apresentou forte oscilação nos valores de SST. Neste ensaio, foram observados valores de SST entre 154 e 263 mg/L. O RALEx contribuiu moderadamente para redução da carga de sólidos suspensos, fornecendo efluente com SST entre 63 e 103 mg/L, com eficiência de remoção média de carga de sólidos de 58,8\% entre 08:00 e 20:00. A concentração de SST do efluente do flotador elevou-se gradativamente, de $12 \mathrm{mg} / \mathrm{L}$, às 08:00, para $22 \mathrm{mg} / \mathrm{L}$, às 14:00, diminuindo para $16 \mathrm{mg} / \mathrm{L}$ às 20:00. A eficiência de remoção de carga de SST promovida pelo flotador entre 08:00 e 20:00 foi de 80,5\%. A 
eficiência de remoção global de sólidos suspensos alcançada pelo sistema RALEx-flotador foi de $92,0 \%$.
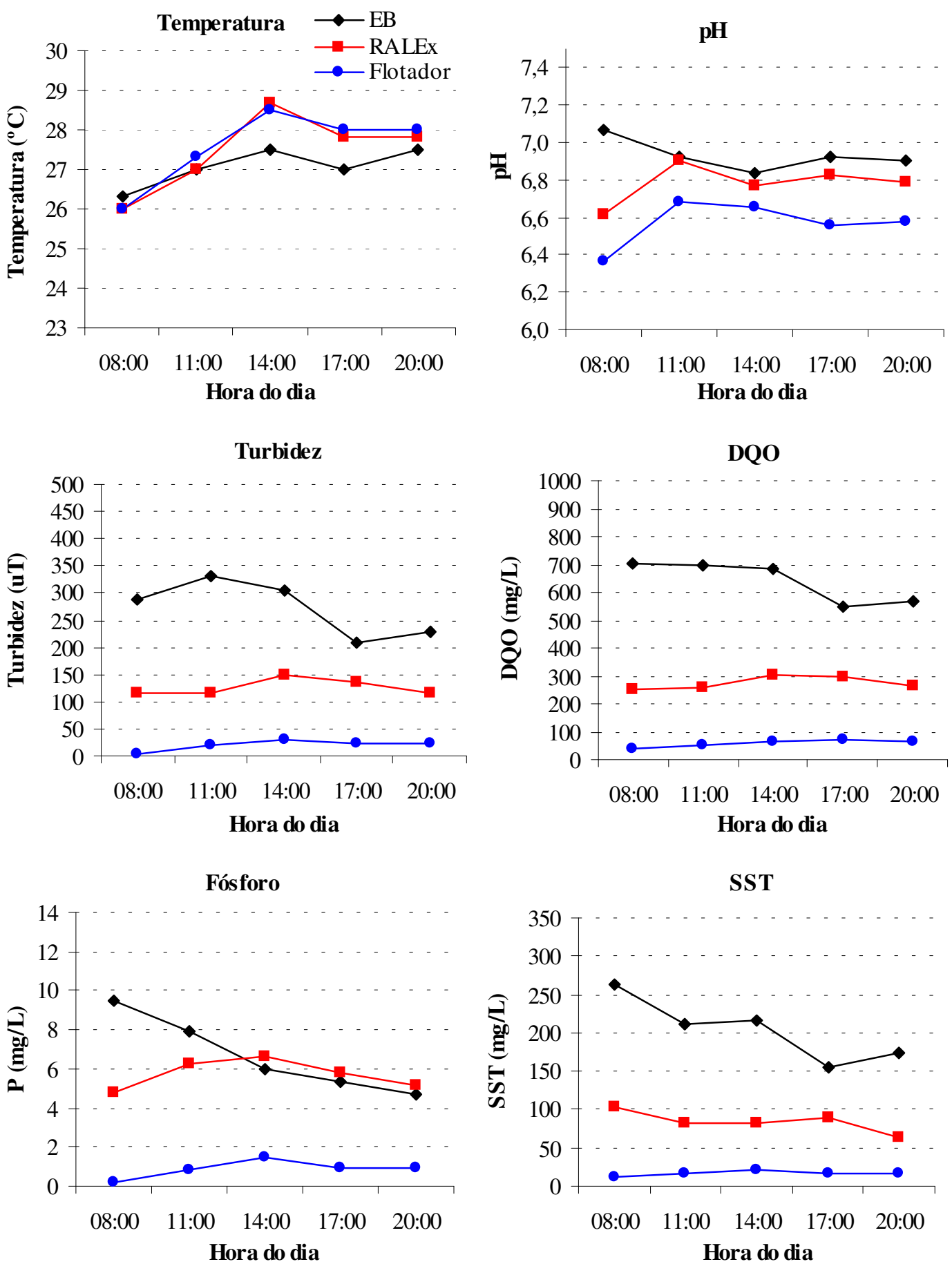

FIGURA 5.48 - Temperatura, pH, turbidez, demanda química de oxigênio, fósforo e sólidos suspensos totais das amostras de esgoto bruto, de efluente do reator RALEx e de efluente do flotador coletadas ao longo do dia de ensaio (15/03/2001).

Ensaios realizados em instalação piloto de coagulação/floculação/flotação por ar dissolvido com escoamento contínuo e efluente do reator RALEx. Data do ensaio: $15 / 03 / 2001 ; \mathrm{DCF}=50 \mathrm{mg} / \mathrm{L} ; \mathrm{Gf}=100 \mathrm{~s}^{-1} ; \mathrm{Tf}=13 \mathrm{~min} ; \mathrm{R}=18 \%$; Psat=450 kPa; $\mathrm{S}^{*}=19,7 \mathrm{~g} / \mathrm{m}^{3} ;$ TAS $=180 \mathrm{~m}^{3} / \mathrm{m}^{2} / \mathrm{dia}$. 
A FIGURA 5.49 apresenta os valores de temperatura, de pH, de turbidez, de DQO, de fósforo e de sólidos suspensos totais do efluente do flotador em função do horário de coleta das amostras quando os seguintes parâmetros operacionais foram adotados: $\mathrm{DCF}=50$ $\mathrm{mg} / \mathrm{L}, \mathrm{Gf}=60 \mathrm{~s}^{-1}, \mathrm{Tf}=20 \mathrm{~min}, \mathrm{R}=18 \%$, Psat $=450 \mathrm{kPa}$ e TAS $=180 \mathrm{~m}^{3} / \mathrm{m}^{2} / \mathrm{dia}$.

A temperatura do esgoto bruto variou entre $26,8^{\circ} \mathrm{C}$, às $08: 00$, e $27,8^{\circ} \mathrm{C}$, às $20: 00$. $\mathrm{O}$ efluente do reator anaeróbio apresentou temperaturas entre $26,3^{\circ} \mathrm{C}$ e $28,2^{\circ} \mathrm{C}$ e o efluente do flotador entre $26,5^{\circ} \mathrm{C}$ e $28,5^{\circ} \mathrm{C}$.

$\mathrm{O} \mathrm{pH}$ do esgoto bruto variou entre 6,6 e 7,0. O efluente do RALEx apresentou $\mathrm{pH}$ entre 6,5 e 6,7 enquanto o $\mathrm{pH}$ do efluente do flotador variou entre 6,3 e 6,7.

A turbidez do esgoto bruto apresentou moderada variação, com valores entre $211 \mathrm{e}$ 357 uT. O efluente do reator anaeróbio sofreu pequena variação de sua turbidez entre 08:00 e 20:00, variando entre 130 e 169 uT. A turbidez do efluente do flotador elevou-se gradativamente, de 5,64 uT, às 08:00, a 74,7 uT, às 14:00. A partir das 17:00, a turbidez sofreu redução em seu valor, até atingir 42,9 uT, às 20:00.

O esgoto bruto apresentou pequena oscilação nos valores de DQO. Neste ensaio, foram observados valores de DQO entre 498 e $791 \mathrm{mg} / \mathrm{L}$. O RALEx contribuiu moderadamente para redução da carga orgânica, fornecendo efluente com DQO entre $266 \mathrm{e}$ $364 \mathrm{mg} / \mathrm{L}$, com eficiência de remoção de carga orgânica de 52,1\% entre 08:00 e 20:00. A DQO do efluente do flotador elevou-se gradativamente, de $42 \mathrm{mg} / \mathrm{L}$, às 08:00, para 180 $\mathrm{mg} / \mathrm{L}$, às 17:00. A partir das 20:00, a DQO do efluente do flotador sofreu redução em seu valor, até atingir $152 \mathrm{mg} / \mathrm{L}$. A eficiência de remoção de carga orgânica promovida pelo flotador entre 08:00 e 20:00 foi de 62,2\%. A eficiência de remoção global de carga orgânica alcançada pelo sistema RALEx-flotador foi de $81,9 \%$.

O esgoto bruto também apresentou forte oscilação nos valores de fósforo. Neste ensaio, foram observados valores de $\mathrm{P}$ entre 5,3 e 9,6 mg/L. O RALEx contribuiu fortemente para equalização da concentração de fósforo no seu efluente, resultando em valores de $\mathrm{P}$ entre 5,4 e $6,8 \mathrm{mg} / \mathrm{L}$. A concentração de $\mathrm{P}$ do efluente do flotador elevou-se gradativamente, de $0,40 \mathrm{mg} / \mathrm{L}$, às $08: 00$, a 4,40 mg/L, às 14:00. A partir das 17:00, a concentração de $\mathrm{P}$ do efluente do flotador sofreu gradativa redução em seu valor para até $2,30 \mathrm{mg} / \mathrm{L}$, às 20:00. A eficiência de remoção de carga de fósforo promovida pelo flotador entre 08:00 e 20:00 foi de $56,1 \%$.

O esgoto bruto também apresentou forte oscilação nos valores de SST. Neste ensaio, foram observados valores de SST entre 186 e 354 mg/L. O RALEx contribuiu moderadamente para redução da carga de sólidos suspensos, fornecendo efluente com SST entre 87 e $121 \mathrm{mg} / \mathrm{L}$, com eficiência de remoção média de carga de sólidos de 57,1\% entre 08:00 e 20:00. A concentração de SST do efluente do flotador elevou-se gradativamente, de $9 \mathrm{mg} / \mathrm{L}$, às 08:00, para $64 \mathrm{mg} / \mathrm{L}$, às 17:00, diminuindo para $51 \mathrm{mg} / \mathrm{L}$ às 20:00. A eficiência de remoção de carga de SST promovida pelo flotador entre 08:00 e 20:00 foi de 62,7\%. A 
eficiência de remoção global de sólidos suspensos alcançada pelo sistema RALEx-flotador foi de $84,0 \%$.
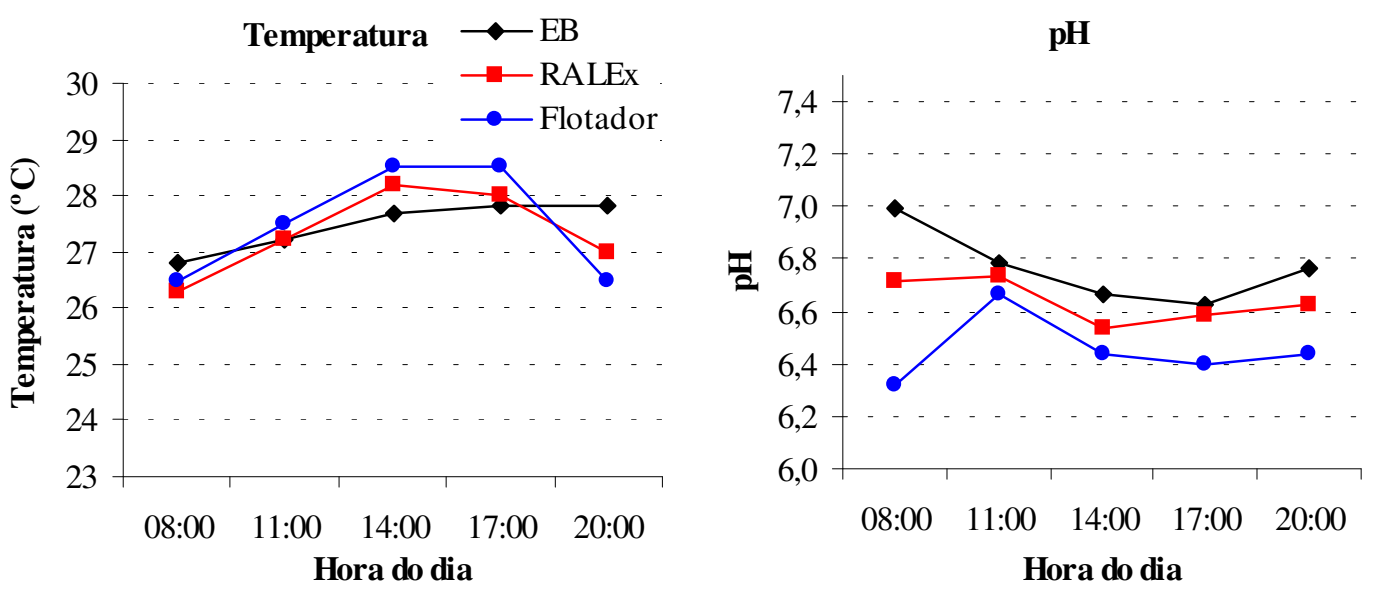

Turbidez
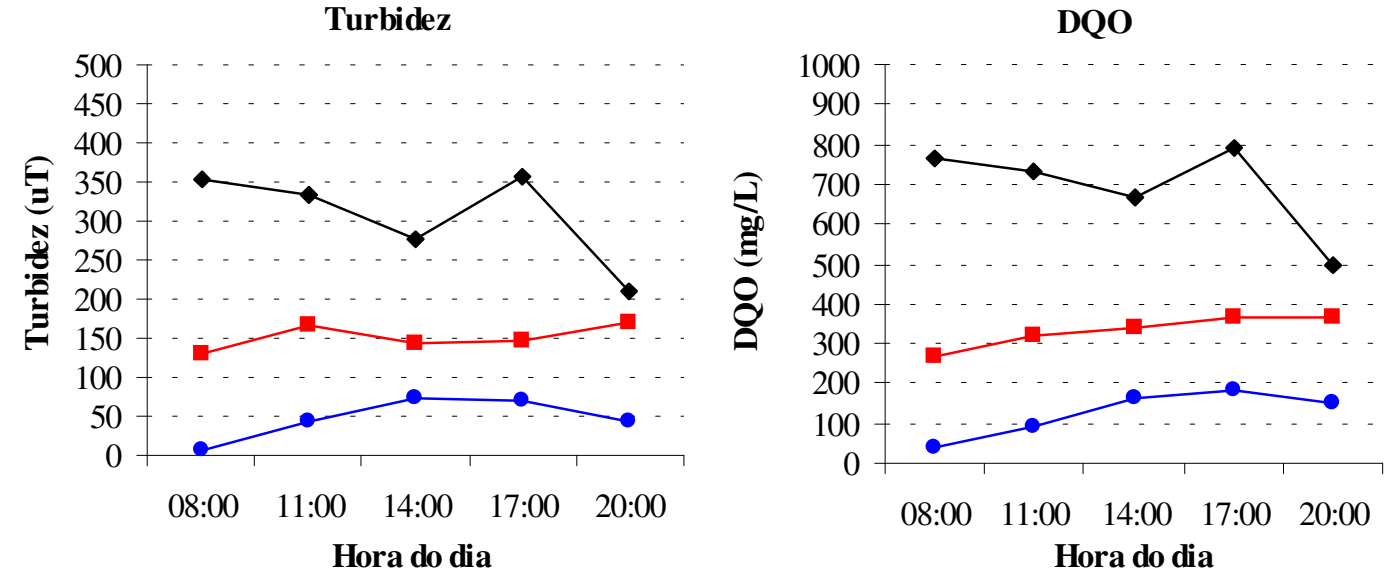

Fósforo
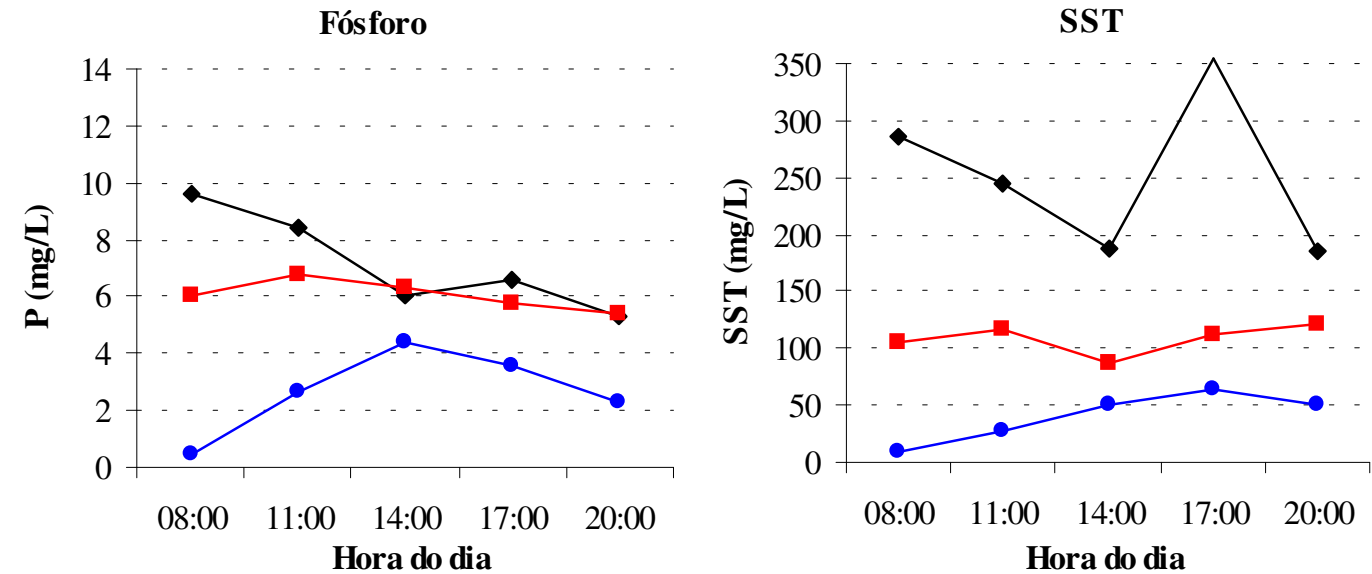

FIGURA 5.49 - Temperatura, $\mathrm{pH}$, turbidez, demanda química de oxigênio, fósforo e sólidos suspensos totais das amostras de esgoto bruto, de efluente do reator RALEx e de efluente do flotador coletadas ao longo do dia de ensaio (16/03/2001).

Ensaios realizados em instalação piloto de coagulação/floculação/flotação por ar dissolvido com escoamento contínuo e efluente do reator RALEx. Data do ensaio: 16/03/2001; DCF=50 mg/L; Gf=60 s-1; $\mathrm{Tf}=20 \mathrm{~min} ; \mathrm{R}=18 \%$; Psat=450 kPa; $\mathrm{S}^{*}=19,7 \mathrm{~g} / \mathrm{m}^{3} ;$ TAS $=180 \mathrm{~m}^{3} / \mathrm{m}^{2} /$ dia. 
A FIGURA 5.50 apresenta os valores de temperatura, de pH, de turbidez, de DQO, de fósforo e de sólidos suspensos totais do efluente do flotador em função do horário de coleta das amostras quando os seguintes parâmetros operacionais foram adotados: $\mathrm{DCF}=50$ $\mathrm{mg} / \mathrm{L}, \mathrm{Gf}=80 \mathrm{~s}^{-1}, \mathrm{Tf}=20 \mathrm{~min}, \mathrm{R}=18 \%$, Psat=450 $\mathrm{kPa}$ e TAS $=180 \mathrm{~m}^{3} / \mathrm{m}^{2} / \mathrm{dia}$.

A temperatura do esgoto bruto variou entre $27,8^{\circ} \mathrm{C}$; às $11: 00$, e $28,0^{\circ} \mathrm{C}$, às $14: 00$. O efluente do reator anaeróbio apresentou temperaturas entre $27,4^{\circ} \mathrm{C}$ e $28,7^{\circ} \mathrm{C}$ e o efluente do flotador entre $27,2^{\circ} \mathrm{C}$ e $28,7^{\circ} \mathrm{C}$.

$\mathrm{O}$ pH do esgoto bruto variou entre 6,8 e 7,1. O efluente do RALEx apresentou pH entre 6,7 e 6,9 enquanto o $\mathrm{pH}$ do efluente do flotador variou entre 6,4 e 6,6.

A turbidez do esgoto bruto apresentou forte variação, com valores entre 192 e 358 uT. O efluente do reator anaeróbio sofreu reduzida variação de sua turbidez entre 08:00 e 20:00, variando entre 129 e 143 uT. A turbidez do efluente do flotador elevou-se gradativamente, de 1,61 uT, às 08:00, a 15,4 uT, às 11:00. A partir das 14:00, a turbidez sofreu redução em seu valor, até atingir 4,9 uT, às 20:00.

O esgoto bruto apresentou moderada oscilação nos valores de DQO. Neste ensaio, foram observados valores de DQO entre 527 e 947 mg/L. O RALEx contribuiu moderadamente para redução da carga orgânica, fornecendo efluente com DQO entre 268 e $340 \mathrm{mg} / \mathrm{L}$, com eficiência de remoção de carga orgânica de 56,5\% entre 08:00 e 20:00. A DQO do efluente do flotador elevou-se gradativamente, de $43 \mathrm{mg} / \mathrm{L}$, às 08:00, para $71 \mathrm{mg} / \mathrm{L}$, às 17:00. A partir das 20:00, a DQO do efluente do flotador praticamente manteve-se estável, com valor de $70 \mathrm{mg} / \mathrm{L}$. A eficiência de remoção de carga orgânica promovida pelo flotador entre 08:00 e 20:00 foi de 80,6\%. A eficiência de remoção global de carga orgânica alcançada pelo sistema RALEx-flotador foi de $91,6 \%$.

O esgoto bruto também apresentou forte oscilação nos valores de fósforo. Neste ensaio, foram observados valores de $\mathrm{P}$ entre 5,1 e 10,3 mg/L. O RALEx contribuiu fortemente para equalização da concentração de fósforo no seu efluente, resultando em valores de $\mathrm{P}$ entre 4,9 e $6,8 \mathrm{mg} / \mathrm{L}$. A concentração de $\mathrm{P}$ do efluente do flotador elevou-se gradativamente, de 0,10 mg/L, às 08:00, a $0,80 \mathrm{mg} / \mathrm{L}$, às 14:00. A partir das 17:00, a concentração de $\mathrm{P}$ do efluente do flotador sofreu gradativa redução em seu valor para até 0,60 mg/L, às 20:00. A eficiência de remoção de carga de fósforo promovida pelo flotador entre 08:00 e 20:00 foi de 90,1\%.

O esgoto bruto também apresentou forte oscilação nos valores de SST. Neste ensaio, foram observados valores de SST entre 139 e 299 mg/L. O RALEx contribuiu moderadamente para redução da carga de sólidos suspensos, fornecendo efluente com SST entre 81 e $115 \mathrm{mg} / \mathrm{L}$, com eficiência de remoção média de carga de sólidos de 56,7\% entre 08:00 e 20:00. A concentração de SST do efluente do flotador elevou-se gradativamente, de $4 \mathrm{mg} / \mathrm{L}$, às 08:00, para $11 \mathrm{mg} / \mathrm{L}$, às 11:00, diminuindo para $6 \mathrm{mg} / \mathrm{L}$ às 20:00. A eficiência de remoção de carga de SST promovida pelo flotador entre 08:00 e 20:00 foi de 92,1\%. A 
eficiência de remoção global de sólidos suspensos alcançada pelo sistema RALEx-flotador foi de $96,6 \%$.
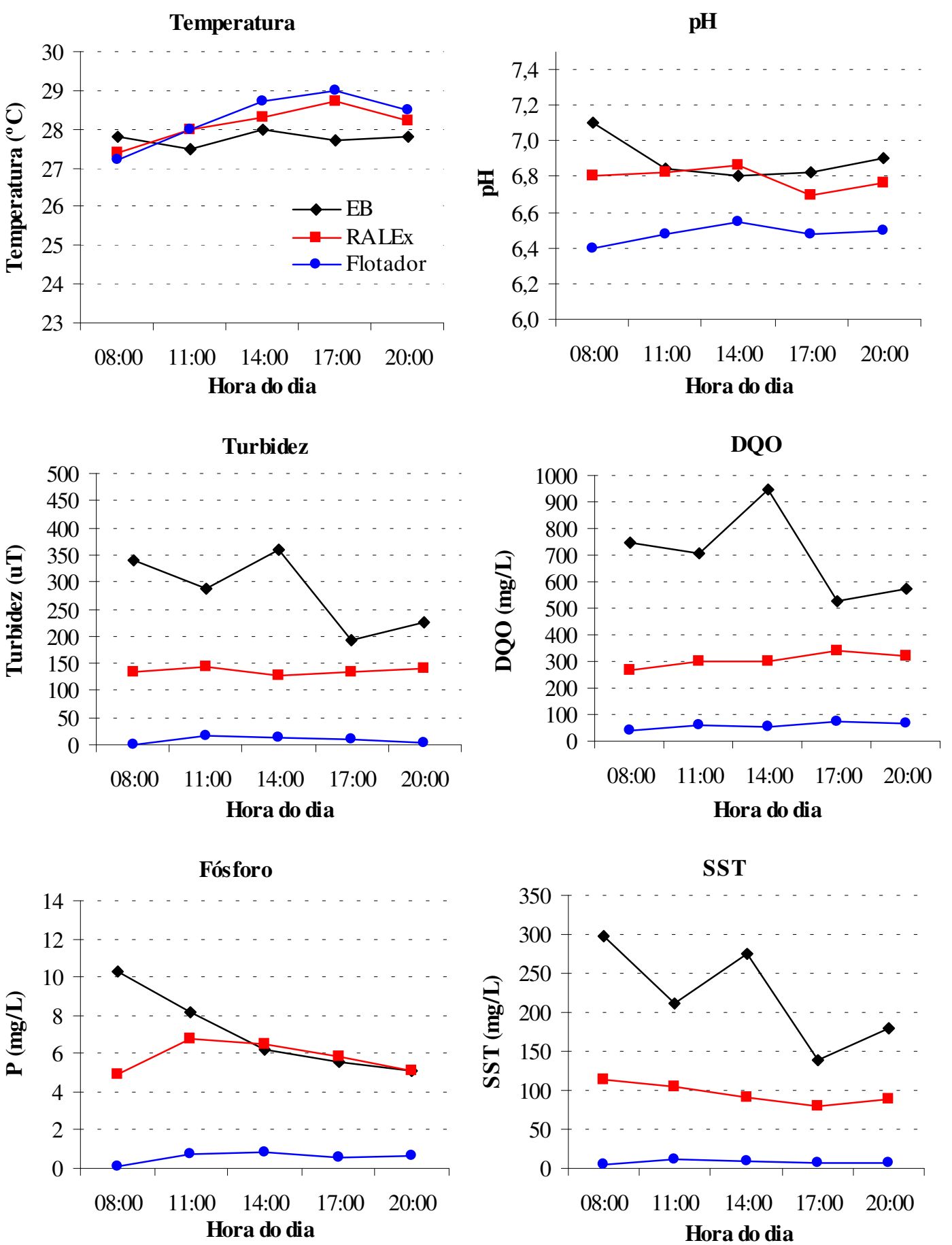

FIGURA 5.50 - Temperatura, pH, turbidez, demanda química de oxigênio, fósforo e sólidos suspensos totais das amostras de esgoto bruto, de efluente do reator RALEx e de efluente do flotador coletadas ao longo do dia de ensaio (20/03/2001).

Ensaios realizados em instalação piloto de coagulação/floculação/flotação por ar dissolvido com escoamento contínuo e efluente do reator RALEx. Data do ensaio: 20/03/2001; DCF=50 mg/L; Gf=80 s-1; Tf=20 min; R=18\%; Psat=450 kPa; $\mathrm{S}^{*}=19,7 \mathrm{~g} / \mathrm{m}^{3} ;$ TAS $=180 \mathrm{~m}^{3} / \mathrm{m}^{2} /$ dia. 
A FIGURA 5.51 apresenta os valores de temperatura, de pH, de turbidez, de DQO, de fósforo e de sólidos suspensos totais do efluente do flotador em função do horário de coleta das amostras quando os seguintes parâmetros operacionais foram adotados: $\mathrm{DCF}=50$ $\mathrm{mg} / \mathrm{L}, \mathrm{Gf}=100 \mathrm{~s}^{-1}, \mathrm{Tf}=20 \mathrm{~min}, \mathrm{R}=18 \%$, Psat $=450 \mathrm{kPa}$ e TAS $=180 \mathrm{~m}^{3} / \mathrm{m}^{2} / \mathrm{dia}$.

A temperatura do esgoto bruto variou entre $26,5^{\circ} \mathrm{C}$; às $08: 00$, e $29,0^{\circ} \mathrm{C}$, às $14: 00$. O efluente do reator anaeróbio apresentou temperaturas entre $26,0^{\circ} \mathrm{C}$ e $30,0^{\circ} \mathrm{C}$ e o efluente do flotador entre $26,0^{\circ} \mathrm{C}$ e $29,0^{\circ} \mathrm{C}$.

$\mathrm{O}$ pH do esgoto bruto variou entre 6,8 e 7,2. O efluente do RALEx apresentou pH entre 6,6 e 6,8 enquanto o $\mathrm{pH}$ do efluente do flotador variou entre 6,4 e 6,7.

A turbidez do esgoto bruto apresentou elevada variação, com valores entre 187 e 458 uT. O efluente do reator anaeróbio sofreu pequena variação de sua turbidez entre 08:00 e 20:00, variando entre 128 e 162 uT. A turbidez do efluente do flotador elevou-se gradativamente, de 1,29 uT, às 08:00, a 38,5 uT, às 14:00. A partir das 17:00, a turbidez sofreu redução em seu valor, até atingir 13,9 uT, às 20:00.

O esgoto bruto apresentou pequena oscilação nos valores de DQO. Neste ensaio, foram observados valores de DQO entre 506 e $788 \mathrm{mg} / \mathrm{L}$. O RALEx contribuiu moderadamente para redução da carga orgânica, fornecendo efluente com DQO entre 302 e $329 \mathrm{mg} / \mathrm{L}$, com eficiência de remoção de carga orgânica de 52,3\% entre 08:00 e 20:00. A DQO do efluente do flotador elevou-se gradativamente, de $29 \mathrm{mg} / \mathrm{L}$, às 08:00, para 118 $\mathrm{mg} / \mathrm{L}$, às 14:00. A partir das 17:00, a DQO do efluente do flotador sofreu redução em seu valor, até atingir $73 \mathrm{mg} / \mathrm{L}$, às 20:00. A eficiência de remoção de carga orgânica promovida pelo flotador entre 08:00 e 20:00 foi de 76,3\%. A eficiência de remoção global de carga orgânica alcançada pelo sistema RALEx-flotador foi de $88,7 \%$.

$\mathrm{O}$ esgoto bruto também apresentou forte oscilação nos valores de fósforo. Neste ensaio, foram observados valores de $\mathrm{P}$ entre 4,5 e 10,3 mg/L. O RALEx contribuiu fortemente para equalização da concentração de fósforo no seu efluente, resultando em valores de $\mathrm{P}$ entre 4,7 e $6,7 \mathrm{mg} / \mathrm{L}$. A concentração de $\mathrm{P}$ do efluente do flotador elevou-se gradativamente, de 0,02 mg/L, às 08:00, a 1,90 mg/L, às 14:00. A partir das 17:00, a concentração de $\mathrm{P}$ do efluente do flotador sofreu gradativa redução em seu valor para até 0,60 mg/L, às 20:00. A eficiência de remoção de carga de fósforo promovida pelo flotador entre 08:00 e 20:00 foi de 86,7\%.

O esgoto bruto também apresentou forte oscilação nos valores de SST. Neste ensaio, foram observados valores de SST entre 132 e 323 mg/L. O RALEx contribuiu moderadamente para redução da carga de sólidos suspensos, fornecendo efluente com SST entre 51 e 149 mg/L, com eficiência de remoção média de carga de sólidos de 56,4\% entre 08:00 e 20:00. A concentração de SST do efluente do flotador elevou-se gradativamente, de $2 \mathrm{mg} / \mathrm{L}$, às 08:00, para $22 \mathrm{mg} / \mathrm{L}$, às 14:00, diminuindo para $10 \mathrm{mg} / \mathrm{L}$ às 20:00. A eficiência de remoção de carga de SST promovida pelo flotador entre 08:00 e 20:00 foi de 88,2\%. A 
eficiência de remoção global de sólidos suspensos alcançada pelo sistema RALEx-flotador foi de $94,9 \%$.
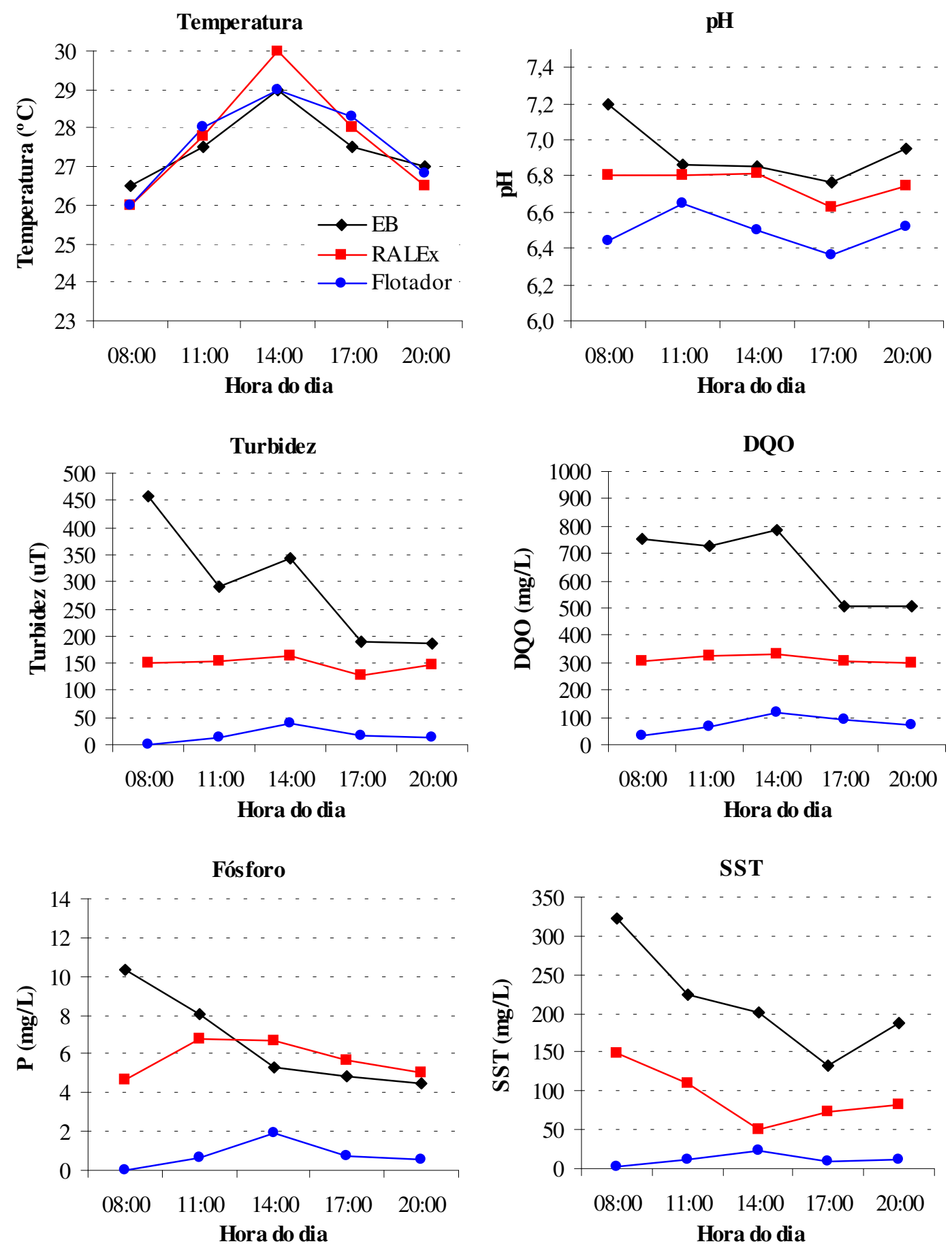

FIGURA 5.51 - Temperatura, pH, turbidez, demanda química de oxigênio, fósforo e sólidos suspensos totais das amostras de esgoto bruto, de efluente do reator RALEx e de efluente do flotador coletadas ao longo do dia de ensaio (21/03/2001).

Ensaios realizados em instalação piloto de coagulação/floculação/flotação por ar dissolvido com escoamento contínuo e efluente do reator RALEx. Data do ensaio: 21/03/2001; DCF $=50 \mathrm{mg} / \mathrm{L} ; \mathrm{Gf}=100 \mathrm{~s}^{-1} ; \mathrm{Tf}=20 \mathrm{~min} ; \mathrm{R}=18 \%$; Psat=450 kPa; $\mathrm{S}^{*}=19,7 \mathrm{~g} / \mathrm{m}^{3} ; \mathrm{TAS}=180 \mathrm{~m}^{3} / \mathrm{m}^{2} /$ dia. 
Durante os ensaios dessa etapa, o sistema de flotação, operado em condições adequadas de coagulação/floculação, apresentou operação fácil, comportamento estável e excelente desempenho devido às características de boa "flotabilidade" dos flocos formados a partir da coagulação química do efluente do reator RALEx.

A análise e discussão dos resultados através da comparação entre as diferentes eficiências de remoção média de turbidez e de carga de DQO, de fósforo e de SST observadas em cada ensaio dessa etapa é relativa em função da variabilidade horária e diária da qualidade do esgoto bruto e da significativa influência da qualidade do efluente do reator RALEx pela qualidade do esgoto bruto, o que não é desejável.

Ainda assim, alguns comportamentos puderam ser observados quando da variação do tempo e do gradiente médio de velocidade de floculação, conforme dados da TABELA 5.7, para $\mathrm{R}=18 \%$.

A qualidade do efluente do RALEx, em termos de turbidez média e de carga de DQO, de fósforo e de SST entre 08:00 e 20:00, durante os ensaios com $\mathrm{Tf}=13 \mathrm{~min}$ associados a Gf de 60 e $80 \mathrm{~s}^{-1}$ foi bastante semelhante. Comparando-os, observa-se que a qualidade do efluente do flotador quando $\mathrm{Gf}=80 \mathrm{~s}^{-1}$ foi significativamente melhor do que quando $\mathrm{Gf}=60 \mathrm{~s}^{-1}$.

Ainda para $\mathrm{Tf}=13 \mathrm{~min}$, comparando os efluentes do RALEx nos ensaios com $\mathrm{Gf}=80$ $\mathrm{s}^{-1}$ e $\mathrm{Gf}=100 \mathrm{~s}^{-1}$, vê-se que a qualidade do segundo era pior do que a do primeiro. Ainda assim, a qualidade do efluente do flotador nos dois ensaios foi semelhante em termos de DQO e de fósforo.

Durante os ensaios com $\mathrm{Tf}=20$ min, a qualidade do efluente do RALEx, em termos de turbidez média e de carga de DQO, de fósforo e de SST entre 08:00 e 20:00, era relativamente semelhante entre os três ensaios.Comparando-os, observa-se que a qualidade do efluente do flotador quando $\mathrm{Gf}=80 \mathrm{~s}^{-1}$ era pouco melhor do que quando $\mathrm{Gf}=100 \mathrm{~s}^{-1} \mathrm{e}$ significativamente melhor do que quando $\mathrm{Gf}=60 \mathrm{~s}^{-1}$. Em termos de remoção de turbidez, de $\mathrm{DQO}$, de fósforo e de $\mathrm{SST}$, os valores alcançados quando $\mathrm{Gf}=80 \mathrm{~s}^{-1}$ eram próximos àqueles quando $\mathrm{Gf}=100 \mathrm{~s}^{-1}$.

A avaliação da adequação do diferentes valores de Gf e de Tf é importante para identificar se a cinética de floculação está maximizada, ou seja, se todo o coagulante adicionado foi efetivamente utilizado na desestabilização das partículas e na formação de flocos adequados ao processo de separação escolhido, neste caso, a flotação. Uma das alternativas de avaliação é a análise da concentração de ferro residual nos efluentes do flotador. Para efetiva coagulação e floculação, pelo menos a parcela de ferro adicionada mediante dosagem de cloreto férrico deve ter sido removida. Para $\mathrm{Tf}=13 \mathrm{~min}$, o aumento de 
Gf resultou em concentrações de ferro cada vez menores. Para $\mathrm{Gf}=60 \mathrm{~s}^{-1}$, houve residual de cerca de 2,75 mgFe/L, unicamente decorrente da adição de cloreto férrico. Para Gf= $80 \mathrm{~s}^{-1}$, este residual foi de $0,26 \mathrm{mgFe} / \mathrm{L}$, indicando melhoria na qualidade de floculação. Para $\mathrm{Gf}=100 \mathrm{~s}^{-1}$, além de não haver residual decorrente da adição de cloreto férrico, a adequada coagulação/floculação/flotação obteve sucesso em remover $0,66 \mathrm{mgFe} / \mathrm{L}$ do ferro inicialmente presente no efluente do RALEx.

Por outro lado, para $\mathrm{Tf}=20 \mathrm{~min}$, a variação de Gf resultou em baixas concentrações de ferro para valores entre 80 e $100 \mathrm{~s}^{-1}$. Para $\mathrm{Gf}=60 \mathrm{~s}^{-1}$, houve residual de cerca de 0,83 $\mathrm{mgFe} / \mathrm{L}$, unicamente decorrente da adição de cloreto férrico. Para $\mathrm{Gf}=80 \mathrm{~s}^{-1}$, além de não haver residual decorrente da adição de cloreto férrico, a adequada coagulação/floculação/ flotação obteve sucesso em remover $0,33 \mathrm{mgFe} / \mathrm{L}$ do ferro inicialmente presente no efluente do RALEx.. Para Gf=100 s$~ s^{-1}$, este residual foi de $0,02 \mathrm{mgFe} / \mathrm{L}$, indicando melhoria na qualidade de floculação em relação ao Gf de $60 \mathrm{~s}^{-1}$ porém piora em relação ao de $80 \mathrm{~s}^{-1}$.

Desta forma, para tempos de floculação entre 13 e 20 min, o valor de Gf demonstrou influir significativamente na eficiência da flotação dos efluentes do reator anaeróbio.

A aplicação de Gf em torno de $80 \mathrm{~s}^{-1}$ proporcionou menor variação nos valores de SST do efluente do flotador nas amostras coletadas em diferentes horários ao longo do dia. Particularmente, o emprego de Gf de $80 \mathrm{~s}^{-1}$ e de Tf de $20 \mathrm{~min}$ (TABELA 5.7, Tf=20 min e $\mathrm{Gf}=80 \mathrm{~s}^{-1}$ ) resultou em valores de SST menores e mais estáveis ao longo da operação do flotador.

Se consideradas as remoções globais do sistema, praticamente não houve diferenças significativas de eficiência de remoção de carga de DQO nos usos combinados de tempo de

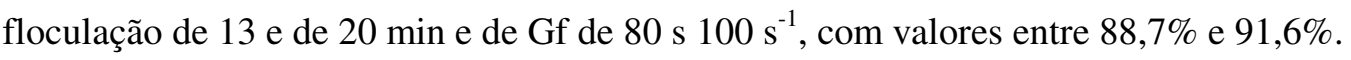

O uso de Gf em torno de $80 \mathrm{~s}^{-1}$ proporcionou menor variação na concentração de fósforo no efluente da FAD nas amostras coletadas em diferentes horários ao longo do dia.

O emprego de $\mathrm{Gf}=60 \mathrm{~s}^{-1}$ não trouxe boa qualidade de coagulação/floculação/ flotação, tendo em vista o elevado residual de ferro, majoritariamente oriundo do $\mathrm{FeCl}_{3}$ adicionado, encontrado nos efluentes do flotador. O uso de dois pares de valores de Tf/Gf (13 min/100 s $\mathrm{s}^{-1}$ e $\left.20 \mathrm{~min} / 80 \mathrm{~s}^{-1}\right)$ resultou em remoção adicional de ferro, indicando excelentes condições do tratamento físico-químico.

Nas melhores condições de operação $\left(\mathrm{Gf}=80 \mathrm{~s}^{-1} ; \mathrm{Tf}=20 \mathrm{~min} ; \mathrm{P}=450 \mathrm{kPa}\right.$; vazão de recirculação igual a $18 \%$ da vazão afluente e aplicação de $50 \mathrm{mg} / \mathrm{L}$ de cloreto férrico), o 
sistema "RALEx/Flotador" produziu efluente com as seguintes concentrações residuais: 53 $\mathrm{mg} / \mathrm{L}$ de DQO, 0,80 mg/L de fósforo, $9 \mathrm{mg} / \mathrm{L}$ de SST e 12,9 uT de turbidez, às 14:00, horário em que o efluente apresentava a pior qualidade ao longo do dia.

TABELA 5.7 - Valores de turbidez média e de carga de DQO, de fósforo e de SST e de concentração de ferro para as amostras de esgoto bruto, de efluente do RALEx e de efluente do flotador, entre 08:00 e 20:00, e respectivas remoções observadas no reator RALEx, no flotador e no sistema conjugado, de acordo com a etapa 5.6.1.1.2.

\begin{tabular}{|c|c|c|c|c|c|c|c|}
\hline & \multicolumn{6}{|c|}{ DCF $=50 \mathrm{mg} / \mathrm{L} ; \mathrm{R}=18 \%, \mathrm{~S}^{*}=19,7 \mathrm{~g} / \mathrm{m}^{3}$, TAS $=180 \mathrm{~m}^{3} / \mathrm{m}^{2} / \mathrm{d}$} \\
\hline & & \multicolumn{3}{|c|}{$\mathbf{T f}=\mathbf{1 3} \min$} & \multicolumn{3}{|c|}{$\mathbf{T f}=\mathbf{2 0} \mathrm{min}$} \\
\hline & & $60 \mathrm{~s}^{-1}$ & $80 \mathrm{~s}^{-1}$ & $100 \mathrm{~s}^{-1}$ & $60 \mathrm{~s}^{-1}$ & $80 \mathrm{~s}^{-1}$ & $100 \mathrm{~s}^{-1}$ \\
\hline \multirow{5}{*}{ 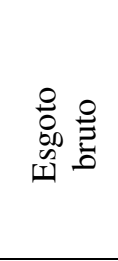 } & Turbidez média (uT) & 205 & 300 & 271 & 306 & 280 & 293 \\
\hline & DQO $(\mathrm{kg} / 12 \mathrm{~h})$ & 39,7 & 46,0 & 47,8 & 51,6 & 52,4 & 49,1 \\
\hline & $\mathrm{P}(\mathrm{kg} / 12 \mathrm{~h})$ & 0,41 & 0,51 & 0,50 & 0,54 & 0,53 & 0,49 \\
\hline & SST $(\mathrm{kg} / 12 \mathrm{~h})$ & 10,6 & 17,5 & 15,2 & 18,8 & 16,5 & 16,0 \\
\hline & Ferro $(\mathrm{mg} / \mathrm{L}) *$ & 1,27 & 2,76 & 1,76 & 2,19 & 2,10 & 1,44 \\
\hline \multirow{5}{*}{ 莺肴 } & Turbidez média (uT) & 103 & 102 & 127 & 151 & 136 & 148 \\
\hline & DQO $(\mathrm{kg} / 12 \mathrm{~h})$ & 17,2 & 17,2 & 20,6 & 24,7 & 22,8 & 23,4 \\
\hline & $\mathrm{P}(\mathrm{kg} / 12 \mathrm{~h})$ & 0,36 & 0,34 & 0,43 & 0,45 & 0,44 & 0,43 \\
\hline & SST $(\mathrm{kg} / 12 \mathrm{~h})$ & 4,3 & 3,8 & 6,3 & 8,1 & 7,1 & 7,0 \\
\hline & Ferro $(\mathrm{mg} / \mathrm{L}) *$ & 0,65 & 0,80 & 1,35 & 1,25 & 0,82 & 0,86 \\
\hline \multirow{5}{*}{ 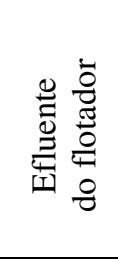 } & Turbidez média (uT) & 46,0 & 14,0 & 19,2 & 47,2 & 9,1 & 16,9 \\
\hline & DQO $(\mathrm{kg} / 12 \mathrm{~h})$ & 7,8 & 4,3 & 4,3 & 9,3 & 4,4 & 5,5 \\
\hline & $\mathrm{P}(\mathrm{kg} / 12 \mathrm{~h})$ & 0,19 & 0,05 & 0,06 & 0,20 & 0,04 & 0,06 \\
\hline & SST (kg/12 h) & 2,2 & 0,6 & 1,2 & 3,0 & 0,6 & 0,8 \\
\hline & Ferro $(\mathrm{mg} / \mathrm{L}) *$ & 3,40 & 1,06 & 0,69 & 2,08 & 0,50 & 0,88 \\
\hline \multirow{3}{*}{ 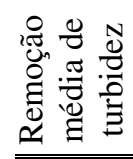 } & RALEx $(\%)$ & 49,7 & 66,0 & 53,1 & 50,8 & 51,5 & 49,6 \\
\hline & FAD (\%) & 55,3 & 86,2 & 84,9 & 68,7 & 93,3 & 88,6 \\
\hline & Sistema $(\%)$ & 77,5 & 95,3 & 92,9 & 84,6 & 96,7 & 94,3 \\
\hline \multirow{3}{*}{ 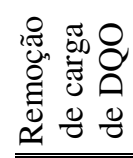 } & RALEx $(\%)$ & 56,8 & 62,6 & 57,0 & 52,1 & 56,5 & 52,3 \\
\hline & FAD (\%) & 54,7 & 75,1 & 79,0 & 62,2 & 80,6 & 76,3 \\
\hline & Sistema $(\%)$ & 80,4 & 90,7 & 91,0 & 81,9 & 91,6 & 88,7 \\
\hline \multirow{3}{*}{ 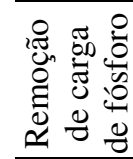 } & RALEx $(\%)$ & 12,2 & 33,2 & 14,3 & 15,6 & 17,3 & 13,3 \\
\hline & FAD (\%) & 47,9 & 85,9 & 85,1 & 56,1 & 90,1 & 86,7 \\
\hline & Sistema $(\%)$ & 54,2 & 90,6 & 87,2 & 63,0 & 91,8 & 88,5 \\
\hline \multirow{3}{*}{ 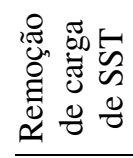 } & RALEx (\%) & 59,6 & 78,5 & 58,8 & 57,1 & 56,7 & 56,4 \\
\hline & FAD (\%) & 49,0 & 82,9 & 80,5 & 62,7 & 92,1 & 88,2 \\
\hline & Sistema (\%) & 79,4 & 96,3 & 92,0 & 84,0 & 96,6 & 94,9 \\
\hline \multirow{3}{*}{ 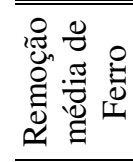 } & RALEx $(\%)$ & 48,8 & 71,0 & 23,3 & 42,9 & 61,0 & 40,3 \\
\hline & FAD (\%) & $-423,1$ & $-32,5$ & 48,9 & $-66,4$ & 39,0 & $-2,3$ \\
\hline & Sistema (\%) & $-167,7$ & 61,6 & 60,8 & 5,0 & 76,2 & 38,9 \\
\hline
\end{tabular}

(*) Os dados de concentração de ferro referem-se à "amostra composta" constituída de amostras coletadas entre 08:00 e 20:00. 
O aumento da quantidade de ar fornecido ao processo, mediante elevação da fração de recirculação (R) de $12 \%$ para $18 \%$, foi bastante benéfico ao desempenho do flotador. Para efeito de discussão, são considerados todos os ensaios com uso de $50 \mathrm{mgFeCl}_{3}$ e de taxa de aplicação superficial de $180 \mathrm{~m}^{3} / \mathrm{m}^{2} / \mathrm{d}$ (etapas 5.6.1.1.1 e 5.6.1.1.2). Quando do uso de $\mathrm{R}=12 \%$, observaram-se remoções de carga de DQO entre 49,6\% e 61,4\%, de fósforo entre $21,1 \%$ e 58,2\% e de SST entre 55,6\% e 68,3\%, resultados apenas satisfatórios Para R=18\%, as remoções de carga de DQO variaram entre $54,7 \%$ e $80,6 \%$, de fósforo entre $35,4 \%$ e $90,1 \%$ e de SST entre $49,0 \%$ e $92,1 \%$, ou seja, excelentes resultados. Considerando-se a remoção global de carga de DQO alcançada pelo sistema RALEx-flotador, o uso de R=18\% sempre forneceu valores acima de $80 \%$. Para $\mathrm{R}=12 \%$, somente um único ensaio resultou em remoção superior a $80 \%$ (TABELA 5.6, $\mathrm{Tf}=20 \mathrm{~min} \mathrm{e} \mathrm{Gf}=80 \mathrm{~s}^{-1}$ ).

Há de se considerar, entretanto, que durante os ensaios com $\mathrm{R}=12 \%$, a carga de SST no efluente do RALEx variou entre 10,8 e $14,4 \mathrm{~kg} / 12 \mathrm{~h}$ e quando $\mathrm{R}=18 \%$ a referida carga oscilou entre 3,8 e $8,1 \mathrm{~kg} / 12 \mathrm{~h}$. Há de se considerar que unidades em escala real apresentam significativa variação de carga de sólidos ao longo do dia. $\mathrm{O}$ uso de $\mathrm{R}=12 \%$ e $\mathrm{P}=450 \mathrm{kPa}$ poderia ser adotado para horários onde a carga de sólidos fosse menor, por exemplo, no período noturno. Para o período diurno, o uso de $\mathrm{R}=18 \%$ e $\mathrm{P}=450 \mathrm{kPa}$ proporcionou maior estabilidade operacional ao sistema.

Com base nestes resultados, pode-se afirmar que a qualidade do efluente do flotador durante os ensaios com $\mathrm{R}=18 \%$ foi significativamente melhor quando comparado aos ensaios com $\mathrm{R}=12 \%$. Notadamente, o aumento da quantidade de ar fornecido resultou em aumento expressivo de desempenho da unidade de flotação e da qualidade final do efluente.

Durante o ensaio com $\mathrm{Tf}=13$ min e $\mathrm{Gf}=80 \mathrm{~s}^{-1}$, a vazão média pós-tratada por flotação foi de $6,229 \mathrm{~m}^{3} / \mathrm{h}$. Considerando esta vazão e as dosagens de cloreto férrico utilizadas ao longo das 12 horas, tem-se que a carga de cloreto férrico empregada foi de $3,74 \mathrm{~kg}$. Com os dados de SST das amostras retiradas da última câmara de floculação (floculado) ao longo do ensaio, vistos na FIGURA 5.47, pode-se estimar a quantidade de lodo flotado. Através da subtração dos valores de SST do efluente do flotador dos valores do efluente floculado e considerando vazão de $6,229 \mathrm{~m}^{3} / \mathrm{h}$ e 12 horas de ensaio, obtém-se valor de $5,72 \mathrm{kgSST}$, peso seco estimado de lodo flotado, equivalente à remoção horária média de 0,48 kgSST, na forma de lodo, ou seja, 77,1 $\mathrm{g}$ de lodo por $\mathrm{m}^{3}$ de esgoto tratado no flotador. Considerando consumo per capita de $200 \mathrm{~L} /$ dia, a população atendida, correspondente a $6,229 \mathrm{~m}^{3} / \mathrm{h}$, foi de 750 pessoas. Desta forma, a produção per capita de lodo foi de 15,3 gSST/pessoa/dia. 
A FIGURA 5.52 apresenta os valores de temperatura, de pH, de turbidez, de DQO, de fósforo e de sólidos suspensos totais do efluente do flotador em função do horário de coleta das amostras quando os seguintes parâmetros operacionais foram adotados: $\mathrm{DCF}=70$ $\mathrm{mg} / \mathrm{L}, \mathrm{Gf}=80 \mathrm{~s}^{-1}, \mathrm{Tf}=20 \mathrm{~min}, \mathrm{R}=18 \%$, Psat $=450 \mathrm{kPa}$ e TAS $=180 \mathrm{~m}^{3} / \mathrm{m}^{2} /$ dia. A temperatura do esgoto bruto variou entre $22,0^{\circ} \mathrm{C}$, às $08: 00$, e $23,0^{\circ} \mathrm{C}$, às 17:00. O efluente do reator anaeróbio apresentou temperaturas entre $21,0^{\circ} \mathrm{C}$ e $23,5^{\circ} \mathrm{C}$ e o efluente do flotador entre $21,0^{\circ} \mathrm{C}$ e $23,8^{\circ} \mathrm{C}$. O pH do esgoto bruto variou entre 7,0 e 7,2. O efluente do RALEx apresentou pH entre 6,8 e 6,9 enquanto o pH do efluente do flotador variou entre 6,6 e 6,8.

A turbidez do esgoto bruto apresentou forte variação, com valores entre 162 e 353 uT. O efluente do reator anaeróbio sofreu forte variação de sua turbidez entre 08:00 e 20:00, variando entre 155 e $283 \mathrm{uT}$. A turbidez do efluente do flotador elevou-se gradativamente, de 15,7 uT, às 08:00, a 37,4 uT, às 17:00. A partir das 20:00, a turbidez sofreu redução em seu valor, até atingir $32,8 \mathrm{uT}$.

O esgoto bruto apresentou moderada oscilação nos valores de DQO. Neste ensaio, foram observados valores de DQO entre 390 e $775 \mathrm{mg} / \mathrm{L}$. O RALEx contribuiu pouco para redução da carga orgânica, fornecendo efluente com DQO entre 320 e $445 \mathrm{mg} / \mathrm{L}$, com remoção de carga orgânica de 38,1\% entre 08:00 e 20:00. A DQO do efluente do flotador elevou-se gradativamente, de $50 \mathrm{mg} / \mathrm{L}$, às 08:00, para $85 \mathrm{mg} / \mathrm{L}$, às 20:00. A remoção de carga orgânica promovida pelo flotador entre 08:00 e 20:00 foi de 81,7\%. A remoção global de carga orgânica alcançada pelo sistema RALEx-flotador foi de 88,7\%.

O esgoto bruto também apresentou forte oscilação nos valores de concentração de fósforo. Neste ensaio, foram observados valores de P entre 6,8 e 11,9 mg/L. O RALEx contribuiu eficazmente para equalização da concentração de fósforo no seu efluente, resultando em valores de $\mathrm{P}$ entre 6,60 e 7,20 mg/L. A concentração de $\mathrm{P}$ do efluente do flotador variou entre 1,40 mg/L, às 11:00, a 2,40 mg/L, às 14:00 e 17:00. Às 20:00, a concentração de $P$ do efluente do flotador sofreu redução em seu valor para 2,00 mg/L. A remoção de carga de fósforo promovida pelo flotador entre 08:00 e 20:00 foi de 71,3\%.

O esgoto bruto também apresentou moderada oscilação nos valores de SST. Neste ensaio, foram observados valores de SST entre 146 e $245 \mathrm{mg} / \mathrm{L}$. O RALEx contribuiu pouco para redução da carga de sólidos suspensos, fornecendo efluente com SST entre 109 e 209 mg/L, com remoção média de carga de sólidos de 20,5\% entre 08:00 e 20:00. A concentração de SST do efluente do flotador variou entre $14 \mathrm{mg} / \mathrm{L}$, às 11:00, e $29 \mathrm{mg} / \mathrm{L}$, às 17:00, diminuindo para $21 \mathrm{mg} / \mathrm{L}$ às 20:00. A remoção de carga de SST promovida pelo flotador entre 08:00 e 20:00 foi de 85,7\%. A remoção global de sólidos suspensos alcançada pelo sistema RALEx-flotador foi de $88,6 \%$. 
Temperatura

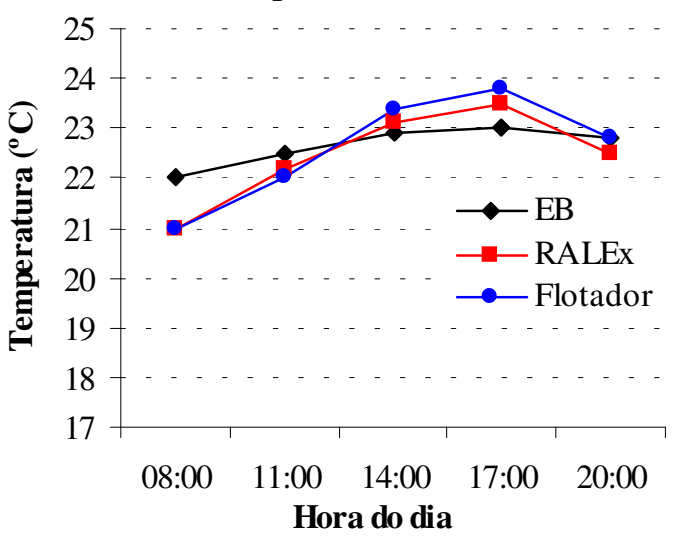

Turbidez

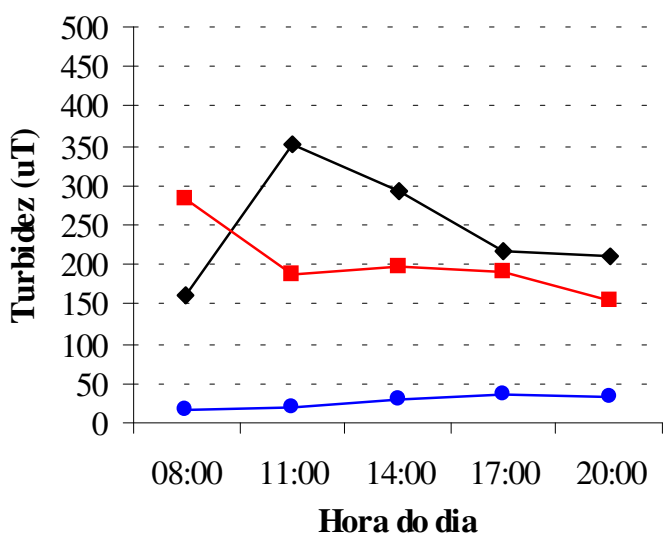

Fósforo

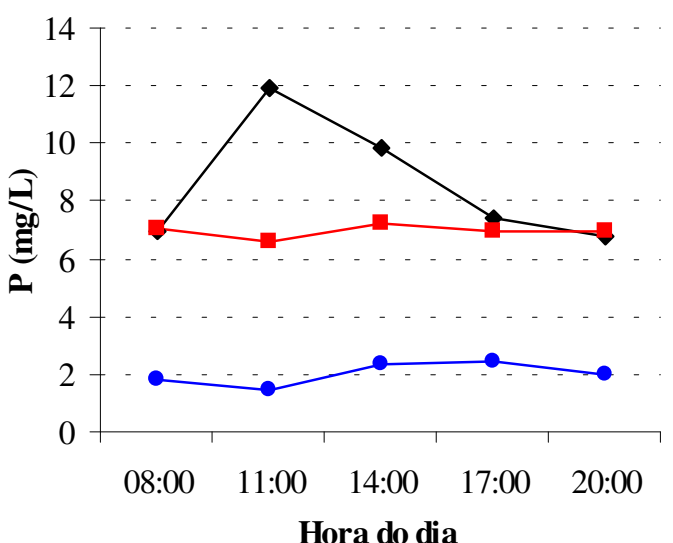

pH
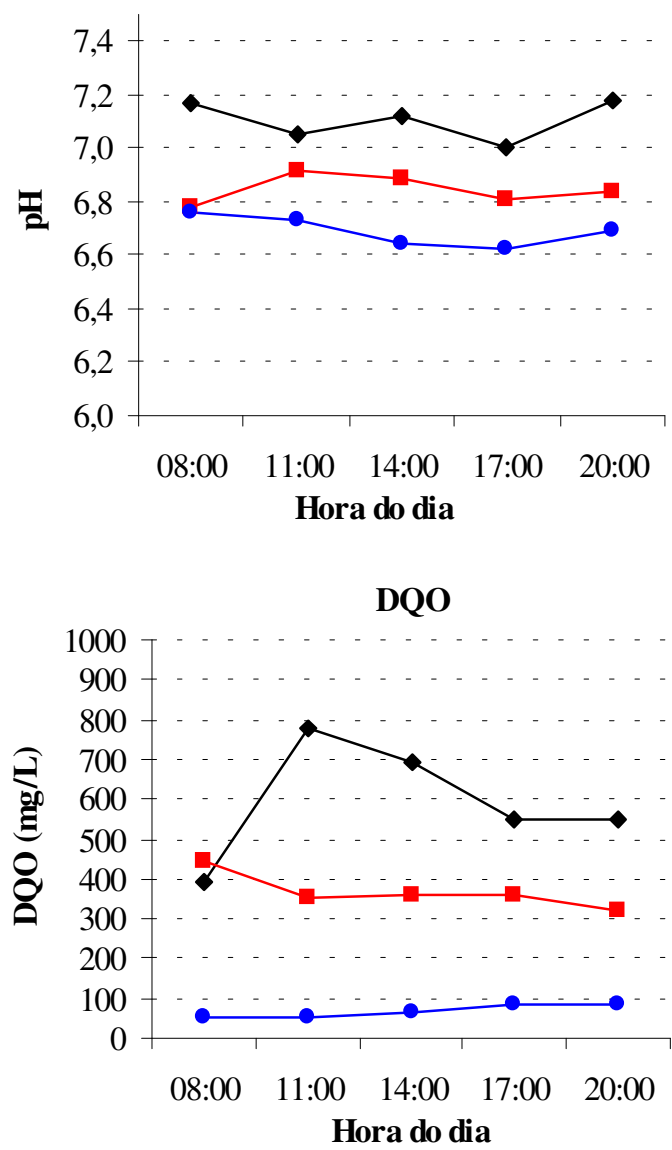

SST

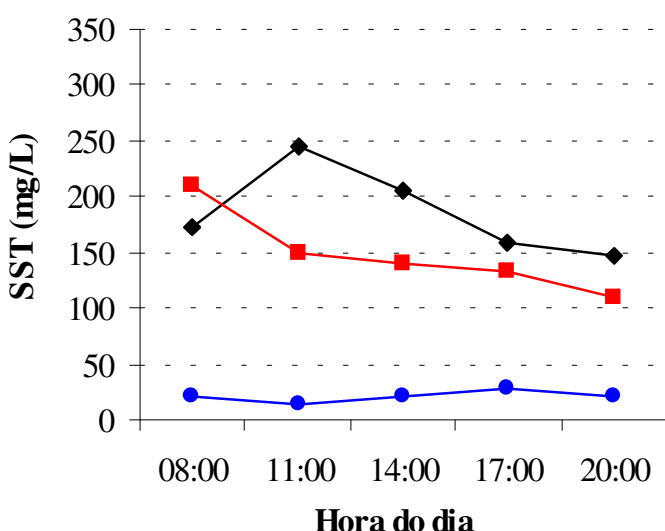

FIGURA 5.52 - Temperatura, pH, turbidez, demanda química de oxigênio, fósforo e sólidos suspensos totais das amostras de esgoto bruto, de efluente do reator RALEx e de efluente do flotador coletadas ao longo do dia de ensaio (24/06/2001). Ensaios realizados em instalação protótipo de coagulação/floculação/flotação por ar dissolvido com escoamento contínuo e efluente do reator RALEx. Data do ensaio: $24 / 06 / 2001 ; \mathrm{DCF}=70 \mathrm{mg} / \mathrm{L} ; \mathrm{Gf}=80 \mathrm{~s}^{-1} ; \mathrm{Tf}=20 \mathrm{~min} ; \mathrm{R}=18 \%$; Psat=450 kPa; $\mathrm{S}^{*}=19,7 \mathrm{~g} / \mathrm{m}^{3} ; \mathrm{TAS}=180 \mathrm{~m}^{3} / \mathrm{m}^{2} /$ dia. 
A FIGURA 5.53 apresenta os valores de temperatura, de pH, de turbidez, de DQO, de fósforo e de sólidos suspensos totais do efluente do flotador em função do horário de coleta das amostras quando os seguintes parâmetros operacionais foram adotados: $\mathrm{DCF}=30$ $\mathrm{mg} / \mathrm{L}, \mathrm{Gf}=80 \mathrm{~s}^{-1}, \mathrm{Tf}=20 \mathrm{~min}, \mathrm{R}=18 \%$, Psat $=450 \mathrm{kPa}$ e TAS $=180 \mathrm{~m}^{3} / \mathrm{m}^{2} /$ dia. A temperatura do esgoto bruto variou entre $18,0^{\circ} \mathrm{C}$; às $08: 00$, e $21,5^{\circ} \mathrm{C}$, às $14: 00$. O efluente do reator anaeróbio apresentou temperaturas entre $21,0^{\circ} \mathrm{C}$ e $22,0^{\circ} \mathrm{C}$ e o efluente do flotador entre $18,0^{\circ} \mathrm{C}$ e $22,0^{\circ} \mathrm{C}$. O pH do esgoto bruto variou entre 6,9 e 7,4. O efluente do RALEx apresentou $\mathrm{pH}$ entre 6,7 e 6,9 enquanto o $\mathrm{pH}$ do efluente do flotador variou entre 6,6 e 6,8. A turbidez do esgoto bruto apresentou moderada variação, com valores entre 218 e 362 uT. O efluente do reator anaeróbio sofreu forte variação de sua turbidez entre 08:00 e 20:00, variando entre 122 e $284 \mathrm{uT}$. A turbidez do efluente do flotador elevou-se gradativamente, de 65,3 uT, às 08:00, a 140 uT, às 17:00. Às 20:00, a turbidez sofreu redução em seu valor, até atingir $129 \mathrm{uT}$.

O esgoto bruto apresentou pequena oscilação nos valores de DQO. Neste ensaio, foram observados valores de DQO entre 546 e $757 \mathrm{mg} / \mathrm{L}$. O RALEx contribuiu moderadamente para redução da carga orgânica, fornecendo efluente com DQO entre 262 e $402 \mathrm{mg} / \mathrm{L}$, com remoção de carga orgânica de 51,7\% entre 08:00 e 20:00. A DQO do efluente do flotador elevou-se gradativamente, de $100 \mathrm{mg} / \mathrm{L}$, às 08:00, para $252 \mathrm{mg} / \mathrm{L}$, às 17:00. Às 20:00, a DQO do efluente do flotador sofreu redução em seu valor, até atingir 241 mg/L. A remoção de carga orgânica promovida pelo flotador entre 08:00 e 20:00 foi de 38,3\%. A remoção global de carga orgânica alcançada pelo sistema RALEx-flotador foi de $70,2 \%$.

O esgoto bruto também apresentou elevada oscilação nos valores de fósforo. Neste ensaio, foram observados valores de P entre 6,4 e 15,6 mg/L. O RALEx contribuiu fortemente para equalização da concentração de fósforo no seu efluente, resultando em valores de $\mathrm{P}$ entre 6,5 e 7,2 mg/L. A concentração de $\mathrm{P}$ do efluente do flotador elevou-se gradativamente, de 3,70 mg/L, às 08:00, a 7,30 mg/L, às 14:00. A partir das 17:00, a concentração de $\mathrm{P}$ do efluente do flotador sofreu gradativa redução em seu valor para até 6,30 mg/L, às 20:00. A remoção de carga de fósforo promovida pelo flotador entre 08:00 e 20:00 foi de $10,3 \%$. O esgoto bruto também apresentou moderada oscilação nos valores de SST. Neste ensaio, foram observados valores de SST entre 167 e 274 mg/L. O RALEx contribuiu razoavelmente para redução da carga de sólidos suspensos, fornecendo efluente com SST entre 77 e 217 mg/L, com remoção média de carga de sólidos de 49,1\% entre 08:00 e 20:00. A concentração de SST do efluente do flotador elevou-se gradativamente, de 38 $\mathrm{mg} / \mathrm{L}$, às 08:00, para $66 \mathrm{mg} / \mathrm{L}$, às 20:00. A remoção de carga de SST promovida pelo 
flotador entre 08:00 e 20:00 foi de 48,9\%. A remoção global de sólidos suspensos alcançada pelo sistema RALEx-flotador foi de 74,0\%.
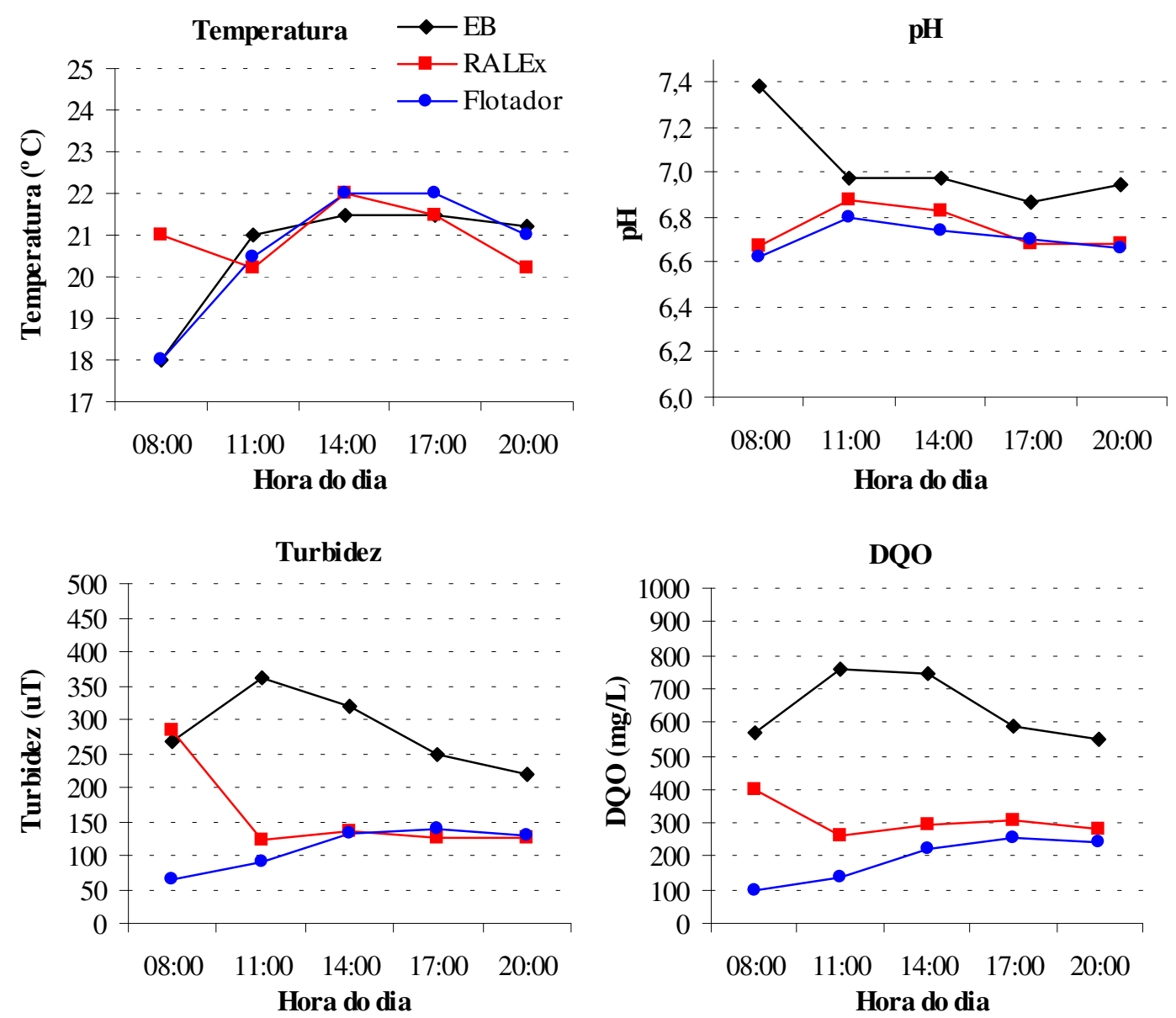

Fósforo
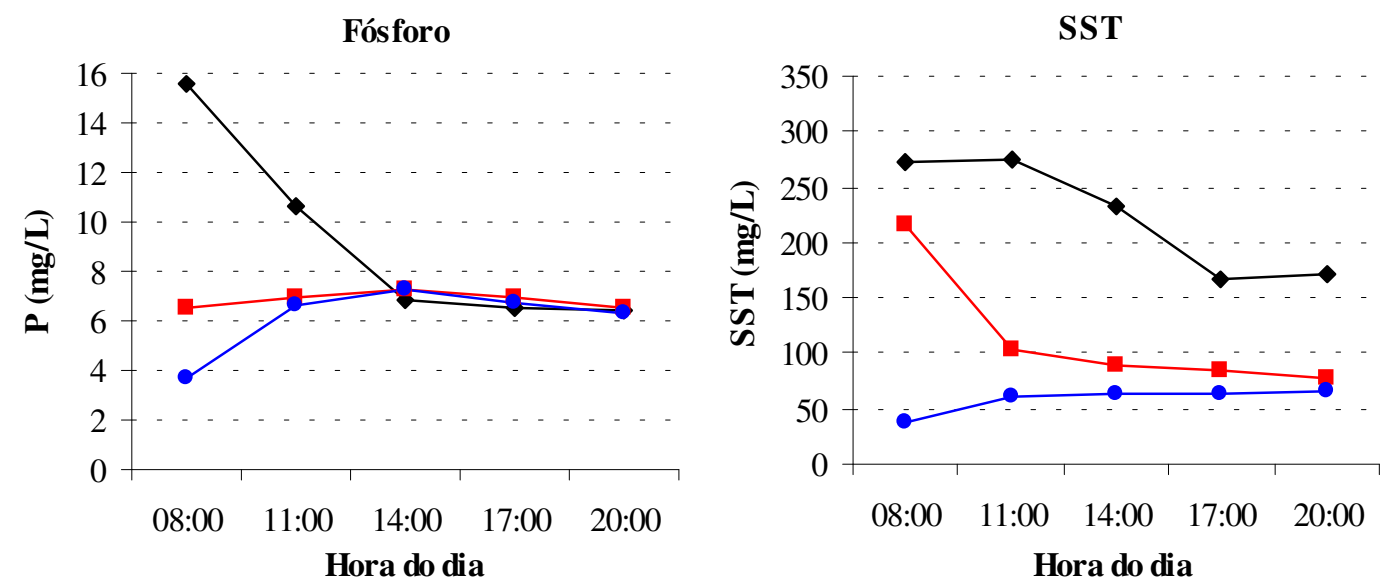

FIGURA 5.53 - Temperatura, pH, turbidez, demanda química de oxigênio, fósforo e sólidos suspensos totais das amostras de esgoto bruto, de efluente do reator RALEx e de efluente do flotador coletadas ao longo do dia de ensaio (22/06/2001). Ensaios realizados em instalação protótipo de coagulação/floculação/flotação por ar dissolvido com escoamento contínuo e efluente do reator RALEx. Data do ensaio: $22 / 06 / 2001 ; \mathrm{DCF}=30 \mathrm{mg} / \mathrm{L} ; \mathrm{Gf}=80 \mathrm{~s}^{-1} ; \mathrm{Tf}=20 \mathrm{~min} ; \mathrm{R}=18 \%$; Psat=450 kPa; $\mathrm{S}^{*}=19,7 \mathrm{~g} / \mathrm{m}^{3} ; \mathrm{TAS}=180 \mathrm{~m}^{3} / \mathrm{m}^{2} / \mathrm{dia}$. 
A FIGURA 5.54 apresenta os valores de turbidez e de DQO do efluente do flotador em função do horário de coleta das amostras quando os seguintes parâmetros operacionais foram adotados: $\mathrm{DCF}=70 \mathrm{mg} / \mathrm{L}, \mathrm{Gf}=80 \mathrm{~s}^{-1}, \mathrm{Tf}=18 \mathrm{~min}, \mathrm{R}=18 \%$, Psat=450 $\mathrm{kPa}$ e TAS=180 $\mathrm{m}^{3} / \mathrm{m}^{2} /$ dia.

A turbidez do esgoto bruto apresentou forte variação, com valores entre 167 e 510 uT. A elevação abrupta da turbidez entre 21:00 e 22:00 é decorrente de forte precipitação pluviométrica na região, com início às 21:25, com conseqüente arraste de sólidos do emissário de esgotos para o interior do reator RALEx. O efluente do reator anaeróbio sofreu moderada variação de sua turbidez entre 08:00 e 23:00, variando entre 68,5 e 144 uT. A turbidez do efluente do flotador elevou-se gradativamente, de 4,2 uT, às 09:00, a 34,9 uT, às 20:00. A partir das 20:00, iniciou-se tendência de queda dos valores de turbidez, atingindo 24,6 uT às 22:00. Entre 22:00 e 23:00, em decorrência da combinação entre fortes ventos e elevado volume de chuvas, a camada de lodo flotado foi rompida, com arraste de parcela do lodo no efluente do flotador, influenciando suas características físico-químicas.

O esgoto bruto apresentou forte oscilação nos valores de DQO. Neste ensaio, foram observados valores de DQO entre 485 e 1062 mg/L. O RALEx contribuiu moderadamente para remoção da carga orgânica, fornecendo efluente com DQO entre 175 e 350 mg/L, com remoção de carga orgânica de 64,4\% entre 08:00 e 23:00. A DQO do efluente do flotador elevou-se gradativamente, de $49 \mathrm{mg} / \mathrm{L}$, às 09:00, a $135 \mathrm{mg} / \mathrm{L}$, às 19:00. A partir das 19:00, iniciou-se tendência de queda dos valores de turbidez, atingindo $101 \mathrm{mg} / \mathrm{L}$ uT às 22:00. Às 23:00, a DQO elevou-se para $166 \mathrm{mg} / \mathrm{L}$ em função do arraste de lodo no efluente do flotador.

A remoção de carga orgânica promovida pelo flotador entre as 08:00 e as 23:00 foi de $62,4 \%$. A remoção global de carga orgânica alcançada pelo sistema RALEx-flotador foi de $86,6 \%$.

A FIGURA 5.55 apresenta os valores de turbidez e de DQO do efluente do flotador em função do horário de coleta das amostras quando os seguintes parâmetros operacionais foram adotados: $\mathrm{DCF}=90 \mathrm{mg} / \mathrm{L}, \mathrm{Gf}=80 \mathrm{~s}^{-1}, \mathrm{Tf}=18 \mathrm{~min}, \mathrm{R}=18 \%$, Psat=450 $\mathrm{kPa}$ e TAS $=180$ $\mathrm{m}^{3} / \mathrm{m}^{2} /$ dia.

A turbidez do esgoto bruto apresentou moderada variação, com valores entre $192 \mathrm{e}$ 394 uT. O efluente do reator anaeróbio sofreu forte variação de sua turbidez entre 09:00 e 20:00, variando entre 76,3 e $202 \mathrm{uT}$. A turbidez do efluente do flotador oscilou entre 2,6 uT, às 10:00, e 8,9 uT, às 16:00. A partir das 16:00, iniciou-se tendência de queda dos valores de turbidez, atingindo 5,0 uT às 20:00. O esgoto bruto apresentou forte oscilação nos valores de DQO. Neste ensaio, foram observados valores de DQO entre 581 e 1116 mg/L. O RALEx contribuiu moderadamente para remoção da carga orgânica, fornecendo efluente com DQO 
entre 227 e $441 \mathrm{mg} / \mathrm{L}$, com remoção de carga orgânica de 55,3\% entre 09:00 e 20:00. A DQO do efluente do flotador oscilou entre $93 \mathrm{mg} / \mathrm{L}$ e $123 \mathrm{mg} / \mathrm{L}$, sendo que em 9 amostras os valores variaram entre 102 e $108 \mathrm{mg} / \mathrm{L}$.

A remoção de carga orgânica promovida pelo flotador entre as 09:00 e as 20:00 foi de 70,6\%. A remoção global de carga orgânica alcançada pelo sistema RALEx-flotador foi de $86,9 \%$.
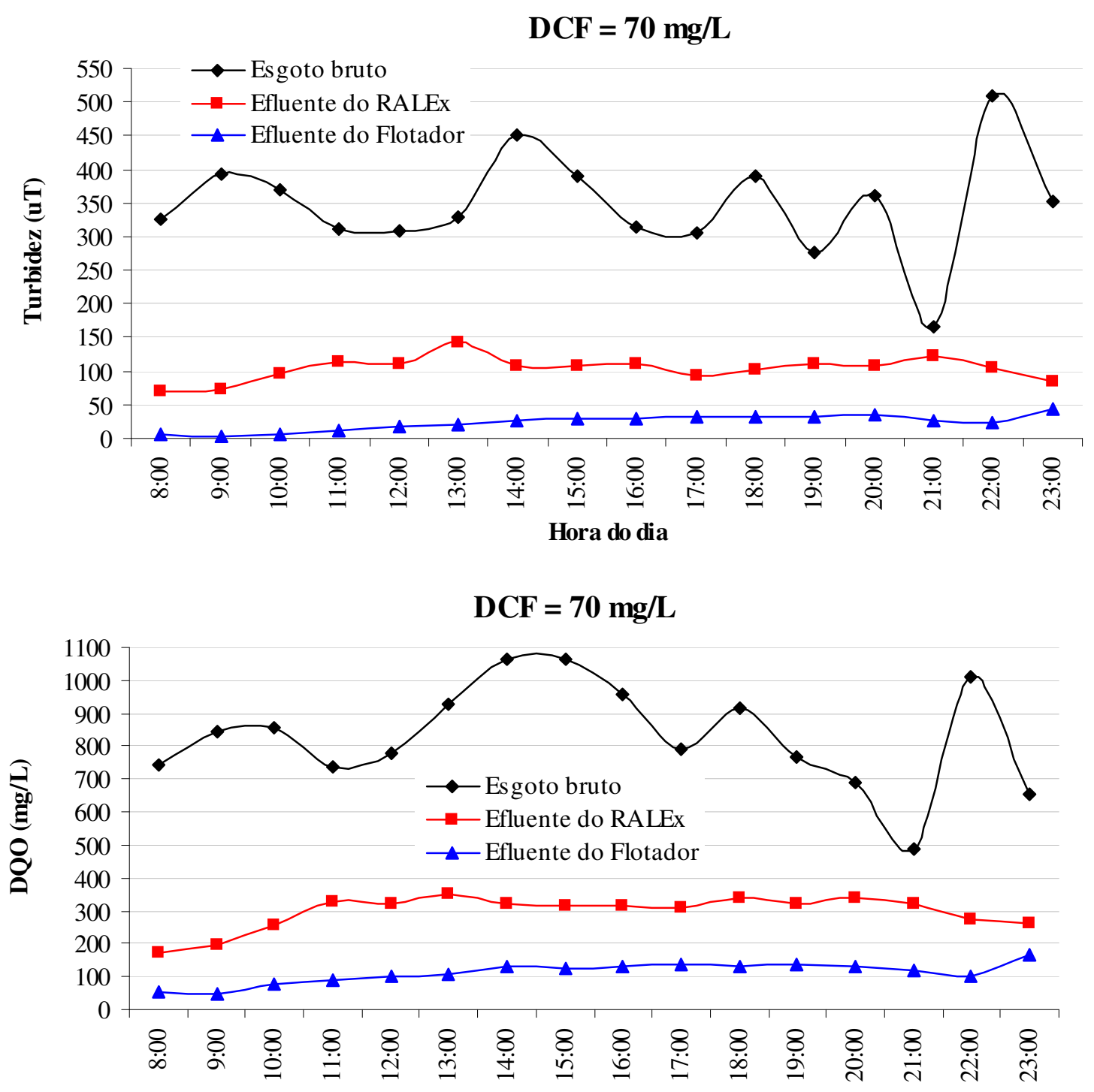

FIGURA 5.54 - Turbidez e demanda química de oxigênio das amostras de esgoto bruto, de efluente do reator RALEx e de efluente do flotador, operado com $70 \mathrm{mg} / \mathrm{L}$ de cloreto férrico, coletadas ao longo do dia de ensaio (13/09/2001).

Ensaios realizados em instalação protótipo de coagulação/floculação/flotação por ar dissolvido com escoamento contínuo e efluente do reator RALEx. Data do ensaio: 13/09/2001; $\mathrm{DCF}=70 \mathrm{mg} / \mathrm{L} ; \mathrm{Gf}=80 \mathrm{~s}^{-1} ; \mathrm{Tf}=18 \mathrm{~min} ; \mathrm{R}=18 \%$; Psat=450 $\mathrm{kPa} ; \mathrm{S}^{*}=19,7 \mathrm{~g} / \mathrm{m}^{3} ; \mathrm{TAS}=180 \mathrm{~m}^{3} / \mathrm{m}^{2} /$ dia. 
Observando os valores de turbidez do efluente do flotador, é possível inferir que a presença de sólidos suspensos nas amostras era bastante reduzida, indicando que o processo físico de separação (flotação) foi bastante eficiente. A presença de matéria orgânica no efluente final somente não pode ser mais reduzida, abaixo de valores de cerca de $100 \mathrm{mg} / \mathrm{L}$, por tratar-se de material dissolvido.
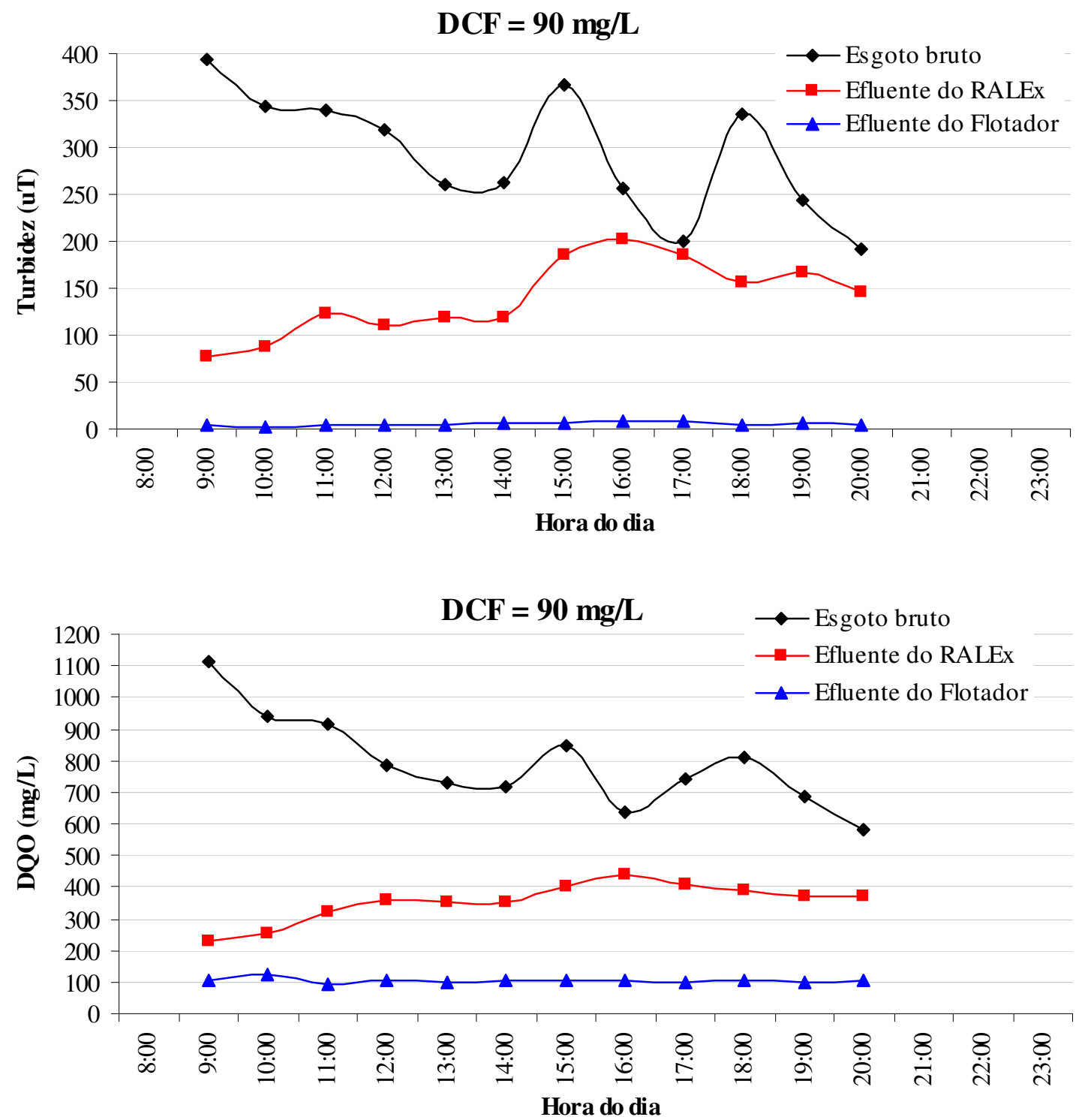

FIGURA 5.55 - Turbidez e demanda química de oxigênio das amostras de esgoto bruto, de efluente do reator RALEx e de efluente do flotador, operado com $90 \mathrm{mg} / \mathrm{L}$ de cloreto férrico, coletadas ao longo do dia de ensaio (17/09/2001).

Ensaios realizados em instalação protótipo de coagulação/floculação/flotação por ar dissolvido com escoamento contínuo e efluente do reator RALEx. Data do 
ensaio: $17 / 09 / 2001 ; \mathrm{DCF}=90 \mathrm{mg} / \mathrm{L} ; \mathrm{Gf}=80 \mathrm{~s}^{-1} ; \mathrm{Tf}=18 \mathrm{~min} ; \mathrm{R}=18 \%$; Psat=450 $\mathrm{kPa} ; \mathrm{S}^{*}=19,7 \mathrm{~g} / \mathrm{m}^{3} ; \mathrm{TAS}=180 \mathrm{~m}^{3} / \mathrm{m}^{2} / \mathrm{dia}$.

O emprego de $90 \mathrm{mgFeCl}_{3} / \mathrm{L}$ garantiu a produção de efluente do flotador com excelente qualidade durante situação de emissão de efluente do RALEx com péssima qualidade. Caracteriza-se, então, mais uma vantagem da flotação como pós-tratamento de efluentes de reatores anaeróbios. Em situações de início da operação de ETE, durante partida biológica dos reatores anaeróbios, a flotação pode atuar como uma barreira, evitando lançamento de efluentes de baixa qualidade em corpos d'água, ainda que, para tanto, volume adicional de lodo seja produzido e deva ser corretamente destinado.

A FIGURA 5.56 apresenta os valores de turbidez e de DQO do efluente do flotador em função do horário de coleta das amostras quando os seguintes parâmetros operacionais foram adotados: $\mathrm{DCF}=$ variável entre 42 e $92 \mathrm{mg} / \mathrm{L}, \mathrm{Gf}=80 \mathrm{~s}^{-1}, \mathrm{Tf}=18 \mathrm{~min}, \mathrm{R}=18 \%$, Psat=450 $\mathrm{kPa}$ e $\mathrm{TAS}=180 \mathrm{~m}^{3} / \mathrm{m}^{2} /$ dia.

Tendo em vista os resultados observados durante os ensaios anteriores quando do uso de diferentes dosagens de cloreto férrico, a aplicação de diferentes valores de DCF foi programada para a operação do flotador ao longo do dia. Estipulou-se DCF de $90 \mathrm{mg} / \mathrm{L}$ até 20:00 do dia 25/09 e entre 11:00 e 20:00 do dia 26/09. Entre 20:00, do dia 25/09, e 02:00, do dia 26/09, determinou-se o uso de $70 \mathrm{mgFeCl}_{3} / \mathrm{L}$. O uso de $60 \mathrm{mgFeCl}_{3} / \mathrm{L}$ foi programado entre 02:00 e 05:00 e entre 08:00 e 11:00 do dia 26/09. O uso de DCF de $40 \mathrm{mg} / \mathrm{L}$ foi estipulado para entre 05:00 e 08:00. Os valores de DCF apresentados nas FIGURAS 5.56 e $\mathbf{5 . 5 7}$ são aqueles efetivamente observados durante os ensaios em medidor volumétrico de vazão da bomba dosadora da solução de cloreto férrico.

A turbidez do esgoto bruto apresentou forte variação, com valores entre 25,4 e 386 uT. O efluente do reator anaeróbio sofreu elevada variação de sua turbidez ao longo das 24 horas, variando entre 72,6 e $261 \mathrm{uT}$, demonstrando comportamento semelhante ao do esgoto bruto. A turbidez do efluente do flotador manteve-se bastante estável ao longo das 24 horas, variando entre 2,03 uT e 5,33 uT, com exceção das amostras coletadas às 23:00 e às 11:00, com valores de 24,5 uT e 9,62 uT, respectivamente. A dosagem de cloreto férrico deveria ter sido superior a $72 \mathrm{mg} / \mathrm{L}$ no período entre 20:00 e 23:00 e superior a $62 \mathrm{mg} / \mathrm{L}$ no período entre 08:00 e 11:00, para evitar o aumento da turbidez do efluente do flotador.

O esgoto bruto apresentou forte oscilação nos valores de DQO. Neste ensaio, foram observados valores de DQO entre 63 e $861 \mathrm{mg} / \mathrm{L}$. O RALEx contribuiu razoavelmente para remoção da carga orgânica, fornecendo efluente com DQO entre 142 e 443 mg/L, com remoção de carga orgânica de $41,3 \%$ durante as 24 horas. A DQO do efluente do flotador 
reduziu-se de $50 \mathrm{mg} / \mathrm{L}$, às 20:00, e de $65 \mathrm{mg} / \mathrm{L}$, às 23:00 para valores menores que $25 \mathrm{mg} / \mathrm{L}$, entre 02:00 e 08:00. A partir de então, iniciou-se tendência de estabilidade dos valores de DQO, de 42 a $48 \mathrm{mg} / \mathrm{L}$, até 20:00. A remoção de carga orgânica promovida pelo flotador entre as 24 horas foi de $88,8 \%$. A remoção global de carga orgânica alcançada pelo sistema RALEx-flotador foi de $93,4 \%$.

O esgoto bruto apresentou forte oscilação nos valores de fósforo, variando entre 1,77 e 11,9 mgP/L. O RALEx contribuiu razoavelmente para equalização da concentração de fósforo no seu efluente, resultando em valores de P entre 3,38 e 6,96mg/L. A concentração de fósforo do efluente do flotador elevou-se de 0,12 para $1,11 \mathrm{mgP} / \mathrm{L}$, em função da redução na dosagem de cloreto férrico. A partir de então, mesmo com redução da DCF para valores de até $42 \mathrm{mg} / \mathrm{L}$, a concentração de fósforo manteve-se entre 0,04 e 0,16 mgP/L. A presença de fósforo no efluente do flotador voltou a elevar-se às 11:00 $(0,51 \mathrm{mgP} / \mathrm{L})$ em função da necessidade de aumento da dosagem de cloreto férrico.O aumento da DCF para $90 \mathrm{mg} / \mathrm{L}$ proporcionou valores entre 0,04 e 0,09 mgP/L no efluente do flotador, entre 14:00 e 20:00. A remoção de carga de fósforo promovida pelo flotador durante as 24 horas foi de $94,2 \%$.

O esgoto bruto apresentou forte oscilação nos valores de SST. Neste ensaio, foram observados valores de DQO entre 65 e $354 \mathrm{mg} / \mathrm{L}$. O RALEx contribuiu moderadamente para remoção da carga de sólidos, fornecendo efluente com DQO entre 58 e $154 \mathrm{mg} / \mathrm{L}$, com remoção de carga orgânica de 45,3\% durante as 24 horas. O SST do efluente do flotador elevou-se de $5 \mathrm{mg} / \mathrm{L}$, às 20:00, para $19 \mathrm{mg} / \mathrm{L}$, às 23:00. A partir de então, reduziu-se para valores menores que $4 \mathrm{mg} / \mathrm{L}$, entre 02:00 e 08:00. Às 11:00, o valor de SST elevou-se novamente para $11 \mathrm{mg} / \mathrm{L}$, em função da necessidade de maior dosagem de cloreto férrico, e partir daí, iniciou-se tendência de estabilidade dos valores de SST, de 3 a $6 \mathrm{mg} / \mathrm{L}$, até 20:00. A remoção de carga orgânica promovida pelo flotador entre as 24 horas foi de 93,1\%. A remoção global de carga orgânica alcançada pelo sistema RALEx-flotador foi de 96,2\%.

Durante este ensaio, a vazão média pós-tratada por flotação foi de $6,036 \mathrm{~m}^{3} / \mathrm{h}$. Considerando esta vazão e as diferentes dosagens de cloreto férrico utilizadas ao longo das 24 horas, tem-se que a carga de cloreto férrico empregada foi de 10,67 kg. Com os dados de SST das amostras retiradas da última câmara de floculação (floculado) ao longo do ensaio, vistos na FIGURA 5.57, pode-se estimar a quantidade de lodo flotado. Através da subtração dos valores de SST do efluente do flotador dos valores do efluente floculado e considerando vazão de $6,036 \mathrm{~m}^{3} / \mathrm{h}$ e 24 horas de ensaio, obtém-se valor de 24,1 kgSST, peso seco estimado de lodo flotado, equivalente à remoção horária média de 1,0 kgSST, ou seja, $166 \mathrm{~g}$ de lodo por $\mathrm{m}^{3}$ de esgoto tratado no flotador. Considerando consumo per capita de $200 \mathrm{~L} / \mathrm{dia}$, a 
população atendida, correspondente a $6,036 \mathrm{~m}^{3} / \mathrm{h}$, foi de 725 pessoas. Desta forma, a produção per capita de lodo foi de 33,2 gSST/pessoa/dia.

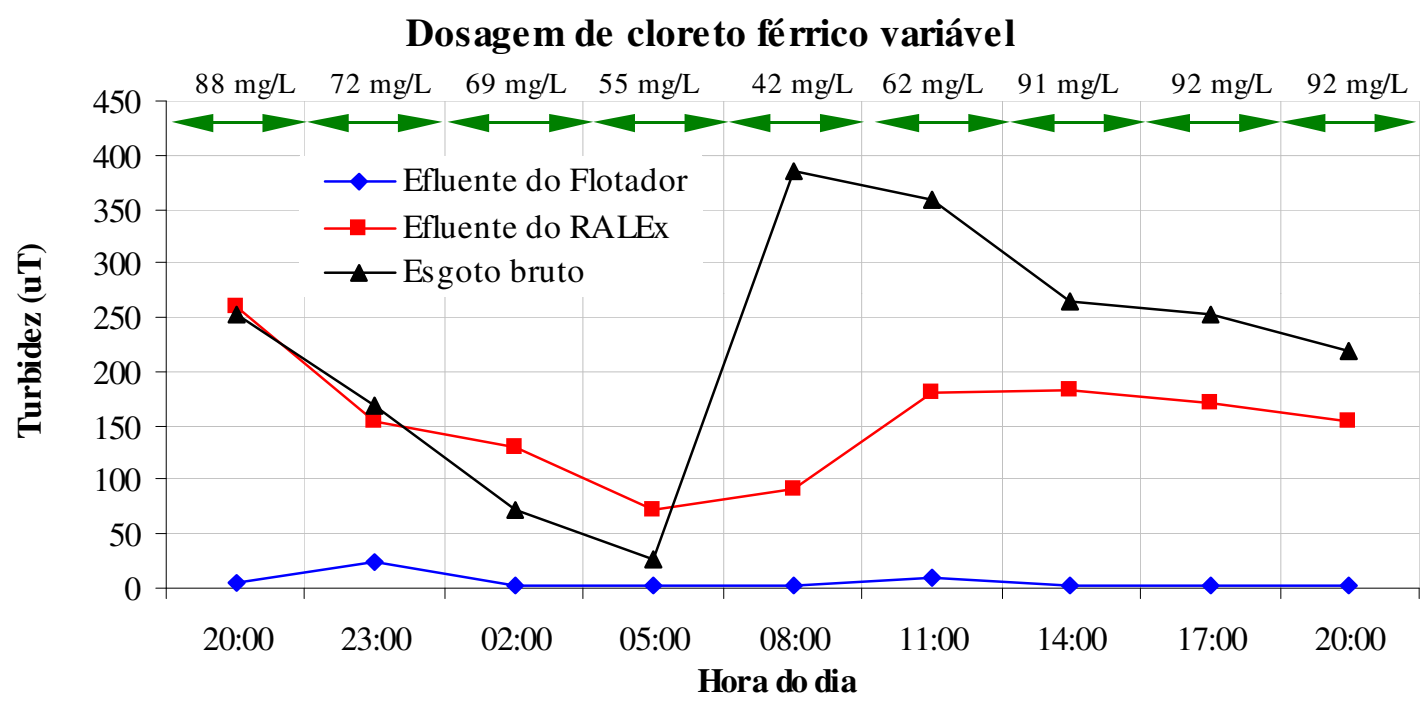

Dosagem de cloreto férrico variável

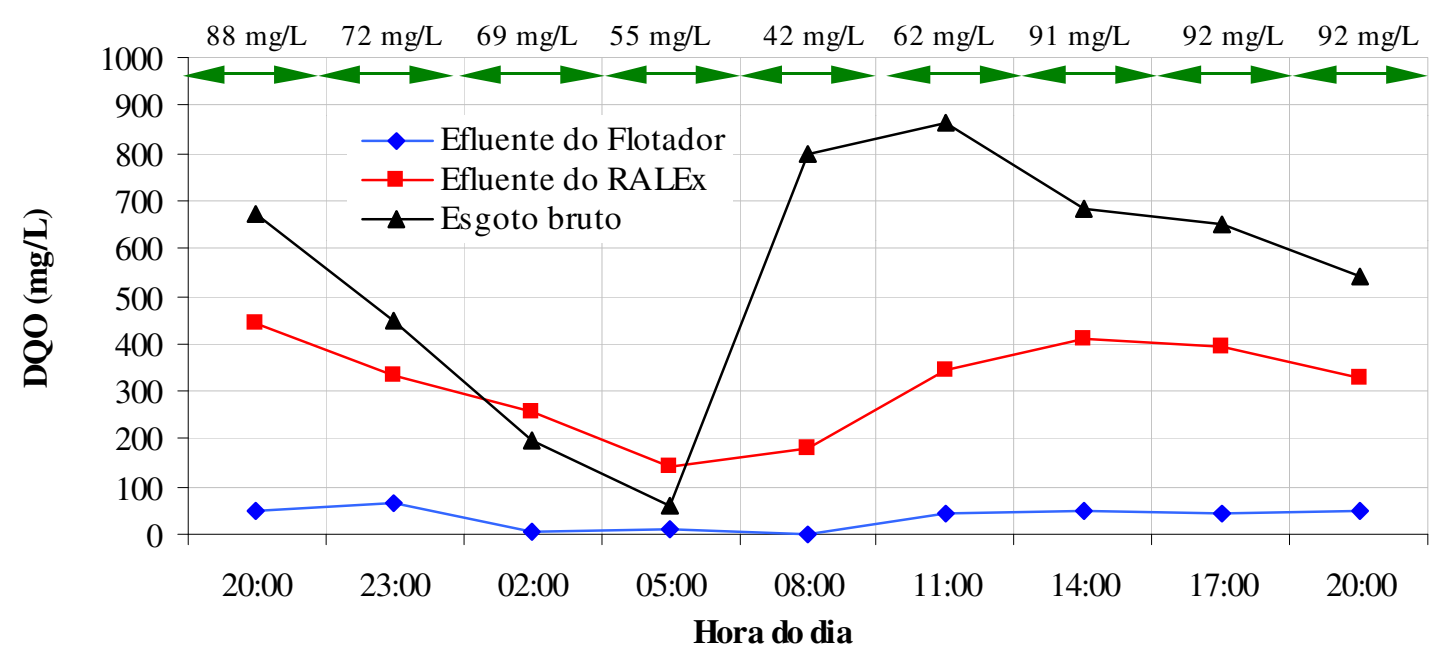

FIGURA 5.56 - Turbidez e demanda química de oxigênio das amostras de esgoto bruto, de efluente do reator RALEx e de efluente do flotador, operado com dosagem variável de cloreto férrico, coletadas ao longo do dia de ensaio (25/09/2001).

Ensaios realizados em instalação protótipo de coagulação/floculação/flotação por ar dissolvido com escoamento contínuo e efluente do reator RALEx. Data do ensaio: 25/09/2001; DCF entre 42 e $92 \mathrm{mg} / \mathrm{L} ; \mathrm{Gf}=80 \mathrm{~s}^{-1}$; $\mathrm{Tf}=18 \mathrm{~min} ; \mathrm{R}=18 \%$; Psat $=450 \mathrm{kPa} ; \mathrm{S}^{*}=19,7 \mathrm{~g} / \mathrm{m}^{3} ; \mathrm{TAS}=180 \mathrm{~m}^{3} / \mathrm{m}^{2} / \mathrm{dia}$. 


\section{Dosagem de cloreto férrico variável}

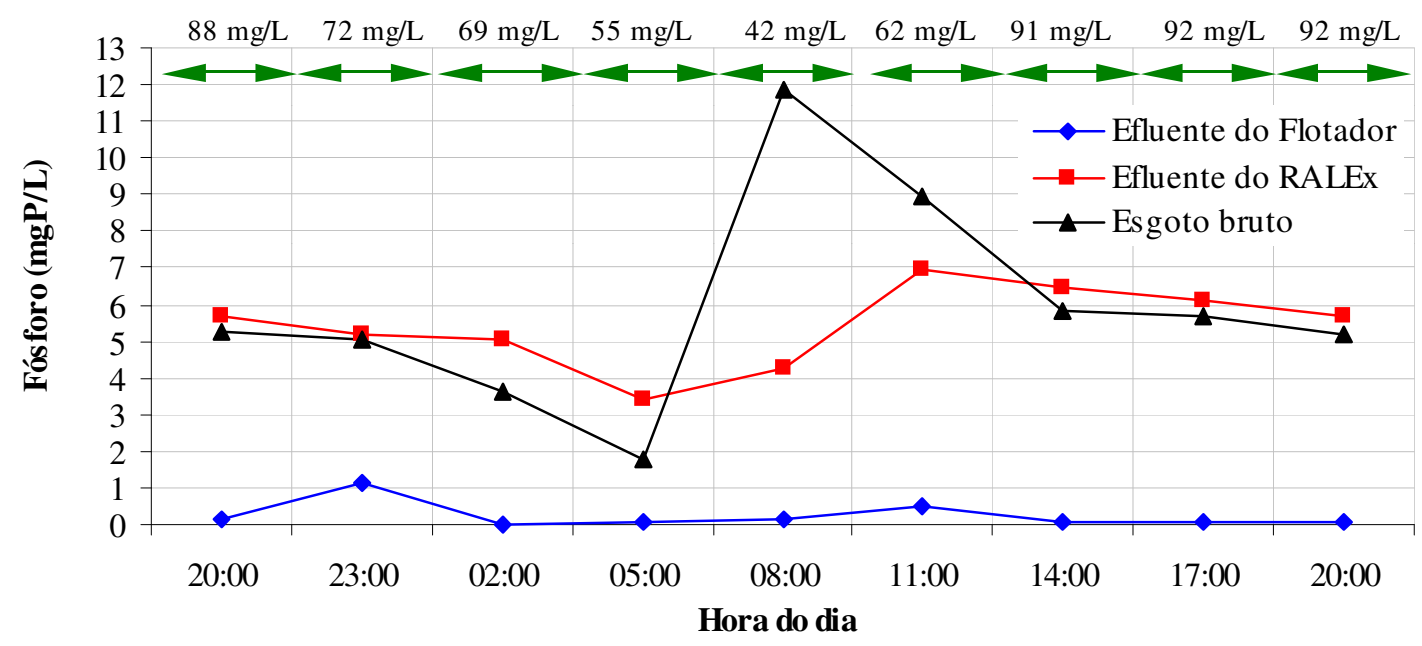

Dosagem de cloreto férrico variável

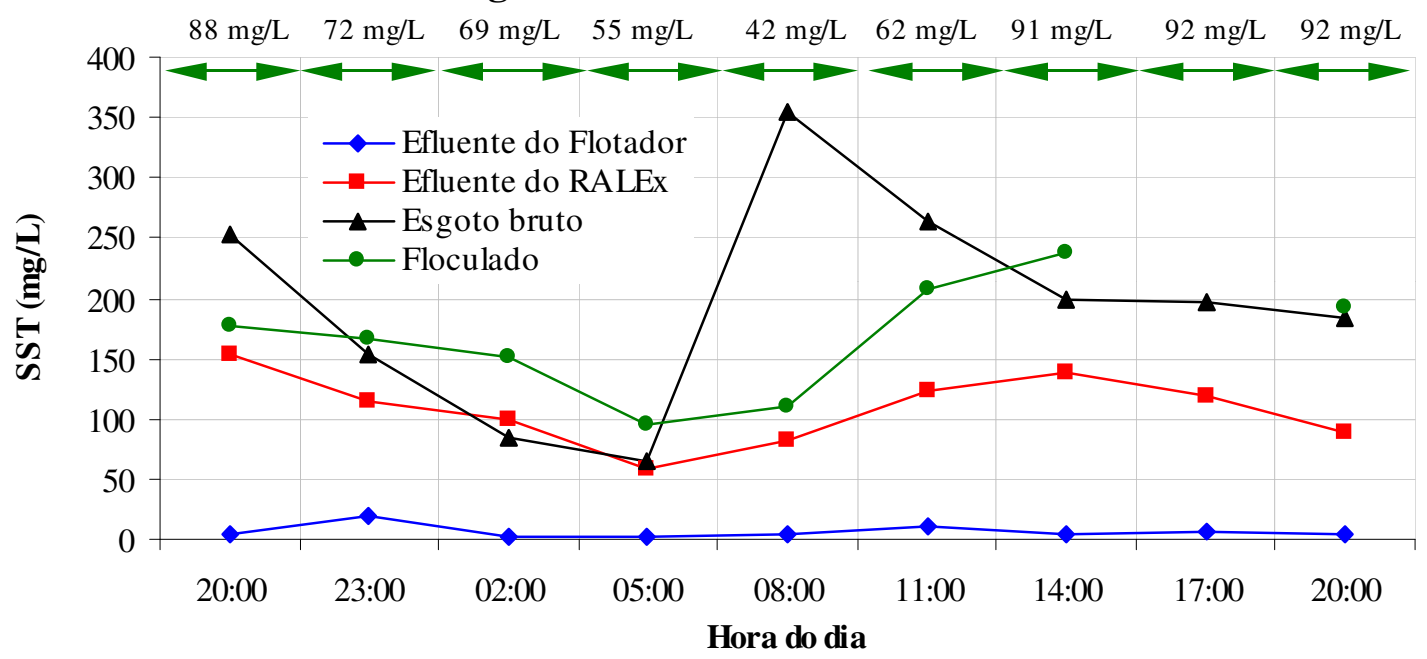

FIGURA 5.57 - Concentração de fósforo e de sólidos suspensos totais das amostras de esgoto bruto, de efluente do reator RALEx e de efluente do flotador, operado com dosagem variável de cloreto férrico, coletadas ao longo do dia de ensaio $(25 / 09 / 2001)$.

Ensaios realizados em instalação protótipo de coagulação/floculação/flotação por ar dissolvido com escoamento contínuo e efluente do reator RALEx. Data do ensaio: 25/09/2001; DCF entre 42 e $92 \mathrm{mg} / \mathrm{L} ; \mathrm{Gf}=80 \mathrm{~s}^{-1}$; $\mathrm{Tf}=18 \mathrm{~min} ; \mathrm{R}=18 \%$; Psat $=450 \mathrm{kPa} ; \mathrm{S}^{*}=19,7 \mathrm{~g} / \mathrm{m}^{3} ;$ TAS $=180 \mathrm{~m}^{3} / \mathrm{m}^{2} /$ dia.

A TABELA 5.8 apresenta a concentração de diversos parâmetros das amostras de esgoto bruto, de efluente do reator RALEx e de efluente do flotador, operado com dosagem variável de cloreto férrico, coletadas ao longo do dia de ensaio (25/09/2001). 
TABELA 5.8 - Concentração de diversos parâmetros das amostras de esgoto bruto, de efluente do reator RALEx e de efluente do flotador, operado com dosagem variável de cloreto férrico, coletadas ao longo do dia de ensaio (25/09/2001).

Ensaios realizados em instalação protótipo de coagulação/floculação/flotação por ar dissolvido com escoamento contínuo e efluente do reator RALEx. Data do ensaio: 25/09/2001; DCF entre 42 e $92 \mathrm{mg} / \mathrm{L} ; \mathrm{Gf}=80 \mathrm{~s}^{-1}$; $\mathrm{Tf}=18 \mathrm{~min} ; \mathrm{R}=18 \%$; Psat $=450 \mathrm{kPa} ; \mathrm{S}^{*}=19,7 \mathrm{~g} / \mathrm{m}^{3} ; \mathrm{TAS}=180 \mathrm{~m}^{3} / \mathrm{m}^{2} /$ dia. $\quad(-)$ amostra não coletada.

\begin{tabular}{|c|c|c|c|c|c|c|c|c|c|c|}
\hline Parâmetro & Amostras & $20: 00$ & 23:00 & 02:00 & 05:00 & 08:00 & $11: 00$ & 14:00 & 17:00 & 20:00 \\
\hline \multirow{3}{*}{$\begin{array}{c}\text { Alcalinidade } \\
\text { total } \\
\left(\mathrm{mgCaCO}_{3} / \mathrm{L}\right) \\
\end{array}$} & EB & - & - & - & - & 248 & 127 & 114 & - & 131 \\
\hline & RALEx & - & - & - & - & 142 & 196 & 161 & - & 157 \\
\hline & Flotador & - & - & - & - & 68 & 122 & 83 & - & 79 \\
\hline \multirow{3}{*}{$\begin{array}{c}\mathrm{DBO}_{5,21} \\
(\mathrm{mg} / \mathrm{L})\end{array}$} & EB & 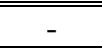 & - & - & - & 436 & 429 & 270 & - & 250 \\
\hline & RALEx & - & - & - & - & 98 & 96 & 160 & - & 115 \\
\hline & Flotador & - & - & - & - & 1 & 23 & 41 & - & 34 \\
\hline \multirow{3}{*}{$\begin{array}{l}\text { Óleos e } \\
\text { Graxas } \\
(\mathrm{mg} / \mathrm{L})\end{array}$} & EB & - & - & - & - & 100 & 109 & 76 & - & 94 \\
\hline & RALEx & - & - & - & - & 49 & 44 & 39 & - & 40 \\
\hline & Flotador & - & - & - & - & 16 & 25 & 21 & - & 20 \\
\hline \multirow{3}{*}{$\begin{array}{c}\text { Carbono } \\
\text { Orgânico } \\
\text { Total }(\mathrm{mg} / \mathrm{L})\end{array}$} & EB & 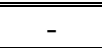 & 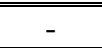 & - & - & 105,3 & 101,5 & 98,0 & - & 75,4 \\
\hline & RALEx & - & - & - & - & 29,3 & 53,1 & 53,3 & - & 52,7 \\
\hline & Flotador & - & - & - & - & 11,4 & 25,3 & 13,5 & - & 16,8 \\
\hline \multirow{3}{*}{$\begin{array}{c}\mathrm{ST} \\
(\mathrm{mg} / \mathrm{L}) \\
\end{array}$} & EB & - & - & - & - & 827 & 737 & 2520 & - & 4459 \\
\hline & RALEx & - & - & - & - & 255 & 377 & 440 & - & 362 \\
\hline & Flotador & - & - & - & - & 166 & 228 & 294 & - & 388 \\
\hline \multirow{3}{*}{$\begin{array}{c}\text { Dureza } \\
\left(\mathrm{mgCaCO}_{3} / \mathrm{L}\right)\end{array}$} & EB & - & - & - & - & 47 & 67 & 255 & - & 477 \\
\hline & RALEx & - & - & - & - & 59 & 16 & 59 & - & 55 \\
\hline & Flotador & - & - & - & - & 30 & 40 & 40 & - & 34 \\
\hline \multirow{3}{*}{$\begin{array}{c}\text { Sulfato } \\
\left(\mathrm{mgSO}_{4}^{-} / \mathrm{L}\right)\end{array}$} & EB & 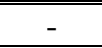 & 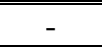 & 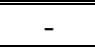 & 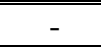 & 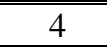 & 36 & 36 & 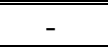 & 21 \\
\hline & RALEx & - & - & - & - & 10 & 16 & 25 & - & 19 \\
\hline & Flotador & - & - & - & - & 9 & 1 & 3 & - & 1 \\
\hline $\begin{array}{l}\text { Cloretos } \\
\left(\mathrm{mgCl}^{-} / \mathrm{L}\right)\end{array}$ & Flotador & - & - & - & - & 50 & 69 & 86 & - & 86 \\
\hline \multirow{3}{*}{$\begin{array}{c}\text { Nitrogênio } \\
\text { Total } \\
(\mathrm{mgNTK} / \mathrm{L}) \\
\end{array}$} & EB & - & - & - & 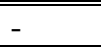 & 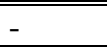 & - & 43 & 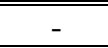 & 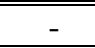 \\
\hline & RALEx & - & - & - & - & - & - & 48 & - & - \\
\hline & Flotador & - & - & - & - & - & - & 42 & - & - \\
\hline \multirow{3}{*}{$\begin{array}{l}\text { Nitrogênio } \\
\text { Amoniacal } \\
\left(\mathrm{mgNH}_{4} / \mathrm{L}\right)\end{array}$} & EB & - & - & - & - & - & - & 18 & - & - \\
\hline & RALEx & - & - & - & - & - & - & 29 & - & - \\
\hline & Flotador & - & - & - & - & - & - & 24 & - & - \\
\hline \multirow{3}{*}{$\begin{array}{c}\text { Nitrato } \\
\left(\mathrm{mgNO}_{3} / \mathrm{L}\right)\end{array}$} & EB & 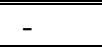 & - & 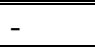 & 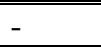 & 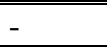 & - & 1,72 & 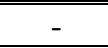 & 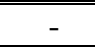 \\
\hline & RALEx & - & - & - & - & - & - & 1,45 & - & - \\
\hline & Flotador & - & - & - & - & - & - & 1,23 & - & - \\
\hline \multirow{3}{*}{$\begin{array}{c}\text { Nitrito } \\
\left(\mathrm{mgNO}_{2} / \mathrm{L}\right)\end{array}$} & EB & - & - & - & - & - & - & 0,001 & - & - \\
\hline & RALEx & - & - & - & - & - & - & 0,001 & - & - \\
\hline & Flotador & - & - & - & - & - & - & 0,005 & - & - \\
\hline \multirow{3}{*}{$\begin{array}{l}\text { Fenóis } \\
(\mathrm{mg} / \mathrm{L})\end{array}$} & EB & 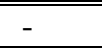 & - & 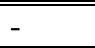 & 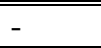 & 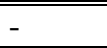 & 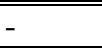 & $<<<0,001$ & - & - \\
\hline & RALEx & - & - & - & - & - & - & $<0,001$ & - & - \\
\hline & Flotador & - & - & - & - & - & - & $<0,001$ & - & - \\
\hline \multirow{3}{*}{$\begin{array}{c}\text { Coliformes } \\
\text { Totais } \\
\text { NMP/100 mL } \\
\end{array}$} & EB & - & - & - & - & - & - & $300 \mathrm{E}+08$ & - & - \\
\hline & RALEx & - & - & - & - & - & 5 , & $172 \mathrm{E}+08$ & - & - \\
\hline & Flotador & - & - & - & - & - & 2, & $613 \mathrm{E}+06$ & - & - \\
\hline \multirow{3}{*}{$\begin{array}{l}\text { Coliformes } \\
\text { Fecais } \\
\text { NMP/100 mL }\end{array}$} & EB & 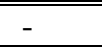 & - & 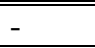 & 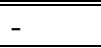 & 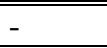 & 4, & $824 \mathrm{E}+07$ & 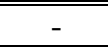 & 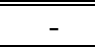 \\
\hline & RALEx & - & - & - & - & - & - & $043 E+08$ & - & - \\
\hline & Flotador & - & - & - & - & - & 2, & $430 \mathrm{E}+05$ & - & - \\
\hline
\end{tabular}


A coleta de amostras entre 08:00 e 20:00, durante os ensaios com dosagem variável de cloreto férrico, permitiu verificar que a unidade de flotação foi responsável pela alteração de diferentes parâmetros de qualidade do efluente do reator anaeróbio. Houve remoção de cerca de $80,0 \% \pm 12,9 \%$ de DBO no flotador, com remoção global pelo sistema de $91,4 \% \pm 7,0 \%$ de DBO. Foi observado, também, que a alcalinidade total foi reduzida em cerca de $47,0 \% \pm 6,3 \%$, que os sólidos totais foram removidos em torno de $35,9 \% \pm 3,9 \%$, que a dureza total se reduziu a cerca de $39,8 \% \pm 8,6 \%$ e que a remoção de sulfatos foi de $92,2 \% \pm 3,6 \%$.

A unidade de flotação também foi responsável pela remoção de $51,7 \% \pm 10,8 \%$ de

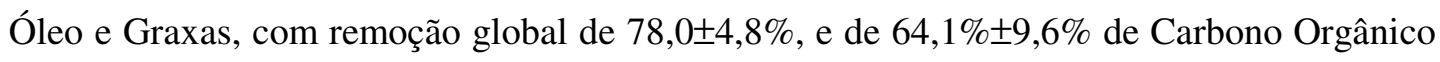
Total, com remoção global de $82,0 \% \pm 6,7 \%$.

A verificação da remoção de compostos nitrogenados e de coliformes foi realizada com somente uma coleta, à 14:00. Observou-se remoção de 12,5\% de NTK, de 17,2\% de nitrogênio amoniacal e de $15,2 \%$ de nitrato. O teor de nitrito elevou-se cerca de $400 \%$, ainda que se mantendo em baixa concentração $(0,005 \mathrm{mg} / \mathrm{L})$. Notadamente, a remoção de nitrogênio por coagulação/floculação/flotação é apenas marginal.

A remoção de coliformes totais, observada após a unidade flotação, foi de 99,5\% e de $99,8 \%$ de coliformes fecais. Esse patamar de remoção permite que a unidade subseqüente de desinfecção atue de forma mais eficaz, visto que houve significativa redução dos coliformes a serem eliminados.

\subsubsection{Ensaios com a instalação protótipo de flotação operada com $T A S=250 \mathrm{~m}^{3} / \mathrm{m}^{2} / \mathrm{d}$.}

São relatados os ensaios com a instalação protótipo de flotação operada com 250 $\mathrm{m}^{3} / \mathrm{m}^{2} / \mathrm{d}$ de taxa de aplicação superficial. Nesses ensaios, foi investigado um valor de fração de recirculação (R de $18 \%$ e $450 \mathrm{kPa}$ ).

A FIGURA 5.58 apresenta os valores de temperatura, de $\mathrm{pH}$, de turbidez, de DQO, de fósforo e de sólidos suspensos totais do efluente do flotador em função do horário de coleta das amostras quando os seguintes parâmetros operacionais foram adotados: $\mathrm{DCF}=70$ $\mathrm{mg} / \mathrm{L}, \mathrm{Gf}=80 \mathrm{~s}^{-1}, \mathrm{Tf}=20 \mathrm{~min}, \mathrm{R}=18 \%$, Psat $=450 \mathrm{kPa}$ e TAS $=250 \mathrm{~m}^{3} / \mathrm{m}^{2} /$ dia. A temperatura do esgoto bruto variou entre $20,5^{\circ} \mathrm{C}$; às $08: 00$, e $22,0^{\circ} \mathrm{C}$, às 20:00. Oefluente do reator anaeróbio apresentou temperaturas entre $19,0^{\circ} \mathrm{C}$ e $22,5^{\circ} \mathrm{C}$ e o efluente do flotador entre $18,7^{\circ} \mathrm{C}$ e $23,0^{\circ} \mathrm{C}$. O pH do esgoto bruto variou entre 6,8 e 7,2. O efluente do RALEx apresentou $\mathrm{pH}$ entre 6,6 e 6,8 enquanto o $\mathrm{pH}$ do efluente do flotador variou entre 6,3 e 6,7. A turbidez do esgoto bruto apresentou moderada variação, com valores entre 243 e 409 uT. O 
efluente do reator anaeróbio sofreu forte variação de sua turbidez entre 08:00 e 20:00, variando entre 173 e 300 uT. A turbidez do efluente do flotador elevou-se gradativamente, de 108 uT, às 08:00, a 145 uT, às 17:00. Às 20:00, a turbidez sofreu redução em seu valor, até atingir $24,7 \mathrm{uT}$.

O esgoto bruto apresentou forte oscilação nos valores de DQO. Neste ensaio, foram observados valores de DQO entre 604 e 1025 mg/L. O RALEx contribuiu reduzidamente para remoção da carga orgânica, fornecendo efluente com DQO entre 262 e 402 mg/L, com remoção de carga orgânica de 42,4\% entre 08:00 e 20:00. A DQO do efluente do flotador elevou-se gradativamente, de $266 \mathrm{mg} / \mathrm{L}$, às 08:00, para $379 \mathrm{mg} / \mathrm{L}$, às 17:00. Às 20:00, a DQO do efluente do flotador sofreu redução em seu valor, até atingir $119 \mathrm{mg} / \mathrm{L}$. A remoção de carga orgânica promovida pelo flotador entre 08:00 e 20:00 foi de 44,4\%. A remoção global de carga orgânica alcançada pelo sistema RALEx-flotador foi de 67,9\%.

O esgoto bruto apresentou pequena oscilação nos valores de fósforo. Neste ensaio, foram observados valores de P entre 5,7 e 8,5 mg/L. O RALEx contribuiu fortemente para equalização da concentração de fósforo no seu efluente, resultando em valores de $\mathrm{P}$ entre 6,4 e 7,2 mg/L. A concentração de P do efluente do flotador elevou-se gradativamente, de 4,50 mg/L, às 08:00, a 6,80 mg/L, às 14:00. A partir das 17:00, a concentração de $\mathrm{P}$ do efluente do flotador sofreu gradativa redução em seu valor para até $0,90 \mathrm{mg} / \mathrm{L}$, às 20:00. A remoção de carga de fósforo promovida pelo flotador entre 08:00 e 20:00 foi de 24,8\%.

O esgoto bruto apresentou moderada oscilação nos valores de SST. Neste ensaio, foram observados valores de SST entre 178 e 309 mg/L. O RALEx contribuiu reduzidamente para remoção da carga de sólidos suspensos, fornecendo efluente com SST entre 92 e 244 mg/L, com remoção média de carga de sólidos de 37,0\% entre 08:00 e 20:00. A concentração de SST do efluente do flotador reduziu-se gradativamente, de $122 \mathrm{mg} / \mathrm{L}$, às 08:00, para $23 \mathrm{mg} / \mathrm{L}$, às 20:00. A remoção de carga de SST promovida pelo flotador entre 08:00 e 20:00 foi de 54,0\%. A remoção global de sólidos suspensos alcançada pelo sistema RALEx-flotador foi de 71,0\%. 

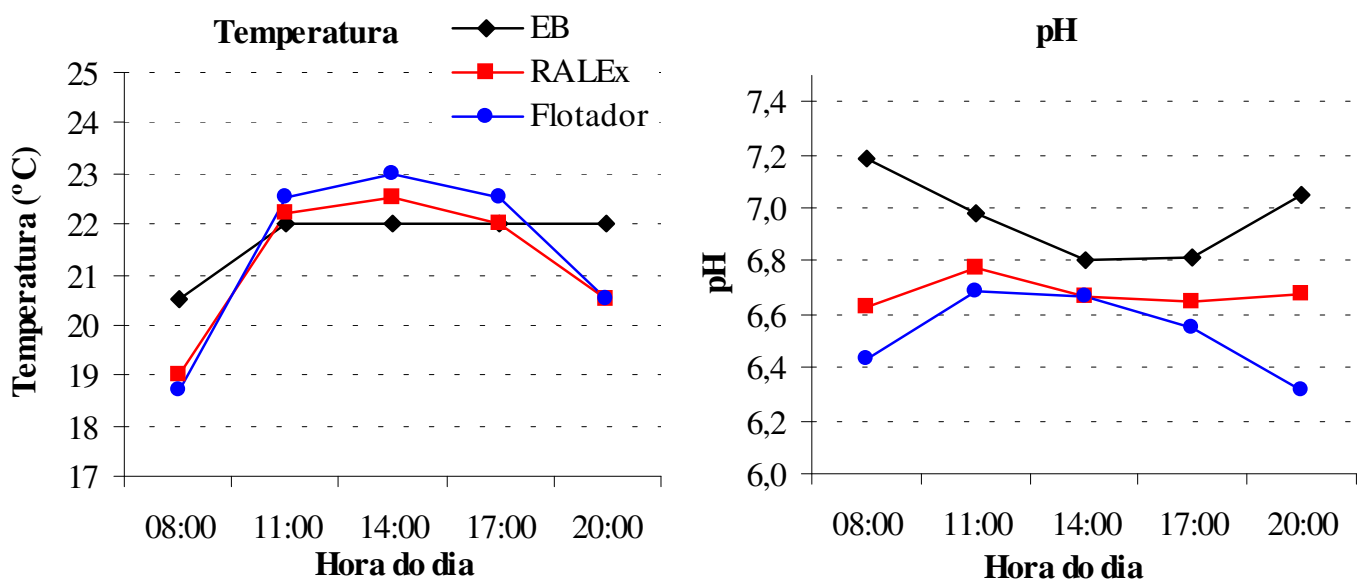

Turbidez
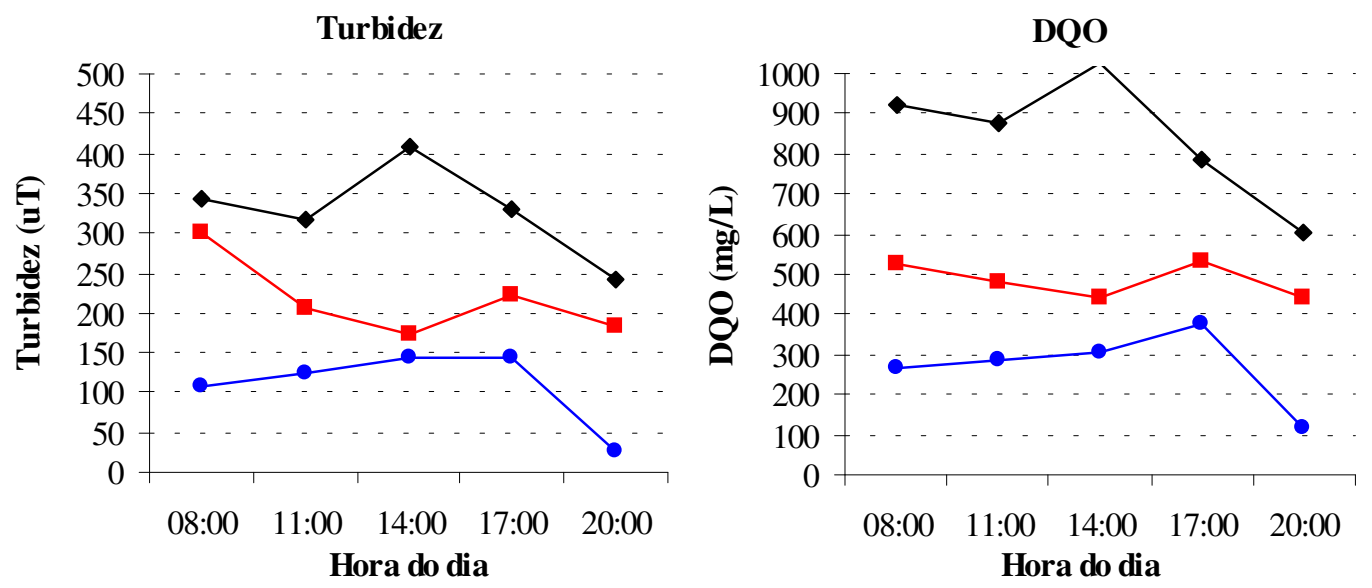

Fósforo
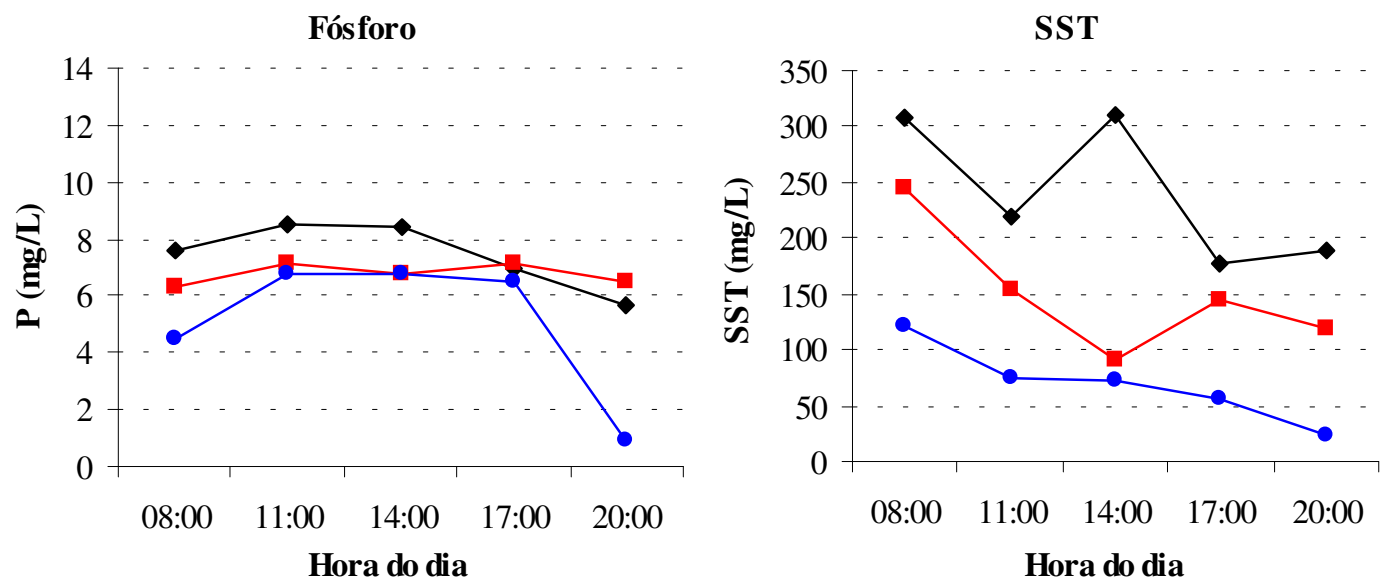

FIGURA 5.58 - Temperatura, pH, turbidez, demanda química de oxigênio, fósforo e sólidos suspensos totais das amostras de esgoto bruto, de efluente do reator RALEx e de efluente do flotador coletadas ao longo do dia de ensaio (13/07/2001).

Ensaios realizados em instalação protótipo de coagulação/floculação/flotação por ar dissolvido com escoamento contínuo e efluente do reator RALEx. Data do ensaio: $13 / 07 / 2001 ; \mathrm{DCF}=70 \mathrm{mg} / \mathrm{L} ; \mathrm{Gf}=80 \mathrm{~s}^{-1} ; \mathrm{Tf}=20 \mathrm{~min} ; \mathrm{R}=18 \%$; Psat=450 $\mathrm{kPa}$; $\mathrm{S}^{*}=17,8 \mathrm{~g} / \mathrm{m}^{3} ; \mathrm{TAS}=250 \mathrm{~m}^{3} / \mathrm{m}^{2} / \mathrm{dia}$. 
A FIGURA 5.59 apresenta os valores de temperatura, de $\mathrm{pH}$, de turbidez, de DQO, de fósforo e de sólidos suspensos totais do efluente do flotador em função do horário de coleta das amostras quando os seguintes parâmetros operacionais foram adotados: $\mathrm{DCF}=50$ $\mathrm{mg} / \mathrm{L}, \mathrm{Gf}=80 \mathrm{~s}^{-1}, \mathrm{Tf}=20 \mathrm{~min}, \mathrm{R}=18 \%$, Psat $=450 \mathrm{kPa}$ e TAS $=250 \mathrm{~m}^{3} / \mathrm{m}^{2} / \mathrm{dia}$.

A temperatura do esgoto bruto variou entre $20,5^{\circ} \mathrm{C}$; às $08: 00$, e $22,5^{\circ} \mathrm{C}$, às $14: 00$. $\mathrm{O}$ efluente do reator anaeróbio apresentou temperaturas entre $19,5^{\circ} \mathrm{C}$ e $23,0^{\circ} \mathrm{C}$ e o efluente do flotador entre $19,5^{\circ} \mathrm{C}$ e $23,0^{\circ} \mathrm{C}$. $\mathrm{O} \mathrm{pH}$ do esgoto bruto variou entre 6,8 e 7,2. O efluente do RALEx apresentou pH entre 6,6 e 6,8 enquanto o pH do efluente do flotador variou entre 6,5 e 6,6. A turbidez do esgoto bruto apresentou moderada variação, com valores entre 203 e 364 uT. O efluente do reator anaeróbio sofreu moderada variação de sua turbidez entre as 08:00 e as 20:00, variando entre 187 e 326 uT. A turbidez do efluente do flotador elevou-se gradativamente, de 25,5 uT, às 08:00, a $115 \mathrm{uT}$, às 17:00, mantendo-se neste patamar até 20:00.

O esgoto bruto apresentou forte oscilação nos valores de DQO. Neste ensaio, foram observados valores de DQO entre 532 e $1029 \mathrm{mg} / \mathrm{L}$. O RALEx contribuiu reduzidamente para remoção da carga orgânica, fornecendo efluente com DQO entre 388 e $564 \mathrm{mg} / \mathrm{L}$, com remoção de carga orgânica de 43,6\% entre às 08:00 e às 20:00. A DQO do efluente do flotador elevou-se gradativamente, de $99 \mathrm{mg} / \mathrm{L}$, às 08:00, a $249 \mathrm{mg} / \mathrm{L}$, às 17:00. A remoção de carga orgânica promovida pelo flotador entre as 08:00 e as 20:00 foi de 57,9\%. A remoção global de carga orgânica alcançada pelo sistema RALEx-flotador foi de 76,2\%.

$\mathrm{O}$ esgoto bruto também apresentou forte oscilação nos valores de fósforo. Neste ensaio, foram observados valores de P entre 7,1 e 13,3 mg/L. O RALEx contribuiu fortemente para equalização da concentração de fósforo no seu efluente, resultando em valores de $\mathrm{P}$ entre 6,2 e 7,4 mg/L. A concentração de $\mathrm{P}$ do efluente do flotador elevou-se gradativamente, de 2,8 mg/L, às 08:00, a 7,0 mg/L, às 14:00. A partir das 17:00, a concentração de fósforo sofreu redução em seu valor até alcançar $6,3 \mathrm{mg} / \mathrm{L}$, às 20:00. A remoção de carga de fósforo promovida pelo flotador entre as 08:00 e as 20:00 foi de 22,7\%. O esgoto bruto também apresentou forte oscilação nos valores de SST. Neste ensaio, foram observados valores de SST entre 175 e $294 \mathrm{mg} / \mathrm{L}$. O RALEx contribuiu pouco para redução da carga de sólidos suspensos, fornecendo efluente com SST entre 121 e $240 \mathrm{mg} / \mathrm{L}$, com remoção média de carga de sólidos de 27,4\% entre às 08:00 e às 20:00. A concentração de SST do efluente do flotador elevou-se gradativamente, de $27 \mathrm{mg} / \mathrm{L}$, às 08:00, para $75 \mathrm{mg} / \mathrm{L}$, às 20:00. A remoção de carga de SST promovida pelo flotador entre as 08:00 e as 20:00 foi de 63,3\%. A remoção global de sólidos suspensos alcançada pelo sistema RALEx-flotador foi de $73,3 \%$. 

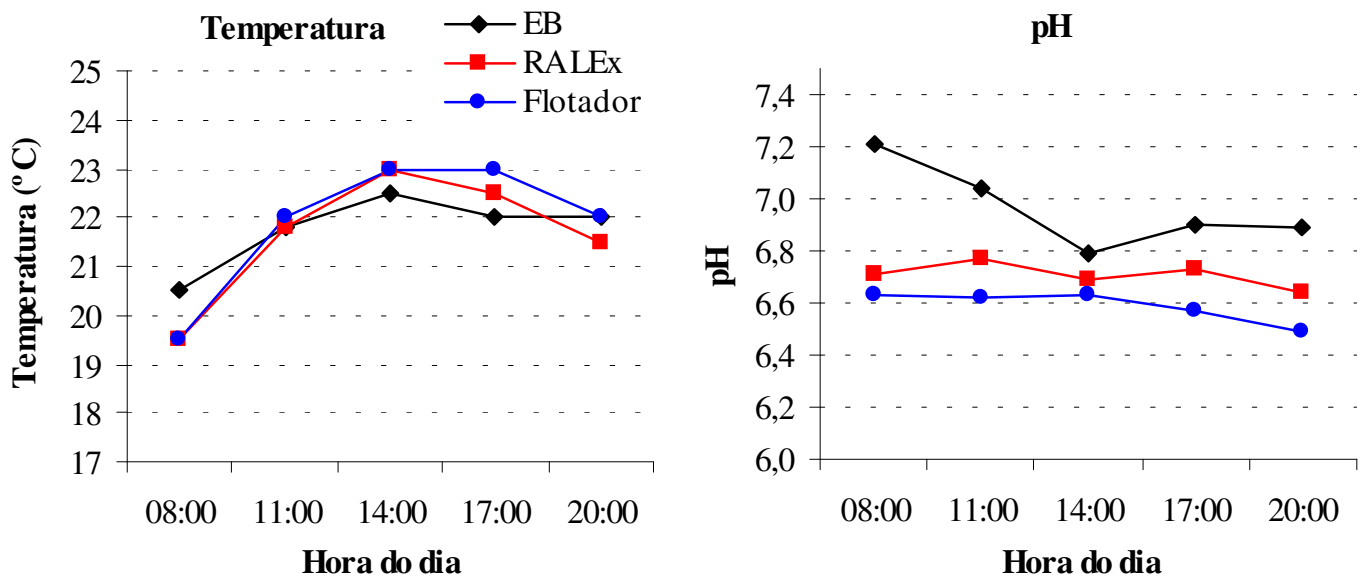

Turbidez
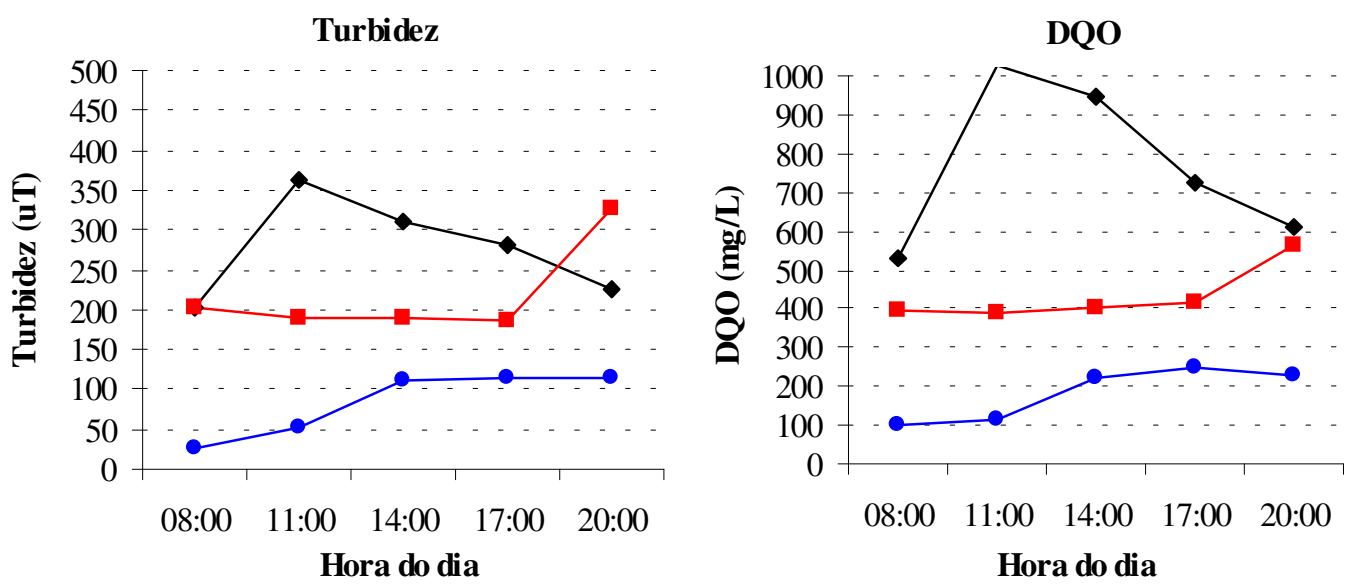

Fósforo
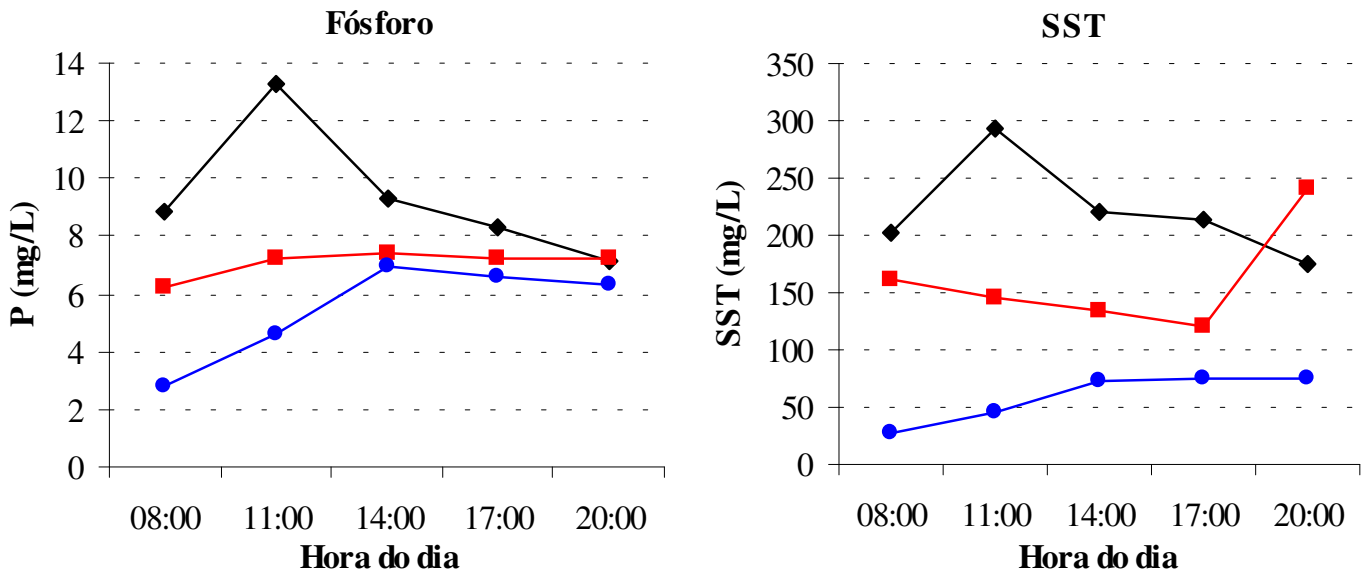

FIGURA 5.59 - Temperatura, pH, turbidez, demanda química de oxigênio, fósforo e sólidos suspensos totais das amostras de esgoto bruto, de efluente do reator RALEx e de efluente do flotador coletadas ao longo do dia de ensaio (30/06/2001).

Ensaios realizados em instalação protótipo de coagulação/floculação/flotação por ar dissolvido com escoamento contínuo e efluente do reator RALEx. Data do ensaio: $30 / 06 / 2001 ; \mathrm{DCF}=50 \mathrm{mg} / \mathrm{L} ; \mathrm{Gf}=80 \mathrm{~s}^{-1} ; \mathrm{Tf}=20 \mathrm{~min} ; \mathrm{R}=18 \%$; Psat=450 kPa; $\mathrm{S}^{*}=17,8 \mathrm{~g} / \mathrm{m}^{3} ; \mathrm{TAS}=250 \mathrm{~m}^{3} / \mathrm{m}^{2} / \mathrm{dia}$. 
A FIGURA 5.60 apresenta os valores de temperatura, de $\mathrm{pH}$, de turbidez, de DQO, de fósforo e de sólidos suspensos totais do efluente do flotador em função do horário de coleta das amostras quando os seguintes parâmetros operacionais foram adotados: $\mathrm{DCF}=30$ $\mathrm{mg} / \mathrm{L}, \mathrm{Gf}=80 \mathrm{~s}^{-1}, \mathrm{Tf}=20 \mathrm{~min}, \mathrm{R}=18 \%$, Psat $=450 \mathrm{kPa}$ e TAS $=250 \mathrm{~m}^{3} / \mathrm{m}^{2} / \mathrm{dia}$.

A temperatura do esgoto bruto variou entre $20,0^{\circ} \mathrm{C}$; às $08: 00$, e $22,0^{\circ} \mathrm{C}$, às $14: 00 . \mathrm{O}$ efluente do reator anaeróbio apresentou temperaturas entre $18,5^{\circ} \mathrm{C}$ e $22,0^{\circ} \mathrm{C}$ e o efluente do flotador entre $18,5^{\circ} \mathrm{C}$ e $22,2^{\circ} \mathrm{C}$. $\mathrm{O} \mathrm{pH}$ do esgoto bruto variou entre 6,7 e 7,4. O efluente do RALEx apresentou pH entre 6,7 e 6,8 enquanto o $\mathrm{pH}$ do efluente do flotador variou entre 6,5 e 6,7. A turbidez do esgoto bruto apresentou forte variação, com valores entre 229 e 429 uT. O efluente do reator anaeróbio sofreu moderada variação de sua turbidez entre 08:00 e 20:00, variando entre 107 e 177 uT. A turbidez do efluente do flotador elevou-se gradativamente, de 49,2 uT, às 08:00, a 142 uT, às 17:00, mantendo-se neste patamar até 20:00.

O esgoto bruto apresentou forte oscilação nos valores de DQO. Neste ensaio, foram observados valores de DQO entre 613 e 1119 mg/L. O RALEx contribuiu moderadamente para remoção da carga orgânica, fornecendo efluente com DQO entre 295 e 439 mg/L, com remoção de carga orgânica de 56,7\% entre 08:00 e 20:00. A DQO do efluente do flotador elevou-se gradativamente, de $145 \mathrm{mg} / \mathrm{L}$, às 08:00, a $335 \mathrm{mg} / \mathrm{L}$, às 20:00. A remoção de carga orgânica promovida pelo flotador entre as 08:00 e as 20:00 foi de 28,7\%. A remoção global de carga orgânica alcançada pelo sistema RALEx-flotador foi de $69,1 \%$.

$\mathrm{O}$ esgoto bruto também apresentou forte oscilação nos valores de fósforo. Neste ensaio, foram observados valores de $\mathrm{P}$ entre 6,2 e 11,5 mg/L. O RALEx contribuiu fortemente para equalização da concentração de fósforo no seu efluente, resultando em valores de $\mathrm{P}$ entre 6,2 e 7,4 mg/L. A concentração de $\mathrm{P}$ do efluente do flotador elevou-se gradativamente, de 4,0 mg/L, às 08:00, a 7,0 mg/L, às 14:00. A partir das 17:00, a concentração de fósforo sofreu redução em seu valor até alcançar $6,4 \mathrm{mg} / \mathrm{L}$, às 20:00. A remoção de carga de fósforo promovida pelo flotador entre as 08:00 e as 20:00 foi de 10,7\%. O esgoto bruto também apresentou forte oscilação nos valores de SST. Neste ensaio, foram observados valores de SST entre 188 e $327 \mathrm{mg} / \mathrm{L}$. O RALEx contribuiu eficientemente para redução da carga de sólidos suspensos, fornecendo efluente com SST entre 80 e $120 \mathrm{mg} / \mathrm{L}$, com remoção média de carga de sólidos de 62,5\% entre 08:00 e 20:00. A concentração de SST do efluente do flotador elevou-se gradativamente, de $43 \mathrm{mg} / \mathrm{L}$, às 08:00, para $73 \mathrm{mg} / \mathrm{L}$, às 14:00. A partir das 17:00, a concentração de sólidos sofreu redução em seu valor até alcançar $68 \mathrm{mg} / \mathrm{L}$, às 20:00. A remoção de carga de SST promovida pelo flotador entre as 08:00 e as 20:00 foi de 39,8\%. A remoção global de sólidos suspensos alcançada pelo sistema RALEx-flotador foi de $77,4 \%$. 


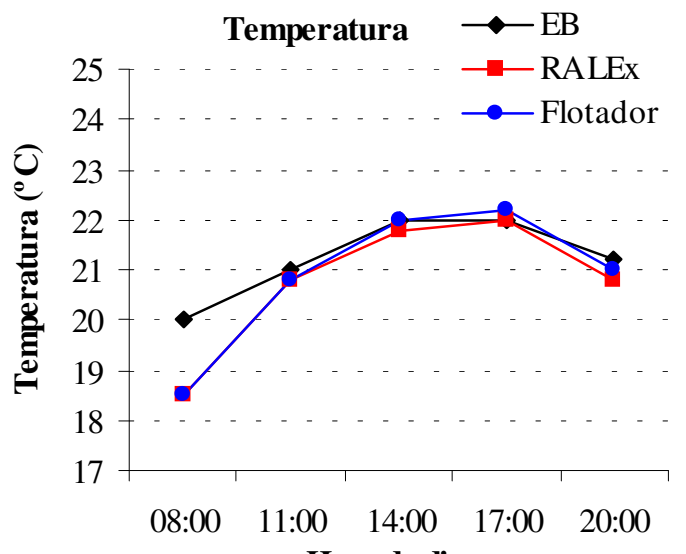

Hora do dia

Turbidez

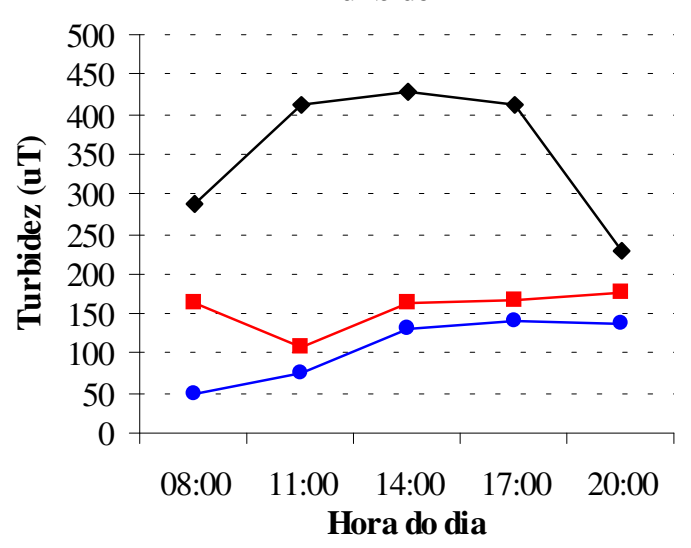

Fósforo

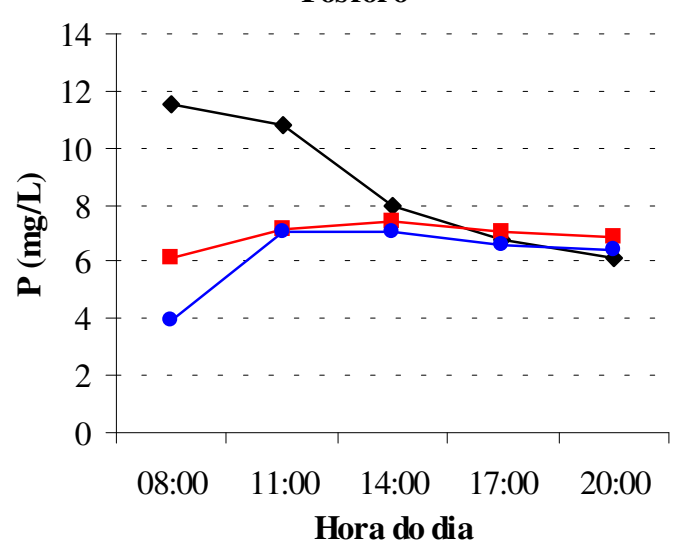

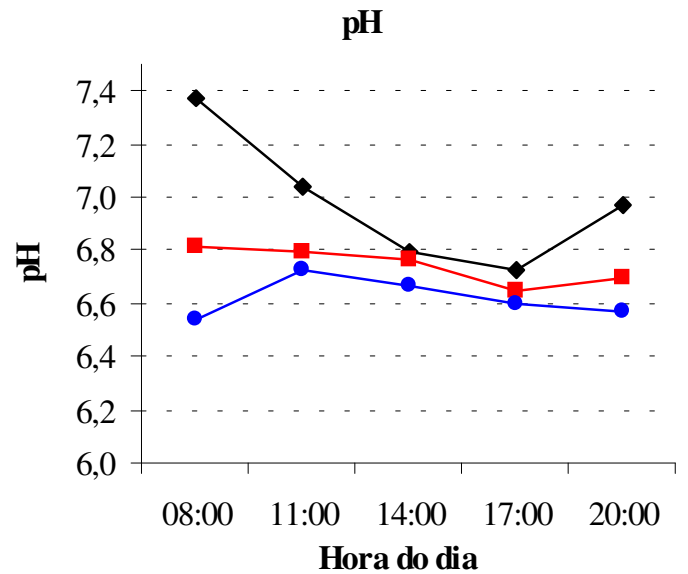
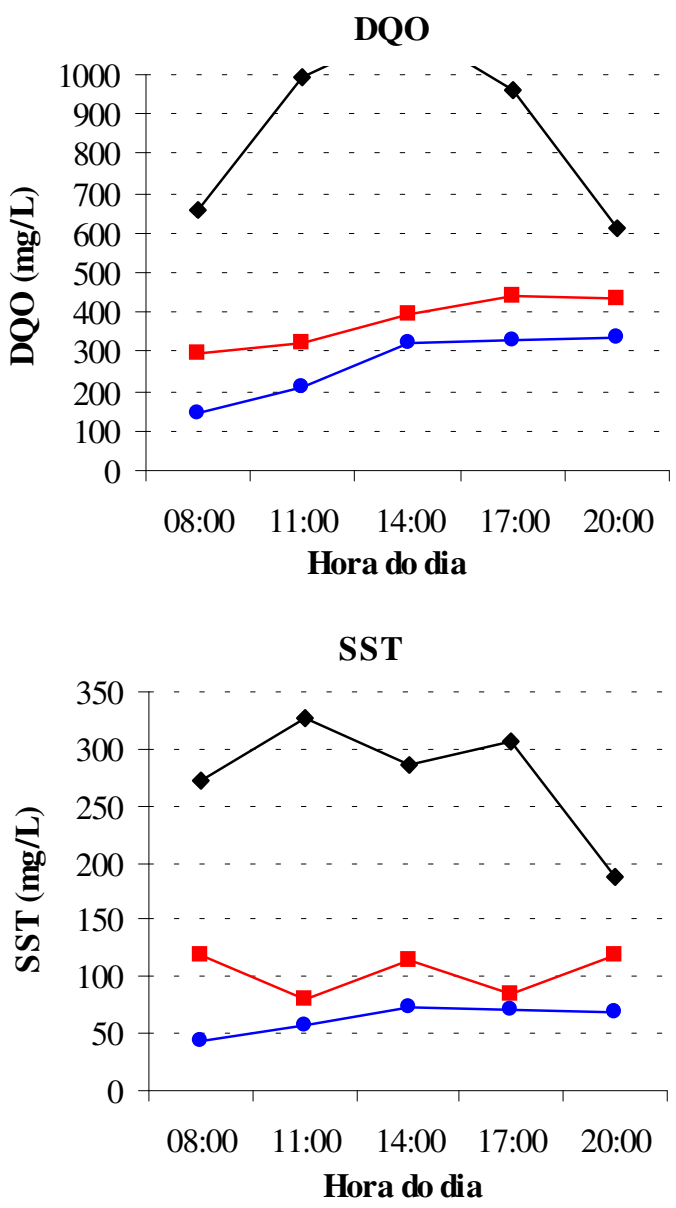

FIGURA 5.60 - Temperatura, $\mathrm{pH}$, turbidez, demanda química de oxigênio, fósforo e sólidos suspensos totais das amostras de esgoto bruto, de efluente do reator RALEx e de efluente do flotador coletadas ao longo do dia de ensaio (29/06/2001).

Ensaios realizados em instalação protótipo de coagulação/floculação/flotação por ar dissolvido com escoamento contínuo e efluente do reator RALEx. Data do ensaio: 29/06/2001; DCF=30 mg/L; Gf=80 s ${ }^{-1} ; \mathrm{Tf}=20 \mathrm{~min} ; \mathrm{R}=18 \%$; Psat=450 kPa; $\mathrm{S}^{*}=17,8 \mathrm{~g} / \mathrm{m}^{3} ; \mathrm{TAS}=250 \mathrm{~m}^{3} / \mathrm{m}^{2} / \mathrm{dia}$. 
A análise e discussão dos resultados através da comparação entre as diferentes eficiências de remoção média de turbidez e de carga de DQO, de fósforo e de SST observadas em cada ensaio desta etapa é relativa em função da variabilidade horária e diária da qualidade do esgoto bruto e da significativa influência da qualidade do efluente do reator RALEx pela qualidade do esgoto bruto, o que não é desejável.

Ainda assim, alguns comportamentos puderam ser observados quando da variação da dosagem de cloreto férrico e da taxa de aplicação superficial, conforme dados da TABELA 5.9, para $\mathrm{R}=18 \%$.

Para ensaios com TAS $=180 \mathrm{~m}^{3} / \mathrm{m}^{2} / \mathrm{d}$, o uso de 50 e $70 \mathrm{mg} / \mathrm{L}$ de cloreto férrico conduziu a bons resultados de remoção de carga de DQO, entre $80,6 \%$ e $81,7 \%$, enquanto para $30 \mathrm{mgFeCl}_{3} / \mathrm{L}$ a remoção foi de apenas $38,3 \%$.

A remoção de fósforo foi a mais influenciada pela variação na dosagem de cloreto férrico. O uso de 50 e $70 \mathrm{mg} / \mathrm{L}$ de cloreto férrico conduziu a resultados satisfatórios de remoção de carga de fósforo, $90,1 \%$ e $71,3 \%$, respectivamente, enquanto para $30 \mathrm{mgFeCl}_{3} / \mathrm{L}$ a remoção foi de $10,3 \%$.

O uso de 50 e $70 \mathrm{mg} / \mathrm{L}$ de cloreto férrico conduziu a bons resultados de remoção de carga de SST, $92,1 \%$ e $85,7 \%$, respectivamente, enquanto para $30 \mathrm{mgFeCl} / 2 / \mathrm{L}$ a remoção foi de $48,9 \%$.

O aumento da taxa de aplicação superficial de 180 para $250 \mathrm{~m}^{3} / \mathrm{m}^{2} / \mathrm{d}$, quando do uso de $30 \mathrm{mgFeCl}_{3} / \mathrm{L}$, resultou em redução de $38,3 \%$ para $28,7 \%$ de remoção de carga de DQO, muito embora mantendo remoções globais em torno de $70 \%$. Quando do uso de 50 e 70 $\mathrm{mgFeCl}_{3} / \mathrm{L}$, houve redução de cerca de $81 \%$ para $57,9 \%$ e $44,4 \%$, respectivamente, de remoção de carga de DQO. Essa redução na remoção de DQO é decorrente do arraste de flocos com o efluente. Esse arraste ocorre porque o aumento da taxa de aplicação superficial resulta em elevação da velocidade descensional do líquido no tanque de flotação, superando a velocidade ascensional de determinada fração de flocos e impedido sua retenção na camada de lodo flotado.

Em se tratando do uso de 50 e $70 \mathrm{mgFeCl}_{3} / \mathrm{L}$, quando do aumento da TAS, verificouse queda significativa na remoção de carga de fósforo para valores de $22,7 \%$ e $24,8 \%$, respectivamente. Quando do uso de $30 \mathrm{mgFeCl}_{3} / \mathrm{L}$, a eficiência de remoção de carga de fósforo praticamente não foi alterada quando do aumento da TAS, mantendo-se em cerca de $10 \%$.

Com comportamento semelhante à remoção de fósforo, a influência do aumento da TAS na remoção de carga de SST, quando foram utilizados $30 \mathrm{mgFeCl}_{3} / \mathrm{L}$, foi pequena, de $48,9 \%\left(\mathrm{TAS}=180 \mathrm{~m}^{3} / \mathrm{m}^{2} / \mathrm{d}\right)$ para $39,8 \%\left(\mathrm{TAS}=250 \mathrm{~m}^{3} / \mathrm{m}^{2} / \mathrm{d}\right)$. Já para 50 e $70 \mathrm{mgFeCl} / \mathrm{L}$, a 
influência foi maior, reduzindo de $92,1 \%\left(\mathrm{TAS}=180 \mathrm{~m}^{3} / \mathrm{m}^{2} / \mathrm{d}\right.$ ) para $63,3 \%$ (TAS $=250$ $\left.\mathrm{m}^{3} / \mathrm{m}^{2} / \mathrm{d}\right)$ e de $85,7\left(\right.$ TAS $=180 \mathrm{~m}^{3} / \mathrm{m}^{2} / \mathrm{d}$ ) para $54,0 \%\left(\right.$ TAS $\left.=250 \mathrm{~m}^{3} / \mathrm{m}^{2} / \mathrm{d}\right)$, respectivamente.

TABELA 5.9 - Valores de turbidez média e de carga de DQO, de fósforo e de SST para as amostras de esgoto bruto, de efluente do RALEx e de efluente do flotador, entre 08:00 e 20:00, e respectivas remoções observadas no reator RALEx, no flotador e no sistema conjugado, de acordo com a etapa 5.6.1.2.

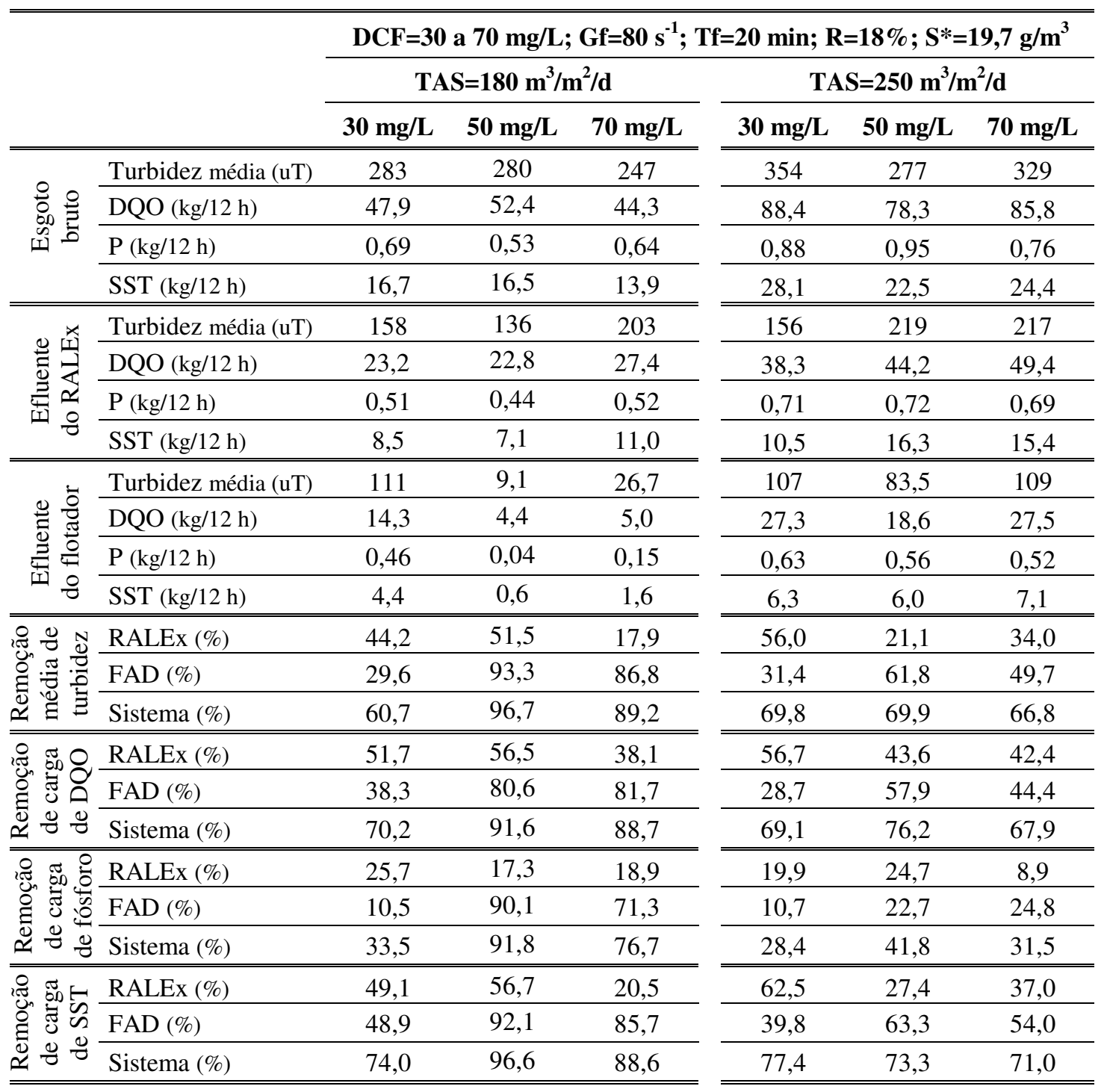

\subsubsection{Ensaios com a instalação protótipo de flotação utilizando cloreto férrico associado a polímero catiônico.}

São relatados os resultados obtidos nos ensaios descritos no item 4.9.3. Nesta etapa da pesquisa foram realizados ensaios com o objetivo de investigar a variação da qualidade do 
efluente do flotador ao longo do dia (entre 08:00 e 20:00) mediante adoção de diferentes parâmetros operacionais do flotador, tais como dosagem de cloreto férrico (DCF) associada à dosagem de polímero catiônico (DP), tempo de floculação (Tf), quantidade de ar fornecida ao processo ( $\left.\mathrm{S}^{*}\right)$ e taxa de aplicação superficial (TAS). Convém lembrar que os parâmetros operacionais adotados apresentam menor amplitude de variação de valores do que aqueles utilizados em laboratório, tendo em vista que os ensaios com o flotateste forneceram dados conclusivos que permitiram estreitar a gama de valores a serem testadas em escala protótipo.

Foram utilizadas dosagens de cloreto férrico de 30 e de $50 \mathrm{mg} / \mathrm{L}$ associadas a 0,4 e $1,0 \mathrm{mg} / \mathrm{L}$ de polímero catiônico. Os valores de gradiente médio de velocidade de floculação foram iguais a $80 \mathrm{~s}^{-1}$. Adotaram-se valores de tempo de floculação entre 14 e 23 min. Frações de recirculação de $12 \%, 15 \%, 18 \%$ e $20 \%$ foram empregadas associadas à pressão de

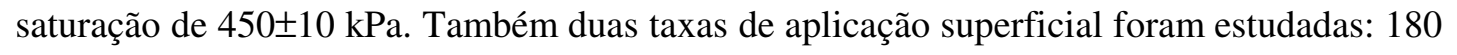
e $250 \mathrm{~m}^{3} / \mathrm{m}^{2} / \mathrm{d}$.

A discussão baseia-se na eficiência de remoção de turbidez, de DQO, de fósforo e de sólidos suspensos totais das amostras não filtradas.

\subsubsection{Ensaios com a instalação protótipo de flotação operada com $T A S=180 \mathrm{~m}^{3} / \mathrm{m}^{2} / \mathrm{d}$.}

São relatados os ensaios com a instalação protótipo de flotação operada com 180 $\mathrm{m}^{3} / \mathrm{m}^{2} / \mathrm{d}$ de taxa de aplicação superficial. Nesses ensaios, foram investigadas duas dosagens de cloreto férrico (30 e $50 \mathrm{mg} / \mathrm{L}$ ) e três valores de fração de recirculação (R entre 12\% e 18\% e $450 \mathrm{kPa})$.

\subsection{Ensaios com a instalação protótipo de flotação operada com $\mathrm{DCF}=30 \mathrm{mg} / \mathrm{L} \mathrm{e}$ $\mathrm{R}=18 \%$.}

São relatados os ensaios com a instalação protótipo de flotação operada com $\mathrm{DCF}=30 \mathrm{mg} / \mathrm{L}, 18 \%$ de recirculação e pressão de saturação de $450 \mathrm{kPa}$. Nesses ensaios, foram investigados dois valores de Tf (14 e $21 \mathrm{~min})$ e dois valores de $\mathrm{DP}(0,4$ e 1,0 mg/L).

A FIGURA 5.61 apresenta os valores de temperatura, de pH, de turbidez, de DQO, de fósforo e de sólidos suspensos totais do efluente do flotador em função do horário de coleta das amostras quando os seguintes parâmetros operacionais foram adotados: $\mathrm{DCF}=30$ $\mathrm{mg} / \mathrm{L}, \mathrm{DP}=0,4 \mathrm{mg} / \mathrm{L}, \mathrm{Gf}=80 \mathrm{~s}^{-1}, \mathrm{Tf}=21 \mathrm{~min}, \mathrm{R}=20 \%$, Psat=450 $\mathrm{kPa}$ e TAS=180 $\mathrm{m}^{3} / \mathrm{m}^{2} / \mathrm{dia}$.

A temperatura do esgoto bruto variou entre $22,2^{\circ} \mathrm{C}$; às $08: 00$, e $23,5^{\circ} \mathrm{C}$, às $20: 00$. $\mathrm{O}$ efluente do reator anaeróbio apresentou temperaturas entre $21,2^{\circ} \mathrm{C}$ e $25,0^{\circ} \mathrm{C}$ e o efluente do flotador entre $20,8^{\circ} \mathrm{C}$ e $25,0^{\circ} \mathrm{C}$.

$\mathrm{O} \mathrm{pH}$ do esgoto bruto variou entre 6,8 e 7,2. O efluente do RALEx apresentou pH entre 6,5 e 6,8 enquanto o pH do efluente do flotador variou entre 6,4 e 6,7. 
A turbidez do esgoto bruto apresentou forte variação, com valores entre 244 e 430 uT. O efluente do reator anaeróbio sofreu forte variação de sua turbidez entre 08:00 e 20:00, variando entre 148 e $327 \mathrm{uT}$. A turbidez do efluente do flotador elevou-se gradativamente, de 28,9 uT, às 08:00, a 149 uT, às 20:00.

O esgoto bruto apresentou forte oscilação nos valores de DQO. Neste ensaio, foram observados valores de DQO entre 620 e $957 \mathrm{mg} / \mathrm{L}$. O RALEx contribuiu razoavelmente para remoção da carga orgânica, fornecendo efluente com DQO entre 328 e 529 mg/L, com remoção de carga orgânica de 43,4\% entre 08:00 e 20:00. A DQO do efluente do flotador elevou-se gradativamente, de $118 \mathrm{mg} / \mathrm{L}$, às 08:00, a $313 \mathrm{mg} / \mathrm{L}$, às 17:00. A remoção de carga orgânica promovida pelo flotador entre as 08:00 e as 20:00 foi de 47,5\%. A remoção global de carga orgânica alcançada pelo sistema RALEx-flotador foi de 70,2\%.

O esgoto bruto também apresentou forte oscilação nos valores de fósforo. Neste ensaio, foram observados valores de $\mathrm{P}$ entre 6,2 e 11,2 mg/L. O RALEx contribuiu fortemente para equalização da concentração de fósforo no seu efluente, resultando em valores de $\mathrm{P}$ entre 5,8 e 7,0 mg/L. A concentração de $\mathrm{P}$ do efluente do flotador elevou-se gradativamente, de 4,2 mg/L, às 08:00, a $6,9 \mathrm{mg} / \mathrm{L}$, às 14:00. A partir das 17:00, a concentração de fósforo sofreu redução em seu valor até alcançar $6,7 \mathrm{mg} / \mathrm{L}$, às 20:00. A remoção de carga de fósforo promovida pelo flotador entre as 08:00 e as 20:00 foi de 8,4\%.

O esgoto bruto também apresentou forte oscilação nos valores de SST. Neste ensaio, foram observados valores de SST entre 136 e $324 \mathrm{mg} / \mathrm{L}$. O RALEx contribuiu razoavelmente para redução da carga de sólidos suspensos, fornecendo efluente com SST entre 105 e 230 mg/L, com remoção média de carga de sólidos de 37,5\% entre 08:00 e 20:00. A concentração de SST do efluente do flotador elevou-se gradativamente, de $32 \mathrm{mg} / \mathrm{L}$, às 08:00, para $63 \mathrm{mg} / \mathrm{L}$, às 17:00. A remoção de carga de SST promovida pelo flotador entre 08:00 e 20:00 foi de 68,0\%. A remoção global de sólidos suspensos alcançada pelo sistema RALEx-flotador foi de 80,0\%. 

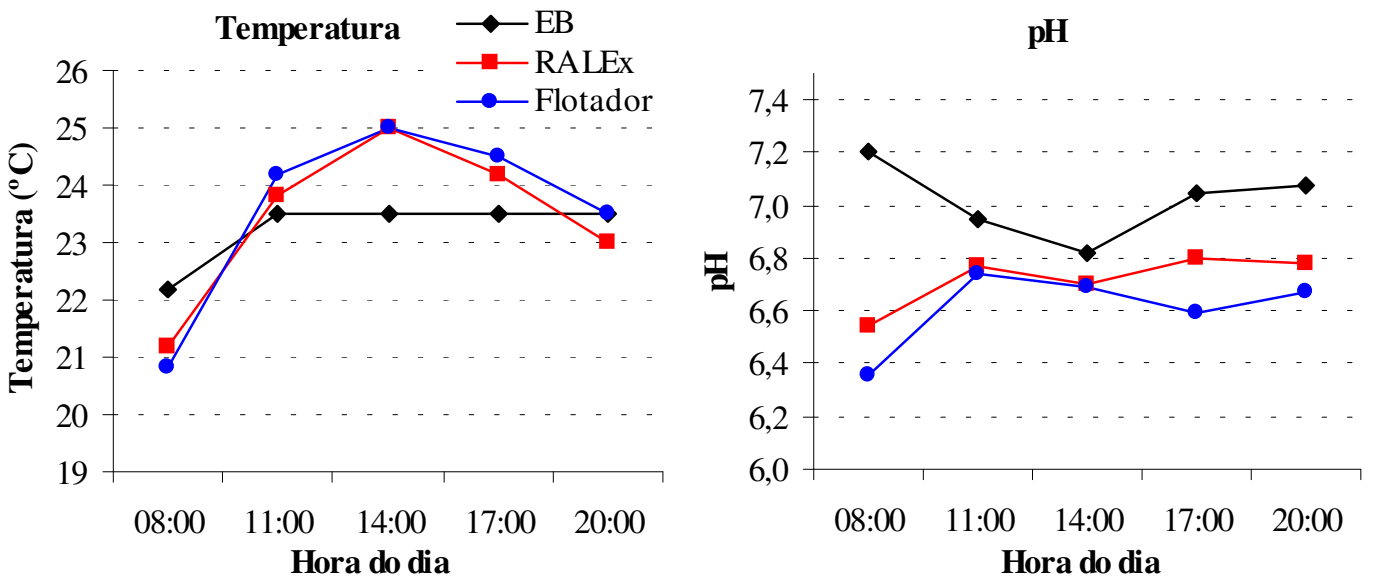

Turbidez
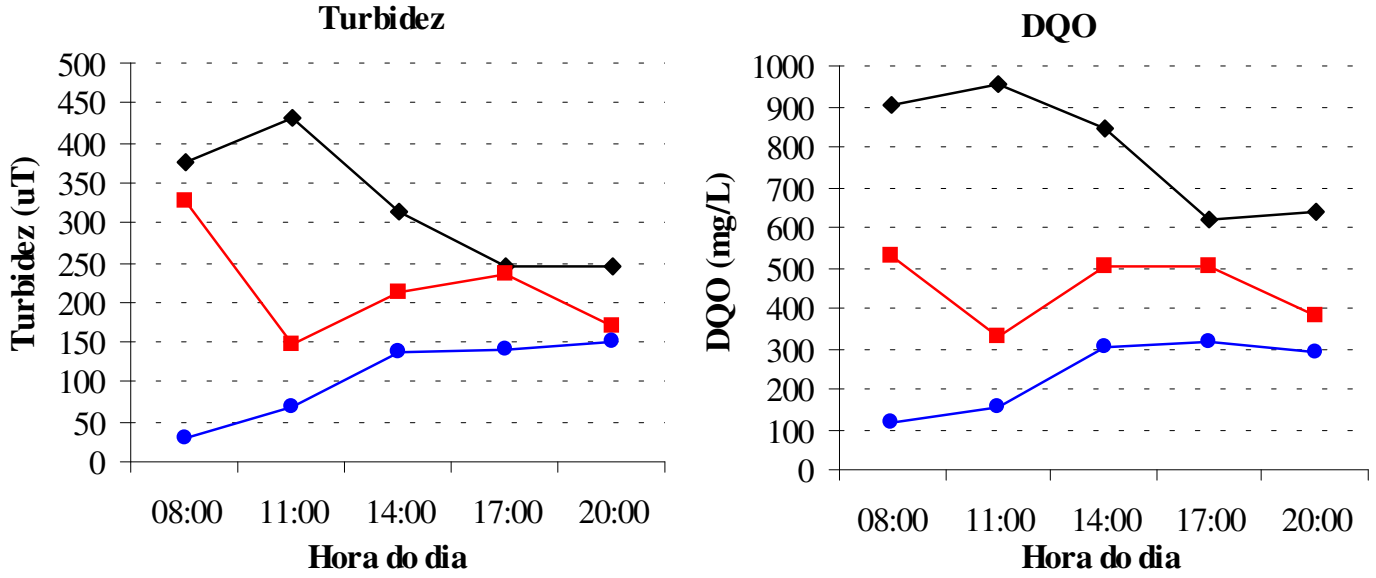

Fósforo
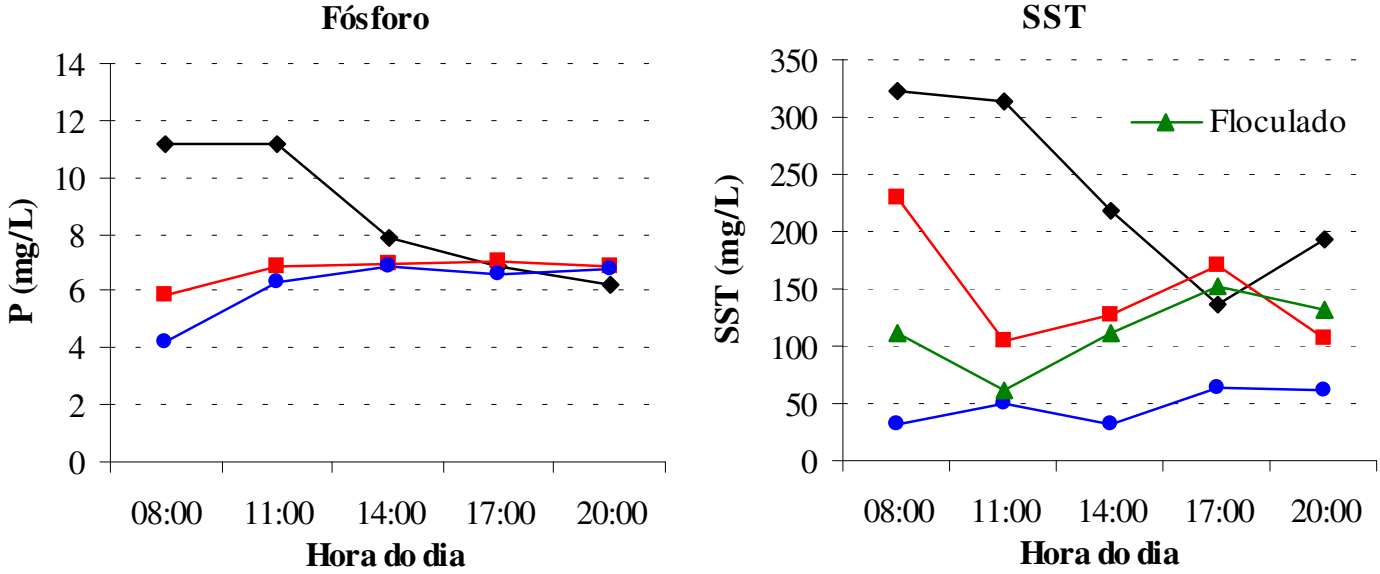

FIGURA 5.61 - Temperatura, pH, turbidez, demanda química de oxigênio, fósforo e sólidos suspensos totais das amostras de esgoto bruto, de efluente do reator RALEx e de efluente do flotador coletadas ao longo do dia de ensaio (20/07/2001).

Ensaios realizados em instalação protótipo de coagulação/floculação/flotação por ar dissolvido com escoamento contínuo e efluente do reator RALEx. Data do ensaio: 20/07/2001; $\mathrm{DCF}=30 \mathrm{mg} / \mathrm{L} ; \mathrm{DP}=0,4 \mathrm{mg} / \mathrm{L} ; \mathrm{Gf}=80 \mathrm{~s}^{-1} ; \mathrm{Tf}=20 \mathrm{~min} ; \mathrm{R}=18 \%$; Psat $=450 \mathrm{kPa} ; \mathrm{S}^{*}=19,7 \mathrm{~g} / \mathrm{m}^{3} ; \mathrm{TAS}=180 \mathrm{~m}^{3} / \mathrm{m}^{2} / \mathrm{dia}$. 
A FIGURA 5.62 apresenta os valores de temperatura, de pH, de turbidez, de DQO, de fósforo e de sólidos suspensos totais do efluente do flotador em função do horário de coleta das amostras quando os seguintes parâmetros operacionais foram adotados: $\mathrm{DCF}=30$ $\mathrm{mg} / \mathrm{L}, \mathrm{DP}=0,4 \mathrm{mg} / \mathrm{L}, \mathrm{Gf}=80 \mathrm{~s}^{-1}, \mathrm{Tf}=14 \mathrm{~min}, \mathrm{R}=20 \%$, Psat=450 $\mathrm{kPa}$ e TAS $=180 \mathrm{~m}^{3} / \mathrm{m}^{2} / \mathrm{dia}$.

A temperatura do esgoto bruto variou entre $21,0^{\circ} \mathrm{C}$; às $08: 00$, e $22,5^{\circ} \mathrm{C}$, às $14: 00$. O efluente do reator anaeróbio apresentou temperaturas entre $20,5^{\circ} \mathrm{C}$ e $22,5^{\circ} \mathrm{C}$ e o efluente do flotador entre $20,0^{\circ} \mathrm{C}$ e $22,5^{\circ} \mathrm{C}$.

$\mathrm{O}$ pH do esgoto bruto variou entre 6,6 e 7,2. O efluente do RALEx apresentou pH entre 6,6 e 6,9 enquanto o $\mathrm{pH}$ do efluente do flotador variou entre 6,6 e 6,8.

A turbidez do esgoto bruto apresentou moderada variação, com valores entre $244 \mathrm{e}$ 376 uT. O efluente do reator anaeróbio sofreu forte variação de sua turbidez entre 08:00 e 20:00, variando entre 141 e 224 uT. A turbidez do efluente do flotador elevou-se gradativamente, de 39,8 uT, às 08:00, a 153 uT, às 20:00.

O esgoto bruto apresentou forte oscilação nos valores de DQO. Neste ensaio, foram observados valores de DQO entre 616 e $941 \mathrm{mg} / \mathrm{L}$. O RALEx contribuiu razoavelmente para remoção da carga orgânica, fornecendo efluente com DQO entre 299 e 511 mg/L, com remoção de carga orgânica de 45,6\% entre 08:00 e 20:00. A DQO do efluente do flotador elevou-se gradativamente, de $107 \mathrm{mg} / \mathrm{L}$, às 08:00, a $340 \mathrm{mg} / \mathrm{L}$, às 17:00. A remoção de carga orgânica promovida pelo flotador entre as 08:00 e as 20:00 foi de 43,4\%. A remoção global de carga orgânica alcançada pelo sistema RALEx-flotador foi de $69,2 \%$.

O esgoto bruto também apresentou forte oscilação nos valores de fósforo. Neste ensaio, foram observados valores de $\mathrm{P}$ entre 6,2 e 11,8 mg/L. O RALEx contribuiu fortemente para equalização da concentração de fósforo no seu efluente, resultando em valores de $\mathrm{P}$ entre 5,8 e $7,3 \mathrm{mg} / \mathrm{L}$. A concentração de $\mathrm{P}$ do efluente do flotador elevou-se gradativamente, de 4,1 mg/L, às 08:00, a $6,9 \mathrm{mg} / \mathrm{L}$, às 14:00. A partir das 17:00, a concentração de fósforo sofreu redução em seu valor até alcançar $6,3 \mathrm{mg} / \mathrm{L}$, às $20: 00$. A remoção de carga de fósforo promovida pelo flotador entre as 08:00 e as 20:00 foi de 9,0\%. O esgoto bruto também apresentou moderada oscilação nos valores de SST. Neste ensaio, foram observados valores de SST entre 192 e $306 \mathrm{mg} / \mathrm{L}$. O RALEx contribuiu razoavelmente para redução da carga de sólidos suspensos, fornecendo efluente com SST entre 73 e 180 mg/L, com remoção média de carga de sólidos de 43,2\% entre 08:00 e 20:00. A concentração de SST do efluente do flotador elevou-se gradativamente, de $28 \mathrm{mg} / \mathrm{L}$, às 08:00, para $82 \mathrm{mg} / \mathrm{L}$, às 17:00. A remoção de carga de SST promovida pelo flotador entre 08:00 e 20:00 foi de 54,4\%. A remoção global de sólidos suspensos alcançada pelo sistema RALEx-flotador foi de $74,1 \%$. 

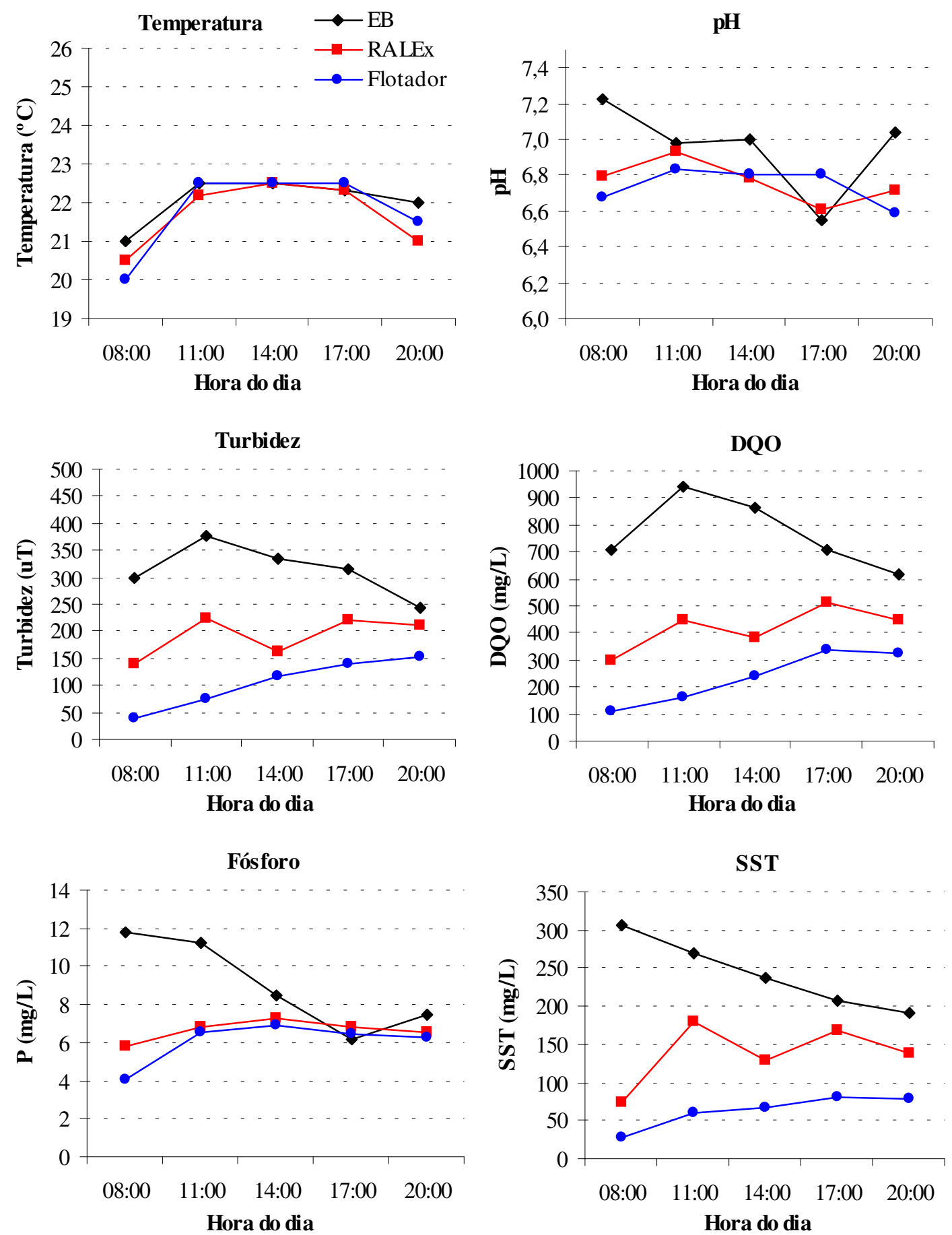

FIGURA 5.62 - Temperatura, pH, turbidez, demanda química de oxigênio, fósforo e sólidos suspensos totais das amostras de esgoto bruto, de efluente do reator RALEx e de efluente do flotador coletadas ao longo do dia de ensaio (24/07/2001).

Ensaios realizados em instalação protótipo de coagulação/floculação/flotação por ar dissolvido com escoamento contínuo e efluente do reator RALEx. Data do ensaio: 24/07/2001; $\mathrm{DCF}=30 \mathrm{mg} / \mathrm{L} ; \mathrm{DP}=0,4 \mathrm{mg} / \mathrm{L} ; \mathrm{Gf}=80 \mathrm{~s}^{-1} ; \mathrm{Tf}=13 \mathrm{~min} ; \mathrm{R}=18 \%$; Psat $=450 \mathrm{kPa} ; \mathrm{S}^{*}=19,7 \mathrm{~g} / \mathrm{m}^{3} ; \mathrm{TAS}=180 \mathrm{~m}^{3} / \mathrm{m}^{2} / \mathrm{dia}$. 
A FIGURA 5.63 apresenta os valores de temperatura, de pH, de turbidez, de DQO, de fósforo e de sólidos suspensos totais do efluente do flotador em função do horário de coleta das amostras quando os seguintes parâmetros operacionais foram adotados: $\mathrm{DCF}=30$ $\mathrm{mg} / \mathrm{L}, \mathrm{DP}=1,0 \mathrm{mg} / \mathrm{L}, \mathrm{Gf}=80 \mathrm{~s}^{-1}, \mathrm{Tf}=14 \mathrm{~min}, \mathrm{R}=20 \%$, Psat=450 $\mathrm{kPa}$ e TAS=180 $\mathrm{m}^{3} / \mathrm{m}^{2} / \mathrm{dia}$.

A temperatura do esgoto bruto variou entre $21,8^{\circ} \mathrm{C}$; às $08: 00$, e $24,0^{\circ} \mathrm{C}$, às $14: 00$. O efluente do reator anaeróbio apresentou temperaturas entre $21,0^{\circ} \mathrm{C}$ e $24,2^{\circ} \mathrm{C}$ e o efluente do flotador entre $21,0^{\circ} \mathrm{C}$ e $24,5^{\circ} \mathrm{C}$.

$\mathrm{O} \mathrm{pH}$ do esgoto bruto variou entre 6,7 e 7,1. O efluente do RALEx apresentou $\mathrm{pH}$ entre 6,6 e 6,7 enquanto o $\mathrm{pH}$ do efluente do flotador variou entre 6,5 e 6,7.

A turbidez do esgoto bruto apresentou moderada variação, com valores entre 245 e 359 uT. O efluente do reator anaeróbio sofreu forte variação de sua turbidez entre 08:00 e 20:00, variando entre 199 e 313 uT. A turbidez do efluente do flotador elevou-se gradativamente, de 21,2 uT, às 08:00, a 156 uT, às 20:00.

O esgoto bruto apresentou forte oscilação nos valores de DQO. Neste ensaio, foram observados valores de DQO entre 604 e $1003 \mathrm{mg} / \mathrm{L}$. O RALEx contribuiu pouco para remoção da carga orgânica, fornecendo efluente com DQO entre 408 e $576 \mathrm{mg} / \mathrm{L}$, com remoção de carga orgânica de 38,5\% entre 08:00 e 20:00. A DQO do efluente do flotador elevou-se gradativamente, de $63 \mathrm{mg} / \mathrm{L}$, às 08:00, a $321 \mathrm{mg} / \mathrm{L}$, às 17:00. A remoção de carga orgânica promovida pelo flotador entre as 08:00 e as 20:00 foi de 58,4\%. A remoção global de carga orgânica alcançada pelo sistema RALEx-flotador foi de 74,4\%.

O esgoto bruto também apresentou forte oscilação nos valores de fósforo. Neste ensaio, foram observados valores de P entre 2,7 e 10,9 mg/L. O RALEx contribuiu fortemente para equalização da concentração de fósforo no seu efluente, resultando em valores de $\mathrm{P}$ entre 6,2 e 7,2 mg/L. A concentração de $\mathrm{P}$ do efluente do flotador elevou-se gradativamente, de 1,5 mg/L, às 08:00, a 6,9 mg/L, às 20:00. A remoção de carga de fósforo promovida pelo flotador entre as 08:00 e as 20:00 foi de 29,0\%.

O esgoto bruto também apresentou moderada oscilação nos valores de SST. Neste ensaio, foram observados valores de SST entre 188 e $326 \mathrm{mg} / \mathrm{L}$. O RALEx contribuiu pouco para redução da carga de sólidos suspensos, fornecendo efluente com SST entre 155 e 245 $\mathrm{mg} / \mathrm{L}$, com remoção média de carga de sólidos de 26,8\% entre 08:00 e 20:00. A concentração de SST do efluente do flotador elevou-se gradativamente, de $17 \mathrm{mg} / \mathrm{L}$, às 08:00, para $81 \mathrm{mg} / \mathrm{L}$, às 17:00. A remoção de carga de SST promovida pelo flotador entre 08:00 e 20:00 foi de 70,2\%. A remoção global de sólidos suspensos alcançada pelo sistema RALEx-flotador foi de 78,2\%. 

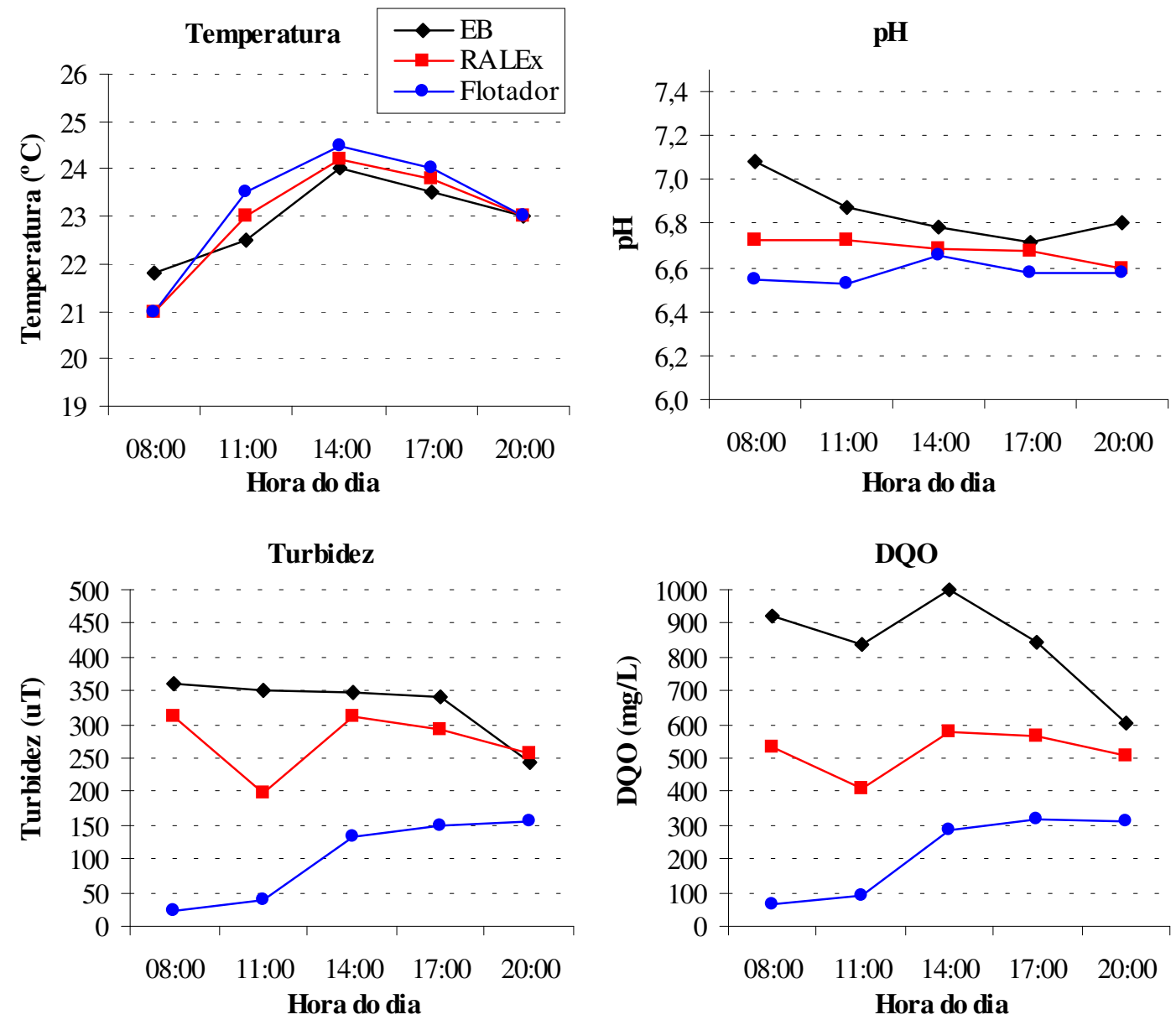

Fósforo
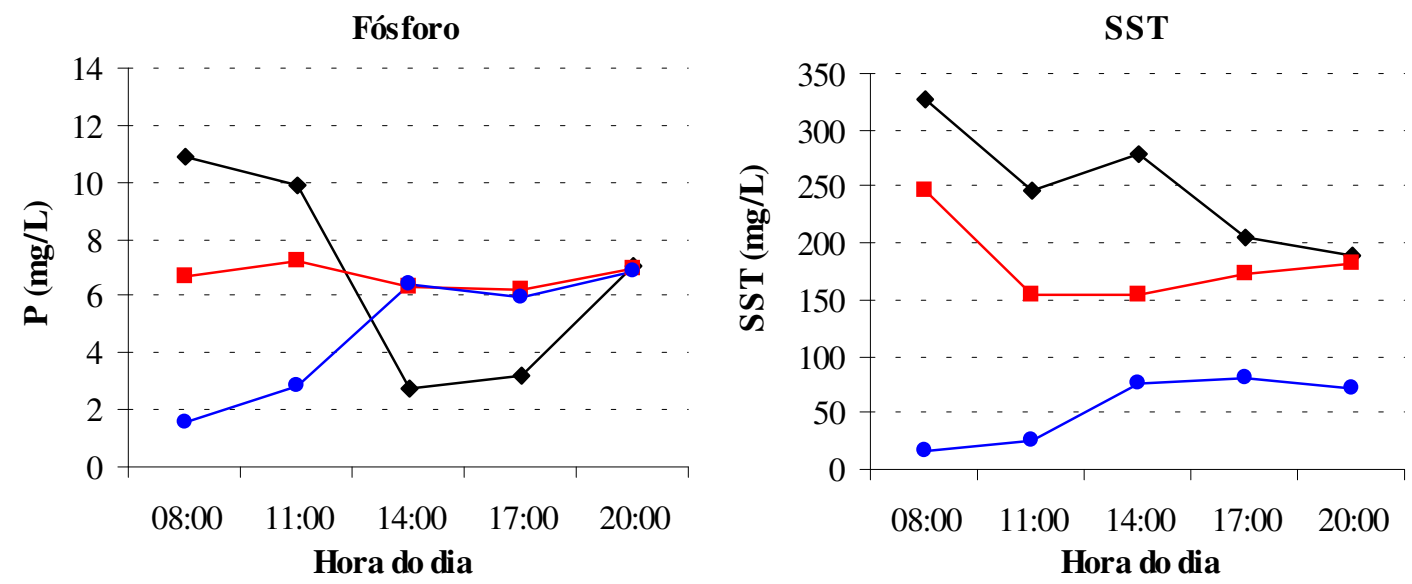

FIGURA 5.63 - Temperatura, pH, turbidez, demanda química de oxigênio, fósforo e sólidos suspensos totais das amostras de esgoto bruto, de efluente do reator RALEx e de efluente do flotador coletadas ao longo do dia de ensaio (25/07/2001).

Ensaios realizados em instalação protótipo de coagulação/floculação/flotação por ar dissolvido com escoamento contínuo e efluente do reator RALEx. Data do ensaio: $25 / 07 / 2001 ; \mathrm{DCF}=30 \mathrm{mg} / \mathrm{L} ; \mathrm{DP}=1,0 \mathrm{mg} / \mathrm{L} ; \mathrm{Gf}=80 \mathrm{~s}^{-1} ; \mathrm{Tf}=13 \mathrm{~min} ; \mathrm{R}=18 \%$; Psat $=450 \mathrm{kPa} ; \mathrm{S}^{*}=19,7 \mathrm{~g} / \mathrm{m}^{3} ; \mathrm{TAS}=180 \mathrm{~m}^{3} / \mathrm{m}^{2} / \mathrm{dia}$. 
A FIGURA 5.64 apresenta os valores de temperatura, de pH, de turbidez, de DQO, de fósforo e de sólidos suspensos totais do efluente do flotador em função do horário de coleta das amostras quando os seguintes parâmetros operacionais foram adotados: $\mathrm{DCF}=30$ $\mathrm{mg} / \mathrm{L}, \mathrm{DP}=1,0 \mathrm{mg} / \mathrm{L}, \mathrm{Gf}=80 \mathrm{~s}^{-1}, \mathrm{Tf}=21 \mathrm{~min}, \mathrm{R}=20 \%$, Psat=450 $\mathrm{kPa}$ e TAS=180 $\mathrm{m}^{3} / \mathrm{m}^{2} / \mathrm{dia} . \mathrm{A}$ temperatura do esgoto bruto variou entre $21,5^{\circ} \mathrm{C}$; às $08: 00$, e $23,5^{\circ} \mathrm{C}$, às $14: 00$. O efluente do reator anaeróbio apresentou temperaturas entre $20,8^{\circ} \mathrm{C}$ e $23,5^{\circ} \mathrm{C}$ e o efluente do flotador entre $21,0^{\circ} \mathrm{C}$ e $24,0^{\circ} \mathrm{C}$. $\mathrm{O} \mathrm{pH}$ do esgoto bruto variou entre 6,7 e 7,1. O efluente do RALEx apresentou $\mathrm{pH}$ entre 6,5 e 6,7 enquanto o $\mathrm{pH}$ do efluente do flotador variou entre 6,4 e 6,7. A turbidez do esgoto bruto apresentou moderada variação, com valores entre 286 e 410 uT. O efluente do reator anaeróbio sofreu moderada variação de sua turbidez entre 08:00 e 20:00, variando entre 187 e 296 uT. A turbidez do efluente do flotador elevou-se gradativamente, de 31,5 uT, às 08:00, a 133 uT, às 20:00.

O esgoto bruto apresentou moderada oscilação nos valores de DQO. Neste ensaio, foram observados valores de DQO entre 720 e 1023 mg/L. O RALEx contribuiu reduzidamente para remoção da carga orgânica, fornecendo efluente com DQO entre 457 e $594 \mathrm{mg} / \mathrm{L}$, com remoção de carga orgânica de 38,5\% entre 08:00 e 20:00. A DQO do efluente do flotador elevou-se gradativamente, de $105 \mathrm{mg} / \mathrm{L}$, às 08:00, para $389 \mathrm{mg} / \mathrm{L}$, às 17:00. Às 20:00, a DQO do efluente do flotador sofreu redução em seu valor, até atingir 363 mg/L. A remoção de carga orgânica promovida pelo flotador entre 08:00 e 20:00 foi de 49,0\%. A remoção global de carga orgânica alcançada pelo sistema RALEx-flotador foi de $68,6 \%$.

O esgoto bruto apresentou elevada oscilação nos valores de fósforo. Neste ensaio, foram observados valores de P entre 6,5 e 11,5 mg/L. O RALEx contribuiu fortemente para equalização da concentração de fósforo no seu efluente, resultando em valores de $\mathrm{P}$ entre 6,0 e 7,1 mg/L. A concentração de P do efluente do flotador elevou-se gradativamente, de 3,50 $\mathrm{mg} / \mathrm{L}$, às 08:00, a 7,00 mg/L, às 17:00. A partir das 20:00, a concentração de $\mathrm{P}$ do efluente do flotador sofreu gradativa redução em seu valor para até $6,10 \mathrm{mg} / \mathrm{L}$. A remoção de carga de fósforo promovida pelo flotador entre 08:00 e 20:00 foi de 13,4\%.

O esgoto bruto apresentou pequena oscilação nos valores de SST. Neste ensaio, foram observados valores de SST entre 292 e $310 \mathrm{mg} / \mathrm{L}$. O RALEx contribuiu razoavelmente para redução da carga de sólidos suspensos, fornecendo efluente com SST entre 107 e 244 mg/L, com remoção média de carga de sólidos de 47,6\% entre 08:00 e 20:00. A concentração de SST do efluente do flotador elevou-se gradativamente, de $27 \mathrm{mg} / \mathrm{L}$, às 08:00, para $83 \mathrm{mg} / \mathrm{L}$, às 20:00. A remoção de carga de SST promovida pelo flotador entre 08:00 e 20:00 foi de 62,0\%. A remoção global de sólidos suspensos alcançada pelo sistema RALEx-flotador foi de $80,1 \%$. 

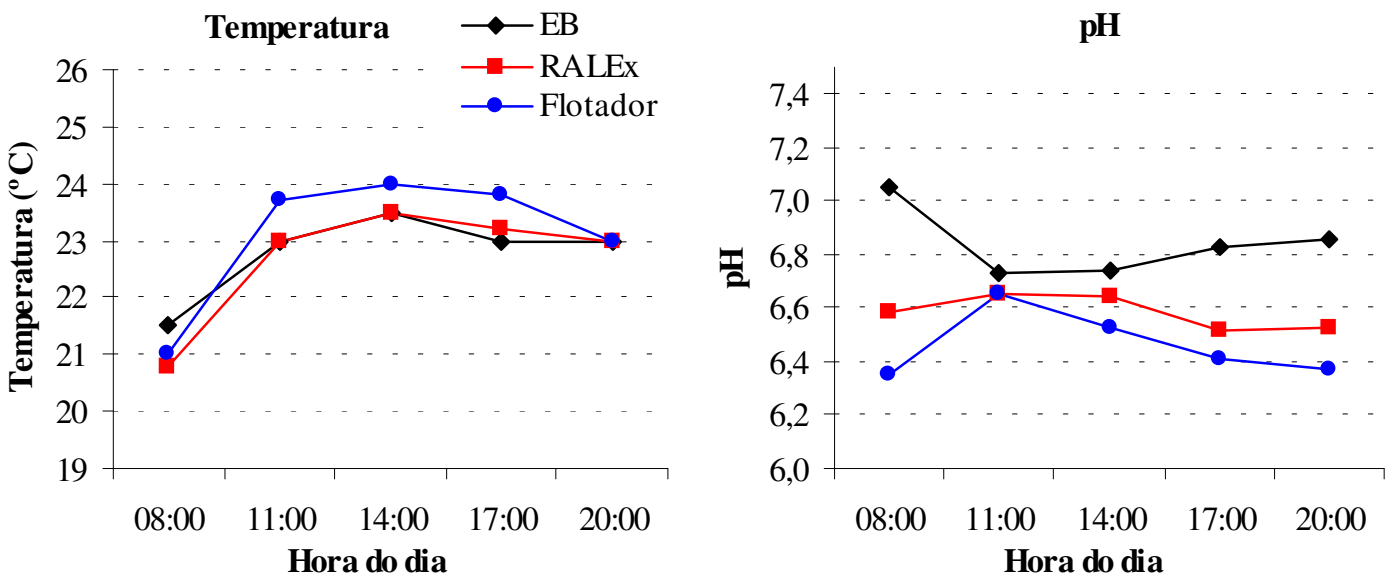

Turbidez
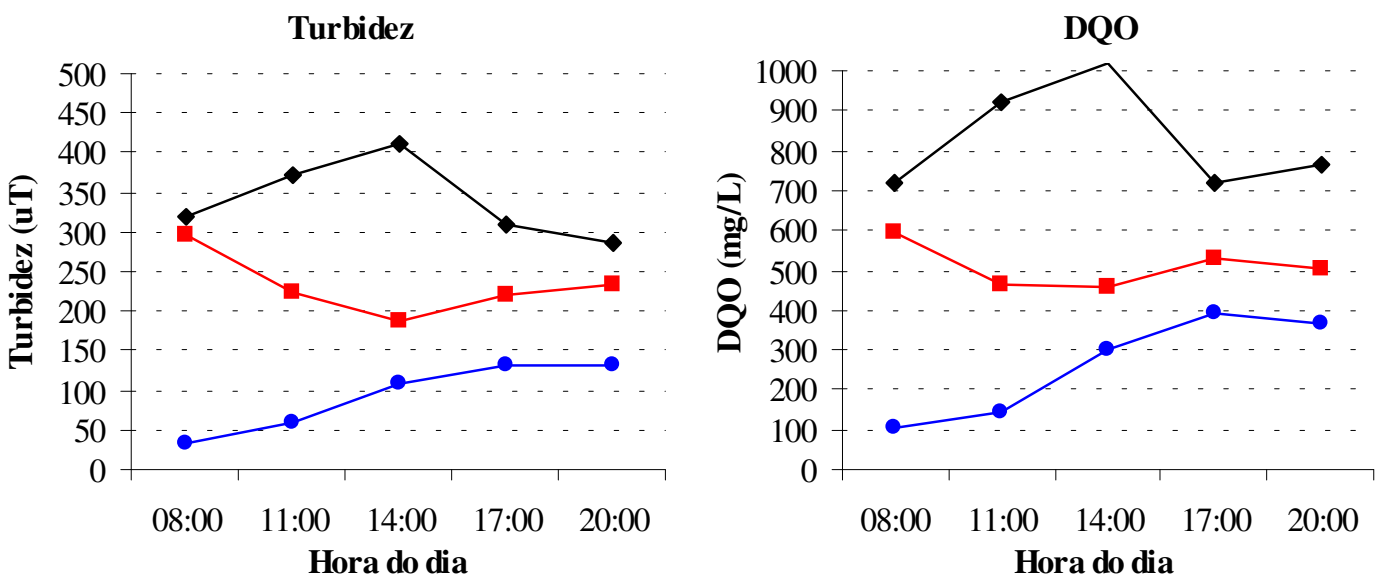

Fósforo
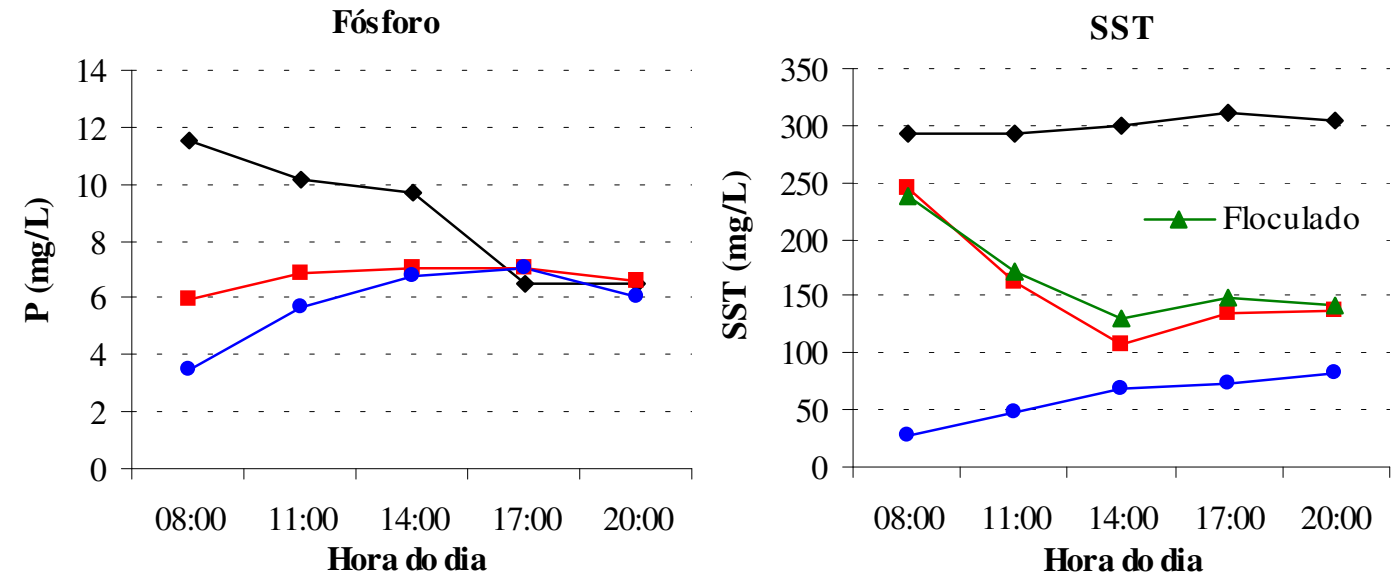

FIGURA 5.64 - Temperatura, pH, turbidez, demanda química de oxigênio, fósforo e sólidos suspensos totais das amostras de esgoto bruto, de efluente do reator RALEx e de efluente do flotador coletadas ao longo do dia de ensaio (26/07/2001).

Ensaios realizados em instalação protótipo de coagulação/floculação/flotação por ar dissolvido com escoamento contínuo e efluente do reator RALEx. Data do ensaio: $26 / 07 / 2001 ; \mathrm{DCF}=30 \mathrm{mg} / \mathrm{L} ; \mathrm{DP}=1,0 \mathrm{mg} / \mathrm{L} ; \mathrm{Gf}=80 \mathrm{~s}^{-1} ; \mathrm{Tf}=20 \mathrm{~min} ; \mathrm{R}=18 \%$; Psat $=450 \mathrm{kPa} ; \mathrm{S}^{*}=19,7 \mathrm{~g} / \mathrm{m}^{3} ; \mathrm{TAS}=180 \mathrm{~m}^{3} / \mathrm{m}^{2} / \mathrm{dia}$. 
Investigando os dados da TABELA 5.10, verifica-se que o aumento do tempo de floculação de 14 min para $21 \mathrm{~min}$, quando a dosagem de polímero era de $0,4 \mathrm{mg} / \mathrm{L}$, resultou em ligeiro aumento da remoção de carga orgânica, de 43,4\% para 47,5\%, pelo flotador. Tendo em vista que a eficiência de remoção de matéria orgânica pelo reator RALEx era semelhante entre os ensaios, a remoção global de matéria orgânica alcançada pelo sistema RALEx-flotador permaneceu estável, em torno de 70\%, para ambos os tempos de floculação utilizados.

Considerando a elevação do tempo de floculação de 14 min para $21 \mathrm{~min}$, quando a dosagem de polímero era de $1,0 \mathrm{mg} / \mathrm{L}$, houve redução na remoção de carga orgânica, de $58,4 \%$ para 49,0\%, e de fósforo, de 29,0\% para 13,4\%, pelo flotador. Além disso, o uso de 21 min de floculação e $\mathrm{DP}=1,0 \mathrm{mg} / \mathrm{L}$ resultou em efluentes flotados com péssima qualidade em termos de presença de matéria orgânica, com resultados ao redor de $400 \mathrm{mg} / \mathrm{L}$ de DQO, no período vespertino.

Investigando a influência da variação da dosagem de polímero catiônico, observa-se que as amostras do efluente do flotador dos ensaios com valores de Tf de 14 min e de DP entre 0,4 e $1,0 \mathrm{mg} / \mathrm{L}$ apresentaram características semelhantes entre si com relação à presença de matéria orgânica, de fósforo e de sólidos suspensos. A maior remoção de carga orgânica quando do uso de $\mathrm{DP}=1,0 \mathrm{mg} / \mathrm{L}$, em comparação com o ensaio com uso de $\mathrm{DP}=0,4$ $\mathrm{mg} / \mathrm{L}$, é explicada pela maior presença de carga orgânica no efluente do reator RALEx, com valores de DQO de até $600 \mathrm{mg} / \mathrm{L}$.

Quando dos ensaios com 21 min de floculação, as eficiências de remoção de carga orgânica pelo flotador foram semelhantes, entre 47,\% e 49,0\%, apesar do aumento da dosagem de polímero de 0,4 para 1,0 mg/L. Entretanto, a qualidade do efluente do flotador do ensaio $4(\mathrm{DP}=1,0 \mathrm{mg} / \mathrm{L})$ foi bastante baixa, com valores ao redor de $400 \mathrm{mg} / \mathrm{L}$ de DQO, no período vespertino.

Considerando a baixa qualidade do efluente do RALEx observada nos meses de inverno, o uso de $30 \mathrm{mgFeCl}_{3} / \mathrm{L}$, ainda que com dosagem adicional de polímero de $1,0 \mathrm{mg} / \mathrm{L}$ e com até 21 min de floculação, não produziu efluente do flotador com qualidade satisfatória, em função da baixa eficiência de coagulação/floculação com $30 \mathrm{mgFeCl} / \mathrm{L}_{3} \mathrm{~L}$ O parâmetro mais afetado em termos de remoção foi o fósforo, com remoção que não ultrapassou $29 \%$. 
TABELA 5.10 - Valores de turbidez média e de carga de DQO, de fósforo e de SST para as amostras de esgoto bruto, de efluente do RALEx e de efluente do flotador, entre 08:00 e 20:00, e respectivas remoções observadas no reator RALEx, no flotador e no sistema conjugado, de acordo com a etapa 5.6.2.1.1.

\begin{tabular}{|c|c|c|c|c|c|}
\hline & & \multicolumn{4}{|c|}{$D C F=30 \mathrm{mg} / \mathrm{L} ; \mathrm{Gf}=\mathbf{8 0} \mathrm{s}^{-1} ; \mathrm{R}=18 \% ; \mathrm{TAS}=180 \mathrm{~m}^{3} / \mathrm{m}^{2} / \mathrm{d}$} \\
\hline & & \multicolumn{2}{|c|}{$\mathrm{DP}=0,4 \mathrm{mg} / \mathrm{L}$} & \multicolumn{2}{|c|}{$\mathrm{DP}=1,0 \mathrm{mg} / \mathrm{L}$} \\
\hline & & $\mathrm{Tf}=14 \mathrm{~min}$ & $\mathbf{T f}=21 \mathrm{~min}$ & $T f=14 \mathrm{~min}$ & $\mathbf{T f}=21 \mathrm{~min}$ \\
\hline \multirow{4}{*}{ 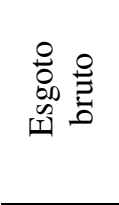 } & Turbidez média (uT) & 313 & 322 & 329 & 339 \\
\hline & DQO (kg/12 h) & 57,4 & 59,2 & 62,9 & 62,0 \\
\hline & $\mathrm{P}(\mathrm{kg} / 12 \mathrm{~h})$ & 0,68 & 0,65 & 0,50 & 0,66 \\
\hline & $\mathrm{SST}(\mathrm{kg} / 12 \mathrm{~h})$ & 18,1 & 17,7 & 18,6 & 22,4 \\
\hline \multirow{4}{*}{ 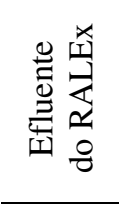 } & Turbidez média (uT) & 192 & 219 & 275 & 233 \\
\hline & DQO $(\mathrm{kg} / 12 \mathrm{~h})$ & 31,2 & 33,5 & 38,7 & 38,1 \\
\hline & $\mathrm{P}(\mathrm{kg} / 12 \mathrm{~h})$ & 0,50 & 0,50 & 0,50 & 0,50 \\
\hline & SST $(\mathrm{kg} / 12 \mathrm{~h})$ & 10,3 & 11,1 & 13,6 & 11,7 \\
\hline \multirow{4}{*}{ 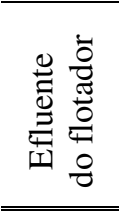 } & Turbidez média (uT) & 104 & 105 & 99,7 & 92,8 \\
\hline & DQO $(\mathrm{kg} / 12 \mathrm{~h})$ & 17,7 & 17,6 & 16,1 & 19,4 \\
\hline & $\mathrm{P}(\mathrm{kg} / 12 \mathrm{~h})$ & 0,45 & 0,46 & 0,35 & 0,44 \\
\hline & SST $(\mathrm{kg} / 12 \mathrm{~h})$ & 4,7 & 3,5 & 4,1 & 4,5 \\
\hline \multirow{3}{*}{ 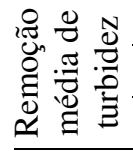 } & RALEx (\%) & 38,8 & 32,0 & 16,4 & 31,4 \\
\hline & FAD (\%) & 45,6 & 52,2 & 63,7 & 60,1 \\
\hline & Sistema $(\%)$ & 66,7 & 67,5 & 69,7 & 72,6 \\
\hline \multirow{3}{*}{ 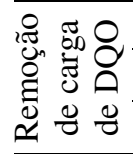 } & RALEx (\%) & 45,6 & 43,4 & 38,5 & 38,5 \\
\hline & FAD (\%) & 43,4 & 47,5 & 58,4 & 49,0 \\
\hline & Sistema (\%) & 69,2 & 70,2 & 74,4 & 68,6 \\
\hline \multirow{3}{*}{ 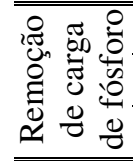 } & RALEx (\%) & 26,5 & 22,5 & 0,9 & 24,2 \\
\hline & FAD $(\%)$ & 9,0 & 8,4 & 29,0 & 13,4 \\
\hline & Sistema $(\%)$ & 33,1 & 28,9 & 29,7 & 34,3 \\
\hline \multirow{3}{*}{ 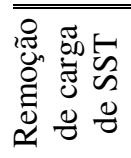 } & RALEx (\%) & 43,2 & 37,5 & 26,8 & 47,6 \\
\hline & FAD $(\%)$ & 54,4 & 68,0 & 70,2 & 62,0 \\
\hline & Sistema $(\%)$ & 74,1 & 80,0 & 78,2 & 80,1 \\
\hline
\end{tabular}

Durante o ensaio com $\mathrm{DP}=0,4 \mathrm{mg} / \mathrm{L}$ e $\mathrm{Tf}=21 \mathrm{~min}$, a vazão média pós-tratada por flotação foi de $6,229 \mathrm{~m}^{3} / \mathrm{h}$. Considerando esta vazão e as dosagens de cloreto férrico utilizadas ao longo das 12 horas, tem-se que a carga de cloreto férrico empregada foi de 2,24 $\mathrm{kg}$ e a carga de polímero foi de 29,9 g. Com os dados de SST das amostras retiradas da última câmara de floculação (floculado) ao longo do ensaio, vistos na FIGURA 5.61, podese estimar a quantidade de lodo flotado. Através da subtração dos valores de SST do efluente do flotador dos valores do efluente floculado e considerando vazão de $6,229 \mathrm{~m}^{3} / \mathrm{h}$ e 12 horas de ensaio, obtém-se valor de 4,92 kgSST, peso seco estimado de lodo flotado, equivalente à remoção horária média de $0,41 \mathrm{kgSST}$, ou seja, $65,8 \mathrm{~g}$ de lodo por $\mathrm{m}^{3}$ de esgoto tratado no 
flotador. Considerando consumo per capita de $200 \mathrm{~L} /$ dia, a população atendida, correspondente a $6,229 \mathrm{~m}^{3} / \mathrm{h}$, foi de 750 pessoas. Desta forma, a produção per capita de lodo foi de 13,1 gSST/pessoa/dia.

Durante o ensaio com $\mathrm{DP}=1,0 \mathrm{mg} / \mathrm{L}$ e $\mathrm{Tf}=21 \mathrm{~min}$, a vazão média pós-tratada por flotação foi de $6,229 \mathrm{~m}^{3} / \mathrm{h}$. Considerando esta vazão e as dosagens de cloreto férrico utilizadas ao longo das 12 horas, tem-se que a carga de cloreto férrico empregada foi de 2,24 $\mathrm{kg}$ e a carga de polímero foi de 74,8 g. Através da subtração dos valores de SST do efluente do flotador dos valores do efluente floculado (FIGURA 5.64) e considerando vazão de 6,229 $\mathrm{m}^{3} / \mathrm{h}$ e 12 horas de ensaio, obtém-se valor de 7,92 $\mathrm{kgSST}$, peso seco estimado de lodo flotado, equivalente à remoção horária média de 0,66 kgSST, ou seja, $106 \mathrm{~g}$ de lodo por $\mathrm{m}^{3}$ de esgoto tratado no flotador. Considerando consumo per capita de $200 \mathrm{~L} /$ dia, a população atendida, correspondente a $6,229 \mathrm{~m}^{3} / \mathrm{h}$, foi de 750 pessoas. Desta forma, a produção per capita de lodo foi de 21,1 gSST/pessoa/dia.

\subsection{Ensaios com a instalação protótipo de flotação operada $\mathrm{DCF}=50 \mathrm{mg} / \mathrm{L} \mathrm{e} \mathrm{com}$ R entre $12 \%$ e $18 \%$.}

São relatados os ensaios com a instalação protótipo de flotação operada com $\mathrm{DCF}=50 \mathrm{mg} / \mathrm{L}$, entre $12 \%$ e $18 \%$ de recirculação e pressão de saturação de $450 \mathrm{kPa}$. Nesses ensaios, foram utilizados um valor de Tf (23 min) e um valor de DP $(0,4 \mathrm{mg} / \mathrm{L})$.

A FIGURA 5.65 apresenta os valores de temperatura, de pH, de turbidez, de DQO, de fósforo e de sólidos suspensos totais do efluente do flotador em função do horário de coleta das amostras quando os seguintes parâmetros operacionais foram adotados: $\mathrm{DCF}=50$ $\mathrm{mg} / \mathrm{L}, \mathrm{DP}=0,4 \mathrm{mg} / \mathrm{L}, \mathrm{Gf}=80 \mathrm{~s}^{-1}, \mathrm{Tf}=23 \mathrm{~min}, \mathrm{R}=12 \%$, Psat=450 $\mathrm{kPa}$ e TAS=180 $\mathrm{m}^{3} / \mathrm{m}^{2} / \mathrm{dia} . \mathrm{A}$ temperatura do esgoto bruto variou entre $21,7^{\circ} \mathrm{C}$; às $08: 00$, e $24,2^{\circ} \mathrm{C}$, às $17: 00$. O efluente do reator anaeróbio apresentou temperaturas entre $22,0^{\circ} \mathrm{C}$ e $24,7^{\circ} \mathrm{C}$ e o efluente do flotador entre $22,0^{\circ} \mathrm{C}$ e $25,0^{\circ} \mathrm{C}$. $\mathrm{O} \mathrm{pH}$ do esgoto bruto variou entre 6,6 e 7,1. O efluente do RALEx apresentou $\mathrm{pH}$ em torno de 6,7 enquanto o $\mathrm{pH}$ do efluente do flotador variou entre 6,5 e 6,6. A turbidez do esgoto bruto apresentou forte variação, com valores entre 230 e 457 uT. O efluente do reator anaeróbio sofreu moderada variação de sua turbidez entre 08:00 e 20:00, variando entre 219 e 279 uT. A turbidez do efluente do flotador elevou-se gradativamente, de 24,9 uT, às 08:00, a 137 uT, às 20:00.

O esgoto bruto apresentou moderada oscilação nos valores de DQO. Neste ensaio, foram observados valores de DQO entre 620 e $1045 \mathrm{mg} / \mathrm{L}$. O RALEx contribuiu 
reduzidamente para remoção da carga orgânica, fornecendo efluente com DQO entre 410 e $674 \mathrm{mg} / \mathrm{L}$, com remoção de carga orgânica de 39,8\% entre 08:00 e 20:00. A DQO do efluente do flotador elevou-se gradativamente, de $150 \mathrm{mg} / \mathrm{L}$, às 08:00, para $376 \mathrm{mg} / \mathrm{L}$, às 17:00. Às 20:00, a DQO do efluente do flotador sofreu redução em seu valor, até atingir 323 mg/L. A remoção de carga orgânica promovida pelo flotador entre 08:00 e 20:00 foi de 49,3\%. A remoção global de carga orgânica alcançada pelo sistema RALEx-flotador foi de $69,5 \%$.

O esgoto bruto apresentou elevada oscilação nos valores de fósforo. Neste ensaio, foram observados valores de P entre 6,5 e 13,7 mg/L. O RALEx contribuiu fortemente para equalização da concentração de fósforo no seu efluente, resultando em valores de $\mathrm{P}$ entre 6,9 e 9,3 mg/L. A concentração de P do efluente do flotador elevou-se gradativamente, de 2,90 $\mathrm{mg} / \mathrm{L}$, às 08:00, a 7,80 mg/L, às 14:00. A partir das 17:00, a concentração de $\mathrm{P}$ do efluente do flotador sofreu gradativa redução em seu valor até alcançar $6,30 \mathrm{mg} / \mathrm{L}$, às 20:00. A remoção de carga de fósforo promovida pelo flotador entre 08:00 e 20:00 foi de 29,0\%.

O esgoto bruto apresentou forte oscilação nos valores de SST. Neste ensaio, foram observados valores de SST entre 185 e $360 \mathrm{mg} / \mathrm{L}$. O RALEx contribuiu pouco para redução da carga de sólidos suspensos, fornecendo efluente com SST entre 152 e $186 \mathrm{mg} / \mathrm{L}$, com remoção média de carga de sólidos de 33,5\% entre 08:00 e 20:00. A concentração de SST do efluente do flotador elevou-se gradativamente, de $30 \mathrm{mg} / \mathrm{L}$, às 08:00, para $75 \mathrm{mg} / \mathrm{L}$, às 14:00. A partir das 17:00, a concentração de SST do efluente do flotador sofreu gradativa redução em seu valor até alcançar $62 \mathrm{mg} / \mathrm{L}$, às 20:00. A remoção de carga de SST promovida pelo flotador entre 08:00 e 20:00 foi de 65,4\%. A remoção global de sólidos suspensos alcançada pelo sistema RALEx-flotador foi de 77,0\%. 

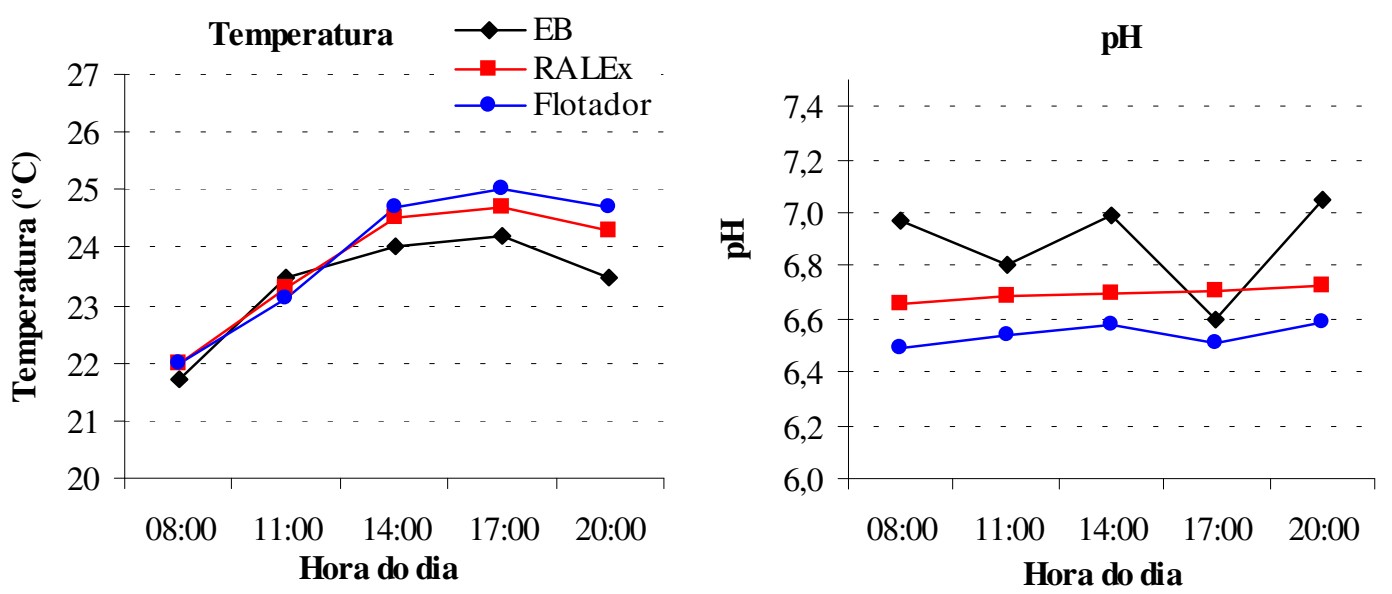

Turbidez
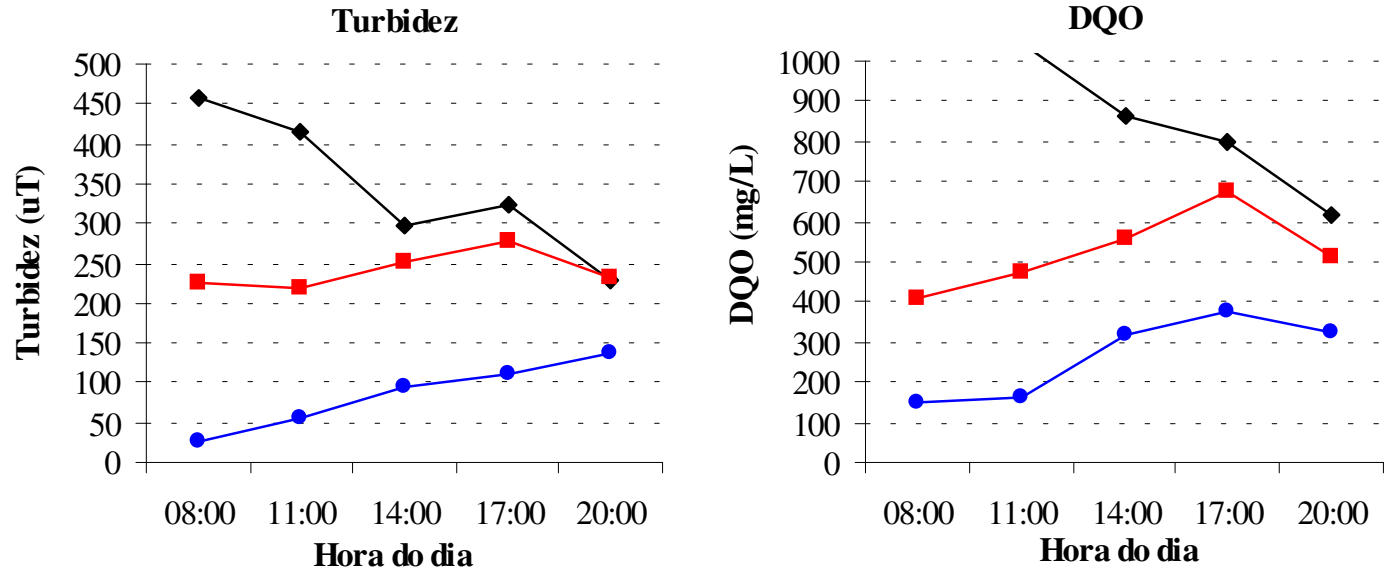

Fósforo
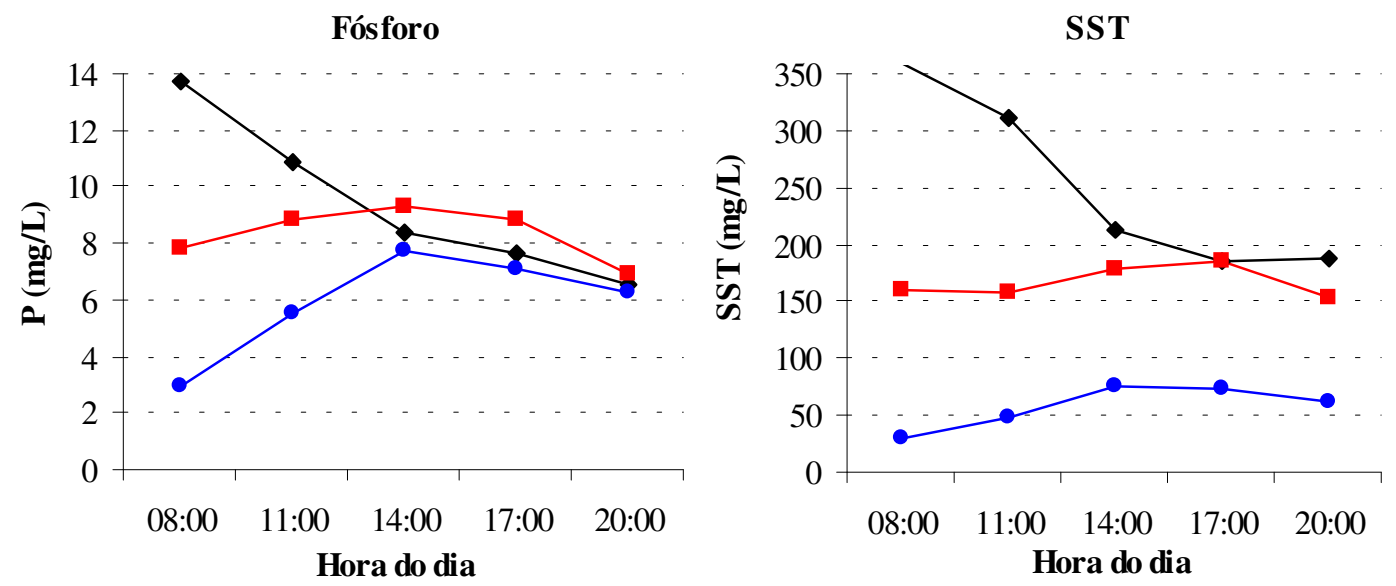

FIGURA 5.65 - Temperatura, pH, turbidez, demanda química de oxigênio, fósforo e sólidos suspensos totais das amostras de esgoto bruto, de efluente do reator RALEx e de efluente do flotador coletadas ao longo do dia de ensaio (06/08/2001). Ensaios realizados em instalação protótipo de coagulação/floculação/flotação por ar dissolvido com escoamento contínuo e efluente do reator RALEx. Data do ensaio: 06/08/2001; DCF=50 $\mathrm{mg} / \mathrm{L} ; \mathrm{DP}=0,40 \mathrm{mg} / \mathrm{L} ; \mathrm{Gf}=80 \mathrm{~s}^{-1} ; \mathrm{Tf}=23 \mathrm{~min}$; $\mathrm{R}=12 \%$; Psat $=450 \mathrm{kPa} ; \mathrm{S}^{*}=13,1 \mathrm{~g} / \mathrm{m}^{3} ; \mathrm{TAS}=180 \mathrm{~m}^{3} / \mathrm{m}^{2} / \mathrm{dia}$. 
A FIGURA 5.66 apresenta os valores de temperatura, de pH, de turbidez, de DQO, de fósforo e de sólidos suspensos totais do efluente do flotador em função do horário de coleta das amostras quando os seguintes parâmetros operacionais foram adotados: $\mathrm{DCF}=50$ $\mathrm{mg} / \mathrm{L}, \mathrm{DP}=0,4 \mathrm{mg} / \mathrm{L}, \mathrm{Gf}=80 \mathrm{~s}^{-1}, \mathrm{Tf}=23 \mathrm{~min}, \mathrm{R}=15 \%$, Psat $=450 \mathrm{kPa}$ e TAS $=180 \mathrm{~m}^{3} / \mathrm{m}^{2} / \mathrm{dia} . \mathrm{A}$ temperatura do esgoto bruto variou entre $22,5^{\circ} \mathrm{C}$, às $08: 00$, e $24,0^{\circ} \mathrm{C}$, às 14:00. O efluente do reator anaeróbio apresentou temperaturas entre $22,0^{\circ} \mathrm{C}$ e $24,8^{\circ} \mathrm{C}$ e o efluente do flotador entre $22,0^{\circ} \mathrm{C}$ e $25,0^{\circ} \mathrm{C} . \mathrm{O} \mathrm{pH}$ do esgoto bruto variou entre 6,6 e 6,9. O efluente do RALEx apresentou $\mathrm{pH}$ entre 6,6 e 6,7 enquanto o $\mathrm{pH}$ do efluente do flotador variou entre 6,3 e 6,5. A turbidez do esgoto bruto apresentou forte variação, com valores entre 199 e 451 uT. O efluente do reator anaeróbio sofreu moderada variação de sua turbidez entre 08:00 e 20:00, variando entre 174 e $274 \mathrm{uT}$. A turbidez do efluente do flotador elevou-se gradativamente, de 15,4 uT, às 08:00, a 71,7 uT, às 17:00.

O esgoto bruto apresentou moderada oscilação nos valores de DQO. Neste ensaio, foram observados valores de DQO entre 543 e $1025 \mathrm{mg} / \mathrm{L}$. O RALEx contribuiu reduzidamente para remoção da carga orgânica, fornecendo efluente com DQO entre 404 e $605 \mathrm{mg} / \mathrm{L}$, com remoção de carga orgânica de 37,2\% entre 08:00 e 20:00. A DQO do efluente do flotador elevou-se gradativamente, de $97 \mathrm{mg} / \mathrm{L}$, às 08:00, para $311 \mathrm{mg} / \mathrm{L}$, às 17:00. Às 20:00, a DQO do efluente do flotador sofreu redução em seu valor, até atingir 199 mg/L. A remoção de carga orgânica promovida pelo flotador entre 08:00 e 20:00 foi de 60,4\%. A remoção global de carga orgânica alcançada pelo sistema RALEx-flotador foi de $75,1 \%$.

O esgoto bruto apresentou elevada oscilação nos valores de fósforo. Neste ensaio, foram observados valores de P entre 6,2 e 11,9 mg/L. O RALEx contribuiu fortemente para equalização da concentração de fósforo no seu efluente, resultando em valores de $\mathrm{P}$ entre 6,7 e $8,3 \mathrm{mg} / \mathrm{L}$. A concentração de P do efluente do flotador elevou-se gradativamente, de 1,10 $\mathrm{mg} / \mathrm{L}$, às 08:00, a 5,50 mg/L, às 14:00. A partir das 17:00, a concentração de $\mathrm{P}$ do efluente do flotador sofreu gradativa redução em seu valor até alcançar 4,30 mg/L, às 20:00. A remoção de carga de fósforo promovida pelo flotador entre 08:00 e 20:00 foi de 51,9\%.

O esgoto bruto apresentou elevada oscilação nos valores de SST. Neste ensaio, foram observados valores de SST entre 159 e $356 \mathrm{mg} / \mathrm{L}$. O RALEx contribuiu pouco para redução da carga de sólidos suspensos, fornecendo efluente com SST entre 155 e $204 \mathrm{mg} / \mathrm{L}$, com remoção média de carga de sólidos de 29,7\% entre 08:00 e 20:00. A concentração de SST do efluente do flotador elevou-se gradativamente, de $14 \mathrm{mg} / \mathrm{L}$, às 08:00, para $54 \mathrm{mg} / \mathrm{L}$, às 17:00. A remoção de carga de SST promovida pelo flotador entre 08:00 e 20:00 foi de $77,5 \%$. A remoção global de sólidos suspensos alcançada pelo sistema RALEx-flotador foi de $84,2 \%$. 

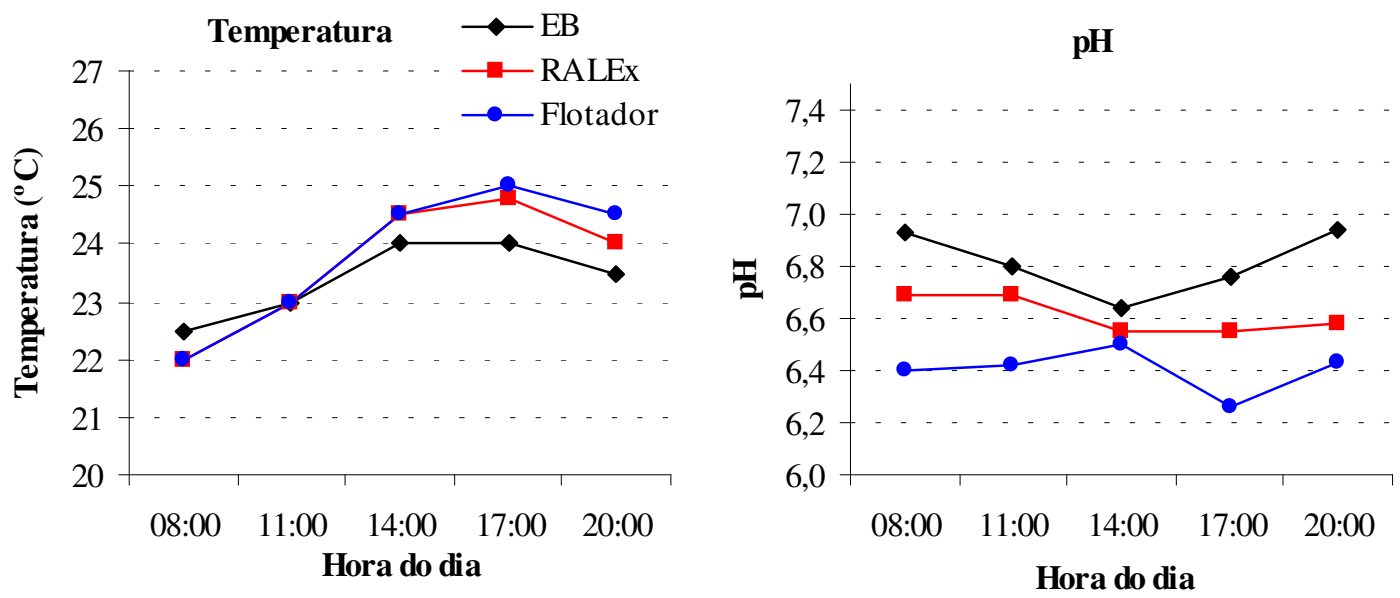

Turbidez
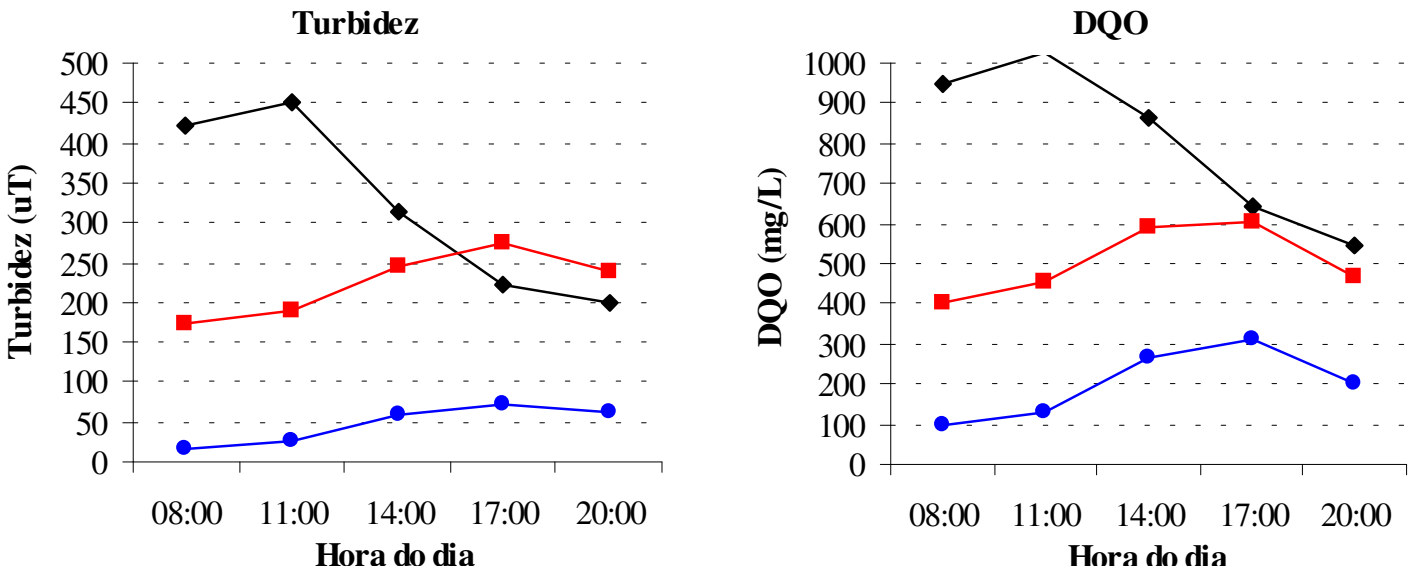

Fósforo
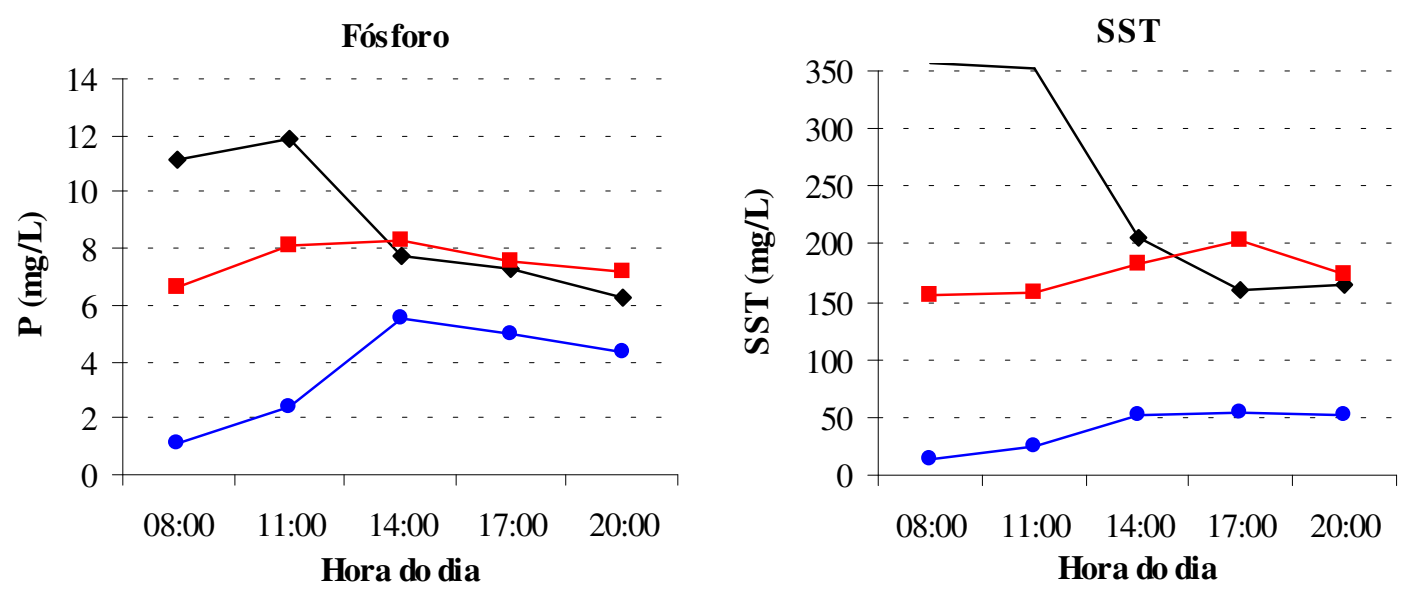

FIGURA 5.66 - Temperatura, pH, turbidez, demanda química de oxigênio, fósforo e sólidos suspensos totais das amostras de esgoto bruto, de efluente do reator RALEx e de efluente do flotador coletadas ao longo do dia de ensaio (05/08/2001).

Ensaios realizados em instalação protótipo de coagulação/floculação/flotação por ar dissolvido com escoamento contínuo e efluente do reator RALEx. Data do ensaio: $05 / 08 / 2001 ; D C F=50 \mathrm{mg} / \mathrm{L} ; \mathrm{DP}=0,40 \mathrm{mg} / \mathrm{L} ; \mathrm{Gf}=80 \mathrm{~s}^{-1} ; \mathrm{Tf}=23 \mathrm{~min}$; $\mathrm{R}=15 \%$; Psat $=450 \mathrm{kPa} ; \mathrm{S}^{*}=16,4 \mathrm{~g} / \mathrm{m}^{3} ; \mathrm{TAS}=180 \mathrm{~m}^{3} / \mathrm{m}^{2} / \mathrm{dia}$. 
A FIGURA 5.67 apresenta os valores de temperatura, de pH, de turbidez, de DQO, de fósforo e de sólidos suspensos totais do efluente do flotador em função do horário de coleta das amostras quando os seguintes parâmetros operacionais foram adotados: $\mathrm{DCF}=50$ $\mathrm{mg} / \mathrm{L}, \mathrm{DP}=0,4 \mathrm{mg} / \mathrm{L}, \mathrm{Gf}=80 \mathrm{~s}^{-1}, \mathrm{Tf}=23 \mathrm{~min}, \mathrm{R}=18 \%$, Psat $=450 \mathrm{kPa}$ e TAS $=180 \mathrm{~m}^{3} / \mathrm{m}^{2} / \mathrm{dia} . \mathrm{A}$ temperatura do esgoto bruto variou entre $22,0^{\circ} \mathrm{C}$, às $08: 00$, e $24,5^{\circ} \mathrm{C}$, às 14:00. O efluente do reator anaeróbio apresentou temperaturas entre $21,5^{\circ} \mathrm{C}$ e $24,7^{\circ} \mathrm{C}$ e o efluente do flotador entre $21,5^{\circ} \mathrm{C}$ e $25,2^{\circ} \mathrm{C} . \mathrm{O} \mathrm{pH}$ do esgoto bruto variou entre 6,5 e 6,9. O efluente do RALEx apresentou pH entre 6,5 e 6,7 enquanto o pH do efluente do flotador variou entre 6,0 e 6,6. A turbidez do esgoto bruto apresentou forte variação, com valores entre 236 e 412 uT. O efluente do reator anaeróbio sofreu moderada variação de sua turbidez entre 08:00 e 20:00, variando entre 169 e 276 uT. A turbidez do efluente do flotador elevou-se gradativamente, de 25,9 uT, às 08:00, a 98,7 uT, às 14:00. A partir das 17:00, a turbidez do efluente do flotador sofreu gradativa redução em seu valor até alcançar 2,13 uT, às 20:00. Uma das possibilidades para esta expressiva queda nos valores de turbidez seria o aumento da dosagem de cloreto férrico decorrente de descontrole da bomba dosadora. Além de ser fato raro, o descontrole da bomba dosadora foi descartado tão logo a amostra flotada foi colhida às 17:00, mediante verificação volumétrica da vazão de solução de cloreto férrico. Em outra data, 25/05/2001, essa mesma situação foi observada (FIGURA 5.35), também sem identificação de suas causas.

O esgoto bruto apresentou moderada oscilação nos valores de DQO. Neste ensaio, foram observados valores de DQO entre 604 e $991 \mathrm{mg} / \mathrm{L}$. O RALEx contribuiu reduzidamente para remoção da carga orgânica, fornecendo efluente com DQO entre 363 e $652 \mathrm{mg} / \mathrm{L}$, com remoção de carga orgânica de 36,0\% entre 08:00 e 20:00. A DQO do efluente do flotador elevou-se gradativamente, de $105 \mathrm{mg} / \mathrm{L}$, às 08:00, para $385 \mathrm{mg} / \mathrm{L}$, às 14:00. A partir das 17:00, a DQO do efluente do flotador sofreu redução em seu valor, até atingir $110 \mathrm{mg} / \mathrm{L}$, às 20:00. A remoção de carga orgânica promovida pelo flotador entre 08:00 e 20:00 foi de 66,8\%. A remoção global de carga orgânica alcançada pelo sistema RALEx-flotador foi de 78,7\%. O esgoto bruto apresentou elevada oscilação nos valores de fósforo. Neste ensaio, foram observados valores de P entre 7,0 e 12,1 mg/L. O RALEx contribuiu fortemente para equalização da concentração de fósforo no seu efluente, resultando em valores de P entre 6,4 e 8,6 mg/L. A concentração de P do efluente do flotador elevou-se gradativamente, de 2,80 mg/L, às 08:00, a 7,20 mg/L, às 14:00. A partir das 17:00, a concentração de $P$ do efluente do flotador sofreu forte redução em seu valor até alcançar 0,20 mg/L, às 20:00. A remoção de carga de fósforo promovida pelo flotador entre 08:00 e 20:00 foi de $59,6 \%$. 

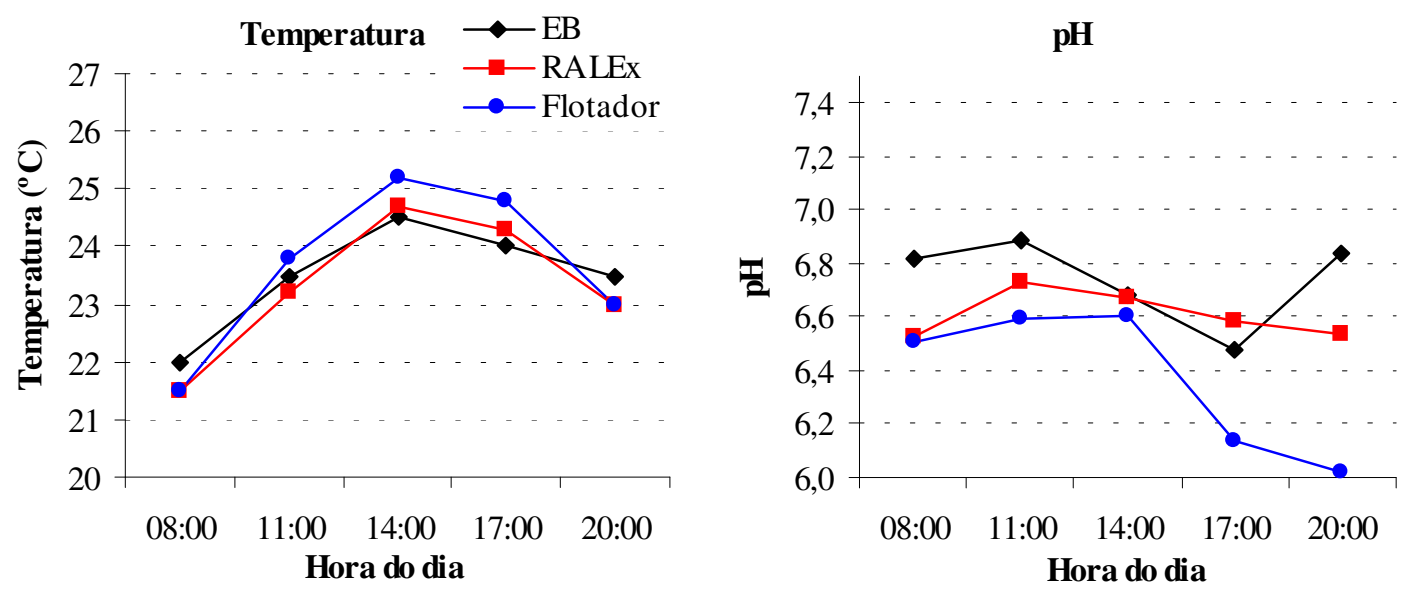

Turbidez
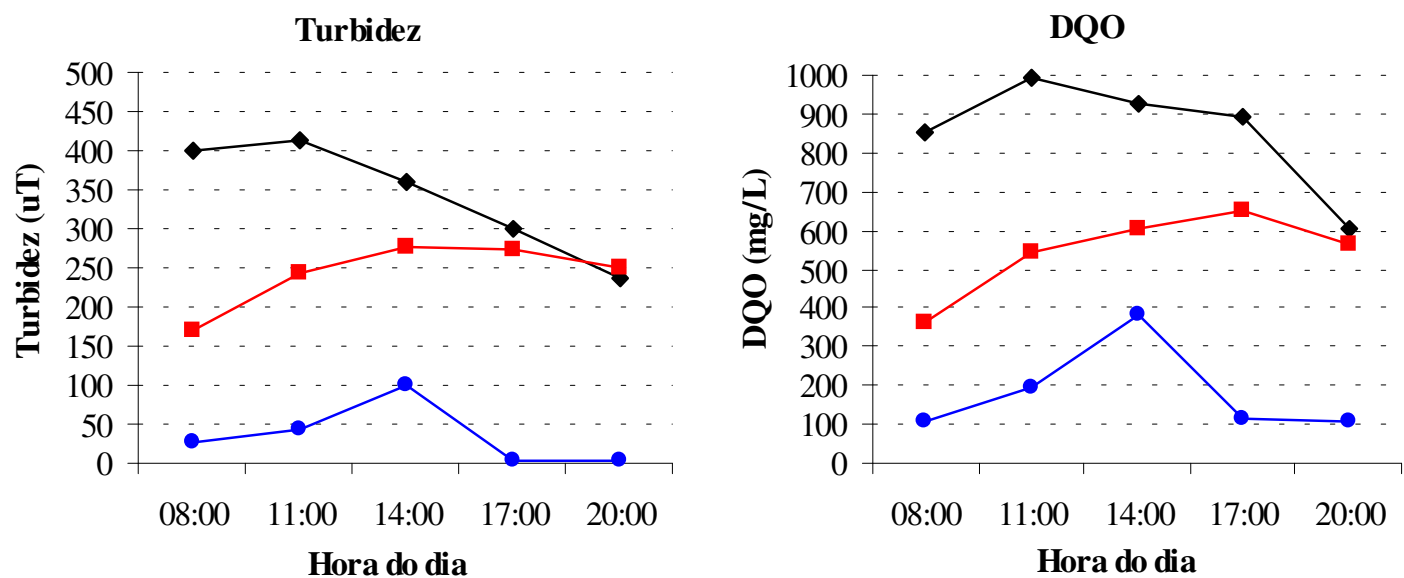

Fósforo
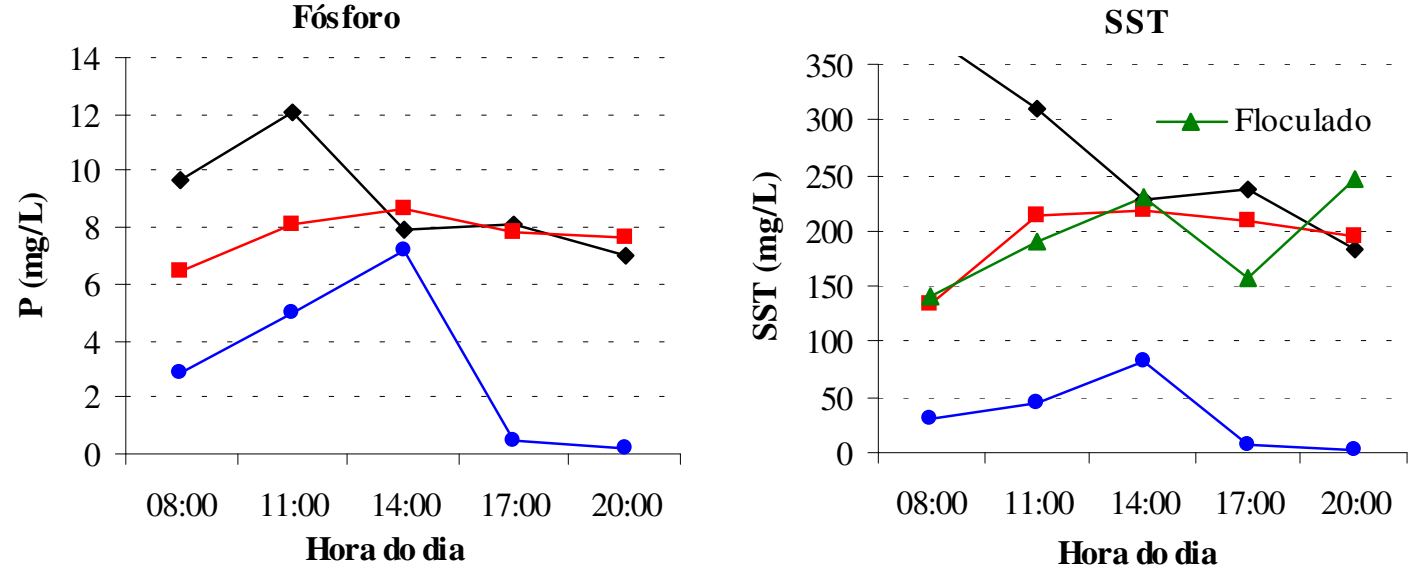

FIGURA 5.67 - Temperatura, pH, turbidez, demanda química de oxigênio, fósforo e sólidos suspensos totais das amostras de esgoto bruto, de efluente do reator RALEx e de efluente do flotador coletadas ao longo do dia de ensaio (04/08/2001).

Ensaios realizados em instalação protótipo de coagulação/floculação/flotação por ar dissolvido com escoamento contínuo e efluente do reator RALEx. Data do ensaio: 04/08/2001; $\mathrm{DCF}=50 \mathrm{mg} / \mathrm{L} ; \mathrm{DP}=0,40 \mathrm{mg} / \mathrm{L} ; \mathrm{Gf}=80 \mathrm{~s}^{-1} ; \mathrm{Tf}=23 \mathrm{~min}$; $\mathrm{R}=18 \%$; Psat $=450 \mathrm{kPa} ; \mathrm{S} *=19,7 \mathrm{~g} / \mathrm{m}^{3} ; \mathrm{TAS}=180 \mathrm{~m}^{3} / \mathrm{m}^{2} / \mathrm{dia}$. 
O esgoto bruto apresentou elevada oscilação nos valores de SST. Neste ensaio, foram observados valores de SST entre 183 e $377 \mathrm{mg} / \mathrm{L}$. O RALEx contribuiu pouco para redução da carga de sólidos suspensos, fornecendo efluente com SST entre 134 e 219 mg/L, com remoção média de carga de sólidos de 27,1\% entre 08:00 e 20:00. A concentração de SST do efluente do flotador elevou-se gradativamente, de $30 \mathrm{mg} / \mathrm{L}$, às 08:00, para $81 \mathrm{mg} / \mathrm{L}$, às 14:00. A partir das 17:00, a concentração de SST do efluente do flotador sofreu forte redução em seu valor até alcançar $3 \mathrm{mg} / \mathrm{L}$, às 20:00. A remoção de carga de SST promovida pelo flotador entre 08:00 e 20:00 foi de 82,9\%. A remoção global de sólidos suspensos alcançada pelo sistema RALEx-flotador foi de $87,6 \%$.

\subsubsection{Ensaios com a instalação protótipo de flotação operada com $T A S=250 \mathrm{~m}^{3} / \mathrm{m}^{2} / \mathrm{d}$.}

São relatados os ensaios com a instalação protótipo de flotação operada com 250 $\mathrm{m}^{3} / \mathrm{m}^{2} / \mathrm{d}$ de taxa de aplicação superficial. Nesses ensaios, foram investigados três valores de fração de recirculação (R entre 12\% e 18\% e $450 \mathrm{kPa}$ ).

\subsection{Ensaios com a instalação protótipo de flotação operada com $\mathrm{DCF}=50 \mathrm{mg} / \mathrm{L} \mathrm{e}$ R entre $12 \%$ e $18 \%$.}

São relatados os ensaios com a instalação protótipo de flotação operada com $\mathrm{DCF}=50 \mathrm{mg} / \mathrm{L}$, entre $12 \%$ e $18 \%$ de recirculação e pressão de saturação de $450 \mathrm{kPa}$. Nesses ensaios, foram utilizados um valor de Tf (23 min) e um valor de DP $(0,4 \mathrm{mg} / \mathrm{L})$.

A FIGURA 5.68 apresenta os valores de temperatura, de pH, de turbidez, de DQO, de fósforo e de sólidos suspensos totais do efluente do flotador em função do horário de coleta das amostras quando os seguintes parâmetros operacionais foram adotados: $\mathrm{DCF}=50$ $\mathrm{mg} / \mathrm{L}, \mathrm{DP}=0,4 \mathrm{mg} / \mathrm{L}, \mathrm{Gf}=80 \mathrm{~s}^{-1}, \mathrm{Tf}=23 \mathrm{~min}, \mathrm{R}=12 \%$, Psat $=450 \mathrm{kPa}$ e TAS $=250 \mathrm{~m}^{3} / \mathrm{m}^{2} / \mathrm{dia} . \mathrm{A}$ temperatura do esgoto bruto variou entre $22,5^{\circ} \mathrm{C}$, às $08: 00$, e $24,0^{\circ} \mathrm{C}$, às 14:00. O efluente do reator anaeróbio apresentou temperaturas entre $21,8^{\circ} \mathrm{C}$ e $24,2^{\circ} \mathrm{C}$ e o efluente do flotador entre $21,5^{\circ} \mathrm{C}$ e $24,0^{\circ} \mathrm{C}$. $\mathrm{O}$ pH do esgoto bruto variou entre 6,8 e 7,2. O efluente do RALEx apresentou $\mathrm{pH}$ entre 6,8 e 6,9 enquanto o $\mathrm{pH}$ do efluente do flotador variou entre 6,3 e 6,5. A turbidez do esgoto bruto apresentou moderada variação, com valores entre 225 e 390 uT. O efluente do reator anaeróbio sofreu moderada variação de sua turbidez entre 08:00 e 20:00, variando entre 112 e 190 uT. A turbidez do efluente do flotador elevou-se gradativamente, de 1,50 uT, às 08:00, a 74,1 uT, às 17:00. Às 20:00, a turbidez do efluente do flotador sofreu gradativa redução em seu valor para até alcançar 54,1 uT.

O esgoto bruto apresentou pequena oscilação nos valores de DQO. Neste ensaio, foram observados valores de DQO entre 632 e 892 mg/L. O RALEx contribuiu 
moderadamente para remoção da carga orgânica, fornecendo efluente com DQO entre 243 e $453 \mathrm{mg} / \mathrm{L}$, com remoção de carga orgânica de 49,7\% entre 08:00 e 20:00. A DQO do efluente do flotador elevou-se gradativamente, de 29,0 mg/L, às 08:00, para $201 \mathrm{mg} / \mathrm{L}$, às 17:00. Às 20:00, a DQO do efluente do flotador sofreu redução em seu valor, atingindo 156 mg/L. A remoção de carga orgânica promovida pelo flotador entre 08:00 e 20:00 foi de 68,0\%. A remoção global de carga orgânica alcançada pelo sistema RALEx-flotador foi de $83,9 \%$.

O esgoto bruto apresentou elevada oscilação nos valores de fósforo. Neste ensaio, foram observados valores de $\mathrm{P}$ entre 4,9 e $8,3 \mathrm{mg} / \mathrm{L}$. O RALEx contribuiu moderadamente para equalização da concentração de fósforo no seu efluente, resultando em valores de $\mathrm{P}$ entre 3,8 e $6,7 \mathrm{mg} / \mathrm{L}$. A concentração de $\mathrm{P}$ do efluente do flotador elevou-se gradativamente, de $0,01 \mathrm{mg} / \mathrm{L}$, às $08: 00$, a 3,40 mg/L, às 17:00. A concentração de $\mathrm{P}$ do efluente do flotador sofreu moderada redução em seu valor até alcançar 2,10 mg/L, às 20:00. A remoção de carga de fósforo promovida pelo flotador entre 08:00 e 20:00 foi de 65,1\%.

O esgoto bruto apresentou elevada oscilação nos valores de SST. Neste ensaio, foram observados valores de SST entre 160 e $290 \mathrm{mg} / \mathrm{L}$. O RALEx contribuiu moderadamente para redução da carga de sólidos suspensos, fornecendo efluente com SST entre 100 e $139 \mathrm{mg} / \mathrm{L}$, com remoção média de carga de sólidos de 49,1\% entre 08:00 e 20:00. A concentração de SST do efluente do flotador elevou-se gradativamente, de $2 \mathrm{mg} / \mathrm{L}$, às 08:00, para $56 \mathrm{mg} / \mathrm{L}$, às 17:00. A partir de então, a concentração de SST do efluente do flotador sofreu redução em seu valor até alcançar $42 \mathrm{mg} / \mathrm{L}$, às 20:00. A remoção de carga de SST promovida pelo flotador entre 08:00 e 20:00 foi de 74,3\%. A remoção global de sólidos suspensos alcançada pelo sistema RALEx-flotador foi de $86,9 \%$. 

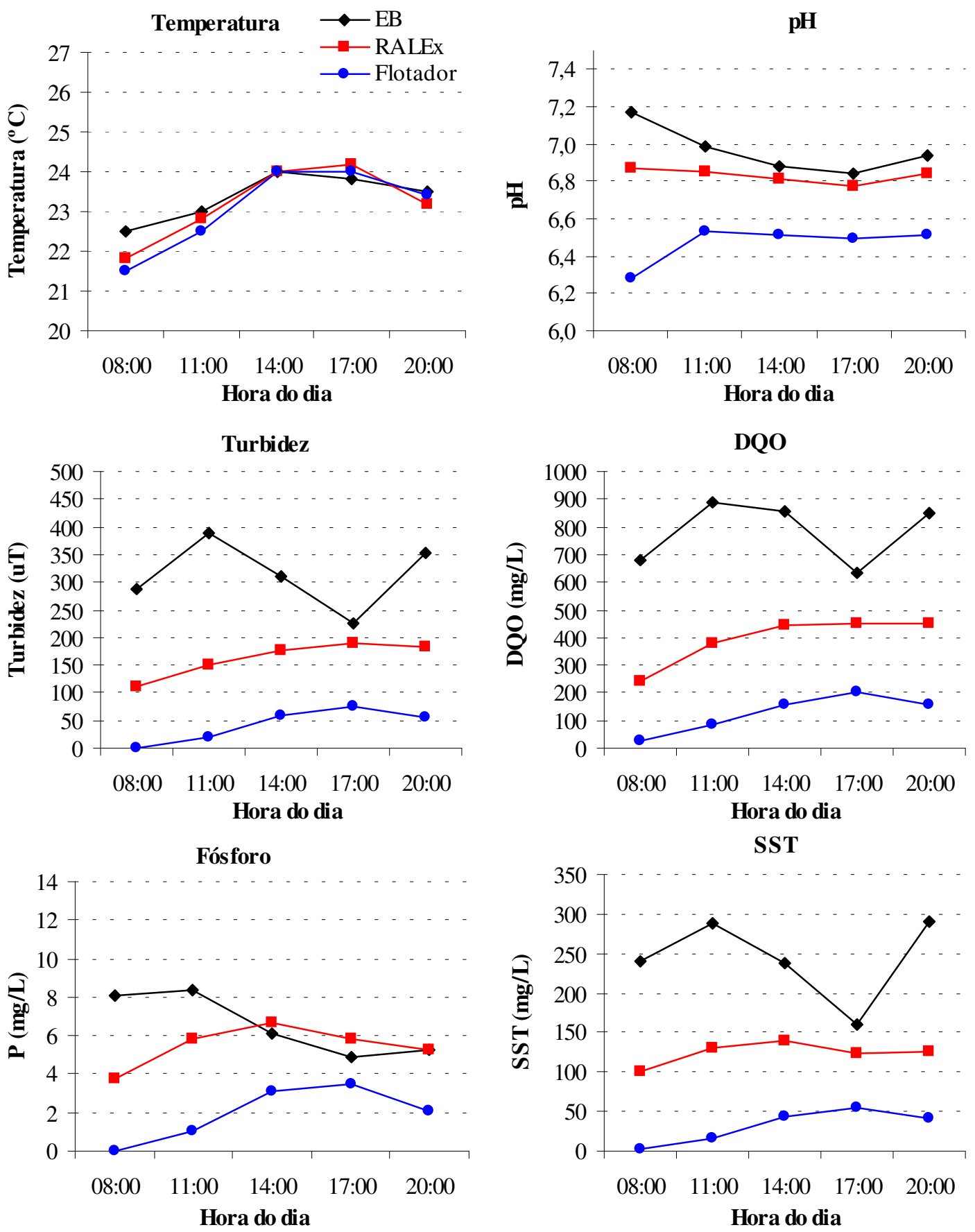

FIGURA 5.68 - Temperatura, pH, turbidez, demanda química de oxigênio, fósforo e sólidos suspensos totais das amostras de esgoto bruto, de efluente do reator RALEx e de efluente do flotador coletadas ao longo do dia de ensaio (19/09/2001). Ensaios realizados em instalação protótipo de coagulação/floculação/flotação por ar dissolvido com escoamento contínuo e efluente do reator RALEx. Data do ensaio: $19 / 09 / 2001 ; D C F=50 \mathrm{mg} / \mathrm{L} ; \mathrm{DP}=0,40 \mathrm{mg} / \mathrm{L} ; \mathrm{Gf}=80 \mathrm{~s}^{-1} ; \mathrm{Tf}=20 \mathrm{~min}$; $\mathrm{R}=12 \%$; Psat $=450 \mathrm{kPa} ; \mathrm{S}^{*}=13,1 \mathrm{~g} / \mathrm{m}^{3} ; \mathrm{TAS}=250 \mathrm{~m}^{3} / \mathrm{m}^{2} /$ dia. 
A FIGURA 5.69 apresenta os valores de temperatura, de $\mathrm{pH}$, de turbidez, de DQO, de fósforo e de sólidos suspensos totais do efluente do flotador em função do horário de coleta das amostras quando os seguintes parâmetros operacionais foram adotados: $\mathrm{DCF}=50$ $\mathrm{mg} / \mathrm{L}, \mathrm{DP}=0,4 \mathrm{mg} / \mathrm{L}, \mathrm{Gf}=80 \mathrm{~s}^{-1}, \mathrm{Tf}=23 \mathrm{~min}, \mathrm{R}=15 \%$, Psat=450 $\mathrm{kPa}$ e TAS $=250 \mathrm{~m}^{3} / \mathrm{m}^{2} / \mathrm{dia} . \mathrm{A}$ temperatura do esgoto bruto variou entre $23,8^{\circ} \mathrm{C}$, às $08: 00$, e $24,5^{\circ} \mathrm{C}$, às $14: 00$. O efluente do reator anaeróbio e o efluente do flotador apresentaram temperaturas entre $23,5^{\circ} \mathrm{C}$ e $25,0^{\circ} \mathrm{C}$. O $\mathrm{pH}$ do esgoto bruto variou entre 6,6 e 7,2. O efluente do RALEx apresentou $\mathrm{pH}$ de 6,8 enquanto o $\mathrm{pH}$ do efluente do flotador variou entre 6,3 e 6,6. A turbidez do esgoto bruto apresentou elevada variação, com valores entre 284 e 818 uT. O efluente do reator anaeróbio sofreu moderada variação de sua turbidez entre 08:00 e 20:00, variando entre 123 e 185 uT. A turbidez do efluente do flotador elevou-se gradativamente, de 2,10 uT, às 08:00, a 69,8 uT, às $18: 20$.

O esgoto bruto apresentou elevada oscilação nos valores de DQO. Neste ensaio, foram observados valores de DQO entre 703 e 1584 mg/L. O RALEx contribuiu eficientemente para remoção da carga orgânica, fornecendo efluente com DQO entre 308 e $382 \mathrm{mg} / \mathrm{L}$, com remoção de carga orgânica de 71,5\% entre 08:00 e 18:20. A DQO do efluente do flotador elevou-se gradativamente, de 47,0 mg/L, às 08:00, para $184 \mathrm{mg} / \mathrm{L}$, às 18:20. A remoção de carga orgânica promovida pelo flotador entre 08:00 e 20:00 foi de 63,2\%. A remoção global de carga orgânica alcançada pelo sistema RALEx-flotador foi de $89,5 \%$.

O esgoto bruto apresentou moderada oscilação nos valores de fósforo. Neste ensaio, foram observados valores de P entre 5,8 e 9,8 mg/L. O RALEx contribuiu moderadamente para equalização da concentração de fósforo no seu efluente, resultando em valores de $\mathrm{P}$ entre 7,0 e 8,6 mg/L. A concentração de P do efluente do flotador elevou-se gradativamente, de $0,20 \mathrm{mg} / \mathrm{L}$, às $08: 00$, a $4,40 \mathrm{mg} / \mathrm{L}$, às 14:00. A concentração de $\mathrm{P}$ do efluente do flotador sofreu moderada redução em seu valor até alcançar 4,20 mg/L, às 18:20. A remoção de carga de fósforo promovida pelo flotador entre 08:00 e 20:00 foi de 62,3\%.

O esgoto bruto apresentou elevada oscilação nos valores de SST. Neste ensaio, foram observados valores de SST entre 197 e 662 mg/L. O RALEx contribuiu eficientemente para redução da carga de sólidos suspensos, fornecendo efluente com SST entre 43 e 99 mg/L, com remoção média de carga de sólidos de 76,7\% entre 08:00 e 18:20. A concentração de SST do efluente do flotador elevou-se gradativamente, de $2 \mathrm{mg} / \mathrm{L}$, às 08:00, para $45 \mathrm{mg} / \mathrm{L}$, às 18:20. A remoção de carga de SST promovida pelo flotador entre 08:00 e 20:00 foi de $64,4 \%$. A remoção global de sólidos suspensos alcançada pelo sistema RALExflotador foi de $91,7 \%$. 

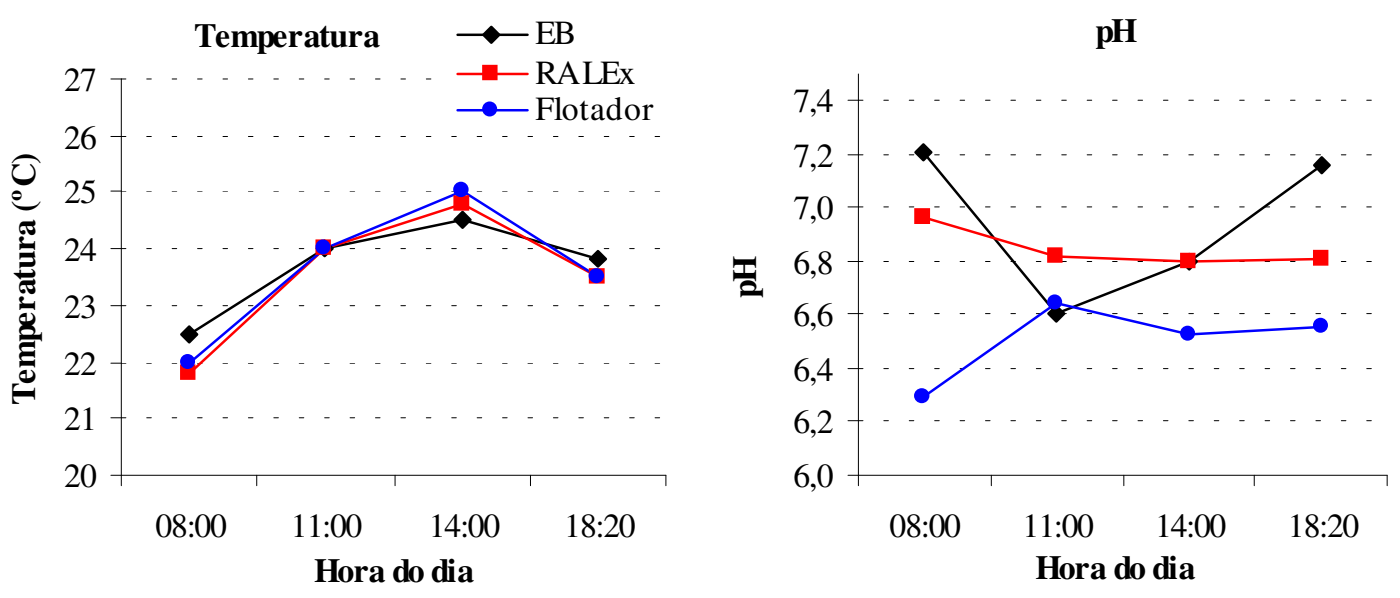

Turbidez
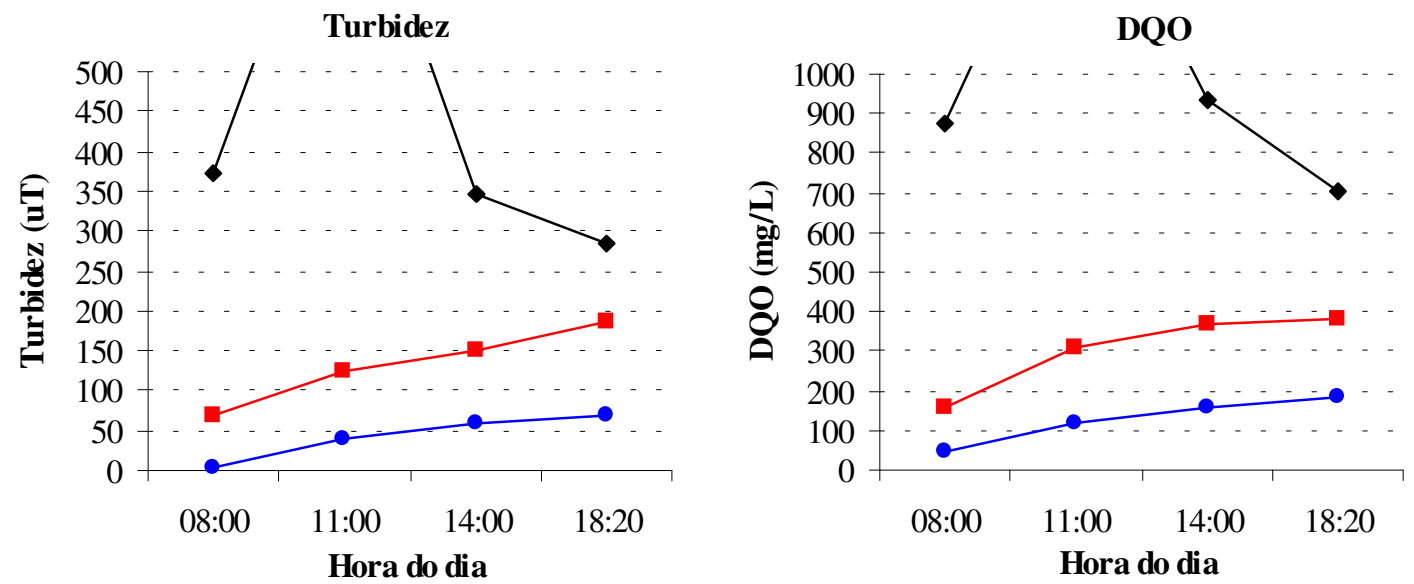

Fósforo
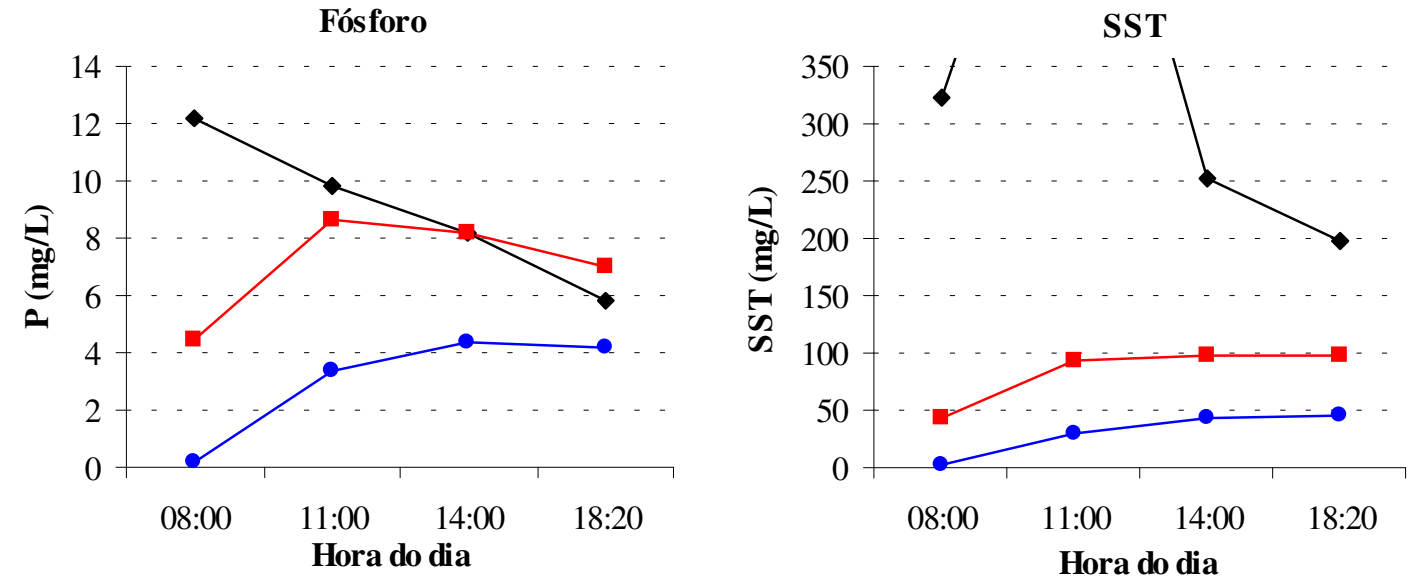

FIGURA 5.69 - Temperatura, $\mathrm{pH}$, turbidez, demanda química de oxigênio, fósforo e sólidos suspensos totais das amostras de esgoto bruto, de efluente do reator RALEx e de efluente do flotador coletadas ao longo do dia de ensaio (22/08/2001).

Ensaios realizados em instalação protótipo de coagulação/floculação/flotação por ar dissolvido com escoamento contínuo e efluente do reator RALEx. Data do ensaio: 22/08/2001; DCF=50 mg/L; DP=0,40 mg/L; Gf=80 s ${ }^{-1} ; \mathrm{Tf}=20 \mathrm{~min}$; $\mathrm{R}=15 \%$; Psat $=450 \mathrm{kPa} ; \mathrm{S}^{*}=16,4 \mathrm{~g} / \mathrm{m}^{3} ; \mathrm{TAS}=250 \mathrm{~m}^{3} / \mathrm{m}^{2} / \mathrm{dia}$. 
A FIGURA 5.70 apresenta os valores de temperatura, de $\mathrm{pH}$, de turbidez, de DQO, de fósforo e de sólidos suspensos totais do efluente do flotador em função do horário de coleta das amostras quando os seguintes parâmetros operacionais foram adotados: $\mathrm{DCF}=50$ $\mathrm{mg} / \mathrm{L}, \mathrm{DP}=0,4 \mathrm{mg} / \mathrm{L}, \mathrm{Gf}=80 \mathrm{~s}^{-1}, \mathrm{Tf}=23 \mathrm{~min}, \mathrm{R}=18 \%$, Psat=450 $\mathrm{kPa}$ e TAS=250 $\mathrm{m}^{3} / \mathrm{m}^{2} / \mathrm{dia} . \mathrm{A}$ temperatura do esgoto bruto variou entre $22,0^{\circ} \mathrm{C}$, às $08: 00$, e $24,5^{\circ} \mathrm{C}$, às 14:00. O efluente do reator anaeróbio apresentou temperaturas entre $21,0^{\circ} \mathrm{C}$ e $25,0^{\circ} \mathrm{C}$ e o efluente do flotador entre $21,5^{\circ} \mathrm{C}$ e $25,0^{\circ} \mathrm{C} . \mathrm{O} \mathrm{pH}$ do esgoto bruto variou entre 6,8 e 7,2. O efluente do RALEx apresentou $\mathrm{pH}$ entre 6,8 e 6,9 enquanto o $\mathrm{pH}$ do efluente do flotador variou entre 6,3 e 6,6. A turbidez do esgoto bruto apresentou moderada variação, com valores entre 246 e 351 uT. O efluente do reator anaeróbio sofreu elevada variação de sua turbidez entre 08:00 e 20:00, variando entre 44,2 e 174 uT. A turbidez do efluente do flotador elevou-se gradativamente, de 3,72 uT, às 08:00, a 74,6 uT, às 20:00.

O esgoto bruto apresentou pequena oscilação nos valores de DQO. Neste ensaio, foram observados valores de DQO entre 503 e $894 \mathrm{mg} / \mathrm{L}$. O RALEx contribuiu eficientemente para remoção da carga orgânica, fornecendo efluente com DQO entre 126 e $346 \mathrm{mg} / \mathrm{L}$, com remoção de carga orgânica de 62,0\% entre 08:00 e 20:00. A DQO do efluente do flotador elevou-se gradativamente, de 43,0 mg/L, às 08:00, para $171 \mathrm{mg} / \mathrm{L}$, às 14:00. A partir de então, a DQO do efluente do flotador manteve-se estável em seu valor, até 20:00. A remoção de carga orgânica promovida pelo flotador entre 08:00 e 20:00 foi de 51,9\%. A remoção global de carga orgânica alcançada pelo sistema RALEx-flotador foi de $81,7 \%$.

O esgoto bruto apresentou elevada oscilação nos valores de fósforo. Neste ensaio, foram observados valores de $\mathrm{P}$ entre 6,8 e $13,1 \mathrm{mg} / \mathrm{L}$. O RALEx contribuiu reduzidamente para equalização da concentração de fósforo no seu efluente, resultando em valores de $\mathrm{P}$ entre 5,5 e 9,0 mg/L. A concentração de $\mathrm{P}$ do efluente do flotador manteve-se estável, em torno de 3,90 e 4,70 mg/L, ao longo do dia. A remoção de carga de fósforo promovida pelo flotador entre 08:00 e 20:00 foi de 44,5\%.

O esgoto bruto apresentou elevada variação nos valores de SST. Neste ensaio, foram observados valores de SST entre 180 e $313 \mathrm{mg} / \mathrm{L}$. O RALEx contribuiu eficientemente para redução da carga de sólidos suspensos, fornecendo efluente com SST entre 33 e 79 mg/L, com remoção média de carga de sólidos de 73,8\% entre 08:00 e 20:00. A concentração de SST do efluente do flotador elevou-se gradativamente, de $4 \mathrm{mg} / \mathrm{L}$, às 08:00, para $49 \mathrm{mg} / \mathrm{L}$, às 14:00. A partir de então, a concentração de SST do efluente do flotador manteve-se estável neste valor, até 20:00. A remoção de carga de SST promovida pelo flotador entre 08:00 e 
20:00 foi de 37,1\%. A remoção global de sólidos suspensos alcançada pelo sistema RALExflotador foi de $83,5 \%$.
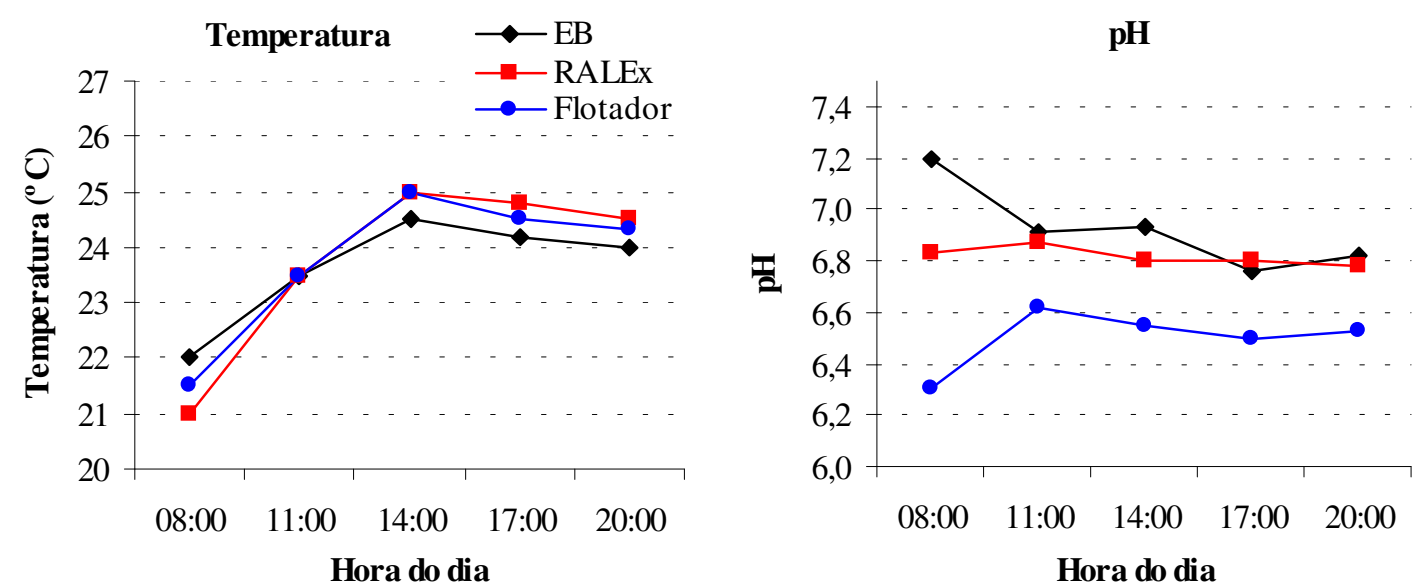

Turbidez
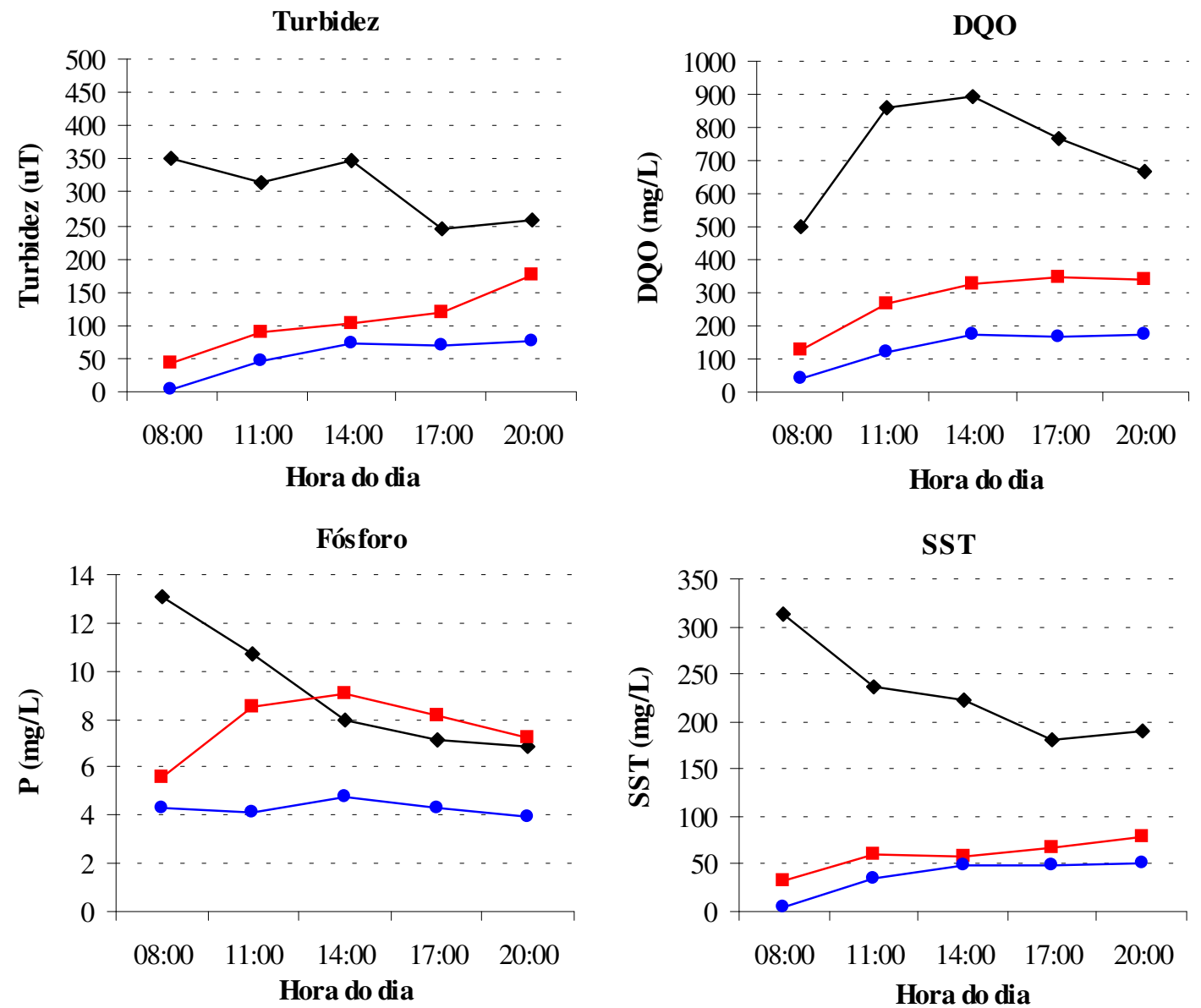

FIGURA 5.70 - Temperatura, pH, turbidez, demanda química de oxigênio, fósforo e sólidos suspensos totais das amostras de esgoto bruto, de efluente do reator RALEx e de efluente do flotador coletadas ao longo do dia de ensaio (21/08/2001). Ensaios realizados em instalação protótipo de coagulação/floculação/flotação por ar dissolvido com escoamento contínuo e efluente do reator RALEx. Data do ensaio: 21/08/2001; DCF=50 mg/L; DP=0,40 mg/L; Gf=80 $\mathrm{s}^{-1} ; \mathrm{Tf}=20 \mathrm{~min}$; $\mathrm{R}=18 \%$; Psat $=450 \mathrm{kPa} ; \mathrm{S}^{*}=17,8 \mathrm{~g} / \mathrm{m}^{3} ; \mathrm{TAS}=250 \mathrm{~m}^{3} / \mathrm{m}^{2} / \mathrm{dia}$. 
O sistema de flotação após o reator RALEx, quando operado em condições adequadas de coagulação/floculação, continuou apresentando operação fácil, comportamento estável e bom desempenho devido às características de boa "flotabilidade" dos flocos formados a partir da coagulação química do efluente do reator RALEx com cloreto férrico associado a polímero catiônico, mesmo para taxas de aplicação superficial elevadas, em torno de $250 \mathrm{~m}^{3} / \mathrm{m}^{2} / \mathrm{d}$.

Quando da variação da quantidade de ar fornecida ao processo, no período de ensaios com emprego de $50 \mathrm{mgFeCl} / \mathrm{L}, 0,4 \mathrm{mg} / \mathrm{L}$ de polímero catiônico, $23 \mathrm{~min}$ de floculação, $180 \mathrm{~m}^{3} / \mathrm{m}^{2} / \mathrm{d}$ e variação entre $12 \%$ e $18 \%$ da fração de recirculação de efluente final pressurizado (R), a qualidade do efluente do RALEx estava muito deteriorada, com DQO oscilando entre 600 e $675 \mathrm{mg} / \mathrm{L}$ entre 14:00 e 17:00! Mesmo fora desse horário, a DQO não foi inferior a $380 \mathrm{mg} / \mathrm{L}$ ! Em termos de presença de matéria orgânica, o efluente do RALEx assemelhava-se ao esgoto sanitário comumente encontrado. Diante desta situação, a eficiência de remoção de carga orgânica e de sólidos suspensos do reator RALEx ficou estável, entre $36,0 \%$ e $39,8 \%$ e entre $27,1 \%$ e $33,5 \%$, respectivamente, ainda que sejam valores muito abaixo do desejado e esperado.O progressivo aumento dos valores de $\mathrm{R}(12 \%$, $15 \%$ e $18 \%$ ) resultou em elevação da remoção de carga orgânica $(49,3 \%, 60,4 \%$ e 66,8\%), da carga de fósforo $(29,0 \%, 51,9 \%$ e $59,6 \%)$ e da carga de sólidos $(77,0 \%, 84,2 \%$ e $87,6 \%)$, conforme TABELA 5.11. Em função da péssima qualidade do efluente do RALEx e da dosagem incompatível com os níveis de presença de matéria orgânica, a DQO do efluente do flotador sempre esteve acima de $100 \mathrm{mg} / \mathrm{L}$, atingindo até cerca de $400 \mathrm{mg} / \mathrm{L}$ entre 14:00 e $17: 00$ !

No período de ensaios com emprego de $50 \mathrm{mgFeCl}_{3} / \mathrm{L}, 0,4 \mathrm{mg} / \mathrm{L}$ de polímero catiônico, $23 \mathrm{~min}$ de floculação, $250 \mathrm{~m}^{3} / \mathrm{m}^{2} / \mathrm{d}$ e variação entre $12 \%$ e $18 \%$ da fração de recirculação de efluente final pressurizado (R), a qualidade do efluente do RALEx havia melhorado, com valores de DQO entre 350 e $450 \mathrm{mg} / \mathrm{L}$ entre 14:00 e 17:00, porém ainda estava relativamente deteriorado. A eficiência de remoção de carga orgânica e de sólidos suspensos do reator RALEx ficou muito instável, variando entre 49,7\% e 71,5\% e entre $49,1 \%$ e $76,7 \%$, respectivamente, apresentando alternadamente desempenhos satisfatórios e ruins, em se tratando de reator anaeróbio. Diferentemente de quando foi adotado TAS $=180$ $\mathrm{m}^{3} / \mathrm{m}^{2} / \mathrm{d}$, o progressivo aumento dos valores de $\mathrm{R}(12 \%, 15 \%$ e $18 \%)$ resultou em redução da remoção de carga orgânica $(68,0 \%, 63,2 \%$ e 51,9\%), da carga de fósforo $(65,1 \%, 62,3 \%$ e $44,5 \%)$ e da carga de sólidos $(74,3 \%, 64,4 \%$ e 37,1\%), conforme TABELA 5.11. Entretanto, observando as FIGURAS 5.60 a 5.62, verifica-se que a qualidade das amostras coletadas ao longo do dia, e mais especificamente, à tarde, são bastante similares entre si, com valores de DQO em torno de $170 \mathrm{mg} / \mathrm{L}$, de $4 \mathrm{mgP} / \mathrm{L}$ e de $45 \mathrm{mgSST} / \mathrm{L}$. 
TABELA 5.11 - Valores de turbidez média e de carga de DQO, de fósforo e de SST para as amostras de esgoto bruto, de efluente do RALEx e de efluente do flotador, entre 08:00 e 20:00, e respectivas remoções observadas no reator RALEx, no flotador e no sistema conjugado, de acordo com a etapas 5.6.2.1.2 e 5.6.3.1.1.

\begin{tabular}{|c|c|c|c|c|c|c|c|}
\hline & & \multicolumn{6}{|c|}{$\mathrm{DCF}=50 \mathrm{mg} / \mathrm{L} ; \mathrm{DP}=0,4 \mathrm{mg} / \mathrm{L} ; \mathrm{Gf}=80 \mathrm{~s}^{-1} ; \mathrm{Tf}=23 \mathrm{~min}$} \\
\hline & & \multicolumn{3}{|c|}{ TAS $=180 \mathrm{~m}^{3} / \mathrm{m}^{2} / \mathrm{d}$} & \multicolumn{3}{|c|}{ TAS $=250 \mathrm{~m}^{3} / \mathrm{m}^{2} / \mathrm{d}$} \\
\hline & & $\mathbf{R}=\mathbf{1 2 \%}$ & $\mathbf{R}=\mathbf{1 5 \%}$ & $\mathrm{R}=18 \%$ & $R=12 \%$ & $\mathrm{R}=\mathbf{1 5 \%}$ & $R=18 \%$ \\
\hline \multirow{4}{*}{ 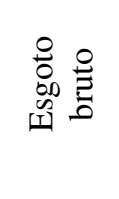 } & Turbidez média (uT) & 344 & 321 & 342 & 313 & 567 & 304 \\
\hline & DQO $(\mathrm{kg} / 12 \mathrm{~h})$ & 65,3 & 60,1 & 63,8 & 78,8 & 121,2 & 74,5 \\
\hline & $\mathrm{P}(\mathrm{kg} / 12 \mathrm{~h})$ & 0,71 & 0,66 & 0,67 & 0,66 & 0,84 & 0,92 \\
\hline & SST $(\mathrm{kg} / 12 \mathrm{~h})$ & 18,8 & 18,5 & 20,0 & 24,5 & 36,1 & 23,0 \\
\hline \multirow{4}{*}{ 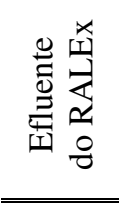 } & Turbidez média (uT) & 241 & 225 & 242 & 162 & 145 & 105 \\
\hline & $\mathrm{DQO}(\mathrm{kg} / 12 \mathrm{~h})$ & 39,3 & 37,8 & 40,9 & 39,7 & 34,5 & 28,3 \\
\hline & $\mathrm{P}(\mathrm{kg} / 12 \mathrm{~h})$ & 0,62 & 0,57 & 0,58 & 0,55 & 0,82 & 0,77 \\
\hline & SST $(\mathrm{kg} / 12 \mathrm{~h})$ & 12,5 & 13,0 & 14,5 & 12,5 & 8,4 & 6,0 \\
\hline \multirow{4}{*}{ 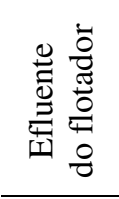 } & Turbidez média (uT) & 84,3 & 47,2 & 35,2 & 41,4 & 42,8 & 52,9 \\
\hline & DQO $(\mathrm{kg} / 12 \mathrm{~h})$ & 19,9 & 14,9 & 13,6 & 12,7 & 12,7 & 13,6 \\
\hline & $\mathrm{P}(\mathrm{kg} / 12 \mathrm{~h})$ & 0,44 & 0,27 & 0,23 & 0,19 & 0,31 & 0,43 \\
\hline & $\operatorname{SST}(\mathrm{kg} / 12 \mathrm{~h})$ & 4,3 & 2,9 & 2,5 & 3,2 & 3,0 & 3,8 \\
\hline \multirow{3}{*}{ 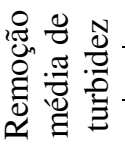 } & RALEx $(\%)$ & 30,1 & 30,1 & 29,2 & 48,3 & 74,4 & 65,3 \\
\hline & FAD $(\%)$ & 65,0 & 79,0 & 85,5 & 74,4 & 70,5 & 49,8 \\
\hline & Sistema (\%) & 75,5 & 85,3 & 89,7 & 86,8 & 92,5 & 82,6 \\
\hline \multirow{3}{*}{ 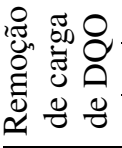 } & RALEx (\%) & 39,8 & 37,2 & 36,0 & 49,7 & 71,5 & 62,0 \\
\hline & FAD $(\%)$ & 49,3 & 60,4 & 66,8 & 68,0 & 63,2 & 51,9 \\
\hline & Sistema $(\%)$ & 69,5 & 75,1 & 78,7 & 83,9 & 89,5 & 81,7 \\
\hline \multirow{3}{*}{ 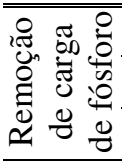 } & RALEx $(\%)$ & 11,7 & 14,5 & 13,8 & 15,6 & 3,3 & 16,0 \\
\hline & FAD $(\%)$ & 29,0 & 51,9 & 59,6 & 65,1 & 62,3 & 44,5 \\
\hline & Sistema (\%) & 37,3 & 58,8 & 65,2 & 70,5 & 63,6 & 53,4 \\
\hline \multirow{3}{*}{ 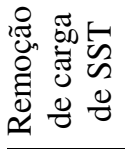 } & RALEx (\%) & 33,5 & 29,7 & 27,1 & 49,1 & 76,7 & 73,8 \\
\hline & $\operatorname{FAD}(\%)$ & 65,4 & 77,5 & 82,9 & 74,3 & 64,4 & 37,1 \\
\hline & Sistema (\%) & 77,0 & 84,2 & 87,6 & 86,9 & 91,7 & 83,5 \\
\hline
\end{tabular}

Durante o ensaio com TAS $=180 \mathrm{~m}^{3} / \mathrm{m}^{2} / \mathrm{d}$ e $\mathrm{R}=18 \%$, a vazão média pós-tratada por flotação foi de $6,229 \mathrm{~m}^{3} / \mathrm{h}$. Considerando esta vazão e as dosagens de cloreto férrico utilizadas ao longo das 12 horas, tem-se que a carga de cloreto férrico empregada foi de 3,74 $\mathrm{kg}$ e a carga de polímero foi de 29,9 g. Através da subtração dos valores de SST do efluente do flotador dos valores do efluente floculado (FIGURA 5.67) e considerando vazão de 6,229 $\mathrm{m}^{3} / \mathrm{h}$ e 12 horas de ensaio, obtém-se valor de 11,92 $\mathrm{kgSST}$, peso seco estimado de lodo flotado, equivalente à remoção horária média de $0,99 \mathrm{kgSST}$, ou seja, $159 \mathrm{~g}$ de lodo por $\mathrm{m}^{3}$ de esgoto tratado no flotador. A população atendida, correspondente a $6,229 \mathrm{~m}^{3} / \mathrm{h}$, foi de 750 pessoas. Desta forma, a produção per capita de lodo foi de 31,8 gSST/pessoa/dia. 
$\mathrm{Na}$ etapa 5.6.1.2, foi realizado ensaio com $\mathrm{DCF}=50 \mathrm{mg} / \mathrm{L}$ em TAS $=250 \mathrm{~m}^{3} / \mathrm{m}^{2} / \mathrm{d}$, na data de 30/06/01. Na etapa 5.6.3.1.1, foi realizado ensaio com $\mathrm{DCF}=50 \mathrm{mg} / \mathrm{L}$ e $\mathrm{DP}=0,4$ $\mathrm{mg} / \mathrm{L}$ em TAS $=250 \mathrm{~m}^{3} / \mathrm{m}^{2} / \mathrm{d}$, na data de 21/08/01. A comparação entre os dois ensaios permitiria verificar se a adição de polímero oferece ao sistema de flotação maior desempenho em taxas mais elevadas. Entretanto, embora as características do esgoto bruto durante os referidos ensaios sejam semelhantes, a qualidade dos efluentes do RALEx nos ensaios foi significativamente diferente, em função da variação de desempenho do reator anaeróbio, decorrente do advento dos meses mais frios (TABELA 5.12).

TABELA 5.12 - Valores de turbidez média e de carga de DQO, de fósforo e de SST para as amostras de esgoto bruto, de efluente do RALEx e de efluente do flotador, entre 08:00 e 20:00, e respectivas remoções observadas no reator RALEx, no flotador e no sistema conjugado, para $\mathrm{DCF}=50 \mathrm{mg} / \mathrm{L}$ e $\mathrm{TAS}=250$ $\mathrm{m}^{3} / \mathrm{m}^{2} / \mathrm{d}$, de acordo com as etapas 5.6.1.2 e 5.6.3.1.1.

\begin{tabular}{|c|c|c|c|}
\hline & \multicolumn{2}{|c|}{ DCF $=50 \mathrm{mg} / \mathrm{L} ;$ Gf $=80 \mathrm{~s}^{-1} ; \mathrm{S}^{*}=19,7 \mathrm{~g} / \mathrm{m}^{3}, \mathrm{TAS}=250 \mathrm{~m}^{3} / \mathrm{m}^{2} / \mathrm{c}$} \\
\hline & & $\mathrm{DP}=0,4 \mathrm{mg} / \mathrm{L}$ & $\mathrm{DP}=\mathbf{0 , 0} \mathrm{mg} / \mathrm{L}$ \\
\hline \multirow{4}{*}{ 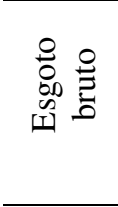 } & Turbidez média (uT) & 304 & 277 \\
\hline & $\mathrm{DQO}(\mathrm{kg} / 12 \mathrm{~h})$ & 74,5 & 78,3 \\
\hline & $\mathrm{P}(\mathrm{kg} / 12 \mathrm{~h})$ & 0,92 & 0,95 \\
\hline & $\mathrm{SST}(\mathrm{kg} / 12 \mathrm{~h})$ & 23,0 & 22,5 \\
\hline \multirow{4}{*}{ 莺离 } & Turbidez média (uT) & 105 & 219 \\
\hline & DQO $(\mathrm{kg} / 12 \mathrm{~h})$ & 28,3 & 44,2 \\
\hline & $\mathrm{P}(\mathrm{kg} / 12 \mathrm{~h})$ & 0,77 & 0,72 \\
\hline & $\mathrm{SST}(\mathrm{kg} / 12 \mathrm{~h})$ & 6,0 & 16,3 \\
\hline \multirow{4}{*}{ 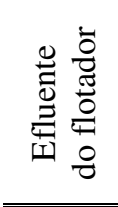 } & Turbidez média (uT) & 52,9 & 83,5 \\
\hline & $\mathrm{DQO}(\mathrm{kg} / 12 \mathrm{~h})$ & 13,6 & 18,6 \\
\hline & $\mathrm{P}(\mathrm{kg} / 12 \mathrm{~h})$ & 0,43 & 0,56 \\
\hline & SST $(\mathrm{kg} / 12 \mathrm{~h})$ & 3,8 & 6,0 \\
\hline \multirow{3}{*}{ 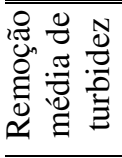 } & RALEx $(\%)$ & 65,3 & 21,1 \\
\hline & FAD (\%) & 49,8 & 61,8 \\
\hline & Sistema $(\%)$ & 82,6 & 69,9 \\
\hline \multirow{3}{*}{ 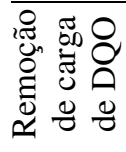 } & RALEx (\%) & 62,0 & 43,6 \\
\hline & FAD (\%) & 51,9 & 57,9 \\
\hline & Sistema (\%) & 81,7 & 76,2 \\
\hline \multirow{3}{*}{ 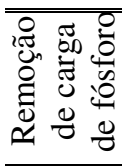 } & RALEx $(\%)$ & 16,0 & 24,7 \\
\hline & FAD (\%) & 44,5 & 22,7 \\
\hline & Sistema $(\%)$ & 53,4 & 41,8 \\
\hline \multirow{3}{*}{ 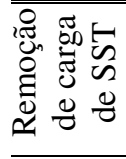 } & RALEx $(\%)$ & 73,8 & 27,4 \\
\hline & FAD $(\%)$ & 37,1 & 63,3 \\
\hline & Sistema $(\%)$ & 83,5 & 73,3 \\
\hline \multirow{4}{*}{ 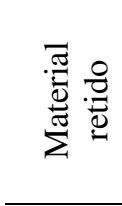 } & Turbidez média (uT) & 52,1 & 135,5 \\
\hline & $\mathrm{DQO}(\mathrm{kg} / 12 \mathrm{~h})$ & 14,7 & 25,6 \\
\hline & $\mathrm{P}(\mathrm{kg} / 12 \mathrm{~h})$ & 0,34 & 0,16 \\
\hline & $\mathrm{SST}(\mathrm{kg} / 12 \mathrm{~h})$ & 2,2 & 10,3 \\
\hline
\end{tabular}


Quando o polímero foi adicionado, a qualidade do efluente final mostrou-se melhor do que quando o cloreto férrico foi utilizado isoladamente, embora este fato possa ser conseqüência da melhor qualidade do efluente do RALEx durante o ensaio com adição de polímero. A diferença significativa de qualidade entre os efluentes do reator anaeróbio e o reduzido número de ensaios não permitiram comparação relevante entre as duas situações. 


\section{CONSIDERAÇões FINAIS ACERCA DA UTILIZAÇÃo dA FLOTAÇÃo POR AR DISSOLVIDO COMO PÓS-TRATAMENTO DE REATOR RALEX}

Com base nos resultados obtidos durante a realização dos ensaios em escala de laboratório do presente trabalho, discutidos no capítulo anterior, consideram-se pertinentes as seguintes observações:

- Para gradiente médio de $600 \mathrm{~s}^{-1}$ e $30 \mathrm{~s}$ de mistura rápida, tempo de floculação de 20 min, gradiente médio de velocidade de floculação de $60 \mathrm{~s}^{-1}$, quantidade de ar fornecida de 19 $\mathrm{g} / \mathrm{m}^{3}$ de efluente, velocidade de flotação de $10 \mathrm{~cm} / \mathrm{min}$ e utilizando amostra do reator RALEx coletada às 08:00, a aplicação de 4,0 mg/L de polímero resultou em diferentes remoções de carga orgânica e de turbidez:

* O uso dos polímeros G992, G9046, G9047, G9048 resultou nos melhores resultados, proporcionando eficiências de remoção de turbidez muito próximas e praticamente constantes para as diferentes velocidades de flotação, na faixa entre $85 \%$ e $87 \%$ para velocidade de flotação de $10 \mathrm{~cm} / \mathrm{min}$ e entre $81 \%$ e $83 \%$ para velocidade de flotação de $25 \mathrm{~cm} / \mathrm{min}$;

* o uso dos polímeros G992, G9046, G9047 e G9048, todos catiônicos e com alto peso molecular, foram aqueles que apresentaram as melhores eficiências de remoção de $\mathrm{DQO}_{\text {bruta, }}$ variando entre $60 \%$ e $74 \%$, e com os menores residuais, entre 35 e 54 $\mathrm{mgO}_{2} / \mathrm{L}$

* o uso dos demais polímeros resultou em remoção de $\mathrm{DQO}_{\text {bruta }}$ entre $28 \%$ e $41 \%$;

* quanto à remoção de DQO $_{\text {filtr, }}$ novamente os polímeros G992, G9046, G9047 e G9048 apresentaram os melhores desempenhos, com eficiência variando de 12\% a $45 \%$, com residuais menores de $28 \mathrm{mgO}_{2} / \mathrm{L}$. É plausível afirmar que a parcela de DQO $_{\text {filtr }}$ removida pelos polímeros era constituída por sólidos coloidais e não dissolvidos e

* o uso de polímero proporcionou à flotação bom desempenho durante operação em elevadas taxas de aplicação superficial. 
$\Rightarrow \mathrm{O}$ uso de polímero isoladamente na floculação dos efluentes de reator anaeróbio constitui-se de alternativa viável para redução do volume de lodo gerado. Entretanto, para maximizar a atuação do polímero, o reator anaeróbio deve ser capaz de produzir efluentes com reduzida presença de DQO em amostra filtrada em membranas com $\phi<1,2 \mu \mathrm{m}$. Quanto maior a presença de matéria orgânica na forma particulada, maior a qualidade dos flocos gerados pelos polímeros, facilitando sua remoção pela flotação.

- Para gradiente médio de $800 \mathrm{~s}^{-1}$ e $30 \mathrm{~s}$ de mistura rápida, tempo de floculação de 20 min, gradiente médio de velocidade de floculação de $60 \mathrm{~s}^{-1}$, quantidade de ar fornecida de $19 \mathrm{~g} / \mathrm{m}^{3}$ de efluente, velocidade de flotação de $10 \mathrm{~cm} / \mathrm{min}$ e utilizando amostra do reator RALEx coletada às $08: 00$, a aplicação de até $30 \mathrm{mgFeCl}_{3} / \mathrm{L}$ associada a dosagens de até 1,0 mg/L de polímero resultou em diferentes remoções de carga orgânica, de fosfato total e de turbidez:

* O uso de $0,4 \mathrm{mg} / \mathrm{L}$ de polímero $\mathrm{G} 9047$ associado a $15 \mathrm{mgFeCl}_{3} / \mathrm{L}$ resultou em valores de DQO na amostra flotada abaixo de $25 \mathrm{mg} / \mathrm{L}$ em médias e altas velocidades de flotação;

* para dosagens de $30 \mathrm{mgFeCl}_{3} / \mathrm{L}$, o uso de $0,4 \mathrm{mg} / \mathrm{L}$ de polímero $\mathrm{G} 9047$ resultou em $96 \%$ de remoção de turbidez, para $25 \mathrm{~cm} / \mathrm{min}$ de velocidade de flotação, e amostra flotada com concentração de fosfato total entre 0,72 e $0,77 \mathrm{mg} / \mathrm{L}$ em médias e altas velocidades de flotação;

* para dosagens de $30 \mathrm{mgFeCl}_{3} / \mathrm{L}$, o uso de $1,0 \mathrm{mg} / \mathrm{L}$ de polímero $\mathrm{G} 9047$ resultou em 98\% de remoção de turbidez, para $25 \mathrm{~cm} / \mathrm{min}$ de velocidade de flotação, e amostra flotada com concentração de fosfato total entre 0,44 e $0,59 \mathrm{mg} / \mathrm{L}$ em médias e altas velocidades de flotação;

* na maior parte dos ensaios, o emprego de polímeros aniônicos e não-iônicos resultou em eficiências de remoção inferiores àquelas observadas para o polímero G9047;

* somente em alguns casos isolados, os resultados observados nos ensaios com os polímeros aniônicos e não-iônicos foram semelhantes àqueles observados com o uso do polímero G9047 e

* vale lembrar que tais remoções observadas na flotação, com uso de baixas dosagens de cloreto férrico, foram possíveis pois o reator anaeróbio apresentava desempenho satisfatório no mês de fevereiro de 2000, data dos referidos ensaios. 
$\Rightarrow$ A adição conjunta de cloreto férrico e de polímero para coagulação/floculação/ flotação dos efluentes de reator RALEx trouxe vantagem adicional ao sistema, mediante elevação da remoção de fósforo, quando comparado ao uso isolado de polímero. Muito embora o uso de baixas dosagens de cloreto férrico $(\leq 30 \mathrm{mg} / \mathrm{L})$ produza efluente final com concentração de fósforo acima do exigido pela legislação, a produção de lodo resultante de seu uso é significativamente inferior em relação a dosagens que resultem na quase completa remoção de fósforo.

- Para gradiente médio de $1000 \mathrm{~s}^{-1}$ e $10 \mathrm{~s}$ de mistura rápida, tempo de floculação de 20 min, gradiente médio de velocidade de floculação de $80 \mathrm{~s}^{-1}$, quantidade de ar fornecida de $19 \mathrm{~g} / \mathrm{m}^{3}$ de efluente, velocidade de flotação de $10 \mathrm{~cm} / \mathrm{min}$ min e utilizando amostra do reator RALEx coletada às 08:00, no período de sua partida, a aplicação de até 40 $\mathrm{mgFeCl}_{3} / \mathrm{L}$ associada a dosagens de até $1,25 \mathrm{mg} / \mathrm{L}$ de polímero resultou em diferentes remoções de carga orgânica, de fósforo total e de turbidez:

* O aumento da dosagem de cloreto férrico entre zero e $40 \mathrm{mg} / \mathrm{L}$ produziu resultados com diferentes comportamentos de acordo com a velocidade de flotação estudada. Para baixas velocidades, menores que $15 \mathrm{~cm} / \mathrm{min}$, o aumento da dosagem de cloreto férrico resultou em redução de turbidez das amostras, variando entre 9,2 uT e 15,5 uT, quando eram utilizados $40 \mathrm{mgFeCl}_{3} / \mathrm{L}$. Entretanto, para altas velocidades de flotação (acima de $15 \mathrm{~cm} / \mathrm{min}$ ), o aumento da dosagem de cloreto férrico produziu amostras com turbidez maior, em decorrência da redução da eficiência de remoção, com valores entre 42,0 uT e 62,2 uT, quando eram utilizados $40 \mathrm{mgFeCl}_{3} / \mathrm{L}$;

* nas faixas de dosagens de cloreto férrico e de polímero catiônico investigadas, o aumento da dosagem de polímero não proporcionou elevação da eficiência de remoção de turbidez;

* o aumento da dosagem de polímero não afetou significativamente a qualidade das amostras coletadas na $\mathrm{Vf}=10 \mathrm{~cm} / \mathrm{min}$ em termos de concentração de fósforo do efluente, para dosagens de cloreto férrico entre 0 e $30 \mathrm{mg} / \mathrm{L}$. Nessas condições, as concentrações de fósforo das amostras variaram entre 3,15 mg/L e 3,60 mg/L. Para $\mathrm{DCF}=40 \mathrm{mg} / \mathrm{L}$, houve aumento na remoção de fósforo a partir de dosagens de 0,75 $\mathrm{mg} / \mathrm{L}$ de polímero, atingindo seu melhor desempenho quando $\mathrm{DPC}=1,25 \mathrm{mg} / \mathrm{L}$, com concentração de fósforo de $1,98 \mathrm{mg} / \mathrm{L}$. O mesmo comportamento pode ser observado para velocidades mais altas de flotação. Para Vf $=25 \mathrm{~cm} / \mathrm{min}$ e DCF entre 0 e $30 \mathrm{mg} / \mathrm{L}$, as concentrações de fósforo das amostras variaram entre 3,10 
$\mathrm{mg} / \mathrm{L}$ e 3,72 mg/L. Para DCF = $40 \mathrm{mg} / \mathrm{L}$, houve aumento na remoção de fósforo com o aumento da dosagem de polímero, atingindo seu melhor desempenho quando DPC $=1,25 \mathrm{mg} / \mathrm{L}$, com concentração de fósforo de $2,40 \mathrm{mg} / \mathrm{L} \mathrm{e}$

* o aumento da dosagem de polímero também não afetou significativamente a qualidade das amostras coletadas na Vf $=10 \mathrm{~cm} / \mathrm{min}$ em termos de DQO. Entretanto, o aumento da dosagem de cloreto férrico proporcionou ligeira redução nos valores de DQO das amostras. Quando não houve adição de cloreto férrico, os valores de DQO das amostras variaram entre 170 e $199 \mathrm{mg} / \mathrm{L}$, e quando foram adicionados $40 \mathrm{mg} / \mathrm{L}$ de cloreto férrico esses valores variaram entre 106 e $129 \mathrm{mg} / \mathrm{L}$. Para velocidades mais altas de flotação $(25 \mathrm{~cm} / \mathrm{min})$ os valores de DQO das amostras não apresentaram comportamento definido em função da variação das dosagens de cloreto férrico e de polímero.

$\Rightarrow$ A qualidade do efluente final foi fortemente dependente da dosagem de coagulante utilizada e da qualidade do efluente do reator anaeróbio. Quando a qualidade do efluente do RALEx apresentava reduzidos teores de matéria orgânica e de SST, compatíveis com o real potencial de um reator anaeróbio, o uso de $0,4 \mathrm{mg} / \mathrm{L}$ de polímero associado a $15 \mathrm{mgFeCl}_{3} / \mathrm{L}$ resultou em valores de DQO abaixo de $25 \mathrm{mg} / \mathrm{L} \mathrm{em}$ médias e altas velocidades de flotação. Se a qualidade do efluente do reator anaeróbio diminuía, mesmo a adição de $40 \mathrm{mgFeCl}_{3} / \mathrm{L}$ não era capaz de produzir efluente com DQO abaixo de $100 \mathrm{mg} / \mathrm{L}$.

$\Rightarrow$ Nesta situação, somente o uso de dosagens superiores a $40 \mathrm{mgFeCl}_{3} / \mathrm{L}_{\text {logrou promover }}$ precipitação efetiva de fósforo. Além da quase nula remoção de fósforo nas demais dosagens de cloreto férrico, o fato de o aumento da dosagem de polímero somente apresentar influência na elevação da remoção de fósforo quando $40 \mathrm{mgFeCl}_{3} / \mathrm{L}$ foram usados comprova que o polímero atua eficazmente em material particulado, ou seja, no precipitado de fósforo.

- Com aplicação de $40 \mathrm{mgFeCl}_{3} / \mathrm{L}$ associada à dosagem de até $1,25 \mathrm{mg} / \mathrm{L}$ de polímero, $1000 \mathrm{~s}^{-1}$ de gradiente médio e $10 \mathrm{~s}$ de mistura rápida, gradiente médio de velocidade de floculação de $80 \mathrm{~s}^{-1}$, quantidade de ar fornecida de $19 \mathrm{~g} / \mathrm{m}^{3}$ de efluente, velocidade de flotação de $10 \mathrm{~cm} /$ min e utilizando amostra coletada às 08:00, no período de partida biológica do reator RALEx, o emprego de valores de tempo de floculação (total e do 
polímero) de até 24 min resultou em diferentes remoções de carga orgânica, de fósforo total e de turbidez:

* Pode-se inferir que tempos totais de floculação entre 18 e 24 min associados a tempos de floculação do polímero entre 12 e 18 min formem combinação mais adequada para remoção de turbidez. A combinação destes valores produziram amostras com turbidez entre 1,7 uT e 2,4 uT, para as diferentes velocidades de flotação testadas;

* a análise visual permitiu verificar que o intervalo de tempo mais adequado para adição do polímero após o início da floculação era de até 12 min, muito embora intervalos com cerca de 6 min já eram suficientes para produzir flocos;

* na faixa de valores investigada, a remoção de DQO e de fósforo não foi influenciada pela variação do tempo de floculação, atingindo eficiências entre $47 \%$ e $54 \%$, com residuais entre 112 e $128 \mathrm{mgO}_{2} / \mathrm{L}$, e entre $92 \%$ e $98 \%$, com residuais entre 0,05 e $0,31 \mathrm{mgP} / \mathrm{L}$, na velocidade de flotação de $10 \mathrm{~cm} / \mathrm{min}$. De maneira geral, todos os valores testados de tempo total e tempo de floculação do polímero produziram bons resultados em termos de remoção de DQO e de fósforo e

* o emprego de 24 min de tempo total de floculação aliado a 12 min e a 18 min de tempo de floculação do polímero resultou em excelentes condições de remoção de turbidez, de DQO e de fósforo.

$\Rightarrow$ Para maximizar a atuação do cloreto férrico, sobretudo em termos de remoção de turbidez e de fósforo, é essencial que haja floculação, de pelo menos 6 min, antes da adição do polímero.

$\Rightarrow$ Desde que haja pelo menos 6 min de floculação com somente cloreto férrico, o uso dos diferentes tempos totais de floculação não afetou significativamente a qualidade do efluente final. Entretanto, somente com tempo total superior a $18 \mathrm{~min}$ de floculação, foi possível obter efluente final com turbidez inferior a 2,4 uT.

- Com aplicação de $40 \mathrm{mgFeCl}_{3} / \mathrm{L}$ associada à dosagem de até $1,25 \mathrm{mg} / \mathrm{L}$ de polímero, $1000 \mathrm{~s}^{-1}$ de gradiente médio e $10 \mathrm{~s}$ de mistura rápida, aplicação de polímero após $6 \mathrm{~min}$ do início da floculação, quantidade de ar fornecida de $19 \mathrm{~g} / \mathrm{m}^{3}$ de efluente, velocidade de flotação de $10 \mathrm{~cm} / \mathrm{min}$ e utilizando amostra coletada às 08:00, no período de partida biológica do reator RALEx, o emprego de valores de tempo total de floculação entre 12 
e 24 min e de gradiente médio de velocidade de floculação entre 40 e $100 \mathrm{~s}^{-1}$ resultou em diferentes remoções de carga orgânica, de fósforo total e de turbidez:

* O aumento do tempo total de floculação de 12 para 24 min resultou em melhoria significativa na remoção de turbidez e de fósforo, independentemente do gradiente médio de velocidade de floculação considerado;

* considerando-se a remoção de turbidez e de fósforo, o emprego de gradientes médios de velocidade de floculação entre 60 e $100 \mathrm{~s}^{-1}$ produziu efluente do flotateste com excelente qualidade;

* o uso de Gf de $40 \mathrm{~s}^{-1}$ mostrou-se desfavorável em todos os ensaios realizados em diferentes tempos de floculação e

* verifica-se, também, que a variação do tempo total e do gradiente médio de velocidade de floculação praticamente não influenciou a remoção de DQO, para a faixa de valores testados.

$\Rightarrow$ Quando houve 6 min de floculação com cloreto férrico somente, o aumento do tempo total de floculação afetou positivamente a qualidade do efluente final, em termos de turbidez e de fósforo.

$\Rightarrow$ A necessidade do uso de gradientes de floculação acima de $60 \mathrm{~s}^{-1}$, quando da adição de cloreto férrico associada a polímero verificada neste estudo, reforça as recomendações propostas por REALI et al. (1998), quando de estudo com adição somente de cloreto férrico. Sendo assim, independentemente dos produtos químicos utilizados, o melhor desempenho da flotação depende de valores de gradiente de floculação mais elevados do que na sedimentação.

- Com aplicação de $40 \mathrm{mgFeCl}_{3} / \mathrm{L}$ associada à dosagem de até $1,25 \mathrm{mg} / \mathrm{L}$ de polímero, $1000 \mathrm{~s}^{-1}$ de gradiente médio e $10 \mathrm{~s}$ de mistura rápida, $24 \mathrm{~min}$ de tempo total de floculação, 18 min de floculação do polímero, $80 \mathrm{~s}^{-1}$ de gradiente médio de velocidade de floculação, velocidade de flotação de $10 \mathrm{~cm} / \mathrm{min}$ e utilizando amostra coletada às 08:00, no período de partida biológica do reator RALEx, o emprego de valores entre $3 \%$ e $30 \%$ de fração de recirculação de efluente pressurizado (R) em $450 \mathrm{kPa}$ resultou em diferentes remoções de carga orgânica, de fósforo total e de turbidez:

* Os valores de R de $12 \%$ e de $18 \%$, ou seja, o fornecimento de ar de 11,4 e de 17,1 $\mathrm{g} / \mathrm{m}^{3}$, para as velocidades de flotação entre 5 e $20 \mathrm{~cm} / \mathrm{min}$, forneceram os melhores resultados de eficiência de remoção de turbidez por flotação, com eficiências bastante próximas entre si (entre $83 \%$ e $86 \%$ ); 
* no que se refere à eficiência de remoção de DQO, para a velocidade de flotação de $10 \mathrm{~cm} / \mathrm{min}$, todos os valores de $\mathrm{R}$ proporcionaram remoções entre $41 \%$ e $51 \%$, sendo que o melhor resultado foi obtido com $\mathrm{R}$ de $18 \% \mathrm{e}$

* em relação à eficiência de remoção de fósforo, os valores de R entre 9\% e 27\% (com exceção de $\mathrm{R}$ de $21 \%$ ) foram mais eficientes, com remoções entre $58 \%$ e $62 \%$. Dentre esses valores de R, o de $18 \%$ forneceu resultados ligeiramente melhores que os demais, embora extremamente próximos.

$\Rightarrow \mathrm{O}$ estudo da necessidade de ar para a flotação apresenta restrições operacionais quando de seu estudo no flotateste. Por tratar-se de ensaio em batelada (flotateste) e a recirculação pressurizada da fração do efluente tratado pressupor sistema contínuo (flotador), os resultados e conclusões parciais tornam-se questionáveis.

$\Rightarrow$ Ainda assim, os resultados observados neste estudo são semelhantes aqueles alcançados por PENETRA et al.(1999b), quando quantidades de ar entre 16 e $19 \mathrm{~g} / \mathrm{m}^{3}$ foram recomendadas.

- Com dosagem de 1,25 mg/L de polímero catiônico, $1000 \mathrm{~s}^{-1}$ de gradiente médio e $10 \mathrm{~s}$ de mistura rápida, 24 min de tempo total de floculação, 18 min de floculação do polímero, $80 \mathrm{~s}^{-1}$ de gradiente médio de velocidade de floculação, quantidade de ar fornecida de $11,4 \mathrm{~g} / \mathrm{m}^{3}$ de efluente, velocidade de flotação de $10 \mathrm{~cm} / \mathrm{min}$ e utilizando amostra coletada às 08:00, no período de partida biológica do reator RALEx, o aumento da dosagem entre 10 e $40 \mathrm{mgFeCl}_{3} / \mathrm{L}$ resultou em diferentes comportamentos de remoções de carga orgânica, de fósforo total e de turbidez:

* O aumento da dosagem de cloreto férrico praticamente não resultou em melhoria na eficiência de remoção da fração solúvel de DQO. Entretanto, em relação à remoção da fração de DQO particulada, verificou-se significativa melhora;

* o aumento da dosagem de cloreto férrico melhorou a flotabilidade dos flocos químicos formados, permitindo a remoção dos sólidos suspensos mas não interferindo na parcela dissolvida da matéria orgânica e

* houve aumento na eficiência de remoção tanto para a fração solúvel, quanto para a fração não dissolvida de fósforo. $\mathrm{O}$ aumento da dosagem foi fundamental para a obtenção de baixos residuais de fósforo. Além disso, o uso de $40 \mathrm{mgFeCl}_{3} / \mathrm{L}$ também melhorou a flotabilidade dos flocos formados e sua remoção. 
- Comparando o desempenho do tratamento físico-químico por flotação do efluente do reator RALEx quando de seu período de operação em equilíbrio dinâmico aparente e durante sua fase de partida, utilizando amostra do reator RALEx coletada às 08:00, algumas considerações são apresentadas:

$\Rightarrow$ De maneira geral, a remoção de fosfato foi fortemente dependente da dosagem de cloreto férrico utilizada. Para obtenção de níveis satisfatórios de remoção de fosfato foram necessárias dosagens de $30 \mathrm{mgFeCl}_{3} / \mathrm{L}$ para o efluente do reator RALEx sendo operado em equilíbrio dinâmico aparente, sendo que para o efluente durante a partida biológica dosagens na faixa de 45 a $65 \mathrm{mgFeCl}_{3} / \mathrm{L}$ foram requeridas;

$\Rightarrow \mathrm{O}$ emprego de polímero catiônico isoladamente forneceu resultados satisfatórios no que se refere à remoção de turbidez e de DQO, embora não tão bons quanto aqueles obtidos com aplicação de cloreto férrico.

$\Rightarrow$ Com relação à remoção de fósforo, como já comentado, o emprego de polímero catiônico não foi capaz de fornecer remoção satisfatória da fração solúvel desse elemento;

$\Rightarrow$ De maneira geral, tais resultados demonstraram que o emprego isolado de polímero catiônico resultou na produção de flocos com elevada velocidade ascensional, fato extremamente positivo pois indica a possibilidade de operação de unidades de flotação em escala real com taxas bastante elevadas. Em outras palavras, permitiria a adoção de unidades mais compactas e, portanto, mais econômicas e

$\Rightarrow$ Durante a operação de partida biológica do reator anaeróbio, a aplicação de pequenas dosagens de polímero catiônico (com alto peso molecular e alta densidade de carga) ou de polímero não iônico (de alto peso molecular), associadas a dosagens entre 15 e 30 $\mathrm{mgFeCl}_{3} / \mathrm{L}$, não permitiu a obtenção da mesma qualidade de efluente final observada nos ensaios com efluente do reator em equilíbrio dinâmico aparente. Para tanto, foram necessárias maiores dosagens de cloreto férrico (variando entre 45 e $65 \mathrm{mg} / \mathrm{L}$ ), para atingir a qualidade desejada.

- Para gradiente médio de $1000 \mathrm{~s}^{-1}$ e $10 \mathrm{~s}$ de mistura rápida, 20 min de tempo de floculação, $80 \mathrm{~s}^{-1}$ de gradiente médio de velocidade de floculação, quantidade de ar fornecida de $19 \mathrm{~g} / \mathrm{m}^{3}$ de efluente e velocidade de flotação de $10 \mathrm{~cm} / \mathrm{min}$, no período de partida biológica do reator RALEx, o emprego de dosagens entre 0 e $85 \mathrm{mgFeCl}_{3} / \mathrm{L} \mathrm{em}$ amostras do efluente do reator RALEx com variação de sua qualidade, mediante sua 
coleta ao longo do dia, resultou em diferentes comportamentos de remoções de carga orgânica, de fósforo total e de turbidez:

* Quando do uso isolado do cloreto férrico na coagulação e floculação de efluente do reator RALEx, durante partida do reator biológico, dosagens iguais ou superiores a $65 \mathrm{mg} / \mathrm{L}$ são necessárias para manutenção da qualidade do efluente do flotateste final, com valores de turbidez inferiores a 15 uT e com remoções superiores a $84 \%$, ao longo do dia;

* a aplicação de valores maiores de $65 \mathrm{mgFeCl}_{3} / \mathrm{L}$ não afetou significativamente a remoção de DQO, indicando que dosagens de cloreto férrico da ordem de $65 \mathrm{mg} / \mathrm{L}$ são suficientes pra manutenção de efluente do flotateste com reduzida concentração de matéria orgânica e elevada remoção global de DQO, da ordem de 91,4\% e

* a remoção de DQO foi significativamente influenciada pela qualidade do efluente do reator RALEx. Fazendo uso de amostra coletada às 08:00, $45 \mathrm{mgFeCl}_{3} / \mathrm{L}$ eram suficientes para promover 90,2\% de remoção global de DQO. Para obtenção de remoção global de 88,6\% de DQO de amostra coletada às 11:00, já foram necessários $65 \mathrm{mgFeCl}_{3} / \mathrm{L}$. Em amostra coletada às 14:00, nenhuma dosagem de cloreto férrico testada foi suficiente para promover remoção global de DQO superior a $80 \%$. Naquela coletada às $17: 00$, dosagem de $65 \mathrm{mgFeCl}_{3} / \mathrm{L}$ foi necessária para remoção global de 80,7\% de DQO. Essa mesma dosagem, às 20:00, foi suficiente para remoção global de $91,4 \%$ de DQO.

$\Rightarrow \mathrm{O}$ aumento da dosagem de cloreto férrico resultou em significativa redução da presença de matéria orgânica na forma de sólidos de diferentes diâmetros nos efluentes coletados no flotateste ao longo do dia. $\mathrm{O}$ aumento da dosagem de cloreto férrico acarretou pequena diferença na remoção de matéria orgânica na forma de sólidos de diâmetro inferior a $1,2 \mu \mathrm{m}$ nos efluentes coletados no flotateste ao longo do dia. Vale destacar que a aplicação de dosagens iguais ou superiores a $65 \mathrm{mgFeCl}_{3} / \mathrm{L}$ possibilitou a quase completa remoção de partículas com diâmetros médios acima de 1,2 $\mu_{\mathrm{m} \text {; }}$

$\Rightarrow \mathrm{O}$ aumento da dosagem de cloreto férrico não acarretou diferença na redução de matéria orgânica na forma de sólidos de diâmetro inferior a $0,45 \mu \mathrm{m}$ nos efluentes coletados no flotateste ao longo do dia. Desta forma, vale ressaltar que a flotação, mesmo em pequenas dosagens de cloreto férrico, apresentou boa eficiência para remoção de sólidos com diâmetros inferiores a $1,2 \mu \mathrm{m}$. Entretanto, para remoção das sólidos com diâmetro superior a $1,2 \mu \mathrm{m}$, dosagens mais elevadas, superiores a $65 \mathrm{mgFeCl}_{3} / \mathrm{L}$, foram necessárias; 
* A remoção de fósforo do meio líquido por processo físico-químico é dependente de dois fatores distintos: i) a precipitação do fósforo na forma dissolvida, com geração de material particulado e ii) a atuação de sistema capaz de promover a separação das fases líquida e sólida. Ou seja, caso parcela do fósforo esteja na forma particulada, sua remoção somente depende de sistema eficiente na separação das fases. Entretanto, caso parcela do fósforo esteja na forma dissolvida, sua remoção depende de sua completa precipitação, gerando material particulado, e, somente então, de sistema eficiente na separação das fases;

* Considerando os níveis de concentração de fósforo encontrados no efluente do reator anaeróbio, dosagens iguais ou acima de $45 \mathrm{mgFeCl}_{3} / \mathrm{L}$ foram suficientes para precipitação de mais de $88 \%$ da carga de fósforo na forma de sólidos com diâmetro médio inferior a $0,45 \mu \mathrm{m}$, resultando em concentrações de fósforo inferiores a 0,50 $\mathrm{mg} / \mathrm{L}$ no efluente do flotateste. O material particulado formado a partir da adição de $45 \mathrm{mgFeCl}_{3} / \mathrm{L}$ não resultou em flocos com boas características de flotabilidade. Somente com a aplicação de $65 \mathrm{mgFeCl}_{3} / \mathrm{L}$, o material particulado formado resultou em flocos com razoável flotabilidade.

$\Rightarrow$ A elevada remoção de fósforo depende, a partir de dosagens de $45 \mathrm{mgFeCl}_{3} / \mathrm{L}$, das características de flotabilidade dos flocos formados, tendo em vista que grande parcela do material dissolvido foi precipitada e

$\Rightarrow$ A aplicação de dosagens gradativamente maiores de cloreto férrico afetou significativamente a remoção de fósforo, até sua quase completa remoção, a partir do uso de $85 \mathrm{mgFeCl}_{3} / \mathrm{L}$.

- Adotando $1000 \mathrm{~s}^{-1}$ de gradiente médio e $10 \mathrm{~s}$ de mistura rápida, 20 min de tempo de floculação, $80 \mathrm{~s}^{-1}$ de gradiente médio de velocidade de floculação, quantidade de ar fornecida de $19 \mathrm{~g} / \mathrm{m}^{3}$ de efluente e velocidade de flotação de $10 \mathrm{~cm} / \mathrm{min}$, no período de partida biológica do reator RALEx, o emprego de dosagens entre 0 e $85 \mathrm{mgFeCl} / \mathrm{L}$ em valores de pH de coagulação entre 4,3 e 6,4 resultou em diferentes comportamentos de remoções de carga orgânica, de fósforo total e de turbidez:

* A redução do pH de coagulação, para valores abaixo de 5,0, proporcionou significativo aumento na remoção de DQO das amostras para $15 \mathrm{mgFeCl}_{3} / \mathrm{L}$ e apenas ligeiro aumento quando $30 \mathrm{mgFeCl}_{3} / \mathrm{L}$ foram usados; 
* ainda que em baixos valores de $\mathrm{pH}$, o uso de $15 \mathrm{mg} / \mathrm{L}$ não produziu efluente com reduzida presença de matéria orgânica. Para $30 \mathrm{mgFeCl}_{3} / \mathrm{L}$ e $\mathrm{pH}$ de 6,3 foi observada DQO da amostra final de $43 \mathrm{mg} / \mathrm{L}$, valor relativamente baixo e

* para dosagens entre 45 e $85 \mathrm{mgFeCl}_{3} / \mathrm{L}$ e valores de $\mathrm{pH}$ entre 4,4 e 6,2, a DQO observada nas amostras flotadas variou entre 25 e $40 \mathrm{mg} / \mathrm{L}$, sem padrão de comportamento definido. Para esta faixa de valores, a redução de $\mathrm{pH}$ de coagulação não elevou a remoção de DQO.

$\Rightarrow$ A redução do pH de coagulação também não influenciou a remoção de matéria orgânica associada a sólidos com diâmetro médio abaixo de $1,2 \mu \mathrm{m}$;

$\Rightarrow$ Nem a adição de cloreto férrico e nem a redução do pH influenciou a remoção de matéria orgânica correspondente a sólidos com diâmetro médio abaixo de $0,45 \mu \mathrm{m}$;

$\Rightarrow$ A redução do $\mathrm{pH}$ de coagulação não elevou significativamente a remoção de fósforo referente a sólidos com diâmetro médio inferior a $1,2 \mu \mathrm{m}$ e a $0,45 \mu \mathrm{m}$, respectivamente, ou seja, a precipitação de fósforo não foi substancialmente influenciada pela variação do $\mathrm{pH}$. Entretanto, como esperado, a remoção de fósforo foi significativamente influenciada pela dosagem de cloreto férrico, em todas as faixas de diâmetros de partículas investigadas;

$\Rightarrow$ Quando adicionado isoladamente, o uso de DCF entre 15 e $30 \mathrm{mg} / \mathrm{L}$ não foi alternativa recomendável para obtenção de efluente com elevada qualidade em termos de turbidez em função dos baixos valores de $\mathrm{pH}$ necessários, ferindo a legislação pertinente. Já para DCF entre 45 e $85 \mathrm{mg} / \mathrm{L}$, tendo em vista que a qualidade do efluente não dependia de baixos valores de $\mathrm{pH}$, seu uso foi recomendável, com a vantagem adicional que nenhuma correção de $\mathrm{pH}$ foi necessária e

$\Rightarrow$ Em situações em que não é necessária baixa turbidez nem reduzida presença de fósforo, o uso de $30 \mathrm{mgFeCl}_{3} / \mathrm{L}$ seria suficiente para obtenção de baixos residuais de matéria orgânica, sem correção do $\mathrm{pH}$.

\section{Com base nos resultados obtidos durante a realização dos ensaios em instalação} piloto de flotação utilizada no presente trabalho, discutidos no capítulo anterior, consideram-se pertinentes as seguintes observações:

- O emprego de recheio em câmara de saturação resultou em saturação de ar na água com valores entre $99,1 \mathrm{mg} / \mathrm{L}$ a 109,2 $\mathrm{mg} / \mathrm{L}$, operando com $\mathrm{TAS}_{\mathrm{CS}}$ entre 340 e $580 \mathrm{~m}^{3} / \mathrm{m}^{2} / \mathrm{d}$. 
Estes valores são significativamente superiores àqueles observados em câmara de saturação sem recheio, tal como em PENETRA (1998), onde a saturação de ar na água variou entre 73,3 e $80,52 \mathrm{mg} / \mathrm{L}$, em TAS $_{\mathrm{CS}}$ entre 28 e $73 \mathrm{~m}^{3} / \mathrm{m}^{2} / \mathrm{d}$.

- Quanto ao emprego do reator RALEx, as seguintes considerações podem ser feitas:

$\Rightarrow$ Conforme dados de ensaios em laboratório, durante a operação do reator em equilíbrio dinâmico aparente, seu desempenho foi suficientemente bom para que a flotação, com dosagens de cloreto férrico abaixo de $30 \mathrm{mg} / \mathrm{L}$, produzisse efluente final de excelente qualidade, a partir de amostras coletadas às 08:00. Quando de sua operação em partida biológica da biomassa, para obtenção da mesma qualidade de efluente do flotateste, dosagens de cloreto férrico entre 45 e $65 \mathrm{mg} / \mathrm{L}$ foram necessárias;

$\Rightarrow$ Comparando-o com reator UASB utilizado por PENETRA (1998), ambos com dados do mês de outubro, conclui-se que o reator RALEx estava sendo operado abaixo de seu real potencial de desempenho, em função das deficiências de projeto. A remoção de carga orgânica observada ao longo de 24 horas pelo reator RALEx, em outubro de 1999, foi de 53\% enquanto a do reator UASB utilizado por PENETRA (1998) foi de $62 \%$, em outubro de 1997. A remoção de carga orgânica observada ao longo de 24 horas no RALEx, considerando amostra filtrada em membrana com 1,2 $\mu \mathrm{m}$, foi de $37 \%$ enquanto a do reator UASB citado foi de $70 \%$. A remoção de carga de sólidos suspensos totais observada no RALEx foi de $47 \%$ enquanto a do reator UASB citado foi de 58\%. A remoção de carga de sólidos suspensos voláteis observada ao longo de 24 horas (out/99) foi de 54\% enquanto a do reator UASB citado foi de 63\%. Mesmo em equilíbrio dinâmico aparente, o desempenho do RALEx manteve-se aquém do esperado, tratando-se desse tipo de reator anaeróbio.

$\Rightarrow \mathrm{O}$ forte aumento da DQO das amostras de efluentes do reator RALEx associado à elevação mediana nos valores de DQO do esgoto bruto resultou na queda da eficiência de remoção de carga orgânica pelo RALEx nos meses de junho, julho e agosto de 2001. Dentre os 14 ensaios realizados entre 01/junho e 06/agosto, 12 deles apresentaram eficiência de remoção de matéria orgânica abaixo de 46\%, entre 08:00 e 20:00. Vale recordar que no período diurno a eficiência parcial relativa é maior que a efetiva eficiência alcançada em 24 horas. Ao longo de todos os ensaios, entre março e setembro de 2001, a remoção média de carga orgânica entre 08:00 e 20:00 foi de 
49,3\%. Notadamente, a biomassa presente no reator RALEx não estava atuando eficientemente, de acordo com a potencialidade de reatores anaeróbios.

$\Rightarrow$ As limitações operacionais do reator RALEx utilizado neste estudo provavelmente influenciaram o desenvolvimento e atuação da biomassa, limitando a capacidade de remoção de matéria orgânica e de sólidos presentes no esgoto sanitário, com conseqüente necessidade de elevação da dosagem média de coagulante utilizada no sistema de flotação para obtenção de efluente final com qualidade desejada.

- Quando da operação do sistema de floculação/flotação com 20 min de tempo de floculação, $80 \mathrm{~s}^{-1}$ de gradiente médio de velocidade de floculação, quantidade de ar fornecida de $19,7 \mathrm{~g} / \mathrm{m}^{3}$ de efluente e $180 \mathrm{~m}^{3} / \mathrm{m}^{2} / \mathrm{d}$ de taxa de aplicação superficial, o aumento da dosagem de cloreto férrico de $30 \mathrm{mg} / \mathrm{L}$ para até $70 \mathrm{mg} / \mathrm{L}$ permitiu as seguintes considerações:

* O uso de 50 e $70 \mathrm{mg} / \mathrm{L}$ de cloreto férrico conduziu a bons resultados de remoção de carga de DQO, entre $80,6 \%$ e $81,7 \%$, enquanto para $30 \mathrm{mgFeCl}_{3} / \mathrm{L}$ a remoção foi de apenas $38,3 \%$, no flotador;

* a remoção de fósforo foi a mais influenciada pela variação na dosagem de cloreto férrico. $\mathrm{O}$ uso de 50 e $70 \mathrm{mg} / \mathrm{L}$ de cloreto férrico conduziu a resultados satisfatórios de remoção de carga de fósforo, $90,1 \%$ e $71,3 \%$, enquanto para $30 \mathrm{mgFeCl}_{3} / \mathrm{L}$ a remoção foi apenas marginal, de $10,3 \%$ e

* o uso de 50 e $70 \mathrm{mg} / \mathrm{L}$ de cloreto férrico conduziu a bons resultados de remoção de carga de SST, $92,1 \%$ e $85,7 \%$, respectivamente, enquanto para $30 \mathrm{mgFeCl}_{3} / \mathrm{L}$ a remoção foi de $48,9 \%$, no flotador.

- Quando da aplicação de $50 \mathrm{mg} / \mathrm{L}$ de cloreto férrico, de quantidade de ar fornecida de $19,7 \mathrm{~g} / \mathrm{m}^{3}$ de efluente e de $180 \mathrm{~m}^{3} / \mathrm{m}^{2} / \mathrm{d}$ de taxa de aplicação superficial, o aumento de 13 para 20 min de tempo de floculação, associados a valores entre 60 e $100 \mathrm{~s}^{-1}$ de gradiente médio de velocidade de floculação, resultou na seguintes considerações:

* Para tempos de floculação entre 13 e 20 min, a variação do valor de Gf demonstrou influir significativamente no desempenho da flotação do efluente de reator anaeróbio;

* a aplicação de Gf em torno de $80 \mathrm{~s}^{-1}$ proporcionou menor variação nos valores de SST do efluente do flotador nas amostras coletadas em diferentes horários ao longo do dia. Particularmente, o emprego de Gf de $80 \mathrm{~s}^{-1}$ e de Tf de $20 \mathrm{~min}$ 
resultou em valores de SST menores e mais estáveis ao longo da operação do flotador;

* se consideradas as remoções globais do sistema, praticamente não houve diferenças significativas de eficiência de remoção de carga de DQO nos usos

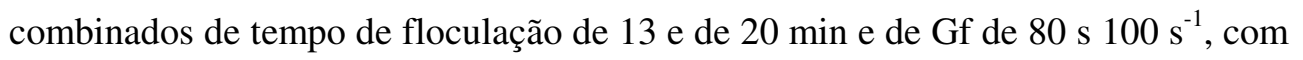
valores entre $88,7 \%$ e $91,6 \%$;

* o uso de Gf em torno de $80 \mathrm{~s}^{-1}$ proporcionou menor variação na concentração de fósforo no efluente da FAD nas amostras coletadas em diferentes horários ao longo do dia;

* o emprego de $\mathrm{Gf}=60 \mathrm{~s}^{-1}$ não trouxe boa qualidade de coagulação/floculação/ flotação, tendo em vista o elevado residual de ferro encontrado nos efluentes do flotador. O uso de dois pares de valores de Tf/Gf (13 min/100 s${ }^{-1}$ e $\left.20 \mathrm{~min} / 80 \mathrm{~s}^{-1}\right)$ resultou em remoção adicional de ferro, com residuais entre 0,50 e $0,69 \mathrm{mgFe} / \mathrm{L}$, indicando excelentes condições do tratamento físico-químico e

* nas melhores condições de operação ( $\mathrm{Gf}=80 \mathrm{~s}^{-1}$; Tf=20 min; $\mathrm{P}=450 \mathrm{kPa}$; vazão de recirculação igual a $18 \%$ da vazão afluente e aplicação de $50 \mathrm{mg} / \mathrm{L}$ de cloreto férrico), o sistema "RALEx/Flotador" produziu efluente com as seguintes concentrações residuais: $53 \mathrm{mg} / \mathrm{L}$ de DQO, 0,80 mg/L de fósforo, $9 \mathrm{mg} / \mathrm{L}$ de SST e 12,9 uT de turbidez, às 14:00, horário em que o efluente apresentava a pior qualidade ao longo do dia.

$\Rightarrow$ Muito embora os resultados de laboratório indiquem que valores de Gf entre 60 e $100 \mathrm{~s}$ ${ }^{1}$ são suficientes para proporcionar boas condições de floculação com conseqüente bom desempenho da flotação, os dados obtidos com o flotador mostraram que a faixa de valores de Gf é mais estreita, entre 80 e $100 \mathrm{~s}^{-1}$. Mais especificamente, o uso de Gf igual a $80 \mathrm{~s}^{-1}$ mostrou-se mais adequado em função da estabilidade da qualidade do efluente produzido ao longo do dia.

- Quando da operação do sistema de floculação/flotação com aplicação de $50 \mathrm{mg} / \mathrm{L}$ de cloreto férrico, de $20 \mathrm{~min}$ de tempo de floculação, de $80 \mathrm{~s}^{-1}$ de gradiente médio de velocidade de floculação e de $180 \mathrm{~m}^{3} / \mathrm{m}^{2} / \mathrm{d}$ de taxa de aplicação superficial, o aumento da quantidade de ar fornecida de 13,1 para $19,7 \mathrm{~g} / \mathrm{m}^{3}$ de efluente resultou em algumas considerações: 
* Quando do uso de $\mathrm{S}^{*}=13,1 \mathrm{~g} / \mathrm{m}^{3}$, observaram-se remoções de carga de DQO entre $49,6 \%$ e $61,4 \%$, de fósforo entre $21,1 \%$ e $58,2 \%$ e de SST entre $55,6 \%$ e $68,3 \%$, resultados apenas satisfatórios;

* para $\mathrm{S}^{*}=19,7 \mathrm{~g} / \mathrm{m}^{3}$, as remoções de carga de DQO variaram entre $54,7 \%$ e $80,6 \%$, de fósforo entre $35,4 \%$ e $90,1 \%$ e de SST entre $49,0 \%$ e $92,1 \%$, ou seja, foram observados excelentes resultados e

* considerando-se a remoção global de carga de DQO alcançada pelo sistema RALExflotador, o uso de $\mathrm{S}^{*}=19,7 \mathrm{~g} / \mathrm{m}^{3}$ sempre forneceu valores acima de $80 \%$. Para $\mathrm{S}^{*}=13,1 \mathrm{~g} / \mathrm{m}^{3}$, somente um único ensaio resultou em remoção superior a $80 \%$.

$\Rightarrow$ Com base nestes resultados, pode-se afirmar que a qualidade do efluente do flotador durante os ensaios com $\mathrm{S}^{*}=19,7 \mathrm{~g} / \mathrm{m}^{3}$ foi significativamente melhor quando comparado aos ensaios com $\mathrm{S}^{*}=13,1 \mathrm{~g} / \mathrm{m}^{3}$. Notadamente, o aumento da quantidade de ar fornecido resultou em aumento expressivo de desempenho da unidade de flotação e da qualidade final do efluente.

$\Rightarrow$ Há de se considerar que unidades em escala real apresentam significativa variação de carga de sólidos ao longo do dia. $\mathrm{O}$ uso de $\mathrm{S}^{*}=13,1 \mathrm{~g} / \mathrm{m}^{3}$ poderia ser adotado para horários onde a carga de sólidos fosse menor, por exemplo, no período noturno. Para o período diurno, o uso de $\mathrm{S}^{*}=19,7 \mathrm{~g} / \mathrm{m}^{3}$ proporciona maior estabilidade operacional ao sistema.

- Quando da operação do sistema de floculação/flotação com aplicação de 30 a 70 mg/L de cloreto férrico, de 20 min de tempo de floculação, de $80 \mathrm{~s}^{-1}$ de gradiente médio de velocidade de floculação e de quantidade de ar fornecida de $19,7 \mathrm{~g} / \mathrm{m}^{3}$ de efluente, o aumento de 180 para $250 \mathrm{~m}^{3} / \mathrm{m}^{2} / \mathrm{d}$ de taxa de aplicação superficial resultou em algumas considerações:

* Quando do uso de $30 \mathrm{mgFeCl}_{3} / \mathrm{L}$, houve redução de $38,3 \%$ para $28,7 \%$ de remoção de carga de DQO, muito embora mantendo remoções globais em torno de $70 \%$. Quando do uso de 50 e $70 \mathrm{mgFeCl}_{3} / \mathrm{L}$, houve redução de cerca de $81 \%$ para $57,9 \%$ e $44,4 \%$, respectivamente, de remoção de carga de DQO;

* em se tratando do uso de 50 e $70 \mathrm{mgFeCl}_{3} / \mathrm{L}$, quando do aumento da TAS, verificouse queda significativa na remoção de carga de fósforo, para valores de 22,7\% e $24,8 \%$, respectivamente. Entretanto, quando do uso de $30 \mathrm{mgFeCl}_{3} / \mathrm{L}$, a eficiência de remoção de carga de fósforo praticamente não foi alterada quando do aumento da TAS, mantendo-se em cerca de $10 \%$; 
* as remoções observadas quando DCF $=30 \mathrm{mg} / \mathrm{L}$ e $\mathrm{TAS}=180 \mathrm{~m}^{3} / \mathrm{m}^{2} / \mathrm{d}$ são ligeiramente inferiores àquelas quando foi utilizado DCF entre 50 e $70 \mathrm{mg} / \mathrm{L}$ e TAS $=250 \mathrm{~m}^{3} / \mathrm{m}^{2} / \mathrm{d}$. O aumento da dosagem de cloreto férrico compensou a elevação da taxa de aplicação superficial e

* com comportamento semelhante à remoção de fósforo, a influência do aumento da TAS na remoção de carga de SST, quando foram utilizados $30 \mathrm{mgFeCl}_{3} / \mathrm{L}$, foi pequena, de $48,9 \%\left(\right.$ TAS $\left.=180 \mathrm{~m}^{3} / \mathrm{m}^{2} / \mathrm{d}\right)$ para $39,8 \%\left(\mathrm{TAS}=250 \mathrm{~m}^{3} / \mathrm{m}^{2} / \mathrm{d}\right)$. Já para 50 e $70 \mathrm{mgFeCl}_{3} / \mathrm{L}$, a influência foi maior, reduzindo de $92,1 \%\left(\mathrm{TAS}=180 \mathrm{~m}^{3} / \mathrm{m}^{2} / \mathrm{d}\right.$ ) para $63,3 \%\left(\right.$ TAS $\left.=250 \mathrm{~m}^{3} / \mathrm{m}^{2} / \mathrm{d}\right)$ e de $85,7\left(\mathrm{TAS}=180 \mathrm{~m}^{3} / \mathrm{m}^{2} / \mathrm{d}\right)$ para $54,0 \%$ (TAS $\left.=250 \mathrm{~m}^{3} / \mathrm{m}^{2} / \mathrm{d}\right)$, respectivamente.

$\Rightarrow$ Notadamente o aumento de taxa de aplicação superficial de 180 para $250 \mathrm{~m}^{3} / \mathrm{m}^{2} / \mathrm{d}$ provocou redução significativa na remoção de turbidez, de DQO, de fósforo e de SST, sendo parcialmente compensada pelo aumento da dosagem de cloreto férrico. Desta forma, deve-se evitar projetar unidades convencionais de flotação que operem em taxas mais elevadas, mesmo durante picos diários de vazão de esgoto bruto afluente à ETE.

- Quando da operação do sistema de floculação/flotação com 18 min de tempo de floculação, $80 \mathrm{~s}^{-1}$ de gradiente médio de velocidade de floculação, quantidade de ar fornecida de $19,7 \mathrm{~g} / \mathrm{m}^{3}$ de efluente e $180 \mathrm{~m}^{3} / \mathrm{m}^{2} / \mathrm{d}$ de taxa de aplicação superficial, o emprego de $90 \mathrm{mgFeCl}_{3} / \mathrm{L}$ resultou em algumas considerações:

$\Rightarrow$ Observando os valores de turbidez do efluente do flotateste, foi possível inferir que a presença de sólidos suspensos nas amostras era bastante reduzida, indicando que o processo físico de separação (flotação) foi bastante eficiente. A presença de matéria orgânica no efluente final somente não pode ser mais reduzida, abaixo de valores de cerca de $100 \mathrm{mg} / \mathrm{L}$, por tratar-se de material dissolvido.

$\Rightarrow \mathrm{O}$ emprego de $90 \mathrm{mgFeCl}_{3} / \mathrm{L}$, embora sendo dosagem bastante elevada, garantiu a produção de efluente do flotador com excelente qualidade durante situação de emissão de efluente do RALEx com péssima qualidade.

$\Rightarrow$ Caracteriza-se, então, mais uma vantagem da flotação como pós-tratamento de efluentes de reatores anaeróbios. Em situações de início da operação de ETE, durante partida biológica dos reatores anaeróbios, a flotação pode atuar como uma barreira, evitando lançamento de efluentes de baixa qualidade em corpos d'água, ainda que, para tanto, volume adicional de lodo seja produzido e deva ser corretamente destinado. 
- Quando da operação do sistema de floculação/flotação com 18 min de tempo de floculação, $80 \mathrm{~s}^{-1}$ de gradiente médio de velocidade de floculação, quantidade de ar fornecida de $19,7 \mathrm{~g} / \mathrm{m}^{3}$ de efluente e $180 \mathrm{~m}^{3} / \mathrm{m}^{2} / \mathrm{d}$ de taxa de aplicação superficial, o emprego de 42 a $92 \mathrm{mgFeCl}_{3} / \mathrm{L}$ ao longo de 24 horas resultou em algumas considerações:

* Muito embora a DQO do efluente do RALEx tenha atingido $433 \mathrm{mg} / \mathrm{L}$, efluente final com DQO sempre inferior a $65 \mathrm{mg} / \mathrm{L}$ foi possível mediante uso de 73,7 $\mathrm{mgFeCl}_{3} / \mathrm{L}$ de dosagem média e

* em $80 \%$ das amostras de efluente final, a concentração de fósforo estava abaixo de $0,16 \mathrm{mg} / \mathrm{L}$, nunca ultrapassando $1,11 \mathrm{mg} / \mathrm{L}$ ao longo das 24 horas, o teor de SST estava abaixo de $6 \mathrm{mg} / \mathrm{L}$, nunca ultrapassando $19 \mathrm{mg} / \mathrm{L}$, e a turbidez abaixo de 5,53 uT, nunca maior que $24,5 \mathrm{uT}$;

$\Rightarrow$ Para maximização da atuação do cloreto férrico, deve-se optar pela variação de sua dosagem ao longo do dia e da noite, de forma que cada adição feita seja proporcional à qualidade do efluente do RALEx.

$\Rightarrow$ Notadamente, neste período de ensaios, o reator RALEx lançava efluente com qualidade inferior àquela já observada durante sua operação em outras épocas. Caso seja utilizado reator anaeróbio que efetivamente produza efluentes de acordo com seu real potencial, dosagens significativamente menores que as aplicadas no presente estudo deverão ser testadas com vistas à redução de lodo gerado e de custos.

- Quando da operação do sistema de floculação/flotação com dosagem de cloreto férrico de $30 \mathrm{mg} / \mathrm{L}$, da dosagem de 0,4 e 1,0 mg/L de polímero catiônico, de $80 \mathrm{~s}^{-1}$ de gradiente médio de velocidade de floculação, da quantidade de ar fornecida de $19,7 \mathrm{~g} / \mathrm{m}^{3}$ de efluente e $180 \mathrm{~m}^{3} / \mathrm{m}^{2} / \mathrm{d}$ de taxa de aplicação superficial, o aumento de 14 min para 21 min de floculação resultou nas seguintes considerações:

* Quando a dosagem de polímero era de $0,4 \mathrm{mg} / \mathrm{L}$, o aumento de Tf resultou em ligeiro aumento da remoção de carga orgânica, de 43,4\% para 47,5\%, pelo flotador. Tendo em vista que a eficiência de remoção de matéria orgânica pelo reator RALEx era semelhante entre os ensaios, a remoção global de matéria orgânica alcançada pelo sistema RALEx-flotador permaneceu estável, em torno de 70\%, para ambos os tempos de floculação utilizados; 
* quando a dosagem de polímero era de $1,0 \mathrm{mg} / \mathrm{L}$, houve redução na remoção de carga orgânica, de 58,4\% para 49,0\%, e de fósforo, de $29,0 \%$ para 13,4\%, pelo flotador. Além disso, o uso de $21 \mathrm{~min}$ de floculação e $\mathrm{DP}=1,0 \mathrm{mg} / \mathrm{L}$ resultou em efluentes do flotador com péssima qualidade em termos de presença de matéria orgânica, com resultados ao redor de $400 \mathrm{mg} / \mathrm{L}$ de DQO, no período vespertino;

* as amostras do efluente do flotateste dos ensaios com valores de Tf de 14 min e de DP entre 0,4 e $1,0 \mathrm{mg} / \mathrm{L}$ apresentaram características semelhantes entre si com relação à presença de matéria orgânica, de fósforo e de sólidos suspensos. A maior remoção de carga orgânica quando do uso de $\mathrm{DP}=1,0 \mathrm{mg} / \mathrm{L}$, em comparação com o ensaio com uso de $\mathrm{DP}=0,4 \mathrm{mg} / \mathrm{L}$, é explicada pela maior presença de carga orgânica no efluente do reator RALEx, com valores de DQO de até $600 \mathrm{mg} / \mathrm{L} \mathrm{e}$

* quando dos ensaios com 21 min de floculação, as eficiências de remoção de carga orgânica pelo flotador foram semelhantes, entre $47 \%$ e $49 \%$, apesar do aumento da dosagem de polímero de 0,4 para 1,0 mg/L. Entretanto, a qualidade do efluente do flotateste quando $\mathrm{DP}=1,0 \mathrm{mg} / \mathrm{L}$ foi bastante baixa, com valores ao redor de 400 $\mathrm{mg} / \mathrm{L}$ de DQO, no período vespertino.

$\Rightarrow \mathrm{O}$ uso de $30 \mathrm{mgFeCl}_{3} / \mathrm{L}$, isoladamente e nas mesmas condições operacionais, não havia produzido bons resultados em termos de remoção de turbidez, DQO, fósforo e SST. A adição de polímero, como auxiliar de floculação, poderia elevar as referidas remoções e produzir efluente com qualidade melhor. Entretanto, com a piora excessiva do efluente do RALEx, houve pequena elevação das remoções especificadas. A qualidade do efluente do flotador não foi satisfatória, com DQO ao redor de $400 \mathrm{mg} / \mathrm{L}$, no período vespertino.

- Quando da operação do sistema de floculação/flotação com dosagem de cloreto férrico de $50 \mathrm{mg} / \mathrm{L}$, da dosagem de $0,4 \mathrm{mg} / \mathrm{L}$ de polímero catiônico, de $80 \mathrm{~s}^{-1}$ de gradiente médio de velocidade de floculação, de $23 \mathrm{~min}$ de floculação, de 180 a $250 \mathrm{~m}^{3} / \mathrm{m}^{2} / \mathrm{d}$ de taxa de aplicação superficial, o aumento da quantidade de ar fornecida ( $\left.\mathrm{S}^{*}\right)$ de 13,1 a $19,7 \mathrm{~g} / \mathrm{m}^{3}$ de efluente resultou em algumas considerações:

* A eficiência de remoção de carga orgânica e de sólidos suspensos do reator RALEx ficou estável, entre $36,0 \%$ e $39,8 \%$ e entre $27,1 \%$ e $33,5 \%$, respectivamente, ainda que sejam valores muito abaixo do desejado e esperado; 
* o progressivo aumento dos valores de $\mathrm{S}^{*}\left(13,1 \mathrm{~g} / \mathrm{m}^{3}, 16,4 \mathrm{~g} / \mathrm{m}^{3}\right.$ e $\left.19,7 \mathrm{~g} / \mathrm{m}^{3}\right)$ resultou em elevação da remoção de carga orgânica $(49,3 \%, 60,4 \%$ e 66,8\%), da carga de fósforo $(29,0 \%, 51,9 \%$ e $59,6 \%)$ e da carga de sólidos $(77,0 \%, 84,2 \%$ e $87,6 \%)$, para $180 \mathrm{~m}^{3} / \mathrm{m}^{2} / \mathrm{d} \mathrm{e}$

* entretanto, para $250 \mathrm{~m}^{3} / \mathrm{m}^{2} / \mathrm{d}$, a eficiência de remoção de carga orgânica e de sólidos suspensos pelo reator RALEx ficou muito instável, variando entre 49,7\% e 71,5\% e entre $49,1 \%$ e $76,7 \%$, respectivamente, apresentando ora bom desempenho ora apenas satisfatório, em se tratando de reator anaeróbio. Diferentemente de quando foi adotado $180 \mathrm{~m}^{3} / \mathrm{m}^{2} / \mathrm{d}$, o progressivo aumento dos valores de $\mathrm{S}^{*}\left(13,1 \mathrm{~g} / \mathrm{m}^{3}, 16,4\right.$ $\mathrm{g} / \mathrm{m}^{3}$ e $\left.19,7 \mathrm{~g} / \mathrm{m}^{3}\right)$ resultou em redução da remoção de carga orgânica $(68,0 \%, 63,2 \%$ e $51,9 \%)$, da carga de fósforo $(65,1 \%, 62,3 \%$ e $44,5 \%)$ e da carga de sólidos $(74,3 \%$, $64,4 \%$ e $37,1 \%$ ). Entretanto, verifica-se que a qualidade das amostras coletadas ao longo do dia, e mais especificamente, à tarde, são bastante similares entre si, com valores de DQO em torno de $170 \mathrm{mg} / \mathrm{L}$, de $4 \mathrm{mgP} / \mathrm{L}$ e de $45 \mathrm{mgSST} / \mathrm{L}$.

$\Rightarrow$ Novamente a baixa qualidade do efluente do RALEx influenciou sobremaneira a qualidade final do efluente do flotador.

$\Rightarrow$ Nos ensaios com uso de $50 \mathrm{mgFeCl}_{3} / \mathrm{L}$, isoladamente e nas mesmas condições operacionais, bons resultados em termos de remoção de turbidez, DQO, fósforo e SST foram observados. A adição de polímero, como auxiliar de floculação, poderia elevar ainda mais as referidas remoções e produzir efluente com qualidade excepcional. Entretanto, com a piora excessiva do efluente do RALEx, houve redução das remoções especificadas e a qualidade do efluente do flotador deteriorou-se.

$\Rightarrow$ Sendo assim, a dosagem adicional de polímero, nos valores investigados, não foi suficiente para manter a qualidade do efluente do flotador em situações de queda de desempenho do RALEx e conseqüente produção de efluentes com baixa qualidade.

$\Rightarrow$ A comparação entre dois ensaios com flotador sendo operado em taxa de aplicação superficial de $250 \mathrm{~m}^{3} / \mathrm{m}^{2} / \mathrm{d}$, ora com dosagem de somente cloreto férrico, ora com dosagem associada de cloreto férrico e polímero, permitiria verificar se a adição de polímero oferece ao sistema de flotação maior desempenho em taxas mais elevadas. Entretanto, ao comparar ensaio realizado com DCF $=50 \mathrm{mg} / \mathrm{L} \mathrm{em} \mathrm{TAS}=250 \mathrm{~m}^{3} / \mathrm{m}^{2} / \mathrm{d}$ e ensaio realizado com DCF $=50 \mathrm{mg} / \mathrm{L}$ e $\mathrm{DP}=0,4 \mathrm{mg} / \mathrm{L}$ em TAS $=250 \mathrm{~m}^{3} / \mathrm{m}^{2} / \mathrm{d}$, embora as características do esgoto bruto durante os referidos ensaios fossem semelhantes, a qualidade dos efluentes do RALEx nos ensaios foi significativamente diferente. 
Quando o polímero foi adicionado, a qualidade do efluente final mostrou-se melhor do que quando o cloreto férrico foi utilizado isoladamente, embora este fato possa ser consequiência da melhor qualidade do efluente do RALEx durante o ensaio com adição de polímero. Porém a diferença significativa de qualidade entre os efluentes do reator anaeróbio e o reduzido número de ensaios para esta situação não permitem comparação relevante entre as duas situações.

- Quando da operação do sistema de floculação/flotação com $80 \mathrm{~s}^{-1}$ de gradiente médio de velocidade de floculação, $180 \mathrm{~m}^{3} / \mathrm{m}^{2} / \mathrm{d}$ de taxa de aplicação superficial e quantidade de ar fornecida ( $\mathrm{S}^{*}$ ) de $19,7 \mathrm{~g} / \mathrm{m}^{3}$ de efluente, as variações da qualidade do efluente do RALEx, da dosagem de cloreto férrico, da dosagem de polímero e do tempo de floculação resultaram em diferentes produções estimadas de lodo (TABELA 5.12):

* Na situação 1, quando o efluente do RALEx apresentava excelente qualidade, o uso de $50 \mathrm{mgFeCl}_{3} / \mathrm{L}$ produziu efluente de boa qualidade com produção estimada média de $0,48 \mathrm{kgSST} / \mathrm{h}$, o menor valor dentre as demais situações. A produção de lodo foi baixa, sobretudo, em função da reduzida carga de SST do efluente do RALEx;

* na situação 2, o efluente do RALEx estava com qualidade intermediária entre a situação 1 e as situações 3, 4 e 5. Por tratar-se de ensaio com duração de 24 horas, optou-se pela variação da dosagem de cloreto férrico ao longo do período, tal como relatado em 5.6.1.1.2, para maximização da atuação do coagulante adicionado. A dosagem média resultante foi de 73,7 mg/L. Em relação à situação 1, houve aumento de $43 \%$ da carga de cloreto férrico utilizada e de $107 \%$ de carga de SST no efluente do RALEx. A produção de efluente do flotador com excelente qualidade nesta situação resultou em produção estimada média de $1,0 \mathrm{kgSST} / \mathrm{h}$, com qualidade de efluente final superior ao obtido na situação 1 .

* as situações 3, 4 e 5 possuíam efluente do RALEx com qualidades relativamente semelhantes;

* o aumento da dosagem de cloreto férrico de 30 (situação 3) para 50 mg/L (situação 4), com dosagem de $0,4 \mathrm{mg} / \mathrm{L}$ de polímero, resultou em significativa elevação da remoção dos diferentes parâmetros de qualidade, sobretudo o fósforo, produzindo, portanto, efluente final de melhor qualidade, com conseqüente aumento na produção estimada de lodo de 0,41 para $0,99 \mathrm{kgSST} / \mathrm{h}$; 
TABELA 5.13 - Dados de produção estimada de lodo para diferentes ensaios durante utilização de instalação piloto de flotação.

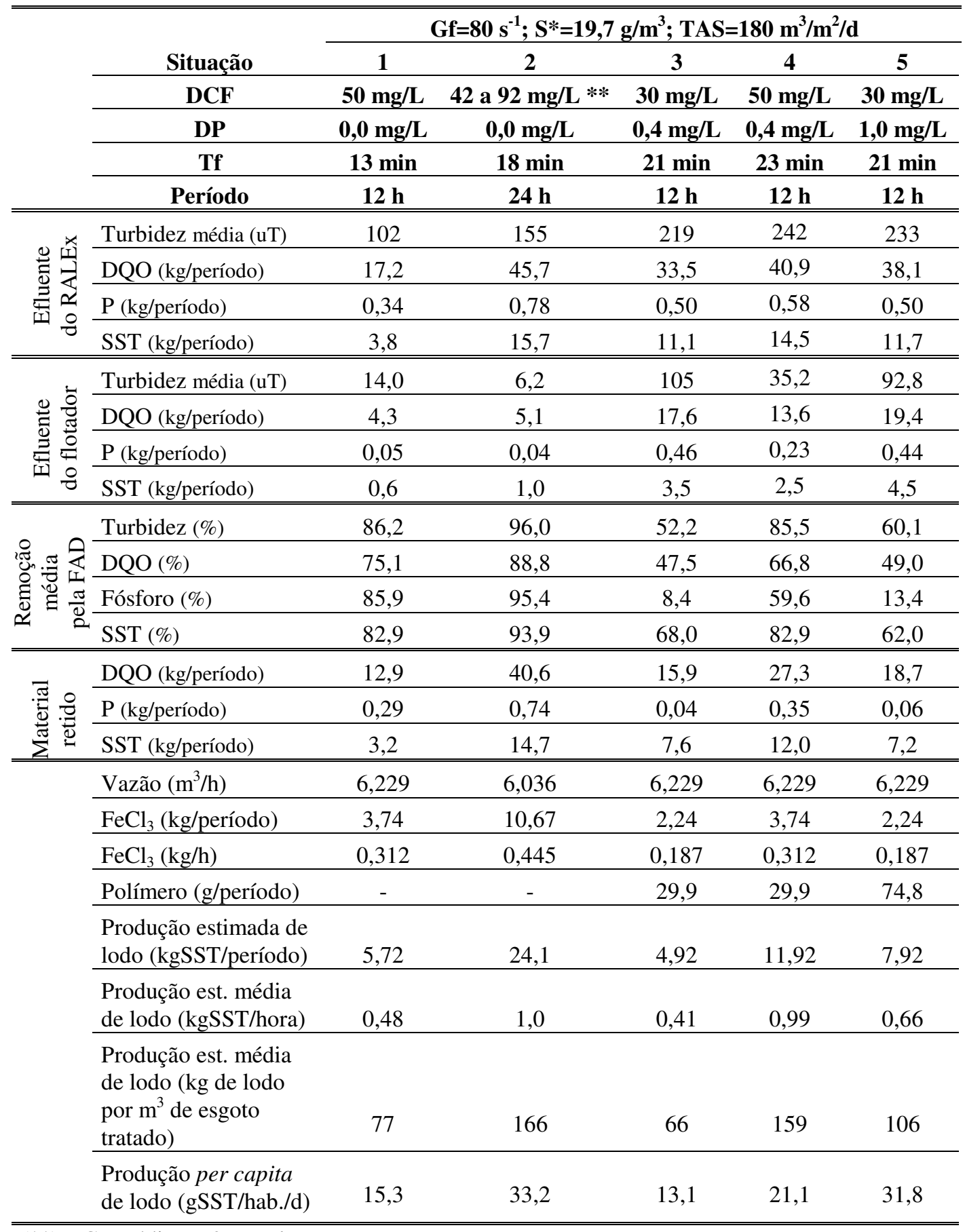

(**) DCF média $=73,7 \mathrm{mg} / \mathrm{L}$

* entretanto, a elevação da dosagem de polímero de 0,4 (situação 3) para 1,0 mg/L (situação 5), com uso de $30 \mathrm{mgFeCl}_{3} / \mathrm{L}$, promoveu a remoção de cargas semelhantes de DQO, de fósforo e de SST. Vale ressaltar que a remoção de fósforo foi 
desprezível. Ainda assim, houve aumento na produção estimada de lodo de 0,41 para $0,66 \mathrm{kgSST} / \mathrm{h}$ e

* na situação 4, o emprego adicional de polímero promoveu aumento significativo na retenção de material na forma de DQO e de SST, quando comparado à situação 1 , com conseqüente aumento na produção estimada de lodo de 0,48 para $0,99 \mathrm{kgSST} / \mathrm{h}$. Ainda assim, em função da baixa qualidade do efluente do RALEx na situação 4, o flotador produziu efluente final com qualidade significativamente inferior ao da situação 1 .

$\Rightarrow$ A comparação entre as diferentes situações permite verificar que a produção de lodo é fortemente dependente da dosagem de coagulante e da qualidade do efluente do reator anaeróbio, sobretudo em termos de sólidos suspensos.

$\Rightarrow$ Dosagens entre 40 e $50 \mathrm{mgFeCl}_{3} / \mathrm{L}$ são suficientes para produção de efluente final com excelente qualidade, sobretudo em termos de remoção de fósforo, e de baixa geração de lodo, desde que o reator anaeróbio produza comumente efluente com baixos teores de sólidos suspensos. Para ocorrências de aumento no teor de sólidos suspensos no efluente do reator anaeróbio, a elevação da dosagem de coagulante é capaz de manter a boa qualidade final do efluente, com contrapartida de geração adicional de lodo.

- Ainda que dependentes da qualidade do efluente do reator anaeróbio, os resultados demonstraram que o sistema envolvendo o emprego de reator anaeróbio seguido de sistema de flotação por ar dissolvido constitui alternativa bastante atraente, capaz de promover elevado grau de tratamento de esgotos sanitários.

- O sistema de flotação após o reator RALEx, quando operado em condições adequadas de coagulação/floculação, apresentou operação fácil, comportamento estável e bom desempenho devido às características de boa "flotabilidade" dos flocos formados a partir da coagulação química do efluente do reator RALEx, mesmo durante períodos de instabilidade de desempenho do reator anaeróbio. 


\section{CONCLUSÕES E RECOMENDAÇÕES}

- Os resultados demonstraram que o sistema composto de reator anaeróbio seguido de sistema de flotação por ar dissolvido constitui-se em alternativa bastante atraente, capaz de promover elevado grau de tratamento de esgotos sanitários.

- O uso do referido sistema proporcionou eficiência de remoção de até $96,7 \%$ de turbidez, 91,6\% de DQO, 91,8\% de fósforo, 96,6\% de sólidos suspensos totais e 76,2\% de ferro, com 3 horas de detenção hidráulica no reator anaeróbio de leito expandido e adição de $50 \mathrm{mg} / \mathrm{L}$ de cloreto férrico na unidade de floculação/flotação.

- Também foi observada a remoção de até $99,8 \%$ de coliformes fecais pelo referido sistema. Essa eficiência de remoção propicia um melhor rendimento da unidade final de desinfecção.

- A unidade de floculação/flotação foi ineficiente na remoção de compostos nitrogenados. Observou-se remoção de apenas 12,5\% de NTK, de 17,2\% de nitrogênio amoniacal e de $15,2 \%$ de nitrato.

- O sistema de flotação, quando operado em condições adequadas de coagulação e floculação, apresentou operação simples, comportamento estável e bom desempenho devido às características de boa "flotabilidade" dos flocos formados, mesmo durante períodos de instabilidade de desempenho do reator anaeróbio.

- Durante a partida dos reatores anaeróbios, no início da operação de uma estação de tratamento de esgoto, a flotação pode atuar como uma barreira altamente eficaz, evitando lançamento de efluentes de baixa qualidade em corpos d'água, ainda que, para tanto, volume adicional de lodo seja produzido e deva ser corretamente destinado.

- Muito embora este trabalho tenha identificado e quantificado os principais parâmetros operacionais mais adequados à flotação, cabe ressaltar que a grande variação da composição físico-química existente entre esgotos sanitários gerados em locais diferentes pode resultar em alterações das condições operacionais que propiciem maior eficiência ao sistema.

- Desta forma, a adoção da flotação, após reatores anaeróbios que tratem esgoto sanitário diferente daquele utilizado neste trabalho, deve necessariamente ser precedida de 
ensaios para investigação das condições operacionais mais adequadas ao esgoto a ser tratado.

- Para a elaboração de projetos de estação de tratamento de esgoto que adotem o sistema composto de reator anaeróbio seguido de flotação por ar dissolvido, recomenda-se que os ensaios para identificação dos parâmetros operacionais mais apropriados sejam realizados conforme método proposto neste trabalho.

Além das conclusões anteriores, os ensaios em escala de laboratório do presente trabalho forneceram resultados que levaram a mais conclusões:

- A adição de polímero, isoladamente ou associado ao cloreto férrico, durante a floculação propiciou que a qualidade de amostra de efluente final coletada em elevada velocidade de flotação fosse semelhante àquela coletada em baixa velocidade de flotação, fato extremamente positivo, pois indica a possibilidade de operação de unidades de flotação, em escala real, com taxas bastante elevadas, permitindo a adoção de unidades mais compactas e, portanto, mais econômicas.

- O uso de polímero isoladamente na floculação dos efluentes de reator anaeróbio constituiu-se em alternativa viável para redução do volume de lodo gerado e manutenção de qualidade satisfatória do efluente final, desde que a remoção de fósforo não seja requerida.

- A maximização da atuação do polímero na remoção de DQO dependeu da capacidade do reator anaeróbio de produzir efluentes com reduzida presença de matéria orgânica em amostra filtrada em membranas com $\phi<1,2 \mu \mathrm{m}$. Quanto maior a presença de matéria orgânica na forma particulada, maior a qualidade dos flocos gerados pelos polímeros, facilitando sua remoção pela flotação.

- O emprego de polímeros catiônicos com alto peso molecular, isoladamente ou associado ao cloreto férrico, resultou na produção de efluentes finais com qualidade superior àquela quando polímeros aniônicos ou não-iônicos foram utilizados.

- A adição conjunta de cloreto férrico e de polímero para coagulação/floculação/flotação dos efluentes de reator RALEx trouxe vantagem adicional ao sistema, mediante elevação da remoção de fósforo, quando comparado ao uso isolado de polímero.

- Em efluente do reator RALEx com elevada presença de material coloidal ou dissolvido, a produção de efluente com boa qualidade, após a flotação, foi fortemente dependente da dosagem de cloreto férrico utilizada. A aplicação adicional de polímero não trouxe ganhos de qualidade em amostra do efluente final coletada em baixa velocidade de 
flotação. No entanto, o uso de polímero propiciou a manutenção da referida qualidade em amostra coletada em velocidades de flotação mais altas.

- O aumento da dosagem de cloreto férrico resultou em significativa elevação da remoção da fração particulada de DQO, em função da melhora da flotabilidade dos flocos formados, propiciando alta remoção dos sólidos suspensos. Porém, praticamente, não influenciou a remoção da parcela dissolvida da matéria orgânica, mesmo quando da correção do pH de coagulação.

- O aumento da dosagem de cloreto férrico foi fundamental para a obtenção de teores de fósforo progressivamente menores no efluente do flotador. Houve aumento na eficiência de remoção tanto para a fração coloidal e dissolvida quanto para a fração particulada de fósforo.

- Para que houvesse maximização da atuação do cloreto férrico, sobretudo em termos de remoção de turbidez e de fósforo, foi essencial a adoção de tempo de floculação de pelo menos 6 min, antes da adição do polímero.

- O aumento de 12 para 24 min de floculação, com pelo menos 6 min de floculação antes da adição de polímero, resultou em melhoria significativa na remoção de turbidez e de fósforo, para todos os gradientes médios de velocidade de floculação estudados.

- Considerando-se a remoção de turbidez e de fósforo, o emprego de gradientes médios de velocidade de floculação entre 60 e $100 \mathrm{~s}^{-1}$ produziu efluente final com excelente qualidade.

4 O uso de até 24 min de floculação e de até $100 \mathrm{~s}^{-1}$ de gradiente médio de velocidade de floculação praticamente não influenciou a remoção de DQO.

- Embora o estudo da necessidade de ar para a flotação apresente restrições operacionais quando de sua investigação no flotateste, aparentemente o fornecimento entre 16 e $19 \mathrm{~g}$ de ar por $\mathrm{m}^{3}$ de efluente para a flotação é suficiente para obtenção de elevada remoção dos flocos.

- Para obtenção de níveis satisfatórios de remoção de fósforo foram necessárias dosagens de $30 \mathrm{mgFeCl}_{3} / \mathrm{L}$ para o efluente do reator RALEx quando operado em equilíbrio dinâmico aparente, sendo que para o efluente durante a partida do reator dosagens na faixa de 45 a $65 \mathrm{mgFeCl}_{3} / \mathrm{L}$ foram requeridas, sem necessidade de correção do $\mathrm{pH}$ de coagulação.

- Quando da correção do pH de coagulação para valores entre 4,0 e 5,0, o uso de 15 a 30 $\mathrm{mgFeCl}_{3} / \mathrm{L}$ isoladamente não foi alternativa recomendável para obtenção de efluente 
com elevada qualidade em termos de turbidez em função dos baixos valores de $\mathrm{pH}$ necessários, ferindo a legislação pertinente. Já para valores entre 45 e $85 \mathrm{mgFeCl}_{3} / \mathrm{L}$, tendo em vista que a qualidade do efluente não dependia de baixos valores de $\mathrm{pH}$, seu uso foi recomendável, com a vantagem adicional que nenhuma correção de $\mathrm{pH}$ foi necessária.

- Em situações onde não fosse necessária baixa turbidez nem reduzida presença de fósforo, o uso de $30 \mathrm{mgFeCl}_{3} / \mathrm{L}$ seria suficiente para obtenção de baixos residuais de matéria orgânica, sem correção do $\mathrm{pH}$.

- Quando do uso isolado do cloreto férrico na coagulação e floculação de efluente do reator RALEx, durante partida do reator biológico, dosagens iguais ou superiores a 65 $\mathrm{mg} / \mathrm{L}$ foram necessárias para manutenção da qualidade do efluente final, com valores de turbidez inferiores a 15 uT, remoção de $90 \%$ de DQO pelo sistema RALEx+FAD e mais de $97 \%$ de remoção de fósforo ao longo do dia.

- Durante partida do RALEx, o emprego de polímero catiônico isoladamente forneceu resultados satisfatórios no que se refere à remoção de turbidez e de DQO, embora não tão bons quanto aqueles obtidos com aplicação de cloreto férrico.

Os ensaios em instalação piloto de flotação do presente trabalho forneceram dados que resultaram nas seguintes conclusões:

- Durante a operação do reator RALEx em equilíbrio dinâmico aparente, seu desempenho foi suficientemente bom para que a flotação, mediante uso de baixas dosagens de cloreto férrico, produzisse efluente final de excelente qualidade, a partir de amostras coletadas às 08:00. Durante o período de partida do RALEx, foram necessárias dosagens mais elevadas, conforme dados de laboratório.

- O reator RALEx estava sendo operado abaixo de seu real potencial de desempenho, em função de limitações operacionais. Mesmo em equilíbrio dinâmico aparente, o desempenho do RALEx manteve-se aquém do esperado, tratando-se desse tipo de reator anaeróbio.

- As limitações operacionais do reator RALEx utilizado neste estudo provavelmente influenciaram o desenvolvimento e atuação da biomassa, sobretudo nos meses mais frios do ano, restringindo a capacidade de remoção de matéria orgânica e de sólidos presentes no esgoto sanitário, com conseqüente necessidade de elevação da dosagem média de coagulante utilizada no sistema de flotação para obtenção de efluente final com qualidade desejada. 
- O uso de 50 e $70 \mathrm{mg} / \mathrm{L}$ de cloreto férrico conduziu a bons resultados de remoção de carga de DQO, de fósforo e de SST, enquanto para $30 \mathrm{mgFeCl}_{3} / \mathrm{L}$ a eficiência de remoção das referidas cargas foi insatisfatória.

- Para tempos de floculação entre 13 e 20 min, a variação do valor de Gf demonstrou influir significativamente no desempenho da flotação do efluente de reator anaeróbio;

- Muito embora os resultados de laboratório tenham indicado valores de Gf entre 60 e $100 \mathrm{~s}^{-1}$ como suficientes para proporcionar boas condições de floculação, com conseqüente bom desempenho da flotação, os dados obtidos com o flotador mostraram

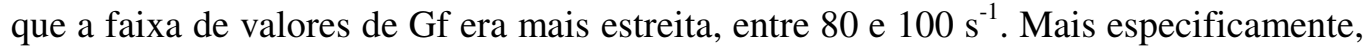
o uso de Gf igual a $80 \mathrm{~s}^{-1}$ associado a Tf de $20 \mathrm{~min}$ mostrou-se mais adequado em função da estabilidade da qualidade do efluente produzido ao longo do dia.

- A qualidade do efluente do flotador, durante os ensaios com $\mathrm{S}^{*}=19,7 \mathrm{~g} / \mathrm{m}^{3}$, foi significativamente melhor quando comparado aos ensaios com $\mathrm{S}^{*}=13,1 \mathrm{~g} / \mathrm{m}^{3}$. Notadamente, este aumento da quantidade de ar fornecido resultou em aumento expressivo de desempenho da unidade de flotação e da qualidade final do efluente.

4 Nas condições do presente estudo, o aumento de taxa de aplicação superficial de 180 para $250 \mathrm{~m}^{3} / \mathrm{m}^{2} / \mathrm{d}$ provocou redução significativa na remoção de turbidez, de DQO, de fósforo e de SST, sendo apenas parcialmente compensada pelo aumento da dosagem de cloreto férrico.

- $\mathrm{O}$ emprego de $90 \mathrm{mgFeCl}_{3} / \mathrm{L}$, embora sendo dosagem bastante elevada, garantiu a produção de efluente do flotador com excelente qualidade durante situação em que o efluente do RALEx se apresentava com má qualidade.

- Para maximização da atuação do cloreto férrico, deve-se optar pela variação de sua dosagem ao longo do dia e da noite, de forma que cada adição feita seja proporcional à qualidade do efluente do RALEx.

- A dosagem adicional de polímero, quando do uso de baixas dosagens de cloreto férrico, não propiciou aumento no desempenho da flotação, já insatisfatório quando do uso isolado de cloreto férrico, sobretudo em consequiência da baixa qualidade do efluente do RALEx.

- A dosagem adicional de polímero catiônico, entre 0,4 e $1,0 \mathrm{mg} / \mathrm{L}$, não foi suficiente para manter a boa qualidade do efluente do flotador, observada quando do uso isolado de 50 a $70 \mathrm{mgFeCl} / \mathrm{L}$, em situações de queda acentuada de desempenho do RALEx.

- A comparação entre as diferentes situações permitiu verificar que a produção de lodo foi fortemente dependente da dosagem de coagulante e da qualidade do efluente do reator anaeróbio, sobretudo em termos de teor de sólidos suspensos. 
- Para ocorrências em que houve aumento no teor de sólidos suspensos no efluente do reator anaeróbio, a elevação da dosagem de coagulante foi capaz de manter a boa qualidade final do efluente, com contrapartida de geração adicional de lodo.

Para ampliar o conhecimento acerca das características do emprego da flotação por ar dissolvido no pós-tratamento de efluentes de reatores anaeróbios, são apresentadas algumas recomendações para estudos posteriores:

$\otimes$ Empregando a mesma unidade piloto de flotação deste estudo, utilizar reator anaeróbio com desempenho adequado às suas potencialidades e que produza efluente com qualidade mais homogênea ao longo do dia. Esta investigação permitiria identificar as dosagens mínimas realmente essenciais para produção de efluente final com excelente qualidade e com conseqüente menor produção de lodo;

$\otimes$ Mediante caracterização biológica e físico-química detalhada, identificar os potenciais usos e/ou formas de disposição final do lodo retirado do sistema de flotação;

$\otimes$ Identificar o(s) parâmetro(s) de qualidade (turbidez, sólidos, DQO, fósforo, etc.) do efluente do flotador que melhor se adequaria(m) ao controle automático da dosagem de produtos químicos, mediante instalação de equipamento de medição contínua do parâmetro escolhido.

$\otimes$ Aprofundar o estudo da cinética da remoção de DQO, de fósforo e de sólidos do efluente do reator anaeróbio pela coagulação/floculação/flotação, procurando identificar as diferentes velocidades de reação e sua respectiva influência na remoção dos diferentes parâmetros e na variação da dosagem de coagulante necessária para manutenção da boa qualidade do efluente final;

$\otimes$ Investigar o emprego de taxas de aplicação superficial mais elevadas mediante uso de unidades de flotação de alta taxa e/ou de gerações mais avançadas do que aquela utilizada neste estudo;

$\otimes$ Estudar a influência da recirculação de parcela do lodo flotado para unidade de mistura rápida no desempenho da instalação piloto de flotação e na possível redução de dosagem de coagulante requerida.

$\otimes$ Recircular parcela do lodo flotado para unidade de tratamento anaeróbio, visando investigar a influência desse procedimento no desempenho do reator anaeróbio tratando esgoto sanitário. 


\section{REFERÊNCIAS BIBLIOGRÁFICAS}

ABDEL-AAL, E.S.A. (1999). Recovery of phosphoric acid from egyptian Nile Valley phosphate tailings. Minerals Engineering, v.13, n.2, p.223-226.

AISSE, M.M.; JÜRGENSEN, D.; LOBATO, M.B. \& ALÉM SOBRINHO, P. (2001). Avaliação do sistema reator RALF e flotação por ar dissolvido, no tratamento de esgoto sanitário. XXI Congresso Brasileiro de Engenharia Sanitária e Ambiental. João Pessoa$\mathrm{PB}$, Anais. CD.

ALÉM SOBRINHO, P. \& JORDÃO, E.P. (2001). Pós-tratamento de efluentes de reatores anaeróbios - uma análise crítica. In: CHERNICHARO, C.A.L. (coordenador), Póstratamento de Efluentes de Reatores Anaeróbios, p.491-513. Belo Horizonte, Projeto PROSAB.

AMIRTHARAJAH, A. (1989). Velocity gradients in rapid mix units. Anais do Seminário Nacional sobre Coagulação e Filtração Direta. São Carlos, Brasil.

ANTE, A.; BESCHE, H.U. \& VOSS, H. (1994). A mathematical model for enhanced biological phosphorus removal. Water Science and Technology, v.30, n.2, p.193-203.

ARANTES, F.M.; VIEIRA, A.G.F.; KATO, M.; FORÊNCIO, L. (2000). Uso de lagoa de polimento para efluentes de reator UASB. In: CHERNICHARO, C.A.L. (coordenador), Pós-tratamento de Efluentes de Reatores Anaeróbios - coletânea de trabalhos técnicos, p.33-42. Belo Horizonte, Projeto PROSAB.

ARSOV, R.; RIBAROVA, I.; TOPALOVA, Y. \& MIHAILOV, G. (1995). On the nitrification-denitrification biological excess phosphorus removal processes. Water Science and Technology, v.32, n.7, p.95-102.

AWWA-APHA \&WPCF (1999). Standard methods for the examination of water and wastewater. A.E. GREENBERG; L.S. CLEESCERI \& L.G. ANDREW; $20^{\mathrm{a}}$ ed., NewYork, USA.

BATES, A.J. (2000). Water as consumed and its impact on the consumer - do we understand the variables? Food and Chemical Toxicology, n.38, p.29-36.

BOLTO, B.A. (1995). Soluble polymers in water purification. Prog. Polym. Sci., v.20, p.987-1041.

BONOMO, L.; NURIZZO, C. \& ROLLE, E. (1999). Advanced wastewater treatment and reuse: related problems and perpectives in Italy. Water Science and Technology, v.40, n.4-5, p.21-28. 
BRATBY, J.R. (1982). Treatment of Raw Wastewater Overflows by Dissolved Air Flotation. Journal WPCF, v.54, n.12, p.1558-65, Dec.

BRATBY, J. \& MARAIS, G.v.R. (1975). Saturator performance in dissolved-air (pressure) flotation. Water Research, n.9, p.926-936.

CALLADO, N.H. \& FORESTI, E. (2001). Removal of organic carbon, nitrogen and phosphorus in sequential batch reactors integrating the aerobic/anaerobic processes. Water Science \& Technology, v.44, n.4, p.263-270.

CAMPOS, J.R. \& PEREIRA, J.A.R. (1999). Reator anaeróbio de leito expandido/ fluidificado. In: Tratamento de esgotos sanitários por processo anaeróbio e disposição controlada no solo / José Roberto Campos (coordenador). - Rio de Janeiro: ABES, 464 pág., Projeto PROSAB.

CAMPOS, J. R.; REALI, M.A.P.; DOMBROSKI, S.A.G.; MARCHETTO, M. \& LIMA, M.R.A. (1996). Tratamento Físico-Químico por Flotação de Efluentes de Reatores Anaeróbios. XXV Congreso Interamericano Ingeniería Sanitaria y Ambiental, México.

CARDOCH, L.; DAY JR., J.W.; RYBCZYK, J.M. \& KEMP, G.P. (2000). An economic analysis of using wetlands for treatment of shrimp processing wastewater - a case study in Dulac, LA. Ecological Economics, v.33, p.93-101.

CARUCCI, A.; LINDREA, K.; MAJONE, M. \& RAMADORI, R. (1995). Dynamics of the anaerobic utilization of organic substrates in na anaerobic/aerobic sequencing batch reactor. Water Science and Technology, v.31, n.2, p.35-43.

CASEY, T.J. \& NAOUM, I.E. (1986). Air saturations for use in dissolved air flotation processes. Water Supply, n.4, p. 69-82.

CATUNDA, P.F.C.; MAYER, M.G.R.; MOREIRA, E.A. \& Van HANDEEL, A. (2000). Acumulação de lodo em lagoas de polimento tratando esgoto digerido. In: CHERNICHARO, C.A.L. (coordenador), Pós-tratamento de Efluentes de Reatores Anaeróbios - coletânea de trabalhos técnicos, p.67-74. Belo Horizonte, Projeto PROSAB.

CHUNG, T.H. \& KIM, D.Y. (1997). Significance of pressure and recirculation in sludge thickening by dissolved air flotation. Water Science and Technology, v.36, n.12-11, p.223-230.

CONWAY, R.A.; NELSON, R.F. \& YOUNG, B.A. (1981). High solubility gas flotation. Journal WPCF, n.53, p.1198-1205.

CORAUCCI FILHO, B.; ANDRADE NETO, C.O.; MELO, H.N.S.; SOUZA, J.T.; NOUR, E.A.A. \& FIGUEIREDO, R.F. (2001). Pós-tratamento de efluentes de reatores anaeróbios por sistemas de aplicação no solo. In: CHERNICHARO, C.A.L. (coordenador), Pós-tratamento de Efluentes de Reatores Anaeróbios, p.35-103. Belo Horizonte, Projeto PROSAB.

CORAUCCI FILHO, B.; CHERNICHARO, C.A.L.; ANDRADE NETO, C.O.; NOUR, E.A.A.; ANDREOLI, F. DE N.; SOUZA, H.N.; MONTEGGIA, L.O.; VON SPERLING, M.; LUCAS FILHO, L.; AISSE, M.M.; FIGUEIREDO, R.F. \& STEFANUTTI, R. (1999). Tecnologia do tratamento de águas residuárias no solo: 
infiltração rápida, irrigação e escoamento superficial. In: CAMPOS, J.R. (coordenador), Tratamento de esgotos sanitários por processo anaeróbio e disposição controlada no solo, p.357-407. Rio de Janeiro: ABES.

CORAUCCI FILHO, B.; NOUR, E.A.A.; FIGUEIREDO, R.F.; STEFANUTTI, R.; KLUSENER FILHO, L.C. \& BROLEZE, S.T. (2000). Estudo de um sistema de póstratamento de efluente com aplicação do método do escoamento superficial no solo: polimento de efluentes de filtros anaeróbios. In: CHERNICHARO, C.A.L. (coordenador), Pós-tratamento de Efluentes de Reatores Anaeróbios - coletânea de trabalhos técnicos, p.1-8. Belo Horizonte, Projeto PROSAB.

CROOT, P.L. \& HUNTER, K.A. (2000). Determination of Fe(II) and total iron in natural waters with 3-(2-pyridyl)-5,6-diphenyl-1,2,4-triazine (PDT). Analytica Chimica Acta, n.406, p.289-302.

CYBIS, L.F. \& PICKBRENNER, K. (2000). Uso de reator seqüencial em batelada para póstratamento de efluentes de tratamento anaeróbio. In: CHERNICHARO, C.A.L. (coordenador), Pós-tratamento de Efluentes de Reatores Anaeróbios - coletânea de trabalhos técnicos, p.157-164. Belo Horizonte, Projeto PROSAB.

EDZWALD, J.K.; WALSH, J.P.; KAMINSKY, G.S. \& DUNN, H.J. (1992). Flocculation and air Requeriments for Dissolved air flotation. Research and Technology. Journal $A W W A, 84(3)$, p. 92-100, março.

ESTEVES, F.A. (1988). Fundamentos de limnologia. Rio de Janeiro, ed. Interciência Ltda. Cap.14, p.216-36: Fósforo.

FEITOSA, P.F.F.; Van HANDEEL, A.; KATO, M.T.; Von SPERLING, M.; LUDUVICE, M.L. \& MONTEGGIA, L.O. (2001). Pós-tratamento de efluentes de reatores anaeróbios por lagoas de polimento. In: CHERNICHARO, C.A.L. (coordenador), Pós-tratamento de Efluentes de Reatores Anaeróbios, p.105-170. Belo Horizonte, Projeto PROSAB.

FERGUSON, J.F. \& HORRES, R.L. (1979). Two steps precipitation of calcium phosphates. Prog. Wat. Tech., suppl.1, p.157-70.

GNIRSS, G. \& PETER-FROLICH, A. (1996). Biological treatment of municipal wastewater with deep tanks and flotation for secondary clarification. Water Science and Technology, v.34, n.3-4, p.257-265.

GONÇALVES, R.F.; ARAÚJO, V.L. \& CHERNICHARO, C.A.L. (1998). Association of a UASB reactor and a submerged aerated biofilter for domestic sewage treatment. Water Science and Technology, v.38, n.8-9, p.189-195.

GONÇALVES, R.F.; CHERNICHARO, C.A.L.; ANDRADE NETO, C.O.; ALÉM SOBRINHO, P.; KATO, M.T.; COSTA, R.H.R.; AISSE, M.M. \& ZAIAT, M. (2001). Pós-tratamento de efluentes de reatores anaeróbios por reatores com biofilme. In: CHERNICHARO, C.A.L. (coordenador), Pós-tratamento de Efluentes de Reatores Anaeróbios, p.171-278. Belo Horizonte, Projeto PROSAB.

GONÇALVES, R.F.; PASSAMANI, F.R.F.; SALIM, F.P.; SILVA, A.L.B.; MARTINELI, G \& BAUER, D.G. (2000). Associação de um reator UASB e biofiltros aerados submersos para tratamento de esgoto sanitário. In: CHERNICHARO, C.A.L. (coordenador), Pós- 
tratamento de Efluentes de Reatores Anaeróbios - coletânea de trabalhos técnicos, p.119-134. Belo Horizonte, Projeto PROSAB.

GRAY, S.R.; HARBOUR, P.J. \& DIXON, D.R. (1997). Effect of polyelectrolyte charge density and molecular weight on the flotation of oil in water emulsions. Colloids and Surfaces, n.126, p.85-95.

HALLIWELL, D.J.; MCKELVIE, I.D.; HART, B.T. \& DUNHILL, R.H. (2001). Hydrolysis of triphosphate from detergents in a rural waste water system. Water Research, v.35, n.2, p.448-454.

HEDBERG, T.; DAHLQUIST, J.; KARLSSON, D. \& SORMAN, L. (1998). Development of an air removal system for dissolved air flotation. Water Science and Technology, v.37, n. 9, p. $81-88$.

HEINRICH, D. (1995). Wastewater treatment in a company with advanced demands for water quality. Water Science and Technology, v.32, n.7, p.143-50.

HENRY, J.G. \& GEHR, R. (1981). Dissolved air flotation for primary and secundary clarification. Sewage Collection and Treatment Report SCAT-9, Canadá.

IVES, K.J. (1984). Introduction. In : IVES, K.J. ed. The scientific basis of flotation. Proceedings of the NATO Advanced Science Institute on the Scientific Basis of Flotation, Cambridge, England, Jul, Martinus Nijhoff Publishers, The Hague, p.349-77.

JAMESON, G.J. (1999). Hydrophobicity and floc density in induced-air flotation for water treatment. Colloids and surfaces, n.151, p.269-281.

JENKINS, D. \& HERMANOWICZ, S.W. (1991). 'Principles of chemical phosphate removal", in Phosphorus and nitrogen removal from municipal wastewater, $2^{\text {nd }}$ ed., R.I. Sedlak, ed., Chelsea, MI, Lewis Publishers.

JING, S.R.; LIN, Y.F.; LEE, D.Y. \& WANG, T.W. (2001). Nutrient removal from polluted river water by using constructed wetlands. Bioresource technology, n.76, p.131-135.

KIURI, H.J. (2001). Development of dissolved air flotation technology from the first generation to the newest (third) one (DAF in turbulent flow conditions). Water Science \& Technology, vol.43, n.8, p.1-7.

KIURU, H.J. \& RAUTIAINEN, J.A. (1998). Biological nutrient removal at a very lowloaded activated sludge plant with high biomass concentrations. Water Science and Technology, v.38, n.1, p.63-70.

KROFTA, M; MISKOVIC, D., BURGESS, D. \& FAHEY, E. (1996). The investigation of the advanced treatment of municipal wastewater by modular flotation-filtration systems and reuse for irrigation. Water Science and Technology, v.33, n.10-11, p.171-179.

LAINÉ, S.; POUJOL, T.; BARON, J. \& ROBERT, P. (1998). Treatment of stormwater to bathing water quality by dissolved air flotation, filtration and ultraviolet disinfection. Water Science and Technology, v.38, n.10, p.99-105.

LAW, I.B. (1996). Rouse-Hill - Austrália first full scale domestic non-potable reuse application. Water Science and Technology, v.33, n.10-11, p.71-78. 
LEININGER, K.V. \& WALL, D.J. (1974). Available air measurements applied to flotation thickener evaluations. Deeds \& Data, WPCF, n.11, p.3-7.

LETTINGA, G., FIELD, J., VAN LIER, J., ZEEMAN, G. \& HULSHOFF POL, L.W. (1997). Advanced anaerobic wastewater treatment in the near future. Water Science and Technology, v.35, n.10, p.5-12.

LICSKÓ, I. (1997). Realistic coagulation mechanisms in the use of aluminium and iron (III) salts. Water Science and Technology, v.36, n.4, p.103-110.

LOVETT, D.A.; TRAVERS, S.M. \& MAAS, R.L. (1984). Treatment of abattoir wastewater by dissolved air flotation. Part 1: Wastewater not pretreated. Meat Research Report No. 9, CSIRO Meat Research Laboratory, Cannon Hill, Austrália.

LUDUVICE, M.; NEDER, K.D. \& PINTO, M.T. (2000). Utilização de lagoas rasas no póstratamento de efluentes de reatores anaeróbios de fluxo ascendente (UASB). In: CHERNICHARO, C.A.L. (coordenador), Pós-tratamento de Efluentes de Reatores Anaeróbios - coletânea de trabalhos técnicos, p.43-56. Belo Horizonte, Projeto PROSAB.

LUNDGREN, H. (1970). Recent advances in air flotation technology. Tappi, v.53, n.2, p.287-89, Feb.

MACHDAR, I.; HARADA, H.; OHASHI, A.; SEKIGUCHI,Y.; OKUI, H. \& UEKI, K. (1997). A novel and cost-effective sewage treatment system consisting of UASB prétreatment and aerobic post-treatment units for developing countries. Water Science and Technology, v.36, n.12, p.189-197.

MARCHETTO, M.M.; CAMPOS, J.R. \& REALI, M.A.P. (2000). Remoção de nutrientes de efluentes de reator anaeróbio utilizando reatores microaerado e com aeração intermitente seguidos de flotação por ar dissolvido. In: CHERNICHARO, C.A.L. (coordenador), Póstratamento de Efluentes de Reatores Anaeróbios - coletânea de trabalhos técnicos, p.165-172. Belo Horizonte, Projeto PROSAB.

MARCHIORETTO, M.M. \& REALI, M.A.P. (2001). Ozonation followed by coagulation/flocculation and flotation as post-treatment of the effluent from an anaerobic baffled reactor treating domestic sewage. Water Science and Technology, v. 43, n.8, pp. 99-106.

MAURER, M. E BOLLER, M. (1998). Modelling of phosphorus precipitation in wastewater treatment plants with enhanced biological phosphorus removal. Water Science and Technology, v.39, n.1, p.147-163.

MENDONÇA, N.M. (1998). Caracterização de material suporte e estudo da partida de um reator anaeróbio de leito expandido utilizado para tratamento de esgoto sanitário. São Carlos. Dissertação (mestrado) - Escola de Engenharia de São Carlos, Universidade de São Paulo.

MENEZES, F.M., AMAL, R. \& LUKETINA, D. (1996). Removal of particles using coagulation and flocculation in a dynamic separator. Powder Technology, n.88, p.27-31. 
MENNELL, M.; MERRILL, D.T. \& JORDEN R.M. (1974). Treatment of primary effluent by lime precipitation and dissolved air flotation. Journal WPCF, v.46, n.11 p.2471-85, Nov.

METCALF \& EDDY (1991). Wastewater engineering: treatment, disposal and reuse. McGraw-Hill, $3^{\text {rd }}$ edition, 1334p.

MORSE, G.K.; BRETT, S.W.; GUY, J.A. \& LESTER, J.N. (1998). Review: phosphorus removal and recovery Technologies. The Science of Total Environment, n.212, p.69-81.

MÜNCH, E.V. \& BARR, K. (2001). Controlled struvite crystallisation for removing phosphorus from anaerobic digester sidestreams. Water Research, v.35, n.1, p.151-159.

MUSETTI, R.A. (2001). Da proteção jurídico-ambiental dos recursos hídricos brasileiros. LED - Editora de Direito.

NASCIMENTO, M.C.P.; CHERNICHARO, C.A.L. \& BEJAR, D.O. (2000). Filtros biológicos aplicados ao pós-tratamento de efluentes de reatores UASB. In: CHERNICHARO, C.A.L. (coordenador), Pós-tratamento de Efluentes de Reatores Anaeróbios - coletânea de trabalhos técnicos, p.107-118. Belo Horizonte, Projeto PROSAB.

NGO, H.H. \& VIGNESWARAN, S. (1996). Application of downflow floating medium flocculator/prefilter (DFF) - coarse sand filter (CSF) in nutrient removal. Water Science and Technology, v.33, n.8, p.63-70.

ODEGAARD, H. \& SKROVSETH, A.F. (1997). An evaluation of performance and process stability of different processes for small wastewater treatment plants. Water Science and Technology, v.35, n.6, p.119-127.

PACKHAM, R.F. \& RICHARDS, W.N. (1975). The determination of dissolved air in water. Technical Memorandum TM 106, Water research Centre, Medmenham, England.

PANT, H.K.; REDDY, K.R. \& LEMON, E. (2001). Phosphorus retention capacity of root bed media of sub-surface flow constructed wetlands. Ecological engineering, n.17, p.345-355.

PASSIG, F.H.; VILLELA, L.H. \& FERREIRA, O.P. (2000). Piracicamirim sewage treatment plant - conception utilizing anaerobic process followed by aerobic process evaluation of operacional conditions and compatibility of the processes. In: VI Latinamerican Workshop-Seminar on Anaerobic Digestion. Recife, Brasil. Novembro.

PENETRA, R.G. (1998). Pós-tratamento físico-químico por flotação de efluentes de reatores anaeróbios de manta de lodo. São Carlos. 140p. Dissertação (mestrado) Escola de Engenharia de São Carlos, Universidade de São Paulo.

PENETRA, R.G.; REALI, M.A.P.; FORESTI, E. \& CAMPOS, J.R. (1999a). Post-treatment of effluents from anaerobic reactor treating domestic sewage by dissolved-air flotation. Water Science and Technology, 40(08), 137-143.

PENETRA, R.G.; REALI, M.A.P. \& CAMPOS, J.R. (1999b). Influência da quantidade de ar dissolvido na flotação de efluentes de reatores anaeróbios UASB. In: XX Congresso Brasileiro de Engenharia Sanitária e Ambiental. Rio de Janeiro, Brasil, 10 a 14 de maio. 
PEREIRA, J.A.R. (1991). Avaliação da eficiência do processo físico-químico com cal no tratamento de águas residuárias domésticas. Campina Grande. 99p. Dissertação (mestrado) - Centro de Ciência e Tecnologia, Universidade Federal da Paraíba.

PEREIRA, J.A.R. (2000). Concepção, construção e operação de reator anaeróbio de leito expandido, em escala real, para tratamento de esgoto sanitário. São Carlos. 339p. Tese (Doutorado) - Escola de Engenharia de São Carlos, Universidade de São Paulo.

PEREIRA, J.A.R.; CAMPOS, J.R.; MENDONÇA, N.M. \& NICIURA, C.L. (1999). Avaliação da perda de carga em um reator anaeróbio de leito expandido, em escala real, utilizado no tratamento de esgoto sanitário. XXVII Congresso Interamericano de Engenharia Sanitária e Ambiental. Anais. Rio de Janeiro.

PINTO FILHO, A.C.T. \& BRANDÃO, C.C.S. (2000). Evaluation of flocculation and dissolved air flotation as an advanced wastewater treatment. Water Science \& Technology, vol.43, n.8, p.83-90.

PRIHA, M. (1994). Bioavailability of pulp and paper mill effluent phosphorus. Water Science and Technology, v.29, n.5-6, p.93-103.

RAMIREZ, J.A.; ZINCHENKO, A.; LOEWENBERG, M. \& DAVIS, R.H. (1999). The flotation rates of fines spherical particles under Brownian and convective motion. Chemical Engineering Science, n.54, p.149-157.

REALI, M.A.P. (1991). Concepção e Avaliação de um Sistema Compacto para Tratamento de Águas de Abastecimento Utilizando o Processo de Flotação por Ar Dissolvido e Filtração com Taxa Declinante. Tese (Doutorado). Escola de Engenharia de São Carlos - Universidade de São Paulo.

REALI, M.A.P. (1994). Proposição de um Modelo Teórico para o Processo de Flotação por Ar Dissolvido. XXIV Congreso Interamericano de Ingenieria Sanitária y Ambiental, de 30/10 a 04/11/1994, Buenos Aires, Argentina. Anais magnéticos, Buenos Aires: AIDIS.

REALI, M.A.P. \& CAMPOS, J.R. (1992). Projeto de Câmaras de Saturação de Sistemas de Flotação por Ar Dissolvido com Recheio de Anéis de PVC. XVII Congresso Interamericano de Engenharia Ambiental e Sanitária, La Habana, Cuba. 22-28 de novembro de 1992. Anais, Havana-Cuba, vol. II, parte 1, p. 283-296.

REALI, M.A.P.; PENETRA, R.G. \& CAMPOS, J.R. (1998). Influência da floculação na flotação de efluentes de reatores anaeróbios UASB. In: XXVI Congreso Interamericano de Ingenieria Sanitaria y Ambiental. Lima, Peru. Novembro.

REES, A.J.; RODMAN, D.J. \& ZABEL, T.F. (1980). Evaluation of dissolved air flotation saturator performance. Water Research Centre TR 143, Water Research Centre, Medmenham, England.

ROBERTS, K.L.; WEETER, D.W. \& BALL, R.O. (1978). Dissolved air flotation performance. Proceedings 33rd Industrial Waste Conference, Purdue University, p.194199.

RÖSKE, I. \& SCHÖNBORN, C. (1994). Interactions between chemical and advanced phosphorus elimination. Water Research, v.28, n.5, p.1103-09. 
SCHMID, L.A. \& McKINNEY, R.E. (1969). Phosphate removal by a lime-biological treatment scheme. Journal WPCF, v.41, n.7, p.1259-75.

SCHOFIELD, T. (2000). Dissolved air flotation in drinking water production. Water Science \& Technology, vol.43, n.8, p.9-18.

SCHÖNBORN, C.; BAUER, H.D. \& RÖSKE, I. (2001). Stability of enhanced biological phosphorus removal and composition of polyphosphate granules. Water Research, v.35, n.13, p.3190-3196.

SCRIVEN, R.J.; OUKI, S.K.; DOGGART, A.S. \& BAUER, M.J. (1999). The impact of physico-chemical water treatment on a novel flotation/filtration process. Water Science and Technology, v.39, n.10-11, p.211-215.

SEGHEZZO, L.; ZEEMAN, G.; VAN LIER, J.; HAMELERS, H.V.M. \& LETTINGA, G. (1998). A review: the anaerobic treatment of sewage in UASB and EGSB reactors. Bioresource Technology, n.65, p.175-190.

SELMER-OLSEN, E.; RATNAWEERA, H.C. \& PEHRSON, R. (1996). A novel treatment process for dairy wastewater with chitosan produced from shrimp-shell waste. Water Science and Technology, v.34, n.11, p.33-40.

SHANNON, W.T. \& BUISSON, D.H. (1989). Dissolved air flotation in hot water. Water Research, n.14, p.759-765.

SHAWWA, A.R. \& SMITH, D.W. (1998). Hydrodynamic characterization in dissolved air flotation (DAF) contact zone. Water Science and Technology, v.38, n.6, p.245-252.

SPEECE, R.E. (1996). Anaerobic Biotechnology for Industrial Wastewaters. Vanderbilt, $1^{\text {st }}$ edition, 394p.

STAMBERG, J.B.; BISHOP, D.F.; WARNER, H.P. \& GRIGGS, S.H. (1970). Lime precipitation in municipal wastewaters. Water - Chemical Engineering Progress Symposium Series, v.67, n.107, p.310-20.

STEINBACH, S. \& HAARHOFF, J. (1998). A simplified method for assessing the saturator efficiency at full-scale dissolved-air flotation plants. Water Science and Technology, v.38, n.6, p.303-310.

TAKAHASHI, M.; KATO, S.; SHIMA, H.; SARAI, E.; ICHIOKA, T.; HATYAKAWA, S. \& MIYAJIRI, H. (2001). Technology for recovering phosphorus from incinerated wastewater treatment sludge. Chemosphere, n.44, p.23-29.

TAYLOR, H.D.; GAMBRILL, M.P.; MARA, D.D. \& SILVA S.A. (1994).Upgrading a lowcost physicochemical wastewater treatment plant to solve operational problems. Water Science and Technology, v.29, n.12, p.247-54.

TIEHM, A., HERWIG, V. \& NEIS, U. (1999). Particle size analysis for improved sedimentation and filtration in wastewater treatment. Water Science and Technology, v.39, n.8, p.99-106. 
UPTON, J.; HAYES, E. \& CHURCHLEY, J. (1996). Biological phosphorus removal at Stratford Upon Avon, UK: the effect of influent wastewater characteristics on effluent phosphate. Water Science and Technology, v.33, n.12, p.73-80.

VAN HANDEEL, A. \& GUIMARÃES, P. (2000). Modelamento do tratamento anaeróbioaeróbio usando-se o reator UASB e lodo ativado em bateladas seqüenciais. In: CHERNICHARO, C.A.L. (coordenador), Pós-tratamento de Efluentes de Reatores Anaeróbios - coletânea de trabalhos técnicos, p.143-156. Belo Horizonte, Projeto PROSAB.

VAN LIER, J.B. \& LETTINGA, G. (1999). Appropriate Technologies for effective management of industrial and domestic wastewaters: the decentralised approach. Water Science and Technology, v.40, n.7, p.171-183.

VASSILERA, M.; AZCON, R., BAREA, J.M. \& VASSILEV, N. (2000). Rock phosphate solubilization by free and encapsulated cells of Yarowia lipolytica. Process Biochemistry, n.35, p.693-697.

VIEIRA, A.G.F.; KATO, M.T. \& FLORÊNCIO, L. (2000). Pós-tratamento em reator EGSB de efluente de reator UASB tratando esgoto doméstico. In: CHERNICHARO, C.A.L. (coordenador), Pós-tratamento de Efluentes de Reatores Anaeróbios - coletânea de trabalhos técnicos, p.87-94. Belo Horizonte, Projeto PROSAB.

VLASKI, A.; VAN BREEMEN, A.N. \& ALAERTS, G.J. (1997). The role of particle size and density in dissolved air flotation and sedimentation. Water Science and Technology, v.36, n.4, p.177-189.

VON SPERLING, M. (1995). Princípios do tratamento biológico de águas residuárias Volume 1: Introdução à qualidade das águas e ao tratamento de esgotos. Departamento de Engenharia Sanitária e Ambiental - UFMG. Belo Horizonte, 240p.

VON SPERLING, M.; VAN HANDEEL, A.C.; JORDÃO, E.P.; CAMPOS, J.R.; CYBIS, L.F.; AISSE, M.M. \& ALÉM SOBRINHO, P. (2001). Pós-tratamento de efluentes de reatores anaeróbios por sistemas de lodos ativados. Pós-tratamento de efluentes de reatores anaeróbios por reatores com biofilme. In: CHERNICHARO, C.A.L. (coordenador), Pós-tratamento de Efluentes de Reatores Anaeróbios, p.279-331. Belo Horizonte, Projeto PROSAB.

VOSLOO, P.B.B.; WILLIANS, P.G. \& RADEMAN, R.G. (1986). Pilot and fuul-scale investigations on the use of combined dissolved air flotation and filtration (DAFF) for water treatment. Water Pollution Control, n.85, p.114-121.

XIE, W.; KONDO, M. \& NAITO, Y. (1994). Study on phosphorus removal using a new coagulation system. Water Science and Technology, v.30, n.6, p.257-62.

WANG, N. \& MITSCH, W. (2000). A detailed ecosystem model of phosphorus dynamics in created riparian wetlands. Ecological Modelling, v.126, p.101-130.

YEOMAN, S.; LESTER, J.N. \& PERRY, R. (1993). Phosphorus removal and its influence on metal speciation during wastewater treatment. Water Research, v.27, n.3, p.389-95. 
YU, H.; TAY, J. \& WILSON, F. (1997). A sustainable municipal wastewater treatment process for tropical and subtropical regions in developing countries. Water Science and Technology, v.35, n.9, p.191-198.

ZABEL, T. (1984). Flotation in water treatment. In : IVES, K.J. ed. The scientific basis of flotation. Proceedings of the NATO Advanced Science Institute on the Scientific Basis of Flotation, Cambridge, England, Jul, Martinus Nijhoff Publishers, The Hague, p.34977.

ZABEL, T. (1985). The advantages of dissolved air flotation for water treatment. Journal AWWA - Management and Operations, p.42-46, Maio. 